



$$
\equiv
$$


tom

8

$$
\text { actors }
$$

3

4 





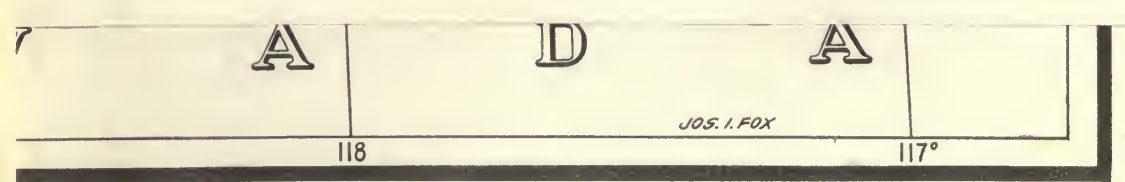




\section{NORTH AMERIGAN FAUNA - - No. 55}

issued

by the

UNITED STATES DEPARTMENT OF AGRICULTURE

BUREAU OF BIOLOGICAL SURVEY

Washington, D. C.

June 1936

\section{THE MAMMALS AND LIFE ZONES OF OREGON}

By VERNON BAILEY, formerly senior biologist, Section of Mammalogy, Division of Wildlife Research

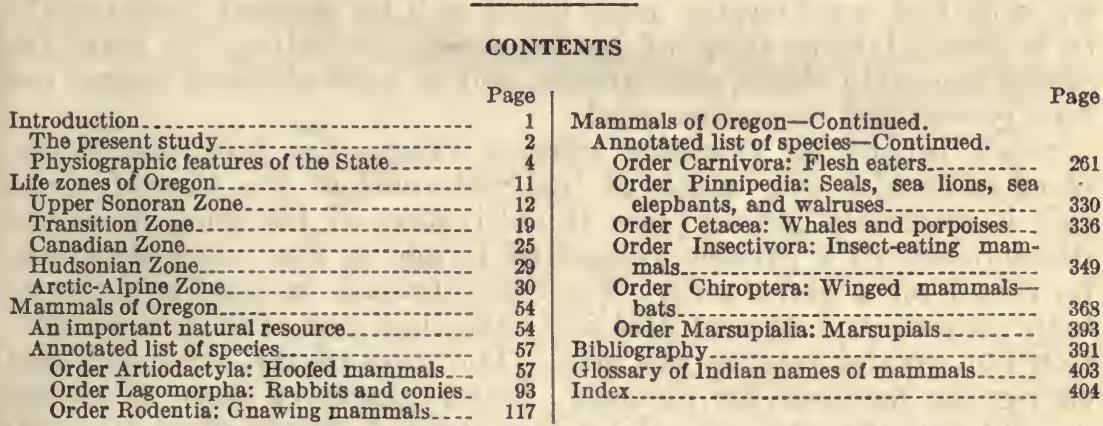

\section{INTRODUCTION}

In the early pioneer days of North America the mild climate, rich-soiled valleys, towering forests, and teeming animal life of the Northwest attracted many adventurous explorers, and before the fur-trapping days were over the basis had been laid for the permanent settlements that held the Territories of Oregon and Washington for the United States. The early history of Oregon is a thrilling romance, full of the stern realities of struggle, endurance, and suffering, leading to eventual victory over appalling obstacles and the development of a great State by a hardy class of people. Even after three-quarters of a century much of the area still remains as public land or is held in large tracts for grazing or lumbering, while national forests protect the best timber. Irrigation already has reclaimed many extensive arid valleys. The extensive lumbering operations have opened up rich lands suitable for agriculture in parts of the valley country, while over the higher levels, on private and public land, reforestation will undoubtedly give better returns than farming. Still other great areas unsuitable for agriculture and of little value for grazing are ideal for native game and wildlife of valuable and attractive forms. 
The first great attraction of the State was its wildlife, game for food and clothing, and fur-bearing animals for trade and international commerce. Agriculture, mining, and lumbering came later and, with other industries, gradually absorbed the wildlife resources, which were not inexhaustible, as they seemed at first. While Oregon is still one of the leading States for hunting, there is today only a fraction of the original supply of game. Some of the most valuable species are extinct or nearing extinction, and others are in need of suitable range and food, of better protection, and a definite plan of management that will build up and insure a future supply not only of game animals but also of the many other attractive and interesting forms of wildlife that add so much to the value of any region. There are great areas of publicly owned forest lands where game is next to the timber in value and where it should always be maintained in controlled abundance. Other types of open-land game, however, are not protected by the national forests and have not been able to compete with the overgrazing of domestic livestock. Much of this public domain is of little or no value for any purpose other than its native wildlife, and considerable areas could well be devoted permanently to a gradual restoration of native forms, including the antelope, desert mountain sheep, sage grouse, and in more elevated ranges the blue grouse and mountain quail.

Stock raising on extensive grazing ranges has been one of the chief industries over much of the State east of the Cascades, but this is gradually giving place to cultivation of the land, or to the development of a greater volume of forage so that more stock can be raised on a given area. The concentration in smaller units of both grazing and agricultural activities does not mean less production but greater returns per acre. The days of the big ranch and easy-going methods are passing. Better grades of stock and more careful management are taking their place. Application of scientific methods will make this, as every other branch of agriculture, more productive. A greater diversity of livestock, including some of our native game animals, may be predicted for the future, with the same advantages that other diversified types of farming have shown. Some of the native animals of Oregon that might well be domesticated or better managed for man's use are the elk, deer, antelope, bighorn, beaver, and muskrat, some of the waterfowl, the sage grouse, blue grouse, sharp-tailed grouse, and mountain quail.

With the future development and progress of the industries, a fuller knowledge of climatic and physiographic conditions will be a distinct advantage. Also a more complete knowledge of the habits, distribution, abundance, and economic relations of the native animals of the State often will save losses of property and waste of time, and will prevent the destruction of harmless, interesting, and useful species.

\section{THE PRESENT STUDY}

The present report is based primarily on field work of the Bureau of Biological Survey, carried on through varying periods since 1888, in addition to such published information as has been found. The systematic survey of the State was begun under the direction of C. Hart Merriam, who in 1896 led in person a small field party 
through the Blue Mountains, Steens Mountains, Warner Mountains, and from the Klamath region north through the Cascades to Mount Hood. Later the field work was carried on under the direction of H. W. Henshaw, and still later under E. W. Nelson, until fairly representative collections of mammals, birds, reptiles, and plants were obtained from every part of the State. The distribution of the species was thus ascertained with considerable detail and the significance of geographic variation generally explained.

Valuable assistance came through the cooperation of the State university at Eugene, the Willamette University at Salem, the State agricultural college at Corvallis, Reed College near Portland, and the fish and game department of the State. The State university was represented in field work by Alfred C. Shelton, under John F. Bovard, and the university collections were made available for working out species and ranges. F. V. Coville and S. F. Blake, Bureau of Plant Industry, rendered valuable assistance in the nomenclature of the plant lists. Morton E. Peck, of the Willamette University, contributed largely in general field work, especially in botany. The agricultural college collection has been drawn upon for such additional material as it afforded, and the fish and game collection through William L. Finley gave every assistance possible, detailing Stanley G. Jewett, R. Bruce Horsfall, and O. J. Murie for field work, and building up a very useful collection of mammals and birds in the Reed College museum. The college museum, under the direction of Harry Beal Torrey, sent one of its student assistants, Mr. Launcefield, into the field on one of the collection trips, and also aided in every way possible with museum material.

Private collectors have generously contributed to a knowledge of the State fauna. Of these, thanks are especially due to A. Brazier Howell, whose collection is now in the Natural History Museum of southern California; H. E. Anthony, now of the American Museum of Natural History in New York; Lee R. Dice, of the University of Michigan; Alexander Walker, of Tillamook, Oreg.; Stanley G. Jewett, long associated with the Biological Survey's game management and predatory-animal control in Oregon; and Ira N. Gabrielson, then in charge of the Bureau's rodent control in the State, later its regional supervisor in the region that includes Oregon, and now Chief of the Bureau.

The Biological Survey field work in Oregon has been carried on at various times and places since 1888 by Theodore S. Palmer, Clark P. Streator, Arthur H. Howell, Albert K. Fisher, Walter K. Fisher, J. Alden Loring, Stanley G. Jewett, Luther Goldman, Morton E. Peck, Alexander Walker, Ned Hollister, Harry H. Sheldon, Robert H. Becker, Edward A. Preble, and the writer. Some of this work has been done sporadically in connection with that in adjoining States, but all has helped. Much information and many important specimens have been obtained from the predatory-animal and rodentcontrol field workers in the Division of Economic Investigations of the Biological Survey formerly under A. K. Fisher and W. B. Bell and now part of the Division of Game Management under Stanley P. Young.

Close and cordial cooperation with officials of the Forest Service has afforded important information on game matters and animal 
statistics that could not otherwise have been obtained. The information gathered from ranchmen, hunters, and others along the way has been of great value in supplementing field notes and has been used freely with credit under specific records.

The natural-history studies of the Mazamas, the mountain-climbing club of Oregon, published in annual reports, have afforded valuable information and have been freely drawn upon, as have the bulletins of the State university, agricultural college, experiment stations, Forest Service, Park Service, and United States Geological Survey.

While the present report puts on record much that is not commonly known about animal life, it represents a beginning rather than the finished product of studies of the State's mammals. Its greatest value should be in enabling a large number of local people to observe correctly and record the habits of animals until much better understood than at present, to know what particular species they are observing, and to obtain definite and accurate information. Much of the animal life is a State and national asset and should be conserved and used to the greatest advantage consistent with wise use and the perpetuation of the species. In some cases this can be done only through the partial or complete control of other species of less value or of destructive habits. Only by applying the most thorough and reliable information can the wildlife of a country be managed efficiently.

\section{PHYSIOGRAPHIC FEATURES OF THE STATE}

The surface features of Oregon (pl. 1) show wide variation, ranging from coastal plains and great inland valleys to broad plateaus, lofty mountain ranges, and snow-capped peaks. Three types of geological formation stand out: The very old nonvolcanic crystalline or metamorphic rocks, the comparatively recent but still ancient lakebasin deposits of the great valleys, and the volcanic deposits of both ancient and comparatively recent times.

\section{VOLCANIC AREAS}

A great part of the State, including most of the Cascade Range and the plains to the eastward, is of volcanic origin, consisting of numerous large and small craters and great areas built up by successive flows of lava. The enormous depth of these lava flows is well shown by the sides of the Deschutes, Columbia, Snake, Grand Ronde, and Imnaha Canyons, by the Kiger Gorge and the east escarpment of the Steens Mountains (pl. 2, A), and by many other cliffs and canyons in the State. In numerous side walls and rimrock cliffs consecutive layers of lava, ranging from 20 to 50 feet and sometimes 100 feet in thickness, may be counted to a height or depth of 2,000 or 3,000 feet. Sometimes these form beautiful series of basaltic columns or layers of royalite, and there are various forms of amorphous lavas, cooled and hardened as they flowed out in surface sheets (pl. $2, B$ ), or in places as shiny black sheets of volcanic glass (obsidian). The vertical cleavage of the lava sheets produces the 

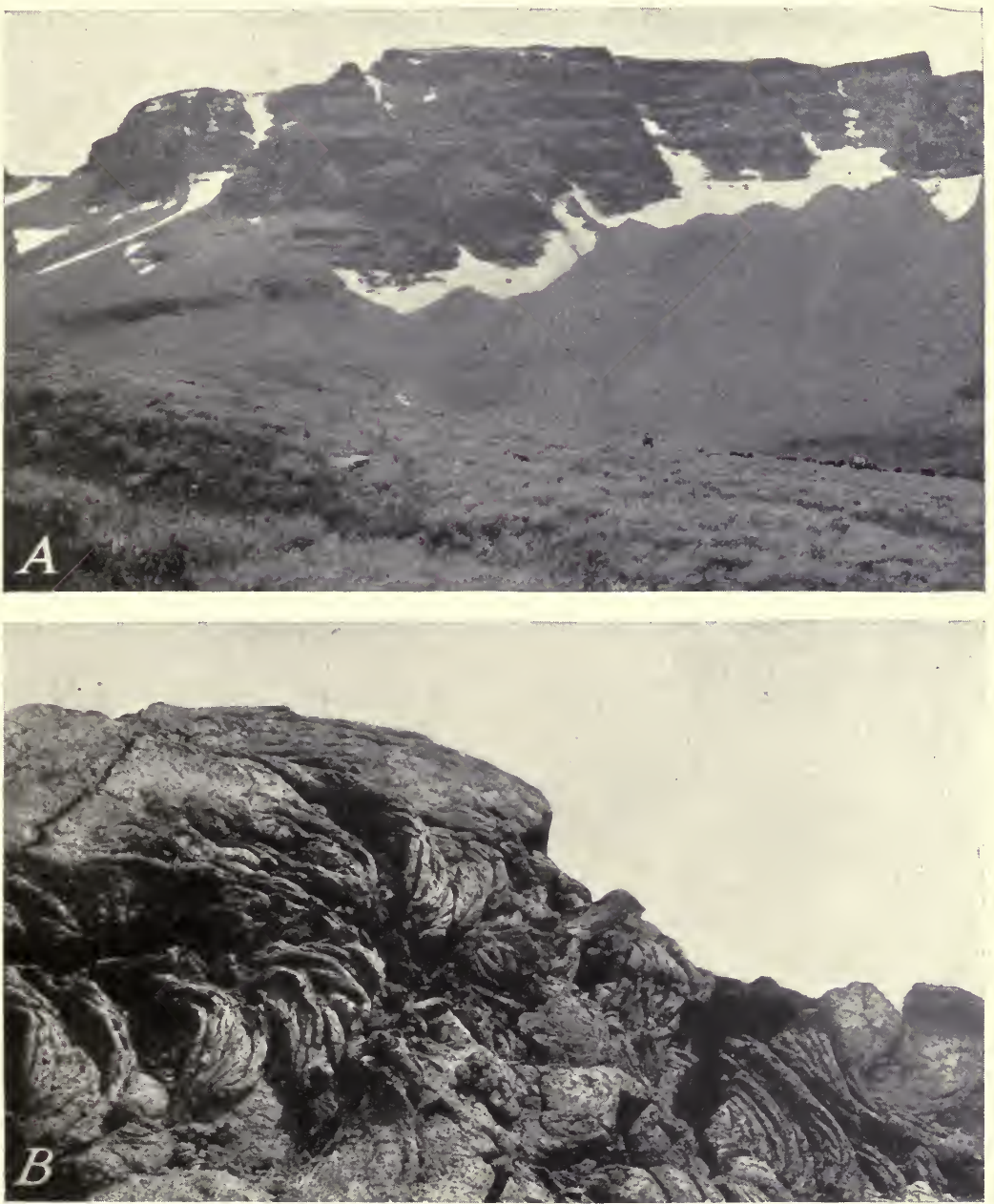

Steens Mountains (9,354 Feet Altitude).

B17230; B16313

$A$, East face, showing successive lava flows and permanent snow banks in head of Kiger Gorge; $B$, comparatively recent flow of surface lava, near Cow Creek Lakes, southeastern Malheur Ccunty (photograph by Edward A. Preble, 1915) 

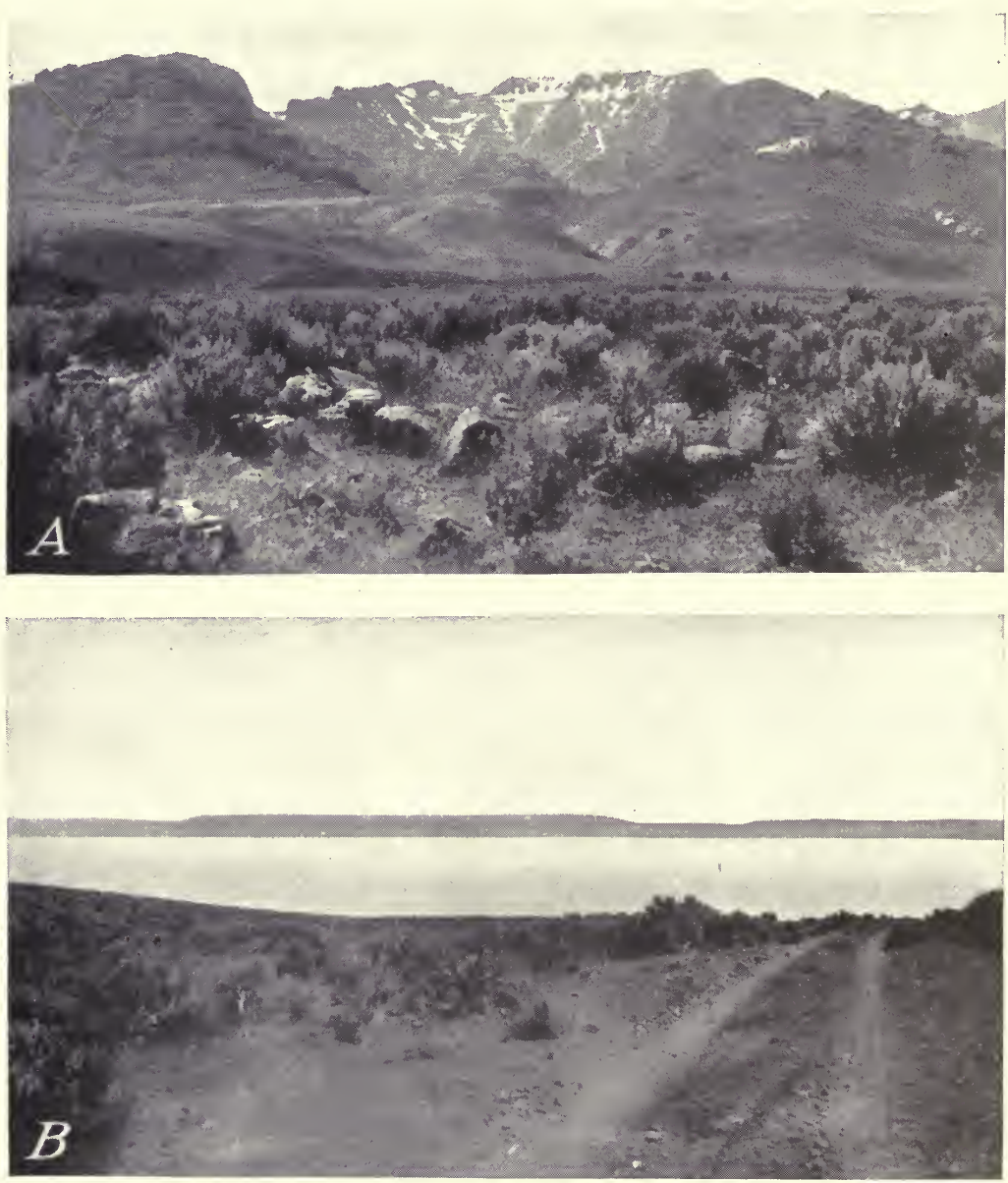

B33207; В33194

$A$, Steens Mountains, from near Alvord Ranch, showing east face of high part of range (July 7, 1927); $B$, Tumtum Lake, Alvord Valley, looking east from near base of Steens Mountains (July 6, 1927). 

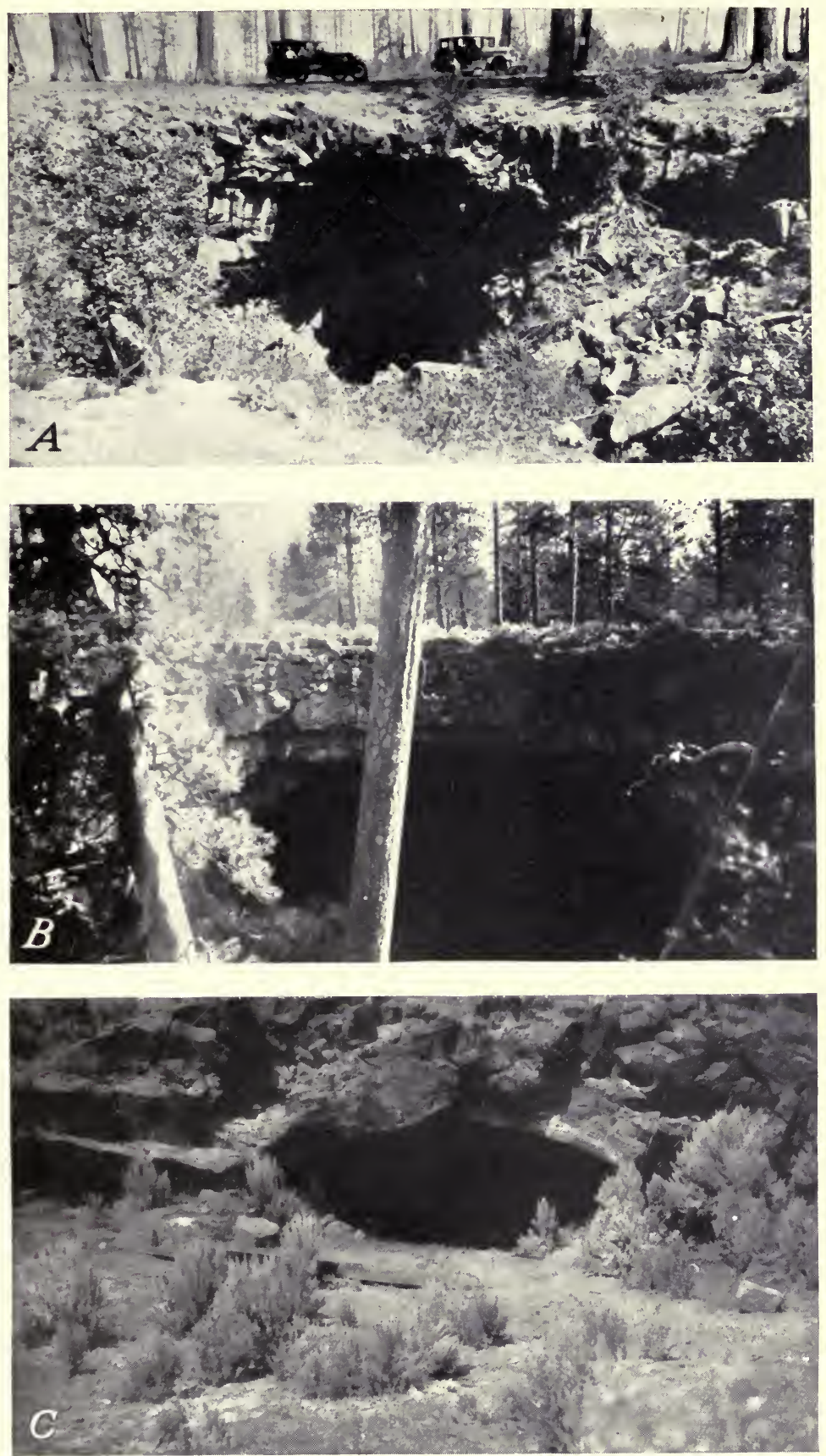

B33203; В33205; В23575

CAVES IN DEschutes and haRney COUNTIES.

$A$, Lava River Cave, 22 miles south of Bend; $B$, one of the Arnold ice caves, 20 miles southeast of Bend; $C$, Malheur Cave, 30 miles east of Malheur Lake. All harbor bats and contain kones of recent mammals 


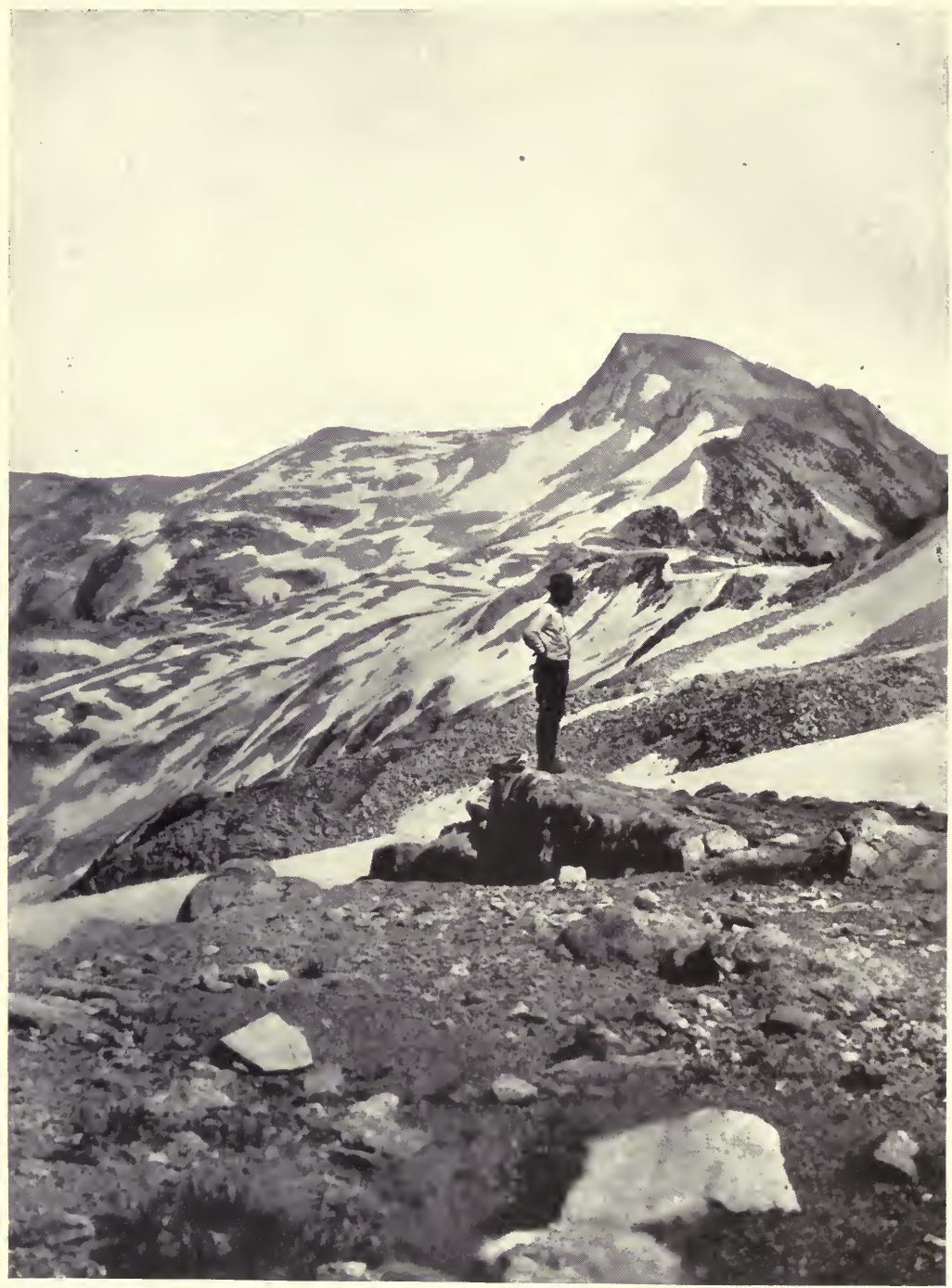

EAGLE CAP PEAK, WALLOWA MOUNTAins.

B4598M Photograph by Stanley G. Jewett, July 20, 1925. 
sheer cliffs and abrupt rimrock effects so common over the eastern part of the State.

The great peaks of the Cascades, from Mount McLoughlin (Pitt) and Mazama on the south to Jefferson and Hood on the north, are all old craters from which the Cascade Range has been augmented by enormous flows of lava that reach both slopes and spread out over the valleys. While the ice-clad peaks, some of them worldfamous spectacles, are of special interest in their fauna and flora and of great value as sources of water, the broad basal slopes of the range, bearing dense forests of valuable timber, are especially important in human economy.

The configuration of surface, various types of erosion, color and character of soils, and to some extent, the character of forest and other vegetation forming the ground cover, are modified by the general volcanic base so widely spread over the State. The general fertility of the valley soils is in part due to their volcanic origin, while even the resulting dark colors are in some cases an advantage in added ability to absorb light and heat from the sun. It is well known that species of plants and animals range to higher altitudes on dark soil than on light and that other high-ranging species range lower down on light-colored soils.

The Paulina, Yamsay, Yanax, and Klamath Mountains, lying east of the Cascades, are of the same volcanic type, but are scattered in lower groups or buttes. Their height reaches generally only to about 7,000 feet, but this is sufficient to give them cold upper slopes with an extra amount of precipitation and relatively heavy growths of timber.

Still farther to the eastward other types of ranges rise abruptly from the desert valleys. While composed mainly of volcanic materials, they appear as elongated ridges with one or both sides broken and pushed up along more or less well-defined fault lines. These include the Winter Range, Warner and Hart Ranges, and the higher and still more striking Steens Mountains.

The Steens Mountains, a boldly tilted uplift from the lava plains of southeastern Oregon, are largely volcanic from near the base to the summit. Their sharply faulted eastern escarpment rises abruptly 5,500 feet above the valley bottom, attaining a total altitude of about 9,354 feet in the highest parts (pl. 3, A). Of them Russell (1903, p. 19) ${ }^{1}$ says in effect:

The eastern slope of that splendid mountain is composed of the broken and eroded edges of sheets of basalt, which dip westward at an angle of about $3^{\circ}$ to $4^{\circ}$ and present an aggregate thickness of not less than 5,000 feet, while the lacustrine sediments beneath their base reach a thickness of at least 1,000 feet. Thin layers of sandstone separate some of the laval flows but even those which rest directly upon each other are easily counted in cross section and some 30 or 100 sheets, averaging about 60 feet thick, are more or less exposed in this escarpment.

Deep canyons are guttered into the sides of the range, and canyon walls expose heavy stratifications of successive lava flows through which the mountains have been pushed up. At the northern end of the range several broad $U$-shaped canyons show evidence of glacial erosion, and several beautiful examples of hanging valleys along the

${ }^{1}$ Citations in italic in parentheses refer to the bibliography, p. 394. 
west side of the Kiger Gorge tell a part of the story of the glacial period. Summer snow banks or ice beds high up on the cold slopes in the old cirques still feed many permanent streams which are cutting sharp V-shaped courses down the valley bottoms to the arid plains below (pl. 3, $B$ ). The top of the range is just an inclined section of the desert pushed up to a height where plant life is still more depauperate than at lower levels. The peaks are merely the jagged edges of a much-eroded ridge with occasional notches cut clear through by the erosive action of ice and water.

Over the great arid plains both east and west of the Steens Mountains are extensive fields of black and barren lavas, poured out by numerous small and medium-sized craters. Although cold and dead now, many of these craters appear so fresh and vivid as to suggest comparatively recent activity. In many places the long streams of wavy and twisted lavas tempt one to feel the rough surface to see if it is still hot. To the student of geology or the tourist it is unnecessary to go to the Hawaiian Islands or farther away than eastern Oregon to study picturesque and fascinating lava fields and craters, cinder cones, or lava caves.

In many of the older lava flows where the surface had hardened over a long gentle slope, the still molten interior of a fresh stream broke out below, and the liquid interior escaping, left great tunnellike subways, some of them miles in length, below heavy roofs of solid rock. The Malheur Caves, the Arnold Ice Caves, the Skeleton Cave, the Horse Caves, and the Lava River Cave are well-known examples (pl.4), but there are many others without name or fame.

Less attractive, but not less important, volcanic features of the State are the vast deposits of pumice, volcanic ash, and volcanic sand. In places these deposits cover the rocks to considerable depths and form great plains, sandy valleys, or deep sections of canyon walls. Notable among these are the great pumice plain between Crater Lake and the Paulina Mountains, the black-sand valleys east and south of the Paulinas and in various valleys farther east, and the numerous smaller but deep deposits along both sides of the Cascades. Such materials have a very practical bearing' on soil fertility and secondarily on distribution of plant and animal life.

Volcanic activity in the State has practically ceased. At present Mount Hood is the only crater giving noticeable signs of remaining activity. Slight fumaroles of gas and steam occur in the old cup near the top of the peak, and at times the steam and sulphur fumes sweep over the summit in stifling gusts. No recent eruptions, however, are known.

\section{NONVOLCANIC AREAS}

Nonvolcanic areas in Oregon are found in some of the peaks and high ridges of the Wallowa and Elkhorn (or Baker) Ranges, in the Siskiyous, in most of the Coast Range country, and in the extensive lacustrine deposits of the older valleys.

The higher parts of the Wallowa Mountains, while surrounded by the heavy base of lava of the Blue Mountain Plateau, are largely composed of such materials as granite, quartzite, limestone, marble, slate, and other nonvolcanic rocks. In general the topographic configuration resembles the Rocky Mountains, and moreover a large 
number of Rocky Mountain species of plants and animals occur. 'The main peaks rise to sharp pinnacles, 9,000 to 9,800 feet in altitude. The highest shown on the Forest Service contour map is the Matterhorn which reaches above the 9,800-foot level. Eagle Cap (pl. 5), formerly supposed to be still higher, is given as 9,675 feet; and Petes Point and Aneroid Point near Aneroid Lake are shown as reaching above the 9,600 -foot contour.

The peaks are sharp and jagged, separated by steep, ice-eaten cirques and upper slopes and deeply cut canyons. Extensive fields of permanent ice and snow persist on the high cold slopes, and one small glacier still clings to the declivity between Eagle Cap and Sentinel Peak. The many glacier-hewn valleys with numerous lateral and terminal moraines and many lake beds scooped out of the solid rock are conspicuous features of the landscape. Wallowa Lake at about 4,500 feet on the northern side of the range is an especially beautiful example of a glacial scoop, deep, long, and narrow, with high lateral and terminal moraines. Higher up some of the numerous small lakes in rocky basins close to the snow banks are frozen over for the greater part of the year, but during the summer they send down torrents of ice-cold water.

The Wallowa Mountains are well supplied with permanent streams that cut their way down through deep and picturesque canyons to the Snake River on the east, the Powder River on the south, and the Grand Ronde on the north. Most of the canyon walls are of basalt or other rocks of volcanic origin, but in many places on the south and east slopes the older geological formations are exposed. Some of these are rich in valuable minerals.

While most of the Blue Mountain Plateau is covered with splendid forests, the higher parts of the range reach near or above timber line and are barren or but sparingly wooded.

The Elkhorn (or Baker) Range, rising abruptly west of Baker City, is similar in general character to the Wallowa Mountains but slightly lower and less rugged. The highest peak, formerly known as "Rock Creek Butte" but changed by the Geographic Board of Oregon to "Hunt Mountain" in honor of Wilson Price Hunt, leader of the John Jacob Astor party in 1811 and so far as known the first white man to see the peak, is given on the Geological Survey quadrangle as 9,097 feet in altitude. Many other points are almost as high, and the crest of the range is well above timber line, with bare peaks and upper slopes snow patched even in late summer.

The high part of the range consists largely of crystalline, sedimentary, and metamorphic rocks, including many ore-bearing formations, but the surrounding country is a part of the Blue Mountain Plateau.

The Siskiyou Mountains, on the southwestern border of the State, represent one of the geologically very old land formations. They are composed largely of granite, quartz, limestone, marble, sandstone shales, and various metamorphic rocks. On the west they extend down to the coast and locally yield valuable deposits of gold and other minerals. Siskiyou Peak at 7,662 feet and Sterling Peak at 7,150 feet reach slightly above timber line on their northern slopes. The higher parts of the mountains are steep and deeply eroded, numerous long narrow spurs or ridges winding down between deep 
V-shaped canyons coursed by rapid streams. In general features, as well as in plant and animal life, this region is a part of the Trinity or Klamath Mountain system of northwestern California, which also extends northward to include the Rogue River Mountains.

It is a well-watered region, and except for the higher peaks and ridge tops it is generally well forested.

The Coast Ranges of western Oregon, lying between the valleys of the Williamette, Umpqua, and upper Rogue Rivers, are largely parts of an elevated and much-dissected plateau, or old coastal plain, deeply eroded into flat-topped ridges with steep, and often terraced, slopes and innumerable deep V-shaped cuts and canyons between. The ridge tops range from 3,000 to about 4,100 feet in height, the highest, Chintimini Mountain, or Marys Peak, just west of Corvallis, being 4,097 feet. Both the Coast Ranges and the coastal plain are largely of sedimentary rocks-sandstones, limestones, shales, or more recent alluvial deposits. In places basalt or other igneous rocks crop out on the surface or are exposed in terraces or canyon walls.

The whole region is well watered. Dense forests and rich undergrowth give a well-rounded and smooth appearance and hide most of the details of surface structure.

The lacustrine and alluvial deposits of the broad valleys of Oregon are of special importance and interest because of their rich mellow soils, easily adaptable to profitable agriculture. Most of the larger valleys, such as the plains of the Columbia east of the Cascades and the Snake River Valley above the Snake River Canyon, owe their deep soil to the deposits of ancient lake beds long since drained by the lowered river channels. The broad rich valleys of the Willamette, the Upper Umpqua, and the Rogue River may be old lake beds or early embayments of the ocean. Nevertheless, parts of the valley floors are constantly receiving additions of silt from the mountains, spread out by innumerable small streams. Other parts are losing their best soil by erosion.

The innumerable inland-lake basins of the high plains of eastern Oregon, each with its own type and age of soil and geological deposits, all lie within the arid area. Generally they are devoted to grazing and ranching, but eventually should include some of the best game lands of the State.

\section{DRAINAGE}

Drainage is of two distinct types-the river and stream drainage to the Pacific Ocean, and the inland-lake or basin drainage of the southeastern part of the State. The river drainage includes the Columbia River system, with its numerous tributaries, and the coastal streams that carry vast quantities of water from the high and humid slopes of the Cascades to the Pacific.

In the more arid southeastern part of the State are many lake basins of purely inland drainage, really a part of the Great Basin area. Among the larger basins are Malheur, Harney, Alvord, Warner, Abert, and Summer Lakes, all occupying lava-encircled valleys and fed by surface waters or very limited streams from springs. Many extensive playas, or dry mud flats, occupy the bottom of other valleys where shallow lakes formed by rains quickly 


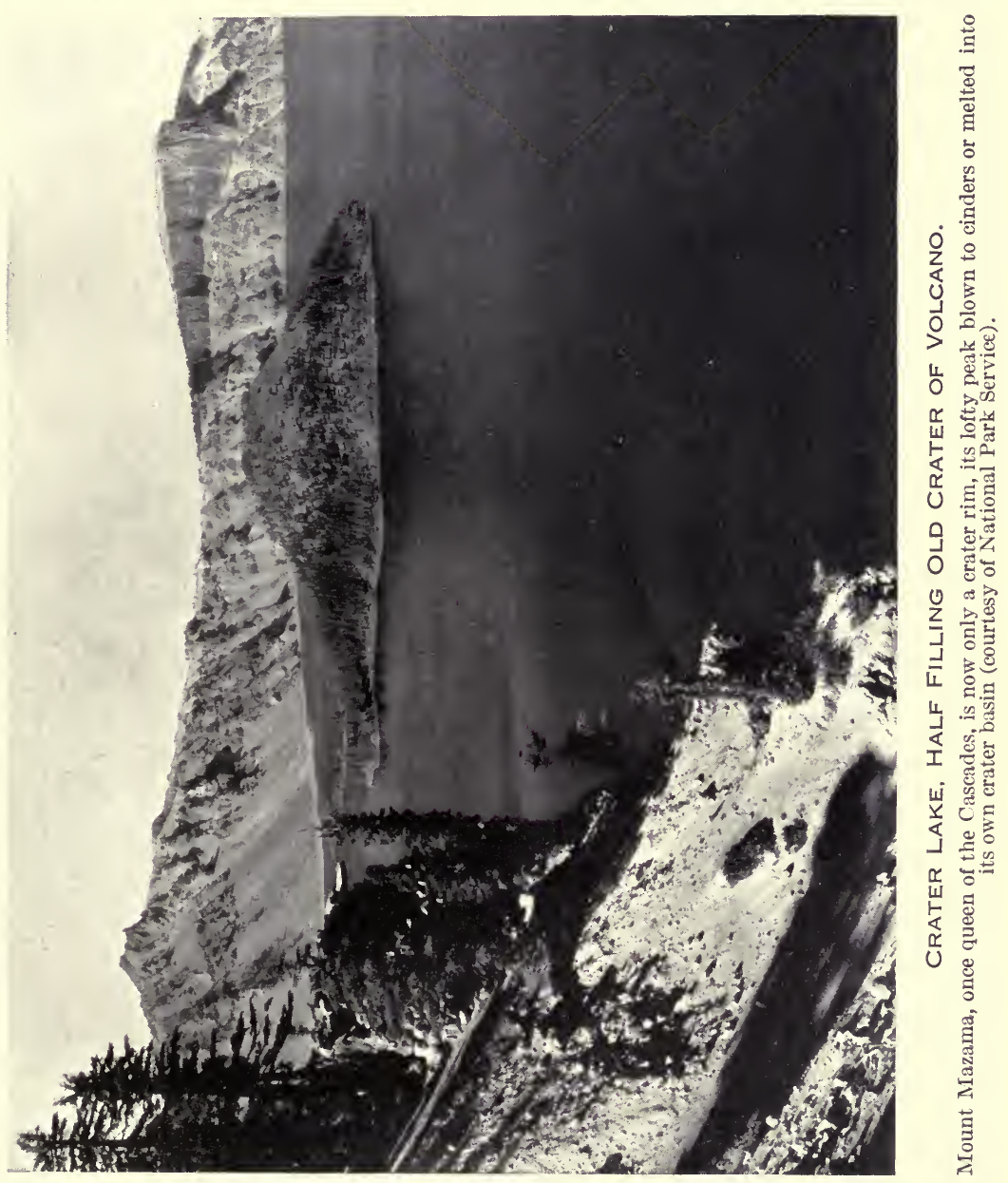



dry up, leaving miles of baked, glistening mud flats. Most of the basin lakes are shallow. The shore lines of some are steadily receding because of the diversion of water for irrigation. Eventually some of these lakes also will be mere playas. Lake Harney has been reduced to that state for a decade. As usual, inland drainage is the result of rainfall that is not sufficient to overflow the valleys and cut out the rims to connect with lower levels. Added to this is an arid climate in which the evaporation over a large surface of standing water more than balances the precipitation over a considerably greater drainage area.

Malheur Lake, which in 1897 when it was first seen by the writer was an enormous tule swamp overflowing into Harney Lake as it did when Peter Skene Ogden first saw it in 1826, was practically dry in 1931, when buffalo skulls were collected in its baked mud bed. Overutilization of the water of streams naturally flowing into it had ruined the hay and grain ranches around the borders of this great fertile valley, lowered the water table until the valleys became a part of the surrounding desert, and destroyed one of the most important wild-fowl-breeding grounds in the State.

Recently these conditions have been corrected by addition of a considerable part of the drainage of the Blitzen River (Donner und Blitzen) to the Lake Malheur Wildlife Refuge, allowing sufficient water to reach the lake to restore it to a normal level and extent of surface and swampy border. The enlarged circle of moist and fertile land restores the ranch values of the valley, and 30 miles of lake and tule swamp restore the spectacular breeding and resting grounds of swans, geese, ducks, pelicans, cranes, egrets, herons, ibises, curlew, and a host of swimming and wading birds and valuable fur bearers.

Goose Lake and the Klamath Lakes, on the southern border of the State, have cut outlets through the southern rim of their basins, and their waters reach the ocean through Pit and Klamath Rivers. At one time these valleys may well have been a part of the Great Basin, with which they still closely agree in climate, flora, and fauna.

Lakes of a yet different type-many of them large, deep, clear, and cold-lie along the higher parts of the Cascade Range in Oregon and serve as reservoirs of snow water that is let down during summer months to thirsty fields below. The best known and most spectacular of these, Crater Lake (pl. 6), half fills its cuplike crater to a depth of 2,000 feet and presents a unique picture of beautiful color and form. Although the lake is without visible outlet, the water remains at a uniform level. It seems not improbable that some of the large streams that burst out below may drain the lake through underground channels in the mountain side. Other lakes owe their origin to lava dams or terminal moraines and generally form the headwaters of important streams.

Still another set of lakes is that of the immediate coastal stripold embayments or estuaries cut off from the ocean. Not much above the ocean level, they remain as land-locked bodies of fresh water held back by sand bars or dunes.

Then, too, there are the prehistoric lakes such as once covered a great area in the Columbia River Valley east of the Cascades, the Snake River Valley above the canyon, the greater Malheur Valley, and the northern end of Lake Bonneville in Alvord Valley. Present 
interest in these ancient bodies of water lies mainly in the rich fossil beds that here and there mark the old shore lines. Some of the "badland" formations of these old beaches bear valuable deposits of prehistoric mammal remains that open an important chapter in the geological history of the State. The John Day Valley, Camp Creek, Malheur, and Owyhee Valley fossil beds are probably the best known.

\section{GLACIATION}

Glaciation as a type of drainage has modified to some extent the higher elevations of the State and is still slowly eating away great cirques and amphitheatres on the upper slopes of Hood, Jefferson, the Three Sisters, McLoughlin (Pitt), the Wallowa, Baker, and Steens Mountains. Ancient moraines show glacial activity much lower on the mountain slopes than at present. Generally this evidence does not extend into the valley country, nor is it conspicuous after the great volcanic period. Glacial lakes are comparatively few in the State, although Wallowa Lake is a beautiful example of a glacial scoop and some of the smaller lakes high up in the mountains owe their origin to the ice. Many, if not most, of the lakes in Oregon, however, owe their origin directly or indirectly to volcanic activity closing up valleys or damming streams of water with streams of lava.

\section{SOIL CONDITIONS}

Soils and land cover, in special cases, exert considerable influence on the distribution of species. Over much of Oregon the firm, rich, dark-colored soils from disintegrated lavas are generally fertile and produce dense plant growth. They vary endlessly, however, in texture, in mineral composition, and in mechanical structure. At one extreme are the fine precipitates of deep-water deposits, forming tenacious clays, commonly called "gumbo." Waxy when wet and hard when dry, they are extremely discouraging to most burrowing rodents. At the opposite are the deep mellow sands, fine and nonadhesive, that form light mellow soils. These always prove a great delight to burrowers.

Only very limited areas of the light, water-washed sands, such as drift and change with every wind, are found, mainly along the Columbia River Valley above The Dalles, around the shores of Harney and Alvord Lakes, and in places along the coast. In these spots the light yellow sands drift back over the river banks, lakes, and seashore in dunes and ridges for considerable distances, giving their color and character to extensive areas. While attracting or developing certain species of plants and animals, these light sands have perhaps crowded out others with different affinities. Sand dunes in the desert are favorite haunts of kangaroo rats, pocket mice, lizards, and horned toads. Another soil type favorable to burrowing species of mammals, as well as horned toads and lizards, is composed of the deep, black, loose sands and volcanic ash, especially conspicuous east and south of the Paulina Mountains. This soil is attractive also to sand- and heat-loving plants.

Owing mainly to soil conditions, the extensive playas of the Alvord Valley and others east of the Steens Mountains, except for brief peri- 
ods after a rain or snow, are more nearly typical desert and more lifeless than any other part of the State. Such level valley bottoms without drainage can produce neither water plants, because they dry up quickly after rainfall, nor dry-land plants, because the occasional sheet of water kills them. Thus devoid of vegetation, they have an animal life limited to occasional antelope, jack rabbits, coyotes, swift foxes, badgers, and lizards that wander over them.

In the more humid areas under the abundant growth of vegetation, the base soil is generally covered with rich humus of varying depths that is especially attractive to burrowing insects and a great variety of small invertebrates. Consequently this same mold-covered soil is most attractive to numerous species of insectivorous mammals and birds and holds the greater part of the shrew and mole population of the State.

\section{PLANT COVER}

Types of vegetation or plant associations, as modified by soil moisture and other local conditions, have a powerful influence on the distribution of species of animals. Next to altitude or latitude the varying degrees of humidity are most influential in determining the characteristics of these plant associations. In a general way the heaviest timber, as well as dense undergrowth, is found in the areas of heaviest annual rainfall and the lightest vegetation in the areas of lightest rainfall. The annual precipitation ranges from a maximum of about 100 inches in places on the coast and in the mountains to less than 10 inches in the valleys of the southeastern part of the State. The gradual change from dense humid forest and undergrowth through open forest, scattered woodlands, sagebrush, and shrubby cover to the low and scattered bunch vegetation of the desert valleys is shown in crossing the State from west to east. Most pronounced is the change following a line drawn from the northwest to the southeast corner. Coastal salt marshes, inland tule swamps, and open grasslands all have a bearing on the distribution of certain species of animal life.

\section{LIFE ZONES OF OREGON}

Owing to its broad extent, wide range of altitude, and varied physiographic features, Oregon shows great diversity of climate and contains 5 of the 7 primary life zones of the continent. (See frontispiece.) Only the hot Lower Austral and Tropical Zones are unrepresented. The Upper Sonoran, the arid western subdivision of Upper Austral Zone, characterized by greasewood, saltbush, and rabbitbrush, covers the low warm valleys of the State east of the Cascades, and enters the Rogue and Umpqua Valleys west of the mountains. The Transition Zone, characterized by the yellow pine, Oregon maple, and mountain-mahogany, occupies the higher valleys and bench lands east of the mountains and has a more humid subdivision in the valley foothills and Coast Ranges west of the Cascades. The Canadian Zone, the zone of spruce, fir, and lodgepole pine, covers the broad high part of the mountains. The Hudsonian Zone, the zone of the whitebarked pine, and dwarfed spruces and hemlocks near timber line, caps or surrounds the highest peaks in a narrow belt, rarely 
over 1,000 feet in vertical extent. The Arctic-Alpine Zone, of very limited extent, caps most of the highest peaks well above all timber growth and includes the dwarf alpine vegetation and a very few species of birds and mammals.

Tables 1 to 8 (pp. 31 to 53 ) show the life-zone distribution of the mammals, reptiles, birds, and plants of the State.

\section{UPPER SONORAN ZONE}

The western arid division of the transcontinental Upper Austral Zone covers most of the Columbia and Snake River Valleys of eastern Oregon, and about half of the higher sagebrush plains area of the State east of the Cascade Range. This part of the zone, with a very limited rainfall and fairly uniform climate, can be treated as a part of the arid Upper Sonoran, with many of the characteristics of the Great Basin area, although the Columbia River Valley with slightly more rainfall shows some peculiarities of note and a part of it could be treated as belonging to the semiarid subdivision of the zone.

West of the Cascades limited areas of the zone are found in the upper Rogue and central Umpqua Valleys. There is a narrow strip along the Klamath River on the southern border of the State, and east of the range a limited area occurs near the Klamath Lakes. These semiarid valleys are marked by plants, birds, and mammals that range mainly in northern California and clearly belong to the California Valley subdivision of the zone.

\section{SEMIARID DIVISION OF UPPER SONORAN ZONE}

In the California Valley division of Upper Sonoran Zone in the Umpqua, Rogue, and Klamath River Valleys the base level is low, about 500,1,200, and 2,000 feet, respectively. Only a narrow upper edge of the zone shows in these valleys; in the Umpqua Valley over the flats and warm slopes in the Roseburg section, east of the Coast Ranges, from 500 up to 1,000 feet; in the Grants Pass and Ashland part of the Rogue River Valley on the open bottoms and warm slopes from about 1,200 to 2,000 feet; and in the Klamath River Valley from about 2,000 to 3,000 feet on the warm exposures. This is below the Klamath Canyon which cuts off the zone from its higher and more arid division around the Klamath Lakes. In all of these valleys the Upper Sonoran elements are largely mixed and blended with Transition species from higher levels, as inevitably occurs in so narrow a zone border, but still with sufficient character to indicate important climatic conditions favorable to southern species as well as some of the less hardy crops.

In these valleys are found the California jack rabbit, Rogue River kangaroo rat, brown-footed wood rat, California meadow mouse, white-toothed pocket gopher, gray fox, ringtail, Pacific pale bat, and such birds as the valley quail, long-tailed jay, brown towhee, house finch, bush tit, and long-tailed chat.

The plants that indicate the zone in these valleys are found mainly on the warm slopes and open flat country, while on cool or shaded 
slopes a far greater number of Transition Zone species generally occur. Those most conspicuously indicating Upper Sonoran are several species of Ceanothus (cuneatus, integerrimus, sanguineus), manzanita (Arctostaphylos viscida), bitterbush (Purshia tridentata), birch-leaved mahogany (Cercocarpus betulaefolius), syringa (Philadelphis gordonianus), cherry (Prunus subcordata), silktassel-bush (Garrya fremonti), skunk bush (Rhus trilobata and diversiloba), serviceberry (Amelanchier florida and pallida), lupines (Lupinus oregonus pusillus and subsericeus), wild licorice (Glycyrrhiza lepidota and glutinosa), Hosackia (Lotus), several species, rabbitbrush (Chrysothamnus nouseosus), and a great number of grasses and herbaceous plants. A few of these species extend northward into the Williamette Valley, indicating an approach in climate to the Upper Sonoran Zone, but not in sufficient numbers of species or abundance of individuals to warrant mapping even the warm slopes of the valley as other than Transition.

In the Columbia River Valley east of the Cascades the climate is slightly warmer and more humid, with greater rainfall in winter, than over the Great Basin area farther south and east. Consequently the fauna and flora are somewhat peculiar, as shown by the following species: Townsend's ground squirrel, northwest pocket mouse, Dalles and Columbia pocket gophers, Scheffer's mole, and little canyon bat. There is generally a greater abundance of grass with a considerable number of other plants not found over the rest of the zone in eastern Oregon. Certain crops are also raised following the winter rainy season, without irrigation but through dryfarming methods and careful tillage.

As a new country becomes settled and the best of the land is brought under cultivation, the native species of plants and animals are eradicated or supplanted by those introduced from other countries, and even the stock range is so overgrazed as to destroy much of the original type of vegetation. It becomes increasingly more difficult to define the life zones. But fortunately over most of Oregon there is still sufficient native life to give a good index to long-established climatic conditions.

The practical value of this knowledge of life zones becomes apparent when a new valley, plain, or slope is brought under cultivation and the question arises as to crops, fruit, or stock best adapted to its climate. In long-cultivated valleys these questions generally have been answered, although often by costly failures. Now experience shows that the successful products of one valley may be safely extended into another having satisfactory indications of the same or closely similar native fauna and flora. In other words the study and careful mapping of life zones gives a practical aid to agricul. ture as well as a guide to management of wildlife resources.

It would not be wise to try to restock the desert ranges of eastern Oregon, once inhabited by the rimrock mountain sheep, with Canadian Zone animals from the high Rocky Mountains, but any of the Upper Sonoran desert forms from Nevada, southern California or Arizona would thrive on these low ranges and canyon walls. Restocking and building up a depleted game supply will requiro careful consideration of life-zone conditions. 


\section{EXTREME ARID DIVISION OF UPPER SONORAN ZONE}

One is impressed by the apparent nonconformity of the elevations of the Great Basin division of Upper Sonoran east of the Cascades over different parts of the State. These variations, however, involve well-known and long-recognized principles of climatic control of distribution. The actual altitudinal limits of zone levels are known to vary considerably with direction and steepness of slope exposure, elevation of base level, aridity, type of prevailing winds, and other less-apparent factors of modification, but the long-established fauna and flora serve as the most reliable index to zone level of any point as determined by average climatic conditions. For instance in the Columbia River Valley with a base level of 100 to 300 feet, the Sonoran Zone extends from the bottom of the valley up to about 2,000 feet on cold northerly slopes, lower on steep, and higher on gradual slopes, and to about 3,000 feet on warm southerly slopes. With a higher base level of about 1,000 feet at the junction of the Grand Ronde River with the Snake River near the northeast corner of the State, the Sonoran Zone extends up to about 3,500 feet on warm slopes in the Grande Ronde and Imnaha Canyons. Still farther up in the Snake River Valley with a base level of 2,150 feet at Ontario, the upper limits of the zone run correspondingly higher, while in the extensive lake-basin valleys of the Malheur, Warner, Abert, and Summer Lakes sections, with base levels of 4,100 to 4,500 feet, the upper limits of the zone reach to approximately 4,500 feet on northerly and 5,000 feet on southerly slopes. The actually coldest points of slope exposure are northeast and the warmest southwest, as pointed out long ago by Merriam (1890, pls. I-II, following index).

Thus the elevation of base level in eastern Oregon is shown to raise the upper limits of the zone in higher valleys fully 2,000 feet by simply holding up the absorbed and radiated heat of the sun's rays to a fairly uniform distance above the surface where they fall upon the earth. Other zone levels are modified in the same manner and by many other generally recognized factors of climate and distribution, but the Upper Sonoran of eastern Oregon most admirably illustrates the general principles of zone modification by change of base level.

A somewhat detailed knowledge of the plant and animal life of a region is necessary for the recognition and full understanding of the life zones in the field. The colored map is at best but a feeble guide to the actual areas which are far more detailed and graphic when spread before one in the garb of their native plant and animal life.

\section{MAMMALS}

In eastern Oregon the Upper Sonoran Zone is clearly indicated by the presence of black-tailed jack rabbits, little speckled and gray ground squirrels (Citellus townsendii, vigitis, and canus), the antelope squirrel, desert wood rat, Oregon grasshopper mouse, silky cliff mouse, large-eared harvest mouse, several species of pocket mice (Perognathus parvus, Zordi, columbianus, and mollipilosus), five-toed kangaroo rats, several species of pocket gophers (Thomomys town- 
sendii, nevadensis, columbianus, and quadratus), the desert fox, a little spotted skunk, and several species of bats. It has long been the winter range of the antelope, mountain sheep, and mule deer.

\section{BREEDING BIRDS}

The Upper Sonoran Zone is characterized by such breeding birds as the cinnamon teal, white-faced glossy ibis, black-necked stilt, mourning dove, burrowing owl, Arkansas kingbird, ash-throated flycatcher, Say's phoebe, Bullock's oriole, western lark sparrow, sage sparrow, Brewer's sparrow, long-tailed chat, catbird, rock wren, canyon wren, and long-tailed chickadee.

\section{REPTILES}

This zone is further characterized by such reptiles as the Oregon rattlesnake (Crotalus confluentus oreganus and lutosus) Heermann's and desert gopher snakes (Pituophis catenifer heermanni and deserticola), western striped racer (Coluber taeniatus), western collared lizard (Crotaphytus collaris baileyi), leopard lizard ( $C$. wistizenii), western brown-shouldered uta (Uta stansburiana), sagebrush swift (Sceloporus graciosus), two horned toads (Phrynosoma douglassii and platyrhinos), and the desert whip-tailed lizard (Cnemidophorus tessellatus).

The greater number of species as well as individuals of reptiles of the State are found in Upper Sonoran Zone, a smaller number in Transition Zone, and practically none in higher zones.

\section{PLANTS}

The plant life characterizing the Upper Sonoran Zone east of the Cascades is largely of desert types, among which desert shrubs are most conspicuous. Along the river valleys the hackberry (Celtis douglasii), a few willows (Salio amygdaloides and argophylla), and wild currants (Ribes aureum) are common, and over the dry slopes are found a few junipers (Juniperus occidentalis), which, with the bitterbush (Purshia tridentata) and sagebrush (Artemisia tridenta$t a)$, reach into the Transition Zone above. Other conspicuous plant indicators of the zone are greasewood (Sarcobatus vermiculatus), saltbushes (Atriplex canescens, nuttallii and confertifolia), woolly sage (Eurotia lanata), Dondia depressa, Grayia spinosa, Tetradymia canescens and spinosa, Artemisia pedata, douglasii, and dracunculoides, rabbitbrush (Chrysothamnus nauseosus and viscidiflorus), wild sunflower (Helianthus annuus), serviceberry (Amelanchier utahensis), sumac (Rhus glabra occidentalis), Mentzelia albicaulis and laevicaulis, wild tobacco (Nicotiana attenuata), little bluebonnets (Lupinus brevicaulis, laxiflorus, medium, mollis, ornatus, saxosus, and others), prairie clover (Psoralea lanceolata scabra), licorice root (Glycyrrhiza lepidota), plantain (Plantago purshii), yellow caper (Cleome lutea), sand dock (Rumex venosus), sandverbena (Abronia mellifera), wild sage (Ramona incana), low evening primrose (Pachylophus canescens), alfileria (Erodium cicutarium), ricegrass (Oryzopsis hymenoides). (See also p. 40.) 
Many of these plants are dominant species over special areas and not only give color and character to the desert but have important value as forage, cover, windbreak, shade, conservers of soil and moisture, or shelter for birds and mammals.

So much is said of the sagebrush and the "sagebrush country" that a word of explanation seems necessary. The name is well fixed by long usage and well defined, but the plants have no relation to the real sages (Salvia) and other pungent mints. The sagebrushes are all shrubby wormwoods of the order Compositae, silveryleaved desert shrubs, strongly and pleasantly aromatic, intensely bitter to the taste, and many of them beautiful and graceful little shrubs or diminutive desert trees.

A pure stand of the commonest of the sagebrushes (Artemisia tridentata) growing over a rich-soiled but arid valley, makes a beautiful display of silvery gray-green and feathery foliage, and a single bush by itself, 2 to 6 feet high, is a perfect diminutive tree that might grace the rarest garden (pl. 7). There are half a dozen distinct species-Artemisia tridentata, angrustifolia, trifida, arbuscula, cana, borealis, pedatifida, spinescens, and some others-all true sagebrushes. They are not good forage plants or they would have disappeared years ago, but in the absence of all other food sheep will live on them for a short time and often browse them severely. Sage hens will eat the leaves when other food is scarce, and even antelope and jack rabbits will nibble them at times. These bushes shade the ground and hold the snow, build up humus, bind the soil, conceal the sage grouse and young antelope, and provide choice fuel for the camp fire. Their pleasant odor is one of the charms of the desert, and the smell of a dried spray brings back the memory of broad valleys and clean wholesome air. The sagebrush has no direct commercial value, but without it or an equivalent, the desert would be poor indeed.

The rabbitbrush, or golden sage, of the genera Chrysothamnus and Tetradymia, are often the dominant shrubby growth over part of the valley country of eastern Oregon, giving a golden glow to the vegetation during the season of flowering or at other times a fine feathery gray from the slender leaves and stems. In either leaf or flower they are graceful and attractive plants and besides the important function of giving cover and protection to the soil they serve as shelter and to some extent as food for the animal life. They belong to the same family as the sagebrush and goldenrods. Each has its own peculiar taste and odor, some rank and repellent, others aromatic and pleasing. The odors of the desert vegetation are as striking as its color and form and to an old inhabitant are among the great attractions of desert life.

Of the true greasewood only one species, Sarcobatus vermiculatus, comes into Oregon. It is abundant in alkaline valley bottoms and often the dominant shrub, giving its shiny bright-green color to miles of alkali-incrusted playa border or the saline shores of basin lakes. It grows where water is abundant not far below the surface and where most other plants cannot endure the mineral carried in the water. The abundant fleshy and juicy leaves, borne on the spinescent twigs, are soft and rounded, like so many smooth green caterpillars, hence the name vermiculatus. They are also very salty 

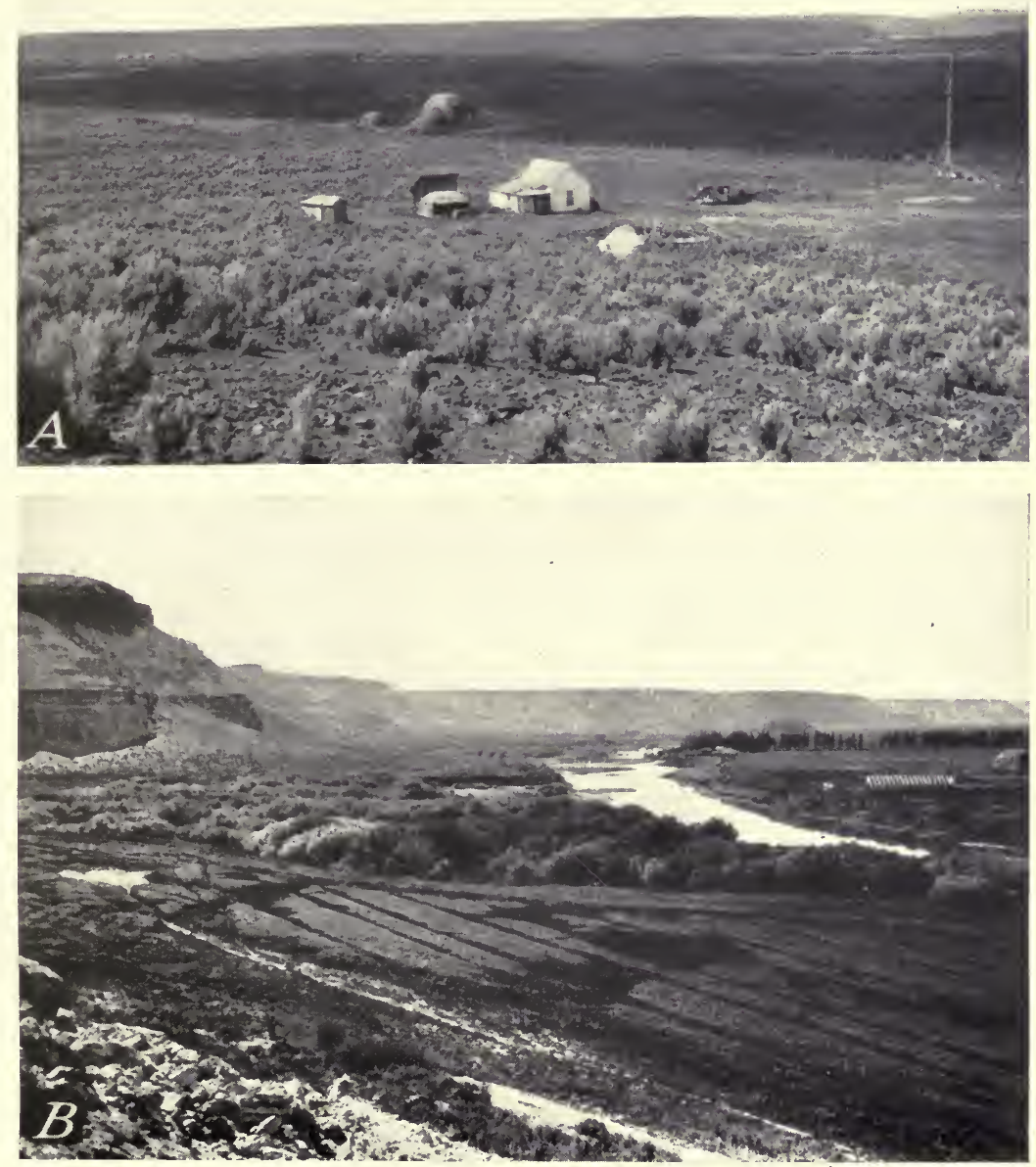

B16314; B

$A$, Hay ranch at Cow Creek Lakes, in typical sagebrush and stock country, in the arid southeastern part of the State (photograph by Edward A. Preble, July 8, 1915); B, irrigated ranches in Owyhee Valley, near Rome, Oreg., where alfalfa is the chief crop on the ranges for grazing cattle and sheep (photograph by Laura A. Mills, July 3, 1927). 

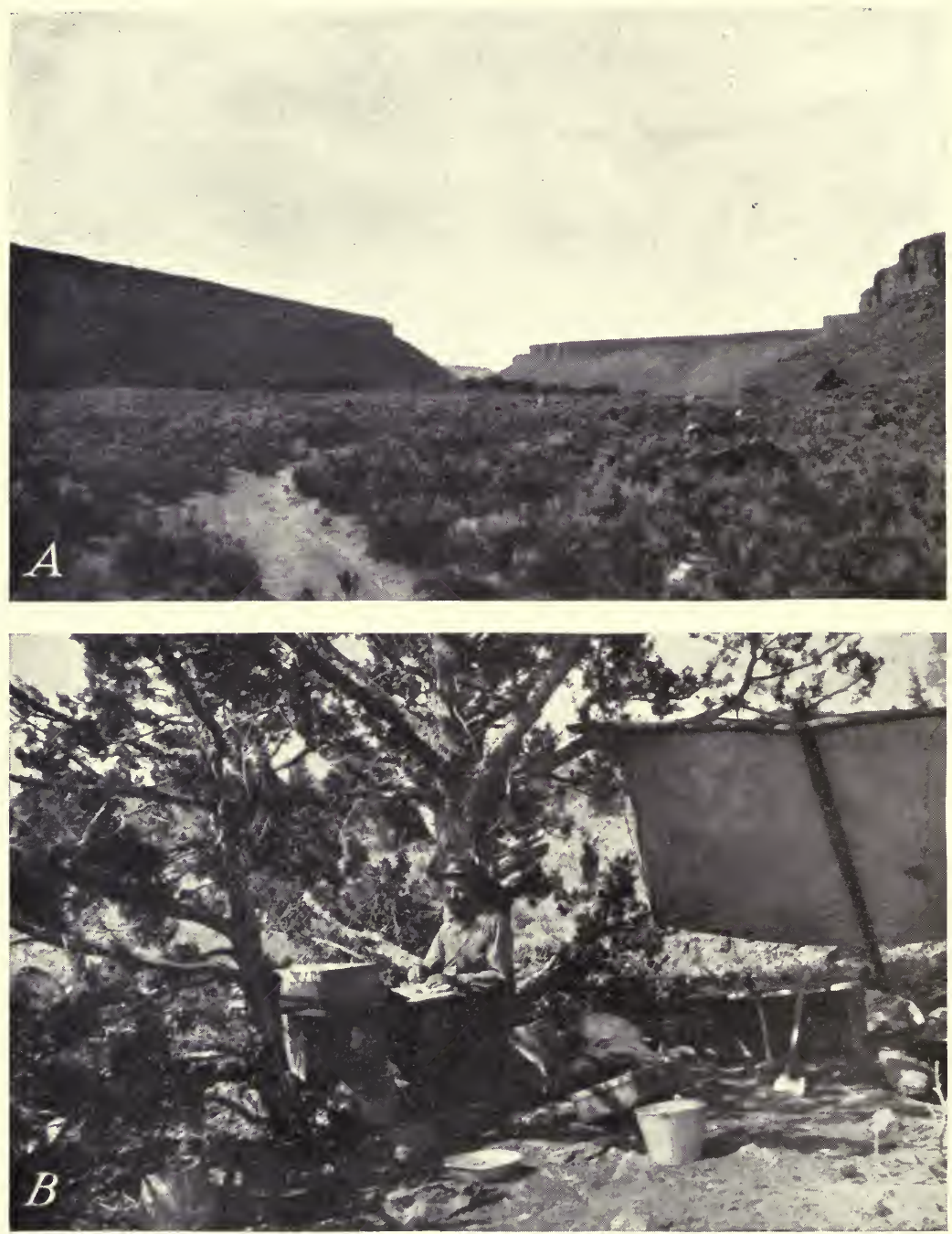

B16300; B16330A

$A$, Typical rimrock valley, White Horse Creek, southeastern Oregon (photograph by Edward A. Preble, June 17, 1915); B, camp of Biological Survey collector (Mr. Preble), in southeastern Oregon, under the junipers, where even a little shade is grateful. 
in flavor but not unpleasant in taste and are generally eaten to some extent by sheep and other stock. The bushes are so very spiny, however, that only the tender tips are browsed off. Many other plants are wrongly called greasewood where the true Sarcobatus does not occur, but the name should not be used for any other bush. Dondia, or Suaeda, and Salicornia (samphire) are closely related to the greasewood and have somewhat the same habits. They are even more addicted to salt and alkaline ground and even more strongly impregnated with salt and soda.

The saltbushes, several species of shrubby Atriplex including canescens, confertifolia, patula, nuttallii, and a number of herbaceous species, are generally common over the desert Sonoran valleys and in places give a dominant character to the low vegetation. They generally indicate the presence of a little salt or alkali in the soil, and the leaves have a not unpleasant saline taste. Generally they are good forage plants and hence are often entirely eradicated over valleys that are overgrazed. A confertifolia with its abundant spinescent twigs is the least likely to be destroyed by overgrazing.

Woolly sage, the beautiful silvery white little shrub, Eurotia Tanata, called by the sheep herders "winterfat", is one of the most valuable forage plants of the desert. Being so desirable as winter forage and so unprotected it is practically exterminated over most of its range, except at such long distances from water that stock cannot get to it.

A few scrubby junipers are found in the canyons and on steep slopes but rarely in extensive stands where accessible for ranch use. Their shade is often grateful and their fragrant wood is prized as camp fuel in the foothills and rim-rock canyons (pl. 8).

Weeds, those hobos of the plant world and the pest of the farmer, have few friends or defenders. Out in the deserts of eastern Oregon, however, they seem to have found a use. Where sheep have eaten everything but the lava rocks and killed out all the native plants, even the sagebrush and cactus, the little exotic mustards, chickweeds, pennycress, tarweeds, prickly lettuce, foxtail, and bromegrass have volunteered to clothe the nakedness of the soil and in many places have bravely succeeded. Over great areas the little seeds of these weeds are the only available food for pocket mice, kangaroo rats, and other small rodents. These plants, too, are the principal food for thousands of sheep.

In 1927, in Klamath Valley the county agent reported a flock of 100,000 sheep, pastured all summer entirely on foxtail and China lettuce, that yielded thousands of fat lambs for market. The cash value of weeds to eastern Oregon would amount to a high figure if it could be estimated, although insignificant compared with the value of native vegetation destroyed by overgrazing.

\section{CROPS FOR UPPER SONORAN ZONE IN EASTERN OREGON}

While arid and much of it unsuited to agriculture because of rough surface or lack of available water, eastern Oregon contains many extensive valleys of rich, mellow soil, with ample water supply for local irrigation. The Columbia River Valley, including the Des$7209^{\circ}-36-2$ 
chutes and John Day Valleys, with an enormous extent of rich land, is being rapidly brought under irrigation. The Snake River Valley, including in Oregon the Malheur and Owyhee River drainage valleys, still largely undeveloped, has a great agricultural future. The northern part of Malheur Lake Valley, including the inland drainage of the Silvies River and Silver Creek, with rich soil and good water has grown into a prosperous agricultural section. In many other valleys small streams and large springs provide water for ranch purposes and livestock centers, while others are used largely by game. These conditions obtain in the valleys of Warner, Goose, Abert, and Summer Lakes, with their limited water supply, and in many smaller isolated valleys over eastern Oregon.

The Klamath Valley section with ample water for its rich-soiled valleys is just awakening from the lethargy of the old days of scattered grazing to its possibilities in terms of industries and intensive agriculture.

Practically all of these valley and basin areas of eastern Oregon lie within the limits of Upper Sonoran Zone, with mild climate and open winters. There is, however, one great disadvantage that cannot be ignored without serious danger of losses and failure. The excessively dry climate of this part of the State during the summer causes occasional frosts at intervals during the growing season, and the irregular frosty nights often destroy flowers, young fruit, or the leaves of tender crops that would otherwise prove profitable. The climate is mild, the growing season is long, and the summer days are hot, but superdried air loses its heat so quickly that a sharp frost at night may follow a hot day in summer. As is well known, it is the moisture in the air that retains and equalizes the heat from the sun's rays, for excessively dry air has little power of retaining heat.

This frost danger has greatly restricted the agricultural value of much of the arid interior of the country, especially that lying at elevations above 4,000 feet, and while many hardy and frost-resistant crops and vegetables can be raised with partial success, the section is generally devoted to stock raising, or has been until much of it, overstocked and overgrazed, no longer produces a food supply to make this industry profitable.

Originally this arid interior when fully stocked with native game and teeming with wildlife was the hunting ground of numerous bands of Indians, who made little impression upon the game until horses and firearms were introduced among them.

Now the game is scarce and scattered and some of the original species are gone past recall, but great areas in eastern Oregon are still better adapted to game production than any other industry and could with practical advantage be utilized for such purposes.

Owing to their low altitude and greater moisture, the immediate valleys of the Columbia and Snake Rivers are comparatively free from the danger of serious frosts. The higher and drier basins, even with the same fauna and flora, must be carefully watched and studied.

In the Rogue and Umpqua River Valleys west of the Cascades, where the proximity to the Pacific Ocean affords a greater moisture content to the summer atmosphere, the danger from frost is not noticeable. Here fruits and tender crops of the Sonoran Zone are produced in their perfection. 
These critical frost conditions apply not only to eastern Oregon but to a more extensive area of the Great Basin, involving parts of eastern California, Nevada, Utah, and southern Idaho. They must be understood if the area is to be developed to its best possibilities.

Detailed information on climate and crop conditions, on recommended farm practices, and on suitable crops for the various sections of Oregon can be obtained in publications of the United States Department of Agriculture and of the Oregon Agricultural College.

\section{TRANSITION ZONE}

The Transition Zone, as the name implies, lies between the Austral, or Sonoran Zone to the south or at lower altitudes, and the Canadian Zone to the north or at higher elevations. It derives a part of its fauna and flora by the overlapping of species of the lower and higher zones. In Oregon and the Pacific Northwest generally, it is unusually broad and well defined with many restricted species of its own.

In Oregon the zone may be divided into four well-marked subdivisions based on different degrees of humidity, varying from an annual precipitation of approximately 100 inches down to 10 or 15 inches. The humid division lying west of the Cascades is characterized generally by heavy forests of pine, hemlock, Douglas fir, western hemlock, and many broad-leaved trees (pl. 9). Along its western edge lies the narrow coast strip, rarely more than a few miles in width, extending from southwestern British Columbia to northwestern California and well marked by the Sitka spruce and accompanying species of plants and animals. Along the eastern side of the Cascades and over the Blue Mountain plateau with a much reduced rainfall, the semiarid or semihumid division of the zone is characterized by open forests of yellow pine (pl. 10, A). On the high plains and plateaus of the southeastern part of the State the more arid division of the zone is devoid of real timber and characterized by mountain-mahogany (pl. 10, B), sagebrush, and the broad-leaved balsamroot. Although blending into each other, these subdivisions of the zone must be treated separately to be understood and recognized.

\section{COAST STRIP OF TRANSITION ZONE}

The coastal strip, or fog belt, as it is sometimes called, gets the first sweep of the damp, cool, but never very cold ocean winds. It has a remarkably even climate throughout the year, with an annual rainfall of 80 to 100 inches. While almost free from frost in winter, it is cold and damp in summer, thus allowing an unusually even temperature with an almost complete overlapping of Transition and Canadian Zone species. It has been mapped first as, one zone and then the other, but the best authorities acknowledge it to be a mixture or overlapping of the two.

To the southward the rainfall decreases slightly, and south of the mouth of the Coquille River the shores are steeper, more abrupt, and consequently drier and slightly warmer. Hence a considerable number of California plants extend up the coast as far as the Coquille and not beyond. On plants alone Peck (1925a, p. 35) divides the strip at this point but the subdivision is not strongly marked in other forms of life. 


\section{MAMMALS}

Aside from seals, sea lions, and sea otters, the mammals that can be considered closely associated with the coast strip are few and only very local subspecies, such as two forms of pocket gophers (Thomomys hesperus and helleri), a meadow mouse (Microtus californicus angusticeps), and possibly a shrew (Sorex pacificus yaquinae). In general, it is occupied by the humid Transition Zone species of land mammals.

\section{BIRDS}

Of birds, the Pacific wren tit and a song sparrow may be characteristic; and the tufted puffin, pigeon guillemot, California murre, several cormorants, and the black oyster catcher are shore or island breeders along the coast. However, the strip is too narrow to restrict many of the free-ranging species such as birds and mammals. A close study might show a considerable number of reptiles, insects, and mollusks.

\section{PLANTS}

For most of the coast strip, the Sitka spruce, the most contorted form of Pinus contorta, and the Port Orford cedar are the dominant forest trees, but many others not restricted to it enter from the adjoining humid Transition or from the higher Canadian Zone.

Western hemlock, lowland white fir, Douglas fir, western yew, and Sitka willow are abundant in the fog belt. They also have a wider range well up into the Cascades. The salmonberry, salal, evergreen blueberry (Vaccinium ovatum), California rhododendron, sweetgale, and Baccharis pillularis are all common in this narrow belt, showing a mixture of southern and northern species. Of mosses, lichens, and other low forms of plant life, a long list of restricted varieties may be expected.

The low beach plants such as Lupinus littoralis, Polygonum paronychia, Abronia latifolia, Fragaria chiloensis, Convolvulus soldanella, and many others indicate an association of light- and sandloving species, somewhat apart from the shaded forest belt and possibly of more southern origin.

The sphagnum bog plants, in or just back of the forested coastal strip, are mainly northern species, such as Oxycocous intermedius, Kalmia glauca, Myrica californica, Gentiana sceptrum, Eriophorum chamissonis, Drosera rotundifotia, and many others that have only a secondary relation to the life conditions of the fog belt.

\section{HUMID DIVISION OF TRANSITION ZONE}

The humid division covers a wide extent mainly of forested country from the coast strip east to the middle-west slopes of the Cascades in Oregon. In altitude it reaches from sea level up to 3,000 and 4,000 feet, respectively, on the cold and warm slopes of Mount Hood, and to approximately 5,000 feet all around Mount McLoughlin (Pitt). The upper edge of the zone varies between these extremes of altitude along both sides of the mountains according to high or low base level of the adjoining valleys.

The degree of humidity to which this subdivision of the zone owes most of its characteristics varies from an average annual pre- 


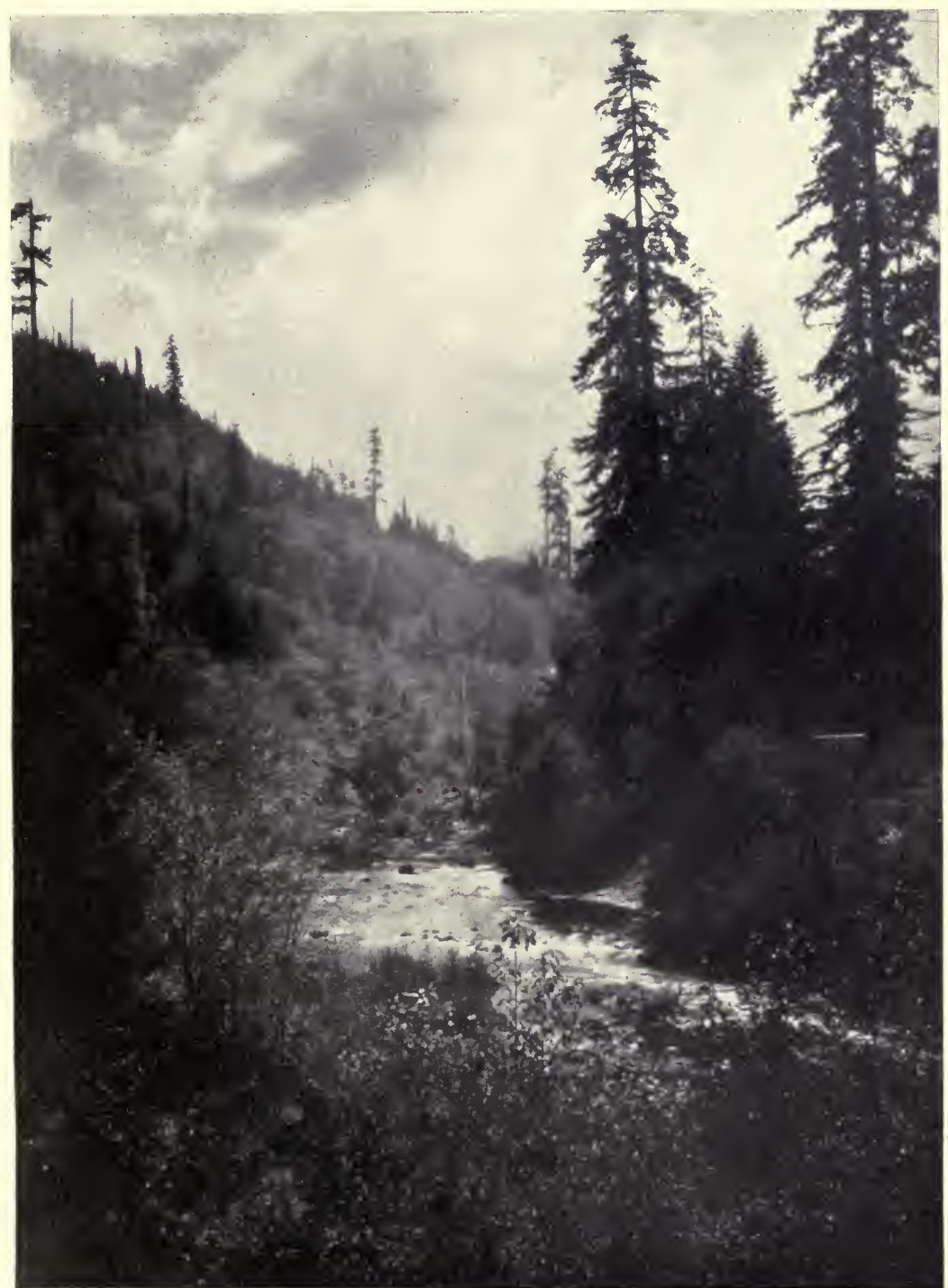

HUMID TRANSITION ZONE TIMBER

B4599M1

Coast mountain section, Tillamook County (photograph by Alex Walker). 

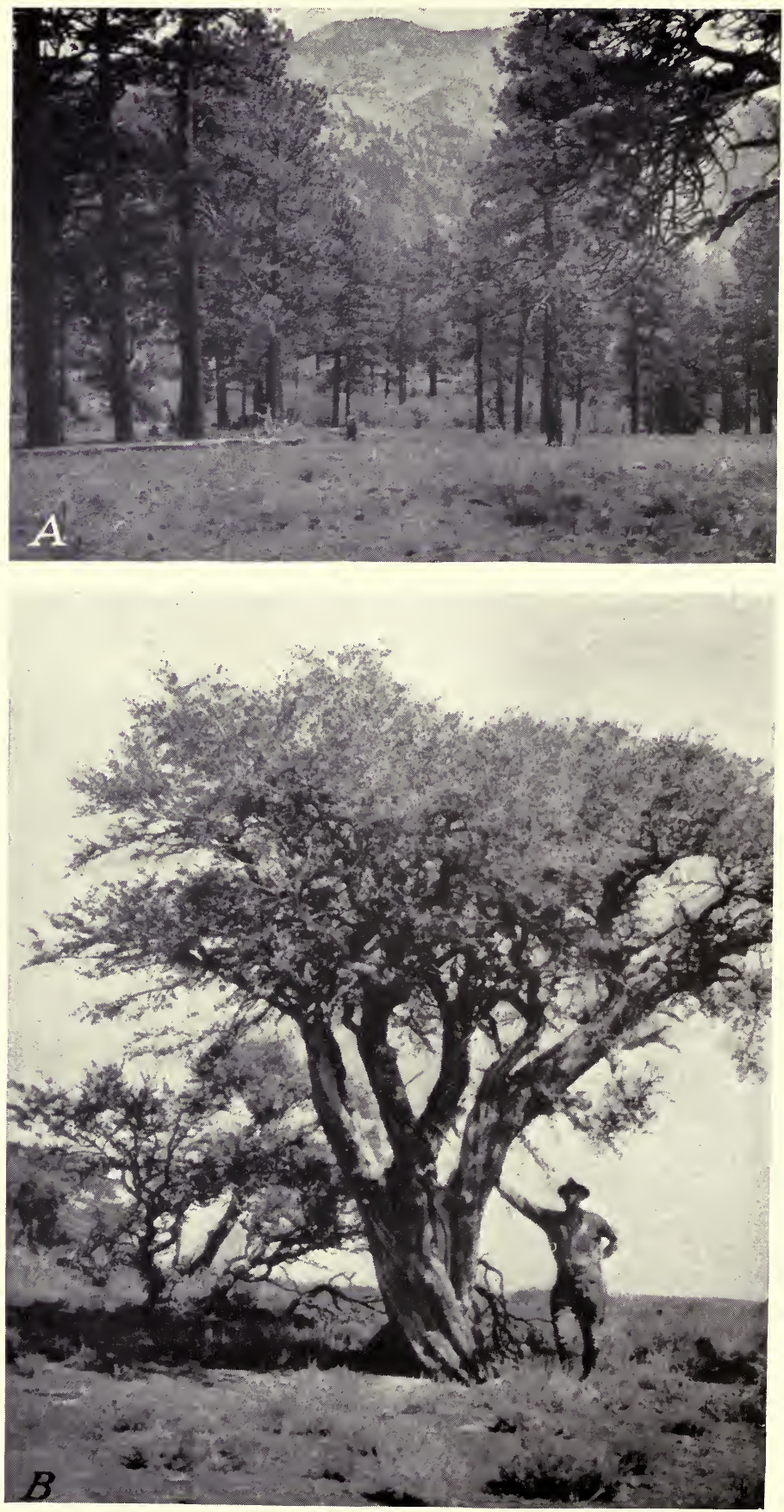

B15959: B

$A$, Yellow pine timber of the Transition Zone, Blue Mountains, near Canyon City (June 26, 1915); $B$, mountain-mahogany, Transition Zone, Lake County (photograph by Stanley G. Jewett). 

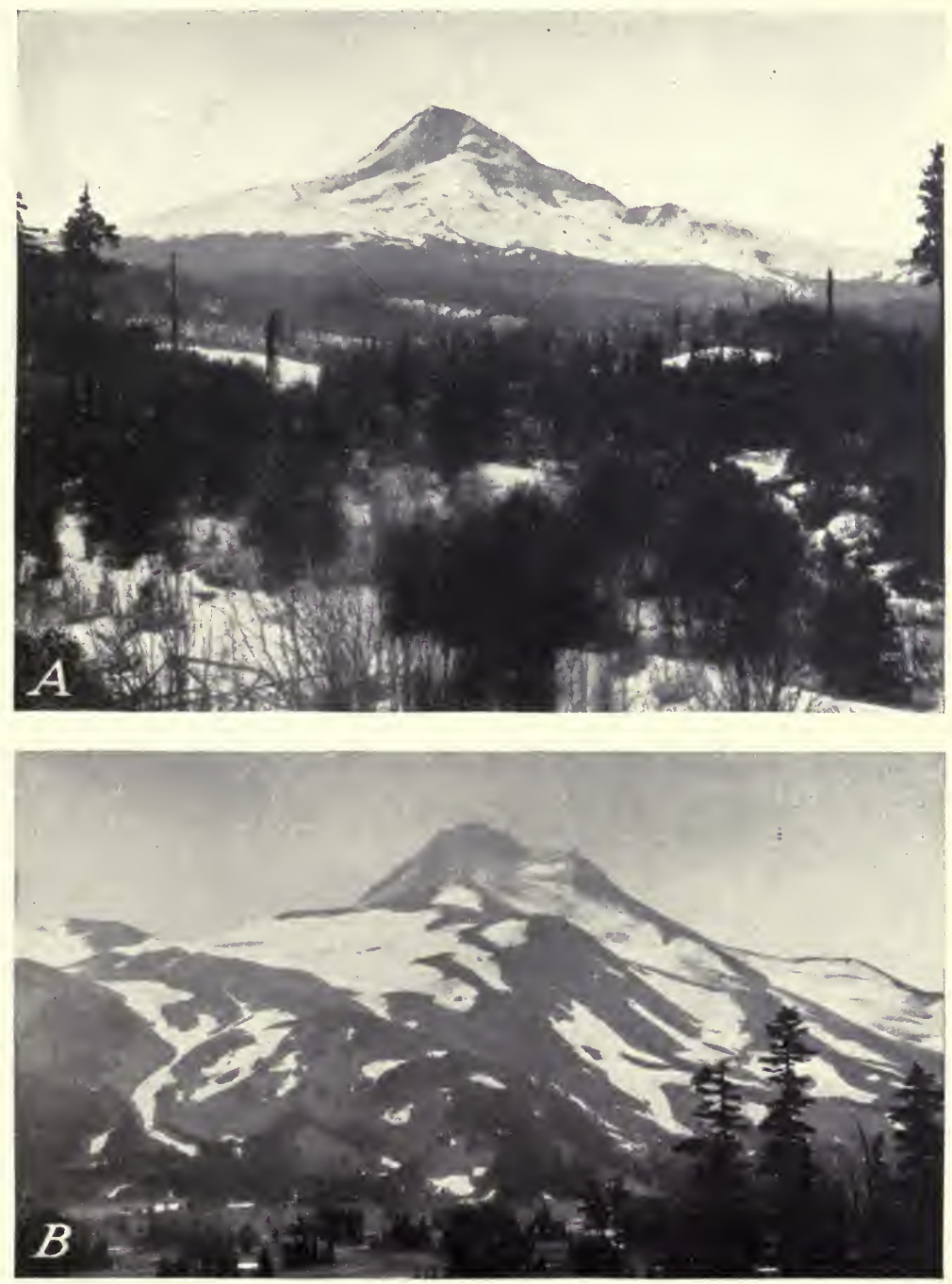

WHERE TIMBER LINE REACHES ITS LOWEST LIMITS.

B20374; В33204

$A$, Mount Hood, 11,255 feet; $B$, Mount Jefferson, 10,523 feet; both views on cold slopes, from the northeast. 


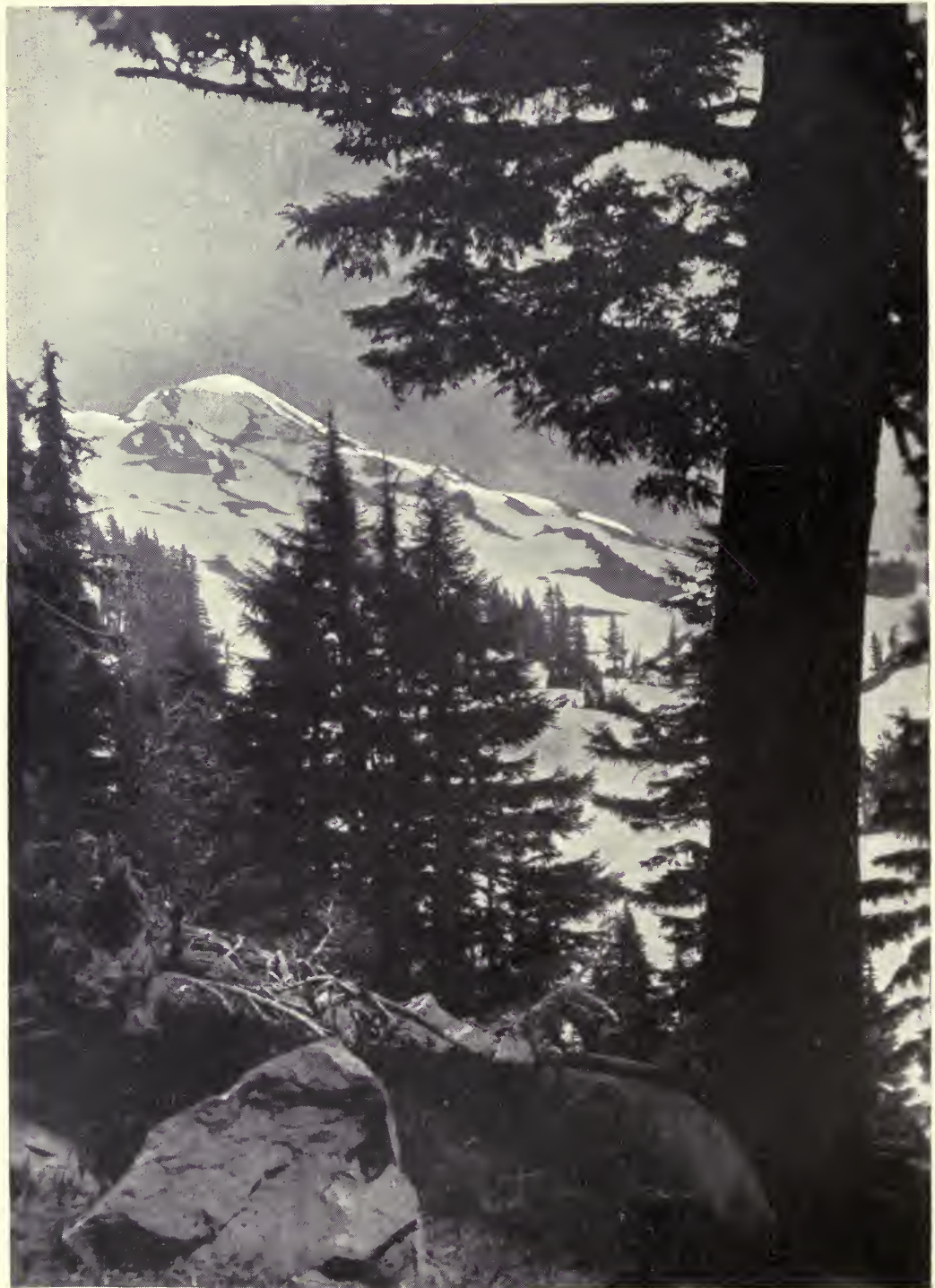

Middle SISTER, OF THE THREE SISTERS PEAKS (10,029 FEeT). Photographed from the northwest June 26, 1923, by Alex Walker. 


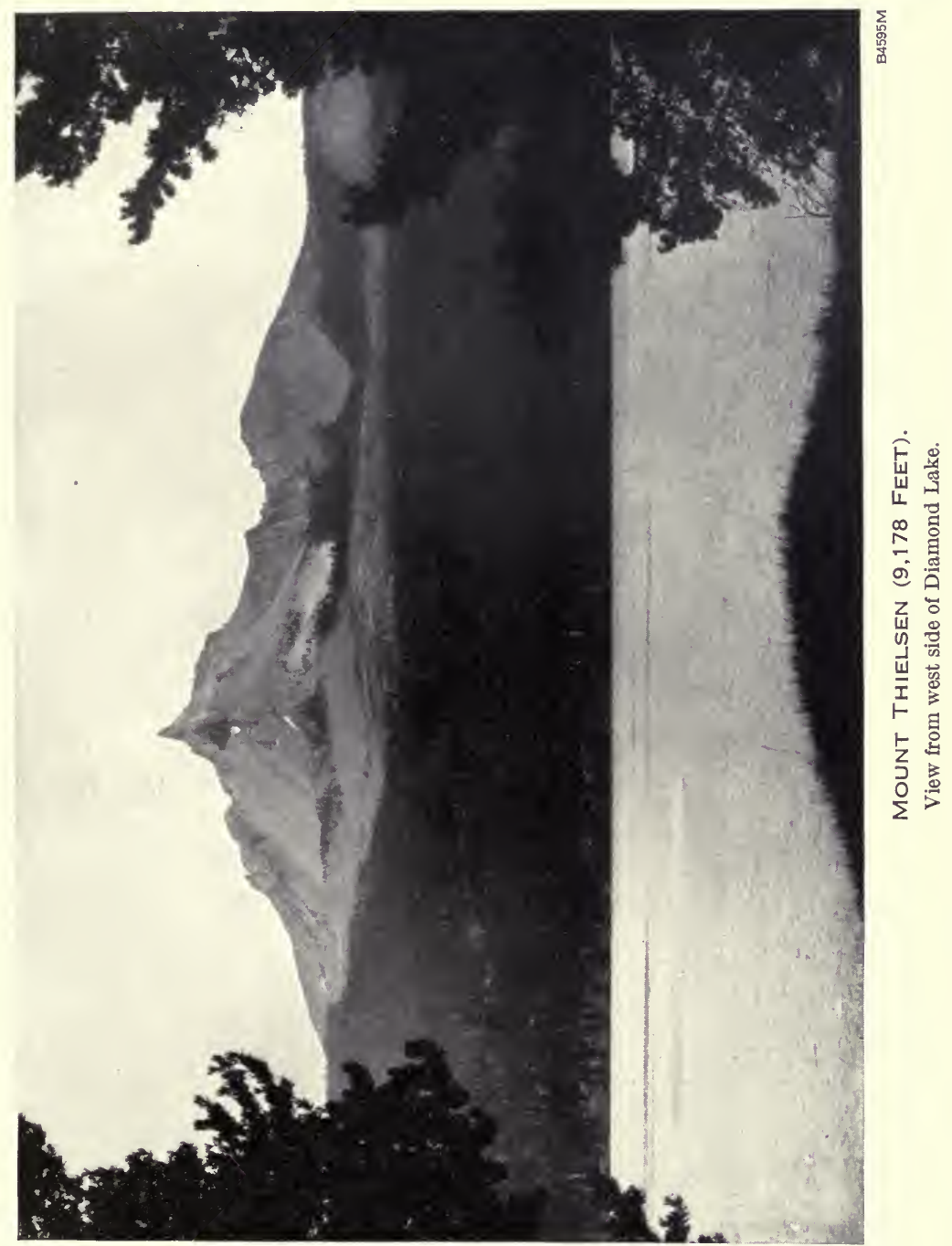




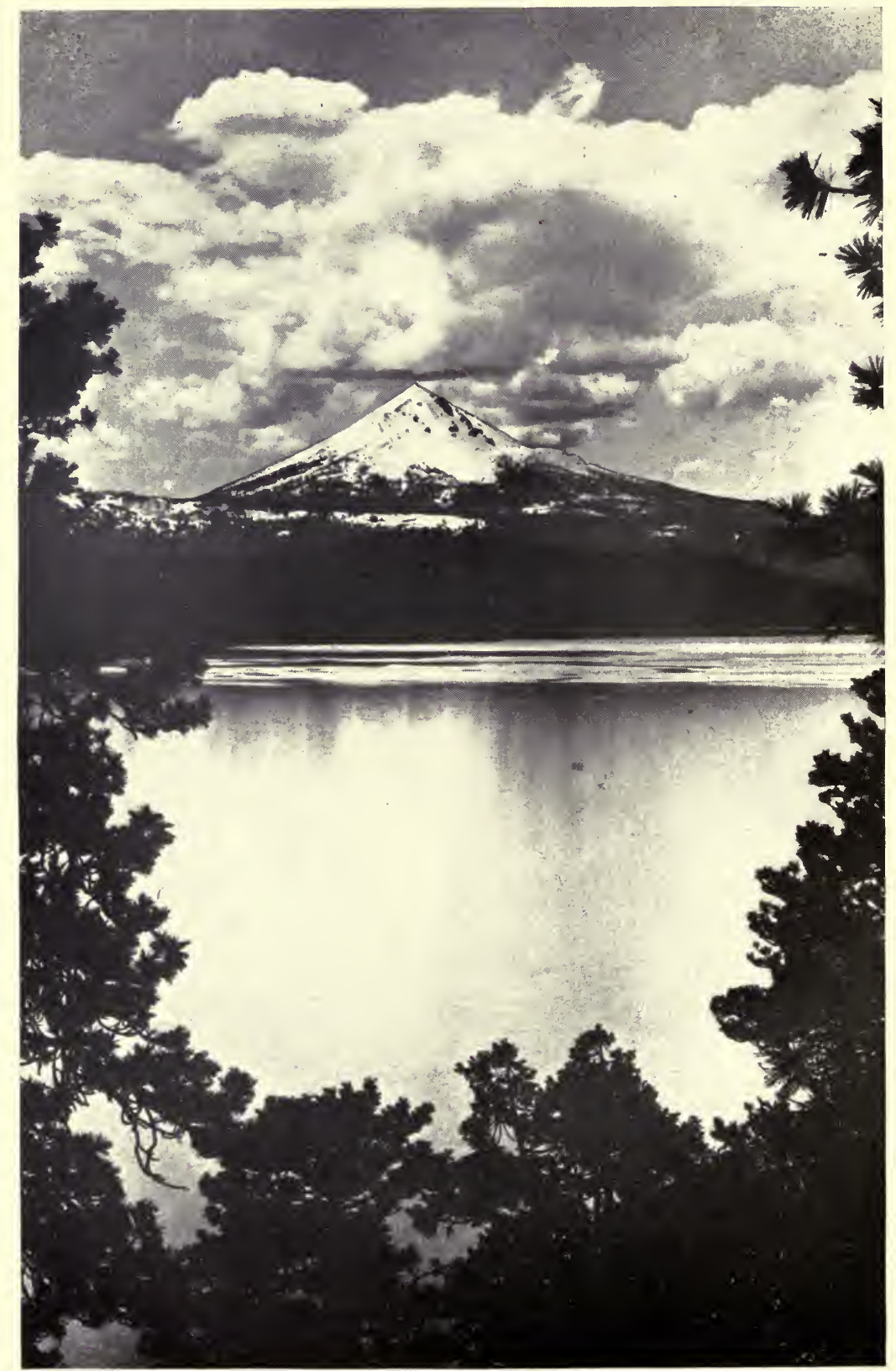

MOUNT MCLOUghlin, FORMERLy MOUNT PITT $(9,493$ FEeT).

View from the southeast across lower end of Klamath Lake, showing approximate levels of the life zones. 
cipitation of 40 inches in the Willamette Valley to 80 inches near the coast and along the upper slopes of the Cascade Range. The greater part of this heavy precipitation occurs during the winter months, when the mountains are being heavily laden with the deep snows that lie late into the spring and in higher zones remain throughout the summer. This abundant supply of water is shown in the magnificent forest growth along the sides of the mountains and toward the coast where the moisture is in still greater abundance. The warmer and drier Willamette and other valleys are conspicuously less-heavily forested and better adapted to general agriculture.

\section{MAMMALS}

Some of the characteristic mammals of the humid Transition Zone of Oregon are Roosevelt's elk, Columbian black-tailed deer, Oregon white-tailed deer, Washington rabbit, Oregon brush rabbit, silver gray squirrel, Douglas's squirrel, Townsend's chipmunk, Douglas's ground squirrel, Oregon flying squirrel, dusky wood rat, ruddy deer mouse, California red-backed mouse, tree mice (Phenacomys longicaudus and silvicola), white-footed phenacomys, Townsend's and gray-tailed meadow mice, Oregon creeping mouse, mountain beavers (Aplodontia rufa and pacifica), jumping mouse Zapus princeps trinotatus), pocket gophers (Thomomys bulbivorus, oregonus, and niger), and northwest coast bobcat (Lynx fasciatus).

\section{BIRDS}

Some of the breeding birds of humid Transition Zone are: Sooty grouse, Oregon ruffed grouse, band-tailed pigeon, California pygmy owl, Harris's woodpecker, northern pileated woodpecker, Lewis's woodpecker, Vaux's swift, Steller's jay, Townsend's warbler, western winter wren, California creeper, Oregon chickadee, chestnutbacked chickadee, wren tit, western golden-crowned kinglet, and black-headed grosbeak.

\section{PLANTS}

The abundant vegetation of this division of the zone is to a great extent peculiar to the Pacific slope and of species that range from western British Columbia to northwestern California. The principal forest trees are sugar pine, Willamette pine, Jeffrey pinē, narrow-cone pine, Douglas fir, western hemlock, lowland fir (Abies (grandis), noble fir (Abies nobitis), white fir (Abies concolor, including lowiana), incense cedar, western red cedar, Oregon yew, Oregon maple, vine maple, Oregon alder, mountain alder, black cottonwood (Populus trichocarpa), tanbark oak, Oregon white oak, California oak, western chinquapin, Oregon ash, madrone, California laurel, cascara, western dogwood, Oregon crab apple, and black hawthorn. The more characteristic shrubs are California hazel, wild cherry, manzanita, Ceanothus thyrsiflorus and integerrimus, Garrya ellyptica, mountain-laurel, salal, purple elderberry, devilsclub, red blueberry, evergreen blueberry, salmonberry, and thimbleberry. Some of these humid Transition Zone species run more or less irregularly along the middle-eastern slope of the Cascades where the low summit of the range allows considerable rain to pass over, but their main abundance will be found on the west slope. 


\section{SEMIARID TRANSITION ZONE}

The semiarid (better called semihumid) division of the Transition Zone as marked by the yellow-pine forests covers the broad basal slopes east and south of the Cascades and the extensive plateau levels of the Blue Mountain section. Its breadth and altitude vary with the configuration of the land, base level, and slope exposure.

On the northeast slope of Mount Hood the Transition Zione reaches from about 1,000 to 3,000 feet in altitude, although but a short distance west of The Dalles (near Mosier) it comes down to the banks of the Columbia River at less than 100 feet above sea level where the cool, moisture-laden winds from the west come up through the river gorge. On the southwest slope of Mount Hood the zone extends from the broad bottom of the Willamette Valley up to about 4,000 feet near Government camp but does not cross over the crest of the range so as to encircle the mountain completely (pl. $11, A)$.

On Mount Jefferson it reaches up to approximately 3,500 feet on cold slopes and to 4,500 feet on warm southwest slopes, showing a slight rise in altitude with slightly raised base level on both sides of the range (pl. 11, $B$ ).

In the vicinity of the Three Sisters Peaks, with a base level of about 3,000 feet on the east and 1,000 on the west, the zone reaches up to about 4,500 feet on northeast slopes and about 4,800 on southwest slopes, although the zone does not reach to the actual base of the peaks nor cross over the crest of the range north or south of them (pl. 12).

Mount Thielsen (pl. 13) and Crater Lake are more nearly in the zonal position of the Three Sisters, mainly above the Transition and passing through Canadian and Hudsonian Zones.

In the Klamath section, with Mount McLoughlin (Pitt) as the highest center, and with base levels of 4,200 feet at Klamath Lake, 3,000 feet in the Klamath River Canyon to the south, and 1,400 feet in the Medford section of the Rogue River Valley on the west, the Transition Zone extends up to approximately 5,000 feet all around Mount McLoughlin (pl. 14). On the southwest slope it reaches from about 2,500 feet, east of Medford, to 5,000 feet on the west base of the mountains, while on the Klamath Valley side it runs from the level of Klamath Lake up to about the same altitude, 5,000 feet, on the northeast slope of the peak. In the Klamath country there is no lower limit of the zone shown on any northeast slope as the Sonoran Zone occupies only the valley bottoms and warm slopes. In the Klamath Canyon directly south of McLoughlin, Transition Zone comes down to 3,000 feet on local cold slopes and to about 4,000 feet on local hot slopes, but this deep, narrow canyon shows all the complications of such types of country.

In the broad expanse of comparatively low country stretching north from Fort Klamath and the Klamath Marshes to the Paulina Mountains, where Transition Zone would naturally be expected, the plant and animal life show a predominance of Canadian Zone species, due to local influences, as noted under Canadian Zone (p. 25).

In the Blue Mountain section, Transition Zone on the Columbia River Valley side extends on northeast slopes from about 2,000 to 
4,000 feet; on the Snake River Valley side on northeast slopes from about 2,800 to 4,800 feet; and on southwest slopes from about 3,500 to 5,500 feet. On the south side of the mountains, with a higher base level, the zone extends on southwest slopes near Burns from about 4,500 feet up to 5,500 feet in the mountain north of there, and on especially steep, dry slopes up to 6,000 feet.

Despite the varying levels of this division of the zone, the climatic conditions are fairly uniform with an average annual rainfall of approximately 20 inches, and it is sufficiently cool to allow generally a fair depth of snow on the ground for several of the winter months. Apparently the only climatic distinction from the treeless arid subdivision of the zone is the slightly greater humidity and the resultant difference in plant and animal life.

\section{MAMMALS}

Of mammals some of the most characteristic species of the semihumid Transition Zone are the Rocky Mountain mule deer, Rocky Mountain elk, Klamath chipmunk, yellow-bellied chipmunk, Oregon and golden-mantled ground squirrels, Gambel's white-footed mouse, brown pocket gopher, and others less restricted to the division.

\section{BIRDS}

Of breeding birds the semihumid division of Transition Zone is characterized in part by Richardson's grouse, pygmy owl, MacFarlane's screech owl, Rocky Mountain hairy woodpecker, white-headed woodpecker, western wood pewee, Oregon towhee, mountain tanager, Audubon's warbler, and pygmy nuthatch.

\section{PLANTS}

The semihumid division of Transition Zone is best characterized by the ponderosa pine, generally growing in clean open forests of great beauty and value. These forests reach their greatest perfection in the Upper Deschutes and Klamath country, but are also well developed over much of the Blue Mountain Plateau. Other characteristic trees of the division are the western tamarack (Larix occidentalis), western birch (Betula fontinatis), and many willows along the streams. The shrubby vegetation is represented by the bitterbush (Purshia tridentata), squawcarpet (Ceanothus prostratus), buckbrush (Ceanothus velutinus), snowberry (Symphoricarpos racemosus), bearberry (Arctostaphylos wva-ursi), and barberry (Berberis repens).

\section{ARID TRANSITION ZONE}

The arid subdivision of Transition Zone in eastern Oregon covers the high valleys, plateau tops, and lower mountain slopes of approximately the southeastern quarter of the State. It includes the mountains and plateaus east of Goose and Summer Lakes and south of the Blue and Maury Mountains, among which the Steens and Warner Mountains are the highest. In flora and fauna it is essentially a part of the Great Basin division of the zone, too arid for timber growth, with an average annual rainfall below 15 inches. 
The Steens Mountains, typical of the Great Basin type of arid ranges, are practically devoid of timber and show much distorted zone levels. Owing to the high base level of approximately 4,000 feet on the east side and 4,500 feet on the west side of the range, the zones are pushed to unusual heights. Transition Zone, as nearly as it can be defined, reaches from about 4,200 to 6,000 feet on the northeast slopes and from about 5,000 to 7,000 feet on the southwest slopes. On the very steep eastern slope of the range there is much crowding and overlapping of the zones, and a general narrowing of Transition and Canadian.

\section{MAMMALS, BIRDS, AND PLANTS}

The mammals most characteristic of the arid Transition Zone are, or have been, the desert mountain sheep, Rocky Mountain mule deer, Idaho rabbit, woodchuck (Marmota flaviventris avara), and pygmy mouse (Microtus pauperrimus).

Its characteristic birds are the sage grouse, Brewer's sparrow, green-tailed towhee, and sage thrasher.

It is practically treeless except for the low mountain-mahogany and some of the high-ranging junipers (Juniperus occidentalis and scoputorum), which often ascend through it. Generally, it is characterized by open sagebrush slopes well covered with sagebrush (Artemisia tridentata, arbuscula, and trifida), Balsamorhiza sagittata, Wyethia amplexicaulis, and Paeonia brownii.

Agriculture in this arid division of Transition Zone is practically limited to stock raising, mainly summer grazing of sheep and cattle. Where water is available for irrigation, there are ranch gardens and some hay, but water is scarce, and in the dry climate frosts are frequent during even the summer months. Ranches are few and far. between and generally control extensive areas of grazing land.

\section{CROP ADAPTATIONS IN TRANSITION ZONE}

While little agriculture, except an occasional irrigated garden, is attempted in the arid Transition Zone, the semihumid bench land of this zone in the Blue Mountain section and along the eastern side of the Cascades produces excellent small-grain and potato crops, in most cases without irrigation. Still better crops of grains, potatoes, alfalfa, and some fruits, however, are grown where irrigation is possible.

In the humid Transition Zone west of the Cascades a great variety of crops are raised-small grains, wheat, oats, rye, barley, peas, hops, clover, vetch, timothy hay, potatoes, vegetables, nuts, and fruits in profusion. Most of the valleys are famous for their flowers, roses of wonderful beauty and variety, gladioli, dahlias, and a great variety of hardy flowering plants. Each valley and every section of a valley have slightly different climatic conditions, and with the varying soil and humidity each one shows special adaptations that cannot be covered by any generalized lists of crops. The only safe course for the grower in selecting crops of special advantage in each location is to follow the advice of the local county agents, the State agricultural college, and the experiment stations. 
Game and fur-bearing animals can be considered a legitimate crop, and much of the Transition Zone, both in the timbered and in the treeless arid divisions, is especially adapted to their production. The wildlife of the forests if well handled is often as valuable as any other forest product.

\section{CANADIAN ZONE}

The Canadian Zone in Oregon covers all but the high peaks and ridges of the higher Cascade, Siskiyou, Blue, and Steens Mountains, and caps many of the lower groups, such as the Paulina, Yamsey, Winter, and Warner Ranges. On Mount Hood at the northern end of the Cascades in Oregon, with a 100-foot base level around three sides of the mountain, the zone runs correspondingly low (fig. 1),

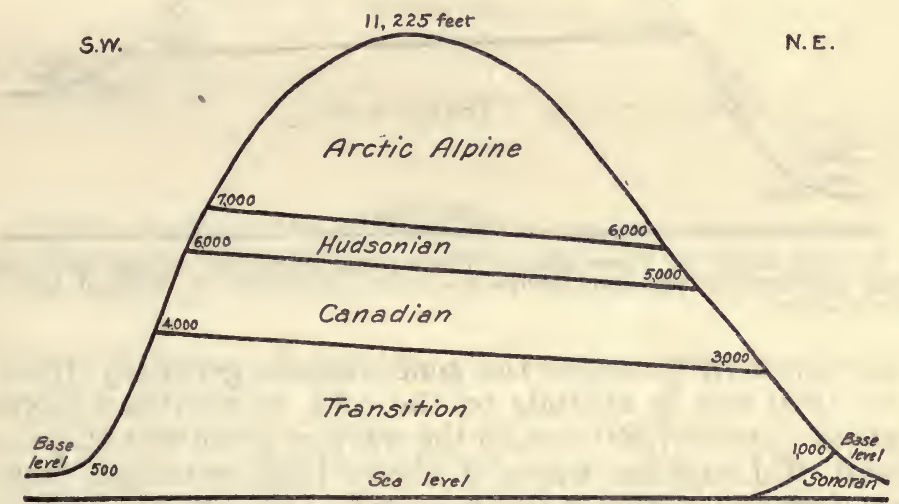

FIGURE 1.- Iife zones on Mount Hood from northeast to southwest exposures, with low base level on both sides and the zones consequently running low.

reaching from 3,000 to 5,000 feet on the cold northeast slopes and from about 4,000 to 6,000 feet on warmer southwest slopes. This lowering of the life zones, in addition to the great height of the peak, accounts for the magnificent display of ice and snow above timber line on Mount Hood.

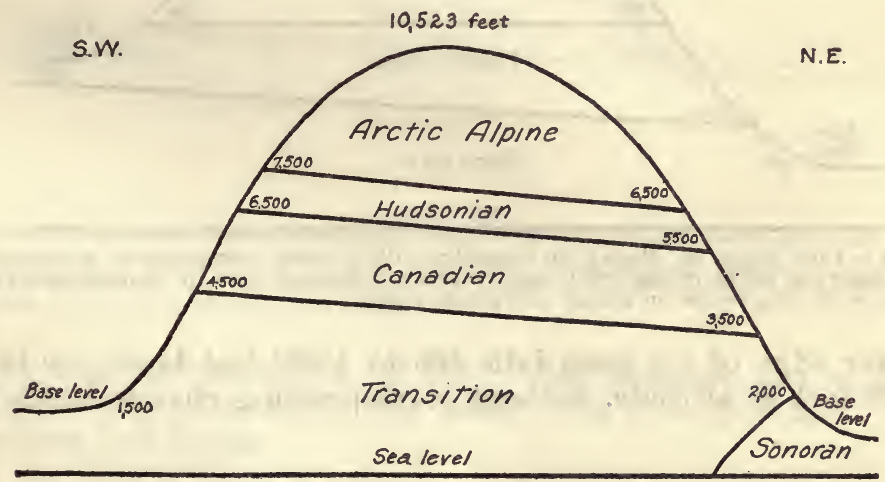

Figurn 2.-Life zones on Mount Jefferson from northeast to southwest exposures, showing approximate altitudes above sea level and slight elevation due to higher base level. 
In the middle section of the Cascades around Mount Jefferson (fig. 2) the zone extends from about 3,500 to 5,500 feet on the northeast slopes and from about 4,500 to 6,500 on the southeast slopes, and around the Three Sisters Peaks (fig. 3) there is a noticeable elevation of the zone to about 4,500 to 6,000 feet on the northeast slopes, and a little under 5,000 to 7,000 on the southwest slopes in conformity with the more elevated base level of the upper Deschutes and Willamette Valleys on the two sides of the range.

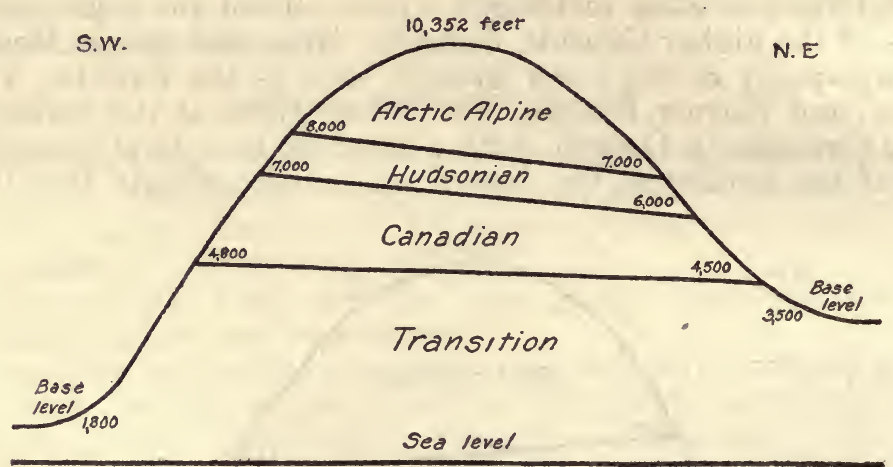

Figune 3.-Life zones on Three Sisters Peaks from northeast to southwest exposures, showing approximate elevation above sea level and effect of elevated base level on northeast slope.

In the southern Cascades the zone extends generally from about 5,000 to 7,000 feet in altitude on the cold, or northeast slopes, and from about 5,500 to 7,500 feet on the warmer southwest slopes, except on Mount McLoughlin, where it shows little variation from 5,000 to 7,000 feet clear around the mountain (fig. 4). In many places west of the mountains with the low base level of nearby valleys,

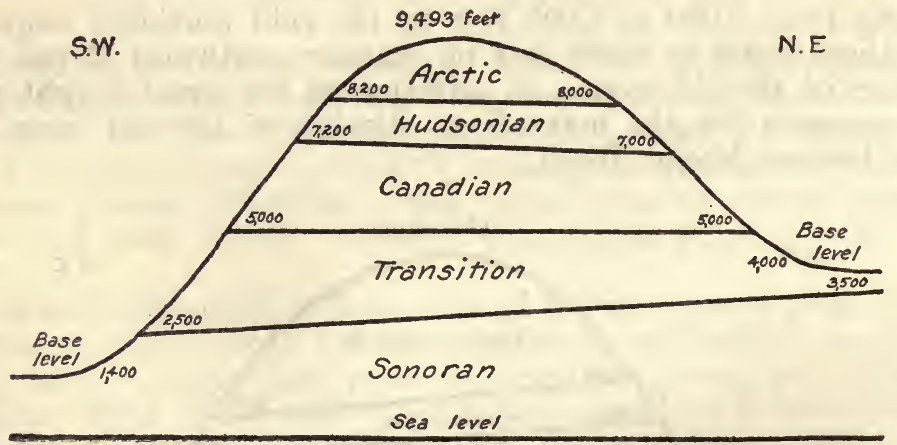

Frgure 4.-Life zones on Mount McLoughlin (Pitt) from northeast to southwest exposures, showing effect of elevated base level on northeast slde in neutralizing the usual difference in zone levels on sunny and shady slopes.

the lower edge of the zone falls 500 to 1,000 feet lower, or to 4,000 or 4,500 feet in altitude, without corresponding change in its upper limit. 
In the Wallowa and Baker Ranges of the Blue Mountains, Canadian Zone covers the high middle slopes from approximately 5,000 to 7,000 feet on the northeast slopes and 6,000 to 8,000 on the warmer southwest slopes, but varying considerably in different parts of the ranges (fig. 5). The highest peaks in the Baker Range reach to 8,920 and 9,097 feet, according to the United States Geological Survey map, while in the Wallowa Range the Forest Service map shows the higher peaks reaching from 9,000 to 9,800 feet. Considerable masses

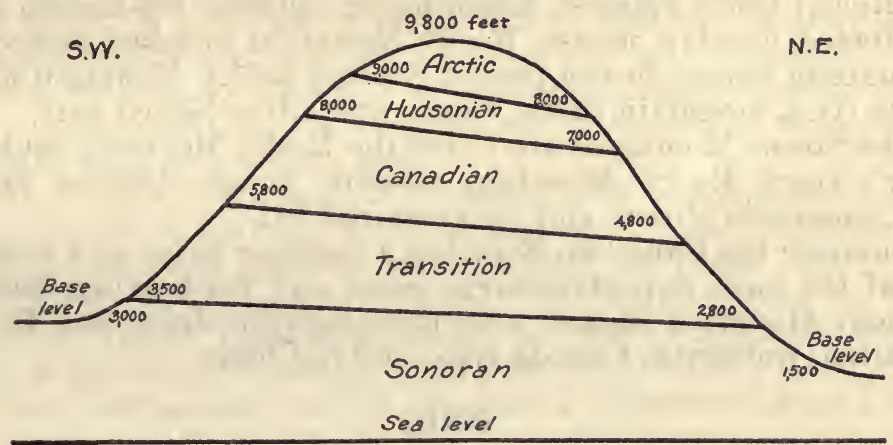

Figure 5.-Life zones in the Wallowa Mountains from the northeast to the southwest exposures, the zones considerably elevated by moderately high base level around two sides of the mountains.

of permanent snow and ice and one small glacier on these peaks indicate their altitude.

The Steens Mountains, with a 4,000- to 5,000-foot base level all around, show the highest zone levels in the State. The Canadian Zone extends from about 6,000 to 7,500 feet on cold slopes and 7,000 to 8,500 feet on warm slopes, but the mountains are so bare of timber and vegetation in general that their zones are not clearly marked

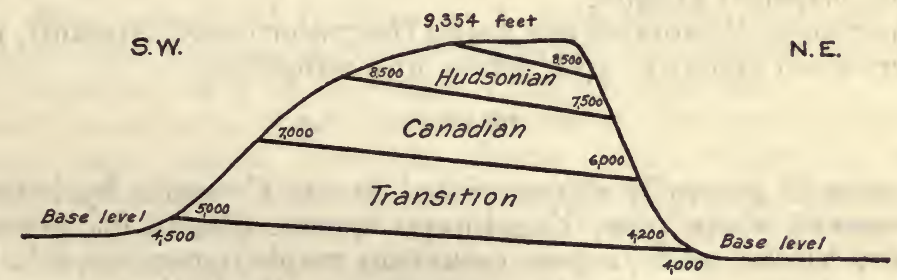

Sonoran

Sea level

Figure 6.-Life zones of the Steens Mountains, showing approximate levels of life zones on northeast and southwest exposures and emphasizing the elevating effect of high base level on the full set of zones.

(fig. 6). The extreme aridity of the climate prevents any real forest growth, while erosion and overgrazing have destroyed much of the native flora and fauna. 


\section{MAMMALS}

In the Cascades the Canadian Zone is characterized by the snowshoe rabbit, brown and dusky conies, Cascade squirrel, flying squirrel, yellow-bellied marmot, red-backed mouse, lemming mouse, largefooted meadow mouse, mountain jumping mouse, Mazama gopher, and mountain mole.

In the Blue Mountains the characteristic mammals are the Rocky Mountain mule deer, elk, mountain sheep, varying hare, Jewett's cony, Richardson's squirrel, Idaho flying squirrel, red-backed mouse, large-footed meadow mouse, Rocky Mountain meadow mouse, Oregon jumping mouse, brown pocket gopher, Rocky Mountain marten, Canada lynx, mountain shrew, hoary and silver-haired bats.

In the Steens Mountains are found the Rocky Mountain mule deer, Taylor's cony, Rocky Mountain meadow mouse, Oregon jumping mouse, mountain shrew, and silver-haired bat.

In summer the Canadian Zone has a peculiar value as a resort for some of the most important large game and fur-bearing mammals, the Rocky Mountain elk and mule deer, bighorn sheep, and formerly for marten, wolverine, Canada lynx, and red foxes.

\section{BIRDS}

Common breeding birds of the Canadian Zone in the Cascades are Barrow's goldeneye, three-toed woodpeckers, Williamson's sapsucker, red-breasted sapsucker, olive-sided flycatcher, black-headed jay, Oregon jay, Cassin's finch, Bendire's crossbill, pine siskin, white-crowned sparrow, Thurber's junco, Rocky Mountain nuthatch, Gambel's chickadee, and ruby-crowned kinglet.

The characteristic birds of the Blue Mountain Canadian Zone include Richardson's and Franklin's grouse, Canada ruffed grouse, Williamson's sapsucker, olive-sided flycatcher, Rocky Mountain jay, Cassin's finch, Bendire's crossbill, siskin, white-crowned sparrow, and ruby-crowned kinglet.

In the Steens Mountains are found the water ouzel, crossbill, junco, white-crowned sparrow, and rufous hummingbird.

\section{PLANTS}

The zone is generally characterized in the Cascades by lodgepole pine, western white pine, Engelmann spruce, Shasta fir, grand fir, silver fir, Alaska cedar, aspen, mountain maple, mountain-ash, highbush cranberry, Shepherdia canadensis, Pachistima myrsinites, Vaccinium erythrococcum, and Xerophyllum tenax.

In the Blue Mountain region dominant plants are lodgepole pine, limber pine, Engelmann spruce, grand and white fir, aspen, balsam poplar, mountain maple, mountain alder, mountain-ash, red elder, Arctostaphylos nevadensis, Shepherdia canadensis, Pachistima myrsinites, Vaccinium scoparium and erythrococcum, Lonicera involucrata and conjugialis, Linnaea borealis, Clintonia uniflora, and many others showing a slight difference from the flora of the same zone in the Cascades.

In the Steens Mountains the plant and animal life of Canadian Zone are similar to those of the Blue Mountain Canadian Zone with a 
much more limited list of species. For flora it can show only two tree species in sheltered gulches, aspen and balsam poplar, some willows along the streams, and considerable other shrubby vegetation of the Blue Mountain or Rocky Mountain types.

\section{HUDSONIAN ZONE}

Hudsonian Zone is the narrow timber-line belt just below the permanent snow and ice fields of the higher peaks of the State. In vertical width it is seldom over 1,000 feet and on the steep upper slopes where found is at most but a narrow belt with a limited number of characteristic forms of life. It varies considerably in altitude on different peaks and ranges, conforming to the other zones in the influence of high or low base level.

On Mount Hood it ranges from about 5,000 to 6,000 feet on cold slopes and 6,000 to 7,000 on warm slopes; on Jefferson 5,500 to 6,500 on cold and 6,500 to 7,500 on warm slopes; on Three Sisters from 6,000 to 7,000 on cold and 7,000 to 8,000 on warm slopes; on Mount McLoughlin (Pitt) from approximately 7,000 to 8,000 all the way around; in the Blue Mountains from 7,000 to 8,000 on cold and 8,000 to 9,000 on warm slopes; and in the Steens Mountains about 7,500 to 8,500 on cold, and 8,500 to 9,354 feet on warm slopes but with poorly defined limits. Thus a difference of 2,000 feet in the level of the zone on corresponding slopes, shown in the State, is traceable to a still greater difference in elevation of base level.

\section{PLANTS}

The plants of Hudsonian Zone, in spite of its scattered sections, are more nearly the same throughout the State than are those of the lower zones. Throughout the Cascades the species are largely the same around all of the peaks high enough to afford the Hudsonian climatic conditions. In the Blue Mountain section the Hudsonian species differ somewhat in showing a close affinity with the Rocky Mountain flora, and in the Steens Mountains the greater aridity cuts out all trees and many of the shrubs from the zone list.

In the Cascades the characteristic species of the zone are the whitestemmed pine, alpine hemlock, alpine larch, alpine fir, alpine juniper, alpine mountain-ash, pink heather, white heather, little wintergreens (Gaultheria ovata and humifusa), little blueberry (Vaccinium scoparium), Lutkea pectinata, wild currant (Ribes howellii), creeping dewberry, white rhododendron, red monkeyflower, smooth alum root, mountain lily (Erythronium montanum), louse-wort (Pedicularis surrecta), grass of Parnassus, stonecrop (Sedum divergens), and twisted polygonum.

In the Blue Mountains around the Wallowa and Baker Range peaks the characteristic Hudsonian Zone plants include all of the timber-line trees of the Cascades, a part of the shrubs and smaller plants, and in addition a considerable number of Rocky Mountain species, such as Ledum glandulosum, Lonicera utahensis, Ribes lacustre (molle?), Dasiophora fruticosa, Erythronium parviflorum, Claytonia Zanceolata, IIoorebekia greenei, Ligusticum leibergi, Merathropta intermedia, Gilia nuttallii, Epilobium fastigiatum and hornemannii, 
Dodecatheon tetrandrum, Angelica lyallii, Saxifraga mertensiana, Rhodiola frigida, Polygonum imbricatum, Pedicularis bracteosa and racemosa, Ranunculus populago, Pentstemon fruticosus, and Aster integrifolius and cusickii.

In the Steens Mountains the Hudsonian Zone is poorly defined, owing to the aridity of the summits, absence of trees and shrubby growth, and greatly denuded.and eroded slopes. Still there is sufficient native life to serve as an approximate guide to the zonal divisions. The principal Hudsonian indicators in plants are dwarf willows, alpine juniper (Juniperus sibirica), thorny gooseberry, red currants, shrubby cinquefoil (Dasiphora fruticosa), dwarf blueberry (Vaccinium scoparium), Kalmia glauca microphylla, Artemisia tilesii, Eriogonum umbellatum and vineum, Saxifraga columbiana, Symphoricarpos acutus, Spraguea multiceps, Polygonum bistortoides, Phacelia sericea, Quamasia leichtlinii, Dodecatheon puberulum, Pedicularis surrecta, Helenium hoopesii, Phteum alpinum, and Delphinium cyanoreios.

\section{ARCTIC-ALPINE ZONE}

Arctic-Alpine, the last belt of dwarf plant and scanty animal life, corresponding to the Arctic tundra of the far north, is represented on most of the peaks in Oregon reaching above 9,000 feet in altitude. On Mount Hood it ranges from about 6,000 feet on northeast and 7,000 feet on southwest slopes upward to the permanent ice and snow, which cover most of the higher parts of the peak; and on Jefferson from 6,500 and 7,500 feet upward. On the Three Sisters the zone lies above 7,000 and 8,000 feet, respectively, on the cold and warm slopes; on Mount McLoughlin (Pitt), above 8,000; in the Blue Mountains and Steens Mountains, above 8,000 and 9,000 feet, varying somewhat in accordance with varying local conditions of slope, soil, wind, and moisture, running lower on steep northerly slopes where the sun's rays are partially cut off and higher on the steep southerly slopes which catch the more nearly vertical rays of the sun. The effect of high and low base level is still apparent in this highest of the life zones.

\section{PLANTS}

In the Arctic-Alpine Zone of the Cascade peaks are such low or prostrate plants as Ranunculus eschscholtzii, Anemone hudsoniana, Antennaria media, Phlox douglasii and diffusa, Pentstemon menziesii, Veronica alpina, Silene sulesdorfi, Saxifraga tolmiei and bongardi, Potentilla flabellifolia, Oxyria digyna, Polygonum newberryi, Gentiana calycosa, Lewisia columbiana, Epilobium alpinum and anagallidifolium, Erigeron salsuginosus, Hieracium gracile, Oreastrum alpigaenum.

Arctic-Alpine Zone in the Blue Mountains is marked by such dwarf vegetation as the dwarf willow (Salix nivalis), Dryas octopetala, Ivesia gordoni, Sieversia rossii, Potentilla flabellifolia, Saxifraga debilis and bongardi, Silene acaulis, Phlox diffusa and douglasii, Arenaria verna, sajanensis and nuttallii, Claytonia megarrhiza, Epilobium alpinum and anagallidifolium, Lewisia nevadensis and triphylla, Dodecatheon jeffreyi, Oxyria digyna, Eriogonum piperi, 
Polygonum viviparum ana minimum, Veronica alpina, Mimulus alpinus, Phacelia sericea, Pedicularis contorta, Gentiana calycosa, Erigeron acris debilis and compositus, Hulsea nana, Arnica parryi, Antennaria media and lanata, Hieracium gracile, Phleum alpinum, and Phegopteris alpestris.

In the Steens Mountains the vegetation is poorly represented in this zone, and the collecting has been but fragmentary. The following plants have been collected and noted as representing the zone on the peaks of these mountains: Ranunculus gloverianus, Gitia nuttallii, Arenaria congesta and aculeata, Alsine borealis, Oxyria digyna, Veronica alpina, Draba nemorosa, Spraguea umbellata and multiceps, Erigeron compositus trifidus, Achillea alpina, and Phleum alpinum.

\section{MAMMALS AND BIRDS}

Of mammals there seems to be no species restricted to the zone in the Cascades in Oregon, as the white goat does not come south of the Columbia River. Of breeding birds the rosy finch is perhaps the only characteristic species. In the Steens Mountains no mammals or birds are confined to the Arctic-Alpine. Collecting in the high peaks of the Wallowa and Baker Ranges has not been sufficiently thorough to establish any species of birds or mammals as breeding and occupying in a restricted sense the Arctic-Alpine Zone.

TABLE 1.-Mammals of Oregon, by life zones

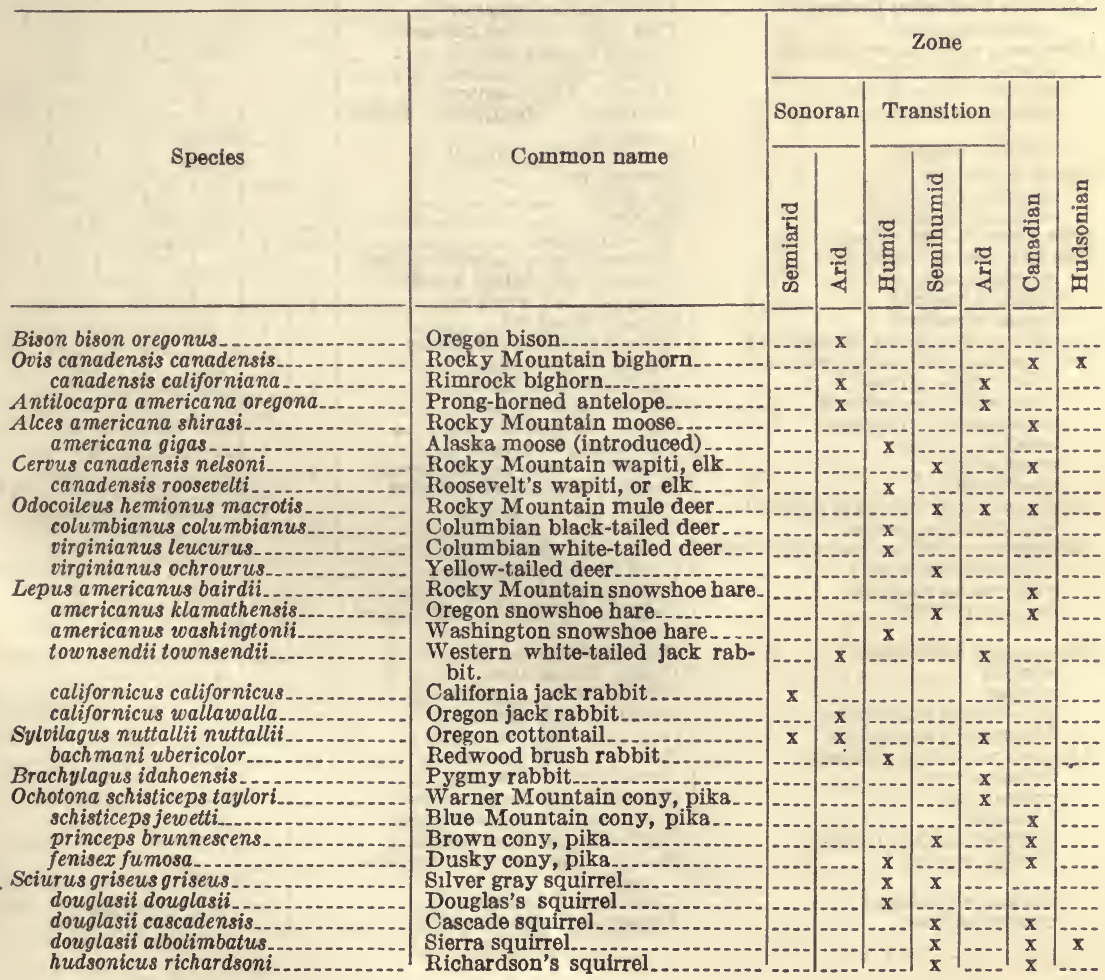


TABLE 1.-Mammals of Oregon, by life zones-Continued

Eutamias townsendii townsendii townsendii cooperi.

townsendii siskiyou.

townsendii senex

a moenus a moenus.

amoenus luteiventris

amoenus ludibundus

amoenus ochraceus.

minimus pictus

Callospermophilus chrysodeirus chrysodeirus.

chrysodeirus trinitatis

chrysodeirus connectens

A mmospermophilus leucurus leucurus

Citellus douglasii.

columbianus columbianus

oregonus

townsendii.

mollis mollis

mollis canus

mollis vigilis.

elegans nevadensis

Marmota flaviventris flaviventris flaviventris avara.

flaucomys sabrinus oregonensis

sabrinus fuliginosus

sabrinus klamathensis.

sabrinus bullatus.

sabrinus banosi

Rattus norvegicus.

rattus rattus

rattus alexandrinus

Mus musculus musculus.

Neotoma cinerea occidentalis cinerea fusca.

fuscipes fuscipes.

lepida nevadensis

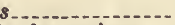

Onychomys leucogaster fuscogriseus

Peromyscus maniculatus rubidus

maniculatus gambellii.

maniculatus sonoriensis

maniculatus artemisiae.

crinitus crinitus

truei gilberti.

truei preblei

Reithrodontomys megalotis megalotis megalotis longicaudus

Clethrionomys californicus californicus. californicus obscurus

californicus mazama

gapperi saturatus

Phenacomys longicaudus silvicola.

albipes.

年

Microtus montanus montanus.

nanus nanus.

canicaudus

townsendii

mordax mordax

mordax angusticeps

mordax abditus.
Townsend's chipmunk Cooper's chipmunk.

Redwood chipmunk

Alen's chipmun

Klamath chipmunk

Yellow-bellied chipmunk

Hollister's chipmunk

Ochraceous chipmunk

Sagebrush chipmunk

Golden-mantled ground squirrel

Tawny-mantled ground squirrel Copperhead ground squirrel.

Antelope squirrel

Douglas's ground squirrel

Columbian ground squirrel

Oregon ground squirrel

Townsend's ground squirrel

Piute ground squirrel

Gray sage squirrel.

Speckled sage squirrel

Pale yellow-bellied marmot...

Oregon flying squirrel

Cascade flying squirre

Klamath flying squirrel..........

Sawtooth Mountain

squirre

flying

Bangs's flying squirrel

Norway rat.

Black rat

Roof rat

House mouse

Western bushy-tailed wood rat. Dusky bushy-tailed wood rat

Dusky-footed wood rat.

Nevada wood rat --------

Oregon grasshopper mouse....

Ruddy deer mouse.

Gambel's deer mouse.

Sonoran deer mouse

Sagebrush deer mouse

Idaho canyon mouse

Gilbert's white-footed mouse

Preble's white-footed mouse

Desert harvest mouse.

California harvest mouse

California red-backed mouse

Dusky red-backed mouse.

Mazama red-backed mouse.

British Columbia red-backed mouse.

Red tree mouse.

Dusky tree mouse

White-footed phenacomys.

Mountain phenacomys.

Olympic phenacomys........... Peale's meadow mouse.

Dwarf meadow mouse

Gray-tailed meadow mouse

Townsend's meadow mouse.

California meadow mouse

Rocky Mountain meadow mouse.

Coast meadow mouse

Tillamook meadow mouse
Zone

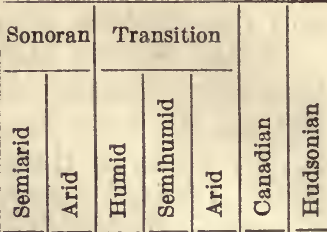


TABLE 1.-Mammals of Oregon, by life zones-Continued

Microtus richardsoni arvicoloides. richardsoni macropus. oregoni oregoni. oregoni bairdi

Fiber zibethicus osoyoosensis zibethicus mergens. zibethicus occipitalis

Castor canadensis pacificus canadensis shastensis canadensis baileyi.

Aplodontia rufa rufa rufa pacifica.

Erethizon epixanthum epixanthum....

Zapus trinotatus trinotatus. trinotaius pacificus.

trinotatus montanus

princeps oregonus .....

Perodipus ordii columbianus.

microps preblei

Ilipodomys heermanni californicus....

heermanni gabrielsoni

Microdipodops megacephalus oregonus

Perognathus parvus parvus. parvus mollipilosus.

lordi lordi. nevadensis

Thomomys bulbivorus. townsendii townsendii

townsendii nevadensis

bottae leucodon

bottae laticeps.

douglasii douglasii.

douglasii oregonus.

niger

monticola mazama

monticola helleri...

monticola nasicus.

\section{hesperus}

quadratus quadratus

columbianus.

Felis concolor oregonensi concolor hippolestes. catus.

Lynx rufus uinta

rufus pallescens. rufus fasciatus. canadensis canadensis

Canis familiaris

lycaon gigas... lycaon nubilus latrans lestes.

Vulpes fulvus cascadensis fulvus macrourus macrotis nevadensis

Mustela longicauda arizonensis

longicauda saturata washingtoni.

xanthogenys oregonensis

cicognanii streatori

cicognanii muricus cicognanii leptus

Lutrcola vison energumenos

Martes caurina caurina

caurina origenes

pennanti pacifica.

$7209^{\circ}-36-3$

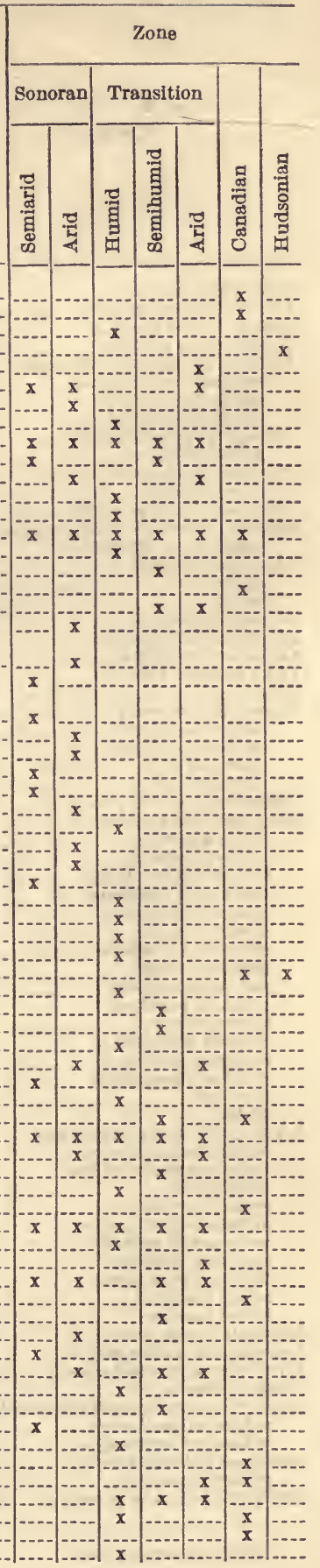

Cascade meadow mouse

Large-footed meadow mouso.

Oregon creeping mouse

Baird's creeping mous $\theta$

Pygmy mouse.

Rocky Mountain muskrat

Nevada muskrat

Oregon coast muskrat.............

Pacific coast beaver.

Shasta beaver

Nevada beaver.

Brown mountain beaver

Pacific mountain beaver

Yellow-haired porcupine.

Northwest jumping mouso

Pacific jumping mouse..

Mountain jumping mouse

Blue Mountain jumping mouse

Columbian five-toed kangaroo rat.

Preble's kangaroo rat

Northern California kangaroo rat.

Gabrielson's kangaroo rat.....

Oregon gnome mouse

Oregon pocket mouse........

Coues's pocket mouse.

Northwest pocket mouse

Nevada pocket mouse

Camas pocket gopher

Townsend's pocket gopher

Nevada pocket gopher

White-toothed pocket gopher

Humboldt Bay pocket gopher.

Douglas's pocket gopher

Oregon pocket gopher

Black pocket gopher

Mazama pocket gopher

Heller's pocket gopher.

Deschutes pocket gopher

Brown pocket gopher.

West coast pocket gopher

Dalles pocket gopher.

Columbia pocket gopher

Rocky Mountain cougar.

House cat

Rocky Mountain bobcat

Cascado bobcat

Oregon bobcat

Canada lynx ..

Domestic dogs.

Plains wolf

Mountain coyote

Rocky Mountain red fox

Nevada long-eared fox.

Oregon gray fox.

Arizona weasel

Cascade weasel

Washington weasel.

Oregon bridled wease

Puget Sound wease

Sierra least weasel

Rocky Mountain least weasel

Western mink

Pacific marten

Rocky Mountain marten.

Pacific fisher.

\begin{tabular}{|c|c|c|c|c|c|c|}
\hline \multicolumn{7}{|c|}{ Zone } \\
\hline \multicolumn{2}{|c|}{ Sonoran } & \multicolumn{3}{|c|}{ Transition } & & \\
\hline 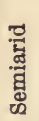 & 营 & 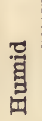 & 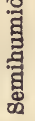 & $\frac{\pi}{4}$ & 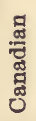 & 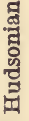 \\
\hline
\end{tabular}

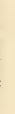


TABLE 1.-Mammals of Oregon, by life zones-Continued

\begin{tabular}{|c|c|c|c|c|c|c|c|c|}
\hline \multirow{3}{*}{ Species } & \multirow{3}{*}{ Common name } & \multicolumn{7}{|c|}{ Zone } \\
\hline & & \multicolumn{2}{|c|}{ Sonoran } & \multicolumn{3}{|c|}{ Transition } & \multirow[b]{2}{*}{ 舆 } & \multirow[b]{2}{*}{ 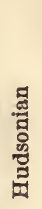 } \\
\hline & & 总 & 范 & 멸 & 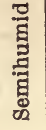 & $\frac{3}{4}$ & & \\
\hline Gulo luscus luscus.... & Wolverine... & & & & & & $\mathbf{x}$ & \\
\hline $\begin{array}{l}\text { utra canadensis pacific } \\
\text { nhydra lutris nereis... }\end{array}$ & Western otter. & $\mathbf{x}$ & & $x$ & - & & -+ & \\
\hline $\begin{array}{l}\text { nhydra lutris nereis } \\
\text { axidea taxus neglecta........ }\end{array}$ & $\begin{array}{l}\text { Sea otter } \\
\text { California badger. }\end{array}$ & $x$ & & $\mathbf{x}$ & $x$ & & & \\
\hline Iephitis occidentalis occident & California skunk. & & & $x$ & & & & 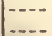 \\
\hline occidentalis spissigrada.. & Puget Sound skunk & & & $\mathbf{x}$ & $-\cdots$ & & & $\cdots$ \\
\hline occidentalis notata..... & Columbla Valley sku & $x$ & & & $-\cdots$ & & & \\
\hline $\begin{array}{l}\text { occidentalis major } \\
\text { Spilogale gracilis saxatilis. }\end{array}$ & $\begin{array}{l}\text { Great Basin skunk } \\
\text { Great Basin spotted }\end{array}$ & & $x$ & -- & $x$ & $x$ & & $-\cdots$ \\
\hline $\begin{array}{l}\text { Spilogale gracilis saxatilis. } \\
\text { phenax latifrons...... }\end{array}$ & $\begin{array}{l}\text { Great Basin spotted sk } \\
\text { Oregon spotted skunk. }\end{array}$ & $x$ & & $x$ & (n) & & $\cdots$ & $\cdots$ \\
\hline Procyon lotor pacifica & North western raccoon. & & & $\dot{x}$ & $\mathrm{x}$ & & & - \\
\hline lotor excelsus. & Snake River Valley & $\cdots$ & $x$ & & & & & (n) \\
\hline Bassariscus astutus raptor.-- & Ringtail & $x$ & & -- & - & & & \\
\hline & $\begin{array}{l}\text { Idaho black bear } \\
\text { Olymplc black be }\end{array}$ & $-\cdots$ & -- & $x$ & $x$ & $-\cdot$ & $x$ & $\cdots$ \\
\hline $\begin{array}{l}\text { americanus altifrontalis. } \\
\text { Ursus klamathensis........... }\end{array}$ & $\begin{array}{l}\text { Olymple black be } \\
\text { Klamath grizzly.. }\end{array}$ & $\mid-\cdots$ & & $x$ & $x$ & ( & & $\cdots$ \\
\hline idahoensis & Idaho grizzly ..... & & & & 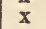 & $-\cdots$ & $-\cdots$ & $\cdots$ \\
\hline mirus.............. & Yellowstone Park & $\ldots$ & $x$ & & $\ldots$ & & & $\cdots$ \\
\hline Eumetopias jubata.. & Steller's sea lion... & $-\ldots$ & $-\cdots$ & $x$ & $-\cdots$ & & & $-\ldots$ \\
\hline Zalophus californianus -- & California sea li & --- & & $x$ & $-\ldots$ & & $\ldots$ & $-\ldots$ \\
\hline Callorhinus alascensis & $\begin{array}{l}\text { Northern fur seal. } \\
\text { Hair seal }\end{array}$ & $-\cdots$ & $-\cdots$ & $x$ & --- & & & $\cdots$ \\
\hline $\begin{array}{l}\text { Phoca richardit richardit..... } \\
\text { Cetaceans }{ }^{2}\end{array}$ & Whales and porpo & $|--\cdot|$ & & & (n) & & & $-\cdots$ \\
\hline Scapanus townsendii..... & Townsend's mole. & $\mid-\cdots$ & $-\cdots$ & $x$ & - n & & & (n) \\
\hline latimanus dilatus.-. & Klamath mole. & $-\cdots$ & &..- & $x$ & & - & $\cdots$ \\
\hline latimanus alpinus... & Mazama mole... & $-\cdots$ & & & $-\cdots$ & -- & $x$ & $-\ldots$ \\
\hline orarius orariu & Coast mole & ---- & $-\cdots$ & $x$ & -1 & & -.. & $-\cdots$ \\
\hline $\begin{array}{l}\text { orarius schefferi.-- } \\
\text { Neurotrichus gibbsii gibbsii.-. }\end{array}$ & $\begin{array}{l}\text { Scheffer's mole.. } \\
\text { Gibbs's mole. }\end{array}$ & $\mathbf{x}$ & & $x$ & $x$ & & & $\cdots$ \\
\hline Sorex palustris navigator.-. & Rocky Mountain water shre & 足 & & & ( & & $x$ & $\mathrm{x}$ \\
\hline ibendirii... & Bendire's sh &..- & & ... & $x$ & & & \\
\hline ben & Palmer's sh & $\cdots$ & $\cdots$ & $x$ & $\ldots$ & & & \\
\hline trowbridgii & Trowbridge' & $\cdots$ & $-\cdots$ & $x$ & - & & $\cdots$ & --- \\
\hline trowbridgii mariposae & $\begin{array}{l}\text { Yosemite shrew } \\
\text { Dusky shrew }\end{array}$ & $-\ldots$ & $\ldots$ & $(-. .-$ & $x$ & & 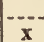 & $x$ \\
\hline obsc & Baird's dus & $-\cdots$ & 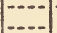 & $x$ & $-\cdots$ & & & \\
\hline iliensis & Cascade du & & & & $\ldots$ & & $\mathrm{x}$ & \\
\hline obsc & Olyn & $\ldots$ & $-\ldots$ & $x$ & $\mathrm{x}$ & & & $\ldots$ \\
\hline pac & Pacific shre & & & $\bar{x}$ & & & & \\
\hline pacificus y & Yaqu & $-\cdots$ & $-\ldots$ & $x$ & & & & \\
\hline vagra? & Vagi & & $-\ldots$ & $\bar{x}$ & $x$ & & & \\
\hline vagrans monticola & Rocky Mountain shrew & $\ldots$ & $\ldots$ & $\ldots$ & $\ldots$ & & $\mathrm{x}$ & \\
\hline vagrans amoen? & Sierr &.-- & $-\ldots$ & -.. & $x$ & & & \\
\hline ornatus trigonirostris...... & & $-\ldots$ & $-\ldots$ & $\ldots$ & $x$ & ...- & & 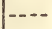 \\
\hline$a m i$ & Mer & $\ldots$ & $\mathbf{x}$ & $-\ldots$ & {$[--$} & & &.- \\
\hline & &.- & $\ldots$ & -... & $-\ldots$ & $x$ & & \\
\hline Myotis californicus californicus & Little Califo & $x$ & $x$ & $\cdots$ & $-\cdots$ & & & \\
\hline $\begin{array}{l}\text { californicus caurinus..-. } \\
\text { subulatus melanorhinus. }\end{array}$ & $\begin{array}{l}\text { Northwest coast } \\
\text { Black-nosed bat }\end{array}$ & & & $x$ & $\cdots$ & & & \\
\hline $\begin{array}{l}\text { subulatus melanorhinus.- } \\
\text { evotis evotis. }\end{array}$ & Little big-eared i & $-\ldots-$ & & $x$ & - & ( n & & $\cdots$ \\
\hline evotis chrysonotus.... & Desert golden bat..... & 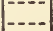 & $x$ & & $-\cdots$ & & & \\
\hline & Dusky bat...... & $\ldots$ & ... & $x$ & & & & \\
\hline & Tejon bat. & $x$ & $x$ & & & & & \\
\hline & Yellc & $-\ldots$ & $\ldots$ & $-\cdots$ & $x$ & $\mathbf{x}$ & & \\
\hline lucifugus alascensis...... & a bat.... & $-\ldots$ & .... & $\mathbf{x}$ & & & & \\
\hline & -legged ba & 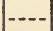 & ... & $\mathbf{x}$ & & & & \\
\hline & & & & & $x$ & & & \\
\hline Eptesicu & Big & -1 & $\cdots$ & $x$ & $\bar{x}$ & $x$ & & \\
\hline & Silver-haired bat.-... & & & & & & $x$ & \\
\hline Pipistrellus hesperus he & Little canyon bat & $-\ldots$ & $x$ & $-\infty$ & & & & $\cdots$ \\
\hline Nycteris cinerea & $\begin{array}{l}\text { Hoary bat } \\
\text { Jack-rabbit bat }\end{array}$ & $\ldots$ & $-\cdots$ & $-\cdots$ & $x$ & $\cdots$ & & \\
\hline $\begin{array}{l}\text { Corynorhinus rafinesqu } \\
\text { rafinesquii pallesce }\end{array}$ & Pale jack-rabbit & -...- & $x$ & $\begin{array}{c}x \\
-\ldots--\end{array}$ & $(--$ & $\mathbf{x}$ & $-\ldots$ & \\
\hline & -rabbit bat. & $x$ & & - & $-\cdots$ & & & \\
\hline Antrozo & Pacific pale bat.. & $\bar{x}$ & .... &.-- &..- & $-\ldots$ &.- & \\
\hline & & $-\ldots$ & $x$ &..-- &.- & & & $\cdots$ \\
\hline Didelphis virginiana virginiana & Virginia opossum... & $\mathrm{x}$ & & & & & & \\
\hline
\end{tabular}

2 Ocean; no zones given. 
TABLE 2.-Reptiles of Oregon, by life zones ${ }^{3}$

LIZARDS

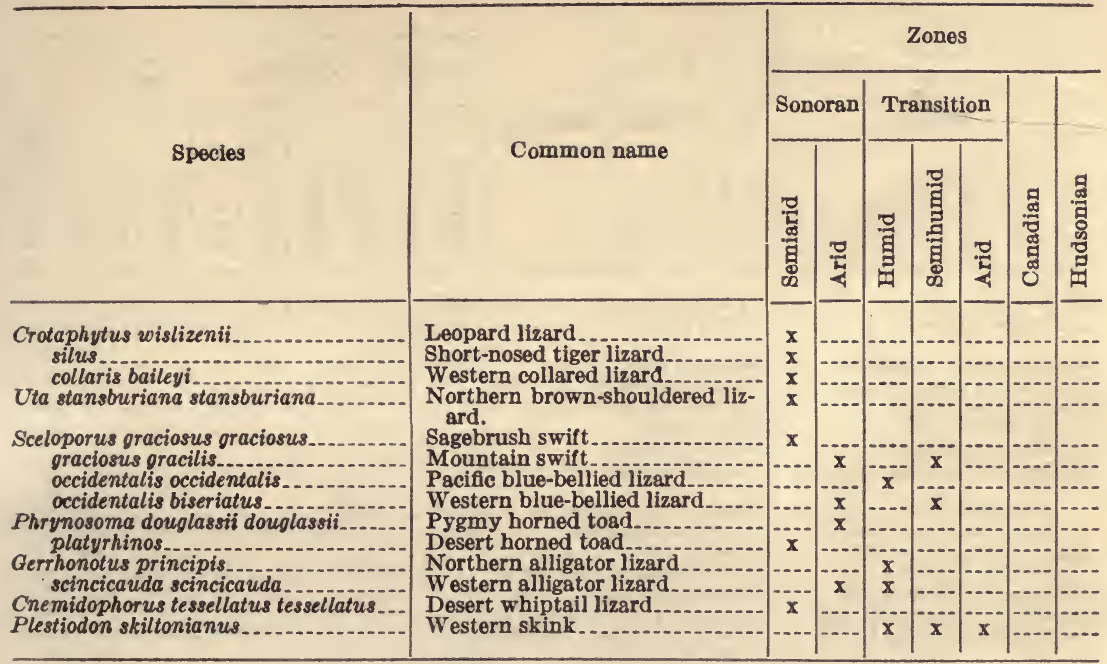

\section{SNAKES}

Charina bottae bottae

Diadophis amabilis

Coluber constrictor mormon taeniatus taeniatus.

Pituophis catenifer catenifer catenifer heermanni. catenifer deserticola.

Contia tenuis

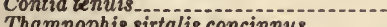
sirtalis infernalis.

ordinoides ordinoides.

ordinoides biscutatus ordinoides vagrans.

Crotalus oreganus. confluentus

\begin{tabular}{|c|c|c|c|c|c|c|c|}
\hline Pacifle rubber snake & & & $x$ & $\mathrm{x}$ & & & \\
\hline Western ringneck snake & 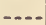 & $x$ & $\mathbf{x}$ & $\ldots$ & & & \\
\hline Western yellow-bellied racer $\ldots$ & $\ldots$ & $\ldots$ & $\ldots$ & $\mathbf{x}$ & & & \\
\hline Western striped racer & $\ldots$ & $x$ & $\ldots$ & $\ldots$ & & & \\
\hline Coast gopher snake & $\ldots$ & $\ldots$ & $x$ & $\ldots$ & & & .... \\
\hline Valley gopher snake & $\ldots$ & $x$ & $\ldots$ & $-\ldots$ & $\ldots$ & & $\ldots$ \\
\hline Desert gopher snake & $x$ & $\ldots$ & $-\infty$ & $\ldots$ & $\ldots$ & & $\ldots$ \\
\hline Sharp-tailed snake & $\ldots$ & $\ldots$ & $\ldots$ & $\mathbf{x}$ & $-\ldots$ & & \\
\hline Western garter snak $\theta$ & $\ldots$ & $\ldots$ & $x$ & $\ldots$ & & & \\
\hline Pacific garter snake & $\ldots$ & $x$ & $\ldots$ & $\mathrm{x}$ & & & \\
\hline Puget Sound garter snake & $\ldots$ & $\ldots$ & $\mathrm{x}$ & $\ldots$. & & & \\
\hline Klamath garter snake & $-\ldots$ & $\mathrm{x}$ & $\mathbf{x}$ & $x$ & - & & \\
\hline Wandering garter snake....... & $x$ &.-- & $\ldots$ & $\bar{x}$ & $\ldots$ & & $\ldots$ \\
\hline Pacific rattlesnake & $\bar{x}$ & $x$ & $\ldots$ & $\ldots$ & & & $\ldots$ \\
\hline Plains rattlesnake & $\bar{x}$ & $\bar{x}$ & $\ldots$ & $\ldots$ & $\ldots$ & $\ldots$ & $\ldots$ \\
\hline
\end{tabular}

\section{TURTLES}

Clemmys marmorata.

Chrysemys marginata bellii.
Pacific terrapin.

Pacific terrapin ..................

Western painted turtle.

$x$
$x$

i Specimen identifications by Remington Kellogg. 
TABLE 3.-Breeding birds of Oregon, by life zones ${ }^{1}$

Species

Gavia immer immer

Colymbus nigricollis californicus.

Aechmophorus occidentalis.

Podilymbus podiceps podiceps. Oceanodroma furcata

leucorhoa beali

Pelecanus erythrorhynchos

Phalacrocorax auritus albociliatus.

penicillatus

pelagicus resplendens

Ardea herodias treganzai. herodias fannini.

Casmerodius albus egretta

Butorides virescens anthonyi.

Nycticorax nycticorax hoactli.

Botaurus lentiginosus.

Ixobrychus exilis hesperis.

Plegadis guarauna.

Branta canadensis canadensis

Anas platyrhynchos platyrhynchos.

Chaulelasmus streperus.

Dafila acuta $t$ zitzihoa

Nettion carolinense.

Querquedula discors. cyanoptera..

Spatula clypeata.

Aix sponsa

Nyroca american
valisineria

Glaucionetta islandica

Histrionicus histrionicus pacificus.

Erismaiura jamaicensis rubida

Mergus merganser americanus

Cathartes aura septentrionalis.

Astur atricapillus striatulus...

Accipiter velox velox.

$$
\text { cooperi. }
$$

Buteo borealis calurus swainsoni. regalis.

(n)

Haliaeetus leucocephalus alascanus.

Circus hudsonicus.

Pandion haliaetus carolinensis

Falco mexicanus. peregrinus anatum. peregrinus pealei. columbarius suckleyi sparverius phalaena

Dendragapus obscurus richardsoni.

fuliginosus fuliginosus

Canachites franklini

Bonasa umbellus togat umbellus sabini

Pedioecetes phasianellus columbianus.

Centrocercus urophasianus.

Colinus virginianus virginianus

Lophortyx californica califor nic californica vallicola

Oreortyx picta palmeri picta picta

Common loon

Eared grebe.

Western grebe

Pied-billed grebe.

Forked-tailed Petrel

Beal's petrel

White pelican ---an--

Farallon cormorant

Brandt's cormorant

Baird's cormorant

Treganza's heron

Northwestern Coast heron

American egret

Anthony's green heron...

Black-crowned night heron.

American bittern

Western least bittern

White-faced glossy ibis

Common Canada goose

Common mallard

Gadwall.

American pintail

Green-winged teal

Blue-winged teal

Cinnamon teal

Shoveler.

wood duck ..............

Redhead.

Canvasback.............

Barrow's goldeneye

Western harlequin duck

Ruddy duck

American merganser-----

Turkey vulture

Western goshawk.

Sharp-shinned hawk

Cooper's hawk

Western red-tailed hawk

Swainson's hawk .........

Ferruginous roughleg

Golden eagle

Northern bald eagle...-...-.

Marsh hawk.

Osprey.

Prairie falcon

Duck hawk

Peale's falcon

Black pigeon hawk

Desert sparrow hawk

Richardson's grouse.

Sooty grouse.

Franklin's grouse.

Canada ruffed grouse

Oregon ruffed grouse

Columbian sharp-tailed grouse.

Sage hen

Eastern bobwhite

California quail

Valley quail

Mountain quail

Plumed quail

Zone

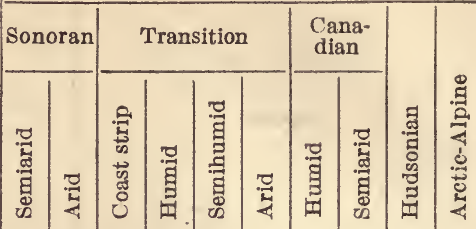

1 Listed with the assistance of Stanley G. Jewett. 
TABLE 3.-Breeding birds of Oregon, by life zones-Continued

\begin{tabular}{|c|c|c|c|c|c|c|c|c|c|c|c|}
\hline \multirow{3}{*}{ Species } & \multirow{3}{*}{ Common name } & \multicolumn{10}{|c|}{ Zone } \\
\hline & & \multicolumn{2}{|c|}{ Sonoran } & \multicolumn{4}{|c|}{ Transition } & \multicolumn{2}{|c|}{$\begin{array}{l}\text { Cans- } \\
\text { dian }\end{array}$} & \multirow[b]{2}{*}{ 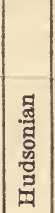 } & \multirow[b]{2}{*}{ 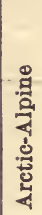 } \\
\hline & & 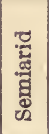 & 일 & 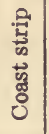 & 믐 & 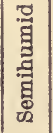 & $\sum_{4}^{2}$ & 兽 & 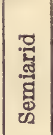 & & \\
\hline rus canadensis tabida.... = .... & ndhill prene & & $\mathbf{x}$ & & & $\mathbf{x}$ & & & & & \\
\hline Rallus limicola limicola & Virginia rail & $\mathbf{x}$ & $\mathbf{x}$ & & $\mathbf{x}$ & $x$ & & & & & \\
\hline Porzana carolina. & Sora & $\mathbf{x}$ & $\mathbf{x}$ & & $\mathbf{x}$ & $\mathrm{x}$ & & $-\cdots$ & & & - n \\
\hline Fulica americana americana... & Americ & $\mathbf{x}$ & $\mathbf{x}$ & & $x$ & $\mathbf{x}$ & & & & & 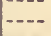 \\
\hline natopus bachmani......... & $\begin{array}{l}\text { Black o } \\
\text { Wester }\end{array}$ & $-\ldots$ & $-\infty$ & $\mathbf{x}$ & --- & $-\cdots$ & & & & & - \\
\hline $\begin{array}{l}\text { Charadrius nivosus nivosus.-.-- } \\
\text { Oxyechus vociferus vociferus.-.-- }\end{array}$ & $\begin{array}{l}\text { Wester } \\
\text { Killdee }\end{array}$ & $\bar{x}$ & $\mathbf{x}$ & $x$ & 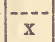 & $x$ & $\bar{x}$ & $\bar{x}$ & $x$ & & --- \\
\hline Capella delicata. & Wilson's snipe..... & $-\ldots$ & & $-\infty$ & $\bar{x}$ & $x$ & $x$ & --- & & & \\
\hline $\begin{array}{l}\text { Numenius americanus ameri- } \\
\text { canus. } \\
\text { Actitis macularia. }\end{array}$ & Long-billed curlew.. & $\mathbf{x}$ & $\mathbf{x}$ & --- & $-\cdots$ & $\mathbf{x}$ & $\mathbf{x}$ & $-\cdots$ & & & 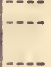 \\
\hline $\begin{array}{l}\text { Catoptrophorus semipalmatus } \\
\text { inornatus. }\end{array}$ & Western willet..................... & $\hat{x}$ & $\hat{x}$ & 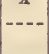 & 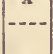 & $\mathbf{x}$ & $\mathbf{x}$ & $\mid \begin{array}{c}x \\
----\end{array}$ & $-\cdots$ & & -- \\
\hline irostra americana....... & & $\mathbf{x}$ & $\mathbf{x}$ & & & & & & & & \\
\hline xicanus_........ & red stilt & $\mathbf{x}$ & $\mathrm{x}$ & & & $\ldots$ & & & & & \\
\hline ls tricolor & Wilson's phalarope... & $\mathrm{x}$ & $\mathrm{x}$ & $-\ldots$ & & $\mathbf{x}$ & $\mathbf{x}$ & & & & - \\
\hline identalis occidentalis.- & Wester & & & $\mathrm{x}$ & & -... & & & & & \\
\hline nicus_.............. & gull & $\mathbf{x}$ & $\mathbf{x}$ & $-\cdots$ & & $\mathrm{x}$ & $\mathrm{x}$ & & & & - \\
\hline 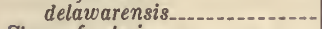 & billed gull............ & $x$ & $\mathbf{x}$ & & & $\mathbf{x}$ & $\mathbf{x}$ & & & & $+\infty$ \\
\hline Slerna forsteri................... & ter's tern................ & $\mathbf{x}$ & $x$ & $-\cdots$ & & $\mathbf{x}$ & $-\infty$ & $-\cdots$ & & & $-\infty$ \\
\hline Hydroprogne caspia imperator - & $-2 .-2-2-2 n$ & $\mathbf{x}$ & $\mathbf{x}$ & $-\infty$ & -- & $-\cdots$ & $-\cdots$ & ---- & & & $\cdots$ \\
\hline Chlidonias nigra surinamensis & Bla & $\mathbf{x}$ & $\mathbf{x}$ & $-\infty-\infty$ & $\cdots$ & $\mathbf{x}$ & $-\cdots$ & $-\cdots$ & & & $\cdots$ \\
\hline Uria aalge californica.......... & Cal & $-\cdots$ & $\ldots$ & $\mathbf{x}$ & $-\cdots$ & $-\ldots$ & $-\cdots$ & $-\cdots$ & & & $-\infty$ \\
\hline Cepphus columba................ & Pigeo & $-\ldots$ & $-\infty$ & $\mathbf{x}$ & $-\cdots$ & $-\cdots$ & $-\cdots$ & $-\cdots$ & --- & &.- \\
\hline Lunda cirrhata & Tufted & $-\ldots$ & ---- & $\mathbf{x}$ & ---- & ---- & $-\cdots$ & -- & & & - \\
\hline Columba fasciata fasciata...... & Band-tailed pigeon & $-\cdots$ & $-a-4$ & $\mathrm{x}$ & $\mathrm{x}$ & $\mathbf{x}$ & $-\infty$ & $-\cdots$ & & & $\cdots$ \\
\hline & Western mourning dove... & $\mathbf{x}$ & $\mathbf{x}$ & $-\infty$ & & $-\infty$ & & & & & $\ldots$ \\
\hline $\begin{array}{l}\text { Coccyzus americanus occiden- } \\
\text { talis. } \\
\text { Tyto alba pratincola }\end{array}$ & California cuckoo. & $\mathbf{x}$ & $\mathbf{x}$ & $\mathbf{x}$ & & & & & & & - \\
\hline urlanei........... & MacFarlane's screech owl. & $\bar{x}$ & $x$ & & & $x$ & $x$ & & & & - \\
\hline$t i \ldots \ldots$ & h owl... & |- - & $-\infty$ & $x$ & $x$ & $\ldots$ & $\ldots$ & & & & - \\
\hline 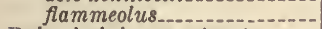 & ech owl. & & & $-\ldots$ & $-\infty-\infty$ & $\mathrm{x}$ & $-\cdots$ & & & & $-\infty$ \\
\hline saturatus..... & $\ldots$ & & -2 & $x$ & $\mathbf{x}$ &.--- & & & & & -5 \\
\hline allescens_..... & Western horned owl & $\mathrm{x}$ & $x$ & $-\ldots$ & & $\mathrm{x}$ & $\mathrm{x}$ & & & & $-\infty$ \\
\hline Glaucidium gnoma pinicola..-- & $\begin{array}{l}\text { Rocky Mountain pygmy } \\
\text { owl. }\end{array}$ & $-\infty$ & & & & $x$ & & & & & -.. \\
\hline lifornicum_....... & fornia pygmy owl..... & & & & & $\mathrm{x}$ & & & & & \\
\hline$l l i$ & owl & $\ldots$ & --- & $\ldots$ & $\mathbf{x}$ & $\ldots$ & $\ldots$ & -- & & & -- \\
\hline с hypugaea.- & owl_... & $\ldots$ & $\mathbf{x}$ & $\ldots-$ & & $\ldots$ & -- & & & & $\ldots$ \\
\hline caurina...... & otted owl ...... & $-\cdots$ & $\cdots$ & $\mathrm{x}$ & $\mathbf{x}$ & $-\cdots$ & $\ldots$ & & & -- & $-\infty$ \\
\hline s.............. & eared owl & $-\infty$ & $\begin{array}{l}x \\
x\end{array}$ & $\cdots-$ & $\mathbf{x}$ & $x$ & $-\cdots$ & $-\cdots$ & & & $\cdots$ \\
\hline $\begin{array}{l}\text { flammeus flammeus.-...-- } \\
\text { Cryptoglaux acadica acadica..-- }\end{array}$ & whet owl & $\begin{array}{c}x \\
---\end{array}$ & $\mathbf{x}$ & $(-\infty--$ & $\mathrm{x}$ & $\begin{array}{l}\mathbf{x} \\
\mathbf{x}\end{array}$ & $-\infty$ & & & & $-\infty$ \\
\hline $\begin{array}{l}\text { Phalaeonoptilus nuttalli nut- } \\
\text { talli. }\end{array}$ & Nuttall's poorwill & $\mathbf{x}$ & $\mathrm{x}$ & & & $\mathbf{x}$ & $\mathrm{x}$ & & & & $-\cdots$ \\
\hline Chordeiles minor hesperis ...... & Pacific nighthawk..- & & & & $\mathbf{x}$ & $\mathrm{x}$ & $x$ & & $\mathbf{x}$ & $\cdots$ & $\ldots$ \\
\hline Chaetura vauxi & 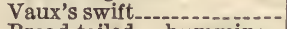 & $-\cdots$ & - & $\mathbf{x}$ & $\mathbf{x}$ & $-\cdots$ & --- & $\mathbf{x}$ & $-\cdots$ & $-\cdots$ & --- \\
\hline $\begin{array}{l}\text { Selasphorus platycercus platy- } \\
\text { cercus. }\end{array}$ & $\begin{array}{l}\text { Broad-tailed humming- } \\
\text { bird. }\end{array}$ & $\mathbf{x}$ & & $-\cdots$ & & $-\cdots$ & $-\cdots$ & $-\ldots$ & & & - \\
\hline tellufus calliope. & $\begin{array}{l}\text { Is hummingbird } \\
\text { pe hummingbird...-- }\end{array}$ & ...- & $\ldots$ & $\mathbf{x}$ & $\mathbf{x}$ & $\mid---$ & $\mid---$ & $\begin{array}{l}x \\
x\end{array}$ & $\begin{array}{l}\mathrm{x} \\
\mathrm{x}\end{array}$ & --- & $-\ldots$ \\
\hline n caurina... & fisher. & $\mathbf{x}$ & $x$ & $\mathrm{x}$ & $\mathrm{x}$ & $\mathbf{x}$ & $x^{-1}$ & $-\cdots$ & $-\cdots$ & -- & $-\infty$ \\
\hline fer............ & $N$ & $-\infty$ & & $\bar{x}$ & $\bar{x}$ & $\cdots-$ & $(--)$ &..- & --- & $-\cdots$ & $\ldots$ \\
\hline cafer collaris. & Hed meker......... & & & $-\cdots$ & $\mathbf{x}$ & $\mathbf{x}$ & & --- & $--\cdots$ & & $\ldots$ \\
\hline Ceophloeus pileatus picinus. & $\begin{array}{l}\text { Western pileated wood- } \\
\text { pecker. }\end{array}$ & & & $\mathrm{x}$ & $\bar{x}$ & $\mathrm{x}$ & $-\cdots$ & $\mathbf{x}$ & $\mathrm{x}$ & $-\cdots$ & $\cdots$ \\
\hline $\begin{array}{l}\text { Balanosphyra formicivora } \\
\text { bairdi. }\end{array}$ & Cálifornia woodpecker.... & $\mathbf{x}$ & & & & & & & & $-\cdots$ & \\
\hline lewis_............ & & $x$ & & $-\cdots$ & $x$ & $\mathbf{x}$ & & $-\cdots$ & $-\cdots$ & --- & $-\ldots$ \\
\hline Sphyrapicus varius nuchalis.... & Red-naped sapsucker & $-\cdots$ & & $(-.--$ & $-\ldots$ & --- & $\cdots$ & ---- & $\mathbf{x}$ & $-\cdots$ & $\ldots$ \\
\hline varius ruber.................... & $\begin{array}{l}\text { Northern red-breasted sap- } \\
\text { sucker. }\end{array}$ & & & $-\cdots$ & & $\mathbf{x}$ & $\ldots$ & $x$ & --- & --- & $-\cdots$ \\
\hline thyroideus thyroideus....... & sucker...- & & & & & & & ---- & $\mathbf{x}$ & $-\cdots$ & $-\cdots$ \\
\hline Dryobates villosus harrisi....... & r...... & $-\cdots$ & $\ldots-$ & $\mathbf{x}$ & $\mathbf{x}$ & --- & $\ldots$ & $\mathbf{x}$ & $-\ldots$ & $-\cdots$ & $-\ldots$ \\
\hline villosus orius & Iodoc woodpecker....... & $-\cdots$ & $-\infty-$ & $\cdots$ & $\cdots$ & $\mathbf{x}$ & $\cdots$ & $\cdots$ & $-\cdots-$ & $-\cdots$ & $\cdots$ \\
\hline villosus monticola.......... & $\begin{array}{l}\text { Rocky Mountain hairy } \\
\text { woodpecker. }\end{array}$ & & & & & $x$ & & & $\mathbf{x}$ & & \\
\hline
\end{tabular}

\footnotetext{
woodpecker.
} 
TABLE 3.-Breeding birds of Oregon, by life zones-Continued

\begin{tabular}{|c|c|c|c|c|c|c|c|c|c|c|c|}
\hline \multirow{3}{*}{ Species } & \multirow{3}{*}{ Common name } & \multicolumn{10}{|c|}{ Zone } \\
\hline & & \multicolumn{2}{|c|}{ Sonoran } & \multicolumn{4}{|c|}{ Transition } & \multicolumn{2}{|c|}{$\begin{array}{l}\text { Cana- } \\
\text { dian }\end{array}$} & \multirow[b]{2}{*}{ 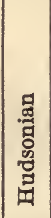 } & \multirow[b]{2}{*}{ 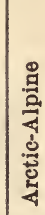 } \\
\hline & & 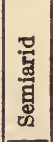 & $\frac{3}{4}$ & 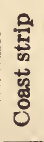 & 兽 & 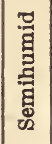 & $\frac{7}{4}$ & 兽 & 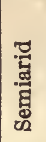 & & \\
\hline Dryobates pubescens leucurus_- & Batchelder's woodp & & & & & $\mathbf{x}$ & $\mathrm{x}$ & & & & \\
\hline $\begin{array}{l}\text { pubescens gairdneri } \\
\text { albolarvatus albolarvatus. }\end{array}$ & $\begin{array}{l}\text { Gairdner's woodpecl } \\
\text { Northern white-h }\end{array}$ & & & $\mathbf{x}$ & $x$ & $\frac{x}{x}$ & & & & & \\
\hline Picoides arcticus.............. & $\begin{array}{l}\text { woodpecker. } \\
\text { Arctio three-toed wood- } \\
\text { pecker. }\end{array}$ & & & & & & & & $\mathbf{x}$ & $\mathbf{x}$ & \\
\hline Picoides tridactylus fasciatus...- & $\begin{array}{l}\text { Alaska three-toed wood- } \\
\text { pecker. }\end{array}$ & & & & & & & & $\mathbf{x}$ & $\mathrm{x}$ & \\
\hline & Eastern kingbird & $x$ & & & & & & & & & \\
\hline vyiarchus cinerascens cinera- & $\begin{array}{l}\text { Arkansas kingbird } \\
\text { Ash-throated flycatch }\end{array}$ & $\begin{array}{l}\mathbf{x} \\
\mathbf{x}\end{array}$ & $\begin{array}{l}x \\
x\end{array}$ & $\cdots$ & $-\cdots$ & & & & $\cdots$ & & - \\
\hline sceps & Ash-lmualed Hycalche & $\mathbf{x}$ & $x$ & & & & $\mathbf{x}$ & & & & -- \\
\hline idonax trailli $t$ & Alder $\mathrm{f}$ & & & & $\mathbf{x}$ & $\mathbf{x}$ & & & & & $\ldots$ \\
\hline ondi..... & Hamm & ... & - & $\cdots$ & $-\infty$ & $\hat{x}$ & -. & & $x$ & & \\
\hline righti........... & Wright's & $\ldots$ & - & $-\ldots$ & $-\cdots$ & $x$ & $\therefore$ & - & $\mathbf{x}$ & & $\cdots$ \\
\hline $\begin{array}{l}\text { griseus } \\
\text { difficilis difficilis }\end{array}$ & $\begin{array}{l}\text { Gray flycatcher } \\
\text { Western flycatcher.- }\end{array}$ & $\cdots$ & $x$ & - & $-\cdots$ & $\bar{x}$ & -- & $\cdots$ & & & $\cdots$ \\
\hline $\begin{array}{l}\text { Myiochanes richardsoni rich- } \\
\text { ardsoni. }\end{array}$ & Western wood pewee & $\cdots$ & (n) & $x$ & $\begin{array}{l}x \\
x\end{array}$ & $\begin{array}{c}x \\
---\end{array}$ & & & -- & & $-\cdots$ \\
\hline Nuttallornis mesoleucus ....... & Olive-sided flycatc & & & & & & & $x$ & $\mathbf{x}$ & & \\
\hline cola....... & Pallid $\mathrm{h}$ & --- & $\mathrm{x}$ & $-\ldots$ & $\ldots$ & $\cdots$ & $\mathbf{x}$ & $\cdots+$ & & & $\ldots$ \\
\hline Tachyci & $\begin{array}{l}\text { Dusky } \\
\text { Violet- }\end{array}$ & $\cdots$ & $\mathbf{x}$ & $x$ & $-\cdots$ & $x$ & $x$ & $-\cdots$ & $\bar{x}$ & & $-\cdots$ \\
\hline Irido & Tree & & & $\bar{x}$ & $\mathbf{x}$ & $\bar{x}$ & & $\mathbf{x}$ & $\mathbf{x}$ & & - \\
\hline Riparia riparia riparia.......- & Bank s & $\mathrm{x}$ & $\mathbf{x}$ & $\mathbf{x}$ & $\mathrm{x}$ & $\mathbf{x}$ & $\mathrm{x}$ & & & & - \\
\hline $\begin{array}{l}\text { Stelgidopteryx ruficollis serri- } \\
\text { pennis. }\end{array}$ & Rough-winged swal & $x$ & $\bar{x}$ & $\mathbf{x}$ & $x$ & $\vec{x}$ & $x$ & & $\cdots$ & & -- \\
\hline ster............ & & $\mathbf{x}$ & $\mathbf{x}$ & $\mathbf{x}$ & $\mathbf{x}$ & $\mathbf{x}$ & $\mathrm{x}$ & -- & & & -- \\
\hline albifrons & Northe & $x$ & $x$ & $x$ & $x$ & $x$ & $x$ & --- & -- & & - \\
\hline apitalis. & $\begin{array}{l}\text { Western martin } \\
\text { Rocky Mountain }\end{array}$ & $\mathbf{x}$ & $-\cdots$ & $\mathrm{x}$ & $\begin{array}{c}x \\
-\cdots\end{array}$ & $x_{-\infty}^{x}$ & $\cdots$ & $-\cdots$ & $x$ & & $\cdots$ \\
\hline (4) & Oregon jay........ & - n lo & $\cdots$ & $\mathrm{x}$ & $\cdots$ & $\cdots$ & $\cdots$ & $x$ & & & \\
\hline & Gray jay & ... & $\cdots$ & & $\cdots$ & $\cdots$ & - & $\ldots$ & $x$ & & \\
\hline rbonacea.- & Coast jay & $\ldots$ & $-\cdots$ & $x$ & $x$ &.-- & $-\cdots$ & $\cdots$ & $\cdots$ & & \\
\hline $\begin{array}{l}\text { stelleri annectens } \\
\text { Aphelocoma californica califor- }\end{array}$ & $\begin{array}{l}\text { Black-headed jay } \\
\text { California jay... }\end{array}$ & $x$ & $\mid$ & $\cdots$ & $\mid--$ & $|--|$ & 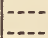 & $\begin{array}{c}x \\
-\cdots\end{array}$ & $x$ & -- & $-\infty$ \\
\hline $\begin{array}{l}\text { nica. } \\
\text { californica woodhousei }\end{array}$ & Woodhouse's & & - & & & & & & & & \\
\hline Pica & & -.. & $x$ & $\ldots$ & (n) & & $\mathbf{x}$ & & & & \\
\hline Corm & & ... & $\mathbf{x}$ & ... & -- & - & $\bar{x}$ & $-\cdots$ & & & \\
\hline & Wes & $x$ & $\mathbf{x}$ & $-\ldots$ & $\cdots$ & $x$ & $-\ldots$ & -... & $\ldots$ & & \\
\hline & Nor & ... & $\cdots$ & $x$ & $-\ldots$ & $\cdots$ & $\ldots$ &..- & & & \\
\hline phalus.. & Pino & $x$ & $x$ & $\cdots$ & $-\cdots$ & -1 & & $\cdots$ & & $-\frac{1}{x}$ & \\
\hline & &.--- & $-\cdots$ & $\cdots$ & $-\cdots$ & $x$ & $-\cdots$ & -- & $\cdots$ & $x$ & $-\cdots$ \\
\hline $\begin{array}{l}\text { Penthestes atricapillus septen- } \\
\text { trionalis. }\end{array}$ & Long-tailed $\mathrm{cl}$ & $-\cdots$ & $x$ & & & $\mathrm{x}$ & & & & & \\
\hline ntalis.... & $\begin{array}{l}\text { Oregon } \\
\text { Mounts }\end{array}$ & & & $\mathbf{x}$ & $x$ & & & & & & \\
\hline rufescens rufescens............... & tnut-backed chicka- & $-\ldots$ & (n) & $\mathrm{x}$ & $x$ & $-\cdots$ & & $x$ & $x$ & -- & \\
\hline is inornatus seques- & Oregon titmouse.. & $\mathbf{x}$ & & & & & & & & & \\
\hline & & $x$ & & & & & & & & & \\
\hline Psalt & & & & $x$ & .... &.- & $-\cdots$ & & .... & & \\
\hline & Cal & $\mathbf{x}$ & - & & $\ldots$ & 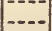 & $\cdots$ & 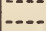 & - & $-\ldots$ & - \\
\hline & Lead-colored bush tit..... & - & $\mathbf{x}$ &.- & $\ldots$ & -..- & $-\ldots$ & 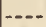 & & & \\
\hline Sitta carolinensis nelsoni. & Rocky Mountain nut- & --- & $\cdots$ & $-\cdots$ & 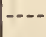 & $\cdots$ & $-\cdots$ & $x$ & $\mathbf{x}$ & & \\
\hline & & & & & $\mathbf{x}$ & $\mathbf{x}$ & & $\mathbf{x}$ & $\mathbf{x}$ & & \\
\hline & & & $\cdots$ & $\mathrm{x}$ & $x$ & & $-\ldots$ & $\mathbf{x}$ & $x$ & & \\
\hline $\begin{array}{r}\text { pygm } \\
\text { Certhia fo }\end{array}$ & $\begin{array}{l}\text { Pygmy nuth } \\
\text { Rocky Mou }\end{array}$ & & & -- & $\cdots$ & $x$ & --- & $x$ & $\mathrm{x}$ & & \\
\hline & Sie &.-- & 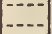 & $\ldots$ & --- & 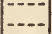 & $-\cdots$ & $\vec{x}$ & $\vec{x}$ & 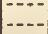 & \\
\hline & & & & $x$ & $x$ &..-- & $\ldots$ & $\ldots$ & & .... & \\
\hline & & 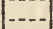 & $\ldots$ & $\mathbf{x}$ & & -...- & & & & & \\
\hline & Dipper & & ....- & $\cdots$ & $\mathbf{x}$ & $\mathbf{x}$ & $\mathbf{x}$ & $\mathrm{x}$ & $\mathbf{x}$ & $\cdots$ & \\
\hline $\begin{array}{l}\text { Troglodytes aedon parkman } \\
\text { Nannus hiemalis pacificus. }\end{array}$ & $\begin{array}{l}\text { Western house wren } \\
\text { Western winter wren... }\end{array}$ & & & $x$ & $\begin{array}{l}x \\
x\end{array}$ & & & & & & \\
\hline
\end{tabular}


TABLE 3.-Breeding birds of Oregon, by life zones-Continued

\begin{tabular}{|c|c|c|c|c|c|c|c|c|c|c|c|}
\hline \multirow{3}{*}{ Species } & \multirow[b]{3}{*}{ Common name } & \multicolumn{10}{|c|}{ Zone } \\
\hline & & \multicolumn{2}{|c|}{ Sonoran } & \multicolumn{4}{|c|}{ Transition } & \multicolumn{2}{|c|}{$\begin{array}{l}\text { Cana- } \\
\text { dian }\end{array}$} & \multirow[b]{2}{*}{ 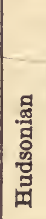 } & \multirow[b]{2}{*}{ 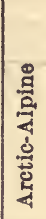 } \\
\hline & & 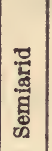 & 龸 & 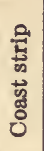 & 宽 & 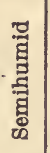 & 娄 & 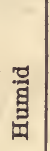 & 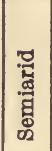 & & \\
\hline Thryomanes bewicki calophonus & Seattle wren & & & & $\mathbf{x}$ & $x$ & & & & & \\
\hline $\begin{array}{l}\text { bewicki drymoecus } \\
\text { Telmatodytes palustris plesius.... }\end{array}$ & San Joaquin wren. & $x$ & $x^{-}$ & & $-\cdots$ & $\cdots$ & & & & & -.... \\
\hline $\begin{array}{l}\text { Telmatodytes palustris plestus.- } \\
\text { palustris paludicola }\end{array}$ & $\begin{array}{l}\text { Western marsh wren } \\
\text { Tule wren }\end{array}$ & $\mathbf{x}$ & & $x$ & $\bar{x}$ & (n- & & & $\cdots$ & & $-\cdots$ \\
\hline Catherpes mexicanus punctula- & Dotted wren & & $x$ & & & & & & & & (n) \\
\hline $\begin{array}{l}\text { Salpincles obsoletus obsoletus... } \\
\text { Dumetella carolinensis.......... }\end{array}$ & $\begin{array}{l}\text { Common rock wren } \\
\text { Catbird. }\end{array}$ & $\mathrm{x}$ & $\begin{array}{l}\mathbf{x} \\
\mathbf{x}\end{array}$ & & & $\mathrm{x}$ & & & & & $\cdots$ \\
\hline Oreoscoptes montanus............. & Sage thrasher & & $\ldots$ & & & & $x$ & & & & - n \\
\hline Turdus migratorius propinquus & Western robin & & $\ldots$ & $x$ & $\mathrm{x}$ & $\mathbf{x}$ & & $x$ & $x$ & & (n) \\
\hline Ixoreus naevius naevius & Pacific varied thrush & -... & $-\cdots$ & $\mathbf{x}$ & $-\cdots$ & $\cdots$ & $\cdots-$ & $\mathbf{x}$ & & & $\cdots$ \\
\hline $\begin{array}{l}\text { naevius meruloides } \\
\text { Hylocichla guttata sequoiensis.-. }\end{array}$ & $\begin{array}{l}\text { Northern varied thrush } \\
\text { Sierra hermit thrush.. }\end{array}$ & & (n... & $\ldots$ & $-\ldots-$ & $-\ldots-1$ & & --- & $\mathbf{x}$ & & $-\cdots$ \\
\hline guttata auduboni & Audubon's hermit thrush. & & 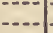 & - n lo & (n) & 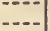 & & $\stackrel{A}{-\infty}$ & $\bar{x}$ & & - \\
\hline ustulata ustulata...... & Russet-backed thrush...... & &...- & $\mathrm{x}$ & $x$ & & & $\mathbf{x}$ & $\mathbf{x}$ &.-- & (n) \\
\hline ustulata swainsoni & Olive-backed thrush....... & & -..- & & & $x$ & & $x$ & $\cdots$ & $\cdots$ & $\ldots$ \\
\hline Sialia mexicana occidentalis.... & Western bluebird &.-- & $\cdots$ & $\mathbf{x}$ & $\mathbf{x}$ & 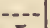 & & $\cdots$ & & & $-\ldots$ \\
\hline 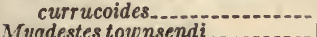 & Mountain bluebird......... & & $-\cdots$ & $\cdots$ & $\cdots$ & $\mathbf{x}$ & $\mathbf{x}$ & 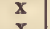 & $\mathrm{x}$ & --- &.-- \\
\hline $\begin{array}{l}\text { Myadestes townsendi.......... } \\
\text { Regulus satrapa olivaceus..... }\end{array}$ & $\begin{array}{l}\text { Townsend's solitaire......- } \\
\text { Western golden-crowned }\end{array}$ & & 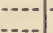 & $x$ & $x-$ & 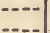 & 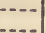 & $\mathbf{x}$ & $x$ & &..-- \\
\hline & kinglet. & & & & & & & & & & $-\infty$ \\
\hline Corthylio calendula cineraceus_- & $\begin{array}{l}\text { Western ruby - crowned } \\
\text { kinglet. }\end{array}$ & & & & & & & $\mathbf{x}$ & $\mathbf{x}$ & & \\
\hline Anthus spinoletta rubescens....- & American pipit............. & & & & & -- & &..-- & & --- & $x$ \\
\hline Bombycilla cedrorum & Cedar waxwing & -1 & $-\infty$ & $x$ & $\mathbf{x}$ & $\mathbf{x}$ & & $\cdots-$ & $-\cdots$ & & $\cdots$ \\
\hline $\begin{array}{l}\text { Lanius ludovicianus excubi- } \\
\text { torides. }\end{array}$ & White-rumped shrike...... & $\mathrm{x}$ & $\mathbf{x}$ & & -.. & $\cdots$ & & $\cdots$ & & $\cdots$ & $\cdots$ \\
\hline Vireo huttoni hutloni. & Hutton's vireo & & $-\cdots$ & $x$ & $\frac{x}{x}$ & $-\cdots$ & & & & & \\
\hline $\begin{array}{l}\text { solitarius cassini........ } \\
\text { otivaceus }\end{array}$ & $\begin{array}{l}\text { Cassin's vire } \\
\text { Red-eyed vi }\end{array}$ & - & 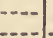 & $\mathbf{x}$ & $\begin{array}{l}x \\
x\end{array}$ & $x$ & 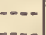 & $-\cdots$ & $-\cdots$ & $-\cdots$ & $-\cdots$ \\
\hline $\begin{array}{l}\text { olvoaceus } \\
\text { gilvus swain }\end{array}$ & Western war & $x$ & $x$ & (n & $\begin{array}{l}x \\
x\end{array}$ & (n) & & & & $\cdots$ & $-\cdots$ \\
\hline Vermivora celata lutescens & Lutescent warbler........... & & 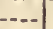 & $x$ & $\bar{x}$ & & & ...- & $-\ldots$ & - n lo & $\cdots$ \\
\hline ruficapilla ridgwayi & Calaveras & &..-- & -..- & $x$ & $\mathbf{x}$ & $\cdots$ & $\mathbf{x}$ & $\mathbf{x}$ & $\ldots$ & $-\cdots$ \\
\hline Dendroica aestiva aestiva & Eastern yellow warbler_...- & $x$ & $x$ & $\cdots-$ & 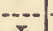 & $x$ & $\cdots$ & $\cdots$ & $\cdots--$ & & $-\cdots$ \\
\hline $\begin{array}{l}\text { aestiva brewsteri. } \\
\text { auduboni auduboni }\end{array}$ & $\begin{array}{l}\text { California yellow warbler. } \\
\text { Audubon's warbler......... }\end{array}$ & -- & (n) & $x$ & $\frac{x}{x}$ & $\frac{x}{x}$ & & 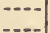 & & & $-\infty$ \\
\hline nigrescens_.............. & Black-throated gray war- &..- & -...- & $\cdots$ & $\vec{x}$ & $x$ & & $\cdots$ & & & $\cdots$ \\
\hline lown & Townsend's & & & & $x$ & $\mathbf{x}$ & & & & & \\
\hline occide & Hermit warbler & & -- & & -.- & $\ldots$ & & $\mathbf{x}$ & $\mathbf{x}$ & & $\ldots$ \\
\hline 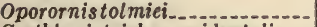 & Macgillivray's war & $\cdots$ & $\cdots$ & $x$ & $x$ & $x$ & $\ldots$ & $\ldots$ & $\ldots$ & & \\
\hline Geothly pistrichas occidentalis ...- & Western yellow-throat. . & $x$ & $x$ & & & ... & & & -... & & - \\
\hline $\begin{array}{r}\text { trichas ariz } \\
\text { Icteria virens lo }\end{array}$ & Pacific yellow-throat......- & -... & $\ldots$ & $\mathbf{x}$ & $\mathbf{x}$ &.-- & & $-\cdots$ & -... & $\cdots-$ & - \\
\hline $\begin{array}{l}\text { Icteria virens longicauda } \\
\text { Wilsonia pusilla pileolata }\end{array}$ & Long-tailed chat_-_-_-..-- & $\mathbf{x}$ & $\mathrm{x}$ & & & $\cdots-$ & & 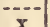 & & & \\
\hline Wilsonia pusilla pileolata....... & $\begin{array}{l}\text { Northern pileolated war- } \\
\text { bler. }\end{array}$ & & & & & & & $x$ & $\mathbf{x}$ & $-\cdots$ & \\
\hline $\begin{array}{l}\text { pusilla chrys } \\
\text { Setophaga ruticil }\end{array}$ & $\begin{array}{l}\text { Golden pileolated } \\
\text { A merican redstart }\end{array}$ & -1 & & $\mathbf{x}$ & $x$ & x-1 & & $\cdots+$ & 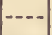 & & $\cdots$ \\
\hline $\begin{array}{l}\text { Setophagar } \\
\text { Dolichonyx }\end{array}$ & $\begin{array}{l}\text { American r } \\
\text { Bobolink }\end{array}$ & & $x$ & & $\ldots$ & & (n-.. & ( n & (n) & & $\cdots$ \\
\hline Sturnella neglecta & Western meadow lark & $x$ & $\hat{x}$ & $\ldots-$. & $\mathrm{x}$ & $x$ & $\bar{x}$ & (n) & (n) & (n) & . \\
\hline $\begin{array}{l}\text { Xanthocephalus xanthocepha- } \\
\text { lus. }\end{array}$ & Yellow-headed blackbird. & & $\bar{x}$ & & & $\cdots-1$ & $x$ & & $-\ldots$ & & - \\
\hline $\begin{array}{l}\text { Agelaius phoeniceus nevadensis } \\
\text { phoeniceus caurinus }\end{array}$ & Nevada $\mathrm{r}$ & $\mathbf{x}$ & $\mathbf{x}$ & & & $\mathbf{x}$ & $\mathbf{x}$ & & & & \\
\hline & Northwestern red & & & $\mathbf{x}$ & $x$ & (2) & - & - & -...- & -..- & \\
\hline $\begin{array}{l}\text { Iclerus bullocki...- } \\
\text { Euphagus cyanoce }\end{array}$ & $\begin{array}{l}\text { Bullock's oriole } \\
\text { Brewer's blackbird. }\end{array}$ & $\begin{array}{c}x \\
x\end{array}$ & $\begin{array}{l}x \\
x\end{array}$ & & & & $\mathrm{x}$ & & (n) & & \\
\hline Molothrus ater artem & Nevada cov & $\vec{x}$ & $\vec{x}$ & - n lo & - n lo & $\mathrm{x}$ & $\mathrm{x}$ & (1) & $\mid-\cdots$ & (n) & .... \\
\hline Piranga ludoviciana & Western tana & $\ldots$ & $\ldots$ & -... & $\ldots$ & $\mathbf{x}$ & & -... &.--- & ...- & $-\ldots$ \\
\hline $\begin{array}{l}\text { Hedymeles melanocephalus me- } \\
\text { lanocephalus. }\end{array}$ & Black-headed grosbeak.... & $x$ & $\ldots$ & & & $x$ & & & & & \\
\hline Passerina amoena & Lazuli bur & $x$ & & & & & & & & & \\
\hline $\begin{array}{l}\text { Hesperiphona vespertina brooksi } \\
\text { Carpodacus purpureus califor- }\end{array}$ & Western e & ...- & $\ldots-$. &..-- & $\mathrm{x}$ & $\mathbf{x}$ & -...- & $-\cdots$ & 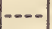 &..-- & \\
\hline $\begin{array}{l}\text { Carpodacus purpureus califor- } \\
\text { nicus. }\end{array}$ & & & 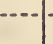 & $\cdots$ & $\mathbf{x}$ & $x$ & & --- & & -.. & \\
\hline mexicanus frontalis & Cassin's purple finch & & & & & & & $\mathbf{x}$ & $x$ & -.. & \\
\hline $\begin{array}{l}\text { mexicanus frontalis } \\
\text { Pinicola enucleator montana...- }\end{array}$ & $\begin{array}{l}\text { Common house finch } \\
\text { Rocky Mountain pine gros- }\end{array}$ & $\mathbf{x}$ & $\mathbf{x}$ & & & & & -- & $-\cdot$ & $x$ & \\
\hline & beak. & & & & & & & & & & \\
\hline & 79 & & & & & & & & & & \\
\hline
\end{tabular}


TABLE 3.-Breeding birds of Oregon, by life zones-Continued

\begin{tabular}{|c|c|c|c|c|c|c|c|c|c|c|c|}
\hline \multirow{3}{*}{ Species } & \multirow{3}{*}{ Common name } & \multicolumn{10}{|c|}{ Zone } \\
\hline & & \multicolumn{2}{|c|}{ Sonoran } & \multicolumn{4}{|c|}{ Transition } & \multicolumn{2}{|c|}{$\begin{array}{l}\text { Cana- } \\
\text { dian }\end{array}$} & \multirow[b]{2}{*}{ 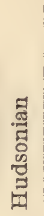 } & \multirow[b]{2}{*}{ 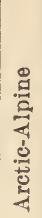 } \\
\hline & & 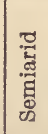 & 娄 & 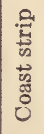 & 을 & 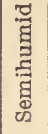 & : & : & 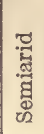 & & \\
\hline Spinus pinus pinus. & Northern pine siskin & & & & & & & $\mathrm{x}$ & $\mathbf{x}$ & & \\
\hline tristis pallidus.... & Pale goldfinch...... & & $\mathrm{x}$ & -.. & & & $x$ & $-\cdots$ & $\therefore$ & & .... \\
\hline tristis salicamans & Willow goldfinch & $\mathrm{x}$ & $\ldots$ & - & $\mathrm{x}$ & $\mathrm{x}$ & $\ldots$ & $-\cdots$ & $\ldots$ & & \\
\hline psaltria hesperophilus.-. & Green-backed goldfinch. & $\mathrm{x}$ & & & & $x$ & -.. & $\ldots$ & $\ldots$ & & \\
\hline Loxia curnirostra bendirei.-. & Bendire's crossbill & & $\ldots$ & - & $\ldots$ & & 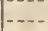 & $\mathrm{x}$ & $x$ & & \\
\hline Oberholseria chlorura & Green-tailed towhee.- & $\ldots$ & & $\ldots$ & - & $\mathbf{x}$ & $\mathrm{x}$ & - & $\ldots$ & & \\
\hline Pipilo maculatus curtatus. & Nevada towhee...... & & & & & $\mathbf{x}$ & $\mathrm{x}$ & ... & & & \\
\hline maculatus oregonus.... & Oregon towhee.... & $\cdots$ & -- & $\mathrm{x}$ & $\mathrm{x}$ & & & -- & & & \\
\hline fuscus crissalis & California towhee. & $x$ & &..- & 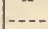 & & ... & $-\ldots$ & $\ldots$ & & \\
\hline $\begin{array}{l}\text { Passerculus sand wichensis } \\
\text { nevadensis. }\end{array}$ & Nevada Savannah sparrow & $\bar{x}$ & $x$ & - & - & $\cdots$ & $\cdots$ & $-\cdots$ & $\cdots$ & & (n) \\
\hline sandwichensis bryanti & Bryant's sparrow & & -... & $-\ldots$ & $\mathrm{x}$ & & $-\ldots$ & -.. & & & \\
\hline $\begin{array}{l}\text { Pooecetes gramineus affinis..... } \\
\text { gramineus confinis....... }\end{array}$ & $\begin{array}{l}\text { Oregon vesper sparrow } \\
\text { Western vesper sparrow } \text { s._. }^{-}\end{array}$ & $-\cdots$ & - & $-\cdots$ & $x$ & $x$ & $\cdots$ & $-\cdots$ & $-\cdots$ & - & -... \\
\hline $\begin{array}{l}\text { Chondestes grammacus striga- } \\
\text { tus. }\end{array}$ & Western lark sparrow ..... & $x$ & $x$ & $\cdots$ & $\cdots$ & $-\cdots$ & $\cdots$ & $(-\cdots$ & $\cdots$ & & \\
\hline $\begin{array}{l}\text { Amphispiza bilineata deserti- } \\
\text { cola. } \\
\text { nevadensis nevadensis..... }\end{array}$ & $\begin{array}{l}\text { Desert sparrow } \\
\text { Northern sage sparrow.... }\end{array}$ & $\ldots$ & $\mathrm{x}$ & & & & .... & -- & & & \\
\hline Junco oreganus shufeldti & Shufeldt's junco...... & $-\infty$ & A & n. & $\mathrm{x}$ & $\mathrm{x}$ & ( n & $\mathrm{x}$ & $\bar{x}$ & & \\
\hline oreganus thurberi....... & Thurber's junco & $\ldots$ & .... & $-\ldots$ & $\cdots$ & .... & $\ldots$ & $\mathbf{x}$ & $\bar{x}$ & & \\
\hline Spizella passerina arizonae..... & Western chipping sparrow. & & -.. & & -... & $\mathrm{x}$ & $\mathrm{x}$ & & & & \\
\hline breweri breweri & Brewer's sparrow & $\ldots$ & $\mathrm{x}$ & -.. & -... & -... & .... & $\mathrm{x}$ & $\ldots$ & $\ldots$ & \\
\hline $\begin{array}{l}\text { Zonotrichia le uc o phrys } \\
\text { leucophrys. }\end{array}$ & & & $\ldots$ & $-\cdots$ & -... & $\ldots$ & $-\cdots$ & $\mathrm{x}$ & $\mathrm{x}$ & & \\
\hline leucophrys pugetensis...... & Puget Sound sparrow & $-\ldots$ & $-\ldots$ & $\mathrm{x}$ & $\mathrm{x}$ & $-\ldots$ & -..- & $-\cdots$ & $-\ldots$ & -- & .... \\
\hline $\begin{array}{l}\text { Passerella iliaca schistacea } \\
\text { Melospiza lincolni lincolni...- }\end{array}$ & $\begin{array}{l}\text { Slate-colored fox sparrow - - } \\
\text { Lincoln's sparrow }\end{array}$ & $-\cdots$ & $\cdots$ & $-\cdots$ & $-\cdots$ & $x$ & -1 & $\mathrm{x}$ & $x-$ & & \\
\hline melodia fallax. & Mountain song sparrow & $\ldots$ & $\ldots$ & $\ldots$ & $-\ldots$ & $\mathrm{x}$ & $\mathrm{x}$ & & -1 & & \\
\hline melodia fisherella... & Modoc song sparrow & $x$ & $\mathrm{x}$ & -1 & (n- & A & $\begin{array}{c}\lambda \\
---\end{array}$ & $-\cdots$ & $-\cdots$ & -1 & \\
\hline melodia morphna... & Rusty song sparrow & $\ldots$ &.-- & $\mathrm{x}$ & $\mathrm{x}$ & $-\ldots$ & $\ldots$ & $\ldots$ & $-\ldots$ & 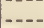 & $-\ldots$ \\
\hline
\end{tabular}

TABLE 4.-Plants of the Upper Sonoran Zone in Oregon

\begin{tabular}{|c|c|c|c|c|c|}
\hline \multirow[b]{2}{*}{ Species } & \multirow{2}{*}{ Common name 1} & \multicolumn{3}{|c|}{ Semiarid } & \multirow{2}{*}{$\begin{array}{c}\text { Arid } \\
\begin{array}{c}\text { Inte- } \\
\text { rior } \\
\text { valleys }\end{array}\end{array}$} \\
\hline & & $\begin{array}{c}\text { Kla- } \\
\text { math } \\
\text { Valley }\end{array}$ & $\begin{array}{l}\text { Rogue } \\
\text { River } \\
\text { Val- } \\
\text { leys }\end{array}$ & $\begin{array}{c}\mathrm{Co-} \\
\text { lumbia } \\
\text { Valley }\end{array}$ & \\
\hline Abronia mellifera & Sandverbena_.. & & & $\mathrm{x}$ & $\mathrm{x}$ \\
\hline Achyrachaena mollis.. & Blowwives ............ & & $\mathrm{x}$ & & \\
\hline $\begin{array}{l}\text { Adenostegia ramosa } \\
\text { viscida }\end{array}$ & Bird-in-the-bush & & & & $\mathrm{x}$ \\
\hline Agropyron lanceolatum & Wheatgrass. & $\mathbf{x}$ & $\lambda$ & & \\
\hline Allium bolanderi.... & Slender onion. & & $\mathbf{x}$ & & \\
\hline Allocarya mollis...-. & Soft borage & & & $\mathrm{x}$ & $x$ \\
\hline Amelanchier utahensi & Utah serviceberry..... & -- & & $\mathrm{x}$ & \\
\hline Amsinckia tessellata & Fiddleneck & & 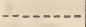 & $\mathrm{x}$ & $\mathrm{x}$ \\
\hline Anogra pallida..... & Pale evening-primrose & & 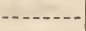 & $\mathbf{x}$ & $x$ \\
\hline & Low evening-primrose & & -........ & .....- & $\mathrm{x}$ \\
\hline Antennaria argentea.. & White pussytoes.................. & & $\mathrm{x}$ & & $\mathrm{x}$ \\
\hline luzuloides............ & Slender pussytoes. & & $--n$ & 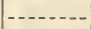 & $x$ \\
\hline Aplopappus carthamoides_-_--_- & Goldenweed & & & & $\mathrm{x}$ \\
\hline lanceolatus & do & & & & $\mathrm{x}$ \\
\hline Arabis whiteadi & Rockcress ................ & & 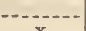 & $x$ & (a) \\
\hline $\begin{array}{l}\text { Arenaria franklini.- } \\
\text { douglasii....... }\end{array}$ & $\begin{array}{l}\text { Franklin sandwort } \\
\text { Douglas sandwort }\end{array}$ & & & & \\
\hline
\end{tabular}

1 Common names have been taken largely from Standardized Plant Names (published by the American Joint Committee on Horticultural Nomenclature). 
TABLE 4.-Plants of the Upper Sonoran Zone in Oregon-Continued

\begin{tabular}{|c|c|c|c|c|c|}
\hline & & & Ser & & Arid \\
\hline Species & Common name & $\begin{array}{c}\text { Kla- } \\
\text { math } \\
\text { Valley }\end{array}$ & $\begin{array}{l}\text { Rogue } \\
\text { River } \\
\text { Val- } \\
\text { leys }\end{array}$ & $\begin{array}{c}\text { Co- } \\
\text { lumbia } \\
\text { Valley }\end{array}$ & $\begin{array}{l}\text { Inte- } \\
\text { rior } \\
\text { valleys }\end{array}$ \\
\hline Artemisia douglasii. & Douglas sagebrush & & & $\mathbf{x}$ & \\
\hline 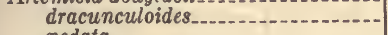 & gon & & $\mathbf{x}$ & $\mathbf{x}$ & \\
\hline (n) & Dwarf sagebrush & & $-\cdots$ & & $\mathbf{x}$ \\
\hline (n) & Bud sagebrush & & & & $\mathbf{x}$ \\
\hline 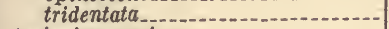 & Big sagebrush..- & $\mathbf{x}$ & & $\mathbf{x}$ & $\mathbf{x}$ \\
\hline - & ed........... & $\bar{x}$ & $\mathbf{x}$ & $\mathbf{x}$ & $\mathbf{x}$ \\
\hline n-nen & Mexican milkweed & & $\mathbf{x}$ & $\mathbf{x}$ & $\mathbf{x}$ \\
\hline nand & Milkvetch. & & $\mathbf{x}$ & & \\
\hline (n) & 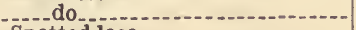 & & $\mathbf{x}$ & -........ & \\
\hline - & - & & & $\mathbf{x}$ & $\mathbf{x}$ \\
\hline & $-2-2-2-2-2-4$ & & $\mathbf{x}$ & & \\
\hline 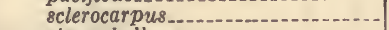 & (non & & $-\cdots$ & $\mathbf{x}$ & $\mathbf{x}$ \\
\hline$-1-2-1-2-1$ & 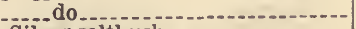 & & $-\ldots . .$. & $x$ & $\mathbf{x}$ \\
\hline 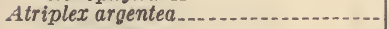 & - & & $-\ldots .$. & & $\mathrm{x}$ \\
\hline 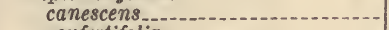 & oush_............... & $-\ldots . . .-1$ & $-\ldots .$. & & $\mathbf{x}$ \\
\hline 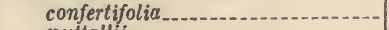 & le & & $-\ldots$ & & $x$ \\
\hline 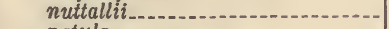 & - & & $\cdots--$ & & $x$ \\
\hline 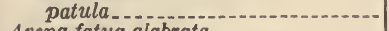 & 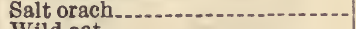 & & 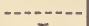 & & $\mathbf{x}$ \\
\hline 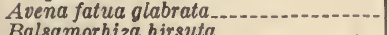 & 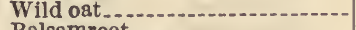 & & $x$ & & \\
\hline ita. & 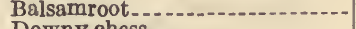 & -- & $-\cdots$ & & \\
\hline 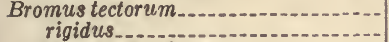 & 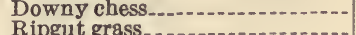 & $\mathbf{x}$ & $\mathbf{x}$ & $\mathbf{x}$ & K \\
\hline 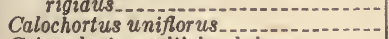 & 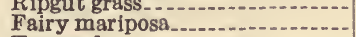 & & $\begin{array}{l}x \\
x\end{array}$ & & \\
\hline andulosa & - & & $\hat{x}$ & & $\mathrm{x}$ \\
\hline$n$ & n-n & - & $-\ldots-$. & & $\mathbf{x}$ \\
\hline $2-2-2-2-2-1$ & anbya. & & & - & $x$ \\
\hline (n) & 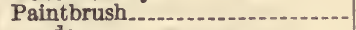 & & -- & $\mathbf{x}$ & \\
\hline 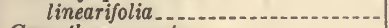 & 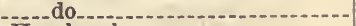 & & & $-\ldots . . .+-$ & $\mathrm{x}$ \\
\hline 每 & ush. & & $\mathbf{x}$ & & \\
\hline (n) & 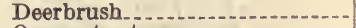 & - n... & $\mathbf{x}$ & & \\
\hline - & - & $\ldots$ & $\mathbf{x}$ & $-\ldots+n-1$ & \\
\hline - & Y & & & $\mathrm{x}$ & \\
\hline 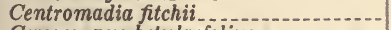 & 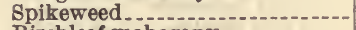 & $-\ldots . . .-1$ & $\mathbf{x}$ & & \\
\hline Cercocarpus betulaefolius. & $\operatorname{any} y_{\ldots} \ldots \ldots$ & $\mathbf{x}$ & $x$ & & \\
\hline is douglasii..................... & 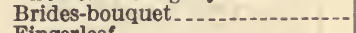 & $\mathbf{x}$ & $\mathbf{x}$ & $\mathrm{x}$ & $\mathrm{x}$ \\
\hline 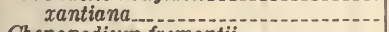 & - & & & & $\mathbf{x}$ \\
\hline tii & (n) & & & & $x$ \\
\hline $\operatorname{dianum}$ & - non & & $\mathbf{x}$ & & \\
\hline 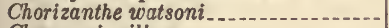 & - & & & & $\mathbf{x}$ \\
\hline 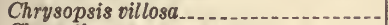 & 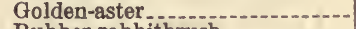 & & $\mathbf{x}$ & $\mathbf{x}$ & $\mathbf{x}$ \\
\hline 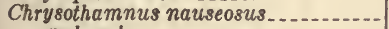 & sh............ & $\mathbf{x}$ & $\mathbf{x}$ & $\mathbf{x}$ & $\mathbf{x}$ \\
\hline - & h................... & $-\infty$ & & & $\mathbf{x}$ \\
\hline 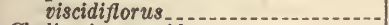 & $h_{-n-n-n}$ & $x$ & & $\mathbf{x}$ & $\mathbf{x}$ \\
\hline (a) & $\theta$ (Oenothera) & & & & $\mathbf{x}$ \\
\hline 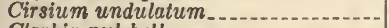 & - & $\ldots$ & $\ldots$ & $\mathbf{x}$ & $\ldots-$ \\
\hline - & 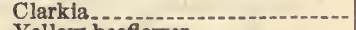 & -. & - & $\mathbf{x}$ & $-\infty$ \\
\hline 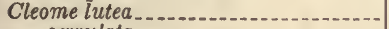 & & - & $\ldots$ & $\mathbf{x}$ & $x$ \\
\hline 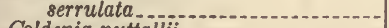 & - & $-\cdots$ & -- & & $x$ \\
\hline$l l i i_{1}$ & 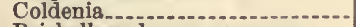 & $\mathrm{x}$ & $-\cdots$ & $\mathbf{x}$ & $x$ \\
\hline linifolius........... & 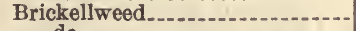 & & $\cdots$ & $\mathbf{x}$ & $x$ \\
\hline - & 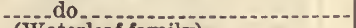 & & $-\cdots$ & $x$ & $x$ \\
\hline$s_{1}, \ldots \ldots \ldots \ldots$ & ily) - & $-\cdots$ & & $\mathbf{x}$ & $x$ \\
\hline hus & Bir & -- & $\mathbf{x}$ & & - \\
\hline$n a_{1} \ldots \ldots \ldots$ & $-2-2 .-2$. & - & $-\infty$ & $\mathbf{x}$ & - \\
\hline pifolium....... & d & & - & $\mathbf{x}$ & \\
\hline - & beard & & & & $\frac{x}{x}$ \\
\hline 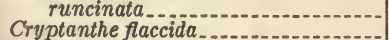 & 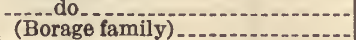 & & - & & $\begin{array}{l}\mathbf{x} \\
\mathbf{x}\end{array}$ \\
\hline ren & Borage fam & $\mathbf{x}$ & & $\mathbf{x}$ & \\
\hline 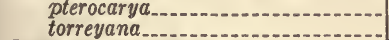 & 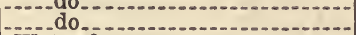 & $x$ & & & $\begin{array}{l}\mathbf{x} \\
\mathbf{x}\end{array}$ \\
\hline nicum & 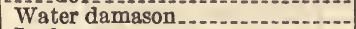 & & n-n & & $\vec{x}$ \\
\hline 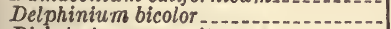 & $2-2-2-2-2-2$ & & $-\cdots$ & & $\mathrm{x}$ \\
\hline itata & (n) & 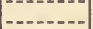 & $x$ & & \\
\hline 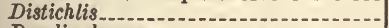 & 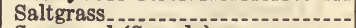 & $x$ & & $x$ & $\mathrm{x}$ \\
\hline Dond & Seepweed (Sureda) & & & $\mathbf{x}$ & \\
\hline & & & & & \\
\hline Draba & Whitlo & & $\mathrm{x}$ & $x$ & $\mathrm{x}$ \\
\hline Elymu & Wild-rye & - n... & $-\infty$ & $\mathrm{x}$ & \\
\hline 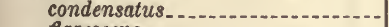 & Giant wild-r. & $\mathbf{x}$ & $-\ldots-n$ & $\bar{x}$ & $\mathbf{x}$ \\
\hline & & $-\infty-\infty-\infty$ & $m-\infty$ & $x$ & \\
\hline & Beardless wild-rye & $\mathrm{x}$ & $x$ & $x$ & $\mathbf{x}$ \\
\hline mmenanthe lutea. & eringbclls........ & & $-\cdots$ & $-\ldots$ & $\mathbf{x}$ \\
\hline 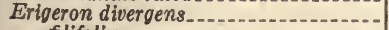 & Fleabane & $-\ldots . . . .$. & - & $-\infty \ldots+\infty$ & $\mathbf{x}$ \\
\hline lius & 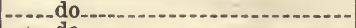 & & -non & $-\ldots-n$ & $\mathbf{x}$ \\
\hline $\begin{array}{l}\text { concinnus } \\
\text { linearis. }\end{array}$ & (n) & $-\cdots+\cdots$ & - n-n & $\begin{array}{l}\mathbf{x} \\
\mathbf{x}\end{array}$ & $\begin{array}{l}\mathbf{x} \\
\mathbf{x}\end{array}$ \\
\hline
\end{tabular}


TABLE 4.-Plants of the Upper Sonoran Zone in Oregon-Continued

\begin{tabular}{|c|c|c|c|c|c|}
\hline & & & Semiarid & & Arid \\
\hline Species & Common name & $\begin{array}{l}\text { Kala- } \\
\text { math } \\
\text { Valley }\end{array}$ & $\begin{array}{c}\text { Rogue } \\
\text { River } \\
\text { Val- } \\
\text { leys }\end{array}$ & $\begin{array}{c}\text { Co- } \\
\text { lumbia } \\
\text { Valley }\end{array}$ & $\begin{array}{l}\text { Inte- } \\
\text { rlor } \\
\text { valleys }\end{array}$ \\
\hline Zriogonum angulosum & (Buckwheat family) ... & & & $\mathbf{x}$ & $\mathbf{x}$ \\
\hline 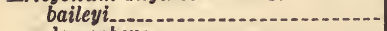 & (2) do & & & & $\bar{x}$ \\
\hline 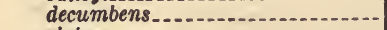 & -.... do do... & & & $\mathbf{x}$ & \\
\hline n & (n) & & & $\mathbf{x}$ & $x$ \\
\hline thecum & 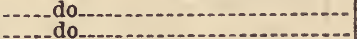 & & & $x$ & $x$ \\
\hline$m$ & - do & & & $\mathbf{x}$ & \\
\hline $\begin{array}{l}\text { nudum } \\
\text { prolifer } u m\end{array}$ & 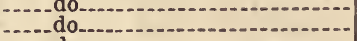 & & & $\mathbf{x}$ & $x$ \\
\hline vimineum & . do.... & $x$ & & $\mathbf{x}$ & 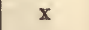 \\
\hline virgatum.... & .......... & & $\mathbf{x}$ & & \\
\hline Eriophyllum multifiorum & 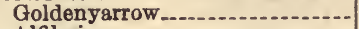 & & & & $\mathbf{x}$ \\
\hline Erodium cicutarium & Alfileria & $\mathbf{x}$ & $x$ & $\mathbf{x}$ & $\mathbf{x}$ \\
\hline 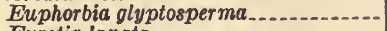 & Spurge & & & $\mathbf{x}$ & \\
\hline Eurotia lanata & Winterfat & $\mathbf{x}$ & & $\mathbf{x}$ & $\mathbf{x}$ \\
\hline ulescens_.......................... & (Aster family) & -...... & $\mathbf{x}$ & & \\
\hline ns & 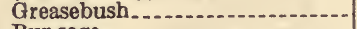 & -+- & 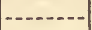 & & $\mathbf{x}$ \\
\hline icanthicarpa................. & (n) & $\ldots \ldots$ & 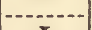 & & $x$ \\
\hline curva & (n) & & $\mathbf{x}$ & & \\
\hline ssimum & Velvetweed... & & & & \\
\hline 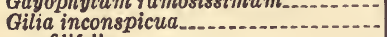 & 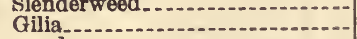 & $\mathbf{x}$ & & $\mathbf{x}$ & $\begin{array}{l}\mathbf{X} \\
\mathbf{x}\end{array}$ \\
\hline (n) & 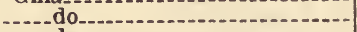 & & & $\mathbf{x}$ & $\hat{x}$ \\
\hline n.mon & - & 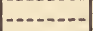 & -... & $\mathbf{x}$ & $\bar{x}$ \\
\hline ria & (n) & $-\ldots .$. & & & $\mathrm{x}$ \\
\hline ria & 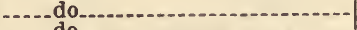 & $-\ldots . .-$ & & & $\bar{x}$ \\
\hline 8 hookeri..................... & 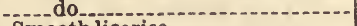 & & & & $\vec{x}$ \\
\hline Glycyrrhiza lepidota & Smooth licor & $\mathbf{x}$ & $\mathrm{x}$ & $\mathbf{x}$ & \\
\hline 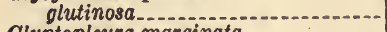 & 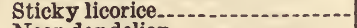 & & $\mathbf{x}$ & & \\
\hline lata & Near dandelion & & - & & $\mathbf{x}$ \\
\hline ifolius_............ & d & & $\mathbf{x}$ & & \\
\hline 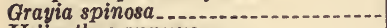 & - & & & & $x$ \\
\hline 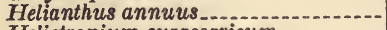 & aflower................... & $\mathbf{x}$ & - & $\mathbf{x}$ & $\mathbf{x}$ \\
\hline avicum & 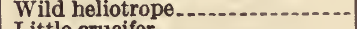 & & & & $\mathbf{x}$ \\
\hline Hutchinsia procumbens............. & - non & $\mathbf{x}$ & & $\mathbf{x}$ & $\mathbf{x}$ \\
\hline hifis & 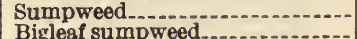 & $\mathbf{x}$ & & $\mathbf{x}$ & $\mathbf{x}$ \\
\hline athifolia.-. & Weed. & & & & $\mathbf{x}$ \\
\hline talis & 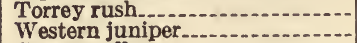 & & & & \\
\hline 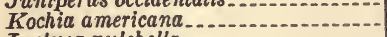 & 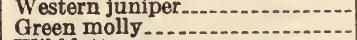 & & & & $\begin{array}{l}\mathbf{x} \\
\mathbf{x}\end{array}$ \\
\hline 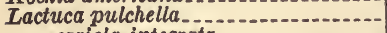 & - & & & $x$ & $x$ \\
\hline integrata................. & Prickly lettuco & $x$ & $x$ & $x$ & $\bar{x}$ \\
\hline 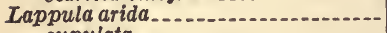 & Stlckseed . . . . . . . . . . . & & & $\mathbf{x}$ & \\
\hline cupulata. & $\ldots$ do & & & & $\mathbf{x}$ \\
\hline num $\ldots \ldots . . . . .$. & 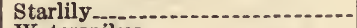 & $-\ldots$ & & $\mathbf{x}$ & $x$ \\
\hline 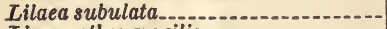 & 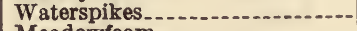 & & & & $\mathbf{x}$ \\
\hline thes gracilis_....................... & Meadowfoam & $-\ldots$ & $\mathbf{x}$ & & $-\ldots+n$ \\
\hline non & - & & $\mathbf{x}$ & & \\
\hline$a_{-\ldots \ldots} \ldots \ldots$ & (Celery family) & $\mathbf{x}$ & $-\ldots$ & $\mathbf{x}$ & \\
\hline 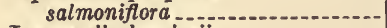 & 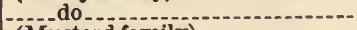 & -..... & - & $\mathbf{x}$ & -....... \\
\hline lla douglasii & y) & - & - & $\mathbf{x}$ & 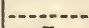 \\
\hline m geyeri & then & $-\ldots$ & $-\ldots-n$ & $\mathbf{x}$ & $\mathbf{x}$ \\
\hline Lupinus brevicaulis & (n) & 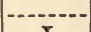 & & & $x$ \\
\hline - non & -....do do & $\mathbf{x}$ &.-- & $\mathbf{x}$ & $x$ \\
\hline (n) & - & $-\ldots$ & $\ldots$ & - & $x$ \\
\hline 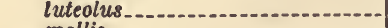 & 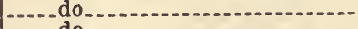 & $-\cdots$ & & & $-\ldots$ \\
\hline mollis......... & 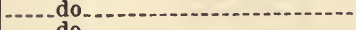 & $-\ldots-1$ & $-\infty$ & & -- \\
\hline ornatus & (n) & 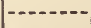 & & $\mathbf{x}$ & $-\cdots$ \\
\hline Us & 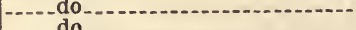 & -- & -- & $\mathbf{x}$ & $\mathbf{x}$ \\
\hline montanus. & 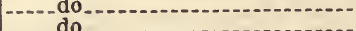 & -- & & & \\
\hline montanus......... & 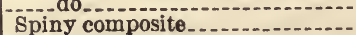 & & & & $\begin{array}{l}\mathbf{x} \\
\mathbf{x}\end{array}$ \\
\hline 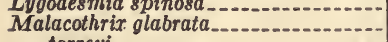 & ix & & & & $\mathbf{x}$ \\
\hline 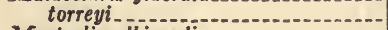 & arix $\ldots \ldots$ & $-\ldots$ & & & $\mathbf{x}$ \\
\hline 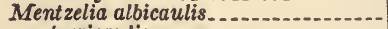 & chen & -........- & & $\mathbf{x}$ & $\bar{x}$ \\
\hline 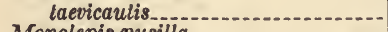 & - & & & $\mathbf{x}$ & $\mathbf{x}$ \\
\hline 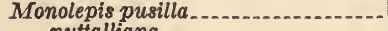 & & - & $-\ldots . . .-1$ & $-\cdots$ & $\mathbf{x}$ \\
\hline (n) & 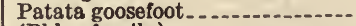 & -........ & -........ & & $\mathbf{x}$ \\
\hline gen & (Phlox family) ... & ........... & (-......... & & $\mathbf{x}$ \\
\hline & Coyote tobacco. & $-\cdots$ & $\ldots$ & $\mathbf{x}$ & $x$ \\
\hline la occidentalis.................... & - & $-\ldots$ & -..-- & & $\mathbf{x}$ \\
\hline 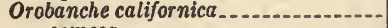 & California broomrape & $-\ldots . . .2$ & & $\mathbf{x}$ & $\mathbf{x}$ \\
\hline nenten & Hairy broomrape & $-\infty-2 n$ & & & \\
\hline & Desert broomrape................... & -...-...- & & $\mathbf{x}$ & 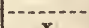 \\
\hline Oryzopsis bloomeri. & Ricegrass & 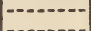 & $-\infty-\infty-\infty$ & & $\mathbf{x}$ \\
\hline vtheca dendroidea........... & (Buckwh & $-\infty-$ & & & x \\
\hline chylophus can & Evening-primrose & & & & \\
\hline
\end{tabular}


TABLE 4.-Plants of the Upper Sonoran Zone in Oregon-Continued

\begin{tabular}{|c|c|c|c|c|c|}
\hline & & & Semia & & Arid \\
\hline Bpecies & Common name & $\begin{array}{l}\text { Kla- } \\
\text { math } \\
\text { Valley }\end{array}$ & $\begin{array}{l}\text { Rogue } \\
\text { River } \\
\text { Val- } \\
\text { leys }\end{array}$ & $\begin{array}{c}\text { Co- } \\
\text { lumbia } \\
\text { Valley }\end{array}$ & $\begin{array}{l}\text { Inte- } \\
\text { rior } \\
\text { valleys }\end{array}$ \\
\hline Parrya menziesii..- & Purple mustard & & & & $\mathbf{x}$ \\
\hline non & Desert pentste & & & & $x$ \\
\hline 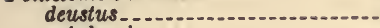 & White pentster & & $x$ & $\mathrm{x}$ & $\mathrm{x}$ \\
\hline gairdneri... & Slender pentst & & & $\mathrm{x}$ & $\bar{x}$ \\
\hline 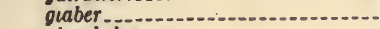 & Blue pentst & & & $\mathbf{x}$ & $\bar{x}$ \\
\hline glandulosus. & Rough pentst & & & $\bar{x}$ & \\
\hline laetus..... & Purple pentste & & $\mathbf{x}$ & & \\
\hline simum & (n) & & & & $x$ \\
\hline 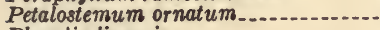 & (n) & & & & $\bar{x}$ \\
\hline Phacelia linearis.. & 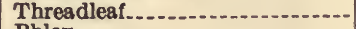 & $\mathbf{x}$ & & $\mathbf{x}$ & $x$ \\
\hline Phlox longiflora... & (n) & $-\cdots-1$ & & $\mathbf{x}$ & $x$ \\
\hline rigida & (n) & -n..... & . & & $\mathbf{x}$ \\
\hline 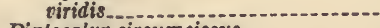 & 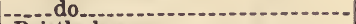 & & & $\mathbf{x}$ & \\
\hline Us & Bristle borage & $\mathbf{x}$ & & $\mathbf{x}$ & $\mathbf{x}$ \\
\hline Llous & 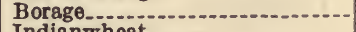 & & & & \\
\hline (n) & (n) & $\mathbf{x}$ & & $\mathbf{x}$ & $\mathrm{x}$ \\
\hline$u m \ldots \ldots$ & 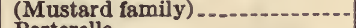 & - & $\mathbf{x}$ & $x$ & \\
\hline 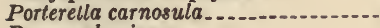 & rella $\ldots$ & & & & $\mathbf{x}$ \\
\hline 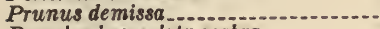 & Chokecherry - & $\mathbf{x}$ & $\mathbf{x}$ & $\mathbf{x}$ & $\mathbf{x}$ \\
\hline bra & - & & & $\mathrm{x}$ & $\mathbf{x}$ \\
\hline nen & - & & . & $x$ & \\
\hline (n) & ed $\ldots$ & & & $x$ & $x$ \\
\hline 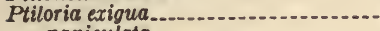 & Ptiloria (Stephanomeria) & & & & $\bar{x}$ \\
\hline nen & 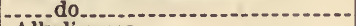 & & & $\mathbf{x}$ & $\mathbf{x}$ \\
\hline 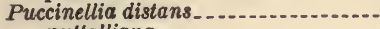 & 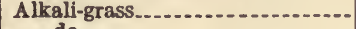 & $\mathbf{x}$ & & & $\mathbf{x}$ \\
\hline Hen & 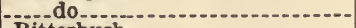 & & & & $x$ \\
\hline 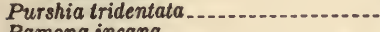 & - non & $\mathbf{x}$ & $x$ & $x$ & $\mathbf{x}$ \\
\hline 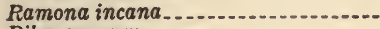 & chenchen & (....... & & & $\mathbf{x}$ \\
\hline 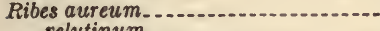 & 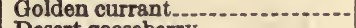 & & & $\mathbf{x}$ & $\mathbf{x}$ \\
\hline velutinum & ry & $\mathbf{x}$ & & & \\
\hline Rigiopappus leptocladus................. & 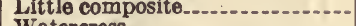 & $-2-\infty$ & $x$ & $\ldots$ & $x$ \\
\hline 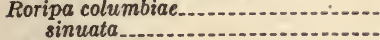 & Watercress.... & $x$ & $-\infty$ & $\mathrm{x}$ & $\cdots$ \\
\hline $\begin{array}{l}\text { sinuata } \\
\text { hus trilobata.... }\end{array}$ & Skunkbush. & $x-$ & & $\mathbf{x}$ & $\ldots$ \\
\hline 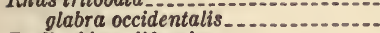 & Western sum & $\mathrm{x}$ & & & \\
\hline 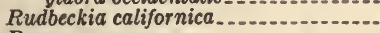 & California c & & $x$ & & \\
\hline nem & Dock & & & & \\
\hline (- & bead & & & $\begin{array}{l}x \\
x\end{array}$ & $x$ \\
\hline (n) & willo & & & $\frac{x}{x}$ & $\mathbf{x}$ \\
\hline 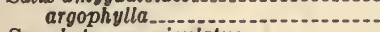 & - & & & & \\
\hline Us...-. & 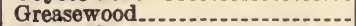 & & & & $\begin{array}{l}x \\
x\end{array}$ \\
\hline$i a_{\ldots} \ldots \ldots \ldots$ & 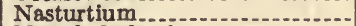 & & & & $\hat{x}$ \\
\hline 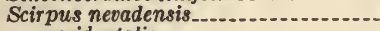 & and & & & & $\mathrm{x}$ \\
\hline 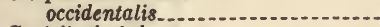 & h & & & & $x$ \\
\hline 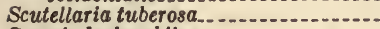 & chen & - non & & & $\hat{x}$ \\
\hline 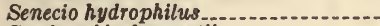 & dsel... & - & $\ldots$ & & $\mathbf{x}$ \\
\hline tii............. & cress & & & & $\mathrm{x}$ \\
\hline 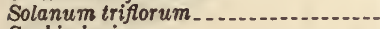 & de.......... & $\ldots$ & & $\mathrm{x}$ & $\mathrm{x}$ \\
\hline 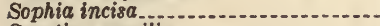 & 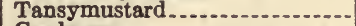 & - & & $\mathbf{x}$ & $\mathbf{x}$ \\
\hline - non & 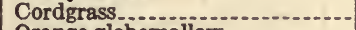 & & & & $\mathbf{x}$ \\
\hline 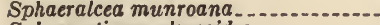 & low & & & $\mathbf{x}$ & $\mathbf{x}$ \\
\hline les_............ & se & &. & & $x$ \\
\hline 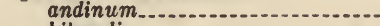 & 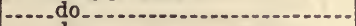 & $\ldots$ & . & - - & $\mathbf{x}$ \\
\hline 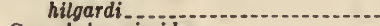 & - & & & & $x$ \\
\hline 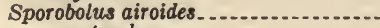 & 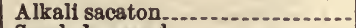 & .......... & $\ldots$ & $x$ & $\cdots$ \\
\hline n. & n. & 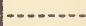 & - & $\mathbf{x}$ & $\ldots$ \\
\hline and & 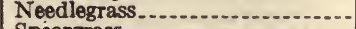 & - & $-\ldots$ & $x$ & $x$ \\
\hline 14 & - non & $\ldots+\ldots$ & $-\cdots$ & $\ldots$ & $\mathbf{x}$ \\
\hline lloides ........ & $T a$ & $------\infty$ & $-\cdots$ & & $x$ \\
\hline Taraxia & Evening-prin & - & &.- & \\
\hline het & $-\ldots$ do $\ldots . . .+$ & & & & $\mathbf{x}$ \\
\hline tanacetifolia.- & & $\cdots$ & & & $x$ \\
\hline Tetradymia canesc & Gray borsebrus & $\mathbf{x}$ & $-\infty$ & & \\
\hline glabrata. & ush $\ldots$ & 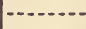 & & & $x$ \\
\hline & sh & & & $\mathbf{x}$ & \\
\hline folium & mustard ............. & & & $x$ & $x$ \\
\hline 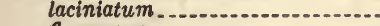 & 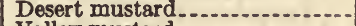 & & & $\mathbf{x}$ & $\mathbf{x}$ \\
\hline 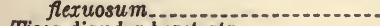 & d & & & & $x$ \\
\hline$a \ldots \ldots$ & 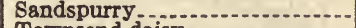 & & & $x$ & $x$ \\
\hline flori & - non & & & $x$ & $x$ \\
\hline riteleia henders & 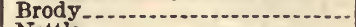 & & $\mathbf{x}$ & & \\
\hline $\operatorname{trace}_{-}$ & & & & & $x$ \\
\hline orucueuta & Ver & & & $\mathbf{x}$ & $\mathbf{x}$ \\
\hline iola beckwithii. & Vlolet....... & & & & $\mathbf{x}$ \\
\hline Zygadenus paniculo & Deathcama & & & & $x$ \\
\hline
\end{tabular}




\section{TABLE 5.-Plants of the Transition Zone in Oregon}

Specles
Abies grandis
Abronia acutalata.
$\quad$ latifolia
Acer macrophyllum
circinatum
Achlys triphylla
Adenocaulon bicolor

$$
\text { retrorsa. }
$$

Agropyron spicatum

Agrostis pallens.

Allium douglasii

Alnus oregona tenuifolia

A melanchier florida.

Anemone deltoides.

Antennaria dimorpha

$$
\text { geyeri. }
$$$$
\text { stenophylla }
$$

Aplopappus lanuginosus nanus. stenophyllus.

Arabis cusickii. holboellii

Arbutus menziesii

Arctostaphylos columbiana patula.tomentosa uva-ursi

Arenaria tenella congesta.

Arnica fulgens.

Artemisia arbuscula.

frigida suksdorfi tripartita

Astragalus agrestis collinus.

misellus.

sclerocarpus

reventus

succumbens

Atriplex patula littoralis.

Baccharis pilularis

Balsamorhiza sagittata

Berberis aquifolium. nervosa

$$
\text { repens. }
$$

Betula fontinalis

Bromus brizaeformis pacificus.

$$
\text { rubens. }
$$

Calamagrostis aleutica rubescens.

Calochortus macrocarpus purdyi.

Carum oreganum

Castanopsis chrysophylla

Castilleja miniata dixoni

Ceanothus integerrimus. prostratus. sanguineus velutinus

Cercocarpus ledifolius

Chamaebatia foliolosa

Cirsium foliosum. lanceolatum. remotifolium

Clarkia rhomboidea

Claytonia siberica. diffusa.

Clematis hirsutissima

Coelopleurum longipes

Collinsia grandifiora.

Conioselinum gmelini

Conoolvulus soldanella

\begin{tabular}{|c|c|c|c|c|}
\hline Common name & $\begin{array}{l}\text { Coast } \\
\text { strip }\end{array}$ & Humid & $\begin{array}{l}\text { Semi- } \\
\text { arid }\end{array}$ & Arid \\
\hline Great silver fir ................... & & $\mathrm{x}$ & & \\
\hline Pink sandverbena & $\mathbf{x}$ & & & \\
\hline 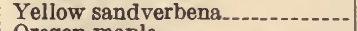 & $\mathbf{x}$ & & & \\
\hline 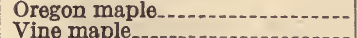 & $\cdots-$ & $\underset{x}{x}$ & & \\
\hline $\begin{array}{l}\text { Vine maple... } \\
\text { Vanillaleaf... }\end{array}$ & & $x$ & & \\
\hline Woods composite. & & $\begin{array}{l}\mathbf{x} \\
\mathbf{x}\end{array}$ & & \\
\hline Sheeplettuce & $\mathrm{x}$ & $-\cdots$ & & \\
\hline Bluebunch wheat & & & $\mathbf{x}$ & \\
\hline (6) & $x^{-\infty}$ & & & $\mathbf{X}$ \\
\hline (n) & $--\ldots-n$ & & $\mathrm{x}$ & \\
\hline - & 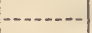 & $\mathbf{x}$ & A & \\
\hline (n) & 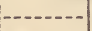 & & $\mathbf{x}$ & \\
\hline (n) & $-\ldots-n$ & $\mathbf{x}$ & $\mathbf{x}$ & \\
\hline - & $-\ldots . .-2$ & $\mathbf{x}$ & $\mathrm{x}$ & \\
\hline 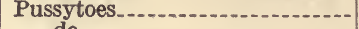 & $-\ldots . .--$ & & $\mathbf{x}$ & \\
\hline (n) & 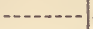 & & $\bar{x}$ & $\mathrm{x}$ \\
\hline (n) & $\cdots-. .$. & & $\mathbf{x}$ & \\
\hline (n) & 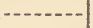 & & & $\mathrm{x}$ \\
\hline (n) & & & & $\mathbf{x}$ \\
\hline 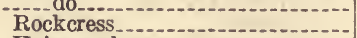 & & & & $\mathbf{x}$ \\
\hline Hairy rockcress. & -- & & $\mathbf{x}$ & $-\ldots$ \\
\hline Rockcress & 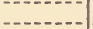 & $\mathrm{x}$ & & (n) \\
\hline nen & - & $\mathrm{x}$ & $\mathbf{x}$ & - \\
\hline$n$ & $-\ldots+n$ & $\begin{array}{l}x \\
x\end{array}$ & & \\
\hline 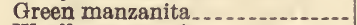 & $-\ldots+\ldots$ & & & -. \\
\hline Woolly manzanita & ...... & $\mathrm{x}$ & $\mathbf{x}$ & 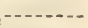 \\
\hline Bearberry & 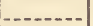 & $\begin{array}{l}\mathbf{x} \\
\mathbf{x}\end{array}$ & & $-\ldots$ \\
\hline Sandwort........ & & $\begin{array}{l}\mathbf{x} \\
\mathbf{x}\end{array}$ & $\mathbf{x}$ & -....... \\
\hline 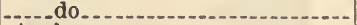 & & & & \\
\hline 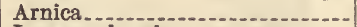 & -- & & $\begin{array}{l}x \\
x\end{array}$ & - n-n. \\
\hline 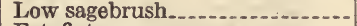 & -- & & ...... & 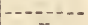 \\
\hline . & --1 & & $---n$ & $\mathbf{x}$ \\
\hline A sagebrush.................. & & & $\mathbf{x}$ & $\mathbf{x}$ \\
\hline Threeleaf sagebrush & -1 & & - & \\
\hline Milkvetch........ & -- & & & $x$ \\
\hline 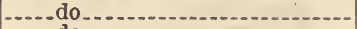 & & & $\mathrm{x}$ & $\mathrm{x}$ \\
\hline (1) & $=--$ & & & - \\
\hline - & $\mathbf{x}$ & - & 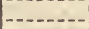 & $-\infty$ \\
\hline 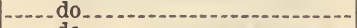 & $\mathbf{x}$ & & - & \\
\hline 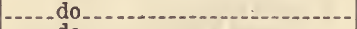 & $-\cdots$ & & $\mathrm{x}$ & - \\
\hline 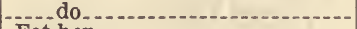 & $-\cdots$ & $-\infty$ & & $\mathrm{x}$ \\
\hline - & $\mathbf{x}$ & $-\cdots$ & & $-\ldots . .$. \\
\hline Kidneywort . . . . & $\mathbf{x}$ & $-\infty$ & - & -.... \\
\hline Balsamroot. & -no & -2 & $x$ & $\mathrm{x}$ \\
\hline Oregon hollygrape & $-\ldots . . .-1$ & $\mathbf{x}$ & & -...- \\
\hline B............. & $\ldots$ & $\mathbf{x}$ & 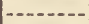 & ....- \\
\hline e. & $-\ldots-n$ & - & $\mathbf{x}$ & $-\infty$ \\
\hline Western birch; red birch..... & $\ldots$ & & $\mathbf{x}$ & $\mathbf{x}$ \\
\hline - non & $-\ldots-\ldots$ & -- & $-\cdots$ & $\mathrm{x}$ \\
\hline 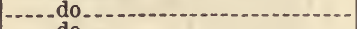 & $\mathbf{x}$ & & $-\cdots$ & \\
\hline 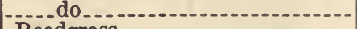 & $-\ldots$ & & & $\mathbf{x}$ \\
\hline Reedgrass........... & $\mathbf{x}$ & 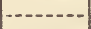 & -.......... & $-\cdots+\cdots$ \\
\hline (n) & -......... & - & $x$ & --- \\
\hline 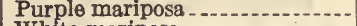 & $-\ldots . . .+$ & $-\ldots$ & $\mathrm{x}$ & -....... \\
\hline White mariposa & 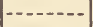 & $\mathrm{x}$ & $-2-1-n$ & \\
\hline W & 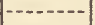 & $x$ & $\mathbf{x}$ & 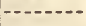 \\
\hline chinquapin & $\mid--2-n$ & $\mathrm{x}$ & $\mathbf{x}$ & $-1 .+2-2$ \\
\hline ian paintbrush & $\mathbf{x}$ & 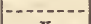 & $-\cdots$ & $-\cdots+\cdots$ \\
\hline serbrush & 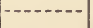 & $\mathrm{x}$ & $--n-1$ & 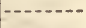 \\
\hline ahala-mat___n & 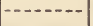 & - & $\mathbf{x}$ & - \\
\hline egon tea-tree & $-\cdots+-\infty$ & X & -- & -- \\
\hline lowbrush & 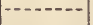 & -- & $\mathbf{X}$ & $x^{--1}$ \\
\hline Mountain-mahogany & $-\infty \ldots+n$ & -- & & 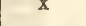 \\
\hline mat & $-\cdots+\cdots$ & -- & $\frac{x}{x}$ & $-102-1$ \\
\hline$\theta \theta^{2}$ & - & $\mathrm{x}$ & - n-n & 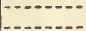 \\
\hline (n) & & $\hat{x}$ & 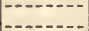 & \\
\hline $\begin{array}{l}\text { der thistle } \\
\text { kia }\end{array}$ & $\ldots$ & & $\mathrm{x}$ & $x^{x}$ \\
\hline Ingbeauty & -......... & $\mathbf{x}$ & & \\
\hline ingbeauty . . & & $x$ & & \\
\hline Clematis. & $\mid-\ldots . .$. & $-\ldots$ & $\mathrm{x}$ & \\
\hline ld parsnip. & $\mathbf{x}$ & $\ldots-n$ & 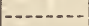 & 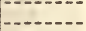 \\
\hline Collinsia . ....... & $-\ldots-n$ & $\mathbf{x}$ & $--2-2$ & 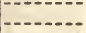 \\
\hline 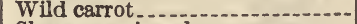 & $\mathbf{x}$ & 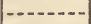 & $-2-n-2$ & $-2-\infty$ \\
\hline orning-glory & $\mathbf{x}$ & -....... & 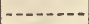 & $-2--$ \\
\hline clfic dogwood & $\mid-\ldots . . .-1$ & $\mathbf{x}$ & $-\ldots . . .2$ & $-\ldots$ \\
\hline estern dogwood & $-\ldots+\ldots$ & $\mathbf{x}$ & $\ldots$ & $-\cdots$ \\
\hline & & & & \\
\hline
\end{tabular}

Cornus nuttallii occidentalis stolonifera 
TABLE 5.-Plants of the Transition Zone in Oregon-Continued

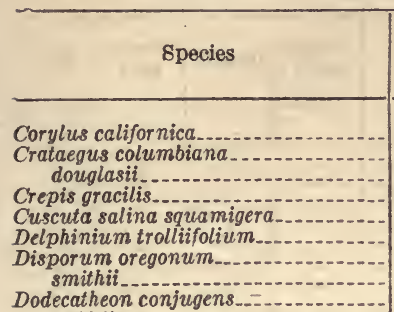

Dodecatheon conjugens latifolium

Drosera rotundifolia.

Dryopteris spinulosa dilatata.

Echinopanax horridum.

Elymus arenarius mollis

Empetrum nigrum.

Erigeron aureus

corymbosus

glaucus. poliospermus

Eriogonum heracleoides.

latifolium

niveum

nudum

ovalifolium

stellatum

sphacrocephalum

Eriophorum chamissonis

Eryngium articulatum.

Erythronium giganteum

Festuca idahoensis megalura. occidentalis

Fragaria chiloensis.

Franseria chamissonis. bipinnatifida.

Frasera nitida speciosa.....

Fraxinus oregona pudica.

Gaillardia aristata

Gelium asperrimum cymosum multifiorum

arrya fremontii. elliptica.

Gaultheria shallon

Gentiana oregana. sceptrum

Geranium viscosissimum

Geum oregonense. macrophyllum.

Gilia aggregata bicolor. capitata. leptalea. harknessii

Glehnia littoralis.

Godetia amoena. guadrivulnera

Grindelia integrifolia nana

Helianthella douglasii

Heuchera micrantha. ovalifolia.

Hieracium longiberbe

Holcus lanatus.

Hookera coronaria douglasii.

Horkelia fusca.

Hydastylus brachypus.

Hydrophyllum tenuipcs.

Hymenopappus filifolius

Iris tenax

Jaumea carnosa

Juncus covillei

eff usus.

falcatus.

orthophyllus

Californla hazel

Columbia hawthorn

Black hawthorn

Hawksbeard

Dodder

Thinleaf larkspur.

Fairybells.

Shootingst

Roundleaf sundew

Mountain woodfern

Devilsclub

Ryegrass

Crowberry

Yellow fleabane

Flat-top fleabano

Beach fleabane

Fleabane.

(Buckwheat family)

..... do.

.... do

.... do

do

Cotton-sedge

Eryngo

Troutlily

Blue bunch fescue

Foxtail fescue

Westernfescue.

Chiloe strawberry

Beach bur-sage.

Silky bur-sage

Green gentian

Deertongue

Oregon ash.

Checkerlily

Yellow missionbells

Gaillardia

Bedstraw

-..-do.

Silktasse

Salal do

Oregon gentian.

Blue gentian

Sticky geranium

Avens

-_do

Scarlet gilia.

Bicolor gilia

Globe gilia.

Slender gilia.

Harkness gilia

Beach-celery

Morning-primrose.

Gumplant.

Little gumplant

Little sunflower

Alumroot

do.

Velvet grass

Harvest brody

Douglas brody.

Brown horkelia.

Golden-eyed-grass

W aterleaf

Woolly composite

Oregon iris

(Composite)

Rush.

..... do.

do do.

do

do

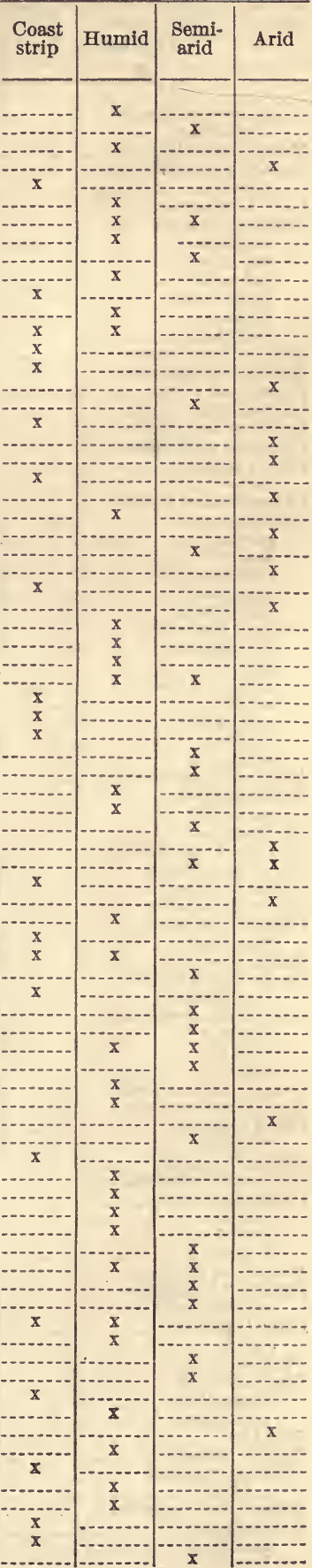


TABLE 5.-Plants of the Transition Zone in Oregon-Continued

\begin{tabular}{|c|c|c|c|c|c|}
\hline Species & Common name & $\begin{array}{l}\text { Coast } \\
\text { strip }\end{array}$ & Humid & $\begin{array}{l}\text { Semi- } \\
\text { arid }\end{array}$ & Arid \\
\hline Juniperus occidentalis ................ & Western juni & & & $x$ & $\mathbf{x}$ \\
\hline scopulorum & Rocky moun & & & $\bar{x}$ & -........ \\
\hline Kelloggia galioides. & Kelloggia. - & & & $x$ & -....... \\
\hline Lactuca pulchella. & Lettuce... & & & $x$ & 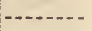 \\
\hline $8 p$ & Wo do _. & & & & \\
\hline Larix occidentalis.. & Western lar & & & $\mathbf{x}$ & - \\
\hline Lathyr? & Beach pea & $\underline{x}$ & & & (n..... \\
\hline 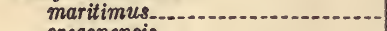 & Shore pea.. & $x$ & & & 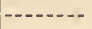 \\
\hline 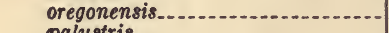 & Oregon pea & & & $x$ & $-\ldots . . .-1$ \\
\hline | & Marsh pea. & & & & \\
\hline (n) & Small-flowe & & & & $\mathbf{x}$ \\
\hline (n) & Low pea.- & & & & $\mathbf{x}$ \\
\hline $\begin{array}{l}\text { polyp } \\
\text { Ledum co }\end{array}$ & Tall pea.. & & & & \\
\hline non & Labra & & & & \\
\hline (n) & Pepp & & & & \\
\hline (n) & Wil & & & & $\boldsymbol{A}$ \\
\hline Lib & Inc & & & $\mathbf{x}$ & \\
\hline (n) & Lo & & $\mathbf{x}$ & & \\
\hline - n & Cree & & & & \\
\hline 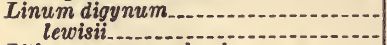 & Yello & & & $x$ & \\
\hline erale & flax.. & & & & \\
\hline ale & on.- & & & & 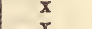 \\
\hline & 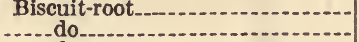 & & - & $\mathbf{x}$ & $\mathbf{x}$ \\
\hline mend & - & & & & $x$ \\
\hline 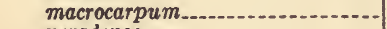 & - & & & $\mathrm{x}$ & $\mathbf{x}$ \\
\hline 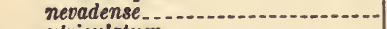 & ..... do do...... & & & 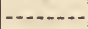 & $\mathbf{x}$ \\
\hline - & 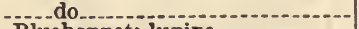 & & $\mathrm{x}$ & & \\
\hline n & $n$ & & $x$ & & \\
\hline - & (n) & & & & $x$ \\
\hline 每 & (n) & $\mathbf{x}$ & & $\ldots$ & \\
\hline nan & | & & $x$ & & \\
\hline (n) & | & & & & $x$ \\
\hline (n) & 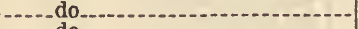 & - & $\mathbf{x}$ & $\mathbf{x}$ & - \\
\hline (n) & - & $x$ & $x$ & $-\ldots .$. & \\
\hline$x^{2}$ & (n) & -.... & & & $x$ \\
\hline$m a_{\ldots} \ldots \ldots \ldots$ & ............... & & & & $x$ \\
\hline 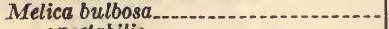 & - & - & & $\mathbf{x}$ & - n...... \\
\hline 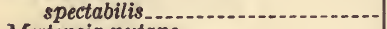 & (ne-nen & ....... & & $\mathbf{x}$ & - n-n \\
\hline 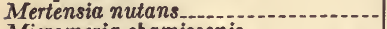 & ............ & - n.... & & $\mathbf{x}$ & $\ldots-n$ \\
\hline ris . . . . . & - & $-\cdots$ & $x$ & - . . & ( \\
\hline - & n................ & $x$ & & $\ldots$ & 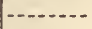 \\
\hline (2) & (n) & $-0-2-0$ & $x$ & $\ldots$ & (.... \\
\hline 10. & 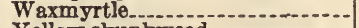 & $x$ & $\ldots \ldots$ & $\ldots$ & - \\
\hline (-2-n & ed $\ldots \ldots \ldots$ & $\cdots$ & & & $\mathbf{x}$ \\
\hline 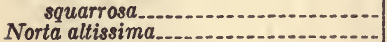 & $d_{\ldots} \ldots \ldots \ldots$ & $-\infty$ & $\mathbf{x}$ & - & $\ldots$ \\
\hline opimalifolius & n. & - & & & $x$ \\
\hline $\begin{array}{l}\text { opulifolius. } \\
\text { iorus. }\end{array}$ & Ninebark & 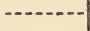 & $\mathbf{x}$ & $\mathrm{x}$ & -......... \\
\hline 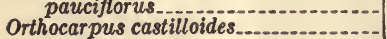 & 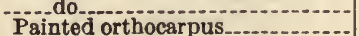 & $x$ & & $\mathbf{x}$ & - on \\
\hline 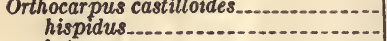 & $x^{\prime}$ & $\mathbf{x}$ & & -2 & (n-n \\
\hline 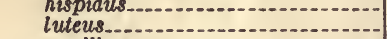 & us & $-\ldots$ & & $x$ & -......... \\
\hline - - - & USS & - & $-\infty$ & $\mathbf{x}$ & $\ldots$ \\
\hline is & 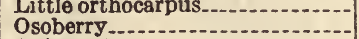 & 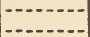 & $\frac{x}{x}$ & $-\ldots$ & -....... \\
\hline 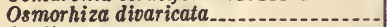 & 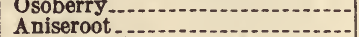 & 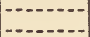 & $x$ & $\cdots$ & n......... \\
\hline 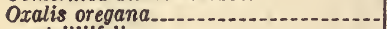 & $\begin{array}{l}\text { Aniseroo } \\
\text { Woodsor }\end{array}$ & 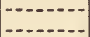 & $x$ & $\mathbf{x}$ & 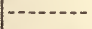 \\
\hline & Woodsor & & $x$ & -- & $-\infty$ \\
\hline nziesii & lecre & & & $-\infty$ & - \\
\hline$a a_{-} \ldots+\ldots+\ldots$ & lat. & & & & 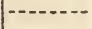 \\
\hline aridu & Beardtong & & $\cdots$ & $-\cdots$ & $x^{-\cdots-1}$ \\
\hline c & ... do & $-\infty$ & & - & $\mathbf{x}$ \\
\hline$-\infty-\infty-\infty$ & $\ldots$ do & $-\cdots$ & & --- & $\boldsymbol{x}$ \\
\hline & $\ldots$ do & $-\infty$ & & $\cdots$ & $\mathbf{x}$ \\
\hline 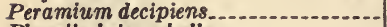 & tain & 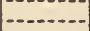 & & & \\
\hline la $\ldots \ldots \ldots$ & 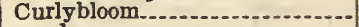 & $\ldots \ldots$ & & $\cdots$ & $x$ \\
\hline & - =...do do... & & & & $\hat{x}$ \\
\hline 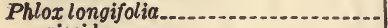 & $\ldots$ & 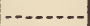 & & & $x$ \\
\hline & 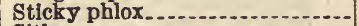 & $\ldots$ & & & \\
\hline 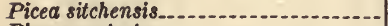 & 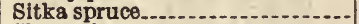 & $x$ & & & \\
\hline nen & - & $x$ & $\ldots$ & & \\
\hline 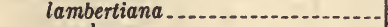 & n. & & $x$ & & \\
\hline 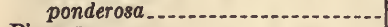 & $n x^{2}$ & & & $\mathrm{x}$ & \\
\hline - non & ey pine. .......... & $\ldots \ldots$ & & & \\
\hline c.................... & & $\mathrm{x}$ & & & \\
\hline - non & & $\mathbf{x}$ & & & \\
\hline & 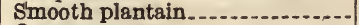 & $\mathbf{x}$ & & & \\
\hline n & & & $\mathbf{x}$ & $\ldots$ & \\
\hline 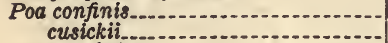 & Bluegrass. & x & & 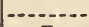 & \\
\hline $\begin{array}{l}\text { cusickii.-. } \\
\text { howellii. }\end{array}$ & [n & & & & \\
\hline
\end{tabular}


TABLE 5.-Plants of the Transition Zone in Oregon-Continued

\begin{tabular}{|c|c|c|c|c|c|}
\hline Species & Common name & $\begin{array}{l}\text { Coast } \\
\text { strip }\end{array}$ & Humid & $\begin{array}{l}\text { Semi- } \\
\text { arid }\end{array}$ & Arid \\
\hline Poa macrantha.. & Bluegrass_. - & & & & \\
\hline & - & & & & $x$ \\
\hline & ....do... & & & & $x$ \\
\hline 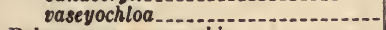 & - . do do.... & & & & $\mathbf{x}$ \\
\hline Polygonum paronychia & Polygonum... & $\mathbf{x}$ & & & $-\infty-\infty \ldots$ \\
\hline parryi. & ..... do do.......... & $-\ldots$ & & $\mathbf{x}$ & \\
\hline (n) & - & & & $\mathbf{x}$ & \\
\hline Polypodium occidentale................ & 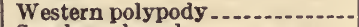 & & $x$ & & \\
\hline 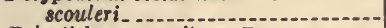 & Scouler polypc & & $\mathbf{x}$ & & - \\
\hline Polvstichu & Hollyfern & & $\mathbf{x}$ & & \\
\hline Populus a & $1 \ldots \ldots . . . . .$. & & & & $\mathbf{x}$ \\
\hline n. & Black cot & & $\mathbf{x}$ & & \\
\hline 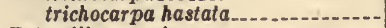 & d.......... & & & $\mathbf{x}$ & \\
\hline 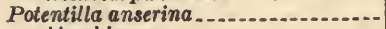 & Silverweed... & $x$ & & & \\
\hline 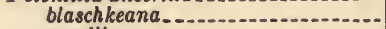 & oil & $\ldots$ & & & $x$ \\
\hline 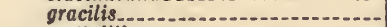 & foil_. & $\ldots$ & $x$ & & not \\
\hline 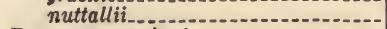 & loill & $-\cdots$ & $\mathbf{x}$ & $x$ & \\
\hline 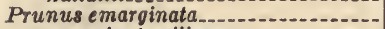 & Bitter cherry. & $\ldots$ & & $x$ & \\
\hline 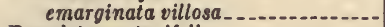 & -...do-....... & $-\infty$ & $\mathbf{x}$ & & \\
\hline 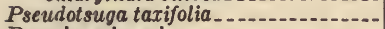 & non & $\ldots$ & $\mathbf{x}$ & $x$ & \\
\hline n-n & 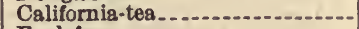 & $\ldots$ & $\mathbf{x}$ & & \\
\hline pubescens....... & 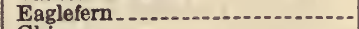 & $-\cdots$ & $x$ & & - \\
\hline 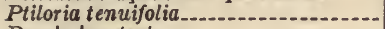 & - & $\ldots$ & $x$ & & \\
\hline n-2-nen & (n) & $-\ldots$ & & & $x$ \\
\hline 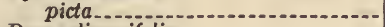 & .....do.... & -....... & & & \\
\hline 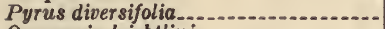 & C-nond & $-\ldots \ldots$ & $\mathbf{x}$ & $-\ldots-.$. & \\
\hline (n) & Camas ........ & -........ & $\mathbf{x}$ & & 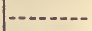 \\
\hline 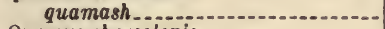 & (n) & -........ & $x$ & $\mathbf{x}$ & \\
\hline solepis & 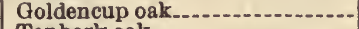 & -........ & $x$ & $-\ldots$ & \\
\hline 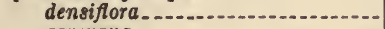 & 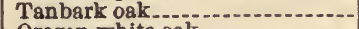 & $\ldots$ & $x$ & 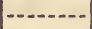 & - \\
\hline 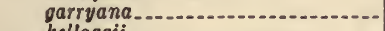 & ak & $\cdots$ & $x$ & & \\
\hline $3 x^{2}$ & oak & $\ldots$ & $x$ & & \\
\hline delphinifolius & (n) & & & $\mathbf{x}$ & \\
\hline 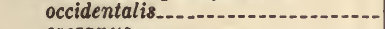 & ..... do do......... & $\ldots$ & $x$ & $-\infty$ & \\
\hline 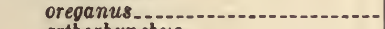 & 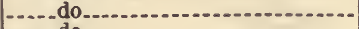 & $\cdots$ & $x$ & $\ldots$ & -........ \\
\hline (n) & naten & $\ldots$ & $x$ & - & $\ldots$ \\
\hline 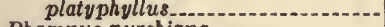 & - Codo do & & & $x$ & \\
\hline 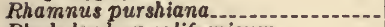 & Cascara & $\ldots$ & $\mathbf{x}$ & 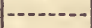 & $-\ldots$ \\
\hline alifornicum ....... & Coast rhodode & $x$ & $x$ & & - \\
\hline 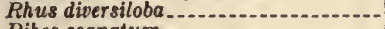 & Polson-0ak & $\ldots$ & 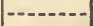 & $\mathbf{x}$ & $\ldots$ \\
\hline - & 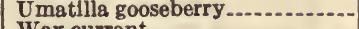 & $\ldots$ & & $x$ & $-\cdots$ \\
\hline 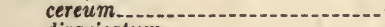 & $\ldots . . . . . . . .$. & $\cdots$ & & $\mathbf{x}$ & -......... \\
\hline 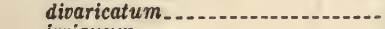 & (n......... & $\ldots$ & $\mathbf{x}$ & - & -......... \\
\hline nen & - n-n...... & $-\cdots$ & & $\mathbf{x}$ & - n-n \\
\hline 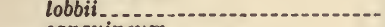 & 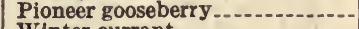 & $-\cdots$ & $\mathbf{x}$ & $\ldots$ & $-2 .-1$ \\
\hline 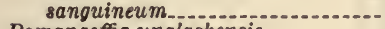 & 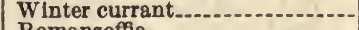 & $--\infty$ & $\mathbf{x}$ & - & $-\cdots$ \\
\hline Romanzoffia unalaskensis.............. & 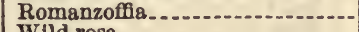 & $x$ & $-\infty$ & - & 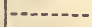 \\
\hline (2) & 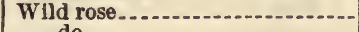 & $-\cdots$ & 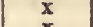 & & $-\ldots$ \\
\hline 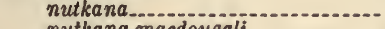 & ...... do $\mathrm{do}_{2} \ldots .$. & -- & $\mathbf{x}$ & 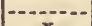 & $\ldots$ \\
\hline |ali_.............. & -..- do.. & & - & $\mathbf{x}$ & \\
\hline 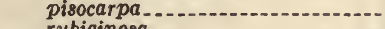 & -...- & -- & $\mathbf{x}$ & $\mathbf{x}$ & (no........ \\
\hline - non & -..- & $-\cdots$ & $\mathbf{x}$ & - & $-\cdots$ \\
\hline (n) & leaf black & $-\cdots$ & $\mathbf{x}$ & - &.- \\
\hline (n) & leaf black & - & $\mathbf{x}$ & - & \\
\hline (n) & $-\cdots$ & $-\cdots$ & 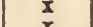 & 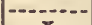 & -- \\
\hline (n) & - n- & $-\infty .+-$ & $x$ & $x$ & - \\
\hline (n) & $-\ldots$ & $x$ & $\mathbf{x}$ & - & \\
\hline - & (n) & $-\infty-\infty$ & & & \\
\hline eginus_.............. & n. & $\mathbf{x}$ & & & \\
\hline & 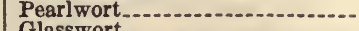 & $x$ & & & \\
\hline 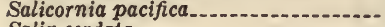 & & $x$ & - & $-\infty-\infty-\infty--$ & \\
\hline - & (2) & -.......... & & $x$ & \\
\hline - & - - - & -........ & & $\mathbf{x}$ & \\
\hline (a) & ........... & 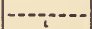 & $\mathbf{x}$ & 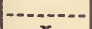 & \\
\hline a & & & & $x$ & $\mathbf{x}$ \\
\hline - & - & $\mathbf{x}$ & -........ & -....... & $-1, \ldots$ \\
\hline 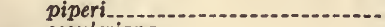 & - & -........ & $x$ & 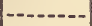 & $-1-2$ \\
\hline 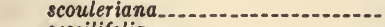 & - n-n-n & - & $\mathbf{x}$ & - - & - \\
\hline 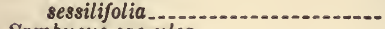 & 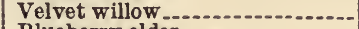 & -......... & $x$ & 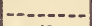 & \\
\hline 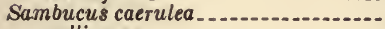 & - n-n-n-n & 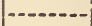 & $x$ & $x$ & $\ldots$ \\
\hline - non & ........... & n.... & $x$ & $x$ & $-\cdots$ \\
\hline$a_{-}$ & & 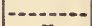 & $x$ & - & $-\cdots$ \\
\hline & $\mathrm{H}$ & & & 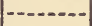 & \\
\hline - & Ga & $\ldots$ & $\mathbf{x}$ & - & \\
\hline Saxifraga & Saxifrage.... & & & $x$ & \\
\hline - & & & $x$ & -2 & \\
\hline Schizonotus discol & & & $\mathbf{x}$ & $\mathbf{x}$ & \\
\hline Scirpus microcarp & Bulrush & & $\mathbf{x}$ & $\frac{\mathbf{x}}{\mathrm{x}}$ & \\
\hline Scribneria bolander & Scribner grass. & & & & \\
\hline
\end{tabular}


TABLE 5.-Plants of the Transition Zone in Oregon-Continued

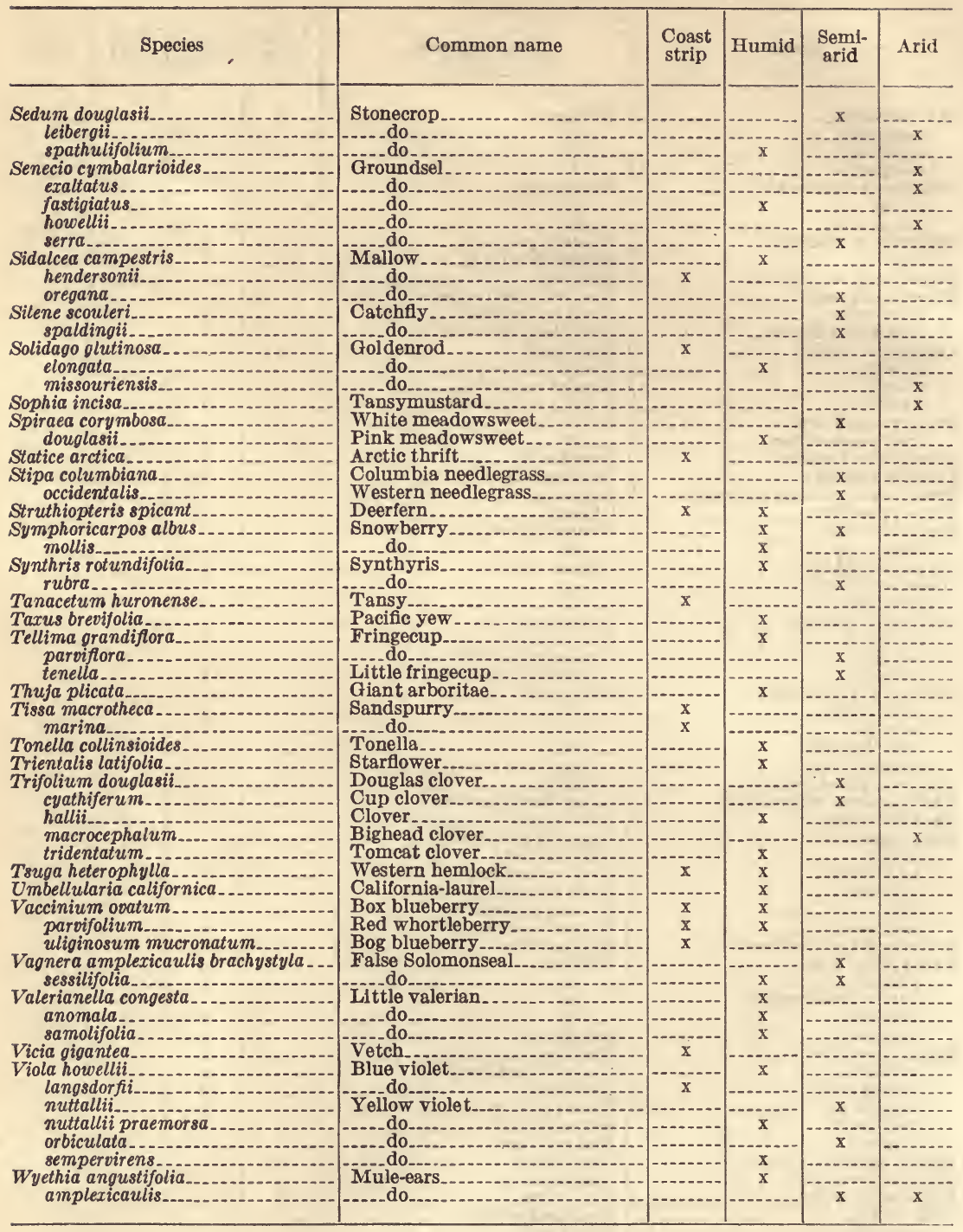


TABLE 6.-Plants of the Canadian Zone in Oregon

\begin{tabular}{l} 
Species \\
\hline Abies amabilis. \\
concolor \\
concolor lowiana \\
grandis \\
nagnifica. \\
shabilis \\
shastensis.
\end{tabular}

Acer douglasii

Aconitum columbianum. howellii.

Alnus tenuifolia.

Angelica genuflexa

Antennaria suffrutescens racemosa

Apargidium boreale

Arabis Nlepharophylla drummondii.

Arctosta phylos nevadensis

Arnica aurantiaca latifolia

Aster modestus

(1) cusickii.

Berberis pumila

Capnoides cusickii

$$
\text { scouleri. }
$$

Castilleja elata miniata.

Cha maecyparis nootkatensis

Chelone nemorosa

Chimaphila umbellata occidentalis

Cimicifuga elata.

Cinna latifolia

Cirsium americanum

Clematis columbiana.

Clintonia uniflora

Coptis laciniata.

Cornus canadensis

Disporum majus.

Dodecatheon alpinum

Drymocallis valida

Echinopanax horridum.

Eriophyllum lanceolatum

Frasera speciosa.

Galium biflor um oregonum

Gilia nuttallii

Heuchera ovalifolia.

Hydrophyllum albifrons.

Juncus regelii.

Juniperus communis montana

Kelloggia galioides

Lepargyrea canadensis

Lilium washingtonianum

Linnaea borealis

Lonicera coerulea involucrata conjugalis.

Luplnus andersoni lyallii lobbii sulphureus.

Mertensia subcordata

Mimulus lewisii. primuloides.

Nemophila brevifiora

Pachistima myrsinites.

Paeonia brownii

Pedicularis attolens bracteosa racemosa

Pentstemon deustus fruticosus. laetus.

$$
\text { newberryi. }
$$

Phalaris arundinacea

Phleum alpinum. $7209^{\circ}-36$

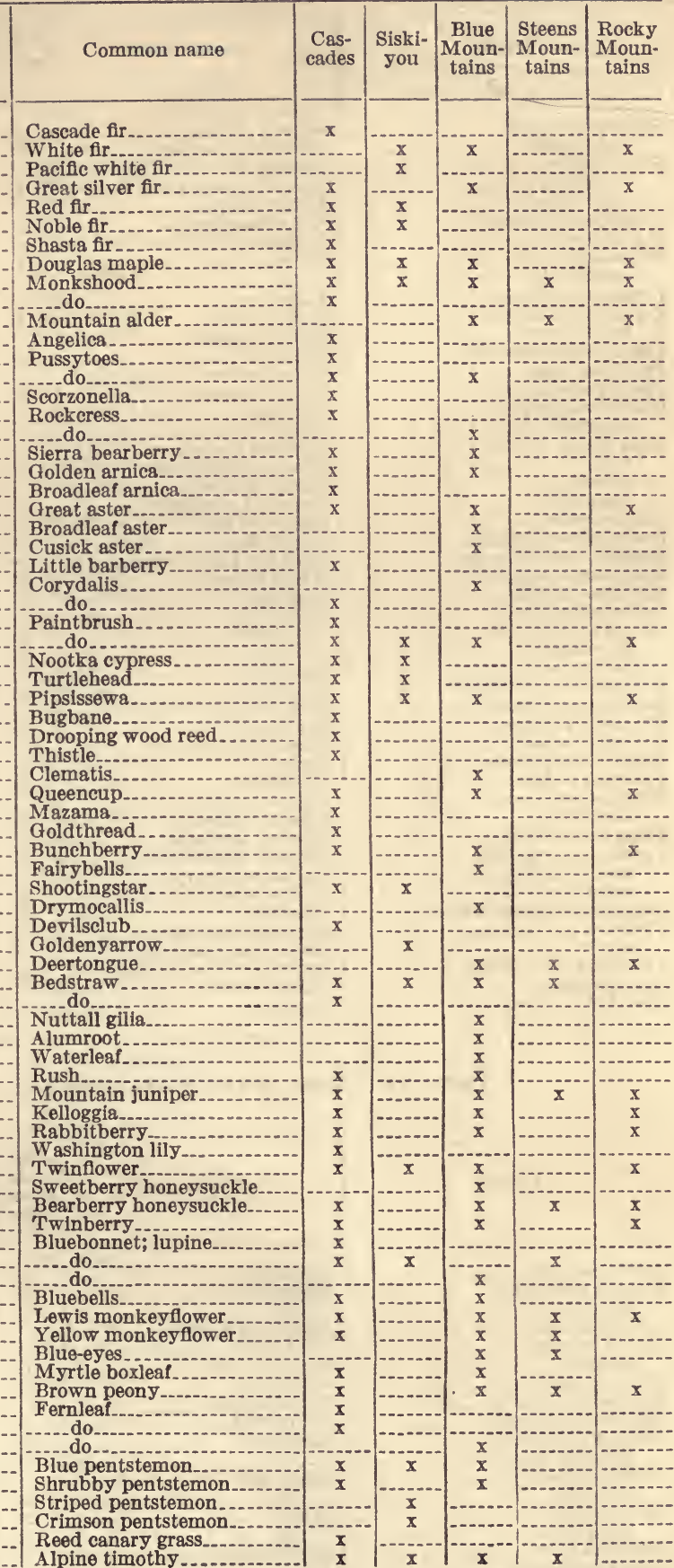


TABLE 6.-Plants of the Canadian Zone in Oregon-Continued

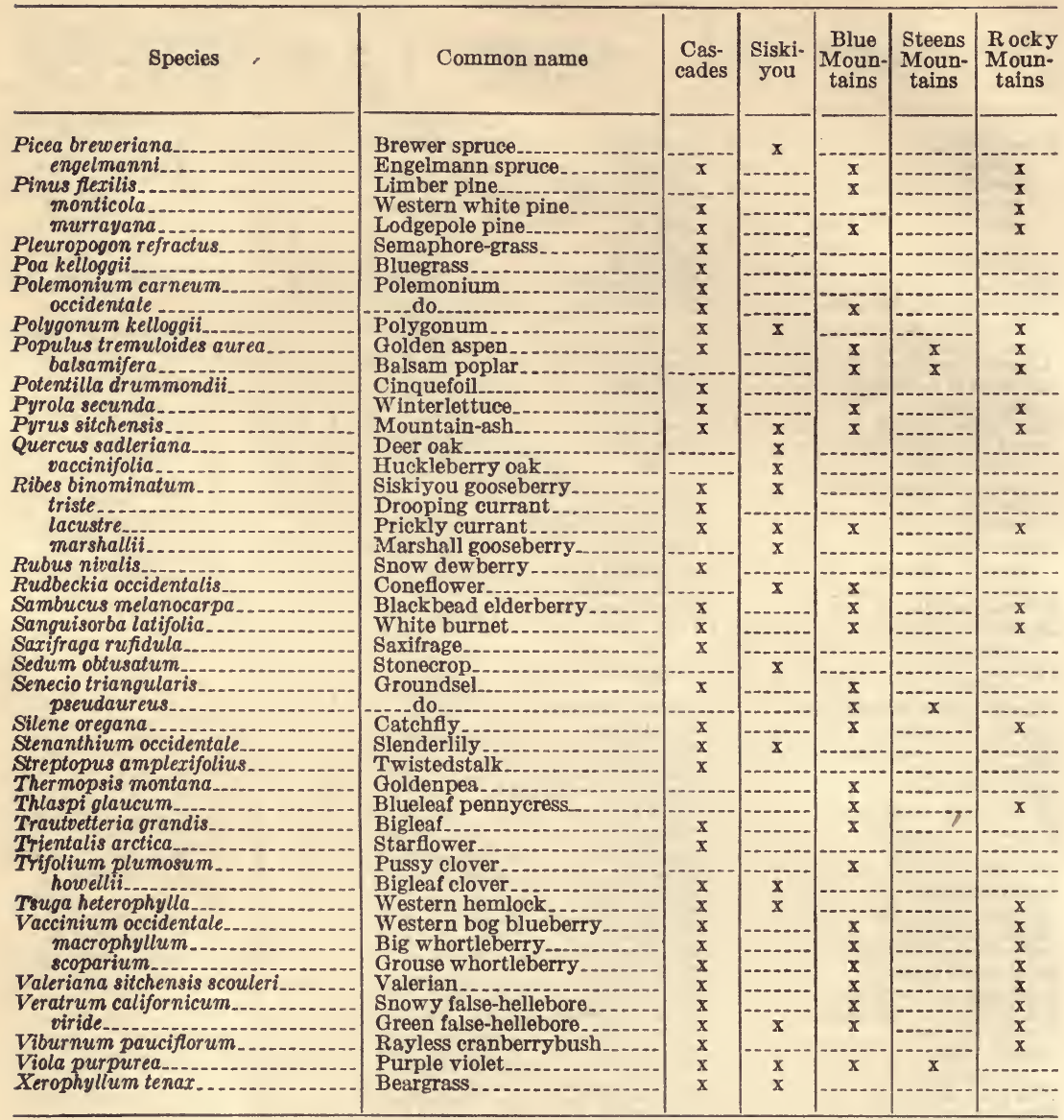

TABLE 7.-Plants of the Hudsonian Zone in Oregon

\begin{tabular}{|c|c|c|c|c|c|c|}
\hline Species & Common name & $\begin{array}{l}\text { Cas- } \\
\text { cade } \\
\text { Moun- } \\
\text { tains }\end{array}$ & $\begin{array}{l}\text { Blue } \\
\text { Moun- } \\
\text { tains }\end{array}$ & $\begin{array}{c}\text { Steens } \\
\text { Moun- } \\
\text { tains }\end{array}$ & $\begin{array}{l}\text { Rocky } \\
\text { Moun- } \\
\text { tains }\end{array}$ & $\underset{\text { North }}{\text { Far }}$ \\
\hline Abies lasiocarpa & Alpine fir.... & $\mathbf{x}$ & $\mathbf{X}$ & $\mathbf{x}$ & $\mathbf{x}$ & $\mathbf{X}$ \\
\hline Agoseris gracilens............... & Sheeplettuce........................ & $\mathbf{x}$ & $\mathrm{x}$ & & & $\ldots$ \\
\hline tris _...... & - do do do & $\mathbf{x}$ & $\mathrm{x}$ & $\cdots$ & & $\ldots \ldots$ \\
\hline Agrostis humilis. & Mountain redtop. & - & $\mathbf{x}$ & 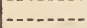 & $x$ & $\ldots . . .$. \\
\hline Allium macrum. & Wild onion. & 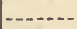 & $\mathbf{x}$ & -..... & $-\cdots$ & $-\ldots$ \\
\hline validum & Swamp onion & $\mathbf{x}$ & & $-\ldots$. & $\ldots$ & $-\ldots$ \\
\hline Alnus sinuata... & Sitka alder & $\mathbf{x}$ & $\mathbf{x}$ & $-\ldots$ & $\mathbf{x}$ & $\ldots \ldots$ \\
\hline Aplopappus greenei............... & Goldenweed & - & $\bar{x}$ & $\ldots .$. & -- & $\ldots$ \\
\hline Aquilegia flavescens..- & 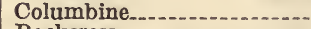 & $\ldots$ & $\mathbf{x}$ & $\ldots \ldots$ & $x$ & $\ldots$ \\
\hline Arabis drummondii... & Rockeress................... & $\mathbf{x}$ & $\mathbf{x}$ & $\ldots \ldots$ & $\ldots$ & $\ldots-$ \\
\hline platysperma & do do _ n & $\mathbf{x}$ & & $-\ldots-n$ & $---n$ & $\ldots$ \\
\hline Arenaria capillaris & Sandwort ..... & - & $\mathbf{x}$ & $-\cdots$ & 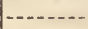 & $-\ldots$ \\
\hline pumicola & 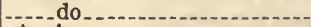 & $\mathbf{x}$ & & $-\cdots$ & $-\infty-\infty$ & $-\ldots$ \\
\hline Arnica latifolia.. & Arnica $\ldots \ldots$ & $\mathbf{x}$ & $\mathbf{x}$ & - n-n & -n. & $-\cdots$ \\
\hline longifolia & - do do & $\mathbf{x}$ & $\mathbf{x}$ & $-2-1-2$ & - n...... & $-2-\ldots$ \\
\hline Artemisia tilesii & Alaska wormwood & $\mathbf{x}$ & $\mathbf{x}$ & $\mathbf{x}$ & 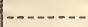 & $-\ldots$ \\
\hline Aster engelmanni & Aster & $\mathbf{x}$ & & $-\cdots-\infty$ & 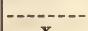 & -..... \\
\hline $\begin{array}{l}\text { foliaceus frondeus } \\
\text { integrifolius }\end{array}$ & -.ndo do n & $\ldots$ & $=\frac{x}{x}$ & 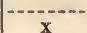 & $\frac{x}{x}$ & 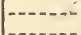 \\
\hline Astragalus hookerianus........... & Balloonpod & $\mathrm{x}$ & $\bar{x}$ & & $\mathbf{A}$ & \\
\hline
\end{tabular}


TABLE 7.-Plants of the Hudsomian Zone in Oregon-Continued

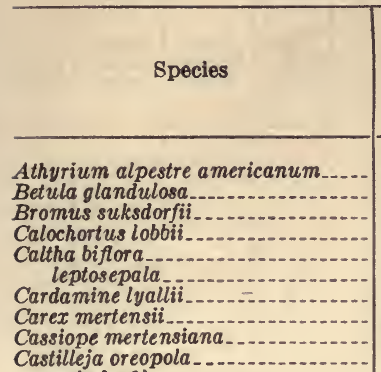

Castilleja oreopola suksdorfii

Chamaecyparis nootkatensis

Cheilanthes siliquosa.

Chelone nemorosa.

Claytonia asarifolia.

Cryptogramma acrostichoides

Dasiphora fruticosa.

Delphinium cyanoreios depauperatum.

Deschampsia atropurpurea

Dodecatheon puberulum tetrandrum

Draba stenoloba

Epilobium clavatum.

fastigiatum.

luteum.

oregonense

Erigeron membranaceus

Eriogonum piperi.

umbellatum vineum.

Eriophorum polystachyon

Erythronium montanum

Eucephalus ledophyllus.

Gaultheria humifusa

Gilia nuttallii.

Helenium hoopesii

Hemieva ranunculifolia.

Heuchera glabra.

Juncoides glabratum piperi.

Juniperus communis sibirica

Kalmia polifolia microphylla

Larix lyallii.

Ledum glandulosum

Ligusticum leibergi tenuifolium.

Lonicera utahensis

Lupinus latifolius subalpinus lyallii.

Mimulus lewisii

Mitella breweri pentandra.

Parnassia fimbriata

Pedicularis bracteosa surrecta.

Pentstemon fruticosus rupicola.

Phacelia linearis newberryi sericea

Phleum alpinum

Phyllodoce empetriformis

Pinus albicaulis.

Poa leptocoma. rhizomata

Polemonium humile

Polygonum bistortoides

Potentilla cascadensis

Quamasia leichtlinii

Raillardella argentea

Ranunculus alismellus populago

Rhodiola integrifolia

Rhododendron albiflorum

Ribes hovellii

montigenum

Alpine ladyfern

Resin birch

Bromegrass

Mariposa

White marshmarigold.

Elkslip.

Bittercress.

Sedge

Moss-heath

Paintbrush

----do.

Nootka cypress.

Oregon cliffbrake

Turtlehead

Spring beauty

Rockbrake.

Shrubby cinquefoi

Larkspur.

Mountain hairgrass

Shootingstar. -.-do

Rockcress

Willowweed Willow do

....-do.

....do.

Fleabane

(Buckwheat family)

.....do.

Cotton-sedge

A valanche-lily

Asteroid.

Creeping wintergreen ....

Gilia.

Orange sneezeweed........

Saxifrage

Smooth alumroot

Woodrush

.....do.

Dwarf juniper

Rocky Mountain kalmia . . Alpine larch

Labrador-tea.

Loveroot

Ütah honeysuckle

Alpine bluebonnet

Lyall bluebonnet

Lowis mimulus.

Bishopscap

-..-do.

Parnassia

Fernleaf

Pentstemon

Curlybloom do

Mountain timothy

Red mountainheath

Whitebark pine.

Redtop.

i.-.do

Mountain polemonium.

Bistort

Cinquefoil

Camas.

Woollyleaf

Buttercup

Roseroot

False-azalea

Howell currant

Gooseberry currant

\begin{tabular}{|c|c|c|c|c|}
\hline $\begin{array}{c}\text { Cas- } \\
\text { cade } \\
\text { Moun- } \\
\text { tains }\end{array}$ & $\begin{array}{l}\text { Blue } \\
\text { Moun- } \\
\text { tains }\end{array}$ & $\begin{array}{l}\text { Steens } \\
\text { Moun- } \\
\text { tains }\end{array}$ & $\begin{array}{l}\text { Rocky } \\
\text { Moun- } \\
\text { tains }\end{array}$ & $\begin{array}{c}\text { Far } \\
\text { North }\end{array}$ \\
\hline & $x$ & & $x$ & \\
\hline & $\mathbf{x}$ & & & \\
\hline$x$ & $x$ & $x$ & $-\ldots$ & \\
\hline$x$ & & & & \\
\hline $\mathrm{x}$ & $x$ & & & \\
\hline & $x$ & & $x$ & \\
\hline $\mathbf{x}$ & $x$ & & $\ldots$ & \\
\hline $\mathbf{x}$ & $x$ & & $x$ & $x$ \\
\hline$x$ & $x$ & & $x$ & $x$ \\
\hline $\mathbf{x}$ & 0. & & $\ldots$ & \\
\hline$x$ & -8 & & & \\
\hline$x$ & $\ldots$. & & & $x$ \\
\hline $\mathbf{x}$ & $\mathbf{x}$ & & & 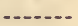 \\
\hline $\mathbf{x}$ & & & & \\
\hline$x$ & $x$ & & & \\
\hline$x$ & $\mathrm{x}$ & & $x$ & $x$ \\
\hline & $x$ & $x$ & $\mathrm{x}$ & $x$ \\
\hline & $x$ & $x$ &.- & $\ldots$ \\
\hline$x$ & $x$ & $\ldots$ & $x$ & $\ldots$ \\
\hline$x$ & $x$ & ......... & $x$ & $x$ \\
\hline & 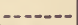 & $\mathbf{x}$ & . & $\ldots$ \\
\hline . & $x$ & - & ........ & \\
\hline$x$ & $x$ & & $x$ & 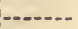 \\
\hline & $x$ & & 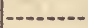 & \\
\hline$x$ & $x$ & & ....... & $-\infty-\infty$ \\
\hline$x$ & $x$ & . & $\mathbf{x}$ & 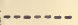 \\
\hline$x$ & & & & $x$ \\
\hline$x$ & $\ldots$ & & & $\ldots \ldots$ \\
\hline & $\mathbf{x}$ & 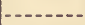 & .... & - \\
\hline & $\mathrm{x}$ & $\ldots$ & $\ldots$ & $\ldots+\ldots$ \\
\hline 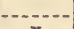 & $\ldots$ & $\mathbf{x}$ & & - \\
\hline$x$ & $\ldots$ & $x$ & .... & $\ldots$. \\
\hline$x$ & $\ldots$ & $\ldots$ & $x$ & $x$ \\
\hline$x$ & $\ldots$ & & $\cdots$ & - - - \\
\hline$x$ & $\ldots$ & & ........ & - \\
\hline $\mathbf{x}$ & $\mathrm{x}$ & $\ldots$ & $x$ & - \\
\hline & $x$ & $\mathbf{x}$ & $x$ & -.... \\
\hline & $\ldots$ & $\mathbf{x}$ & -0. & - \\
\hline$x$ & $\ldots$. & $-\ldots$ & $\mathbf{x}$ & $\ldots$ \\
\hline$x$ & $\ldots$ & & $\ldots$ & $x$ \\
\hline $\mathbf{x}$ & - & & $x$ & $\ldots$ \\
\hline $\mathbf{x}$ & $x$ & & ter & - \\
\hline $\mathbf{x}$ & $x$ & & $x$ & $x$ \\
\hline & $x$ & $x$ & & -...... \\
\hline$x$ & $\ldots$ & -...... & $x$ & ....... \\
\hline- & $x$ & . & $x$ & 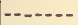 \\
\hline & $x$ & .......... & $x$ & $\ldots . .$. \\
\hline $\mathbf{x}$ & 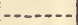 & & . & -..... \\
\hline & $x$ & & $x$ & $\ldots$ \\
\hline $\begin{array}{l}\mathbf{x} \\
\mathbf{x}\end{array}$ & -.... & $\ldots$ & - & -...... \\
\hline$x$ & $-0-\infty$ & . & - & $\ldots$ \\
\hline$x$ & $\mathbf{x}$ & . & $x$ & $-\ldots$ \\
\hline$x$ & ... & - & - & $-\ldots$ \\
\hline$x$ & $x$ & & $\mathbf{x}$ & $\mathbf{x}$ \\
\hline$x$ & $x$ & ......... & $x$ & -..... \\
\hline$\ldots$ & $x$ & - & $x$ & - \\
\hline$x$ & $\mathrm{x}$ & & $x$ & $\mathbf{x}$ \\
\hline & $x$ & $\ldots$ & $x$ & ....... \\
\hline$x$ & $\ldots$ & $=-$ & $\ldots$ & $\ldots \ldots$ \\
\hline$x$ & $\ldots$ & $x$ & .......... & $\ldots+\ldots$ \\
\hline$x$ & $\ldots$ & $\ldots-\infty$ & . & n- \\
\hline$\ldots$ & $\ldots$ & $x$ & - & $\ldots$ \\
\hline 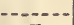 & $x$ & $x$ & ..... & $-\infty-\infty-\infty$ \\
\hline$x$ & $x$ & nen & $\mathbf{x}$ & 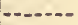 \\
\hline$x$ & $x$ & $\ldots$ & $\mathbf{x}$ & $-\ldots$ \\
\hline$x$ & $\ldots$ & 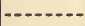 & -........ & - \\
\hline$x$ & ...... & . & ......... & ......... \\
\hline$x$ & $x$ & 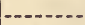 & $\mathbf{x}$ & $x$ \\
\hline $\mathrm{x}$ & $x$ & $x$ & $\mathrm{x}$ & $x$ \\
\hline$x$ & $\ldots . . . .-$. & - & - & $\ldots$ \\
\hline & $-\ldots$ & $\mathrm{x}$ & 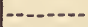 & $\ldots+\ldots$ \\
\hline$x$ & 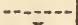 & - & - & $-\infty-\infty-\infty$ \\
\hline$x$ & $\mathrm{x}$ & n-non & $-\infty-\infty .+\infty$ & $\ldots$ \\
\hline $\begin{array}{l}\mathrm{X} \\
\mathrm{x}\end{array}$ & $--+-\infty-\infty$ & - & $-0.0-0$ & $\ldots+\ldots$ \\
\hline $\mathrm{x}$ & $\mathbf{x}$ & - & $\mathbf{x}$ & $\cdots$ \\
\hline 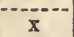 & $\frac{x}{x}$ & 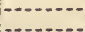 & $x$ & $x$ \\
\hline & & & & \\
\hline
\end{tabular}


TABLE 7.-Plants of the Hudsonian Zone in Oregon-Continued

\begin{tabular}{|c|c|c|c|c|c|c|}
\hline Species & Common name & $\begin{array}{l}\text { Cas- } \\
\text { cade } \\
\text { Moun- } \\
\text { tains }\end{array}$ & $\begin{array}{c}\text { Blue } \\
\text { Moun- } \\
\text { tains }\end{array}$ & $\begin{array}{l}\text { Steens } \\
\text { Moun- } \\
\text { tains }\end{array}$ & $\begin{array}{l}\text { Rocky } \\
\text { Moun- } \\
\text { tains }\end{array}$ & $\begin{array}{c}\text { Far } \\
\text { North }\end{array}$ \\
\hline 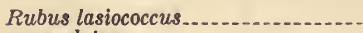 & Downy dewberry ............. & $\mathbf{x}$ & & & & \\
\hline 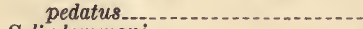 & Dwarf dewberry ............. & $\mathrm{x}$ & -...- & $-\ldots$ & $-\cdots$ & $\ldots$ \\
\hline Salix lemmoni.............. & Lemmon willow & $\mathrm{x}$ & - n...... & - n........ & - n......... & \\
\hline Saussurea americana..... & (Compositae) & $-\ldots$ & $\mathbf{x}$ & - n...... & $\mathrm{x}$ & $\ldots$ \\
\hline Saxifraga bronchialis ....... & Saxifrage & $-\cdots$ & $\mathbf{x}$. & $-\cdots$ & $\mathbf{x}$ & $\mathbf{x}$ \\
\hline columbiana................ & - . do do & . & & $\mathrm{x}$ & $\ldots$ & \\
\hline mertensiana $\ldots \ldots$ & -.... do do.............. & -- & $\mathbf{x}$ & $-\cdots$ & - & $x$ \\
\hline odontoloma - - & - & $\mathrm{x}$ & $\mathbf{x}$ & & & - \\
\hline odontophylla. & - & & $\mathrm{x}$ & & & $-\ldots$ \\
\hline Sedum debile.... & Stonecrop & $-\ldots$ & $-\cdots$ & $\mathrm{x}$ & & $-\cdots$ \\
\hline 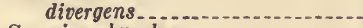 & 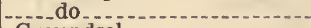 & $\mathrm{x}$ & $\ldots$ & - & & 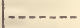 \\
\hline Senecio subnudus............ & 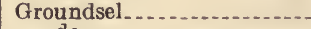 & $\mathbf{x}$ & $\mathbf{x}$ & & & \\
\hline triangularis.................. & - do $d_{0}$ & $\mathrm{x}$ & $\mathbf{x}$ & & $\mathbf{x}$ & - \\
\hline Silene oregana & Catchfly & & $\mathbf{x}$ & -- & $\ldots$ & $-\ldots$ \\
\hline Sorbus occidentalis................ & Mountain-ash & $\mathrm{x}$ & - & $\ldots$ & - & $-\ldots$ \\
\hline Sparganium minimum & Bur-reed & $\mathrm{x}$ & & & -......... & $\ldots$ \\
\hline Spiraea densiflora & Pink spirea & $\mathrm{x}$ & $\mathbf{x}$ & & $\mathbf{x}$ & $-\ldots$ \\
\hline Symphoricarpos acutus . . . . . . & Snowberry & $\mathrm{x}$ & & $\mathbf{x}$ & & \\
\hline Tofieldia inter media & Boglily & $\mathbf{x}$ & $\mathbf{x}$ & - & & $-\cdots$ \\
\hline Tsuga mertensiana $\ldots . . .$. & Mountain hemlock & $\mathrm{x}$ & $\mathrm{x}$ & -...... & $\ldots$ & $\mathbf{x}$ \\
\hline Vaccinium deliciosum & Timberline whortleberry.... & $\mathrm{x}$ & & -- & & \\
\hline scoparium & Grouse whortleberry & $\mathrm{x}$ & $\mathbf{x}$ & & & - n \\
\hline Valeriana sitchensis............... & Valerian . . . & $\mathrm{x}$ & $\mathbf{x}$ & $\ldots$ & 1 & $\mathrm{x}$ \\
\hline Viburnum pauciflor $u m \ldots . . . . .$. & Rayless cranberrybush...... & $\mathbf{x}$ & & -...- & $-\cdots+$ & 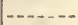 \\
\hline 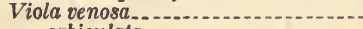 & Yollow violet...................... & 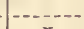 & $\mathbf{x}$ & $\mathbf{x}$ &.- & -........ \\
\hline $\begin{array}{r}\text { orbiculata } \\
\text { Zugenus eleogns }\end{array}$ & do & $\mathbf{x}$ & & $-\ldots$ & & \\
\hline 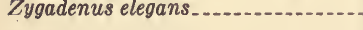 & Deathcamas........................ & & $\mathrm{X}$ & & & \\
\hline
\end{tabular}

TABLE 8.-Plants of the Arctic-Alpine Zone in Oregon ${ }^{1}$

\begin{tabular}{|c|c|c|c|c|c|c|}
\hline Species & Common name & $\begin{array}{c}\text { Cas- } \\
\text { cade } \\
\text { Moun- } \\
\text { tains }\end{array}$ & $\begin{array}{c}\text { Blue } \\
\text { Mioun- } \\
\text { tains }\end{array}$ & $\begin{array}{c}\text { Steens } \\
\text { Moun- } \\
\text { tains }\end{array}$ & $\begin{array}{l}\text { Rocky } \\
\text { Moun- } \\
\text { tains }\end{array}$ & Arctic \\
\hline lchillea alpina..- & Alpine yarrow & & & $x$ & & \\
\hline Agrostis hiemalis geminata & Tickle grass............... & $\mathbf{x}$ & $\mathbf{x}$ & & $\mathbf{x}$ & $\mathbf{x}$ \\
\hline rossae & Ross redtop. & & $\mathrm{x}$ & $-\ldots . . .-1$ & & $\mathrm{x}$ \\
\hline 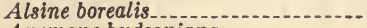 & Starwort & & $\mathbf{x}$ & $\mathbf{x}$ & & $\mathbf{x}$ \\
\hline Anemone hudsoniana & Windflower & $\mathrm{x}$ & $\mathbf{x}$ & 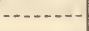 & & \\
\hline Antennaria media & 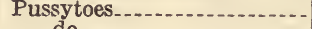 & $\mathbf{x}$ & $x$ & & $x$ & \\
\hline (-1) & - do do n & $\mathbf{x}$ & $\mathbf{x}$ & & $\mathbf{x}$ & \\
\hline 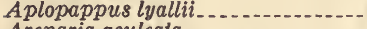 & Goldenweed & $-\ldots$ & $\mathbf{x}$ & -........ & $\mathbf{x}$ & \\
\hline (n) & 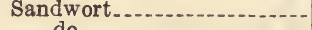 & & & $\mathbf{x}$ & & \\
\hline (2) & - - do do n & - & $\mathbf{x}$ & -.......... & $\mathbf{x}$ & \\
\hline (n) & 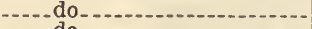 & - & $\mathrm{x}$ & $\ldots$ & $x$ & $x$ \\
\hline n-2hen & - do do n & $\mathbf{x}$ & $\mathbf{x}$ & -..- & $\mathbf{x}$ & $\mathrm{x}$ \\
\hline 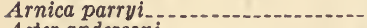 & Arnica & -...- & $\mathbf{x}$ & $-\ldots . . .2$ & $\mathbf{x}$ & \\
\hline 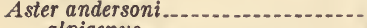 & Mountain aster................. & $\mathrm{x}$ & - & $-\ldots . . .-$ & - & \\
\hline $\begin{array}{l}\text { alpigenus. } \\
\text { Athyrium alpe }\end{array}$ & Timber line aster & $\mathrm{x}$ & -- & -....... & & \\
\hline $\begin{array}{l}\text { Athyrium alpe } \\
\text { Campanula sc }\end{array}$ & Alpine lady fern & -.... & $\mathrm{x}$ & -......... & & - \\
\hline $\begin{array}{l}\text { Campanula scabrella } \\
\text { Cardamine bellidifolia }\end{array}$ & Alpine bellflower & $\mathbf{x}$ & $x$ & $-\ldots+\cdots$ & $\cdots$ & 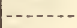 \\
\hline $\begin{array}{l}\text { Cardamine bellidifolia } \\
\text { Claylonia megarrhiza }\end{array}$ & Bittercress. . . & $\mathbf{x}$ & $\cdots$ & $\cdots$ & & \\
\hline $\begin{array}{l}\text { Claylonia megarrhiza } \\
\text { Collomia debilis }\end{array}$ & Springbeauty.................... & $\ldots$ & $\mathrm{x}$ & $-\ldots \ldots$ & $\mathbf{x}$ & \\
\hline $\begin{array}{l}\text { Collomia debilis.. } \\
\text { Crepis nana..... }\end{array}$ & Little collomia. ............... & $\mathrm{x}$ & $\cdots$ & $-\ldots$ & $\cdots$ & \\
\hline $\begin{array}{l}\text { Crepis nana } \\
\text { Danthonia intern }\end{array}$ & Dwarf crepis..................... & & $\mathrm{x}$ & $\ldots$ & $x$ & $\mathrm{x}$ \\
\hline Danthonia intermedia & 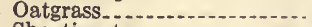 & $\mathrm{x}$ & $\mathbf{x}$ & -........ & $\mathbf{x}$ & \\
\hline $\begin{array}{l}\text { Dodecatheon jeffreyi. } \\
\text { Douglasia laevigata }\end{array}$ & Shootingstar . . & $\mathrm{x}$ & $\mathbf{x}$ & 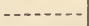 & $\mathbf{x}$ & \\
\hline $\begin{array}{l}\text { Douglasia laevigata..... } \\
\text { Draba lemmoni }\end{array}$ & Douglasia ....................... & $\mathrm{x}$ & & & & \\
\hline Draba lemmoni... & Whitlowgrass & & $\mathbf{x}$ & $\cdots$ & $\mathbf{x}$ & \\
\hline aureola...... & 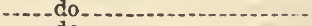 & $x$ & & & & \\
\hline $\begin{array}{r}\text { nemo } \\
\text { Druas oct }\end{array}$ & & & & $x$ & & \\
\hline Drvas octopetala. & White dry & & $\mathrm{x}$ & 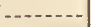 & $\mathrm{x}$ & $\mathrm{x}$ \\
\hline Epilobium alpinum & Alpine willow weed .......... & $\mathbf{x}$ & $\mathbf{x}$ & $-\ldots . . .$. & $\mathbf{x}$ & $x$ \\
\hline anagallidifolium & Puirple willowweed.......... & $\mathbf{x}$ & $\mathbf{x}$ & $-\ldots . . . .$. & $\mathbf{x}$ & $x$ \\
\hline delicatum & Tall willowweed ............. & & $\mathbf{x}$ & $\ldots . . . . .$. & $x$ & \\
\hline 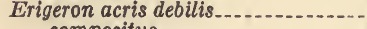 & Fleabane & -....... & $\mathbf{x}$ & (n........ & $x$ & \\
\hline compositus _. & 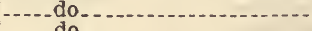 & $\cdots$ & $\mathbf{x}$ & 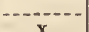 & $\mathbf{x}$ & \\
\hline $\begin{array}{l}\text { compositus trifidus } \\
\text { salsuginosus }\end{array}$ & do $x^{2}$ & $x$ & $\begin{array}{l}\mathrm{x} \\
\mathrm{x}\end{array}$ & $\mathbf{x}$ & $x$ & $\mathrm{x}$ \\
\hline
\end{tabular}

1 Taken in part from Piper (1906) and in part from lists of plants collected or identifled in the fleld by the writer and checked by Morton $\mathbf{E}$. Peck. At best the list is fragmentary, but the species are so grouped as to show the relationship of the Blue Mountain and Steens Mountain flora to that of both the Cascades on the west and the Rocky Mountains on the east. 
TABLE 8.-Plants of the Arctic-Alpine Zone in Oregon-Continued

\begin{tabular}{|c|c|c|c|c|c|c|}
\hline Species & Common name & $\begin{array}{c}\text { Cas- } \\
\text { cade } \\
\text { Moun- } \\
\text { tains }\end{array}$ & $\begin{array}{c}\text { Blue } \\
\text { Moun- } \\
\text { tains }\end{array}$ & $\begin{array}{l}\text { Steens } \\
\text { Moun- } \\
\text { tains }\end{array}$ & $\begin{array}{l}\text { Rocky } \\
\text { Moun- } \\
\text { tains }\end{array}$ & Arctic \\
\hline Eriogonum coryphaeum & (Buckwheat family) ......... & & $\mathbf{x}$ & & $\mathbf{x}$ & \\
\hline piperi. & W & & $\hat{x}$ & 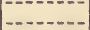 & $\mathbf{x}$ & \\
\hline Eritrichium howardi & Moss-forget-me-not. & & $\mathrm{x}$ & -...... & & \\
\hline Festuca ovina brachyphylla & Alpine fescue & $\mathrm{x}$ & & - & $\mathrm{x}$ & $\mathrm{x}$ \\
\hline viridula & Greenleal fescue.. & $\hat{x}$ & $x$ & $---2--$ & $\mathbf{x}$ & \\
\hline Gentiana calycosa. & Gentian & $\mathrm{x}$ & $\mathbf{x}$ & $-2-2-2$ & $\mathbf{x}$ & \\
\hline Gilia debilis & Alpine gilia.... & $\mathbf{x}$ & $\mathbf{x}$ & 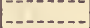 & $\mathbf{x}$ & \\
\hline $2-2-2-2-2-2-2-1$ & Nuttall gilia... & & & $\mathrm{x}$ & & \\
\hline Hieracium gracile & Hawkweed & $\mathbf{x}$ & $x$ & $-\ldots$ & $\mathbf{x}$ & $x$ \\
\hline Hulsea nana. & Alpine hulsea.-. & $\mathbf{x}$ & $\mathbf{x}$ & $---n-2$ & & \\
\hline Ivesia gordoni..... & Chipmunktail & & $\mathrm{x}$ & 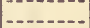 & $x$ & \\
\hline Juncus mertensianus & Rush & $x$ & $\hat{x}$ & $---n-2-$ & $\dot{x}$ & $\mathrm{x}$ \\
\hline parryi & 2. do do & $\hat{x}$ & $\bar{x}$ & 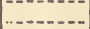 & $\mathbf{x}$ & \\
\hline subtrifiorus & - & $\hat{x}$ & $\mathrm{x}$ & $-\ldots+\infty$ & $\mathbf{x}$ & $\mathrm{x}$ \\
\hline Leptarrhena amplexifolia & Saxifrage...... & $\mathbf{x}$ & & $-\infty-\infty$ & A & $\boldsymbol{a}$ \\
\hline Lewisia columbiana & Columbla bitterroot. & $\hat{x}$ & 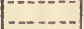 & 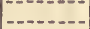 & & \\
\hline densis & Nevada bitterroot & & $\mathrm{x}$ & 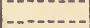 & $\mathrm{x}$ & \\
\hline triphylla & Threeleaf bitterroot. & $\mathrm{x}$ & $\mathbf{x}$ & 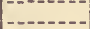 & $\bar{x}$ & \\
\hline Lomatium angustatum & Biscuit root. & $\mathbf{x}$ & $x$ & $-2---2$ & $\mathbf{x}$ & $x$ \\
\hline Lutkea pectinata & Mountainmat... & $\mathrm{x}$ & $\hat{x}$ & 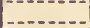 & & \\
\hline Mimulus alpinus & Alpine mimulus & & $\mathbf{x}$ & - & $\mathbf{x}$ & \\
\hline rubellus & Red mimulus. & & $\mathrm{x}$ & - n-n & & \\
\hline Oxyria digyna & Mountain-sorrel & $\mathrm{x}$ & $\bar{x}$ & $x$ & $\mathrm{x}$ & $\mathrm{x}$ \\
\hline Pedicularis contorta & Fernleaf. & & $\mathrm{x}$ & $-\infty-$ & $\mathbf{x}$ & \\
\hline Pentstemon men ziesii & Pentstemon & $x$ & $\hat{x}$ & & & \\
\hline men ziesii davidsoní & 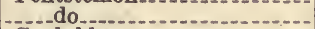 & $\mathbf{x}$ & & $x^{-\infty}$ & & \\
\hline Phacelia sericea & Curlybloom & & $x$ & & $\mathbf{x}$ & $\mathbf{x}$ \\
\hline Phleum alpinum & Mountain timothy & $x$ & $\vec{x}$ & $x$ & $\hat{x}$ & $\mathbf{x}$ \\
\hline Phlox diffusa. & Phlox. & $\mathbf{x}$ & $\bar{x}$ & - & & \\
\hline douglasii & do do & $\hat{x}$ & $\mathbf{x}$ & - $-2-2-2$ & $\mathbf{x}$ & \\
\hline Phyllodoce gla ndulifiora & Cream moun tainheath. & $x$ & & -....... & $\mathbf{x}$ & $x$ \\
\hline Polygonum davisiae & Polygonum & $\vec{x}$ & $\cdots-1>$ & 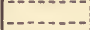 & & \\
\hline minimum & 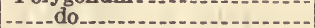 & $\vec{x}$ & $x$ & 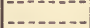 & $\mathbf{x}$ & $\mathrm{x}$ \\
\hline ryi & - do do & $\mathbf{x}$ & & $-\cdots$ & & \\
\hline viviparum & do & & $\bar{x}$ & - non & $\mathbf{x}$ & $\mathbf{x}$ \\
\hline Potentilla flabellifolia & Cinquefoil & $\mathrm{x}$ & $\bar{x}$ & - n- & - & $\mathbf{x}$ \\
\hline dissecta & ( & & $x$ & 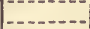 & $x$ & \\
\hline Pulsatilla occidentalis & American pasqueflower & $\mathrm{x}$ & & 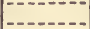 & & $x$ \\
\hline Ranunculus eschscholtzii.............. & 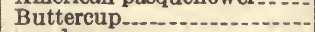 & $\hat{x}$ & $\mathrm{x}$ & 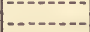 & & $\mathbf{x}$ \\
\hline suksdorfit & do do & & $\hat{x}$ & 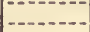 & & \\
\hline Salix nivalis & Snow willow & 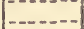 & $\hat{x}$ & 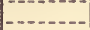 & $\mathrm{x}$ & - \\
\hline Saxifraga bongardi & Saxifrage & $\mathrm{x}$ & $\mathbf{x}$ & 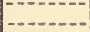 & $\dot{x}$ & $\mathbf{x}$ \\
\hline 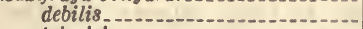 & - & -..... & $\mathbf{x}$ & -...- & $\bar{x}$ & \\
\hline tolmiei & - do & $\mathrm{x}$ & $\hat{x}$ & & & \\
\hline Scirpus caespitasus & Sedge $\theta_{0}$ & $\hat{x}$ & $\frac{\lambda}{x}$ & (n) & $\mathbf{x}$ & $\mathbf{x}$ \\
\hline ecio fremontii & 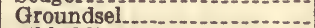 & & $\hat{x}$ & & & \\
\hline baldia procumbens & Sibbaldia & $a_{--}^{-}$ & $\mathbf{x}$ & & & \\
\hline $3-2-1-2-2-2-2-1$ & Sieversia...... & $-\infty$ & $\frac{d}{x}$ & 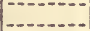 & $\mathbf{x}$ & $\mathbf{x}$ \\
\hline 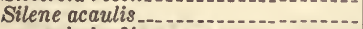 & Moss campion. & 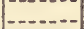 & $x$ & 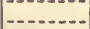 & $\mathbf{x}$ & $\mathrm{x}$ \\
\hline 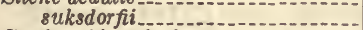 & Mountain campion & $x$ & & 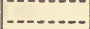 & & \\
\hline Smelowskia calycina. & Arctic crucifer & $\mid-\ldots$ & $x$ & 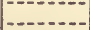 & $x$ & $x$ \\
\hline Spraguea multiceps & Pussypaws.................... & & - & $\mathbf{x}$ & & \\
\hline umbellata.... & 1 hod do & $x$ & $x$ & $\mathrm{x}$ & $x$ & \\
\hline Thlaspi alpestre. & Alpine pennycress... & $\bar{x}$ & $x$ & $-\ldots+\ldots$ & $\mathrm{x}$ & \\
\hline Trisetum spicatum & Spike trisetum. & $\bar{x}$ & $x$ & - - - n-n- & $\mathbf{x}$ & $x$ \\
\hline Veronica alpina.. & Alpine speedwell & $\hat{x}$ & $\mathrm{x}$ & $\mathrm{x}$ & $x$ & $\mathbf{x}$ \\
\hline
\end{tabular}




\section{MAMMALS OF OREGON}

\section{AN IMPORTANT NATURAL RESOURCE}

Since the advent of the white man, the mammal life of Oregon has been an important factor in the development of the State, as it had been for ages before in maintaining the original native population. The quest of valuable furs brought hardy pioneers into the region, and the abundance of game enabled them to live and carry on extensive explorations that yielded a valuable knowledge of the country and its resources. As man and domestic animals filled the more fertile parts of the country, the abundance of native life decreased; but in many parts of the State the game and fur-bearing animals still have a high value and can be maintained in reasonable numbers. Other forms of life destructive to game, livestock, poultry, and crops must be controlled and kept within reasonable bounds, while many of the useful species need careful protection and encouragement. The merely harmless but interesting forms of small mammals may have a real value of interest and education that should not be overlooked in our human economy. Whatever may be our attitude toward the native wildlife, our course should be guided by a full knowledge of all of the species, their physical characters, distribution, natural or controlled abundance, natural habits, and as far as possible their relations to our own lives and industries.

The object of the present report is not only to give as full information as possible on all of the mammals of Oregon, but to give information that will enable others to go ahead with future studies based on present knowledge, until far better means for understanding, appreciating, managing, and controlling our native fauna are attained.

A sequence of species has been adopted that brings many of the more important animals ahead of the smaller and more obscure kinds, and while not entirely in systematic order, this sequence seems logical for practical use.

Both common and scientific names of the species are given, as well as native Indian names wherever possible, some of which eventually may well replace our names of less satisfactory application. Some of the native names wcre obtained direct from the Indians; others are quoted from manuscripts or publications as indicated by initials of the writers. ${ }^{2}$

Most of the measurements of the mammals are in millimeters as taken in the field by collectors and include total length, from tip of nose to tip of tail vertebrae in a straight line; length of tail from tip of vertebrae to base with tail held straight at right angles to back; hind foot from tip of heel to tip of longest claw with toes held straight; and length of ear from the inner notch at base to tip, unless otherwise stated.

\footnotetext{
${ }^{2}$ Vernon Bailey, W. H. Dall, George M. Dawson, David Douglas, Luther J. Goldman, George Bird Grinnell, Lewis and Clark, Maximilian Prince of Wied, C. Hart Merriam, George Suckley, J. K. Townsend.
} 
Weights are given in grams for the small mammals, and pounds and ounces for the larger species.

The reports of the numbers of the larger mammals estimated to inhabit the various districts of the national forests (table 9), while rarely showing actual counts, are based on careful observations made throughout the year by rangers and supervisors and are the best records available of the numbers present on the forest areas. The national forests of Oregon cover nearly half the State and support much more than half the large game animals. The records are especially valuable as showing year by year the approximate increase or decrease of the species and as affording a basis for intelligent control efforts, or regulation of hunting. The annual game census of the Forest Service, district 6, for 1929, which has been selected because the data for that year are the most nearly complete for the various classes, gives the number of licensed hunters on the forests as 25,873 ; the number of mule deer killed by hunters as 2,864 ; blacktailed deer, 1,768; elk, 89; and black bear, 538. The report gives 7,113 deer and 19 elk killed by predatory animals.

Other notes of interest in the report are 3,201 coyotes killed on the forests by Biological Survey hunters, 85 by forestry officials, and 3,043 by local hunters and trappers. Of bobcats, 295 are reported taken by the Biological Survey hunters, 12 by forestry officials, and 1,369 by local trappers. Of mountain lions, 9 are credited to the Biological Survey hunters, 1 to forestry officials, and 134 to local hunters.

Elk, deer, antelope, sage grouse, and porcupines are reported to be increasing.

Predatory animals are reported as generally decreasing in abundance. 


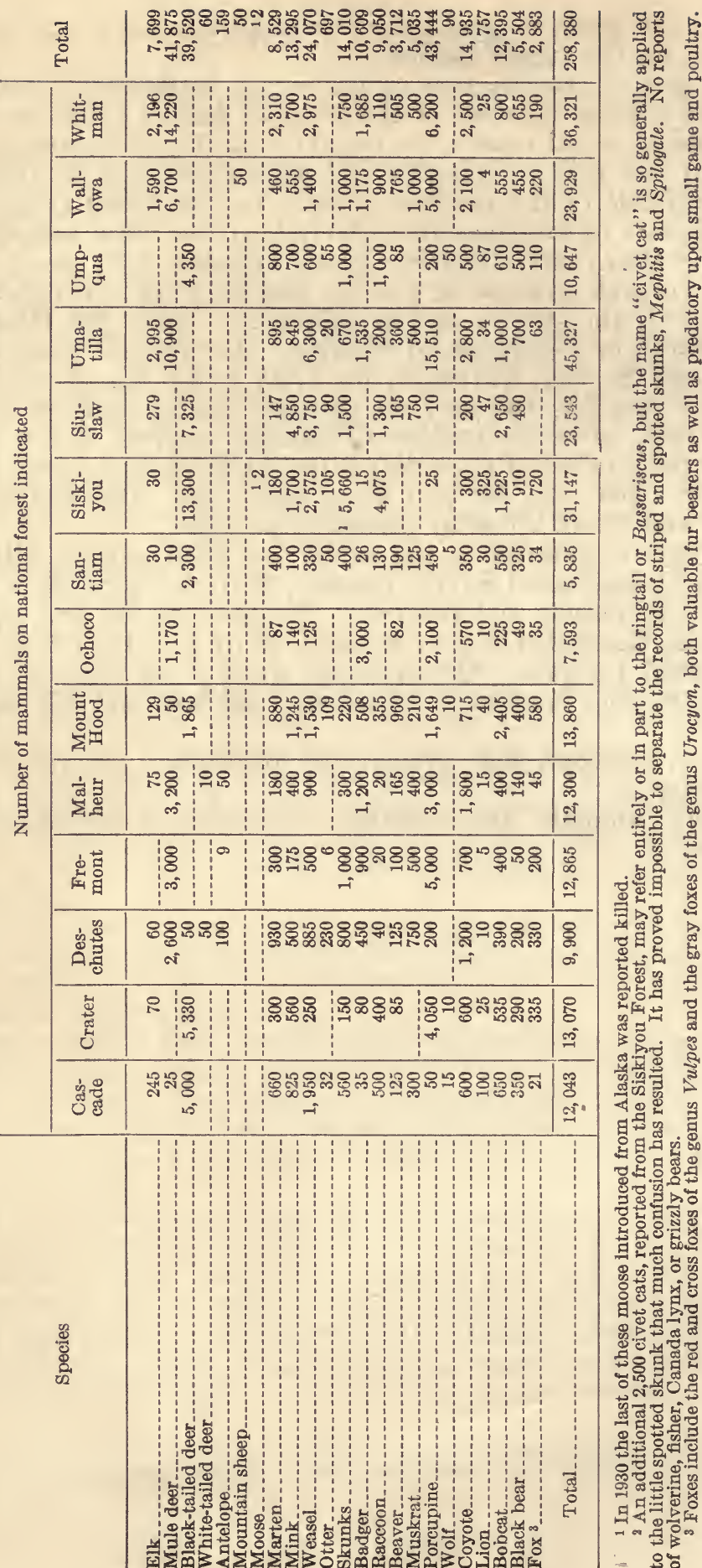




\title{
ANNOTATED LIST OF SPECIES
}

\section{ORDER ARTIODACTYLA: HOOFED MAMMALS}

\author{
Family BOVIDAE: Cattle, Sheep, and Goats
}

\section{BISON BISON OREGONUS BAILEY}

OrdaON Bison, or BuFfalo; Goo'-choo or Goot'tsoo of the Piute (C. H. M.) ; Goo'-CHOO of the Pit River Indians (C. H. M.) ; TU-PETSE-QUOTSU of the Piute at Burns (V. B.) ; YUно of the Klamath (C. H. M.)

Bison bison oregonus Bailey, Biol. Soc. Wash. Proc. 45: 47-48, 1932.

Type--Skull and skeleton, collected at Malheur Lake, Oreg., by Geo. M. Benson, November 1931.

General description.- Similar in characters to Bison bison bison of southwestern Texas, but slightly larger, with relatively longer and straighter and less abruptly tapering horn cores, indicating wider and straighter horns of a somewhat larger animal. The rostrum or arch formed by the upper premaxillary bones is slightly longer and relatively narrower than in southern specimens; interpterygoid fossa wider and larger; auditory inflations smaller than in typical Texas skulls; molars larger. No external characters are or can ever be known as the form is long extinct. The cranial characters distinguishing it incline somewhat toward those of the much larger athabascae but are no nearer to it on the one hand than to southern Texas specimens on the other.

Distribution and habitat.-Buffalo once inhabited eastern Oregon in considerable abundance (fig. 7). On November 1, 1826, Ogden (1910, p. $20 \%$ ) in charge of a large

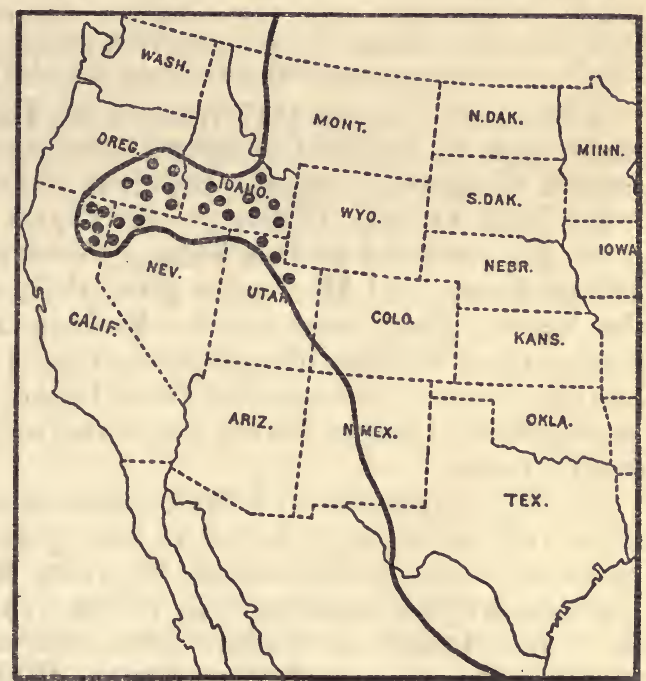

EIGURE 7.-Range of buffalo, Bison bison oregonus, in Oregon and adjoining States, with border line of original range. Spots indicate actual records. party of trappers penetrated the interior of Oregon to Harney Lake, which he graphically describes, and he notes in his journal, "Buffalo have been here and heads are to be seen."

In 1873, O. C. Marsh found the bones of a buffalo, much decomposed but perfectly characteristic, on Willow Creek in the southeastern foothills of the Blue Mountains, which would mean somewhere between the present towns of Vale and Ironside (J. A. Allen, $18 \% 6 a, p .119)$.

In 1915 W. F. Schnabel gave to the Biological Survey an old horn of a buffalo picked up near Cow Creek Lake, Malheur County, Oreg., the preceding summer, and he told E. A. Preble of a skeleton in a cave several miles southwest of Jordan Crater. In a later letter dated March 21, 1916, Schnabel wrote:

I went to the cave for the buffalo skeleton and it was gone. I have found two more heads on the Owyhee River and they are there to this day. The 
old chief Yakima Jim, about 110 years old, told me that when he was a boy there were lots of buffalo around the Cow Creek Lakes country, but he says they were all killed during a hard winter.

Under date of April 29, 1916, Schnabel wrote:

The last time old chief Yakima Jim was at my ranch was in 1889 or thereabouts. He told me the last of the buffalo were killed during a hard winter when the snow was so deep they could not get grass and that a good many tumbled over the high bluffs on the Owyhee River. I know where there are two skulls near the Owyhee River. Mr. Riley M. Horn, who has a cow ranch on the Owyhee back of my old ranch at the Cow Lakes can show you where they are. The horn I have mailed you today was found about 30 yards from the Caldwell and Jordan Valley stage road near the Ditton Ranch on Cow Creek in 1915. This horn is in good condition, but thin and apparently from a young bull.

In a still later letter, October 30,1916 , Schnabel wrote from Caldwell, Idaho:

I have just returned from a trip to my old cattle ranch at Cow Creek Lakes. Where the creek has washed a channel about 6 feet deep I found a buffalo head imbedded in the old lake formation about 4 feet below the surface. The horns had been carried away and the skull is very old and fragile.

A letter received in 1917 from R. M. Horn, referred to by Schnabel, states that he had found several buffalo skulls at different places in eastern Oregon during the previous 18 or 20 years.

In 1826 Ogden (1909, p. 355) and in 1834 Townsend (1839, $p .82 \mathrm{ff}$.) recorded buffalo ranging west across southern Idaho to the Malad River, and Hornaday gives their range as along both sides of the Snake River west to the Fishing Falls $(1889, p$. 383). This brings them within historic time close to the eastern line of Oregon, but they soon after vanished from Idaho, as they had evidently disappeared from Oregon before the white man could take a hand in their destruction.

In 1921 fragments of buffalo bones mixed with those of deer, antelope, and cattle were found in the open mouth of Malheur Cave, a large volcanic tunnel about 18 miles southeast of Malheur Lake. Various large animals and in recent years cattle had evidently used this open tunnel as shelter from storms, and the debris near the mouth included many broken bones. While partly protected from the weather, the bones were in a mass of moist earth and still had a fresh and sound appearance indicating no great age. A few pieces of jaws containing molar teeth, a long dorsal process of a cervical vertebra, and some other bones brought back were identífied by J. W. Gidley and O. P. Hay, of the United States National Museum, as unmistakably buffalo.

William Renwick, of Folly Farm, recently told of finding a fairly complete buffalo skull in Barren Valley, east of the Steens Mountains, in 1907, and A. E. Brown, on his ranch near Malheur Cave, says that James Muse found buffalo skulls on his place in the tules at the west end of Malheur Lake in 1884. Brown saw the skulls and was sure they were buffalo.

Early in December 1930, L. E. Hibbard at Burns took the writer to the office of R. M. Duncan, who had three buffalo skulls, recently picked up on the dry bed of Malheur Lake. An old bull and a cow skull he had promised to a friend in Portland for the Oregon State Museum, but he gave the writer the skull of a young bull and told 
where others could be found on the lake bottom. With Elmer Williams the writer visited the lake next day and obtained 9 more skulls, 1 contributed by J. O. Ausmus, a rancher living on the lake shore near the mouth of Silvies River, who also showed where the best skulls were to be found.

During recent dry years the water of Malheur Lake has receded to a small area of some few thousand acres, leaving many miles of dry, cracked, mellow bottom that was formerly soft mud to considerable depths. Over this dry bed white objects, quite different from the thousands of snow geese, were seen here and there, sometimes half a dozen from one point. These all proved to be buffalo skulls lying on the surface of the ground, and in every case where the skull had not been recently moved the whole skeleton was found buried under it. Evidently the animals had bogged down in search of water at some dry period long ago when the water had receded; or else, in attempting to cross the lake on the ice in winter or to get out to open water, they had broken through and drowned in the oozy mud of the bottom. Generally the skeletons were scattered, but in some natural depressions, that may have been regular watering holes, there were several skeletons close together. In a couple of hours dozens of skeletons were seen from which 8 of the best were saved and a box of 10 sent to the United States National Museum.

Some of the skulls were fairly complete with full sets of teeth in the jaws. Others were broken or partly disintegrated. In view of the fact that they had been there for over a century they showed excellent preservation. Hundreds of others have been seen and reported, and many obtained by local collectors will give important study material. Thanks to the efforts of George M. Benson, of the Biological Survey, there are now two almost complete skeletons with good skulls of large old bulls in the Bureau's collection. These, with many skulls picked up and contributed by others, afford a fine series for comparison and study.

Ausmus told the writer that many old pieces of skulls and unmistakable buffalo bones had been found for years past in the tules along the lake shore when the water was low, but never in such numbers or in so good condition as those now exposed over the lake bottom. Duncan also told of another buffalo skull recently taken from a spring on the Double-O Ranch (OO) west of Harney Lake, by Gus Hurlburt, marking the westernmost record from the Malheur Valley.

In 1929 Stanley G. Jewett sent the writer a piece of buffalo rib picked up by Robert Sawyer, of Bend, on the site of Old Camp Warner, near Hart Mountain, on the east side of Warner Lake and giving the westernmost Oregon record of buffalo remains so far made known. This is especially important in connecting up the Malheur Valley range with the California range.

Merriam (1926, pp. 211-214) has traced the buffalo well into northeastern California through definite and reliable Indian records, showing its presence only two generations ago in the Madeline Plains country, near Eagle and Honey Lakes, and in Alturus and Surprise Valleys, as well as at half a dozen places named for them on the Nevada side of the line. Old Indians of several tribes said that their fathers had killed the buffalo on their own territory, and while one tribe considered them permanent residents in Pine Creek 
Valley on the west side of Eagle Lake, the Indians generally believed that the buffalo came in small bands from farther north. This would mean that they came in from Goose Lake and Warner Lake Valleys, the natural highways from the ancient range of the buffalo in eastern Oregon. Probably also they came through the broad, open, grassy, and well-watered Quinn River Valley by way of Buffalo Creek and Buffalo Spring, Nev., below McDermitt and south through the broad, open southern end of the Alvord Valley.

In 1916 Captain Louis, a chief of the band of Piute Indians near Burns, and for several years a scout with General Crook, told the writer that there used to be buffalo all over the Malheur Valley. He thought he was then (1916) about 70 or 80 years old, saying he was a young man, not married, at the time of the Modoc War. His grandfather, he said, was here when there were plenty of buffalo over the valley. They went into the mountains in summer and came down into the valleys in winter and were hunted by the Indians. He could remember, when a boy, seeing some of the very old men with much-worn buffalo skins as robes, and he found, he said, buffalo bones and horns in Malheur Lake when it was unusually low. His grandfather had told him about the buffalo going away. The Indians followed them east to Crane Creek, to Malheur River, and then across Snake River, over to the Bannock country. He thought they left here about 100 years ago, but was not very clear in his dates. The Indians still have a song calling the buffalo to "come back, come back, and do not go away again." They sing it with the drum as they dance and try to keep alive the flickering flame of ancient hunting lore.

It seems probable that these buffalo, which at one time were able to maintain an existence among purely primitive people, were forced to withdraw before the horseback Indians even before deadly firearms came into general use among them. Lewis and Clark found horses abundant among the Nez Percés in 1805; and in 1814 Franchere (1904, p. 339), while among the Umatilla Indians of the Columbia River, said:

They are almost always seen on horseback and are in general good riders. They pursue the deer and penetrate even to Missouri to kill buffalo, the flesh of which they dry and bring it back on their horses to make their principal food during the winter.

The Territory of Missouri of that time was of course no farther distant than what is now western Montana and but little farther than the Malheur Lake section from which the buffalo had probably already disappeared.

Even after most of the buffalo had gone from Idaho the Oregon Indians followed them beyond. On October 13, 1843, Fremont (1845, p. 17/4) was overtaken near the Malheur River by a party of Cayuse Indians returning from a buffalo hunt to the Rocky Mountains.

There is no question that only a few generations back buffalo covered in considerable numbers many of the large valleys of southeastern Oregon and that they disappeared after the introduction of horses among the Indians and before many firearms were obtained. A thrilling page of history seems to be missing, when red hunters first mounted on horses learned their power to overtake and kill with comparative ease and certainty big game as well as their less for- 
tunate enemies. The balance of nature was disturbed almost as much by the advent of horses as by that of gunpowder.

It is an interesting fact that buffalo, once native to Oregon, will thrive if returned to suitable valleys, but in even these great open valleys such dangerous and migratory animals must be restrained by strong fences. Although the Oregon subspecies is extinct the plains species is no longer in danger of extermination. There is an abundance available for breeding purposes. They are hardy and prolific, and there is no reason why Oregon should not have buffalo steaks and buffalo robes as well as a good showing of one of our most interesting forms of native wildlife.

\section{[OREAMNOS AMERICANUS AMERICANUS (BLAINVILLE) 2a}

Mountain Goat; White Goat; White Buffalo; Pieyanin of the Klikitat (Chambreau) ; KoxnIK of the Wasco

Ovis montanus Ord, Guthrie's Geog., 2d Amer. ed., p. 292 (description on pp. 309-310), 1815, earliest name but preoccupied by Ovis montanus the mountain sheep.

$R$ [upicapra] americana, Blainville, Bull. Sci. Soc. Philomath, Paris, p. 80, 1816.

Mazama dorsata Rafinesque, Amer. Monthly Mag. 2:44, 1817 (Renaming Ovis montanus Ord).

Oreamnos Rafinesque, Amer. Monthly Mag. 2: 44, 1817.

Oreamnos montanus Merriam, Science (n. s.) 1: 19, 1895.

Oreamnos americanus americanus (Blainville) Hollister, Biol. Soc. Wash. Proc. $25: 185-186,1912$.

(All based on Ord's Ovis montanus after Lewis and Clark. Rafinesque's genus Mazama apparently applies to a Mexican deer; his Oreamnos seems to be the earliest generic name available for the mountain goat.)

Type locality. - Cascade Range near the Columbia River in Oregon or Washington." This refers merely to the place near which Lewis and Clark saw their skins and the blankets woven of their wool among the Indians.

General characters.-Not a true goat, buffalo, or antelope, but structurally nearest to the Old World antelopes, with which it agrees in permanent hollow sheathed horns, similar to those of the chamois, one of its nearest relatives. Size considerably larger than the mountain sheep; form low and heavy, high over the shoulders with stout neck and large head; tail a mere rudiment; legs heavy and strong; feet large with heavy hoofs and small secondary hoofs (dewclaws) on all four feet; horns black, small, slightly recurved, with annular bases and smooth, sharp points; hairy coat long, with coarse mane, beard, and. chaps and fine dense wool over rest of body; color normally pure white all over except black horns, hoofs, nose, lips, and eyelids.

Measurements.-A large male from British Columbia collected by E. A. Preble: Total length, $1,740 \mathrm{~mm}$; tail, 100 ; hind foot, 360 . Weights of large males have been estimated at 300 to 500 pounds. A large male killed west of North Yakima, Wash., was reported by $\mathbf{A}$. S. Harmer as 8 feet 3 inches from tip of nose to tip of tail; horns 10 inches; weight 507 pounds (Outdoor Life, 1915, p. 459).

Distribution and habitat.-White goats do not now and perhaps never did inhabit Oregon, but they have been so often reported from the State that some explanation seems necessary. In the original description of the species in 1815 Lewis and Clark in their journal notes reported them along the lower Columbia River in 1804 and 1805 and say:

We have seen only the skins of these animals which the native dress with the wool and the blankets which they manufacture from the wool.-They live in great numbers on the chain of mountains forming the commencement of the wooded country on the coast (the Cascades) and passing the Columbia between the falls and the rapids.

2a Hypothetical. 
Later, Ord, as ignorant as Lewis and Clark of the real range of the animal, credited it to both Washington and Oregon, and he was followed by Richardson (1829), J. K. Townsend (1839), Suckley and Gibbs (1860), Grinnell and Fannin (1890), Hornaday (1906), and even G. S. Miller in 1924.

Goats are still common on Mount Saint Helens and the Goat Rocks half way between Mount Rainier and Mount Adams, and they have been reported in comparatively recent times from the north slopes of Mount Adams in Washington. So far as known, however, there is no authentic record of their occurrence south of the Columbia River in Oregon in recent years. The discovery of their bones in cave deposits near Mount Shasta in northern California, by John C. Merriam et al. in 1903 (Sinclair, 1904, p. 18) is evidence that they once ranged this far south, and it is not improbable that in the days of Lewis and Clark they may have occupied Mount Hood and perhaps other snowy peaks of the Cascades in Oregon. Hood, Jefferson, Three Sisters, and several other peaks of the range are perfectly adapted to mountain goats; and the fact that before the introduction of domestic sheep, they were the only animals except dogs with warm woolly fleeces, may well account for a receding range in a region well occupied by a primitive native people. Now their fine woolly fleeces are in less demand, and they might easily be protected on the higher peaks of Oregon where they would form a most interesting and attractive feature of wildlife.

A record of mountain goats occupying the Blue Mountains, made by Lee $R$. Dice, cannot be ignored, although it seems very doubtful. He says: "Goats are reported by Floyd Kendall [Forest Ranger on the Imnaha] to have occurred at one time in the Blue Mountains of Washington but they are now absent from the region" $(1919, p .21)$. On the Washington end of the Blue Mountains there is no suitable country for goats, but in the high peaks of the Wallowas, the southern section of the Blue Mountains in Oregon, they would find ideal range and might well thrive if once established. They have also been reported from the Seven Devils Mountains of Idaho, just across the Snake River Canyon from the Blue Mountains, but this, too, is a doubtful record as the animals are now not positively known nearer than the Sawtooth Mountains of central Idaho. Still there is the possibility that in earlier times they may have occupied the high peaks of both the Seven Devils and the Wallowas. Further evidence on this point should be sought.

If mountain goats ever ranged in this corner of Oregon it would naturally be the Montana form, Oreamnos americanus missoulae (Allen), described from the mountains north of Missoula and ranging througout the Bitterroots and mountains of central Idaho.

So often have the female or young male mountain sheep with slender, curved horns been mistaken for mountain goats during the spring season, when the faded winter coats at a distance appear almost white, that goat records must be fully verified to be reliable. While many such records appear in literature of mountain goats south to the borders of Mexico, the present range of the species is known to reach south in the Rocky Mountains only to central Idaho and in the Cascades to southern Washington.] 


\section{OVIS CANADENSIS CANADENSIS SHAW}

Rocky Mountain Bighorn; Mountarn SheEP; EMaH-KI-Kini of the Blackfeet (G. B. G.)

Ovis canadensis Shaw, Naturalists Miscellany 15: text to plate $610,1804$.

Type locality.-Mountains on Bow River, near Exshaw, Alberta.

General characters.-Large for a sheep; head and skull massive, with heavy coiled wrinkled, permanent, horns in the old males (pls. 15 and 16); females with small, slender, slightly curved horns; tail a mere rudiment, dewclaws present on all 4 feet; hair coarse, smooth, and dense in winter coat with a mere trace of fine wool concealed close to the skin, short and harsh in summer. Summer pelage dark gray or slaty drab all over except a large white patch covering rump, white stripes down back of hind legs from rump patch to heels, short white stripes down back of front legs and small whitish areas on front and back of belly, around nose, and on ears; tail and line along back dark brown. In winter, pelage light gray fading to lighter gray in spring.

Measurements.-Adult female from type region in Alberta: Total length, $1,540 \mathrm{~mm}$; tail, 46 ; foot 140 . Male from same region: Total length, 1,580; tail, 98; foot, 410. Upper tooth row in typical male canadensis 81 to 86.

Distribution and habitat.-These sheep of the high peaks are represented in the Biological Survey collection by one skin of the fine old ram, from the Wallowa Mountains above Wallowa Lake, taken about 1890 and presented by Harzinger of $\mathrm{La}$ Grande to Stanley G. Jewett, in 1923, for the Bureau's collection. There is no skull, but the skin is complete and in fairly good condition, taken evidently in late summer or early autumn while in the dark summer coat. In color and pattern the skin agrees perfectly with the typical Ovis canadensis canadensis from Alberta in comparable pelage, dark slaty drab all over except the large white rump patch, white stripes from rump patch down back of legs to heels, short white stripes down back of front legs, and a little soiled whitish on front and back of belly and around nose and ears. The little stump of a tail is brown, and a brown line from it along the back completely divides the white rump patch above. No measurements are possible, but in size the skin and hoofs seem to equal those of comparable specimens of typical canadensis. The only skull seen from the Blue Mountain region is a fragment of cranium with horn cores picked up on the Wenaha River, and contributed to the Biological Survey collection by W. H. Kendall. So far as it shows characters this skull agrees with canadensis rather than with $O$. c. californiana.

In the Blue Mountain section sheep have held out longer than elsewhere in the State, and there only may be found a few (fig. 8). In 1889 the carcass of a dead sheep was found on the side of Strawberry Butte and up to 1915, the writer was told, old horns were occasionally found there, although no sheep had been known there for many years. In the Baker Range there seems to be no record of their recent occurrence, although they were said to have formerly occupied these snowy peaks.

In 1897 C. Hart Merriam was told that sheep had formerly occupied Strawberry Butte and the Green Horn Mountains, and that one had been killed within 5 miles of Austin in 1895 .

In 1897 they still occupied the high ridges among the Wallowa Mountains in considerable numbers. In September of that year the writer found their tracks above timber line along the ridges above Aneroid Lake and saw one fine old ram lying down in a grassy 
basin far below but still among banks of permanent snow. When next in these mountains in 1915 he saw tracks of only domestic sheep, but was told that a few of the wild species could still be found in the most inaccessible places and on some of the high ledges along the rim of the Snake River Canyon.

The same year Jewett reported a few sheep remaining on the headwaters of the Minum River and on the divide toward Aneroid Lake. One sheepman told him of seeing 13 head in July of that year, and another had seen their tracks on the trail between East Eagle Creek and the Minum. Further information indicated a small bunch of sheep ranging on the rough divide between the canyons of the Imnaha and the Snake Rivers east of the Cloverdale crossing.

In 1924 the Forest Service reported 45 and in 1925, 43 sheep on the Wallowa National Forest. In 1927 Jewett estimated a possible number of 50 sheep in this last herd in the State.

In 1927 the Forest Service reported 40 on the Wallowa National Forest; in 1928, 45 ; in 1929, 50 ; in 1930,60 ; in 1931, 61; in 1932, 60 ; and in 1933,50 .

An effort was made to protect these remnants of vanishing species, and a State game preserve was created to include the scattered bands, but it was later abandoned.

The Wilderness area, recently established by the Forest Service to include the higher part of the Wallowa Mountains, may serve to rescue these splendid animals from extermination if it does not encourage an overabundance of mountain lions and bobcats, their greatest enemies next to man. Coyotes, too, will penetrate to the open country above timber line in the hope of feasting on mountain mutton, but with a proper check on predatory species it should be possible to bring back the bighorns to adorn again these inspiring mountains.

Their summer range is practically all on the Wallowa and Whitman National Forests, but in winter they descend to the canyon walls of the Snake River and Imnaha Canyons, where especial protection should be afforded and careful restrictions provided to keep them from contracting diseases of domestic sheep. With proper management this last remnant of one of Oregon's most valuable and interesting forms of big game could be increased and extended to other suitable areas in the State. Left alone to take their chances the end will soon be, as in the rimrock sheep, complete disappearance.

\section{OVIS CANADENSIS CALIFORNIANA DOUGLAS}

RImrock Shemp; LAVA-BeT Sheirp; TsNoon of the Warm Springs Indians at The Dalles; QuoIPA of the Piute at Burns

Ovis californianus Douglas, Zool. Jour. 4: 332, 1829.

Type locality.- "Falls of the Columbia", near the mouth of the Deschutes River.

General characters.-Size about the same as canadensis, horns generally more spreading and open, less closely coiled (pl. 17), upper molar series longer and heavier, nasal bones averaging wider. Coloration unknown except from immature and much-faded skins from the Steens Mountains, but these show extensive areas of white which with the general pale colors suggest the desert 


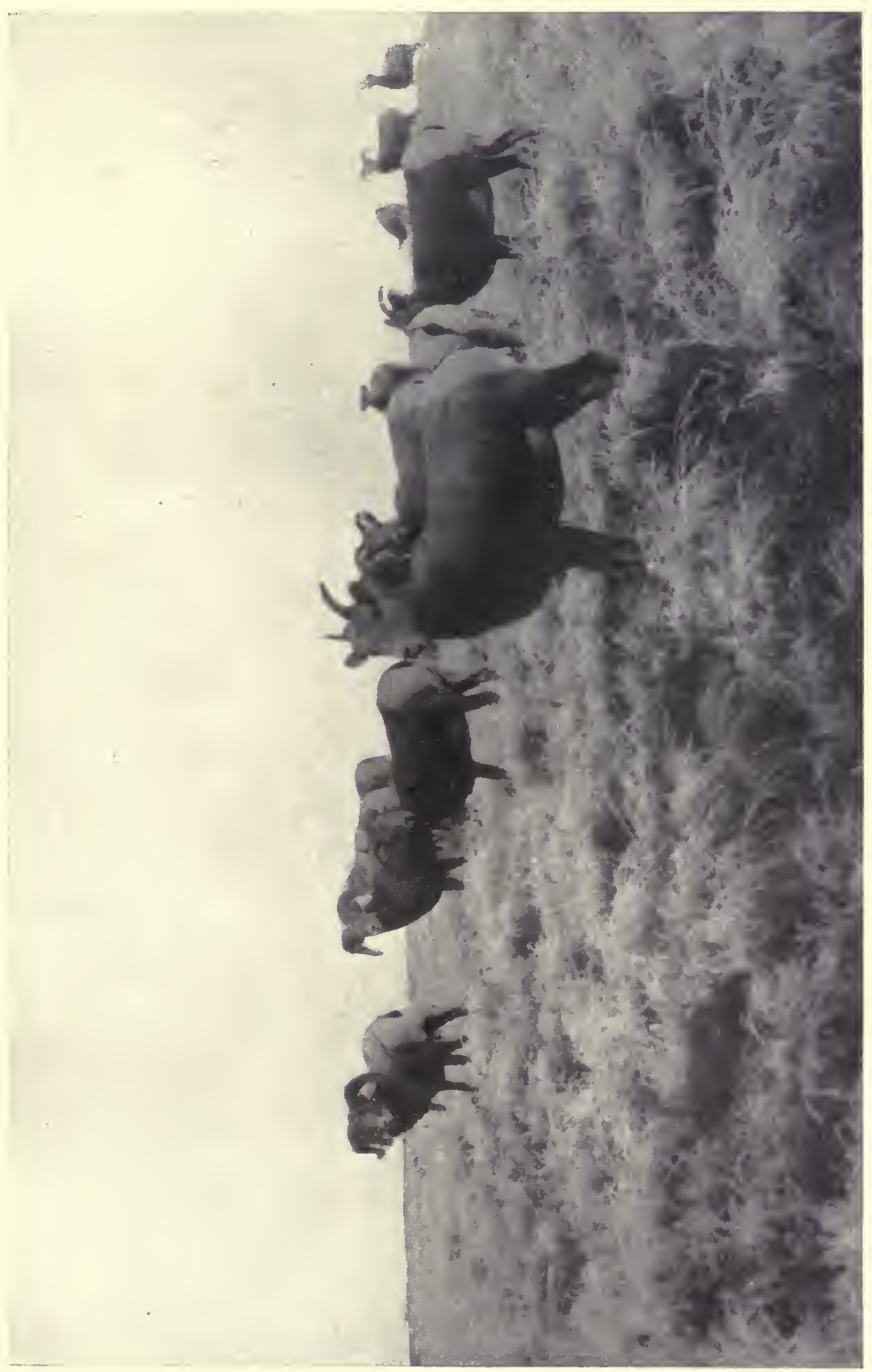

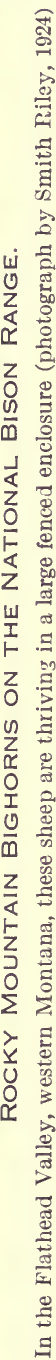




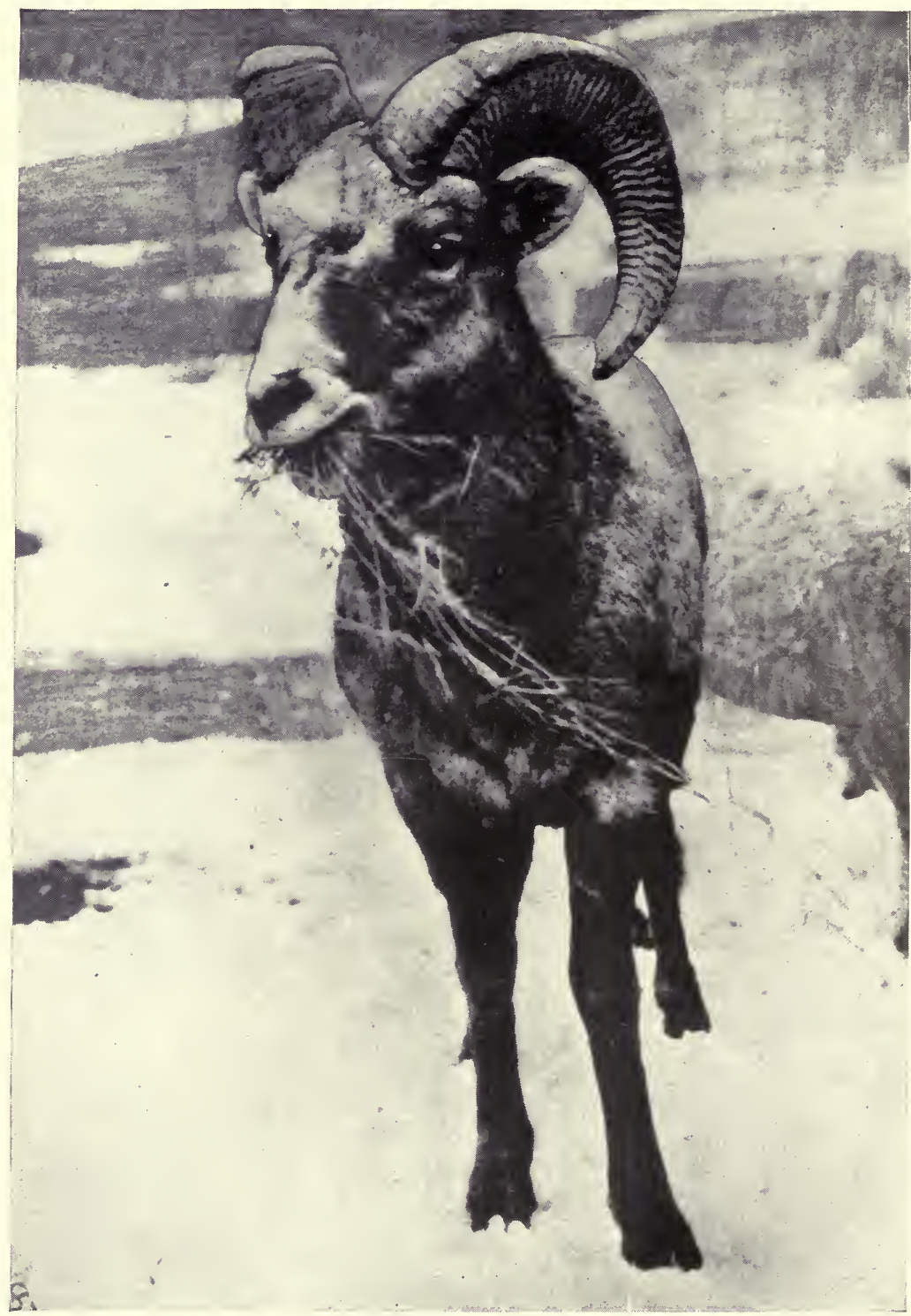

SIX-YEAR-OLD RAM IN GLACIER NATIONAL PARK.

Showing the heavy, upright horns of typical Ovis canadensis (courtesy of the National Park service). 

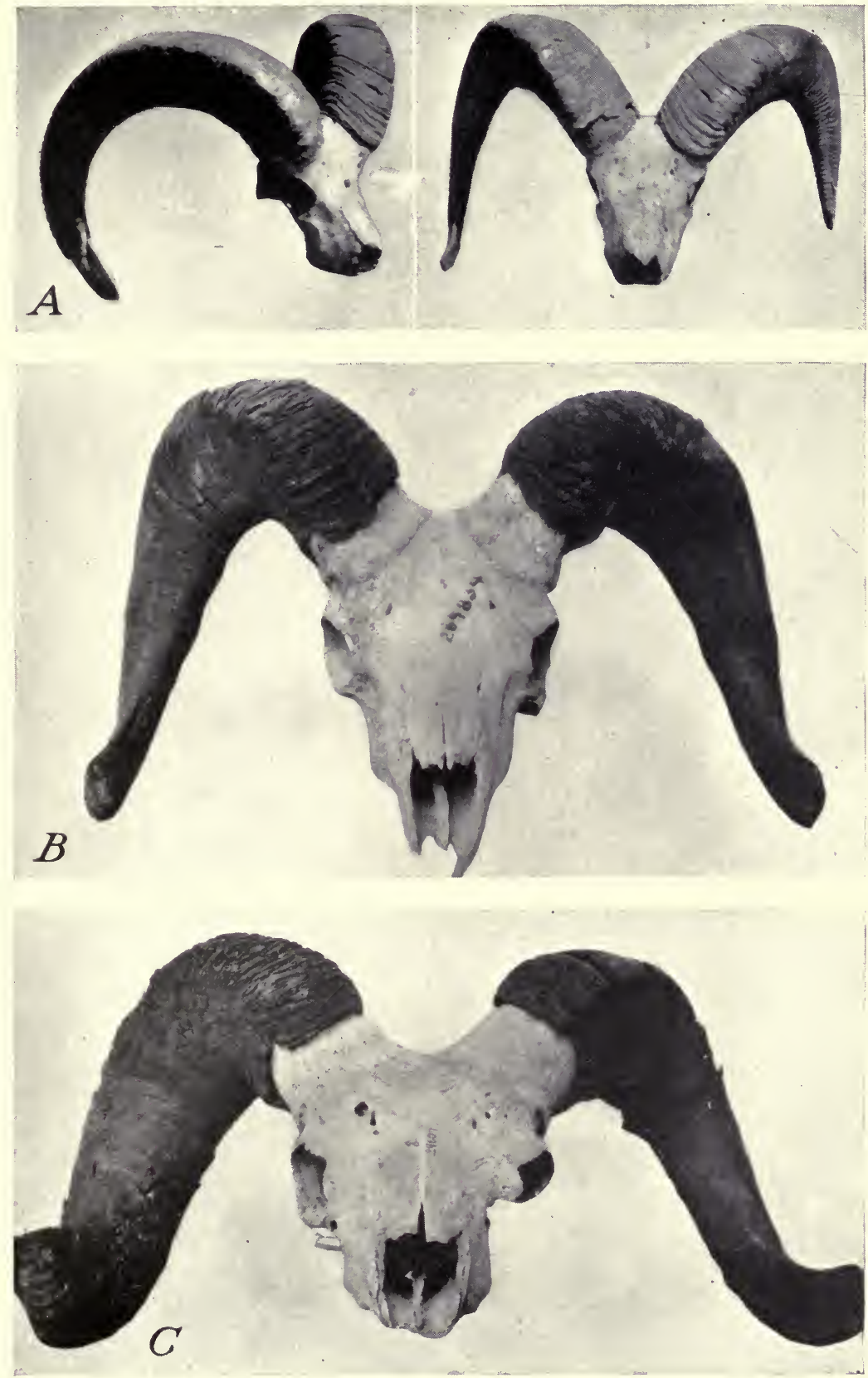

B17244; B17243; 84626M; 84625M HEADS OF OLD RAMS OF THE RIMROCK SHEEP FROM EASTERN OREGON, $A$, From Lava Caves west of 'Tule Lake, just below the California line; $B$, from Niggerrock Canyon, Malheur County (south of Vale); $C$, from Hampton Butte, Crook County. 

sheep farther south. Upper molar series 85 to $90 \mathrm{~mm}$ in old rams against 81 to 86 in typical canadensis. No body measurements known.

History of the name "Ovis californianus."-On Sunday, August 27, 1826, David Douglas on his way down the Columbia River from Walla Walla to Fort Vancouver traveled to a point 15 miles below the mouth of the Deschutes River. Earlier in the day at the "Great Falls of the Columbia ", which he locates about 6 miles east of The Dalles, he procured the horns of a mountain sheep from an Indian and tried to barter for the skin of one of these animals which the Indian was wearing as a shirt. Three years later these horns and his notes on this skin furnished the foundation for his description of Ovis californianus, which he reported as "said' to be found in subalpine regions of Mts. 'Wood" [sic]. St. Helens, and Vancouver, but more numerous in the mountainous districts of the interior of California."

From his journal it is evident that Douglas never saw a mountain sheep alive and his information in regard to their range was all second-hand and more or less at fault. It is not improbable that the horns which became the type of the species were taken within a mile of where he procured them. The subalpine range may have been borrowed from the narrative of Finley, of Spokane, who described to him the range of the northern Rocky Mountain form from the high ranges east of there and promised to try to get a specimen for him. His attributing their range to Mount Hood, Mount St. Helens, and Mount Adams, where no one has found them since seems very questionable, as the heavy winter snowfall would permit only a short summer occupation of the high parts of these peaks. On the other hand, well into the present generation, mountain sheep have been common along the canyon walls of the Deschutes River to near its

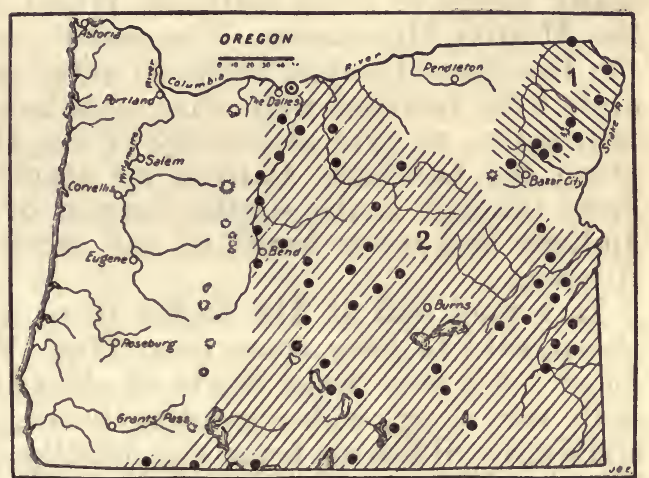

FIGURe 8.-Range of Rocky Mountain bighorn and Oregon bighorn in Oregon: 1 , Ovis canadensis canadensis; 2 . O. c. californiana. Type locallty circled.

mouth, and before the days of rifles they undoubtedly followed the terraced lava walls of the Columbia River Valley at least on the Oregon side, both above and below the mouth of the Deschutes River.

In fact, on December 8,1825 , about 9 months before Douglas found his specimens, one of the hunters of Peter Skene Ogden killed a sheep in the rough little range of mountains about 40 miles south of The Dalles still known as the "Mutton Mountains", and after crossing to the east side of the Deschutes River Canyon near the mouth of Warm Springs Creek a few days later Ogden reported a fine herd of sheep but "too swift for us" $(1909, p p$. 340, 342).

On February 4 of the following winter, Ogden reports four sheep killed near the headwaters of Burnt River $(1909, p .352)$. On January 1, 1827, somewhere in the Klamath Lake section not definitely located he reports a "goat killed". and on May 30 of the same year somewhere in the Warner Lake country he says: "An bex" killed today and a young one taken alive. I shall feed it on mare's milk until we reach Fort Vancouver" (1910, pp. 212, 219).

Distribution and habitat.-Originally mountain sheep inhabited every canyon, cliff, and lava butte as well as many of the rough lava beds of Oregon east of the Cascade Mountains (fig. 8). They were common until recent years in the Steens and Warner Mountains and are still found in the Wallowa Mountains and along the canyon

2b The names "goat" and "ibex" were undoubtedly applied to the female and young male sheep, names that are frequently misapplied to the animal even at the present
day.

$7209^{\circ}-36-5$ 
walls of the Imnaha River. In the Biological Survey collection are about 15 specimens, all more or less imperfect, of heads and horns and bones picked up at or near Fossil, Maupin, Hampton, Sheephead Mountains, Pine Mountains, Ureka Station, Adel, Steens Mountains, Hart Mountain, Crowley, Watson (10 miles northwest), Jordan Creek, Nigger Rock Canyon, Mahogany Mountains, in South Ice Cave, 40 miles south of Burns, and near Lower Klamath Lake.

There are also records of sheep seen within the memory of many now living over most of the extensive lava beds and buttes of eastern Oregon. In 1916, the writer visited a camp of Warm Springs Indians near The Dalles and talked with several of the older Indians about sheep. They knew the animal very well and promptly gave him its name as Tsnoon. They said a long time ago plenty of these sheep lived all along the Deschutes River Canyon and in the rough, rocky range of hills south of Warm Springs shown on maps as the Mutton Mountains. The eastern end of this range drops into the Deschutes Canyon about 40 miles south of The Dalles and presents lofty terraced walls that must have been a paradise for mountain sheep, as were also many of the almost inaccessible lava cliffs along the Deschutes Canyon up nearly to Bend. Leading into it from the east is the similar canyon of the Crooked River. These Indians had never heard of any sheep on Mount Hood or Mount Adams.

In a pool hall at The Dalles there were three mounted heads of sheep, said to have come from High Valley, on the desert east of Bend. All were large heads of old rams of the same general type with very long, wide-spreading horns, not very heavy at the base, strikingly different from the usually closely coiled, heavy-based, tapering horns of typical canadensis. In 1915 Lon Vobrath of Bend told Jewett of seeing two mountain sheep in the Deschutes Canyon, a short distance above the mouth of Metolius River in 1885.

From the John Day River near Fossil, where no sheep had been known for 50 years, two incomplete skulls were sent to the Biological Survey by O. A. Philbrick in 1915 and 1918. One of these is an incomplete cranium with horn cores but no horns or teeth. The other is a nearly complete cranium of a 7-year-old ram with good horns and most of the upper teeth in place. These heads from about 60 miles southeast of the actual type locality certainly may be considered typical of the species. Another incomplete head, secured at Maupin by Jewett in 1927, is from still nearer to the type locality of the species.

Farther up the John Day River on Bridge Creek, Jewett was told by old settlers who came there in 1873 of bands of 50 or more mountain sheep seen in the John Day section, but he did not learn when the sheep had become extinct, only that none had been seen for a long time.

In 1916, at Burns, the writer was told by Dibble, proprietor of the Burns Hotel, that 25 years ago mountain sheep were numerous on all the rimrock of the surrounding country, from Burns to Bend, on the rough rim of Dry Basin, on Glass Mountain, Rams Rock, Juniper Mountain, in the Warner and Abert Mountains, around Christmas Lake, and even out on the sagebrush plains. He said they used to come down to the domestic sheep herds when these were first brought 
into this part of the State and that the old rams would attack the bucks in the tame herds. The sheep herders carried guns and often shot them to keep them out of the herds. One of the cowboys roped a ram out on the desert 65 miles southwest of Burns, and about 25 years before a ranch owner on Buck Creek shot a huge old ram on the rimrock close to his house. He said the sheep were common in the lava beds near Bend and all along the Deschutes River Canyon. A few years after the tame sheep came into the country, he said, the mountain sheep began to die of scab and he thought this disease caused their rapid disappearance.

An old Indian, Captain Louis, head of the Piute Band near Burns, told the writer practically the same in regard to the range of the sheep, but said they were common all over the rimrock of the plains country of eastern Oregon before the white man came. $\mathrm{He}$ said they crossed the sagebrush valleys so commonly that his father used to hunt them on horseback with bow and arrows. He said they left the Steens Mountains in Winter, going west to Warner Valley and Summer Lake and east to the desert ranges east of Alvord Valley. Many wintered on the low foothills between the Steens Mountains and the great Alvord Playa. This part of the mountains he called in his language Tudu paenaque Quoipa tevewa-which means, hills where the sheep go in winter. He said his people hunted the animals with bows and arrows on the Steens Mountains, where they could get very close to them along the crest of the range. This undoubtedly accounts for the unusual number of broken obsidian arrow points scattered over the top of this range. Captain Louis thought there might still be a few sheep in the Wagontire and Juniper Mountains, where some of his people reported them in the fall of 1915, and that there might be a few still in the Steens Mountains.

In 1916 E. L. Hibbard, of Burns, gave the writer the mounted head and nearly complete skin of a 2-year-old ram that he had killed in the Steens Mountains in November 1906, and the incomplete head and horns of a 4-year-old ram picked up there. The writer also examined another mounted head of a 4 -year-old ram that he had and a fine pair of horns of a 10-year-old ram, all from the Steens Mountains. Hibbard thought at that time that there might be a few sheep in the Steens Mountains, but he had not known of any since 1909, when a band of 10 and another of 6 had been seen. Sheldon was told that one had been killed in 1911 by Clifford Grosbeck, of Narrows, and this may well have been the last sheep in the Steens Mountains section. In 1916 a thorough search over a larger part of the range by $\mathrm{H}$. $\mathrm{H}$. Sheldon and the writer failed to reveal any trace of them. Sheldon carried the search from Kiger Gorge to Wild Horse Canyon and over the rough Alvord slopes and pockets for several days without finding a trace of them.

In 1896 Merriam and the writer found a few along the crest of the range near Wild Horse Canyon, but even then they were no longer numerous and the domestic sheep covered most of their original range to the crest of the mountains.

'In the rough country east of the Steens Mountains the sheep seem to have entirely disappeared, although there are occasional reports of a few at some remote point. On a trip through the south- 
eastern part of the State in 1915, Preble reported them as formerly common in most of the rough desert ranges and on the canyon walls. From Jordan Valley he wrote:

Sheep have been harassed so long in these desert ranges that they have been practically gone for many years and I have been unable to find any heads. There are said to be a few in Red Canyon, in the Juniper Mountains just east of the Oregon line, but there is no possibility of any in the ranges north of here.

Later he was told that there might be a very few in the northern part of the Mahogany Mountains, east of the Owyhee River. On the hills in the rough lava country about Cow Creek Lake in the southern part of the Mahogany Mountains, he was told, they had been very common, but had practically disappeared about 1885 . W. F. Schnabel told him that they had evidently died of some disease, as they were found lying about everywhere. In a letter of March 21, 1916, Schnabel wrote:

I can vouch for the extermination of the sheep. Many people think they were killed by cowboys and game-hogs. It is not so. They all perished during the winter of 1884 and 1885. They did not starve but were killed by some disease. I found their carcasses everywhere and grass and feed were plentiful in those days.

H. D. Glover, in sending some old heads and horns of mountain sheep from this region, wrote on February 13, 1916: "About the last mountain sheep seen around here was along in the nineties. There were a great many here in the eighties up to 1885."

On April 6, 1917, R. M. Horn, of Nyssa, Oreg., wrote:

There are no mountain sheep on the Owyhee near the Duncans Ferry country nor have there been for 15 years. They had a disease similar to the scab that affects domestic sheep and died from that disease. Old settlers tell me they believe the mountain sheep caught the scab from the domestic sheep as they had never been known to have it before the domestic sheep brought it into the country.

At Riverside in 1916 the writer learned from Harry Fairman that two mountain sheep had been killed on the rimrock of the high butte just north of the station about 1894, but these were the last he had known in that section.

In south-central Oregon the sheep also disappeared after the country was settled by white men. In 1905 James H. Gaut was told by people living west of lower Klamath Lake that mountain sheep had been numerous on the lava ridges near there up to 1885 and that the last was killed in 1890. In 1916 the writer secured two old heads, one with horns and the other without, from the lava beds near lower Klamath Lake, but could get no direct information on how long they had remained there nor when the sheep were last known in these almost impenetrable lava fields. One of the Klamath Indians said that, when he was a little boy, his father used to go down there to kill them. In 1914 Harry Telford wrote from Fort Klamath:

I could find no record of mountain sheep ever occurring near Fort Klamath. Mr. Reams who had cattle in the lava beds in the early days says they were plentiful there up to the winter of 1879 and ' 80 , when he thinks they were winter-killed. A large number of cattle and sheep had been run in the lava beds during the summer and fall of 1879 and had taken most of the feed, and the hard winter following finished them. 
In 1888 Merriam saw in a hardware store in Portland a mounted ram, said to have come from the Siskiyou Mountains, and more recently he was told by the Shasta Indians that sheep formerly occurred on the Siskiyou Mountains and also on Goosenest and Bogus Mountains close to the Oregon line. (1921, p. 239.)

In 1897 the writer was told by settlers that mountain sheep had been numerous in the rocky ridges about Silver Lake in Lake County, but had then almost disappeared. A few were said still to occupy the high ridges northeast of Abert Lake.

In 1914 Luther J. Goldman made a trip into the Warner Mountains to learn if any sheep remained there. He was told by the old inhabitants that at one time sheep had been even more numerous than antelope, ranging from 4,500 feet altitude in Warner Valley up to the summit of Mount Warner (Hart Mountain on recent maps). Accounts varied as to when they were last seen on this mountain, which seems to have been their last stand in this section. Some reported the last seen as 10 years ago, others as 6 years ago, and one trapper who had wintered near Hart Mountain claimed to have seen two rams only 2 years before (1912). Ranchers of long residence in the country told him that the cause of the extermination of mountain sheep was the close grazing of the range by domestic cattle and sheep, which left but scant feed for the wild sheep, which weakened and died of starvation or fell an easy prey to their animal enemies.

To anyone who has followed closely the history of the disappearance of our mountain sheep, it is clear that they have been destroyed by scabies, the disease commonly known as scab among domestic sheep, wherever infected domestic herds have penetrated the range of the wild species. Like smallpox and measles among the early Indian tribes, scabies swept away whole bands and left only scattered bunches that later succumbed to the disease or were finished by hunters or predatory animals. Death was not from starvation, as so often reported, for the wild sheep can always find feed on steep slopes and rough cliffs quite inaccessible to domestic herds. The insidious mites left on the bushes and ground soon become attached to the healthy wild sheep and produced scabby skins, sores, fever, and lingering death. Unfortunately this rimrock sheep of the low country is apparently extinct, but some other form from the same life zones-arid Upper Sonoran and Transition-could be introduced, and, with proper protection from infected herds as well as from hunting and natural enemies, would doubtless thrive here in its place.

What more delightful or useful adventure could be imagined than to take a tract of the roughest lava-bed country in eastern Oregon, now idle and worthless, fence a section with inexpensive coyote-proof fencing, 6 feet high, stock it with a ram and a few ewes of some of our native sheep preferably Ovis nelsoni from Nevada, and give these noble and valuable game animals a chance to thrive on this most favorable range? Old Indians, early settlers, and a few big-game hunters have pronounced the mutton of mountain sheep far superior to that of any domestic sheep or of any other game animal of North America. On good range the ewes often raise twins and increase their numbers about as rapidly as domestic sheep. They will live 
and thrive all the year around in deserts where no other stock or game can, and with proper management they would make profitable many areas now only picturesque. Moreover they would add to the picturesqueness of any rocky range, peak, cliff, or canyon wall, or to rough black lava fields and sagebrush basins between where they would find just the food and shelter to their liking. Who would not enjoy living for a part of each year where a magnificent old bighorn could be seen on a cliff above or a band of ewes and young following a heavy horned leader up a terraced wall, bounding upward from ledge to ledge to look back from the skyline above? To him who has the time, the means, and vision to add such a resource to our national wealth and progress and pleasure the world will owe a debt of undying appreciation.

\section{Family ANTILOCAPRIDAE: Prong-horned Antelope}

\section{ANTILOCAPRA AMERICANA OREGONA BAILEY}

Orbgon Pronghorn; Prong-horneid antelope; Prongbuck ; American ANTELOPE; TE-NA' of the Piute; CHA-o of the Klamath (C. H. M.)

Antilocapra americana oregona Bailey, Biol. Soc. Wash. Proc. 45: 45-46, 1932.

Type.-From Hart Mountain (Mount Warner), Oreg., collected by Luther J. Goldman, September 22, 1914.

General characters. - The pronghorn is about the size of a small deer, very slender, graceful, and swift; horns deciduous, flat, each with one flattened prong and recurved tip ; hoofs simple; no dewclaws; tail short ; colors cinnamon buff with strongly contrasted black-and-white markings on head and neck; a rump patch of white is spread at will into a great white rosette or closed down, is small and inconspicuous. Young similar in color to adults with white of sides and rump at first obscured. It is neither a true antelope nor a goat, but belongs to a family of one-pronged deciduous-horned animals, including one species and several geographic subspecies peculiar to North America.

The Oregon specimens represent a fairly well marked form distinguished as follows: Size about as in Antilocapra americana, or slightly larger, with relatively larger feet, longer horns, slightly paler coloration, less black about face and mane, and less white on crown and shoulder stripes. Color of body bright cinnamon brown, becoming dark tawny on mane and pale cinnamon on legs and ears; muzzle, eyelashes, spots over anterior corner of eyes, edges of ear tips, and in males spot at angle of jaw, black or blackish; forehead dark grayish cinnamon; crown and nape dull gray or dark cinnamon without conspicuous white markings.

Skull.-Similar to that of americana with slightly larger, more rounded audital bullae. Horns in type specimen very long, slender, and wide-spreading, but in another buck from the type locality about as in average americana. In a large old male from the Carnegie Museum, collected at Hart Mountain, Oreg., September 11, 1927, by O. F. Fuehrer, the horns are very long and broad with moderately heavy basal and lateral knobs or tubercules, less extremely developed than in peninsulae from Baja California, but much more so than in typical americana or mexicana.

Measurements.-Of type: Total length, $1,473 \mathrm{~mm}$; tail, 90 (measured dry) ; hind foot, 431; ear from crown, 155 (measured dry). Skull: Basal length, 240 ; nasals, 94 ; alveolar length of upper molar series, 70 ; interorbital width, 109 ; outer orbital width, 140 ; occipital width, 84 ; horns from base over curve, 379 and 355 (tip gone) ; spread of tips, 400. Hoofs: Hind hoof, base to tip, 63 ; height of front edge, 40 ; width of one heel, 17; of both heels, 37. Front foot, base to tip, 66; height of front edge, 41 ; width of one heel, 25 ; of both heels, 52.

Specimens examined from Oregon.-Six from Hart Mountain east of Warner Lake, and a skull from Adel, near the south end of Warner Lake. 
Distribution and habitat.-Antelope originally covered practically the western half of the United States from Mexico to Canada, including all of the open sagebrush country of eastern Oregon, over not only the valley and plains area, but the open mesas and flat-topped mountain ranges, and in summer even over the broad, flat top of the central part of the Cascade Range (fig. 9). A few were found in the Rogue River Valley by early explorers. Records are few and far back for the immediate valley of the Columbia River, but it seems possible that they were kept out of this valley even in prehistoric times by the numerous Indians living along the river. At the present time a few shrunken herds occupy the country between Hart Mountain and the Steens Mountains, and small bunches stray back and forth over some of the surrounding valleys.

The early expeditions into what is now Oregon made little mention of antelope, mainly because the explorers rarely entered the open plains country, where these animals were most abundant. On December 5, 1825, Peter Skene Ogden, on his way from Fort $\mathrm{Nez}$ Perce (now Wallowa) to The Dalles and up the west side of the Deschutes River, mentions in his journal an antelope killed by an Indian about a day's journey south of the present town of 'The Dalles, the first meat he had been able to obtain on the trip (1909, p. 339). Again, on January 24, 1826, Ogden records two antelope killed as his

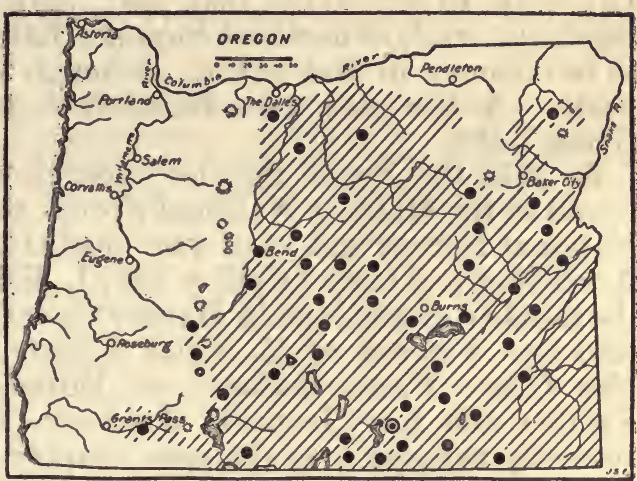

Figurb 9.-Range of Oregon antelope in Oregon: Antilocapra americana oregona. Type locality circled.

party of trappers proceeded slowly up the North Fork of the John Day River. In his several trapping expeditions for the few following years across the Blue Mountain country to Snake River and along the Malheur and Owyhee Valleys, and in the Malheur and Klamath Lake section, he rarely mentions antelope. As beaver were his principal quest, this may have been only from lack of interest in other game. On August 28, 1834, Townsend reported one killed on the upper Powder River $(1839, p .145)$. In his journal, September 27, 1841, Titian $\mathrm{R}$. Peale reported 5 antelope seen and 1 killed in the Rogue River Valley. In 1914, Harry Telford, of Klamath Falls, reported on the authority of Reams, one of the oldest settlers, whose veracity he vouches for, that in the early days antelope were plentiful in the Klamath Valley and other valleys in the. lower part of Klamath County, where they were said to have been found up to 1884.

Except in the vicinity of tribes of hunting Indians and along the traveled highways, antelope seem to have held their own or increased in abundance up to the time of settlement of the Territory half a century ago and to have remained locally in great abundance till much more recent times. 
In 1896, when the first work of the Biological Survey was begun in Oregon, Clark P. Streator reported them common in the Warner Lake and Alvord Valleys, and in the sagebrush country along both sides of the Steens Mountains. The same year, Merriam, Preble, and the writer found them fairly abundant in the Silver Creek section, on the Steens Mountains, and in the Beatys Butte, Guano Lake, and Hart Mountain section, along Paulina Creek and the upper Deschutes River, in the Klamath marshes, and on the Pumice Desert between Crater Lake and Diamond Lake. The same year they were reported by George Bird Grinnell, on authority of Lester B. Hartman, as plentiful on the Pumice Desert at the head of the North Fork of Umpqua River, where several hundred had been seen $\left(189^{\prime \prime}, p .6\right)$.

In 1897 Captain Applegate, in Swan Lake Valley, just east of Klamath Falls, told the writer that antelope had not been seen in that valley for 10 years, although formerly they had almost always been visible in the open part of the valley. On the way north from Lakeview to Prineville that year, antelope tracks were seen in the sagebrush valleys north of Summer Lake, and the animals were said to be common in that section, although none was seen by the writer's party. A few also were found that year between Tule Lake and Goose Lake.

In 1910 the Forest Service supervisors reported antelope as still found in the Malheur National Forest, as very scarce in the Deschutes National Forest, and as of very doubtful occurrence in the Umpqua. According to Finley $(1908, p$. 295) L. E. Hibbard, of Burns, estimated the number of antelope in Harney County at not more than 2,500, and said that a bunch of 45 , which 5 years previously had lived on the Rye Grass Flats southeast of Burns, had entirely disappeared. Farther east from Ironside, Anthony $(1913, p .5)$ reported antelope formerly ranging over the open country in northern Malheur County in large numbers, where as late as 1908 a band of fifteen or twenty had been reported near Ironside.

In 1913 Stanley G. Jewett and Harry Telford estimated about 2,000 antelope in the Hart Mountain section ${ }^{3}$ of southern Oregon. The following year, Luther J. Goldman visited the Hart Mountain section where he found antelope fairly common, usually in small bunches, not more than 25 being seen together at a time.

In 1915 Jewett made a careful survey of the antelope in eastern Oregon and sent a full report to the Biological Survey. In the country lying east of Warner Lakes and south to the Nevada line in Lake County, he estimated approximately 1,000 head of antelope; in Malheur County, 500; Harney County, 300; Crook County, 30; and Klamath County, 10; a total of 1,840 for the State. He was also told by sheepmen at Willows of a bunch of 18 antelope having recently been seen in Morrow County south of Heppner. $\mathrm{He}$ learned also from a cattleman of an antelope seen on June 10, on the open hills south of Lookout Mountain and east of Prineville, and was told that Big Summit Prairie at the east base of Lookout Mountain had been a favorite summer range of antelope only a few years before.

\footnotetext{
3 Called Warner Mountain region in field reports to include the long low range east of Warner Valley.
} 
In 1916 Deputy Game Warden F. W. Triska, of Burns, estimated about 1,200 antelope in the country lying between the Warner (Hart) and Steens Mountains, an estimate agreeing well with that of Jewett 2 years before for a part of this same area. Other estimates, running up to 5,000 and even 10,000 antelope in this section seem to have been mere wild speculation.

In 1915 Preble made a trip through the southeastern part of the State and reported antelope in the vicinity of Crooked Creek, Owyhee River, and in the Cedar Mountains. The same year L. J. Goldman reported 25 or 30 in the Mahogany Mountains of eastern Oregon. Also that year, J. C. Bartlett counted 72 antelope in Barren Valley (Oreg. Sportsman 3:85, 1915), and the following year E. F. Mickey, of Jordan, wrote to the Biological Survey that while riding the range for 2 weeks in late winter he had counted 186 antelope between Barren Valley and Crooked Creek. During the previous winter, Mickey estimated a possible 600 or 700 antelope in southeastern Oregon.

\section{In a letter of January $8,1916, \mathrm{~K}$. N. Dahle wrote to the Biological Survey as follows:}

I think I can give you a fairly accurate account, as I am riding nearly ali the time and know nearly all of the antelope. Between the head waters of the south fork of Malheur River and Harney Valley, 50 head; Stockade Mountain, Soldiers' Springs, etc., 250 head; Piute Lake region and Saddle Buttes, 300; Juniper Mountain, Bull Creek, and Rhinhart ranch, 325; Crowley to Willow Springs, 75; Star Mountain and Rooster Comb, 100; Willow Springs, Antelope Flat, and Dry Creek, 250. In fact, 1,500 would be a safe estimate in the territory covering a scope of country 75 miles long by 65 wide. The antelope are noticeably fewer than when I came to the country nine years ago. Since the sheep got so numerous on the Lava Desert, the antelope have been robbed of their main winter browse, and are forced to subsist largely on sagebrush and dry bunch-grass.

Along the Malheur River Valley, Jewett, in 1910, reported a few antelope occasionally seen by cattlemen and sheep herders. He saw one fine buck about 20 miles north of the Cedar Mountains and was told that about 14 antelope were living in that general section.

In 1916 the writer was told that there were still a few antelope scattered over the more inaccessible mesa tops back from Riverside. A few were also reported that year in the Malheur Valley, but they were very scarce and shy. A few were reported that year also on the mesas along the northern and western slopes of the Steens Mountains.

In August 1916, Olaus J. Murie made a trip from Warner Lake through Guano Lake Valley north to Desert Lake which was then the main watering place of the principal antelope herd. $\mathrm{He}$ says the lake is a shallow basin surrounded by lime hills and rimrocks. There was still a little water in it, but completely hidden from view by a kind of aquatic plant on which it is believed the antelope feed. The lake is said to go dry usually in summer and then the antelope go to desert springs for water. These springs are in a box canyon not far from the lake, forming a series of pools and ledges of rock. There were 4 or 5 containing water when he was there. He counted 75 antelope in sight at one time and presumed it was the same herd which came each day. While not with the antelope enough to make a reliable estimate of their numbers, he considered the previous esti- 
mate made by Jewett as amply covering the number of 1,500 in this herd.

In 1924 Jewett estimated approximately 2,000 anterlope in Oregon, all in the extreme arid southeastern quarter of the State. Nelson, in 1925 , estimated from the latest reports, 2,039 antelope in southeastern Oregon and considered them as unquestionably increasing (1925 p. 4\%). On the writer's hurried trip over eastern Oregon in December 1930, the antelope were reported as showing a slight increase, attributed to the decrease in numbers of predatory animals. In 1931 Jewett estimated not less than 5,000 antelope in the State, mostly in Lake, Malheur, and Harney Counties.

The Forest Service game reports for 1932 gave an estimate of 150 antelope on the Deschutes National Forest, 75 on the Fremont, and 30 on the Malheur.

Several attempts to create an antelope refuge in Guano Valley have failed through opposition of local sheepmen, who have even been accused of destroying the antelope to save the forage and water for their flocks. In 1928 a small sanctuary was obtained by the National Audubon Society for the protection of antelope in northwestern Nevada (pls. 18, 19) close to the Oregon line where many of the Guano Valley antelope come in winter after the local herds have moved farther south, showing the truly migratory habits of the species. This refuge, now appropriately called the Charles Sheldon Wildlife Refuge, has done much to save the Oregon herd, and a recent Executive order extending the refuge area north across the Oregon line through Guano Valley to include Hart Mountain should insure the perpetuation of the antelope in eastern Oregon.

General habits.-These graceful animals, like the swallows among birds, have been always the wonder and admiration of naturalists and sportsmen. They are unique in shedding and renewing each year the hollow horns and are remarkable also for the wonderful flashlight display of the great white rosette of long hairs over the rump, which are raised at will until it is the most conspicuous object in the landscape, or closed down until scarcely noticeable at a distance. In the very young, these white hairs of the rump are concealed by a thin layer of fine, brown hairs, which apparently disappear within a few weeks when the young are able to escape enemies by running with the mother. Few animals afford such wonderful contrasts in directive and protective coloration, or such perfect adaptation to the open country.

They are primarily animals of the open, depending for protection on remarkable vision and speed. The prominent eyes on opposite sides of the head look forward and backward apparently catching the slightest motion on the whole horizon. On occasion the animals penetrate open forest country, usually to pass from one valley to another, but they are rarely surprised near any cover. An inordinate curiosity regarding any object or motion which they do not understand often leads to their destruction, but usually they are so wary and swift that until long-range rifles came into general use they were fairly safe from most of their enemies.

In habits they are more or less migratory or roving, often leaving one valley for another which affords better protection or forage and in winter seeking the warm valleys and in summer the higher 
mesas and mountain parks. In some places, their spring and fall migrations extend over at least several hundred miles, while in others they merely go back and forth over the higher and lower levels. Many of the antelope of southern Oregon are reported as wintering in the valleys of northern Nevada. It is not improbable that it is the migratory habits which keep the species so uniform in character over a wide range from Canada to Mexico and the Missouri River nearly to the Pacific. The characteristics of several subspecies show but slight contrasts.

Breeding habits.-In eastern Lake County, Oreg., Finley and Jewett captured two small young on May 25, 1927, but probably the breeding season is not very different from that in northern Nevada where the fawns are dropped about the middle of May (Nelson, 1925, p. 19), or in the Yellowstone Park country where the antelope mate in October and the young are born in May or June. Twins are common. If protected from enemies the antelope would increase very rapidly. As would be expected from their habitat in the open grassland, the young are without spots or marking, their buffybrown colors blending well with the dry grasses as they flatten themselves close to the ground.

The horns of the bucks are shed in November, soon after the October rutting season is over. A new skin begins to grow over the flattened bony horn cores and pushes off the hard outer shell. This new hairy, black skin grows, thickening and hardening, first at the tip, then gradually downward during the winter and following spring, until new solid horns are ready for the fall fighting and mating season.

Food habits.-The antelope is a good illustration of how little is known of the habits of our native animals. Supposedly they are grass feeders. Domesticated individuals may be seen picking grass and other plants, but there is some evidence to show that they are not mainly grass feeders. In winter, at least, they pick the tips and buds from a great variety of bushes and plants that come above the surface of the snow, but they also seek the warmer slopes and sheltered spots where dry grass may be obtained. Too, they will eat dry hay of various kinds when other food is covered by deep snow. They are fond of alfalfa, dry or green, and often may be seen in an alfalfa patch picking daintily among the leaves and heads. Undoubtedly, a great variety of plant flowers and seeds are included in their diet, for they are dainty feeders, picking skillfully here and there. Usually they are plump and in good condition, although rarely showing much accumulation of fatty tissue.

Economic status.-Half a century ago the antelope was one of the most abundant game animals over the western half of the continent, inhabiting an immense area of country. Today, their numbers are shrunken to comparatively small bands, mainly in Wyoming, Montana, Colorado, California, New Mexico, Texas, Arizona, Nevada, and Oregon. If the decrease in their numbers continues as in the pastthough recently they have slightly increased-a few more years will number them among extinct species. For ages past they furnished food to native tribes, and during the exploration and settlement of the country, they played an important part in supplying food to explorers, pioneers, and settlers. Their destruction, however, has 
been unnecessarily rapid and wasteful-a part of the national disgrace that characterizes our treatment of so many of our best game animals. It would seem now a national duty, as well as an honor, to protect in a few scattered areas remnants of the species for the pleasure and admiration of future generations. No better places could be found for antelope preserves than on some of the wide expanse of thin-soiled lava fields of eastern Oregon, where the animals are still in sufficient numbers to stock the country, if given adequate protection.

Antelope meat, which by many is considered one of the rarer delicacies afforded by our native game, is tender, juicy, and delicate, with a flavor unlike that of any other meat. It has been in such demand as to hasten the destruction of the species, but under no circumstances will it again be brought into general use for a long period. Eventually, when the habits of the animals are sufficiently understood, so that their breeding in captivity can be assured and controlled, it might again be added to our list of choice viands.

No animal could be more gentle, affectionate, and lovable than young antelope when carefully reared and tamed. They quickly learn to follow a person and love to be fondled and petted. Only the males in maturity ever become cross or dangero'us. In many cases a single antelope has been kept for years in a small yard with only a low fence to restrict its range, and in their native climate they seem healthy and hardy if kept from the fatal sheep scab and other domestic diseases that have played an important part in their reduction.

Extensive areas in southeastern Oregon that have been so long overgrazed that they will not support even domestic sheep would still carry a limited number of antelope and gradually improve in forage, general vegetation, and carrying capacity. The numbers of antelope, mountain sheep, mule deer, and sage grouse originally ranging over this arid land would, if wisely managed, add an actual cash value as well as a spectacular attraction to exceed by far any present value attached to the areas.

\section{Family CERVIDAE: Moose, Elk, Deer, and Caribou}

\section{ALCES AMERICANA GIGAS Miller}

Alaska Moose; Giant Moose

Alces gigas Miller, Biol. Soc. Wash. Proc. 13: 57, 1899.

Type locality.-North side of Tustumena Lake, Kenai Peninsula, Alaska.

General characters.-Very large, largest of the North American deer; antlers broadly flattened, many pronged in front, annually deciduous; hoofs deerlike, long and slender with well-developed and wide-spreading secondary hoofs or dewclaws; tail very short; color mainly blackish but with grizzling of brownish black on sides, and clear brownish on legs, ears, and median line of belly.

Measurements.-Type, an old male: Total length, 3,149 mm; tail, 101; height at shoulder, 2,034.

Distribution and habitat.-The moose inhabit the timbered portions of Alaska. In October 1923, five moose calves from the Kenai Peninsula, Alaska, were released near Lake Tahkenitch, Oreg., just north of 


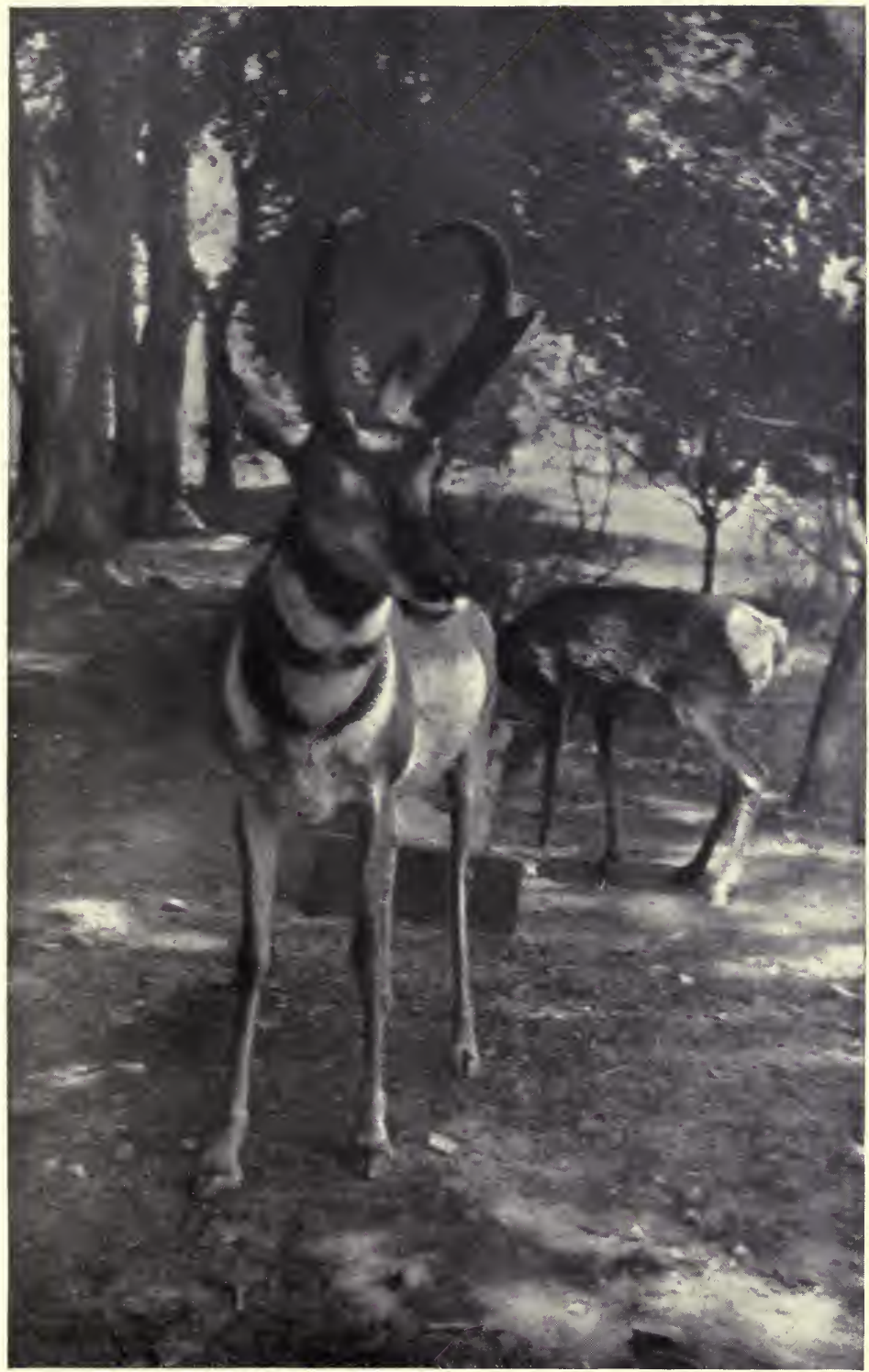

FOUR-YEAR-OLD BUCK ANTELOPE.

One of the young brought from northwestern Nevada in 1924 to the Grand Canyon of Arizona (photographed July 29, 1928). 

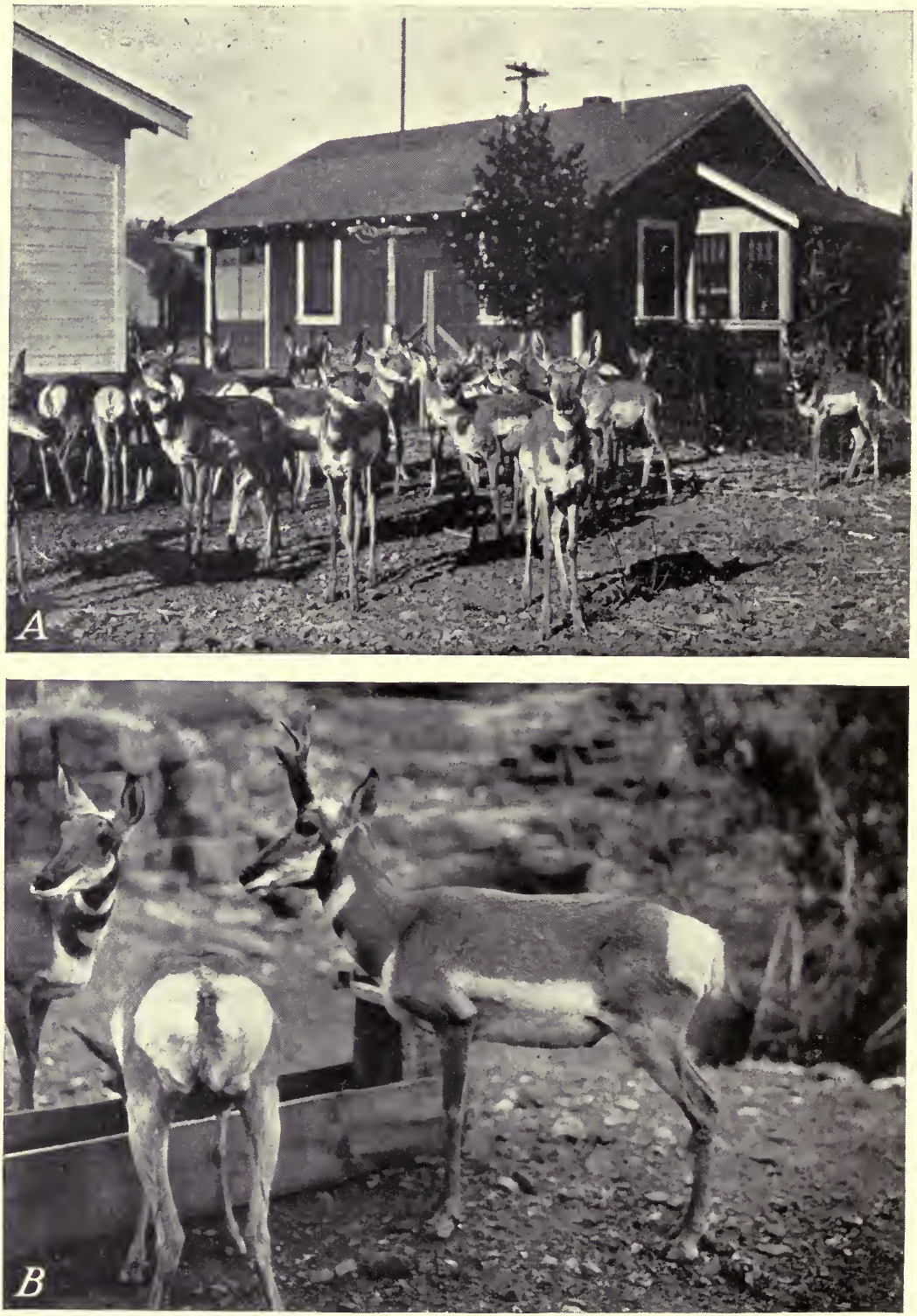

B2517M; 口

$A$, Young antelope on ranch in northwestern Nevada, captured and raised by hand for restocking depleted ranges (photographed when $31 / 2$ months old by E. R. Sans, September 4, 1924); $B$, 3-year-old Nevada antelope in Grand Canyon (photographed by C. F. Welch in 1927). 
the mouth of the Umpqua River in western Douglas County. On March 30, 1925, State Game Warden A. E. Burghduff, writing to the Biological Surey, reported these moose in excellent condition with indications that the 3 cows would calve that spring. He said the moose had not gone entirely wild but remained semidomesticated in the vicinity where released and could be readily approached at any time. They were seen daily by hunters and fishermen, and there seemed every indication that the planting was proving a complete success. The weight of the larger of the 2 bulls was then estimated at 1,000 pounds.

Under date of February 20, 1928, Jewett wrote that the most recent report on the moose near the mouth of the Umpqua River was to the effect that there were 2 cows and 1 bull of the original planting from Alaska, 1 yearling born in 1926, and 3 calves born in 1927, making a total of 7 animals. Of the original 5 head, 1 had been killed by a railroad train and another, which became considerable of a pest about the ranches and dooryards, had been wounded so badly by a local gunner that it had died. In the game-census reports of the Forest Service only 2 moose were reported on the Siuslaw National Forest in 1929, against 9 in 1928, and 6 in 1927. In a letter of February 2, 1931, Jewett says the Alaska moose of Oregon are no more. The last bull was shot by a State deputy warden at Tahkenitch Lake, in Douglas County, after it had been wounded and blinded by a charge of bird shot by some local resident.

\section{ALCES AMERICANA SHIRASI NELSON}

\section{Rocky Mountain Moose}

Alces americanus shirasi Nelson, Biol. Soc. Wash. Proc. 27 : 72, 1914.

Type locality.-Snake River, 4 miles south of the Yellowstone Park, Lincoln County, Wyo.

General characters.-About the same size or slightly smaller and grayer than typical Alces americana of eastern North America; head, neck, ears, and legs especially grayish brown.

Measurements.-Type specimen, adult male: Total length, 2,540 mm; hind foot, 762 .

Distribution and habitat.-The Rocky Mountains from northwestern Wyoming and central Idaho northward to British Columbia.

A published note by Dice, on the authority of Forest Ranger Floyd Kendall, reports moose as formerly occurring in the Blue Mountains but no longer found there $(1919, p$. 20). Probably the nearest point at which they now occur is central Idaho, but there are old records for the Salmon River and Payette Mountains in central and western Idaho, and it would not be strange if at times in their early abundance they occasionally extended across the Snake River into the Blue Mountain country, which was well suited to their needs. If so the form would undoubtedly be the same as the Yellowstone Park moose.

Other early records or any old horns or bones ever found in this section should be carefully preserved and put on record as throwing light on the original range of this important big-game species. 
CERVUS CANADENSIS NELSONI BAILEY

Rocky Mountain Wapiti ; Euk; Patuoha of the Piute at Burns, Oreg.

Cervus canadensis nelsoni Bailey, Biol. Soc. Wash. Proc. 48: 188, 1935.

Type locality.-Yellowstone National Park.

General characters. - Next to the moose and the Roosevelt elk, these are the largest of our North American deer. Antlers deciduous, large, long, with rounded beams and branches, normally with six prongs each in adult males; tail a mere pointed stub, 2 or 3 inches long; hoofs heavy and rounded, cowlike; upper canine teeth present in both males and females. In winter pelage, body light buffy gray; tail and rump patch, chin, eyering, inside and base of ear, white or buffy; head, neck, breast, and legs, dark brown, or nearly black on throat, with belly reddish brown; metatarsal gland white in buffy ring. Summer pelage, rusty brown or light bay, rump but little lighter; head, neck, and legs, brownish. Young, tawny, thickly spotted with white over back and sides.

Measurements.-Two-year-old male from the Gros Ventre, Wyo.: Total length, $2,015 \mathrm{~mm}$; tail, 160 ; hind foot, 670 ; measured in the flesh. Ear (dry), inside measurement, 190; outside from upper base to tip, 230 . Skull of 4-year-old bull from Nebraska, basal length, 414; orbital width, 202 ; length of upper molar series, 130.

Distribution and habitat.-The elk of the Rocky Mountain region originally occupied the whole of the Blue Mountain timbered plateau in northeastern Oregon, but there seems to be no record to indicate that the range ever connected with that of the herds on the west side of the Cascades. Some of the original stock are still found in the Blue Mountain country, where they have doubtless become mixed with those introduced from the Yellowstone National Park in 1913. As these were undoubtedly the same form, the mixture is of little consequence and may even serve to add new strength to the herd (fig. 10).

At Burns in 1920 some of the old residents said that in the early days elk were found in plenty all through the Blue Mountains, and that horns were picked up along the Silvies River where Burns now stands. Mr. Moore, of Klamath Falls, tells that in 1876 he saw an elk in the tule swamp on the Blitzen River between Malheur Lake and the Steens Mountains. In December 1930, when Malheur Lake nearly dried up, elk horns and bones were found on the dry bed where the water had receded near the mouth of Silvies River. In 1878 Charles E. Bendire reported elk in the Wallowa Lake section, in the mountains east of Umatilla on the head of Silvies Creek, and on the head of Bear Creek in the Blue Mountains. Ten years later, in 1889, elk were reported in Forest and Stream near the head of John Day River. In 1919 George G. Cantwell, while working in the Blue Mountains, 25 miles north of Enterprise, wrote that "old settlers tell me that 35 years ago elk were plentiful almost everywhere throughout this section of the mountains." In crossing the Blue Mountains from the north in 1895-96, the writer saw old elk horns at the ranches and was told that there were still a few elk in the wildest parts of these mountains. They were scarce then, reaching their lowest ebb later, about 1910, not long before the Yellowstone elk were brought in.

In 1912 and 1913 the imported elk were placed in the fenced enclosure known as "Billy Meadows" on the Imnaha National Forest. In 1914 the herd in the pasture was said to comprise 28 animals, in- 
cluding the 8 calves born that spring. Later the herd was reported as rapidly increasing, and in 1917 some of these were captured and transported to the Cascade Range and liberated near Crater Lake Reserve. Later reports have shown that the elk are increasing in the Blue Mountain forests. In 1915 Jewett reported quite a band ranging over the region of Meadow Creek on the Whitman National Forest, where miners and sheepmen estimated their numbers at 50 or more. The same year Peck reported elk signs frequent in the Canadian Zone in Baker County between the Beaver Meadows and the head of Anthony Creek, and farther west elk were reported spreading through the lodgepole pine forests west of the Grand Ronde Valley, and farther south about the headwaters of the John Day River. The Oregon Sportsman for April 1915 reported 37 elk in the Billy Meadows pasture and an estimate of 265 in Wallowa County. In 1916, 56, including 17 calves, were reported in the Billy Meadows pasture, 110 in Umatilla County, and 175 in Union County. In 1918, 74 were reported in the Billy Meadows pasture.

Table 10 shows the number of elk on the national forests since 1926, according to the estimates of the Forest Service. Most of these may be considered Rocky Mountain elk from introduced stock but may include some Roosevelt's elk from native stock on the west slope of the Cascades. The totals indicate a steady increase in numbers.

\section{TABLE 10.-Elk on national forests in Oregon}

[Data from estimates by U. S. Forest Service]

CERVUS CANADENSIS NELSONI

\begin{tabular}{|c|c|c|c|c|c|c|}
\hline Forest & 1926 & 1929 & 1930 & 1931 & 1932 & 1933 \\
\hline $\begin{array}{l}\text { Mount Hood } \\
\text { Santiam } 2 \\
\text { Cascade } \\
\text { Rogue River } \\
\text { Deschutes. } \\
\text { Malheur. } \\
\text { Ochoco } \\
\text { Umatilla } \\
\text { Wallowa } \\
\text { Whitman }\end{array}$ & $\begin{array}{l}(1) \\
(1) \\
(1) \\
(1) \\
(1) \\
{ }^{1} 47 \\
2,035 \\
669 \\
912\end{array}$ & $\begin{array}{l}\text { (1) } \\
(1) \\
(1) \\
(1) \\
(1) \\
{ }^{1} 75 \\
2,995 \\
1,590 \\
2,195\end{array}$ & $\begin{array}{r}137 \\
20 \\
256 \\
60 \\
71 \\
(1) \\
(1) \\
3,100 \\
2,151 \\
2,597\end{array}$ & $\begin{array}{r}125 \\
20 \\
265 \\
80 \\
105 \\
(1) \quad 5 \\
3,085 \\
2,515 \\
3,225\end{array}$ & $\begin{array}{r}125 \\
20 \\
275 \\
50 \\
110 \\
180 \\
15 \\
2,785 \\
2,770 \\
3,690\end{array}$ & $\begin{array}{l}115 \\
2330 \\
\text { (1) } \\
\text { (1) } \\
\text { (1) } 20 \\
3,080 \\
2,265 \\
5,665\end{array}$ \\
\hline Total & 3,663 & 6,855 & 8,392 & 9,425 & 10,020 & 11,475 \\
\hline
\end{tabular}

CERVUS CANADENSIS ROOSEVELTI

\begin{tabular}{|c|c|c|c|c|c|c|}
\hline $\begin{array}{l}\text { Siuslaw } \\
\text { Siskiyou }\end{array}$ & (1) 25 & $\begin{array}{r}279 \\
30\end{array}$ & $\begin{array}{r}430 \\
35\end{array}$ & $\begin{array}{r}440 \\
35\end{array}$ & $\begin{array}{r}390 \\
40\end{array}$ & $\begin{array}{r}350 \\
45\end{array}$ \\
\hline Total & 25 & 309 & 465 & 475 & 430 & 395 \\
\hline Grand total & 3,688 & 7,164 & 8,857 & 9,900 & 10,450 & 11,870 \\
\hline
\end{tabular}

1 No estimate available.

2 Santiam and Cascade Forests now consolidated in Willamette National Forest.

3 Formerly Crater.

Note. - No estimates available for 1927 or 1928.

General habits.-The range of the elk of the Blue Mountain section is apparently continuous with the Rocky Mountain form to which the name Cervus canadensis has been generally applied. Apparently their habits are the same, as they occupy typical Rocky Mountain forest country, moving up with the snow banks to the 
higher peaks and ridges in summer and down into the warm canyons in winter. When few in numbers and scattered in small bands they are almost as shy and wary as the deer, but where more numerous they collect in larger bands and in winter often come into the settlements in search of food. If undisturbed they soon become comparatively tame, as they have in Yellowstone Park and the Jackson Hole section, where they follow the loads of hay and eat it from the sleighs or even from people's hands. In the mild canyons of Oregon, however, they will never suffer from deep snows or cold weather, and on the steep canyon walls they find abundance of forage that cannot be reached by domestic stock. With the mule deer and mountain sheep they will climb the steep, rocky cliffs for forage that even the domestic sheep cannot reach.

Their only danger now seems to lie in overstocking of the range and starvation after the food supply is exhausted. This can be obviated by making a careful study of the carrying capacity of the range and by the annual removal of the surplus by shipments, hunting, or scattering out to new ranges.

Breeding habits.-The mating season begins in September and runs into October, when the bulls are in prime fighting trim and their flute-like calls and challenges are heard through the forests. Savage fighting takes place for mastery of the herds and the heaviest, strongest bulls drive out the weaker and pass on their progeny to the betterment of future generations. The calves are born in May and June and are kept hidden away until late in summer, when, after losing their spots, they join the herds, but they are not all weaned before the early part of November. The bulls shed their antlers in March and April and the new sets grow, harden, shed the velvet, and are ready for fighting again in August.

Food habits.-While depending in summer largely on grass and succulent vegetation for food, elk also eat much browse, and in winter their main food is the tips and buds and twigs of trees and bushes, with such dry grass and low vegetation as are available. In times of deep snow they often gather the twigs and leaflets of evergreens, and to some extent the tree mosses and lichens. They are eager for salt, often making long journeys to natural salt licks. Doubtless elk could be kept to some extent in desired areas by a properly placed salt supply.

Economio status.-There is no finer game animal nor one affording better meat than the elk in its prime, and many thousands could be maintained on the national forests and the rough unoccupied land in Oregon without detriment to livestock or agricultural interests. A good supply for hunting could eventually be provided if the animals could be properly protected. Besides, few game animals are more easily raised in captivity or become more fully domesticated and tolerant of fences. The breeding of elk for market has long been advocated by the Biological Survey, and in 1910 a bulletin on raising elk and deer in captivity was published but is out of print. 


\section{CERVUS CANADENSIS ROOSEVELTI MERIAM}

Roosevelt's WaptTi ; Roosevelt's ElK; Olympia ElK; Molok of the Wasco

Cervus roosevelti Merriam, Biol. Soc. Wash. Proc. 11: 272, 1897.

?C [ervus] occidentalis Hamilton Smith, Griffith's Cuvier, Animal Kingdom, v. 4, p. 101, 1827.

Type-Collected on Mount Elaine, near Mount Olympus, Wash., by Hans and Chris Emmet, October 4, 1897.

General characters.-Size of Cervus canadensis nelsoni or slightly larger. Color darker, horns shorter, heavy and often flattened, or "webbed", toward the ends. In winter pelage, the body is dark buffy brown to dark gray-brown; tail, rump patch, chin, eyering, inside of ear, and spot at base rich fulvous or buffy brown; head, neck, legs, and breast dark brown or blackish; belly reddish chestnut; metatarsal gland white. Spring coat is darker than fall, as fulvous tips of body hair wear off; rump patch is yellow. Summer coat is not seen, but probably nearly uniform deep rusty or bay.

Measurements of type.-Measured in the flesh: Total length, 2,490; tail, 80 ; ear (dry), inside from notch to tip, 208, outside from upper base to tip, 225. Skull of type: Basal length, 455; orbital width, 219 ; upper molar series, 138. Weight of large bull estimated by Forest Ranger Chris Morganroth at 1,500 pounds.

Distribution and abundance.- Unfortunately there is not a good museum specimen available for comparison of the elk from western O regon. Several heads and many pairs of horns have been examined in the coast country of Oregon, however, and they appear to be all of this very dark

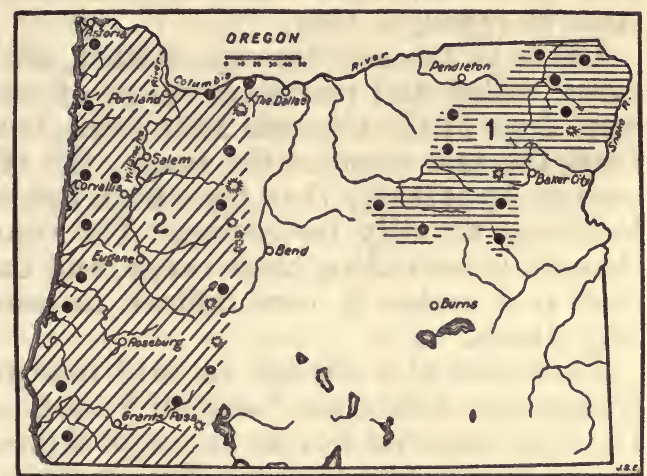

Figore 10.-Range of Rocky Mountain elk and Roosevelt's elk in Oregon: 1, Cervus canadensis nelsoni; 2 , C. c. roosevelti. form, with heavy and relatively short antlers (fig. 10). There are still considerable numbers of these elk (pl. 20) in the coast ranges from the Columbia to the southern border of the State, and it is to be hoped that good speci-

The name $C$ [ervus] occidentalis Hamilton Smith, in Griffith's Cuvier, Animal King. dom, v. 4, pp. 101-103, and pl. opposite p. 95, 1827; and v. 5, p. 308, 1827, was based in part on a drawing and description obtained from a voyageur near Montreal who had "traveled in the fur countries" and had a sketch of an elk with abnormal horns evidently combining some of the characters of the mule deer, and in part on 1 of 2 pairs of horns in the British Museum "that there is some reason to believe were brought to England by Captain Vancouver." The drawings of these horns of immature animals merely show small double forks near the tips and no real characters of any species of elk. The description of an animal with tufted tail 5 or 6 inches long could apply onjy to the mule deer and the white markings on chin and ears and inside the legs could have applied to the Rocky Mountain elk, but not to this darkest of our species of elk with no white except a small spot on the metatarsal gland. The statement, apparently from the voyageur, that it resides in the utmost limits of North America beyond the Rocky Mountains and the possibility that the horns in the British Museum may have been brought to England by Captain Vancouver, and if so, may have come from the region of Puget Sound, has led several authors to use this name for the elk of the Olympic Mountains. Even if Vancouver did bring these horns to England, he may have picked them up in California, where another well-marked form of elk occurs, and on the next page (p. 309, v. 5) the statement that the mule deer inhabits the remotest parts of northwestern America, while as a matter of fact it does not go beyond the crest of the Cascade Range or into the country of the Olympic elk, shows how vague the knowledge of geography was at that time. There is so much doubt as to the application of the name occidentalis to the form of elk inhabiting the Olympic Mountains and the coast ranges of western Oregon that it seems unwise to use it instead of a name in current use based on known characters, a good type specimen, and a definite type locality.

$7209^{\circ}-36-6$ 
mens of both summer and winter skins, accompanied by skulls and flesh measurements, will be preserved for museum collections and study before it is too late.

Originally the elk inhabited the western slope of the Cascade Mountains and the region thence to the coast over all of western Oregon. In 1805 Lewis and Clark on their way down the Columbia reported elk as seen near The Dalles; as plentiful across the river from Camas, Wash.; three killed near Point Adams, several near Cape Horn, and many taken during the winter just below the mouth of the Columbia (1893, v. 2, pp. 671, 734, 743 , 754, 794, 795, 798, 920, 935). In 1811-14 Franchere reported them as abundant throughout a great part of the Willamette Valley (1904, pp. 24\%, 314, 323). In 1841 Wilkes reported them as plentiful in the vicinity of Willamette Falls $(1845, p p .348,386)$. In 1841 Peale reported elk in the mountains south of the Columbia River of unusual size and in considerable numbers $(1848, p$. 306). From observations made about 1854, Suckley and Gibbs reported them as abundant in the mountains west of Astoria (1860, p. 133).

Later as the country was settled, elk were reported from almost every valley and mountain range of western Oregon, including the west slope of the Cascade Mountains, but there seems to be no record from the east slope of the range. In recent years, under rigid protection, apparently they have been holding their own, while in some localities actually increasing. The continual spread of settlement, though, is restricting their range, and the greater number of hunters each year makes it more difficult to prevent poaching in out-of-theway places.

Forest Service officials in 1910 reported elk as very scarce in the Siskiyou and Siuslaw National Forests, as formerly abundant in the Umpqua National Forest, and approximately 15 head ranging on each of the Crater and Cascade National Forests. In 1913, according to the Oregon Sportsman, there were 6 or 7 small herds in the Loon Lake district, about 35 miles from Roseburg. In 1914 the same periodical mentioned about 48 elk in Lane County, a band of 25 on the head of Drift Creek in Lincoln County, and a small band in Wasco County near the southeast slope of Mount Hood. In 1915 elk were reported as increasing in southern Oregon, where 31 were counted in 1 day. One was seen in Tillamook County, and 2 or 3 small bands in Clackamas County. In 1916 the animals were said to be increasing in Lane, Lincoln, and Douglas Counties, 8 were counted in Coos County, and a few in Tillamook and Clatsop Counties. In 1917 numbers were reported in Lane County, a herd of 80 was estimated in the Fall Creek country in Coos County, a small band of 35 or 40 in Curry County, and a few in Columbia County.

In the official report of game animals on the national forests of Oregon for the years 1924, 1925, and 1926, a slight decrease in number of elk is shown on the Cascade and Siskiyou Forests, and an increase on the Crater, Hood, Santiam, and Umpqua. The number reported for 1926 on the Crater was 16, the Siskiyou 25, the Santiam 40, Mount Hood 130, and the Cascade 225 elk. This total of 436 elk on the national forests of western Oregon probably covers the greater part of the Roosevelt's elk in the State in 1926. In 1929 the 
Forest Service reported on the Cascade 245, Crater 70, Deschutes 60 , Mount Hood 129, Santiam 30, Siskiyou 30, Siuslaw 279, a total of $843 \mathrm{elk}$ in western Oregon. Most of these however, were introduced Rocky Mountain elk.

In the big-game report of the Forest Service for 1932, 40 elk were estimated on the Siskiyou National Forest and 390 on the Siuslaw, all that can be positively ascribed to Cervus c. roosevelti, although some of those from the west slope of the Cascades may belong to this native form.

General habits.-Originally the elk of Oregon were largely animals of the open country as well as of the forest, but with the settlement of the open valleys they were soon driven back into the denser timber and brush land of uninhabited mountain ranges. Naturally they have held their own longer in the impenetrable forest and chaparral of the coast ranges, where the large game have all found a natural refuge.

They are gregarious, often gathering in large bands that keep tcgether through the fall and winter, and, in part, throughout the year. The bulls shed their horns in February or March. The new horns soon begin to start from the bases and grow rapidly through the summer. By September they are full grown, hardened, and the velvet covering is peeling off. The bulls then begin to try their horns on bushes and small trees, to challenge and bugle, and engage in fierce combats with rivals for control of the herds. Only the most powerful and vigorous bulls are able to pass on their characters to future generations and so insure a strong race.

Breeding habits.-The mating season is mainly, in October, and the calves are born in June. One young is the rule. Twins are a rare exception. The young are irregularly spotted over the sides and back with white on a dark fulvous or tawny coat that is highly protective in coloration. They are hidden away in the bushes until old enough to run with the mother, when they gather into the bands again.

Food habits.-While largely grazing animals, elk also browse on a great variety of bushes, leaves, twigs, and branches of trees, and to some extent on tree lichens. They are especially fond of the devilsclub, raspberry and salmonberry bushes, willows, blueberry bushes, vine maples, cherry, Ceanothus, Holodiscus, and wild rose. A great variety of herbaceous plants, including pea vines and clovers, are. eaten, as well as the rich mountain grasses. They have the advantage of domestic stock in a far wider range of food plants, and at all seasons in this region they are assured an ample food supply. Deep snow within their range is of rare occurrence and of short duration, so that winter losses of this elk are rare.

\section{ODOCOILEUS HEMIONUS MACROTIS (SAY)}

\section{Rocky Mountain Mute DefR; Tuhưa of the Piute at Burns}

Cervus macrotis Say, Long's Exped. to the Rocky Mountains, 2: 88, 1825. 2-v. ed.)

Type locality.-Mora River, near the present town of Mora, N. Mex.

General characters. - Size, largest of our North American small deer; antlers forked, often in adults twice forked; ears very large; tail 5 or 6 inches long, slender, with bushy black tip; hoofs slender and pointed; metatarsal gland 
above the middle of the metatarsal bone and 4 or 5 inches in length, conspicuously marked by long, coarse hair; skull long and large with deep lachrymal pits ; molar teeth light. Winter pelage: Body dark gray, with much black on the breast, forehead, nose, mane, and tip of tail; rest of tail, large rump patch, and back part of belly whitish or buffy; face usually dull gray, rarely whitish (pl. 21, A). Summer coat: Yellowish or rusty brown instead of gray. Young: Fawn color, thickly spotted, with white over back.

Measurements.-Of an adult male: Total length, 1,720 mm; tail, 130; hind foot, 510; ear (dry), inside, 200, outside, from base to tip, 240. Skull: Basal length, 290 ; orbital width, 142 ; length of upper molar series, 81.

Weights of adult bucks are generally given as 200 to 300 pounds, but very large, fat old bucks have been recorded as high as 400 to 450 pounds. Most of these weights are based on dressed deer that have been brought home and weighed bodily or in pieces and a correction of 20 percent of the dressed weight added for the live weight, so that a slight factor of uncertainty is introduced. A full or empty stomach may make a difference of 10 or 20 pounds. A large

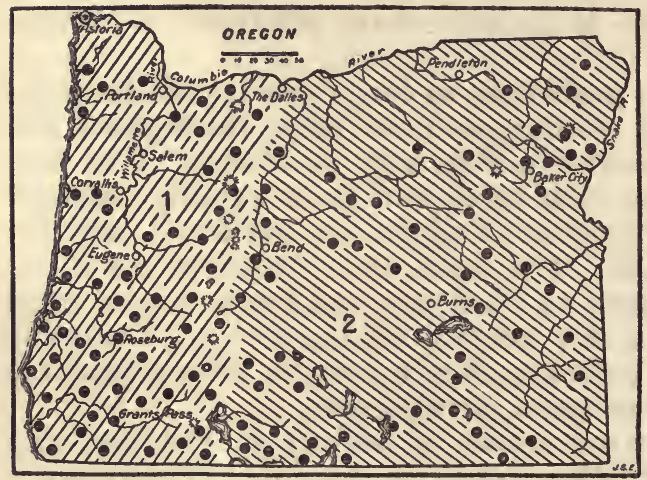

Frgure 11.-Range of Columbian black-tailed and Rocky Mountain mule deer in Oregon: 1,Odocoileus columbianus columbianus; 20 . hemionus macrotis. Type locality circled. buck from the head of the Grand Ronde River weighed dressed 260 pounds (Amer. Field 72: 502, 1909). In Wallowa County 100 bucks were reported killed in October 1913, of which several dressed 250 to 275 pounds (Oregt. Sportsman 1 (4): 17). One large mule deer buck was killed by George B. Marsden, of Burns, that dressed 314 pounds (Oreg. Sportsman 1 (4) : 14). George Humphries records a buck killed at Dog Lake, Lake County, that weighed 415 pounds, but this was not given as dressed weight and is assumed to have been weighed entire (Evening Herald, Klamath Falls Aug. 26, 1916). The California Fish and Game Commission records a buck in Modoc County of 350 pounds dressed (Calif. Fish and Game, January 1924, p. 19) and Seton records one vouched for by Dr. Tinsman, of Adin, Calif, close to the Oregon line, that dressed 380 pounds (1927, $v$. 3, p. 326).

Distribution and habitat.-Mule deer originally occupied practically the whole of eastern Oregon, including the dry eastern slope of the Cascade Mountains (fig. 11). At the present time they are found throughout the rough, mountainous parts of this area, well back from settlements and where they have received adequate protection. They are absent from most of the open country. They are holding their own in the very rough parts of the Blue Mountains, in the Steens Mountains, and in some of the desert ranges along the eastern part of the State, and in recent years are showing remarkable increases in some sections.

Unlike the Columbian black-tailed and white-tailed deer, mule deer are largely animals of the open country or open forests, and especially of the steepest, roughest slopes to be found. Generally they do not depend on dense cover for protection from their enemies, but more on their swift flight and the advantage in being able to run rapidly up or down rough slopes. At one time they were common out over the sagebrush plains, where every little canyon draw and rocky ridge afforded them shelter and protection. In these 

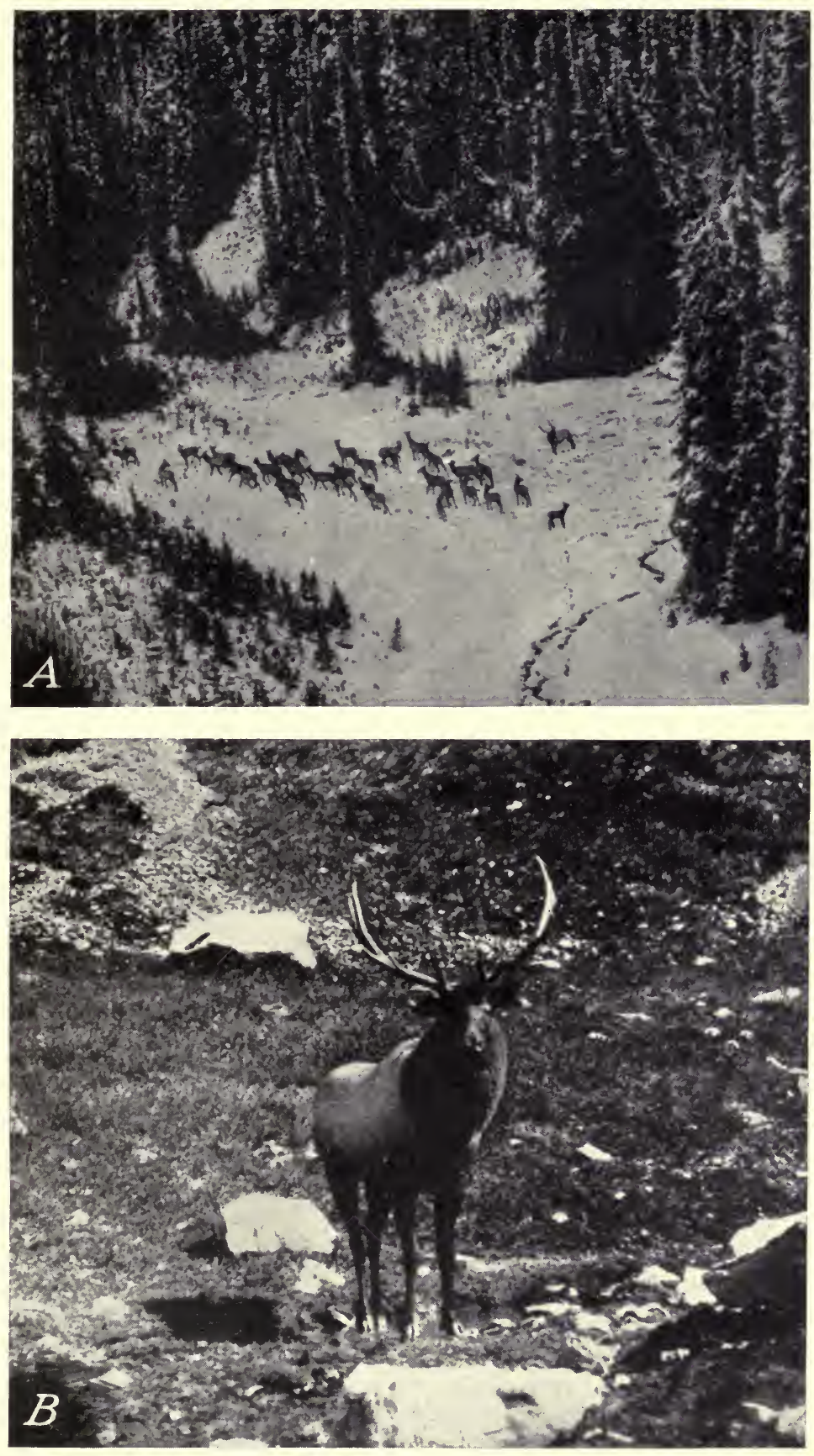

B4601M; B4602M

$A$, Roosevelt's elk in typical habitat in dense forest country, Olympic Mountains (photograph by W. J. Mathewson); $B$, young bull elk in fall, with heavy neck and mane (photograph by Wm. Everett, courtesy of the Forest Service). 

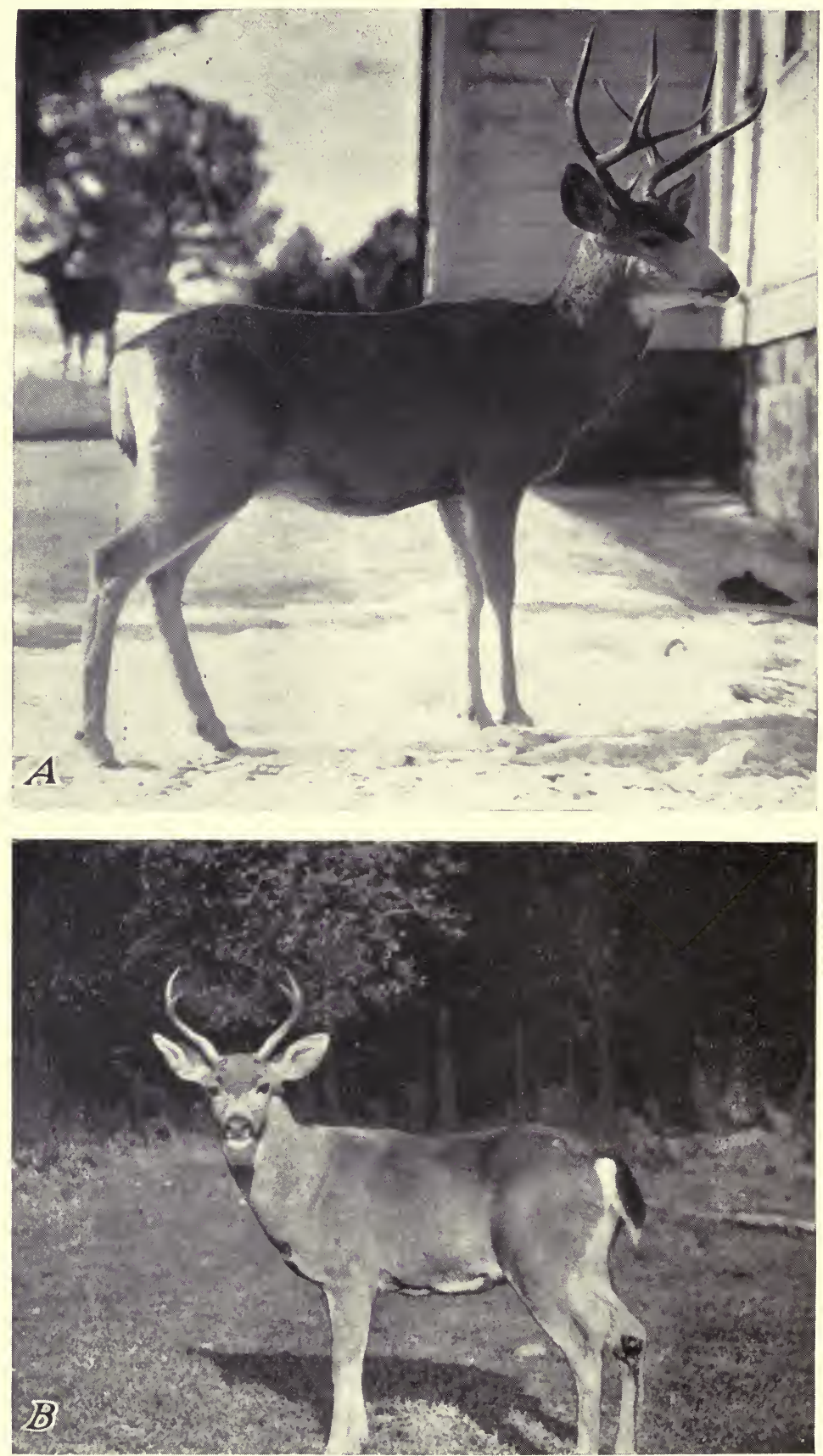

B4605M; B4604M

A, Rocky Mountain mule deer buck in early winter coat, in Yellowstone Park (photographed by M. P. Skinner); $B$, black-tailed deer from western Oregon (photographed by Wm. Everett, courtesy of the Forest Service) 
open situations, however, they have been so easily killed that they are now practically confined to the forests and steep mountain slopes.

Abundance.-In the Lower Deschutes Valley and the Columbia River Valley east of the Cascades mule deer have been scarce for a long time, owing probably to the great amount of hunting in proximity to well-settled agricultural valleys. But the best reports available indicate an increase on the national forests and unoccupied mountainous areas of eastern Oregon.

Table 11 shows a steady increase in the number of mule deer estimated by the Forest Service on national forests from 1926 until 1931. In 1932 the total decreased appreciably, and in 1933 a slight decrease continued. As some of the ranges were overstocked, this may however, represent a healthy tendency. The figures refer only to deer on the national forests but probably include three-fourths of the deer of eastern Oregon. A few hundred whitetails would be included.

TABLE 11.-Mule deer on national forests in Oregon

[Data from estimates by U. S. Forest Service]

\begin{tabular}{|c|c|c|c|c|c|c|}
\hline Forest & 1926 & 1929 & 1930 & 1931 & 1932 & 1933 \\
\hline $\begin{array}{l}\text { Wallowa } \\
\text { Umatilla_. } \\
\text { Whitman } \\
\text { Malheur- } \\
\text { Ochoco } \\
\text { Deschutes. } \\
\text { Fremont }\end{array}$ & $\begin{array}{l}4,500 \\
8,850 \\
7,209 \\
2,570 \\
1,400 \\
1,625 \\
2,500\end{array}$ & $\begin{array}{r}6,700 \\
10,900 \\
14,220 \\
3,200 \\
1,170 \\
2,600 \\
3,000\end{array}$ & $\begin{array}{r}8,300 \\
11,275 \\
15,580 \\
3,360 \\
1,360 \\
2,800 \\
3,425\end{array}$ & $\begin{array}{r}10,300 \\
12,200 \\
19,550 \\
4,710 \\
1,850 \\
2,860 \\
4,100\end{array}$ & $\begin{array}{r}10,640 \\
8,795 \\
12,600 \\
5,010 \\
3,635 \\
3,055 \\
4,000\end{array}$ & $\begin{array}{r}11,250 \\
7,950 \\
11,250 \\
5,010 \\
3,565 \\
2,995 \\
3,980\end{array}$ \\
\hline Total.... & 28,654 & 41,790 & 46,100 & 55,570 & 47,735 & 46,000 \\
\hline
\end{tabular}

NoтE.-No estimates avallable for 1927 or 1928.

General habits.-As might be expected from the prominent eyes and the very large ears, thes deer depend for protection from enemies largely on their keen senses. Their favorite bed ground during the daytime is on a steep slope often near the crest of a ridge overlooking a wide scope of country, where the approach of any enemy will be detected.

To some extent the mule deer are locally migratory. Usually as the deep snows of winter come on they leave the higher slopes and work down into the foothills, canyons, and valley draws where bare ground and an abundance of food are generally found on steep, sunny slopes, or in brushy bottoms. In spring and early summer they migrate back toward the higher levels, and the bucks, especially, with their sensitive, growing horns, seek the crests of wind-swept ridges during the worst of the fly time.

The bucks shed their antlers during the latter part of winter, varying from January to March. In April the new set begins to grow, and by July the beautiful brown velvet-covered antlers are practically full grown. In September the velvet peels from the hardened beams and prongs, which are soon polished and ready for the fall season of fighting.

Breeding habits.-The mating season throughout the Rocky Mountain region seems to be mainly in November. These deer are to some extent gregarious and migratory. During the mating season an old 
buck will sometimes gather a few does and keep off the smaller bucks, but more generally he will stay with one doe for a few days and then seek another mate. In places the herds or bunches remain together for at least a part of the winter. More often, though, they get scattered out and are kept more or less stirred up and on the move. Usually twin fawns are born in June, rarely 1 and as rarely 3 , beautifully spotted with white over a tawny or fawn-colored back and sides. The spotted coat is worn until the first molt in August or September, when the fawns are well grown and running with the mother.

Food habits.-Mule deer are mainly browsing animals, picking the buds, tips, leaves, flowers, and seed capsules from a great variety of bushes and plants. Mountain-mahogany is one of their favorite food plants, and the leaves, buds, and seed capsules are often closely browsed. Bitterbush (Purshia) and various species of Ceanothus are eaten, and raspberry and rosebushes are closely cropped. Only in early spring do they feed to any extent on green grass or newly sprouted grains. Generally no trace of grass is found in the stomach contents.

The practice of killing bucks only should be carefully considered. As soon as there are too few bucks for the number of does the restriction should be removed until the herd again becomes well balanced in sexes-not more than 5 does to 1 buck. Studies of game management have not gone far enough to determine definitely how often a season of hunting both sexes should be allowed, or whether an occasional open season on does is preferable. But in many States these important questions are being earnestly considered. When each doe is not bearing and raising her usual two fawns, there is some good reason, generally not enough male deer, or too many coyotes or bobcats on the breeding grounds.

Economio status.-Over much of the rough arid mountain country of eastern Oregon the mule deer is the most valuable game animal, suited as it is to a type of country in which neither domestic stock nor other game animals will thrive. If given proper protection these areas could support thousands of deer and provide good hunting where now there is little or none. The usual method of unrestricted hunting soon cleans out the deer in the open country they naturally inhabit; and only a limited license system, based on the estimated number of deer to be spared each year in each area, would serve to maintain the breeding stock as desired.

\section{ODOCOILEUS COLUMBIANUS COLUMBIANUS (RICHARDSON)}

Columbian Black-tailled Deger; Blacktail; Elula of the Wasco; Moos-mus of the Klamath (O. H. M.)

Cervus macrotis var. columbiana Richardson, Fauna Boreali-Amer., v. 1, p. 257, 1829.

Cervus lewisii Peale, U. S. Exploring Exped., v. 8, pp. 39-41, 1848. Type from mouth of Feather River, Calif.

Type locality.-Mouth of Columbia River.

General characters.- Smaller than the mule deer, and darker, with forked antlers (pl. 21, B), medium-sized metatarsal glands, lower down on the hind legs than in the mule deer and higher up than in the whitetails; tail, bushy, not 
so long as that of the whitetail, and much wider than that of the mule deer, whole upper surface black, whole lower surface white; ears large; skull relatively short and wide, with deep lachrymal pits and light molar teeth. Winter pelage (September to June), rich brownish gray, darker or blacker along median line of back from nose to tail; full top of tail, forehead, nose, and brisket black or blackish; legs tawny, lower surface of tail, inside of ears, and edges of lips white; back of belly, inside of front legs, and chin whitish. Summer pelage: Body rich tawny, top of tail, dorsal line, forehead, and nose blackish ; back of belly, inside of legs, throat, and lips white. Fawns thickly spotted with white over dark tawny upper parts.

Measurements. - Of adult male: Total length, 1,640 mm; tail, 180; hind foot, 450. Ear (dry), inside, 160, outside, from base to tip, 180. Skull: Basal length, 233; orbital width, 128; length of molar series, 71. Weight of large bucks about 200 pounds, but there are records of 200 and 219 pounds dressed.

Distribution and habitat.-The Columbian blacktails inhabit the region from the summit of the Cascade and northern Sierra Nevada Mountains west to the Pacific (fig. 11). In Oregon, they occupy also most of the eastern slope of the Cascade Range to its timbered base, their range meeting, but rarely overlapping, that of the Rocky Mountain mule deer. They are peculiarly animals of the dense forest and chaparral country of both mountains and lowlands, but they do not extend into the open desert country. Formerly they were abundant over most of their range, and they have held their own better, perhaps, than any other species of western deer. In many parts of western Oregon, they are still abundant, and with proper protection can be maintained in large numbers wherever the country is not thickly settled. The dense forests and almost impenetrable thickets which they inhabit protect them not only from natural enemies but to a great extent from excessive hunting.

Abundance.-In former days, from the time of the early explorations in Oregon-Lewis and Clark in 1805 and 1806, Henry Thompson in 1813, Franchere in 1814, David Douglas in 1825, Nathaniel J. Wyeth in 1832, Townsend in 1839, Wilkes and Peale in 1848, and others-up to the beginning of the Biological Survey field work of 1888 , there seems to have been no mention of excessive abundance of deer in western Oregon. Such statements as "observed", "specimen obtained", "plenty of deer", "a few observed", "in great abundance (Franchere)", "considerable deer found here", "deer abound (Wyeth)", would seem to indicate no greater numbers locally than during recent years. The greater abundance of wolves, mountain lions, and other predatory animals in earlier times evidently kept the number of deer at a low ebb. In recent years the deer have been crowded from much of their old range in the valleys by settlements and much hunting, but in unsettled areas and on the national forests they seem to be holding their own or slightly increasing.

Table 12 shows the numbers of black-tailed deer on the national forests in Oregon, according to Forest Service estimates. The figures naturally include a few white-tailed and mule deer along the eastern slope of the Cascades. Because of the great extent of foothill, semiforested, and chaparral country in the State it seems probable that as many more deer occupy the range outside national forests and that the total black-tailed population for the State in any year may possibly be twice the total estimated as in the national forests. 
TABLE 12.-Black-tailed deer on national forests in Oregon

[Data from estimates by U. S. Forest Service]

\begin{tabular}{|c|c|c|c|c|c|c|}
\hline Forest & 1826 & 1929 & 1930 & 1931 & 1932 & 1833 \\
\hline $\begin{array}{l}\text { Mount Hood } \\
\text { Santiam }{ }^{1} \\
\text { Cascade } 1 \text { River } \\
\text { Rogue Rive } \\
\text { Umpqua } \\
\text { Siskiyou } \\
\text { Siuslaw }\end{array}$ & $\begin{array}{r}2,500 \\
2,000 \\
4,765 \\
3,645 \\
(3) \\
20,000 \\
6,450\end{array}$ & $\begin{array}{r}1,865 \\
2,300 \\
5,000 \\
5,330 \\
4,350 \\
13,300 \\
7,325\end{array}$ & $\begin{array}{r}5,227 \\
2,410 \\
5,227 \\
5,050 \\
3,200 \\
13,500 \\
6,950\end{array}$ & $\begin{array}{r}5,250 \\
2,510 \\
5,250 \\
7,565 \\
3,250 \\
14,000 \\
7,000\end{array}$ & $\begin{array}{r}2,340 \\
2,010 \\
5,460 \\
6,060 \\
3,000 \\
13,900 \\
7,845\end{array}$ & $\begin{array}{r}2,470 \\
17,295 \\
4,610 \\
2,900 \\
6,100 \\
12,300\end{array}$ \\
\hline Total & 39,360 & 39,470 & 41,564 & 44,825 & 40,615 & 35,675 \\
\hline
\end{tabular}

1 Santiam and Cascade Forests now consolidated in Willamette National Forest.

Formerly Crater.

8 No estimate available.

NoTE.-No estimates available for 1927 or 1928.

The number of deer legally killed each year, if known, would be of great importance as an index to numbers maintained on the range, but only meager data are available. In 1916 Deputy Game Warden J. M. Thomas reported 318 deer killed in Coos County, and estimated 7,500 remaining (Oreg. Sportsman 5 (1): 43, 1917). In 1916 Joe L. Skelton, of Klamath Falls, estimated 5,000 black-tailed deer in the western part of Klamath County west of Klamath Lakes (Oreg. Sportsman 5 (1):17, 1917). Deputy Game Warden Orrin Thompson, of Roseburg, the previous year estimated 2,000 deer killed in Douglas County (Oreg. Sportsman 4 (1): 47, 1916). The same year Curry County, with a human population of only 2,628, was estimated to contain 20,000 deer (Oreg. Sportsman 4 (4) :242, 1916). It is evident that the available range and food supply would in many localities support a far greater number of deer than at present occupy western Oregon.

General habits.-Unlike the mule deer, which depend upon watchfulness and rapid flight, these timber-loving deer hide in the thickest parts of the forest, coming cautiously out at evening to feed, and depending largely on stealth and caution for protection, in which their dark colors aid them in avoiding observation. Usually they are resident wherever they occur, but in some parts of their mountain range they are driven down by deep snows of winter to the lower slopes, and in summer work their way back to the upper slopes and wind-swept crests where the flies and mosquitoes are less troublesome. Like other species of deer they become very tame and unsuspicious when not hunted or chased by dogs, but when much hunted quickly become wary and difficult to find.

Breeding habits.-The mating season is usually in October or November, and the fawns are born in May or June, although there are many records of earlier breeding and of fawns born in March and April, indicating a prolonged and irregular mating season. The spotted coat of the fawns (pl. 22) changes to the gray coat of the adult in autumn, and even before the change the fawns are sometimes found running with their mothers. The horns of the bucks are shed in January or February and renewed during the spring and summer months. By the first of September the velvet has 


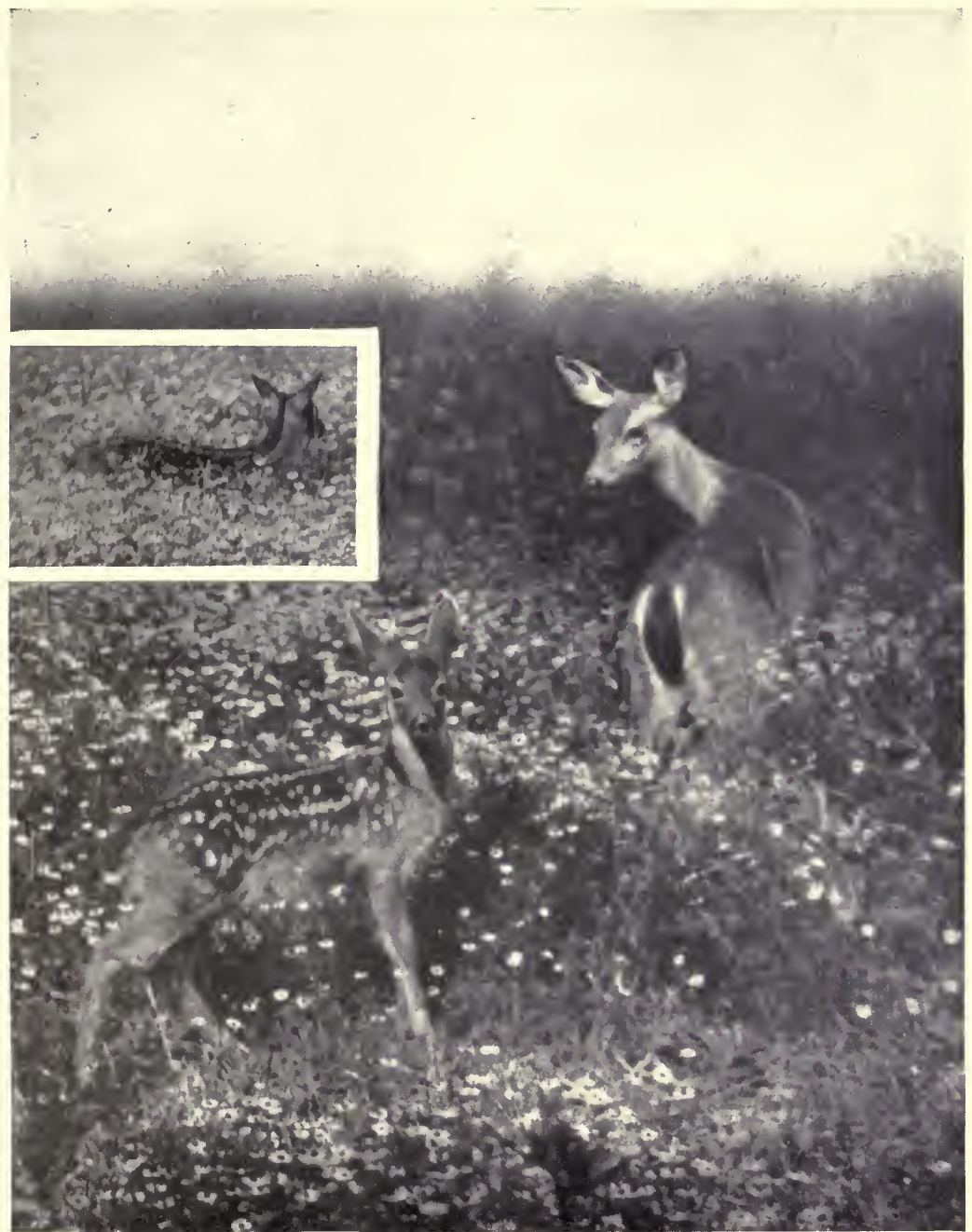

B4603M

BLACK-TAILED DOE AND FAwns from Cottage Grove, OReg. Photograph by C. A. Bartell. 


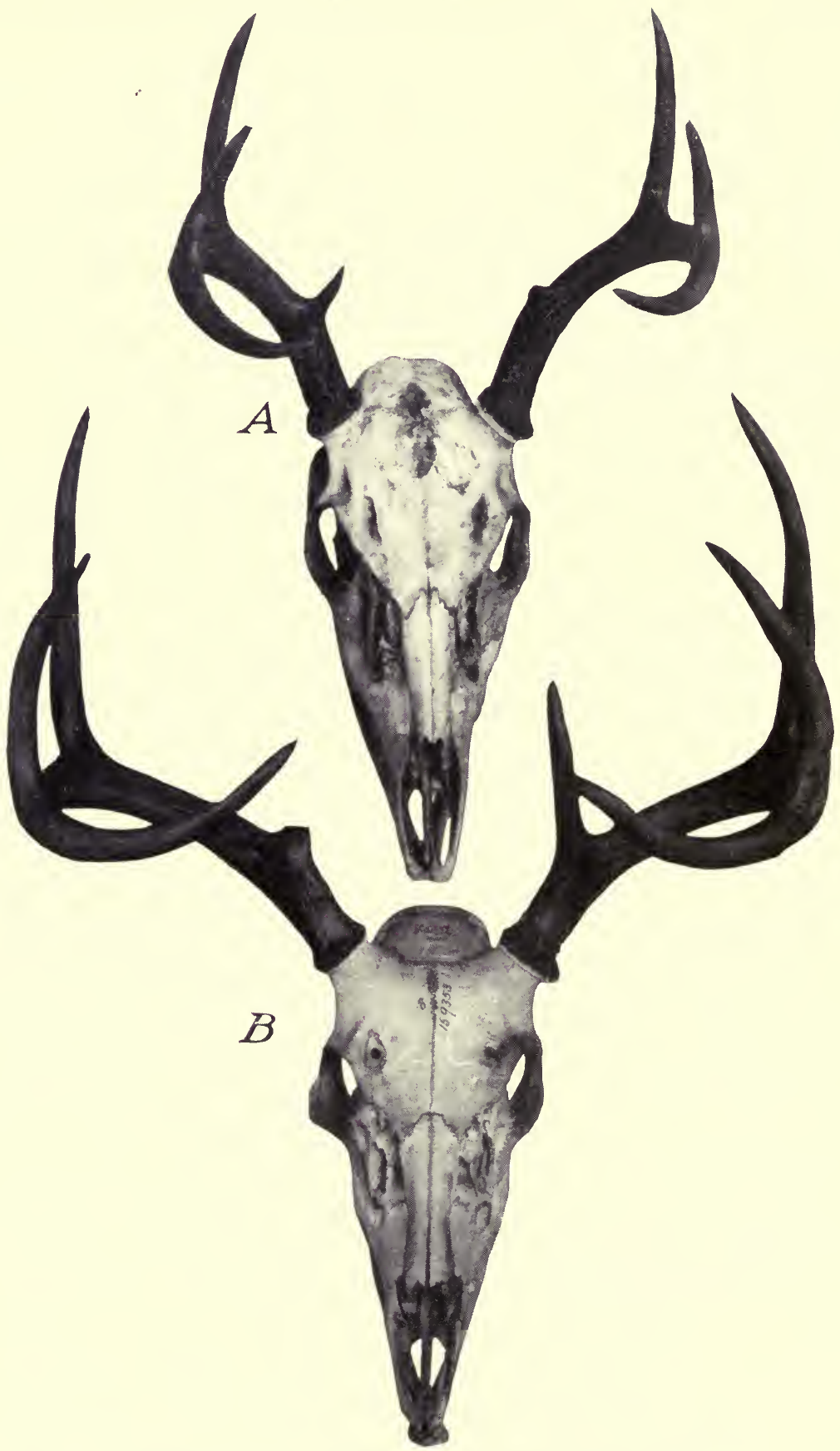

SKulls AND ANTLERS OF White-TAiled DEER.

$A$, Adult buck of the Columbian whitetail (Odocoileus virginianus leucurus), from near Roseburg, Oreg., collected by Stanley G. Jewett in 1915; B, type of Idaho whitetail (O. virginianus ochrourus) from Coolin, Idaho, collected by Frank Lemmer, Decembe: $19 \mathrm{c} 8$ 
usually disappeared and the horns are hard and in good fighting trim.

Food habits.-Most of the food of these deer consists of browse from the leaves, buds, tips of branches, seed capsules, and berries of a great variety of trees, shrubs, and other plants. Not a trace of grass could be found in the stomachs of a considerable number examined, but this does not prove that they do not at times eat green grass. They are fond of the leaves, buds, and seeds of many species of Ceanothus, commonly called buckbrush or lilac, also of the evergreen barberries, willows, mountain-mahogany, snowberry, blueberry, raspberry, salmonberry, salal, and rose. In the fall they regularly fatten on the abundant acorns as these fall from the trees or are picked from the shrubby oaks. Flowers, fruit, ferns, fungi, and lichens are also acceptable food. But this list of plants is a mere fragment of what they undoubtedly choose as food. In a dense, brushy, and forested country there is scarcely a limit to the food supply for such animals. Most of the plants eaten are not taken by any domestic stock. They are fond of salt and visit salt licks and the ocean beaches. For the most of the year they are in good condition. In the fall they become very fat and furnish one of the most delicious of wild meats.

Economic status.-The value of these game animals, living almost entirely on the waste products of the country and furnishing a valuable meat supply and a means of attracting a large number of people to outdoor sport and exercise each year, cannot be overestimated. The importance, therefore, of protecting and maintaining them in large numbers is evident, and a thorough study of the habits, needs, distribution, and abundance of the deer should form a basis for actual control and maintenance of the game supply.

\section{ODOCOILEUS VIRGINIANUS LEUCURUS (DOUGLAS)}

Columbian White-taileid Deer; Whitetail; Flagtall; Fantail; Mowitch of the Indians (D. D.)

Cervus leucurus Douglas, Zool. Jour. 4 : 330, 1829.

Type locality.-Falls of the Willamette and mouth of Columbia River, Oreg. (Description based on specimens from both places.)

General characters.- Small, about as in typical virginianus or smaller; tail not very long; skull small (pl. $23, A$ ) ; horns small and slender and closely incurved; ears small; metatarsal glands, as usual in the whitetails, small and below middle of metatarsus; skull slender with shallow lachrymal pits and light molar teeth. Winter pelage (adult male from near Roseburg taken Jan. 4) : Body dark brownish gray, slightly darker along back of neck; forehead dark brown; brisket, edge of ear tips, eyelids, nose pad, 3 spots on top and sides of nose and 2 on sides of lower lip blackish; top of tail and legs clear ochraceous; tip and lower surface of tail, belly, throat patch, lower lip and edges of upper lips, inside and spot at base of ears, inside of legs to and including heel gland and stripe down front legs to hoofs, leg and foot glands white; sides of nose and eyering light gray; base of hairs on top of tail dusky. Summer pelage and young not seen, but Douglas says they change to reddish brown in summer and that the young are spotted with white until the middle of the first winter. Skulls of 3-or 4-year-old bucks from near Roseburg are small and slender with slender rostrums, flat frontal regions, deep pits above orbits, narrow nasals and palates and very small, slender, closely incurved antlers.

Measurements.-Tanned skin from near Roseburg, adult male: Total length, $1,575 \mathrm{~mm}$ (62 in.) ; tail, 178 (7); hind feet imperfect; ear, inside, 110 (41/2), 
with larger horns, heavier skull ( $\mathrm{pl} .23, B$ ), longer tail, but very similar coloration. Not so large or dark as boreatis. Winter pelage, upper parts dark buffy gray, becoming bright ochraceous on top of tail, legs, and edges of belly; forehead and top of head dark brown; brisket dusky; eyelids, nose pad, 3 spots on top and sides of nose and 2 on sides of lower lip black; sides of nose and eyering light gray; tip and lower surface of tail, belly, throat patch, and lower lip, inside of ears, inside of legs to below heels and knees, metatarsal and foot glands white. Summer coat (June 25 from Coeur d'Alene Mountains) : Upper parts bright tawny or light bay, legs but little lighter, not yellowish as in macrourus, and with no real black on top of tail as in macrourus and borealis. Young spotted with white over back and sides. Skull very similar to that of macrourus with about the same type of horns, larger, more massive and with much heavier horns than in leucurus.

Measurements.-Type: Total length, 1,752 $\mathrm{mm}$; tail, 265; hind foot, 483 ; ear (dry), inside, 120, outside, base to tip, 150. Skull of type: Basal length, approximately 275 ; nasals, 100 ; orbital width, 120 ; postorbital width, 105 ; brain case, 75 ; mastoid width, 91 ; upper molar series, 74 ; lower molar series, 84.

Distribution and habitat.-This mountain valley form of the western white-tailed group apparently occupies the lake and stream valleys of Idaho, northwestern Montana, southeastern British Columbia, and parts of eastern Washington and Oregon, east of the Cascades (fig. 12). There are specimens from Buck Creek in Grant County, and Davis Creek in the southwest corner of Crook County, that are referred to this form.

Until specimens of typical Odocoileus leucurus were recently obtained by Jewett from near Roseburg, Oreg., the deer of eastern Oregon, Idaho, and northwestern Montana were supposed to belong to that species. Comparison of the material showed that this northern Rocky Mountain valley deer is a well-marked form of the white-tailed group.

Lewis and Clark in 1805 and 1806 and Douglas in 1825 and 1826 recorded these deer along the west base of the Rocky Mountains, but they included them with either leucurus or macrourus, in which they were followed by later authors. Ogden in his journal of November 18, 1826, while on the Deschutes River, southeast of the Paulina Mountains records "seven white-tailed deer brought in" (1910, p. 210). Newberry (1857) in 1855 reported them on the Deschutes (lat. $43^{\circ} 27^{\prime}$ and $43^{\circ} 40^{\prime}$ ). Jewett and Murie collected three specimens on Davis Creek, a branch of the upper Deschutes, in January 1913, and 2 years later Jewett reported them along the Metolius River west of the Deschutes, and on Mill Creek at the northeast base of Mount Hood. In the John Day Valley he was told that they were formerly very common throughout the valley, and there were still a few in some of the more remote valleys north and south of the river. He also reported them as formerly common in the Powder River Valley and along Pine Creek and gave some reports of whitetails seen in recent years. In 1916 he saw one in Fox Valley north of the John Day River. Preble and the writer obtained reports of them in 1896 near Elgin in the Grand Ronde Valley and saw one on the ridge west of the valley. According to numerous reports from Forest Service officials, hunters, and residents, it appears that these deer were once an abundant species throughout the valley and stream bottoms of the Blue Mountain section, and there are evidently a few remaining in out-of-the-way places. 
In 1916 William F. Schnabel, of Caldwell, Idaho, wrote to the Biological Survey that in 1880 he saw two white-tailed deer on top of the Mahogany Mountains, in eastern Malheur County, the only ones he ever saw there, although he had seen hundreds of them on the Snake River Plains in Idaho.

At Klamath Falls a Mr. Moore, an old resident, told the writer of killing a white-tailed deer near Fort Klamath about 1885. There are also records of deer south and west of Lower IIlamath Lake that may be provisionally placed under this subspecies.

In the California Academy of Science collection are a pair of old white-tailed deer antlers from Ashland, Oreg., collected by William C. Butler in 1898, and labeled, in B. W. Evermann's handwriting, "old horns from the wall." These are typical heavy, rough antlers of $O$. $v$. ochrourus and may well have been brought from Davis Creek or anywhere, but they are not the $O$. v. leucurus type of antlers. Two other pairs of interlocked antlers in the academy collection, nos. 5579 and 5580, are labeled " eastern Oregon, bequest of Tom C. Grant, March 12, 1926." They seem to be typical $O$. v. ochrourus. They are old and yellow and may have been picked up long ago, possibly in the John Day River country.

Another very important pair of antlers in the academy collection comes from Modoc County, Calif., well below the Oregon line labeled "South Fork of Pit River in the Warner Mountains. No. 877, John Rowley collection, collected October 1911, by L. H. Sisson, of Alturas." They are heavy rough antlers with heavy base and long brow points of typical $O$. $v$. ochroumes and mark the southernmost point from which specimens have been examined.

General habits.-There is very little on record of the habits of these deer in Oregon, except that they are found mainly in thickets and willow bottoms along the streams and valleys. In recent years they are sometimes found back in the hills, crowded back probably by settlements. Like most of their group they are secretive and would rather hide than run. In the more extensive thickets and forests of Idaho and Montana they are still abundant in favorable locations, but over much of their ranges they are doomed to be crowded out by settlements, or killed by predatory animals as they gather on winter ranges and are easily pulled down by coyotes and dogs in the deep snows.

\section{ORDER LAGOMORPHA: RABBITS AND CONIES}

Family LEPORIDAE: Rabbits and Hares

\section{LEPUS AMERICANUS BAIRDII HAYDEN}

\section{Rocky Mountain Snowshoe HaRe}

Lepus bairdii Hayden, Amer. Nat. 3:115, 1869.

Type locality.--Near Fremont Peak, Wind River Mountains, Wyo.

General characters.-In size intermediate between the cottontails and the jack rabbits, ears moderately long, feet large and hairy, tail small, not conspicuously white underneath. Summer coat, upper parts rusty gray, with much black on rump, back, and ears; belly, chin, inside of legs, feet, edges of ears, and sometimes speck on crown, white. Winter coat usually pure white, with sometimes a trace of gray or buffy over head; back of ear tips dusky. Young are grayish brown, without much white. 
Measurements.-Total length, $447 \mathrm{~mm}$; tail, 40 ; hind feet, 143; ears (dry), inside from notch to tip, 68.

Distribution and habitat.-This Rocky Mountain form of the snowshoe hare comes into eastern Oregor over most of the Blue Mountain Plateau. There are specimens in the Biological Survey collection from Wallowa, Strawberry Butte, and from near Sumter, and in the Jewett collection from the Ochoco National Forest, from 15 miles north of Burns, and from Sled Springs, 22 miles north of Enterprise (fig. 13). Numerous records cover the Canadian Zone forest area of these mountains. In Oregon, however, their range apparently does not connect with that of klamathensis in the Cascade Mountains. They are denizens of the deep forests and dense thickets, sometimes ranging to near timber line through both Canadian and Hudsonian Zones.

General habits.-While often common, these hares are less conspicuous than most other species, because in summer they hide away

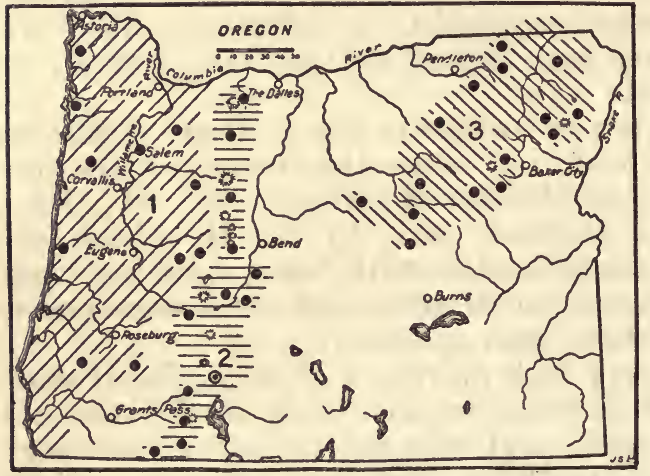

FIGURE 13.--Range of the three forms of snowshoe hares in Oregon: 1, Lepus americanus washingtonii; 2, L. a. klamathensis; $3, L$. a. bairdii. Type locality circled. in the dense growth, where their shadowy colors afford them excellent concealment. In winter their tracks and runways are often conspicuous; but the $r$ abbits, when pure white, are practically invisible on the snow fields except in motion. They are fleet of foot and have little trouble in saving themselves when directly pursued but are much hunted. by the Canada lynx, bobcats, and owls, which stealthily pounce upon

them. At times they become fairly numerous and again are extremely scarce, their abundance varying from unknown causes in different years or series of years.

Breeding habits.-The young of this snowshoe hare are born in May or June, usually 4 to 6 in a litter. They are well furred at birth and soon are running about getting a part of their living from the tender green vegetation.

Food habits. - In summer these hares feed on the tender green vegetation, grasses, clover, and a great variety of plants, but in winter their food is mainly buds, tips, and bark from the branches of shrubs and young trees. In spring in a good rabbit thicket the wild dogwood, raspberry, and a great variety of other bushes will be found nipped off as though by a sharp knife, and the peeled tips and stems lie scattered over the ground where they have been eaten. As the snow gets deeper the rabbits are brought up to a fresh and ever-abundant supply of shrubby food, and the wintertire seems to be their season of greatest activity and most vigorous bodily condition. While not becoming fat as many animals do, they often show between the shoulders two narrow strips of tallow, which indicate their condition. 
Economic status.-These hares are perhaps the best of all for food and are almost always sound and healthy. They are much hunted and usually prized as game animals. In some parts of the country they are protected by game laws. Generally, however, they are able to protect themselves quite effectively where there is considerable extent of dense forest growth. In very rare cases they have been known to cut young fruit trees and ornamental shrubbery during the winter, but usually they are not in a position to do any serious damage. In mountainous regions they may be considered practically harmless and of considerable value as game. In some of the national parks and in forest areas where not hunted they show little fear of man and often become half tame around camps and cabins, thus affording one of the most attractive features of wildlife.

\section{LEPUS AMERICANUS KLAMATHENSIS MERRIAM}

Oregon Snowshom Hare; ChI of the Klamath (C. H. M.) ; Elocus of the Wasco

Lepus klamathensis Merriam, North Amer. Fauna No. 16, p. 100, 1899.

Type-Collected at Fort Klamath, Oreg., January 25, 1898, by B. L. Cunningham.

General characters.-Size about as in the other snowshoe hares, ears medium, tail small, feet large and hairy; brown in summer, and either brown or white in winter. Summer fur, upper parts grayish brown with back and edges of ear tips black; throat brownish ; belly, chin, inside of legs, top of feet, outer edges of ears, and sometimes speck on crown white. Winter fur: Some individuals are merely slightly grayer than in summer, but most are pure white all over except for dusky spots on back of ear tips. Young, like summer adults, but duller with little or no white below.

Measurements.-Total length, $414 \mathrm{~mm}$; tail, 39 ; hind foot, 126; ear (dry), from notch to tip, 64. Weight of adult male, by Dice, $1,068 \mathrm{~g}=2$ pounds 5 ounces. (1926, p.9.)

Distribution and habitat.-Found throughout the Cascade Mountains in Oregon from Mount Hood south to California, and in the Sierra Nevada Mountains south at least to Lake Tahoe (fig. 13). Along the western base of the Cascades these snowshoe hares grade into Lepus washingtonii of the coast region, and along the east base they come down as low as the edge of lodgepole pine and spruce timber and across into the Paulina Mountains. Their range is mainly in the forest and thickets of Canadian Zone, where they are generally distributed but never very numerous.

General habits.-These forest hares are shy, secretive, and rarely seen unless driven from their hiding places under low evergreen bushes in the forest or dense thickets of willows in the creek valleys. Even then they are not easily seen as they slip away under cover or behind logs, trees, or bushes. Their well-worn trails and their pellets are often the only evidence of their presence. In winter their large tracks on top of the snow or their well-worn and often deep runways are better evidence of their presence and numbers, but the white coats of most of the hares keep them well concealed even in the open.

In March 1914 Harry Telford, of Klamath Falls, found them plentiful in the lodgepole-pine thickets on the head of Wood River, where they had burrows under the snow in brushy places and around the tops of down trees. 
Of food and breeding habits very little is known of this particular subspecies, but there is no reason to suppose that they differ materially from those of bairdii and other members of the group in similar situations.

\section{LEPUS AMERICANUS WASHINGTONII BAIRD}

\section{Washington Snowshoe Hare; Brown Hare; Red Rabbit}

Lepus washingtonii Baird, Acad. Nat. Sci. Phila. Proc. 7 : 333, 1855.

Type.-Collected at Steilacoom, Wash., by George Suckley, April 1, 1854,

General characters.-Approximate size and general form of the varying hares, but more rusty or reddish brown at all seasons, not changing to white in winter. Summer and winter fur, dark grizzled rusty or reddish brown over upper parts and throat; top of very small tail and back of ear tips blackish; belly, chin, inside of legs, edges of ears, and sometimes toes and speck on crown white; underside of tail buffy or gray. Young similar to adults, with less white.

Measurements.-Average of five adults: Total length, $429 \mathrm{~mm}$; tail, 41 ; hind foot, 125; ear (dry), from notch to tip, 62. Weight 2 pounds to 2 pounds 7 ounces. Dice records a female carrying embryos at $1,720 \mathrm{~g}=3$ pounds 12 ounces.

Distribution and habitat.-These brown rabbits occupy the lower country west of the high Cascades of Washington and Oregon, ranging to the tops of some of the coast ranges and probably all, but only onto the western foothills of the Cascades (fig. 13). Their dark, rich colors are a product of the humid west-coast climate of abundant rain and little snow, of dense shadowy forests and dark fern and chaparral undergrowth. Just how far south they go is not known, a specimen from near the headwaters of Rogue River being the southernmost of any examined. It is not improbable that they may range to the southern border of the State in humid Transition Zone of the coast region.

Specimens from the western foothills of the Cascades clearly show intergradation with klamathensis, which occurs higher up the slope, and there now seems ample evidence of the intergradation of all the western forms of this group.

General habits.-The Washington hares are mainly forest dwellers, but in many extensive areas of dense shrubby growth they find even safer cover and better protection than in the forests. They are rarely seen except as occasionally one hops out into a road or trail or dodges back into impenetrable cover. Their dark colors are highly protective, but most of their enemies are such stealthy hunters as owls and cats, which pounce upon them unawares. On the upper slope of Chintimini Mountain the writer came on one lying freshly killed in the trail where a bobcat had evidently just dropped it. It was still warm and made a good specimen.

In Oregon these rabbits are so scarce and so well hidden as to be of little value as game, but they add to the forest the interest and lure of a rare animal.

Breeding habits.-Dice reports females containing 3, 4, and 5 embryos and the mammae varying in number from 4 to 5 pairs, usually 1 pair of pectoral and 3 pairs of abdominal, but in one case 2 pairs of pectoral and 3 of abdominal.

On April 15, 1916, Alex Walker found a small young at Tillamook, measuring only $153 \mathrm{~mm}$ in total length, and probably only a few days or a week old. Dice found females containing small embryos on 
July 26, 28, and 29. At the same time, on July 28, a half-grown young was collected which would seem to indicate more than one litter of young in a year $(1926, p .7)$.

\section{LEPUS TOWNSENDII TOWNSENDII BACHMAN}

Western White-tamed Jack Rabit; Poolalik of the Walla Walla and Nez Percé (J. K. T.)

Lepus tounsendii Bachman, Jour. Acad. Nat. Sci. Phila. 8:90, 1839.

Type locality.-Walla Walla, Wash.

General characters. - A rather heavy-bodied rabbit of about the same size and weight as the black-tailed, Lepus c. wallawalla, but with less length of body, legs, and ears; tail large and mostly white at all seasons; whole body usually turning white in winter. In summer pelage, head, body, and legs clear gray; edges and back of ear tips and eyelids black; narrow line along top of tail gray or dusky; feet and throat buffy gray; most of tail, belly, chin, eyering, and back of ears white. Full winter pelage generally all pure white, except edges and back of ear tips and eyelids black, and sometimes gray or buffy markings on ears, face, and feet. In the low, warm valleys many do not turn white in winter, but become lighter, frosted gray. Young more buffy gray than adults.

Measurements.-Average of typical adults: Total length, $575 \mathrm{~mm}$; tail, 79; hind foot, 149 ; ear (dry), inside from

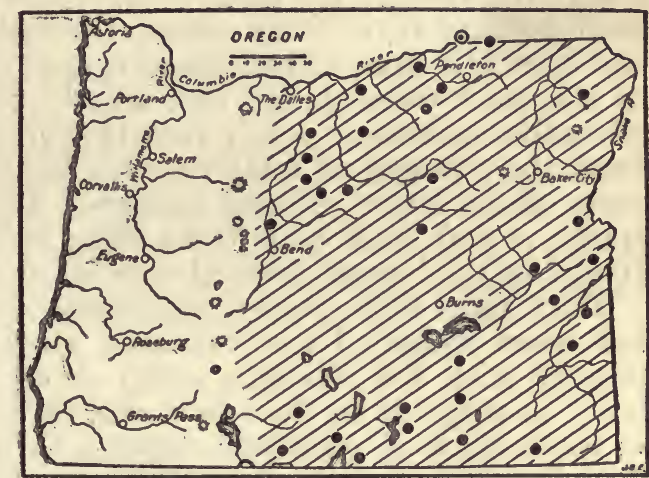

TIGURE 14.-Range in Oregon of Townsend's bare, or white-tailed jack rabbit, Lepus townsendii townsendii. Type locality circled.

notch to tip, 100, upper base to tip, 120. Weight given by Dice of specimen taken at Wallula, Wash., adult female, $3,070 \mathrm{~g}=6$ pounds and 13 ounces; of two other females from Kiona, Wash., 2,020 and $2,690 \mathrm{~g}$; and of a male, 2,090 $\mathrm{g}$ (1926, p. 7).

Distribution and habitat.-In varying numbers these rabbits cover practically all of the open country of Oregon east of the Cascade Mountains and range north into British Columbia, south into $\mathrm{Ne}$ vada and California and east to western Wyoming and Colorado (fig. 14). From the plains of the Columbia at 100 feet above sea level in Upper Sonoran Zone they range up over the high valleys and plateau tops in grassy and sagebrush country, and in the mountains often find their way to the open slopes above timber line, well into Hudsonian if not Arctic-Alpine Zones. Their main range and abundance, however, are in Transition Zone. Their boundaries except on the south are largely formed by timbered areas, which they do not enter. On the east they grade into the subspecies campanius of the northern Great Plains region, but to the south are held back by some of the potent, invisible forces controlling zonal distribution. Their greatest abundance seems to be on the high plains of the Columbia where at times they become almost as numerous as the black-tailed "jacks" on the lower areas. In 1834 J. K. Townsend $(1839, p .325)$ in his description of them at the type locality said they never turn white in winter. They are used by the Indians and $7209^{\circ}-36-7$ 
whites as food. The Indians kill them with arrows and in winter take them with nets, several hundred in a day.

General habits.-These are primarily rabbits of the grassy plains where they crouch, well concealed, in shallow, scooped-out forms under tufts of grass or in the shadows of weeds or low bushes, and only when almost stepped on burst from cover with a startling flash of white and striking colors that might well cause a momentary hesitation in a hungry coyote while the rabbit is getting safely under way. It certainly gives the hunter somewhat the same thrill as a white-tailed deer bounding from cover, or the prairie chicken bursting from the grass, and the first glance makes the rabbit seem twice its real size. With their puffy white tails and the white and black backs of their erect ears showing as they bound high and far, they are as remarkable for their conspicuous appearance as they are for their baffling invisibility when crouched with tails and ears down, and eyes half shut. Their speed is apparently about the same as that of the black-tailed jacks, and usually permits them to escape from all native enemies in a fair race, though not from the greyhound nor from the strategy of relay or pack hunting, nor from the attack of some of the larger winged hunters. The writer has measured their tracks in soft snow and found them clearing from 4 feet to 17 feet 10 inches, the longest leaps always following 2 or 3 shorter hops.

They have little power of defense except concealment or flight, but when wounded and captured alive, they will kick and strike fiercely with the straight, sharp claws of the hind feet, inflicting long, deep gashes in the hands of a careless hunter. When wounded or captured they sometimes utter a shrill scream of pain or terror, but otherwise seem to our coarse ears to have no voice.

They are active at all seasons of the year and with their dense coats of pure-white fur are able to withstand the coldest of weather and deep' snows. They burrow deep in the snowdrifts and dig long tunnels from which they can escape at either end, and in which they sit during the day, screened from the eagle eyes of enemies soaring overhead. They have many enemies. The coyote and bobcat pounce upon them unawares, or when soft snow puts them at a disadvantage, and at times wolves hunt them systematically and successfully. Eagles hunt them, and hawks and owls undoubtedly get many of the young.

Breeding habits.-In this group of rabbits the mammae are in 4 pairs, arranged along the sides of the belly, on 2 long parallel mammary glands. They are generally given as 1 pair of inguinal, 2 pairs of abdominal, and 1 pair of pectoral. The young are usually 4 to 6 and at birth are surprisingly well developed, heavily furred, with eyes open and incisors showing. They are nursed until about quarter grown and able to shift for themselves.

Food habits.-In summer these rabbits nibble dainty grasses and wild clovers and a great variety of tender green plants, but the minute sections of grass stems in the large spheroidal pellets show grass to form the bulk of their food. In winter they eat the buds, twigs, and bark of bushes and young trees, and the increasing depths of snow serve to lift them to higher levels and a fresh supply of food. In times of scarcity the tips of sagebrush, rabbitbrush, and such unpalatable browse are eaten, but only when the more acceptable 
kinds are exhausted or are not available. Berry, and other fruit bushes, and trees are generally favorites. Clover, alfalfa, grains, and many garden vegetables are eagerly eaten when available. In some cases standing crops and haystacks are seriously reduced.

Economic status.-In some cases these rabbits do considerable mischief to grainfields, alfalfa, and clover meadows, and even gardens, but their greatest damage is probably to the grazing and in winter to stacks of hay, at which they often gather in large numbers. Locally they also destroy some young fruit trees by cutting off the tops or eating the bark from the trunks as high as they can reach. Over most of their range, however, they are not sufficiently numerous to do noticeable damage and their value as food and game is sufficient to overbalance their slight consumption of forage and crops. They are rarely infested with parasites. Usually they are in good condition and make excellent eating. They have a good market value, and over part of their range might well be given sufficient protection to prevent undue reduction of their numbers.

\section{LEPUS CALIFORNICUS CALIFORNICUS GRAY}

\section{CaLIFornia Jack RaBbit}

Lepus californica Gray, Zool. Soc. London, Proc. p. 88, 1836 (nomen nudum). Lepus californicus Gray, Charlesworth's Mag. Nat. Hist. 1: 586, 1837.

Lepus californicus vigilax Dice, Univ. Mich., Mus. Zool., Occasional Papers, 166, p. 11, 1927.

Type.-Collected at St. Antoine, Calif. (near Jolon, Monterey County), by David Douglas in 1831.

General characters.-Large, ears very long; dark, brownish gray, with upper surface of tail and tips of ears black. Winter pelage, upper parts dark buffy brown, darkened by long black outer hairs; top of tall and back of ears near tips black; lower parts and flanks dark buff or salmon. Summer pelage paler and grayer than in winter. Young heavily furred at birth, dark, coarse gray, becoming paler and less grizzled when half grown.

Measurements.-Average of typical specimens: Total length, $604 \mathrm{~mm}$; tail, 95; hind foot, 131; ear (dry), from notch, 125, upper base to tip, 145. Weight, variously given as 5 to 7 pounds.

Distribution and habitat.-These big rabbits extend from California northward into the open country of the Rogue, Umpqua, and Willamette Valleys, commonly reaching as far north as the country about Salem, and more rarely to the Columbia River (fig. 15). Nominally an Upper Sonoran Zone species, they often crowd a little beyond the upper limits of this zone. Generally they occupy the open spaces, natural prairies, clearings, old fields, and pastures, but more than most other jack rabbits they enter the thickets and patches of chaparral of the valley slopes. In most of their Oregon range they are not numerous, although in favorable locations fairly common. On November 26, 1930, nine of their crushed bodies were counted on the road from Eugene to Salem, recent victims of traffic.

General habits.-During the day these big brown hares lie concealed in a shallow form under some weed or tuft of dry grass where their brown colors blend perfectly with the dry vegetation and dark soil. Often depending on their protective coloration, they will lie 
until almost stepped on before bounding out and away in great leaps with a startling display of legs and ears and, to anything but a greyhound, a hopeless display of speed. Toward evening they may be seen hopping about, nibbling at various green plants or loping: along to the néarest clover patch or grainfield for a choice supper, but always alert with sensitive ears erect and constantly changing position and bulging eyes keen for any approaching enemies. While mainly nocturnal they are also active during the evening and morning hours, and at any time of day if disturbed. They see well in bright sunlight, as well as at night, the pupils of their eyes enlarging and contracting to suit the light conditions.

Breeding habits. - The females have normally 6 mammae, 2 pairs of abdominal and 1 pair of pectoral, arranged on 2 long mammary glands on the sides of the belly. The young are usually 2 to 6

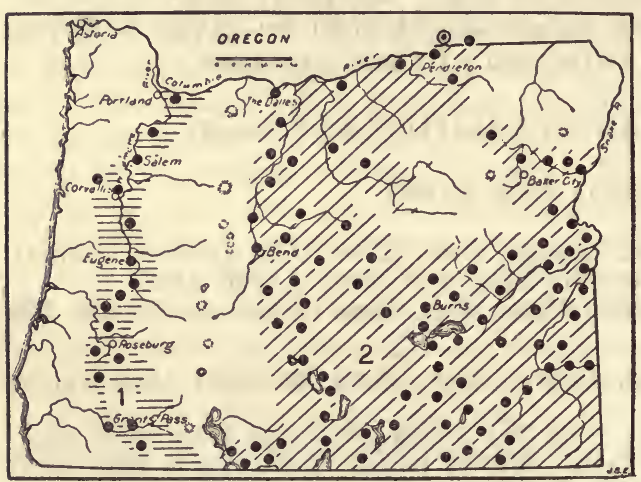

FIgUre 15.-Range of the California and Oregon jack rabbits in Oregon : 1, Lepus californicus californicus; $2, L$. c. wallawalla. Type locality circled.

in number, densely furred when born, with eyes open and incisor teeth well deve loped. Just how or where the young are kept hidden away until old enough to run and take care of themselves seems not to be generally known. The breeding season appears to be very irregular, and in favorable years it is probable that several litters are raised.

Food habits.-Green grass and a great variety of wild plants are eaten by these rabbits, but their favorite food seems to be clover, alfalfa, growing grains, and garden vegetables. In winter, or when other green vegetation is scarce, they eat buds, twigs, and bark, and seem especially fond of the bark of young fruit trees, such as apple, pear, peach, and plum. During the dry time of late summer they are most inclined to visit fields and gardens where succulent food may be obtained.

Economic status.-In Oregon these rabbits seem generally sound and healthy and are good for food and game. They are rarely so numerous as to be of serious importance in destruction of crops or orchards, and in most cases a few simple precautions will prevent losses. Orchards of young trees are most likely to suffer from them in winter or dry weather, but a paper or wire netting or wood veneer wrapped around each tree up about 20 inches will prove ample protection, or the few rabbits that visit the orchard may be hunted down and killed. In a country of abundant vegetation they have little effect on grazing or forage crops, but in grainfields or gardens they may do slight damage at times. There seems to be no record of their increasing to such numbers in Oregon as to become a menace to agriculture as they have at times in California. 


\title{
LEPUS CALIFORNICUS WALLAWALLA MERRIAM
}

\author{
OREGON JACK RABBIT; KA-MOO of the Piute
}

Lepus texianus wallawalla Merriam, Biol. Soc. Wash. Proc. 17:137, 1904.

Type-Collected at Touchet, Wash., by Clark P. Streator, September 18, 1890.

General characters.-Slightly smaller and slenderer than typical californicus; clearer gray with only a slight suffusion of pinky buff, top of tail and back of ears with the same black areas. Winter pelage, upper parts clear iron gray with a pinkish buff suffusion, darkened by tips of long black hairs; top of tail and back of ear tips bright black (pl. 24); lower parts whitish bordered with buffy; tip and under side of tail buffy gray. Summer pelage, paler and clearer gray. Young at hirth densely furred, coarse buffy gray, later paler and finer gray.

Measurements.-Average of adults: Total length, $581 \mathrm{~mm} ;$ tail, 101; hind foot, 135; ear (dry), from notch to tip, 120, upper base to tip, 140. Weight of large individuals given by Dice as approximately 5 to 6 pounds.

Distribution and habitat.-These jack rabbits cover practically all of the arid sagebrush plains of eastern Oregon, from the eastern base of the Cascades to the foothills of the Blue Mountains and into Idaho, and from the Columbia River south into Nevada, mainly in Upper Sonoran Zone; they are so free of foot, however, that zonal boundaries are considerably overstepped. In places they enter the edge of open timber, but their main range is on the sagebrush, rabbitbrush, and greasewood plains (fig. 15).

Abundance.-Their greatest abundance is usually in the wide low valleys where water or moist areas insure at all times a supply of green food. In lesser numbers they are scattered over the widest areas at long distances from water or moist land. They fluctuate in numbers over a series of years and seem to have a more or less regular increase to maximum abundance, then a rather rapid decrease to minimum, and again a long, slow period of increase, covering several years. In the summer of 1896 in central and southern Oregon, they were very common, and in July and August of 1916 on his way across eastern Oregon the writer found them in great abundance from the eastern edge of the State to the Malheur Valley and westward. Apparently they were then at their maximum abundance. They were being destroyed in great numbers and also were suffering heavy mortality from various diseases. Again in 1920 across this same route the writer found them in even greater numbers, apparently again at the crest of their abundance and also rapidly dying off from disease. Their abundance can best be illustrated by the numbers killed. In 1915 Harney County was paying a bounty of 5 cents each for rabbit scalps. Records show that during that year $1,029,182$ scalps were presented for bounty on which $\$ 51,459.10$ was paid out (Oreg. Sportsman, $4(2): 155,1916)$. In 1914 several rabbit drives were organized in the vicinity of Silver Lake, Lake County, and more than 6,000 rabbits were thus destroyed (Oreg. Sportsman, 2 (3): 15, 1914). In the following year, in a rabbit drive in Lake County, 2,000 rabbits were killed (Oreg. Sportsman, $3(6): 128,1915)$. In 1916 about 100 sportsmen of Union County made a rabbit drive near Telocaset and with shotguns killed about 2,000 rabbits, about a thousand of which were picked up and saved. These few cases give some idea of the abundance of the rabbits in the years of plenty. 
In August 1920, on the south side of Malheur Lake, the rabbits were especially abundant along the edges of the lake marshes, where they gathered in from the sagebrush plains, which at that season were exceedingly dry and where little green food was available. Along the edges of this valley they could be seen at all times of the day. Standing at one point in the open just before sundown the writer counted 69 rabbits. In an old barnyard of about an acre where the saltgrass was especially green he counted at one time (about 5 p. m.) 39 rabbits feeding on the grass. Hundreds and thousands could be counted as one walked through the sagebrush or traveled along the roads. These numbers, however, do not apply to the whole of their range, but usually to local areas where they have gathered in from less favorable country. In the immediate Malheur Valley at that time 5 jack rabbits to the acre were estimated, but for their general range not more than 1 to the acre. As they range over nearly half of the State, the total number of these jack rabbits may reach $20,000,000$ or more.

General habits.-Jack rabbits are largely nocturnal, but their eyes adapt themselves to light or darkness, so that they see well both at night and in the daytime. Unless disturbed, they normally sleep during the middle of the day and probably during the middle of the night also. They are especially active throughout the evening from a little before sundown until it is too dark for human eyes to follow them. They also are active early in the morning, especially just before sunrise; but if the nights are cold, they usually sit and warm themselves in the early sunlight before hopping quietly away to their forms under the bushes.

They are a homeless lot, moving where there is food and sleeping where they happen to be at bedtime. Sometimes they merely creep into the shade of a bush and sit there throughout the day unless disturbed, again they dig out a neat form in the shade of a bush or weed, fitting it to their body and smoothing it underneath until sometimes the body is half sunk into the ground. The forms vary from an inch to 2 or 3 inches in depth, and some of them seem to have been used for a considerable time. Others are merely temporarily dug out and apparently never returned to. They serve various purposes. In hot weather they give better contact of the body with the cool earth, and in cold weather provide partial shelter from cold winds. At all times they aid in concealing the rabbit from its numerous enemies.

The rabbits make well-worn and conspicuous trails and runways through the brush or weeds, through meadows, fields, and even over the dusty or sandy surface of the desert valleys. In many places seen from the roads and railway trains, these rabbit trails are a conspicuous feature of the landscape and indicate to some extent the abundance of the animals. While the rabbits are peculiarly solitary in habits, they are often so numerous as to appear social animals. Usually, however, they seem to pay no attention to each other, even where so numerous as to be feeding or sitting close together. Still they appear to be on friendly terms, and it is rare to see any animosity or even playfulness among them. Apparently they have no calls or voices for communication with each other, and rarely make any sound except when captured or wounded, when they sometimes 
utter a shrill squeal or scream in very distressed tones. One night near the writer's cabin pitiful screams were heard repeated in fainter and fainter tones until they died out in the darkness. In the morning one of these rabbits was found just back of the cabin. It had been killed and partially eaten by some small carnivore, apparently a skunk, possibly the little spotted skunk that lived under the cabin. It was probably a sick rabbit.

Usually jack rabbits are ease-loving animals, hopping quietly about in search of dainty grasses, nibbling and chewing contentedly in the meadows, but always on guard with long ears tilted and turned to catch the faintest sound of possible enemies. Their keen eyes are also constantly on duty; and, unless well hidden where there is a chance of escaping observation, they are quick to take alarm and speed away at the first sign of danger. A healthy rabbit in good running condition will easily outdistance any of its native enemies, wolves, foxes, coyotes, and all but the swiftest-running hunting dogs. In eastern Oregon their speed has frequently been tested by automobile speedometer and found to be about 35 miles per hour at a maximum. They are frequently run over in the roads and killed by cars speeding beyond this. When sick or diseased, however, their speed is greatly reduced and they are easily picked up by almost any of their enemies, even becoming so stupid and slow as to become a prey to skunks and badgers.

Breeding habits.-The increase of rabbits is at times very rapid. Again in dry seasons or in times of scarce food it seems to be relatively slow. The normal number of young in a litter is apparently 4 to 6 , but sometimes may be as many as 8 . The mammae are arranged in 6 pairs, 2 each of inguinal, abdominal, and pectoral, on 2 long parallel mammary glands. The females give a copious supply of milk, and the young are nursed until nearly half grown before being turned adrift to shift for themselves. Little is definitely known of the dates of birth and the number of litters raised in a year, as both apparently vary with the character of the season and the food supply. In June, young are found varying from just out of the nest and hopping about, to half grown, but as late as the middle of July young that are not half grown are often seen, indicating an irregular breeding season or that more than one litter is raised during the season. The young are well developed and well furred at birth, but there is very little actual knowledge of their early life history.

Food habits.-While the Oregon jack rabbits are mainly desert animals that depend largely upon growing vegetation, at least during the summer period, apparently green grass forms the greater part of their food, and the youngest, tenderest grass is selected, and most of it is nibbled off before it is large enough for even sheep to graze. On favorite feeding grounds the best grasses are often cut down close to the surface of the ground. In very dry times when the young grass is not growing, the best of the other green grass blades are taken, even the saltgrass and tougher varieties. Tules and a great variety of other green plants along the marsh borders are also eaten. At Malheur Lake they were feeding on pigweeds (three or more species), greasewood, leaves and young twigs, shadscales (Atripleso and Grayia), rabbitbrush (Tetradymia and Chrysothamnus), and even some of the tips of sagebrush (Artemisia), but the stomach con- 
tents and the pellets showed that grass formed the greater bulk of their food in this section. Alfalfa and clover are their favorite foods, for which they will come long distances from the surrounding country. Also any growing grains and most garden vegetables are eagerly sought and eaten when available. In winter their native food consists largely of browse-buds, twigs, and bark, of a great variety of small bushes and young trees-and a deep snow helps by raising them to a fresh and more abundant food supply. They are also very fond of well-cured hay and will gather from all the surrounding country at haystacks, either of meadow grasses or alfalfa, the latter being apparently their favorite winter food. At times they gather in such numbers as to cause heavy losses to unprotected stacks. They often gather along the banks of ditches and edges of ponds and streams, but the writer has never seen them actually drink water, and believes that they are in search of fresh vegetation, from which apparently they get most of their water supply. As much of their food consists of saline plants, they seem not to be attracted to salt, as rabbits are in many other places.

Economic status.-In moderate numbers these jack rabbits would have a value as game animals. Even when abundant they might be utilized to advantage. Usually when not abundant they are in fairly healthy condition and are good food, especially the not-fully-grown young of the year, which may be used in country districts when other game is out of season and meat is scarce. As many of the diseases with which they are troubled are merely local parasites under the skin or in the body cavities, the use of the animals as food need not be seriously affected. As game animals these rabbits afford some sport in hunting either with dogs or as still hunted in the open sagebrush areas. To obtain a jack rabbit running at full speed through the sagebrush requires a degree of skill with a shotgun fairly comparable with wing shooting. With a rifle, they tax the best marksmanship. If their numbers could be kept down to a harmless abundance, free of disease, they could well rank as a food and game animal.

On the other hand, when uncontrolled, they become one of the most serious of farm rodent pests. Especially in the arid part of eastern Oregon their destruction of forage and crops has been a serious handicap in the development of the country. The destruction of grass and other forage plants by the rabbits takes just that much from the support of livestock on the range and in pastures and fields. Like most arid regions the sagebrush plains were originally fully stocked with native animals so that in dry times there was only sufficient food for those present. Later, as the game was killed and the country filled up with sheep, cattle, and horses, the open range generally became overgrazed and the vegetation greatly reduced in abundance. At present on much of the open range there is barely enough food left for the jack rabbits without any stock, and parts of the country have been practically given over to them. In seasons of unusual drought the food supply for the rabbits becomes so reduced that these animals have to seek the valley bottoms for a more permanent supply. Thus their inroads on meadows and pasture land become serious. In the Malheur Valley much of the 

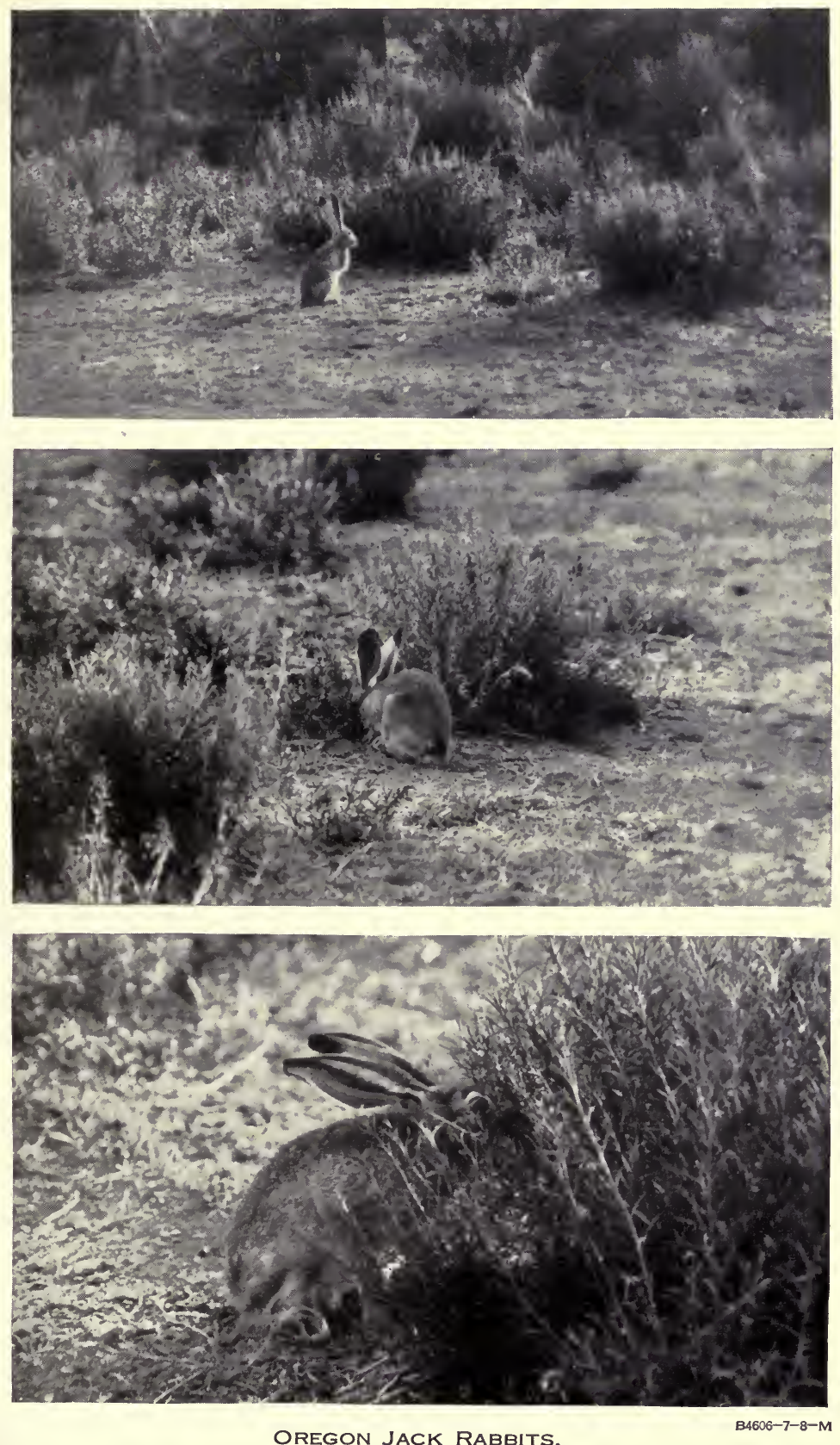

In typical rabbitbrush and sagebrush habitat in eastern Oregon (photographs by O. J. Murie). 

pasture land has been reduced in its carrying capacity for stock 10 to 20 percent by the rabbits.

In the Malheur Valley in August of 1920 on 1 square yard of salt grass meadow 403 rabbit pellets were picked up; most of the summer's accumulation. These were mostly old and dried out until very light, but they weighed $46 \mathrm{~g}$, almost 2 ounces. One hundred fresh pellets that had not been rained on weighed $20 \mathrm{~g}$. These are rounded, slightly flattened bodies about one-half inch in greatest diameter, entirely the undigested particles of plant tissue, mainly the hard bits of grass stems. At 2 ounces to a square yard there would be 605 pounds, or over a quarter of a ton of dry pellets to an acre. Just how much green grass this would represent is at present only a conjecture, but certainly twice the weight of the pellets and probably more. They must at least represent more than their weight in cured hay. In most of the valley bottoms they covered the ground in great abundance, often making a complete layer over the surface where the rabbits had been feeding. Around the bases of the greasebushes they were especially numerous, but they had generally been washed off the bare spots. The amount of vegetation represented by these pellets is enormous. Various estimates of the forage taken by the rabbits range from 20 to 90 percent, but these estimates are for local areas. To be sure they return to the soil some slight value as fertilizer, but nothing to compare with the heavy loss of vegetation.

In fields of alfalfa and grain the depredations of these rabbits are often serious, and small fields in a rabbit-infested valley are sometimes entirely destroyed. Raising crops without rabbitproof fences has been practically abandoned in many of the valleys. Even so-called "rabbitproof fences" are not a complete protection, as some of the rabbits almost invariably find their way under or over these fences, so insistent are they on getting at the choice food supply. A supplementary protection of corral traps in the corners of the fields has in some cases proved effective in capturing the rabbits after they obtain entrance into the fields.

Young orchards of almost any kind of fruit trees are sure to be injured, and in some cases completely destroyed, unless protected by rabbitproof fences or by wrapping each tree with paper, wood veneer, or tin as high as the rabbits can reach.

Natural enemies.-Rabbits are extensively preyed upon by coyotes, foxes, bobcats, badgers, skunks, eagles, hawks, owls, and ravens. Many animals that cannot catch them in a fair race, pounce upon them while hiding in their forms or pick them up when diseased and unable to escape. In the Malheur Valley ravens kill and eat a great many, but only in the last stages of their diseased condition.

Diseases.-During August 1920 at Malheur Lake the rabbits were dying off rapidly from various diseases, almost as many dead as alive being seen along the trails, and many sick individuals so far gone as to be so stupid that they could be approached and picked up by the ears without attempting to escape. Many were watched in their last death struggles and then examined for symptoms. Most of these were heavily infested with Cuterebra larvae, and some had both eyes destroyed or so crowded with these parasites as to be unable to see. The writer counted as many as seven large grubs in the head of one rabbit, and they were often scattered over the 
body just under the skin. Many of the rabbits also had tapeworm larvae in large bunches of transparent fluid with white specks in it under the skin and in the body cavities. Sometimes these bunches were as large as a man's fist, and several of them on one side of the rabbit's body seriously interfered with his speed in running. In some of the individuals the body cavities were largely filled with these cysts or groups of parasitic larvae. Other rabbits were dying apparently from other diseases that were not parasitic. One examined after the death struggle was found to have a greatly enlarged heart filled up with white hard tissue, congested and spotted liver, congested lungs, with many hemorrhagic spots, enlarged and softened kidneys, and dark red muscle. Apparently the most destructive disease, which carries off thousands of them at times of their greatest abundance, is tularemia, a dangerous and often fatal disease when conveyed to the human system through careless handling of infected rabbits. The disease may be conveyed not only by contact of the rabbit blood and body juices with the hands or human skin, but by the bite of ticks and flies that have been in contact with the rabbits. Experiments have shown that the germs of tularemia are not destroyed in lightly cooked or rare meat, but well-cooked rabbit meat may be safely eaten.

One of the Bureau's field collectors, R. H. Becker, after collecting series of specimens of these rabbits in 1916, at the height of an epidemic among them, was taken with all the symptoms of tularemia-infected finger, swollen glands, fever, and general debility, supposed at the time to be from blood poisoning, and necessitating hospital treatment at several periods during the summer. Complete recovery was not until the following year, and since the discovery of this disease there seems little doubt that his case was tularemia.

Protection from rabbits.- Some of the means of defense against the depredations of jack rabbits have been fencing, rabbit drives, organized hunts, shooting, trapping, snaring, and poisoning. Fencing is effective if carefully done and used in connection with permanent traps to capture the rabbits as they go through regular openings or in the fence corners after they have obtained admittance to the enclosure. At Riverside, a Mr. Fairman made a trap under the fence enclosing his haystacks by digging a deep pit and covering it with a tilting cover so the rabbits would fall in as they passed through this only opening in the fence. Sometimes he would take out as many as 15 rabbits from this pit in the mornings and use them to feed his hens, hogs, and dogs. At a ranch on Crooked Creek in the Owyhee River Valley, H. H. Sheldon examined the traps in the corners of a large field enclosed by rabbitproof fence. As fast as rabbits gained admittance they were driven into these corral traps in the corners from which they escaped by a small door into a small corral where they were killed with clubs. At each of these points was a pile of carcasses which well substantiated the ranchman's statement that he had killed 4,000 rabbits during the summer by this method.

Many of the ranchmen have reported shooting over 100 rabbits a day with .22-caliber rifles. Near Crane one ranchman had shot 
240 rabbits in his spare time during July around the edges of his 20 -acre rye field. Drives and hunts have been referred to above.

Poisoning is generally considered the most effective means of combating rabbit pests, but this must be done with great care to avoid the danger of killing domestic stock, especially in winter when the rabbits are most effectively destroyed by poisoned alfalfa around the stacks. Poisoning is best carried on under the directions of experts of the Biological Survey rodent-control force in cooperation with the local county agents.

\section{SYLVILAGUS NUTTALLII NUTTALLII (BACHMAN)}

\section{Oregon Cottontail; Sagebrush Cottontail; Ta-Pu-oo of the Piute}

Lepus muttallii Bachman, Jour. Acad. Nat. Sci. Phila. 7: 345, 1837.

Lepus artemisia Bachman, Jour. Acad. Nat. Sci. Phila. 8: 94, 1839.

Walla Walla, Wash.

Type.-Collected in eastern Oregon (near Vale), by Thomas Nuttall in 1834.

General characters.-Size medium for a cottontail, ears rather long; tail large and cottony below. Winter fur, upper parts light cinnamon gray, darkened by black tipped hairs; sides and rump ashy gray; nape, throat, and legs clear cinnamon; upper edges of ears blackish; lower side of tail, belly, chin, inside of legs, and top of feet white; soles brown ish. Summer coat darker and duller. Young, fur soft and fuzzy, finer and more buffy gray than in adults.

Me as urements.-Total length, $352 \mathrm{~mm}$; tail, 44 ; foot, 90 ; ear (dry), inside, 60 , outside, 70. Weight of adults about 2 pounds. Dice (1926, p. 18) gives 2 males as 768 and $737 \mathrm{~g} ; 4$ females as 868 , 916,923 , and $985 \mathrm{~g}$.

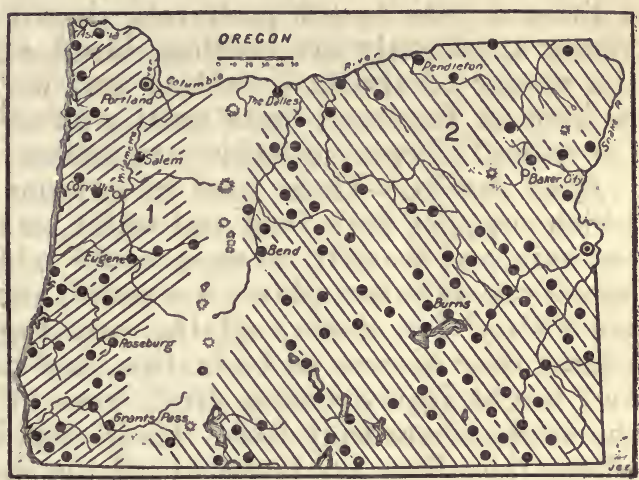

Figure 16.-Range of the brush rabbit and cottontail in Oregon: 1, Sylvilagus bachmani ubericolor; 2, \$. nuttallii nuttallii. Type locality circled.

Distribution and habitat.-These cottontails are generally common over the open sagebrush valley country of Oregon east of the Cascades, mainly in Upper Sonoran Zone, but also in places extending slightly into the open edges of Transition Zone. They evidently also extend into the Rogue River Valley where Luther J. Goldman reported them near Ashland and collected' a half-grown specimen (fig. 16).

Generally they are found near rocks or cliffs where safe cover is afforded from a host of enemies or else in or near thick brush or some protecting cover. The numerous lava flows of east Oregon afford endless chains of rimrock, escarpments, and rocky slopes where they find safe retreats from which to forage out as far as brushy cover will afford protection.

General habits.-These little rabbits are not very fleet and are well aware of their disadvantage before coyotes, foxes, bobcats, or even the common yellow dog. In a country of badgers and skunks 
they do not dare to enter burrows, so their only protection is to keep within easy reach of rocky cover. They are almost as quick and skillful in running over masses of broken lava and dodging into its deep caverns as the little rock cony. Their abundance seems always to depend on the nature of available cover. In the rock slides around the base of a basaltic butte near Riverside they were especially common, and the writer often saw several at a time scampering for their dens. Almost every talus slope at the base of a rimrock shelters a few or many.

Like other rabbits they are largely nocturnal but usually begin their evening activities before sundown, and are fond of sitting in the morning sun to warm up after a chilly night. Often in preference to sitting in a dark corner under the rocks all day they occupy a shaded form under a sagebrush, so close to the rocks that only a few quick leaps are necessary to gain a place of greater safety.

Breeding habits.-Adult females have usually 4 pairs of mammae arranged in 2 pairs of abdominal and 2 of pectoral on 2 long parallel mammary glands. The young, usually 4 to 6 in number, are born in April, May, June, and July; but whether there is more than 1 litter a year is not positively shown by the dates. At birth the young apparently are hairless, blind, and much less developed than the young of the jack rabbits and wood hares. They are said to be kept in fur-lined nests until able to run about. Few details of the animal's breeding habits are known.

Food habits.-Their food in summer is mainly green vegetation, which supplies both food and water, as there are often months without rain and usually no open water within reach. Green grass and numerous succulent plants are eaten, and sometimes fields or gardens are visited for clover, alfalfa, growing grain, or other crops. In winter they browse on buds, tips, and bark of many shrubby plants and might injure young fruit trees or shrubbery planted close to the rocks where they live. Their rounded pellets, scattered thickly where they live, are made up of the indigestible particles of plant fiber, much of which shows bits of grass stems and leaves in summer, and bits of bark and woody tissue in winter.

Economic status.-Generally these little rabbits are free from disease, plump, and in good condition. Occasional Cuterebra, larvae of botflies, are found under the skin but do not necessarily injure the rabbits as food. The young are especially delicious broiled or fried, while even the oldest and largest are good in stews or pot roasts with a bit of bacon or fat pork included. To many campers, ranchers, and newly located settlers, they have an especial importance when other fresh meat is not available. To the community at large their game value is second to that of few other mammals.

Since the discovery of tularemia among rabbits has shown the danger to human beings of this disease, especial care should be exercised in handling any rabbits. Rubber gloves have been recommended to prevent the blood or body juices getting on the hands. Examination of the liver and internal organs of the rabbits will usually show if they are in a healthy condition and suitable for food. Thorough cooking should be ensured to render rabbit meat safe as a food. Well-cooked stew or fricassee is considered safe. 
Locally they may occasionally do slight damage to crops or young trees, but in most cases this can be prevented at no great trouble or expense, and the economic value of the rabbits for game and food should entitle them to a reasonable degree of protection.

\section{SYLVILAGUS BACHMANI UBERICOLOR (MILLER)}

\section{Rejwood Brush Rabitt; Oregon Brush Rabbit}

Lepus bachmani ubericolor Miller, Acad. Nat. Sci. Phila. Proc., p. 383, 1899.

Type.-Collected at Beaverton, Oreg., by A. W. Anthony, February 25, 1890.

General characters. - Small and form compact; tail, ears, and legs short; colors dark gray, without any white. Winter fur, upper parts dark rusty brown, grizzled and clouded with black-tipped outer hairs, fading to clearer brown toward spring; sides more grayish; top of feet, bottom of tail, belly, and chin light gray or buffy gray. Summer coat slightly lighter brownish with less black. Young almost the same as adults but fur more woolly or fuzzy in appearance.

Measurements.-Total length, $310 \mathrm{~mm}$; tail, 28 ; hind foot, 75 ; ear (dry), from notch inside, 52, from upper base to tip, 60. Weight of adults, 1.25 to 2 pounds. Dice gives weight of 3 adult females from Blaine as 768,848 , and $899 \mathrm{~g}$, respectively.

Distribution and habitat.-These dark-colored brush rabbits occupy the humid coast section of Oregon from the Columbia River south to California, and, with the redwoods, south to Monterey Bay (fig. 16). Generally they inhabit the brushy valley country and have not been taken high up even on the coast ranges. A. K. Fisher reported them at Glendale, at about 1,700 feet in the Umpqua Mountains, and they extend up the McKenzie River Valley as far as McKenzie Bridge at 1,800 feet. Their eastern limit of range seems to be the western base of the Cascade Mountains. There are no specimens of $S . b$. ubericolor from the upper Rogue River Valley above Grants Pass and the presence of $S$. nuttallii there would indicate that they do not occupy this more open and arid valley.

They are strictly brush rabbits, being most abundant where dense cover of bushes affords safe retreats, but often found in the grassy or weedy openings within easy reach of the thickets. They rarely enter dense timber, and it may be the timbered slopes of the mountains that keep them at low altitudes. Their short legs render the more open valley spaces unsafe.

General habits.-Trusting in their concealing colors, these little rabbits often sit motionless by the roads or trails and are passed by unnoticed. On damp mornings they are fond of sitting in the roads or trails basking in the early sunshine and drying the dewdrops from their coats, but they soon hop away to some well-concealed form under grass, sedges, weeds, or low bushes, where they sit during most of the daytime. Even more than most cottontails they are mainly nocturnal, and in the daytime are usually seen as frightened from their forms or chased by dogs. In the early evening they may often be seen nibbling the clover leaves and tender grass blades along the edges of open fields and pastures.

Breeding habits.- Very little is known, or on record, of the breeding habits of this group of cottontails, but they have the same number and arrangement of mammae-2 pairs of abdominal and 2 pairs of pectoral-as the other species of the genus and probably similar breeding habits. 
Food habits.-Their food consists mainly of green grass, clovers, and a great variety of tender plants, also of some buds and twigs and barks of bushes. Usually they find abundance of green food at all seasons so that comparatively little browse is eaten.

Economic status.-Generally these little rabbits are plump, sound, and healthy, and as good as any of the group for food. Their value as game and food is not generally appreciated because of the abundance of larger game over most of their range, but as the valleys become more populous they will remain after other game animals are forced out.

The slight damage to crops or bushes that they may occasionally do is insignificant and in most cases easily preventable.

\section{BRACHYLAGUS IDAHOENSIS (MERRIAM)}

\section{Pygmy Rabbit; Sage Rabbit; Tse-gu-0o of the Piute}

Lepus idahoensis Merriam, North Amer. Fauna, No. 5, pp. 75-78, 1891.

Type.-Collected in Pahsimeroi Valley, Idaho, by Vernon Bailey and B. $\mathbf{H}$. Dutcher, September 16, 1890.

General characters. - A very small rabbit with short, wide skull, short ears, short legs, soft fur, large audital bullae, minute, all gray tail; and unique

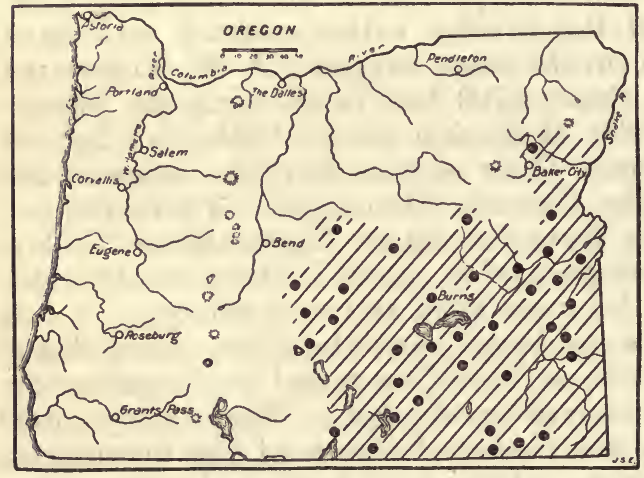

FIGURE 17.-Range of the pygmy rabbit, Brachylagus idahoensis, in eastern Oregon. coloration (pl. 25). Winter pelage in very long, silky fur; upper parts clear lavender, fading to maltese blue, plain drab, or light bluish gray; nape, back of ears, throat, feet, and legs cinnamon buff; belly and chin whitish. Summer coat, upper parts dull, dark gray, with buffy or cinnamon nape; feet and legs cinnamon; throat and tail buffy gray; belly and chin whitish. Young, dull buffy gray with clear buffy feet and nape, and pale buffy lower parts.

Me a surements.-Total length, $300 \mathrm{~mm}$; tail, 18 ; hind foot, 71; ear (dry), inside, 45 ; upper base to tip, 58 . Weight about 1 pound. Dice (1926, p. 28) gives 4 females as weighing $360,384,446$, and $512 \mathrm{~g}$, respectively. Grinnell, Dixon, and Linsdale give average of 12 females as $423 \mathrm{~g}$ and of 6 males as $405 \mathrm{~g}(1930, p$. 554).?

Distribution and habitat.-The pygmy rabbit was first discovered in 1890 near Big Lost River, Idaho, and since then has been traced over a large part of the Great Basin, the sagebrush plains in Idaho, Nevada, Oregon, and southern Washington, and into the edges of California and Montana, in both Upper Sonoran and Transition Zones (fig. 17). In Oregon they extend from the southern foothills

7 Grinnell, Dixon, and Linsdale have placed these pygmy rabbits under the genus Sylvilagus on the ground of showing skeletal characters and certain habits suggesting relationship with the brush rabbits of the west-coast region. On the other hand they almost might be placed in the genus Ochotona, in another family, on the characters of short legs, short ears, much reduced tails, and vocal accomplishments. It seems better, however, not to upset the present familiar use of these names until much more thorough studies of all related groups are made and a permanent system of character values established. 
of the Blue Mountain Plateau and the eastern base of the Cascade Range over about the southeastern quarter of the State, wherever the sagebrush is sufficiently dense to protect them from enemies. They are absent from all open country where there is not an abundance of Artemisia tridentata or Chrysothamnus and hence have numerous wide gaps in their range. Locally they are abundant, but only where conditions are most favorable. Over wide areas they do not occur.

General habits.-The pygmies are burrowing rabbits, living in well-made underground dens ( $\mathrm{pl} .25$ ) of their own construction and usually in family groups, or at least the old and young together. Their burrows are unmistakable in both size and general plan, being generally about 4 inches in diameter and entering the ground on one side of a sturdy sagebrush and coming out on the other. There are always 2 and sometimes 3 or more doorways for entrance and escape, and while a badger is digging down on one side of the bush the rabbit can pop out and escape on the other side. Some old dens have been used for years and have many openings and seem to run deep down. Those dug out have been rather simple, only 1 or 2 feet deep and 6 or 8 feet long. Occasionally a new burrow has not been dug clear through, but these are generally avoided. No trace of nests or food was found, nor anything but enlarged chambers where the rabbits could sit and turn around comfortably.

The burrows are used as refuges by the young, or as last resorts by adults when hard pressed, the rabbits depending more on their trails and regular runways for protection. The trails lead away from the burrows, through and under the densest sagebrush, and at frequent intervals between sturdy trunks where no larger animal can follow. The rabbits are not swift and would be easily caught in the open, but they disappear as if by magic in the shadows of the bushes. A ranch boy at Imperial told the writer that he had caught them on foot when they were forced out of the center of a patch of grain he was mowing, but that was in the down grain and stubble. In their trails, the writer could not catch even the young in a fair race.

Apparently they are more diurnal than most of our rabbits, as they are often seen moving about in the sagebrush at any time of day, although more often jumped out of their shady retreats under the bushes. As many as eight have been collected in an hour, and probably 40 seen in that time. Some were sitting near their doorways, others in shallow forms under the bushes, and others feeding or hopping along the trails.

Dispositions.-Often several sage rabbits are seen near together, but they seem not to notice each other. One half-grown young of the year and a larger one that the writer drove into one burrow and dug out were found close together in the farthest end of a side tunnel. They were evidently not of the same family as the larger one tried to keep the other out, making a scolding quer, quer, quer at it, until finally both were driven down. When kept in a cage together they frequently quarreled, and the second day, while unwatched, the larger one killed the other, tearing the skin off its back and cutting deep into the flesh with the knife-like hind toenails. Later the writer discovered these savage weapons by receiving sev- 
eral long cuts across his hands in trying to hold the rabbit long enough to move him to another cage. After a time the rabbit became quite gentle and would sit in one's lap or crawl under one's coat for a nap.

Voices.-Thomas Large, of Eden, Idaho, has reported these rabbits making a "barking sound like a half-grown chicken" from the mouth of their burrows, probably the same call that was heard at Voltage, Oreg. It is not unlike the sound sometimes made by a cony (Ochotona) from deep down under the rocks and may have the same use as a warning to others.

Breeding habits.-Adult females have the mammae arranged in 5 pairs - 1 inguinal, 2 abdominal, and 2 pectoral-on 2 long mammary glands, and the number of young at a birth are shown by sets of embryos to be usually 5 to 8 . There is some evidence that two litters are raised in a season, but little is known of the actual breeding habits.

Food habits.-At Crane, Oreg., in July 1916, when these little sage rabbits were abundant, many stomachs were examined and all were found filled, mainly with green leaves of sagebrush (Artemisia tridentata). Their flesh also smelled and tasted strongly of this plant. One man said he had seen them up in the tops of the bushes picking sage leaves, but the writer has some doubt of the correctness of this observation. The animal observed may have been a ground squirrel. A few green leaves and stems of rye were found with the sage leaves near a grainfield. In other places and at other seasons, May to August, the writer found their flesh flavored with Artemisia. At Malheur Lake in August 1920 they had been feeding on A'rtemisia and Tetradymia leaves, a little pigweed (Chenopodium), and other little green plants and grasses. In captivity, they ate rolled oats, three species of Chenopodium, Atriplex nuttalli, Sarcobatus, Dondia, dock, nettles, many grasses, including saltgrass, cabbage, cantaloup, and apple parings, the last three the most eagerly.

Their winter food is probably more exclusively sagebrush as at Paradise, Nev., S. E. Piper reported them in February 1908 as " not eaten by the inhabitants because of their strong taste of sage."

Economic status.-Although more prolific than other rabbits, these little fellows have but slight economic importance. While plump, generally healthy, and sometimes excellent eating, their small size and usual flavor of sagebrush render them of little game or food value. On the other hand, their short legs and inability to live away from dense cover keeps them back from clearings and settlements, and almost precludes any serious damage to crops, while their food habits are not of a nature to reduce seriously the grazing capacity of a range. As pets for children they might have especial advantage in the small size, short legs, and gentle dispositions.

\section{Family OCHOTONIDAE: Rock Conies}

\section{OCHOTONA SCHISTICEPS TAYLORI GRINNELL}

Warner Mountain Cony; Taylor's Cony; Pika

Ochotona taylori Grinnell, Biol. Soc. Wash. Proc. 25: 129, 1912.

Type-Collected on Warren Peak (9,000 feet), Warner Mountains, Calif., by W. P. Taylor, July 18, 1910. 

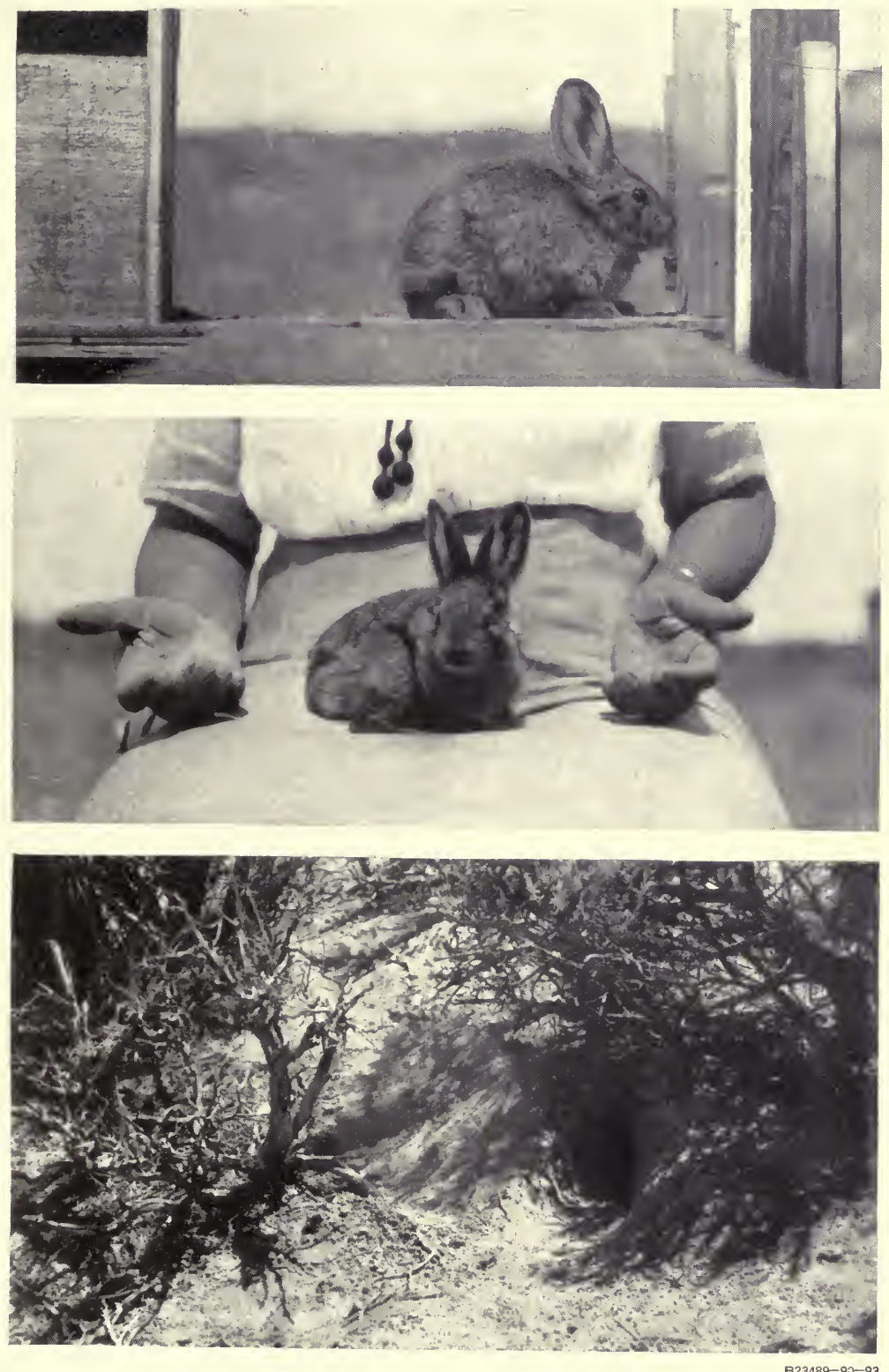

PYgMY RABBIT AND ITS BURROW UNDER SAgEBRUSH, EASTERN OREgon. 

General characters.-This little short-eared, short-legged, almost tailless animal is very similar to Ochotona schisticeps from the northern Sierra Nevada but darker colored. Summer fur, upper parts dark buffy gray, much darkened over back by black-tipped hairs; top of head and face clear dark gray; lower parts buffy or cinnamon; back of ears and soles of hind feet dusky or black; edges of ears and top of feet buffy. Half-grown young similar to adults. Winter fur unknown.

Measurements.-Total length, $180 \mathrm{~mm}$; hind foot, 27; ear (dry), inside 18.

Distribution and habitat.-These dark-colored little rock conies go with the dark-colored lava fields of southeastern Oregon and northeastern California. There are specimens from the type locality, Madeline Plains, and Sugarloaf Mountain in northeastern California, and in Oregon from the northern end of the Warner Mountains, Adel, Jack Lake (20 miles northeast of Adel), Fort Warner Creek, Guano Valley, and the northern end of the Steens Mountains. Others reported from west of Lower Klamath Lake, Drews Creek, and the lava beds near the head of the Owyhee River are undoubtedly of the same form (fig. 18). While at present they seem to be scattered and of irregular occurrence, their distribution probably is far more continuous and connected than we now realize, as their vertical range reaches from 5,000 to 9,000

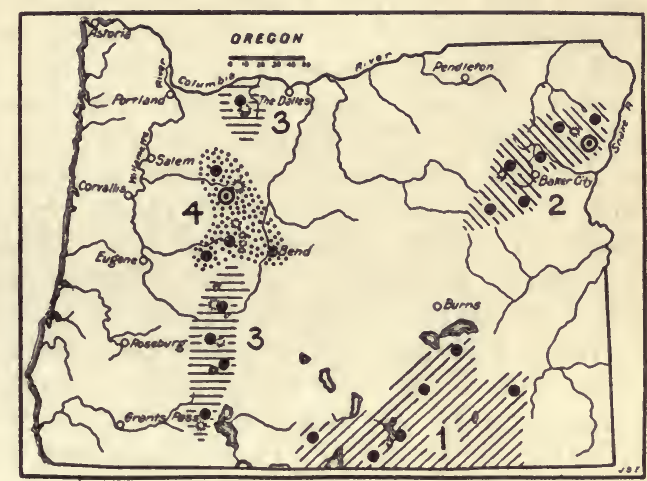

FIgURD 18. - Range of four forms of conies in Oregon : 1 , Ochotona schisticeps taylori; $2, O$. s. jevetti; 3, O. princeps brunnescens; 4, O. fenisex fumosa. Type localities circled.

feet, and they seem to occur wherever there is suitable cover and extent of slide rock, or broken talus.

General habits.-While in no way related to the conies of the Bible, these animals are a "feeble folk" and make their homes in the rocks. Otherwise, they would be eaten up by a host of hungry enemies. Neither cold nor hot weather has terrors for them, for deep in their rocky caverns they can keep cool in the hottest season, and buried under the deep snows of winter they are comfortable and safe even above timber line. On fur-cushioned feet they scamper over the roughest rocks, silent and surefooted, alert and keen of sight and hearing, and quick to dive below at the first sign of danger.

In a way they are social animals, working either together or independently, but always keeping track of each other by occasional calls and warning each other of danger. Their regular note is a nasal squeak, well described as like the bleating of a young lamb, a slow eamp, eamp, repeated at varying intervals and with a force and energy expressive of inquiry, alarm, or excitement. Usually the call is made from the top of a rock or the doorway of a cavern between rocks, but sometimes it is faintly heard from deep below $7209^{\circ}-36-8$ 
the surface, or it may run into a trill of alarm as the animal dives down the nearest crevice.

Breeding habits.-In the Steens Mountains Sheldon reported the mammae of females arranged in 2 pairs, 1 pair of inguinal and 1 of pectoral, on 4 widely separated mammary glands; but in the fully adult females there seem to be generally 1 pair of inguinal and 2 pairs of pectoral. There are no records of number of young for this form, but in others sets of 3 to 5 embryos have been noted. Very little is definitely known of their breeding habits. The half-grown young are out by July and by September are actively helping with the hay gathering.

Food habits.-The food of rock conies is entirely vegetable, green or dry. In summer they eat the tender green grasses and clovers and a host of other plants, including the leaves, flowers, buds, and stems of most of the species growing on or around the rock slide; and in autumn these same plants are cut and carried under the shelter of some large boulder and stacked up green to cure for winter food. The plants dry slowly and keep as green and fresh as the best cured hay, and there is generally an ample supply for a long winter under the deep snow. Sometimes their haystacks are made up mainly of grass, but more often they are a mixture of all the plants available. In the Warner Mountains, the writer recognized in one the leaves and twigs of aspen, Ceanothus velutinus, wild currant, Spiraea, Symphoricarpos, Eriogonum, Phacelia, mint, and grass, but there were many other plants represented. In the Steens Mountains $H$. $H$. Sheldon saw them feeding on the leaves of the bitterbrush, Purshia. They sometimes store even the green twigs of sagebrush.

Economic status.-Few rodents are so entirely harmless as these little fellows or of more fascinating interest where they can be watched and studied. Although good eating they are too small to be classed as game. May they long remain to stack their hay and enliven the rock slides with their cheery squeaks.

\section{OCHOTONA SCHISTICEPS JEWETTI HOWELL}

\section{Blue Mountain Cony; Jewetr's Cony}

Ochotona schisticeps jewetti Howell, Biol. Soc. Wash. Proc. 32: 109, 1919.

Type.-Collected at head of Pine Creek, near Cornucopia, Oreg., by Stanley G. Jewett, September 3, 1915.

General characters.-Darker colored than schisticeps and paler than taylori. Summer pelage, upper parts cinnamon gray, becoming ashy gray across back of neck; ears dark gray or dusky with whitish margins; feet and belly buffy; throat and cheeks cinnamon; chin whitish.

Measurements.-Total length, $182 \mathrm{~mm}$; hind foot, 31; ear (dry), from notch to tip, 18. Weight: Dice gives 2 males as weighing 178 and $180 \mathrm{~g}$, and 2 females as 150 and $182 \mathrm{~g}$, respectively. $(1926, p$. 3.)

Distribution and habitat.-In the higher parts of the Blue Mountains these gray conies occupy the granite and other gray rock slopes from the base of the mountains at 5,000 feet up to above timber line at 10,000 feet. In no place has the writer found them in the darkcolored lava rock with which their colors would not harmonize. 
There are specimens from, Pine Creek, near Cornucopia, near Anthony, Forks of Imnaha, Crescent Peak in the Wallowa Mountains, Aneroid Lake, Bourne, near Austin, Strawberry Butte, and Strawberry Lake. Others reported in the Wallowa and Baker ranges undoubtedly belong to the same species (fig. 18). Extensive masses of broken rock on the mountain slopes, sometimes the talus from high cliffs, sometimes old moraines or washed-out rock beds are their usual homes; but always there must be a safe depth under the surface of the rocky mass to afford cover and protection. Rarely, if ever, are they found beyond the cover of their rocky strongholds.

General habits.-So perfectly do these little gray bodies harmonize with the broken rocks among which they live that they are rarely seen until their familiar call note, a slow nasal eamp, or amp, is squeaked from the rock slide. Even then one's eyes may fail to detect the form until the head is turned, the ears raised for another amp, or some other motion catches the eye. Although gentle and timid they have much curiosity and cannot refrain from peeping at one from one point and then another; and if the observer has patience the animals usually come closer and closer until often good photographs can be obtained. The writer has had them within 4 feet of the camera, but could not change the focal distance before they were gone. Their furry soles make no sound on the rocks and never miss their footing, and but for their shrill little voices few people would ever know of their presence.

Their busiest, and perhaps most noisy season, is during haygathering time late in summer, especially just before a rain or snowstorm, when they work with frantic haste and energy.

Breeding habits.- On the north slope of Strawberry Butte, July 10, 1915, Jewett collected 2 females that contained 4 foetuses each, and on the same date collected a half-grown young. This may mean that 2 litters are raised in a season, but more probably that the breeding season is irregular and that the young of the previous year do not breed so early as do the more fully adult females.

Food habits.-Like all of the family they are great storers, and their winter food is better known than the summer, as the well-cured plants in their stacks of winter hay are as easily recognized as in the herbarium. Usually the plants stored include all of the species within easy reach of the home rock-slide, and a few feet beyond its margins-grasses, small herbaceous plants, weeds, and bushes.

On the side of Crescent Peak, above Aneroid Lake in the Wallowa Mountains, in mid-September 1897, they were found up to 500 feet above timber line, where they were still working about, digging out a few little plants that stuck up through newly fallen snow and adding them to already full larders in dry cavities under the rocks. The previous year up to July 13, on Strawberry Butte, they had not begun to store their winter's hay, and only the sticks and refuse of the previous winter's stacks were to be found. In the early part of August 1915, near Bourne, in the Baker Range, Jewett found them with small stores largely composed of chokeberry leaves. 
OCHOTONA PRINCEPS BRUNNESCENS HOWELL

Brown Cony; Cascade Cony

Ochotona fenisex brunnescens Howell, Biol. Soc. Wash. Proc. 32 : 108, 1919.

Type.-Collected at Keechelus, Wash., by George G. Cantwell, August 23, 1917.

General characters.-Slightly larger than the other Oregon forms, rather uniformly brownish. Summer fur, whole upper parts, except ears, uniform cinnamon brown, slightly darkened over back by black-tipped hairs; ears blackish, margined with white; belly buffy; throat clear cinnamon. Half-grown young very similar to adults in coloration.

Measurements.- Total length, $205 \mathrm{~mm}$; hind foot, 34 ; ear (dry), from notch 20. Weight: Two males, 143 and $152 \mathrm{~g}$; of 2 females 153 and $170 \mathrm{~g}$, respectively, (Dice, 1926, p. 3).

Distribution and habitat.-Extending from British Columbia down through the Cascades of Washington, these brown conies occur on Mount Hood, and in the high part of the range on Mount Thielsen at Crater Lake and Anna Creek, and on and around Mount McLoughlin, mainly above the black lava flows of the lower levels (fig. 18). Generally the rock slides in which they live are of the dark-gray basalts, more or less covered with lichens and mosses, with which their colors harmonize perfectly.

General habits.-Like other species of the group, the brown conies live in the cavities of deep masses of broken rocks, the talus from cliffs and peaks, or the slide rock on steep slopes, where they feed and play and squeak in summer, stack their hay under the rocks in autumn, and live buried under deep snow in winter. In the spring only the sticks and hard parts of their haystacks remain under the rocks with handfuls of little dry, hard, shotlike pellets to mark their feeding and sitting places and runs. In summer their interesting ways are readily observed by all who visit the mountains, but little is known of their winter life deep under the snow and rocks.

\section{OCHOTONA FENISEX FUMOSA HOWELL}

\section{DUSKY CONY}

Och.otona fenisex fumosa Howell, Biol. Soc. Wash. Proc. 32: 109, 1919.

Type.-Collected at Permilia Lake, west base of Mount Jefferson, Oreg., by J. Alden Loring, October 4, 1897.

General characters.-Medium size, and very dark. Whole upper parts dark grayish brown, much darkened over the back by black-tipped hairs, sides more brownish; ears dusky with buffy margins; lower parts and feet buffy or brownish gray; soles of hind feet dusky; darkest in fresh fall pelage. Young similar to adults. 19.

Measurements.-Total length, $200 \mathrm{~mm}$; hind foot, 32 ; ear (dry), from notch,

Distribution and habitat.-This very dark-colored cony is merely a local color-form inhabiting the fresh, dark lava flows of the lower slopes of the Cascade Range south of Mount Hood. There are specimens from the west slope of Mount Jefferson, the Clackamas River, 15 miles above Estacada, a few miles above McKenzie Bridge, and around the base of the Three Sisters Peaks. Those reported by Stanley G. Jewett and R. Bruce Horsfall from near Multnomah 


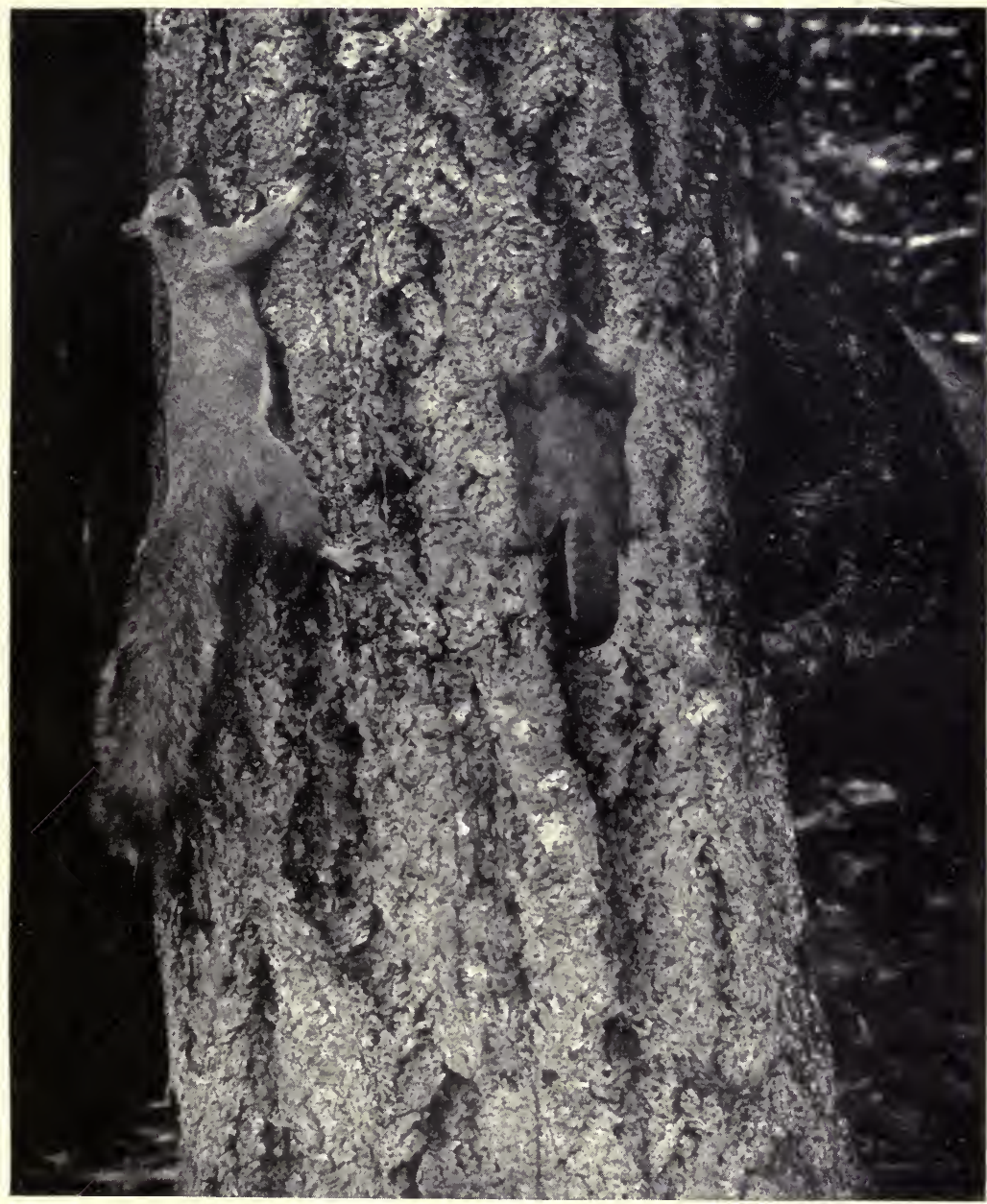

Bi5569

SILVER GRAY SQUIRREL AND FLYING SQUIRREL. 

Falls, and by Luther J. Goldman from the Paulina Mountains, also may be this form (fig. 18).

General habits.-From other forms, the dusky conies differ only in adaptation to their peculiar habitat, dark lava rocks and a humid climate, the two factors that seem to have produced the darkcolored race. They live under and among the rocks, run over the rough surfaces with their well-cushioned feet, or sit still and invisible at their dark doorways. The shade of more or less dense vegetation around the edges of the rock slides where they gather their food conceals and protects them from hungry and keen-eyed enemies.

At the base of the Three Sisters one very small young was taken the middle of July, but generally the young were not yet appearing at the surface of the rocks and the old conies were keeping very quiet.

Their winter stores of food seem to include most of the plants within reach of their homes, but only the left-over refuse has been examined, and the species of plants have not been listed.

A marten caught in a trap set for mountain beaver had its stomach well filled with cony fur and in other places martens have been found hunting them. As a source of marten food conies may have a greater value than some more conspicuous game animals.

\title{
ORDER RODENTIA: GNAWING MAMMALS
}

\author{
Family SCIURIDAE: Squirrels, Chipmunks, and Woodchucks
}

\section{SCIURUS GRISEUS GRISEUS ORD}

Silver Gray Squirrel; Columbian Gray Squirriet; Cudon of the Wasco at The Dalles

Sciurus griseus Ord, Jour. Phys. $87: 152,1818$, from description by Lewis and Clark.

Type locality.-The Dalles, Oreg. No type specimen.

General characters.-Large ( $\mathrm{pl} .26$ ) ; tail very long and plumose; ears rather long, not tufted. Upper parts clear bright gray, much frosted by white-tipped hairs; tail gray above and below, edged and tipped with white beyond an obscure zone of concealed black; top of feet dark gray; back of ears rusty brown; whole lower parts, except tail, white. Color essentially the same at all seasons; fur short and harsh in summer, full and soft in winter pelage.

Measurements. - Total length, $570 \mathrm{~mm}$; tail, 270; hind foot, 82; ear (dry), from notch, 28. Weight: Grinnell and Storer give the weight as 26 to 32 ounces. $(1924, p .196$.

Distribution and habitat.-These great tree squirrels occupy the Transition Zone forests of western Oregon on both sides of the Cascade Range, and extend northward to Puget Sound and southward through the Sierra Nevada of California (fig. 19). In places they reach the coast but are more common in the interior valleys with the oaks, maples, yellow pines, and sugar pines.

General habits.- Usually much hunted and among the shyest of wild game, these handsome squirrels are rarely seen except where given special protection, which they are quick to recognize and to which they respond with full confidence. In a few Oregon towns they occupy the much-frequented parks and become as fearless as 
any other park squirrels. In the forest the most stealthy methods and much patience are necessary to get sight of one, and then, when the observer is discovered, the squirrels vanish as if by magic on the opposite sides of trees and branches, where they hide with such skill and persistency that rarely can one be seen again unless two people work together on opposite sides of the tree.

Their homes are generally in hollow trees where these can be found, but large leaf and stick houses are also built in the forks or branches of trees, well-matted structures sometimes as large as a half-bushel measure with thick walls and a dry, warm nest cavity in the center. These are especially the summer nests, but in some cases evidently are used also through the winter.

The squirrels are usually silent and shy, but where permanently protected or far back in the forest where rarely hunted, an occa-

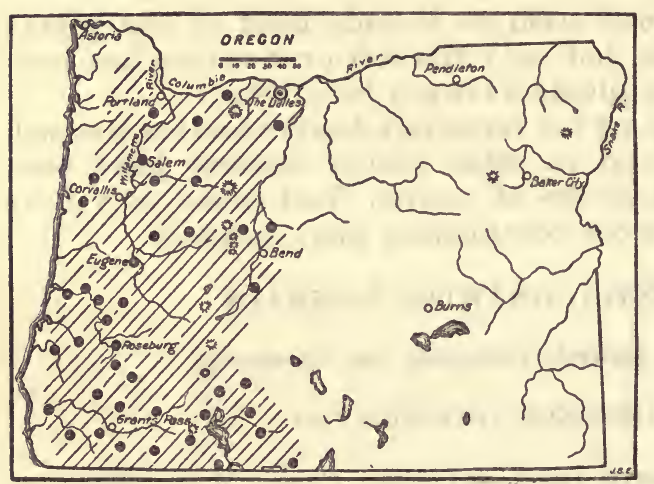

FIGURE 19.-Range of Oregon gray squirrel, Sciurus griseus griseus, in Oregon. Type locality circled. sional husky bark is he a rd, not unlike the voice of the eastern gray squirrel if this were more than doubled in volume, but slower and hoarser, a soft chuff, chuff, chuff, seem ingly both a call and a warning signal of danger. The writer has heard it only in late summer or autumn when the nearly full-grown young were out feeding in the treetops.

Breeding habits.-The adult fem a les have 4 pairs of mammae-1 inguinal, 2 abdominal, and 1 pectoral-and the usual number of young in a litter in apparently 4. The main mating season seems to be in January and February, as indicated by a note from C. H. Townsend in Shasta County, Calif., where on January 13, 1883, he collected 5 males. The males, he said, gather in groups in January and February, and frequently he shot half a dozen males out of a single tree $(188 \%, p .174)$. This is the same as the gray squirrel custom in the mating time. On March 25, 1855, at Fort Dalles, Suckley records a "female having young was seen" (1860, p. 95). In California a female containing 2 small embryos was taken April 27 , by Frank Stephens, and another with 2 embryos on June 2, by A. S. Bunnell. Another collected by J. F. Ferry in Humboldt County, Calif., October 30, was nursing young. These early and late dates indicate 2 litters a year while the small number of 2 embryos only mean the first litters of last year's young, which are irregular in their time of breeding. Adult squirrels are usually very regular in their dates of breeding, and with the eastern gray squirrel the question of a second litter seems to depend entirely on the food supply.

Food habits.-The presence of the squirrels can often be told by the remains of their meals, the scales of large pine cones scattered over the ground under the feeding trees or the scattered shells 
of acorns and jackets of Umbellularia nuts on the ground. The large cones of the sugar pine furnish one of their favorite foods, and as soon as the seeds are full grown the cones are cut off and let drop to the ground or carried to safe perches on branches of the tall trees, where the scales are cut away and the seeds eaten. No smaller squirrel could handle these heavy cones, which are often over a foot long. The cones of yellow pine and Jeffrey pine are eaten in the same way, and in places the cones of Douglas fir furnish some food. Acorns of any available species of oak are a standard food of these squirrels, and the large nuts of the Oregon myrtle, Umbellutaria californica, when abundant, are extensively eaten. The seeds of many other trees and shrubs are probably eaten, and in places there have been reports of these squirrels eating bark from the branches of trees-evidently cases of starvation when other food supply had failed.

Economic status.-The recent development of nut culture as an extensive industry in the Willamette Valley has placed these squirrels on the list of local rodent pests-and quite naturally. A wellladen grove of English walnuts or giant filberts soon draws the squirrels from the neighboring pine groves in considerable numbers and in many cases bushels of the nuts are eaten or carried away to be stored for winter use. In some cases a small grove of nut trees is entirely stripped of fruit before it is ripe enough for harvest. Naturally the nut growers use every possible means of protecting their crops, but shooting, trapping, and poisoning have not proved satisfactory and the Biological Survey has been appealed to for help. At last accounts, trapping the squirrels alive in simple wire cage traps seems the most promising method of control.

Probably no squirrels excel these in value as game and food, and during the early settlement and development of the State they have played an important part, which for generations to come will continue, if they are given the protection they merit. Another value rated by many above that of game is the opportunity for everyone to see these beautiful creatures unafraid and loping with plumy tails over the grass or frisking in the trees of fully protected woods and parks, or even coming to take nuts from the hands of delighted children. At Ashland, the tameness of these great squirrels makes them an attractive feature of the beautiful city park.

\section{SCIURUS DOUGLASII DOUGLASII BACHMAN}

Douglas's Squirrel; Orange-betllied Chickaree; Ap-Poe-Poe of the Chinook (J. K. T.)

Sciurus douglasii Bachman, Zool. Soc. London, Proc., p. 99, 1838.

Type locality.-Near the mouth of the Columbia River.

General characters.- Small as in the red-squirrel group, ears short and slightly tufted, tail bushy, wide, and flattened. Summer pelage, upper parts dark brownish gray from mixture of orange and black-tipped hair; ear tufts and stripe on each side of the body black; middle of tail reddish brown, edged and tipped with orange beyond a dusky submarginal zone, and a broad subterminal area of black; whole lower parts and top of feet dark rich orange. Winter pelage, back and top of tail dark rufous; sides olive gray; lower parts orange obscured by dusky hairs; side stripes indistinct; top of feet dark gray. 
Half-grown young just out of the nest similar to summer adults, but more olive gray above and paler orange below.

Measurements.-Adult of about average size: Total length, $310 \mathrm{~mm}$; tail, 125 ; foot, 50 ; ear (dry), 20.

Distribution and habitat.-This darkest and most richly colored of the small tree squirrels occupies the humid coast region of Oregon, and north through the coast region of Washington (fig. 20). Specimens from as far south as the mouth of the Rogue River are typical of the species, but in the Umpqua and Willamette Valleys they show a tendency to paler coloration and a gradation toward the form occupying the Cascade Mountains. While not usually found in the open valley country, they are abundant throughout the heavily forested coast ranges of the State.

General habits.-Like all of the chickarees, these are bright, active, and at times noisy little denizens of the forest. From their homes in hollow trees or their leafy nests among the branches they range

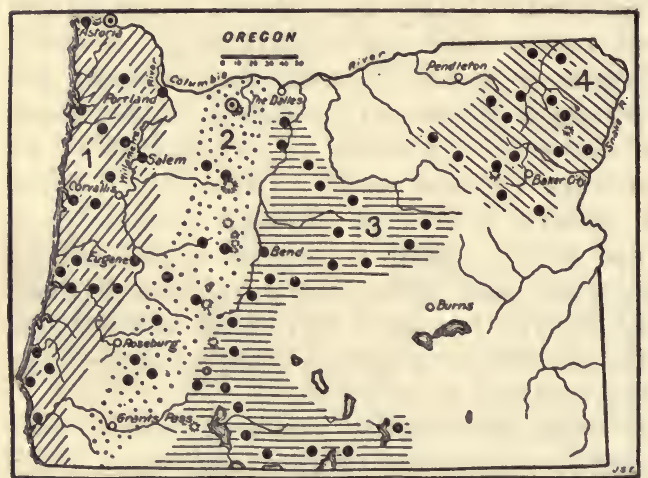

FIGURD 20.--Range of four forms of the spruce squirrels or chickarees in Oregon: 1 , Sciurus douglasii douglasii: 2 , S. d. cascadensis; 3, S. d. albolimbatus; 4 , s. hudsonicus richardsoni. Type localities circled. through the woods, each squirrel or each family claiming its own territory, and usually defending its premises from intrusion in a vigorous manner. At times they come out along the rail fences or travel from tree to tree a short distance from the timber, but usually they keep within easy reach of trees or large bushes, which are their only protection against numerous enemies. As a ch i ckaree sits on the branches of a tree eating a nut or shelling the seeds from a cone, its eyes and ears are keenly alert for danger or trespassers. If a squirrel of another family approaches, it is vigorously chased away, and often far beyond the boundary that could rightfully be claimed. If a larger enemy appears, a vigorous scolding or long chattering announces to other squirrels a possible danger. As one passes through the quiet forest he will occasionally hear a low chirrrr from the treetops, which is neither a warning of danger nor a complaint of aggression, but seems more of a conversational nature. At certain times in the year, especially in the spring and before the young are out of the nest, the animals are mainly silent and are rarely seen, but as soon as the young are out, they are noisy and active for the rest of the summer, and especially so during the storing season of autumn.

Breeding habits.-The young of the Douglas's squirrel, usually 4, but sometimes as many as 6 or 7 are brought forth in warm nests apparently at irregular times during the summer. At Portland, Fisher collected a female on June 24, 1897, which contained 7 small embryos, and at Tillamook, on June 30, 1897, he took another which contained 4 large embryos. There are other records of embryos 
later in the season and of females nursing young well into the fall. The females have 4 pairs of mammae- 1 inguinal, 2 abdominal, and 1 pectoral-and while 4 seems to be the usual number of young, it is probable that $S$ is the maximum number. The young are blind and naked at birth and remain in the nest for a considerable time. When they first come out of the hollow trees or leafy nests, they are usually nearly half grown, and are soon able to climb about and take care of themselves. They remain together as a family, however, until practically full grown, the mother caring for and protecting them as long as they are in need of her help. The young apparently, in some cases at least, keep together during the first winter, storing and feeding from the common supply about their home range. A hollow tree, with entrance at the top, side, or bottom, is a favorite nest site for these squirrels, especially for raising the young. It has many advantages in safety and possibly warmth; but nests built by the squirrels of twigs and leaves and lined with moss, in the branches of evergreens, are more often used in this region of sound timber, where there are few hollow trees. These leaf and moss nests are well matted and woven together in a great ball securely anchored among the branches and entered by 1 or sometimes 2 doors at the side. The central cavity is well lined with soft moss or bark fiber, and the thick walls and roof are impervious to wind and rain. Where hollow trees are not available, these nests are always used.

Food habits.-A great part of the food of these squirrels consists of the rich, oily seeds of the conifers, the Douglas fir, Sitka spruce, hemlocks, balsams, and pines. As soon as the cones are full grown and the seeds within are half ripe in summer, they are cut off and carried to branches or regular feeding places, where the scales are clipped off and the seeds eaten out from underneath. As the cones ripen in autumn, great numbers are cut from the trees and stored in shallow pits in the ground or under logs and roots of trees. These usually furnish much of the food for the following winter and even later. Where hazel and oak occur, the nuts and acorns are eagerly sought for food. A great variety of seeds, berries, and mushrooms are also eaten. At times even buds and bark serve to tide over a period of scarcity of more acceptable foods. McLellan records seeing one of these squirrels carry a large apple in its mouth, and at another time he found them eating the red and black blueberries. Fisher found them drinking the sap where red-breasted sapsuckers had punctured willow trees. They are actire throughout the year and seem usually to have an abundant food supply available.

Economic status. - In rare cases one, or a family, of these squirrels may do some slight mischief by collecting the nuts or fruit or grain not intended for their use. There are few complaints of damage by them, however, and in most cases it is necessary only to shoot or trap a few individuals to prevent further losses. Although sometimes considered edible, they are too small to be valuable as game. Their food is so largely the seeds of conifers that their flesh often has an unpleasant flavor of pitch or turpentine. Their greatest value, however, is associated with their cheery note and their bright interesting ways as they scamper and sing in the forest. Without them the forest would lose one of its greatest charms. 


\section{SCIURUS DOUGLASII CASCADENSIS ALLEN}

\section{Cascade Squirrex; Yellow-bellied Chickaree}

Sciurus douglasii cascadensis Allen, Amer. Mus. Nat. Hist. Bull. 10: 277, 1898.

Type-Collected on Mount Hood (near timber line on west slope), Oreg.

General characters.-Similar to douglasii, but lower parts yellow instead of orange, and long tail hairs tipped with white instead of orange. Summer pelage, upper parts dark brownish gray, with black stripe along each side and black ear tufts; tail dark gray, rusty above, with white edgings and tip beyond obscure dusky zone and subterminal area of black; lower parts and feet pale orange or yellow. Winter pelage, often worn through June; upper parts dark gray with rusty back and top of tail, and obscure black side stripes; tail much flattened and edged with white; top of feet gray; lower parts salmon or buffy, clouded with gray or dusky.

Measurements of type.-Total length, $320 \mathrm{~mm}$; tail, 130; foot, 50 ; ear, 20.

Distribution and habitat.-These Cascade squirrels inhabit the whole Cascade Range from Mount Hood south through the Umpqua, Rogue River, Siskiyou, and Trinity Mountains, and down the coast ranges of northwest California, grading into douglasii on the west and albolimbatus on the east of the Cascades (fig. 20). They occupy the pine, spruce, and hemlock forests of practically the whole Cascade Range in Oregon, but as Allen pointed out, they show every intergradation between the dark and rich douglasii and the paler albolimbatus, and a definite border to their range cannot be satisfactorily given. They range from near timber line down to the edges of the valleys.

General habits. - These, like all of their group, are tree squirrels, and are never found far from the edges of the forest, although often coming to the ground and scampering over logs and rocks and along fences from tree to tree, or from grove to grove. Their homes are in hollow trees, or where these are not available, in nests of leaves, twigs, and moss, which they construct among the branches of evergreens. During the spring they are silent and shy, and therefore inconspicuous; but late in June after the young are out of the nests, the squirrels become noisy and are much in evidence. During the busy season of autumn, while storing their winter supply of food, they are most energetic and vigorous in their work, putting in long days, and often scolding and fighting to hold their feeding and storing grounds.

Breeding habits.-The 4 to 6 or 7 young are born in early summer and in July begin to leave the nests as half-grown squirrels. It seems doubtful if more than one litter of young is raised in a season, as the time is all too short for raising the litter and gather-

8 The writer finds no character on which to separate this form from Sciurus douglasii mollipilosus Aud. and Bach., 1841, from the coast section of northern California. Rather than use that name, however, which is likely to fall before the older name S. lanuginosus Bachman, 1838, when material is obtained from the type locality, Fort McLaughlin, on Hunter I'sland, north of Vancouver Island, in British Columbia the Oregon name cascadensis is used provisionally untll this group of squirrels can be thoroughly revised in the light of the great amount of material at present available. The type of lanuginosus in the Academy of Natural Sciences in Philadelphia is an albino and gives no clue to specific characters, and the status of the name will not be known until specimens are collected at the type locality. Rather than add further confusion by any provisional change of name, Allen is here followed in his use of cascadensis for the squirrel of the Cascade Mountains in Oregon. 
ing the necessary stores of winter food, especially in the mountains where the summers are short and the winters long.

Food habits.-Most of the food of these squirrels consists of the seeds of conifers of whatever species fall within their range. If the cones of one species fail, there is usually an abundance on some other pine, spruce, or hemlock, and the squirrels gather where the food is most abundant. As soon as the seeds are ripe, the cones are cut from the trees and great quantities buried underground, or in cavities of rocks, under logs or roots of trees, where they can be found during the winter no matter how deep the snow. As soon as the snow falls, the squirrels make long tunnels over the surface of the ground, and as the snow hardens these are kept open and in use throughout the winter. Fresh snow piling up deeper and deeper is a help rather than a hindrance to their winter activities. High up in the mountains, where the snow often reaches a depth of 10 or 15 feet, the squirrels are as active during the winter as lower down where little snow has accumulated, and are as healthy and happy as in the spring. Little heaps of cone scales show where the squirrels have been in the habit of eating their meals-on some low branches of trees or under the snow in comfortable quarters well protected from cold and wind, and safe from enemies. Sometimes a bushel or more of freshly cut cone scales are found in a heap. Under some trees the accumulation of scales dropped year after year reaches a depth of several feet in a mass of many bushels. Other seeds, nuts, fruits, berries, mushrooms, and insects are eaten to a more or less extent, but the cones furnish most of the food.

Economic status.-Complaints of mischief by these squirrels are rarely heard. Many of the ranchers, campers, and foresters in the mountains appreciate their cheerful notes and bright, interesting ways. To the forester they are even a great help in furnishing the tree seeds necessary for reforesting, as a share of the cones they have stored are often taken and always are found to contain sound seeds. It is also evident that while the squirrels consume for food vast quantities of tree seeds, great numbers of the buried cones are never claimed but remain just underneath the surface of the ground where they may grow and help to replenish the open spaces in the forest. These little squirrels might well be considered the original foresters of the mountain slopes.

\section{SCIURUS DOUGLASII ALBOLIMBATUS ALLEN}

\section{Sterra Chickaree; GowaCK of the Klamath (C. H. M.)}

Sciurus hudsonius californicus Allen, Amer. Mus. Nat. Hist. Bull. 3:165, 1890. Preoccupied.

Sciurus douglasii albolimbatus Allen, Amer. Mus. Nat. Hist. Bull. 10: 453, 1898.

Type-Collected in Blue Canyon, Placer County, Calif., by J. A. Allen, October 13, 1886.

General characters.-Slightly larger than douglasii with pale yellowish or white belly and white frosted tail. Summer pelage, upper parts dark brownish gray, with black ear tufts and stripe along each side; tail dark gray, bordered and tipped with pure white beyond dusky zone and subterminal black area; lower parts pale yellowish or buffy or almost white, shading into yellow on sides of legs and top of feet. Winter pelage, back rusty; sides 
gray, with black stripe obscured; tail more frosted along sides and at tip; lower parts white; sides of feet buffy.

Measurements.-Total length, $340 \mathrm{~mm}$; tail, 142; foot, 53; ear (dry), 21. Weight: 218 to $299 \mathrm{~g}$ (73/4 to $81 / 4$ ounces). (Grinnell and Storer, 1924, p. 203.)

Distribution and habitat.-This chickaree extends throughout the whole length of the Sierra Nevada Mountains, and northward to Mount Shasta, and the Klamath and Warner Mountain country in Oregon, and east of the Cascades to the Paulina, Maury, and southern part of the Blue Mountains south of the John Day River (fig. 20). Along the east base of the Cascades they grade into cascadensis, but in the Blue Mountains they are sharply distinct from Sciurus hudsonicus richardsoni, which occurs north of the upper John Day River. They occupy both Canadian and Transition Zones and in places extend into the Hudsonian where forest trees are sufficiently large and numerous to furnish homes and food. Their greatest abundance is in the spruce, fir, and lodgepole pine forests, where conditions seem most favorable for protection and an ample food supply.

General habits.-These mountain squirrels differ in habits from other forms of the douglasii group only in adaptation to higher country and more arid climate. They occupy the coniferous forests and climb to the tops of the tallest trees, even the giant sequoias, from which they cut the cones to be gathered and stored for food. At times they are shy and silent and rarely seen, but again noisy and conspicuous. Nelson says that in districts where they are common they may be heard at all hours of the day, but especially early in the morning. Their common note is a trilling or bubbling noise which is liquid and musical in effect and difficult to locate. It it more like the song of some strange bird than the note of a mammal.

John Muir has written one of his most delightful chapters on this little squirrel but makes the mistake of calling it the Douglas squirrel, of which it is a well-marked subspecies (mountains of California).

Breeding habits.-Apparently the young of the Sierra chickaree are not produced until some time in June, as they usually do not appear out of the nests until July. The usual 4 to 6 young are raised in the trunks of hollow trees, or the leafy nests among the branches. As soon as the young are out of the nests the mother squirrels are very solicitous and alert, watching for enemies and scolding any intruders, warning the young and sending them scurrying to cover at the first warning of real or imaginary danger.

F ood habits.-Like others of the group these squirrels live in great part on the rich oily seeds of conifers, gathered from the hemlocks, spruces, firs, Douglas spruce, lodgepole, yellow, and Jeffrey pines, and even the huge cones of the sugar pine, and the little round cones of the giant sequoias. They often store bushels of cones in hollows and cavities, or tuck them under logs and roots-enough food to last nearly or quite the year around. They are great storers and in a good cone year are sure of ample food for the winter, if they are not robbed. They also gather acorns from some of the oaks within their range and such other nuts and seeds as are available. Fruit, berries, and mushrooms are also eaten and possibly a wider range of insect and animal food than is generally known. When other food is scarce or locked up by snow and ice, these squirrels can always eke out a living on buds and bark cut from twigs of trees or bushes. The 
tips of branches are cut off, the bark eaten back of the terminal buds or tufts of leaves, and the leaves and peeled sticks dropped to the ground. At times under the pines, especially the lodgepole, the snow or ground will be found carpeted with branch tips thrown down by the squirrels, but the trees seem not to suffer from this occasional pruning.

Economic status.-A closer study of habits is necessary before the economic status of these squirrels, especially in the semiarid forests, is fully determined. Their consumption of tree seeds may well be offset by their habit of planting cones for food, and usually leaving some where they may grow and spread the forest. Their accumulations of cones, stored for food, are often levied upon by the forest rangers, to whom the gathering of seeds is an official duty. The squirrels thus win the good will of the Forest Service, but their greatest value is in the life and interest and music with which they fill the forests.

\section{SCIURUS HUDSONICUS RICHARDSONI BACHMAN}

\section{Richardson's Squirret; Black-TaIled Squirret}

Sciurus richardsoni Bachman, Zool. Society London, Proc., p. 100, 1838.

Type.-Collected at head of Big Lost River, Idaho.

General characters.-This is a very dark form of the red squirrel group, with always white belly and mainly black tail. Summer coat, upper parts dark rusty gray, ear tufts and legs rusty; stripe along side black; tail mainly clear black, dark gray centrally toward base; lower parts white. Winter coat, back and top of tail deep rufous; sides rusty gray with trace of black stripe; ear tufts black; long brush and sides of tail black, sometimes slightly edged with rusty; feet gray; lower parts white or slightly grizzled.

Measurements.-Total length, $340 \mathrm{~mm}$; tail, 130; foot, 52; ear (dry), 22.

Distribution and habitat.-From the mountains of Idaho these squirrels extend across into the Blue Mountains of Oregon where they occupy the pine and spruce forests north of the John Day River Valley, almost if not quite meeting the range of albotimbatus, but showing no trace of intergradation (fig. 20). They occupy the forests from timber line down through the yellow pines, at times even coming down to the willows and cottonwoods along the stream valleys. Their greatest abundance, however, seems to be in the spruces and lodgepole pines of Canadian Zone.

General habits.-No marked peculiarities of habits distinguish these Rocky Mountain squirrels from the yellow-bellied forms of western Oregon, and one cannot be sure of a difference in the voices of any of the whole red-squirrel group. They are all the same bright, active, little forest singers, at times bold and impudent, and again shy and wary. Their long $c h r-r-r-r-r-r-r-r-r$, whether given from the top of a spruce tree on a mild morning in September, or from a snowy branch above the deep crusts in January, is always a happy song, but with many shades of pitch and tone that probably mean more to the squirrel tribe than to our coarser ears. A great variety of barking and scolding, chattering, and talking notes may be mere expression of feeling, but more probably have definite meanings to themselves.

The old squirrels are mainly solitary in habits, each occupying and vigorously defending the section of forest where his nest, food, 
and winter stores are located, but calling and answering neighbor squirrels from their equally well-protected areas on all sides. Quarrels and fights over boundaries are not uncommon. These differences, though, are generally settled before the winter stores are completed, and rights once established are generally respected.

Breeding habits.-The 4 to 6 young in a litter of these squirrels are usually born in June but are rarely seen out of the nests until a month later. At birth they are naked, blind, and helpless, but in the soft, warm lining of hollow trunks, or the big grass-ball nests in the branches, they are cared for by devoted mothers until, as nearly half-grown, well-furred, and bushy-tailed little squirrels, they are first allowed to come out of the nests. Even then they continue to nurse until they have learned to find and eat the flowers and green seeds of trees and plants, and make an independent living for themselves. The old squirrels furnish a copious supply of milk from the 4 pairs of mammae, arranged in rows on the 2 long parallel and continuous mammary glands, extending under the skin from the pectoral to the inguinal region. There seems no evidence that more than 1 litter of young is ever raised in a season.

Food habits.-Most of the food of these forest-dwelling squirrels consists of the seeds of conifers, from the little seeds of spruce and hemlock and fir to the larger nutlets of some of the pines. Other seeds, buds, bark, and mushrooms are eaten at times. When the cone crop fails, the squirrels are sometimes forced to seek other feeding grounds. In April 1911, H. E. Anthony in a letter from Ironside, Oreg., wrote that Richardson's squirrels had come down the previous fall into the valley where they remained all winter among the ranches, raiding grain bins and root cellars. The cone crop in the mountains was almost or quite a failure, and no doubt this was the cause of the migration to the valley. This was the first time in 10 or 15 years, he said, that it had occurred. Again in September 1913 , he wrote that the squirrels were again working down, several being seen 6 or 7 miles from the timber, following the lines of willows along the creeks. He went up into the pines and found again that there were practically no cones. These notes have an important bearing on the often-reported migratory habits of squirrels.

In a good cone year the bushels of cones stored under the trees, under logs, in hollow places in the ground, or in the old heaps of cone scales, usually last well through the winter, though not beyond the coming of the next cone crop. A failure of this food supply, therefore, is a serious matter to the squirrels.

Economio status.-On account of their small size these squirrels are rarely used as game, but in absence of any other food, one will make a substantial meal, roasted over the coals and eaten without salt. Indirectly they have a value as food for marten, fisher, and other fur-bearing animals of the forest, but like many of our birds their highest value is in the element of life, music, and beauty that render our forests attractive. Their assistance to the foresters in gathering cones generally wins them the good will and protection that they well deserve.

Their value as seed planters in forest extension is generally recognized as far outbalancing their consumption of seeds for food. Many 
of the cones are buried beyond the shadows of the tree, and often an accident leaves these cones and seeds to grow during the next summer.

\section{EUTAMIAS TOWNSENDII TOWSENDII (BACHMAN)}

Townsend's ChIPMUNK; QUIS-QUis of the Chinook (J. K. T.)

Tamias townsendii Bachman, Jour. Acad. Nat. Sci. Phila. 8: 68, 1839.

Tamias townsendi littoralis Elliot, Field Columbian Mus. Pub. Zool. 3 : 153, 1903, from Marshfield, Oreg.

Type.-Collected along Lower Columbia River (probably lower mouth of Willamette) about 25 miles below Portland, Oreg., by J. K. Townsend in 1834.

General characters.-Large for a chipmunk; tail long and bushy; ears large; fur long and lax; colors dull and dark. Summer pelage, back with 3 black and 2 outer brown stripes, and 4 yellow is h stripes between; sides of head with 2 yellowish and 3 brown stripes; sides and most of upper parts and feet snuff brown; tail bright rusty brown below, black above and on tip and margins, above frosted with buffy tipped

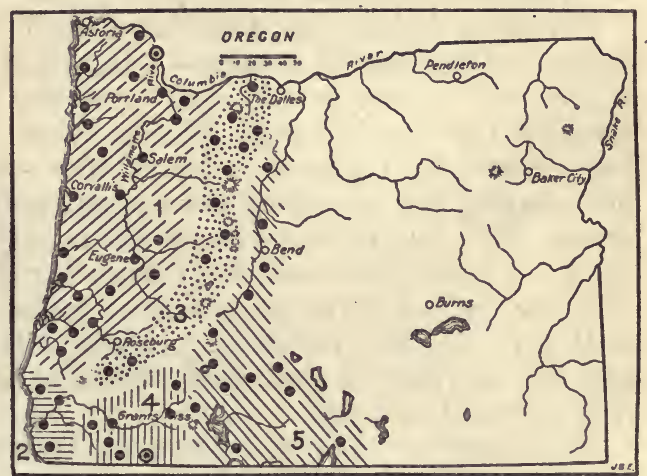

Figure 21.-Range of five chipmunks in Oregon: 1 , Eutamias townsendii townsendii; $2, E$. $t$. ochrogenys; $3, E$. $t$. cooperi; $4, E$. $t$. siskiyou; $5, E . t$. senex. Type localities circled.

hairs; a patch back of each ear, and throat and belly, white. Winter pelage slightly darker above with stronger markings of black and white. Young similar to adults in summer.

Measurements.-Average of several adults: Total length, $258 \mathrm{~mm}$; tail, 115; foot, 38; ear (dry), 16.

Distribution and habitat.-These large dark chipmunks occupy the coast region west of the Cascade Mountains from southern British Columbia south to Myrtle Point, Oreg., including the Coast Ranges and the Willamette and lower Umpqua River Valleys, where they occupy the forests and dense thickets (fig. 21).

General habits.-Chipmunks of this group have strangely marked habits, which go well with their large size, long plumy tails, and soft fur. They are quiet and gentle in actions, keeping much in the shadows and under the bushes out of sight. Often they would pass unnoticed but for their birdlike voices, musically whistled chippers of alarm, or the soft far-away chuck, chuck, chuck of contentment given from a branch, stump, or log, as the plumy tail is slowly waved from side to side. Though the nervous scurry characteristic of the smaller species is lacking, they are quick when escape is necessary-expert climbers and skillful at hiding in trees, bushes, hollow logs, or holes in the ground.

Their real homes are in underground burrows, where warm nests and ample stores of nuts and seeds afford all the comforts of chipmunk life. In the fruitful country they inhabit there is no occasion for strenuous exertion. Like most of the squirrel family they are daylight workers, beginning activities with the first clear dawn, and retiring to their nests for the night with the twilight shadows. 
Hibermation.-In the mild climate where these chipmunks occur, hibernation is apparently rather irregular, if it be true hibernation. At Salem in November 1893, Streator reported them as common, but not very active. McLellan found them common at Drain, in November 1894, but later at Oakland, in November and December, and at Olalla, in December, he could not find any, although they were said to be there in summer. At Wells, December 1 to 5, 1904, Hollister could find none, although they were reported as common earlier in the season. At Philomath, in March 1919, Cantwell was told that they were active and about all winter.

Breeding habits.-In females of the Townsend's chipmunk the mammas are arranged in 4 pairs- 1 inguinal well back, 2 abdominal, and 1 pectoral-about evenly spaced on the 2 long mammary glands extending the whole length of the belly. From 4 to 6 embryos have been noted in females collected for specimens in April and May, but usually the young do not appear aboveground until some time in June. By August the young are nearly full grown and apparently each one lays up its own food store for the winter. It seems doubtful if more than 1 litter of young is raised in a season. In some cases only 2 or 3 embryos occur, probably in young of the previous year, but the increase is generally sufficient to keep up the normal abundance of the animals.

Food habits.-Like most species, Townsend's chipmunks have a wide range of foods, including nuts, acorns, seeds, berries, and other fruits, roots, bulbs, green vegetation, insects, and other small animal life. At Multnomah Falls, Merriam noted one that lunched with his party in a friendly way, coming repeatedly to the table spread on the ground, and stuffing his cheek pockets with food, showing a preference for bread and grapes, which he carried away to his den across the creek. He would quickly return for more, running fearlessly among the members of the party seated on the ground, and gathering up the food thrown to him. At Wilson River, Fisher reported them eating salmonberries and other berries, and along the coast country McLellan noted them feeding on salmonberries, red and black elderberries, gooseberries, crab apples, plums, and prunes; also the seeds of maple, boxelder, rose, thistles, grasses, and grains. The writer has found them feeding also on raspberries, thimbleberries, blackberries, salal berries, seeds of spruce and hemlock cones, and a great variety of other seeds. Hazelnuts and acorns are much sought for winter stores.

Economic status.-In many places these chipmunks are common in the timber and thickets along the edges of fields of grain and berries and other fruits, and it would be strange if they did not make some inroads on the crops. In one place McLellan reported the trunks of plum and prune trees wrapped with tin to keep the chipmunks from getting the fruit, but there have been few com. plaints against them. The abundance of wild berries, nuts, and seeds undoubtedly prevents serious injury to domestic products.

Their consumption of tree seeds may have some influence on the welfare of the forests, and with other rodents they may help to keep down some reforestation that should naturally occur. On the other hand, the burying and storing of seeds may in some cases where left to grow be of great value in forest extension. 
EUTAMIAS TOWNSENDII COOPERI (BAIRD)

COOPER'S CHIPMUNK

Tamias cooperi Baird, Acad. Nat. Sci. Phila. Proc. 7 : 334, 1855.

Type.-Collected at Klickitat Pass, Cascade Mountains, Wash., by J. G. Cooper in 1853.

General character s.-Similar to typical townsendii, but paler, the browns more mixed with gray. Summer pelage, back with 3 black and 2 outer brown stripes, 2 grayish white, and 2 yellowish gray stripes; sides of head with 2 whitish and 3 blown stripes; sides and most of upper parts and feet grayish brown; tail pale rusty brown underneath with black top and tip and margins, frosted above with white tips of long hairs; patch back of each ear and lower parts white or whitish. Winter pelage and color of young scarcely different from summer.

Measurements.-Average of adults: Total length, $250 \mathrm{~mm}$; tail, 112; foot, 36 ; ear (dry), 16.8.

Distribution and habitat.-These chipmunks occupy the Cascade Range from southern British Columbia south to Mount Jefferson and thence southwest along the west side of the range to Glendale in the Rogue River Mountains, mainly in Transition Zone, but in places also in Canadian Zone (fig. 21).

General habits.-Like other forms in the group these are mainly forest chipmunks, although often found in the underbrush or out in dense chaparral, or along fence rows at a distance from the main forest. They climb trees readily but depend on their burrows, hollow logs, or trees for refuge, or on flight under cover of dense brush and low vegetation. In voice and habits generally they seem not to differ from typical Eutamias townsendii.

Breeding habits.-On the slopes of Mount Hood at 2,800 feet, Cantwell found them out on the snow, on March 23, actively running about in their mating activities. At McKenzie Bridge the writer's party found the young out of the nests in the latter part of June, most of them not long abroad and scarcely half grown. There seems to be no evidence of any second litters of young, which, since August and September is their time for harvesting and storing winter food, would mature too late to permit securing of the necessary stores and carrying on the vital processes of hibernation.

Food habits. - The food of Cooper's chipmunks consists mainly of nuts, seeds, berries, roots, green vegetation, and insects, varying with the season and the local supply. Along the west base of Mount Jefferson in October, they were feeding extensively on the seeds of dogwood, Cornus nuttallii, the scarlet berries of which were found scattered on logs and stumps all through the woods. On Mount Hood, in September, they were gathering the seeds from hemlock cones, getting the rich little seeds from under each scale as it was clipped off, and leaving piles of cores and scales where they were feeding.

Economio status.-Except for the fact that Cooper's chipmunks live more in the mountains and less in agricultural regions their economic relations are practically the same as those of Townsend's chipmunk.

$7209^{\circ}-36-9$ 


\section{EUTAMIAS TOWNSENDII OCHROGENYS MERRIAM}

\section{REDWOOD CHIPMUNK}

Eutamias townsendi ochrogenys Merriam, Biol. Soc. Wash. Proc. 11: 195, 1897.

Type.-Collected at Mendocino, Calif., by J. E. McLellan in 1894.

General characters.-Distinguished from typical townsendii by its rich rusty yellow lower parts, and more contrast in lighter summer, and darker winter pelage; tail the same as in townsendii. Size about the same.

Measurements.-Average of adults : Total length, $265 \mathrm{~mm}$; tail, 116; foot, 38; ear (dry), from notch, 17.

Distribution and habitat.-The redwood chipmunks occupy a narrow coastal strip from Port Orford, Oreg., south to Bodega Bay, Calif. There are Oregon specimens from Port Orford, Gold Beach, State Line, and the Rogue River Mountains about 18 miles back from the coast. To the north they apparently grade into Eutamias townsendii and to the east into the siskiyou form (fig. 21). They are found mainly in the redwoods of the coast region of northern California and extend slightly beyond them in Oregon, in the coast division of Transition Zone.

General habits.-In voice, actions, and habits, generally, these chipmunks are not noticeably different from typical townsendii. In the redwood forests where they climb over the logs and trunks of the great trees, they find the deepest shade and richest colors of any forest in the country, and have taken on similar rich coloration for their own protection. In the deep forest shadows they would be lost but for their shrill, whistling chipper, or the slow chuck, chuck, chuck, and the graceful waving from side to side of the plumy tails as they sit on points of brown bark or against the huge trunks.

Their food includes a wide range of nuts, seeds, berries, fruits, plants, and insects found in the southern part of the State, as well as the nuts of the tanbark oak and California buckeye.

\section{EUTAMIAS TOWNSENDII SISKIYOU HOWELL}

\section{SISKIYOU ChIPMUNK}

Eutamias townsendii siskiyou Howell, Jour. Mammal. 3: 180, 1922.

Type.-Collected in Siskiyou Mountains, Calif., near summit of White Mountain at 6,000 feet, by $\mathrm{N}$. Hollister, in 1909 .

General characters. - Slightly smaller than Eutamias townsendii and much paler; nearest to $E$. $t$. senex, but showing gradation toward $E$. $t$. ochrogenys, and evidently grading into both of these forms as well as into $E$. $t$. cooperi. Summer pelage, back with 1 black and 4 brown stripes and 4 gray stripes (pl. 27, A) ; sides of head with 2 gray and 3 brown stripes; sides grayish brown; tail almost as in typical townsendii; spot back of each ear light gray; lower parts lightly washed with ochraceous. Winter pelage duller, darker, and grayer than in summer.

Measurements.-Average of adults : Total length, $255 \mathrm{~mm}$; tail, 110 ; foot, 36.5; ear (dry), 16.6 .

Distribution and habitat.-This chipmunk is found in the Siskiyou Mountains of northwestern California and southwestern Oregon, and the Rogue River spur of the Cascades west of Crater Lake, in Transition Zone, and also in the limited areas of Canadian on the Siskiyous (fig. 21). Its range is more open and less humid than that of townsendii or ochrogenys, but less so than that of senex. 
General habits.-Hollister, who collected the type of this form and wrote of its habits in the Siskiyou Mountains, says that these chipmunks were common above 3,000 and 4,000 feet altitude, and most abundant in the pine forests of the Canadian Zone near the summits of the ridges. In the open rocky and chaparral-covered areas they were wild and hard to collect, but in the forest areas they were more numerous and easily secured for specimens. Sixty-nine, including young of the year and adults, were taken in the Siskiyou Mountains in September and October of 1909. Several of those taken were infested by grubs, Cuterebra, and the scrotum and testes were often completely destroyed by these parasites.

In September, he says, they were feeding a great deal on the little wild cherries (Prunus emarginata) and were often seen up in the bushes gathering the red fruit. During October they were feeding more on acorns and pine nuts and it was remarkable that their cheek pouches would hold so much. One had its pouches full of wild currant seeds, another was carrying 2 acorns, and another 5 acorns, in its pockets. Different individuals had $3,5,6,17$, and 19 seeds of sugar pine, and others had $4,5,11,23$, and 65 seeds of mountain pine in their pockets.

\section{EUTAMIAS TOWNSENDII SENEX (ALLEN)}

\section{Allen's Chipmunk; Was-la of the Klamath (C. H. M.)}

Tamias senex Allen, Amer. Mus. Nat. Hist. Bull. 3 : 83, 1890.

Type.-Collected at Summit of Donner Pass, Placer County, Calif., by Lyman Belding in 1885 .

General characters.-Smallest of the subspecies of this group, tail less plumy, colors palest, fur relatively harsh and thin in summer. Summer pelage, back with 5 brown (rarely 1 or 3 blackish) stripes and 4 light gray stripes; sides of head with 2 light gray and 3 brown stripes; sides rich rusty brown; feet ochraceous; tail below light rusty brown, top and edges and tip black, frosted with white-tipped hairs; patch back of each ear light gray; lower parts white or creamy. Winter pelage clearer gray.

Measurements.-Average of several adults: Total length, $243 \mathrm{~mm}$; tail, 103 ; foot, 36; ear (dry), 17 . One adult male collected by Joseph Grinnell measured $250 ; 110 ; 36 ; 16$; and weighed $89.8 \mathrm{~g}$; others weighed as high as 100,108 , and $123 \mathrm{~g}$, respectively.

Distribution and habitat.-In Oregon these chipmunks range from Mill Creek and Warren Springs, east of Mount Jefferson southward, keeping mainly east of the Cascades, and in the Paulina, Yamsey, Klamath, and Warner Mountains (fig. 21). In California they inhabit the Sierra Nevada and Cascades to the Yosemite; also Warner Mountains, Modoc County. They occupy Transition and Canadian Zones in the drier, more open parts of the forests, especially the yellow pine and lodgepole pine areas.

General habits.-These gray chipmunks are in habits as well as general characters the farthest removed from typical townsendii of any of the subspecies. Smaller, quicker, more dependent on escape in open places, they are more like some of the other forms of mountain chipmunks in general acivities. Still they have the shrill voice and the lateral waving of the less plumy tail common to the townsendii group. Primarily forest dwellers and expert climbers, they are often found running over logs or rocks or through dense tangles of Ceanothus or shrubby oak chapparal, and their homes are usually 
in burrows or natural cavities underground. Sometimes they live in hollow logs or clefts among the rocks, but the permanent homes seem to be underground, where the winter stores are located near the frostproof nests.

Breeding habits.-Like other members of the townsendii group these chipmunks have 4 to 6 young, born in May or June and appearing aboveground in July. These have barely time to grow up and store their winter's food before the first snows come, in September or October, and bury them up for 5 or 6 months, until the March thaws bring them out to begin another breeding cycle.

Food habits.-Acorns, chinquapins, hazelnuts, seeds of pines, spruces, and hemlocks, cherries, berries, seeds of grasses, and a great variety of plants, roots, tubers, green vegetation, flowers, insects and small animal life, and around camp, scraps of bread, pancakes, grains, and most camp supplies, are eaten or stored for the winter food supply. They are very fond of the fruit and seeds of the little bitter cherry (Prunus emarginata) and are often seen up in the bushes gathering them. The writer has found as many as 112 of these little cherry pits in the cheek pouches of one chipmunk, and the pulp of the fruit is often found in their stomachs. Manzanita berries, currants, gooseberries, raspberries, thimbleberries, blueberries, and strawberries are eaten, and the seeds often separated and stored. Many species of mushrooms are eaten, and the little bulbs or tubers of fireweed (Gayophytum), and traces of insect remains, are usually found in the stomachs.

They do not become fat in autumn as do most hibernating animals, and the large stores of food laid up for winter and spring use may indicate only incomplete or partial hibernation during the long, cold winter of deep snows.

Economic status.-This mountain species is found mainly above the zone of agriculture and its vital relations are with the forest. The extent to which the forest suffers by the loss of tree seeds eaten by chipmunks is not easily determined, but it may be considerable at times. The habit of hoarding the food supply in deep burrows prevents the general distribution of seeds as by the squirrels and most of the seeds thus hoarded are eaten or if left would decay. In a few cases the burrows are dug out by badgers or skunks, the chipmunk eaten, and the seeds scattered; but this may not be of sufficiently common occurrence to have a great value. On the whole a large number of chipmunks must, in some cases, retard the reforestation of the mountains, especially where the lower vegetation is closely grazed by domestic animals and little rodent food is obtainable except from tree seeds. In places it may be necessary in future to destroy by artificial means many of the rodent population before a stand of young timber can be renewed on cut-over or burnt-over ground; but once a good stand of timber is established and grazing controlled, there is some protection afforded the forest by the chipmunks in the destruction of insects and planting of seeds. It would certainly be a great mistake wholly to condemn or attempt a wholesale destruction of the chipmunks, as they have a practical value besides being one of the brightest, most friendly, and attractive forms of animal life in our forests, parks, and national recreation areas. 

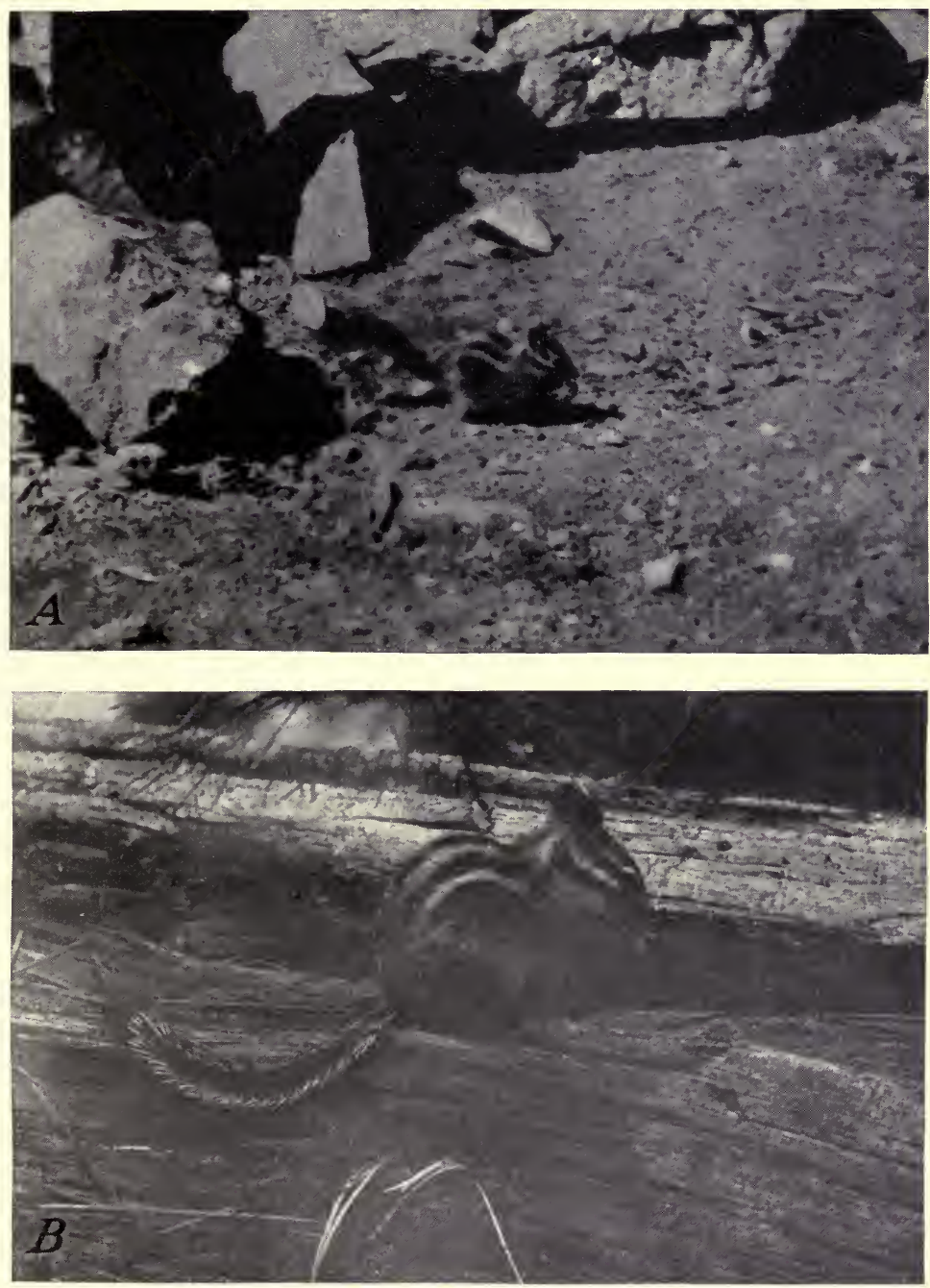

B3896M; B15922

1, Siskiyou chipmunk at the Oregon Caves; $B$, Klamath chipmunk near Fremont, Oreg. (photograph by Luther J. Goldman). 



\section{EUTAMIAS AMOENUS AMOENUS (ALLEN)}

\section{KLAmath Chipmunk; Was-Ia of the Klamath (C. H. M.)}

Tamias amoenus Allen, Amer. Mus. Nat. Hist. Bull. 3 : 90, 1890.

Eutamias amoenus propinquus Anthony, Amer. Mus. Nat. Hist. Bull. 32: 6, 1913. Type from Ironside, Oreg.

Type-Collected at Fort Klamath, Oreg., by J. H. Merrill in 1887.

General characters.-A small, richly colored chipmunk, with slender tail, pointed ears, and nine stripes on the back (pl. 27, B). Summer pelage: Back with 3 black, 2 brown, 2 gray, and 2 white stripes; sides of head with 3 dark and 2 white stripes; sides, shoulders, and lower surface of tail rich rufous or orange brown; top and margins of tail black, overlaid with buffy brown; back of ears mainly black; belly whitish or slightly ochraceous. Winter pelage: Slightly duller and more grayish. Young as in summer adults.

Measurements.-Total length, $197 \mathrm{~mm}$; tail, 84; foot, 31; ear (dry), from notch, 13.8.

Distribution and habitat.-These little chipmunks cover most of Oregon east of the Cascades, a large part of northeastern California and central Idaho (fig. 22). They do not occur in the open plains country of the Columbia River Valley, nor the sagebrush valleys of southeastern Oregon, and are replaced by the yellow-bellied subspecies $h u$ teiventris in the northern part of the Blue Mountain plateau.

They range through Transition and Canadian Zones, mainly in openforest country and often out over the rocks and brush beyond the edge of the forest, but never far into the open valleys or sagebrush plains.

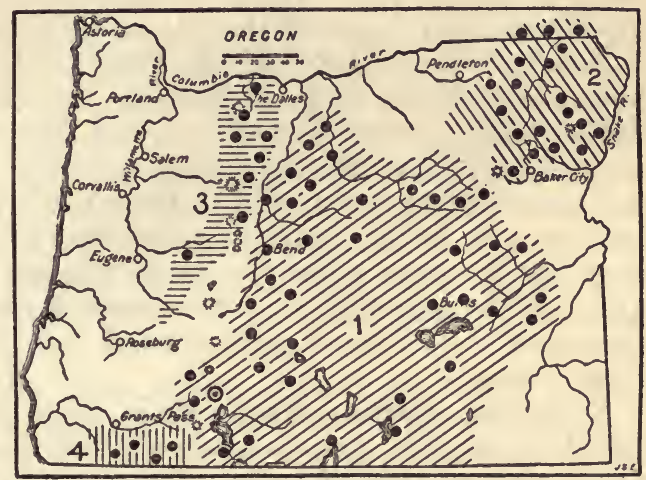

Figure 22.-Range of four chipmunks of the amoe nus group in Oregon: 1, Eutamias amoenus amocnus; $2, E$. a. luteiventris; $3, E$. a. ludibundus; 4 , E. a. ochraceus. Type locality circled.

A specimen in the United States National Museum collection taken by J. K. Townsend, probably in 1834, and labeled "Columbia River, Oregon ", apparently came from the vicinity of The Dalles.

General habits.-While expert climbers, often seen running up trees, Klamath chipmunks generally are found on the ground running over logs and rocks or climbing about in the bushes. Their homes are generally underground, in hollow logs, or in clefts of the rocks, and from these the chipmunks range out for considerable distance, keeping close to safe cover above or below the ground. Their bright colors are often seen flashing through the leaves or bushes and their shrill chipper of alarm or curiosity is heard along the trails. Sometimes a slow, soft chuck, chrack, chuck is heard from a distance-as one sits on a stump, log, or low tree branch-a chipmunk calling quietly to his friends far and near. Their voices have many degrees of pitch, time, and quality that may mean much to members of their own clan, but little to uninitiated ears. 
In places where they come around camps and cabins they often become very tame and will even take food from the hand. Generally, however, they are shy and timid and have need to be constantly alert for enemies.

Hibernation.-When the snow gets deep they disappear, and no tracks are seen until spring. At Fort Klamath, Harry Telford said they had not appeared when he left there on March 9, 1914, and that the first one noted at Klamath Falls that year was on March 12. The fact that they do not become very fat in the fall makes it somewhat doubtful if true hibernation is practiced. Further observations are needed to settle this point.

Breeding habits.-As usual in chipmunks the mammae of the females are arranged in 4 pairs -1 inguinal, 2 abdominal, and 1 pectoral. The young are usually 4 or 5 , as shown by embryos in specimens collected in April, May, June, and July. This variation in dates may mean two litters of young in a season or merely the irregular breeding of females of different ages. The young do not appear out of the nest until nearly half grown and well able to take care of themselves. Little is known of the actual breeding habits or of the early lives of the young in their underground nests.

Food habits. - The food of these beautiful little chipmunks is composed largely of seeds of various flowering plants, grasses, berries, bulbs, roots, green vegetation, and insects. The animals are great storers, and their cheek pouches are often found distended with seeds or other food to be carried to their underground storehouses for winter use. It is not definitely known, however, whether those stores near their warm nests are eaten during the winter, or whether the animals sleep soundly in hibernation during the long, cold, snowy time and save their hoarded food for the early spring when other food is scarce.

Economic status.-From their wide range and abundance these small chipmunks may be of considerable economic importance. Their actual destruction of crops is rarely of consequence, although small grainfields in the woods or on newly cleared land sometimes show ragged borders where they have harvested the grain for their winter stores. Their consumption of grass seeds and clover seeds may have a slight effect on the grazing capacity of the range, but apparently their eager search for the rich oily seeds of pines and other conifers leaves little chance for these valuable trees to reproduce and reforest the land. In places, where artificial reforestation is undertaken, it has been found necessary to destroy the chipmunks and other rodents. This is not difficult as they readily take poisoned grain, and successful methods of control at slight expense have been perfected by the Biological Survey.

Where rapid reforestation is not necessary and no serious damage is being done by the chipmunks, there is some practical value attached to them as insect destroyers and an esthetic value in adding a delightful feature of life and interest to the forests and mountains. In many camps and ranger stations, tin-lined cupboards and storage boxes are provided to protect supplies, so the chipmunks can be left to run at will about the buildings and afford much interest and com- 
panionship. Although nervous and timid, they are easily tamed so as to take food from the hand and even climb over a person in search of nuts or seeds.

\section{EUTAMIAS AMOENUS LUTEIVENTRIS (ALLEN)}

YeLLOW-BeiLIED ChIPMUNK

Tamias quadrivittatus luteiventris Allen, Amer. Mus. Nat. Hist. Bull. 3: 101, 1890.

Type-Collected at Upper Waterton Lake, north end of Glacier National Park, Mont., by Elliott Coues in 1874.

General characters. - Slightly larger than $E$. amoenus with blacker stripes on the back and more completely buffy or yellow belly. Summer pelage with 5 black, 2 creamy white, and 2 gray stripes; sides of face with 3 dark and 2 light stripes; sides and shoulders bright rufous; lower parts, feet, and lower surface of tail dull ochraceous; top and edges of tail blackish, washed with ochraceous; back of ears buffy and blackish. Winter pelage duller and grayer. Young as in summer adults.

Measurements.-Average of typical specimens: Total length, $221 \mathrm{~mm}$; tail, 102 ; foot, 33 ; ear, 13.5 .

Distribution and habitat.-With a wide range in the Rocky Mountain region of Canada, western Montana and Wyoming, and central Idaho, these yellow-bellied chipmunks extend into northeastern Oregon in the Wallowa and northern part of the Blue Mountains, and there merge into amoenus to the south and west (fig. 22). They are forest chipmunks, occupying mainly Transition and Canadian Zones, but sometimes found well up in Hudsonian close to timber line. They prefer the more open forests and are most abundant in the yellow-pine Transition Zone area. They also live in the brush or among rocks but never out in the open country.

General habits.-In habits these yellow-bellied chipmunks differ little from their near relative, Eutamias amoenus. They occasionally climb trees but depend mainly for protection on burrows in the ground, hollow logs, or broken rocks. They are skillful climbers, however, and run up trunks, through the branches, and through the tops of bushes in search of food. When alarmed, they generally rush to the ground and with a shrill chipper disappear under the first cover or into the nearest hole.

Over most of their range the winters are long and cold, and the snow deep. Late in October, or in November, the chipmunks disappear and are not seen again until some time in March. This is their long, sleepy time. Then comes the spring awakening and the breeding season of April, May, and June; then the play month of July, when the young are out and frisking about, not taking life too seriously; then the harvest months of August and September, the busy time of the year, when food must be gathered to last through the winter and spring, and a warm nest must be made deep underground below the frost line.

Breeding habits.-As the deep snow begins to melt in March, the chipmunks tunnel up through it to the surface and begin to travel in all directions from their burrows, and soon the males are actively searching for mates. At Wallowa Lake on April 9, 1919, G. G. Cantwell reported them out over the snow that still covered the ground. 
They were silent but very active, and a dozen or more caught in traps were all males. The females were evidently remaining at home, but were not inactive, as specimens collected by Cantwell at Sled Springs in the Imnaha Forest on April 26 contained small embryos. At Elgin the writer found females late in May nursing young, but the young are not usually seen out of the nest until well along in June, when nearly half grown. Two to six embryos found in the females examined would indicate a normal number of young in a litter as 4 or 5. Whether more than one litter is raised in a season is not definitely known.

Food habits.-During the summer much of their food consists of fruit, berries, green seeds, flowers, and even green foliage, roots and bulbs or tubers, with a mixture of grasshoppers and other insects and small animal life, but later in the season, as seeds, grains, and nutlets ripen, these form more of the food and are stored up for a winter supply. The seeds of conifers are eagerly sought, and grass seeds form a substantial portion of the food and stores.

The chipmunks do not become very fat in the fall, and the question of complete or partial hibernation has not been fully determined.

Economia status.-Aside from their possible influence in retarding reforestation and reseeding of forage plants, these chipmunks have little effect upon agriculture or human industries. In camps and forest cottages supplies are easily protected from them. In rare cases a few may have to be destroyed where doing mischief, but this is not difficult. Their value as food for numerous fur-bearing animals and as an attractive form of wildlife generally far outweighs their occasional destructive habits.

\section{EUTAMIAS AMOENUS LUDIBUNDUS HoLlister}

\section{Hollister's Chipmunk; Canadian Mountain Chipmunk}

Eutamias ludibundus Hollister, Smithsn. Misc. Collect. 56: 1, 1911.

Type.-Collected at Yellowhead Lake, British Columbia, Canada, by $\mathbf{N}$. Hollister, 1911.

General characters.-Conspicuously larger than E. amoenus with bushier and browner tail, and blacker back stripes. Summer pelage with 5 black, 2 gray, and 2 white stripes on back; sides dull rufous; tail bright rufous with black top and edge, the long hairs tipped with rufous; feet ochraceous, throat, inside of legs, and middle of belly whitish.

Measurements.-Average of typical specimens: Total length, $217 \mathrm{~mm}$; tail, 96 ; hind foot, 33.5 ; ear, 12.2 .

Distribution and habitat.-These chipmunks range from the Rocky Mountains of northern Alberta and British Columbia southward along the Cascades to Mount Hood, 'Three Sisters, and O'Leary Mountain in Oregon (fig. 22). Specimens from the east slope of the Cascades, from Wapinitia, Warm Springs, and Mill Creek, show the nearest approach to typical $E$. ludibundus, but all of the Oregon specimens are more or less intermediate in characters. They are the small chipmunks of the Mount Hood and the northern Cascades in Oregon, most abundant in the yellow pine forests of the lower slopes, but also ranging to near timber line at Cloudcap Inn and to the top of the range on McKenzie Pass. They are not often found in dense forests but prefer the half-open timber, old burns, and lava fields. 
General habits.-In habits, Hollister's chipmunk is practically indistinguishable from the Klamath chipmunk, with which it intergrades to the southward, the same nervous active little sprite, but easily distinguished by voice and actions from the larger, slower Cooper's chipmunk, with which it comes in contact along its western border line.

\section{EUTAMIAS AMOENUS OCHRACEUS HOWELL}

\section{Yeliow Chipmunk; Ochraceous Chipmunk}

Eutamias amoenus ochraceus Howell, Jour. Mammal. 6: 54, 1925.

Type.-From Siskiyou Mountains, Studhorse Canyon, Calif.

General characters. - Slightly larger and paler than typical amoenus. Summer pelage usually with only 1 black dorsal stripe, 4 brown and 4 whitish stripes, sometimes 5 brown and 4 gray, and sometimes 3 black, 2 brown, 2 gray, and 2 whitish; stripes on sides of head, and patch back of ears, conspicuously white; sides bright ochraceous; lower parts and feet buffy; lower surface of tail pale ochraceous, edges and top black with buffy tipped hairs. Winter pelage darker and grayer, the back with 3 black and 4 gray stripes.

Distribution and habitat.-This pale form of chipmunk has a rather restricted distribution in the Siskiyou Mountains of southwestern Oregon and northwestern California (fig. 22). There are typical specimens from near Ashland and along the line of the railroad over the Siskiyous, but the limits of range have not been well established.

At the type locality Hollister collected two specimens in the canyon at 6,500 feet altitude, but was unable to get more or to find them in other parts of the western end of the range.

General habits.-Apparently nothing has been written on the habits of these chipmunks to indicate that they are in any way different from those of typical amoenus over its wide range.

\section{EUTAMIAS MINIMUS PICTUS (ALLEN)}

Sagebrush Chipmunk; Great Basin Chipmunk; Desert Chipmunk; PaINTed ChIPMUNK

Tamias minimus pictus Allen, Amer. Mus. Nat. Hist. Bull. 3: 115, 1890. Eutamias minimus scrutator Hall and Hatfield, Calif. Univ. Pubs., Zool. 40 (6) : 325, 1934. Type from White Mountains, Calif.

Type.-Collected at Kelton, Utah, by Vernon Bailey, June 1888.

General oharacters.-Very small (pl. 28, $A$ ), form slender, tail long, color gray with 9 narrow stripes on back. Summer pelage, back with 5 black, 2 light gray, and 2 dark gray stripes; sides and feet and middle of tail below buffy gray; sides, top, and tip of tail black, with gray tips to long hairs; belly white or light gray. Winter fur clearer gray with less buffy.

Measurements.-Average: Total length, $200 \mathrm{~mm}$; tail, 86 ; foot, 30 ; ear (dry), 12. An adult female at Malheur Lake measured $190 ; 93 ; 31 ; 14 \mathrm{~mm}$, and weighed $33 \mathrm{~g}$.

Distribution and habitat.-These tiny chipmunks occupy most of the sagebrush valleys of the Great Basin region, including the sagebrush plains of Oregon east of the Cascade Mountains, in upper Sonoran and Transition Zones (fig. 23). They are rarely found in the timber or away from sagebrush, in which they climb as other larger chipmunks do in the trees and larger bushes.

General habits.-The homes of these little chipmunks are in burrows in the ground which they dig or borrow from other rodents, and 
from which they range out widely for food and exploration through the Lilliputian forests of sagebrush. They run swiftly from cover to cover, with tails erect, darting over open ground from one patch of sagebrush to the next, then through the branches and tops of the bushes, or, pausing a moment on one of the highest twigs to inspect the country for danger, with a sharp little chipper are off again in another direction.

When at a long distance from a burrow or other safe retreat these chipmunks run so swiftly and hide so skillfully in the bushes that specimens are not easily obtained. Even on a good hunting horse the writer has been led many an exciting chase without securing a specimen, while on foot it is useless to pursue one. A little patience and skill, however, will yield more specimens than hard hunting. A few squeaks of the lips will bring one to the top of a sage bush where with alert ears and lashing tail he will answer back in excited

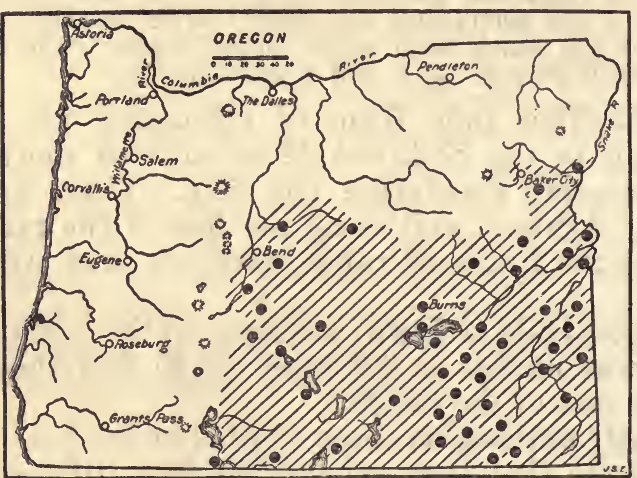

FIgURE 23.-Range of the sagebrush chipmunk, Eutamias minimus pictus, in Oregon. chippers and fall an easy prey to his nervous curiosity. More specimens are secured in mousetraps set among the sage bushes than in any other way, as the chipmunks are eager for rolled oats or almost any of the baits used for rodents.

B reeding habits. Little is known of the breeding of these chipmunks other than that the female has 4 pairs of mammae-1 inguinal, 2 abdominal, and 1 pectoral-and that 4 and 5 are the usual numbers of embryos found in those collected for specimens in May. There seems to be no evidence of more than one litter being raised in a year, but there might be a second litter under favorable circumstances, such as mild climate, abundance of food, and freedom from persecution of enemies. The young are generally nearly full grown by harvest time in the fall, and apparently each makes its stores independently.

Food habits. - The sagebrush furnishes food as well as shelter for these tiny squirrels, its abundance of minute seeds being gathered and carried away in the cheek pouches all through the late summer, fall, and early winter. In return for this food supply, the sagebrush is to some extent protected from insects by the chipmunks, which in summer often subsist largely upon the little green caterpillars that devour its leaves. The stomachs of the chipmunks often show traces of grasshoppers and numerous other insects, but the bulk of their food generally consists of seeds of a great variety of flowering plants and grasses, berries, green vegetation, roots, bulbs, and fungi. They are fond of grain and often gather around the edges of fields to feast on this unusual food supply and store as much as possible for winter use. They do not become very fat in the fall and probably do not hibernate for any long period, if at all. 
Economic status.-Except very locally these little chipmunks are not destructive to crops, but their consumption of seeds of grass and other useful plants may have considerable influence on abundance of vegetation in the arid valleys where they live. Their consumption of insects must partly, or may wholly, compensate this loss of vegetation. A closer study of food habits is necessary to decide the balance of account for or against them.

\section{CALLOSPERMOPHILUS CHRYSODEIRUS CHRYSODEIRUS (MFRIAM)}

Golden-mantled Ground Squirrel; Yellow Head; Calico Squirrict; Chil-tas of the Klamath (C. H. M.) ; Wo-TAH of the Piute at Burns

Tamias chrysodeirus Merriam, North Amer. Fauna No. 4, p. 19, 1890.

Type-Collected at Fort Klamath, Oreg., by Samuel Parker, in 1888.

General characters.-Larger and heavier than the true chipmunks; ears prominent; tail moderately bushy; feet large with naked soles and palms; toes 5 on each foot, thumb a mere rudiment; mammae in 4 pairs-1 inguinal, 2 abdominal, and 1 pectoral; internal cheek pouches ample. Summer pelage, sides of back with 4 black and 2 white or buffy stripes; middle of back, rump, and hams rusty gray; shoulders, neck, cheeks, arms, and lower surface of tail, bright ochraceous tawn $\mathrm{y}$; crown hazel; lower parts and feet buffy gray, or dull ochraceous; upper surface of tail black, washed with pale ochraceous. Young, as in summer adults. Winter pelage with the same black and whitish stripes but without the golden mantle and with general coloration much duller and grayer; lower surface of tail as in summer.

Measurements.-Average of five adults: Total length, 258

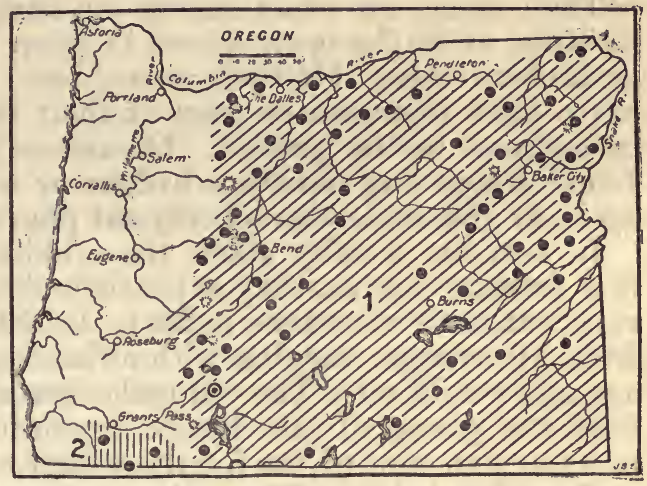

Figure 24.-Range of two forms of Callospermophilus in Oregon: 1, Callospermophitus chrysodeirus chrysodeirus; $2, C$. c. trinitatis. Type locality circled.

$\mathrm{mm}$; tail, 90 ; foot, 40 ; ear (dry), 15. Weight: 135 to $239 \mathrm{~g}$ ( $4 \frac{314}{4}$ to $81 / 2$ ounces) (Grinnell and Storer, 1924, p. 173).

Distribution and habitat.-This ground squirrel is one of the most widely ranging forms of the genus, showing only slight variation from the southern Sierra Nevada Mountains of California north to Mount Hood and the Columbia River in Oregon, and from the western slopes of the Sierra. Nevadas and Cascades east through most of the mountain ranges of Nevada, eastern Oregon, and into southern Idaho (fig. 24). Apparently the Columbia River Canyon is sufficient barrier on the north to separate them sharply from Callospermophilus lateratis saturatus of the Cascades of Washington, while the Snake River Canyon on the east separates them as sharply from $C . l$. cinerascens of central Idaho.

Their principal range is in Transition and Canadian Zones, but in places they reach up into Hudsonian and in other places down into Upper Sonoran Zone. Generally they inhabit the timber, but in the edges of the valleys come down along lines of rocky cliffs and ledges where they find safe cover among the rocks and ample food supply from the bushes and small plants. 
General habits.-In habits as well as structure they are between the arboreal squirrels and the true ground squirrels. They are not good climbers, but occasionally climb trees if no other escape is possible. They are fond of running over logs, stumps, and rocks, or sitting on logs, fences, or some other elevated perch where a wide view is obtained; but their homes are in underground burrows, to which they quickly retreat if alarmed. In disposition they are less nervous and active than the chipmunks, often sitting for a long' time without a motion and finally gliding away without a sound or a flip of the tail.

Their voices are not frequently heard, and the single shrill whistle, or sharp squeak, is so ventriloquial that often it is not associated with the animal. The single call is not frequently repeated, which renders it still more difficult to locate.

Like all of the true squirrels and chipmunks they are strictly diurnal, working only during daylight hours, and like the ground squirrels they hibernate for a long period during cold weather.

Their homes are often among the rocks, either in clefts and cracks in cliffs, or in the open spaces in steep rock slides, masses of talus, or broken rocks. Of their nests, dens, and storehouses under rock cover little is known or even of their breeding and wintering nests in burrows in the ground. Occasionally a nest and food cache is found where dug out by a badger or a bear, but always so messed up as to give little idea of original plan and structure.

In autumn, usually about the middle of September, or with the first freezing nights, they enter their dens for the winter and do not reappear until some time in May, the dates of entering and emerging from hibernation varying with altitude and weather, as well as with age and condition. The old males become fat and enter hibernation first, the young of late litters remaining out latest to acquire the necessary amount of fat for the winter.

Breeding habits.-The mating season of these squirrels begins in spring soon after they emerge from hibernation, and the young are generally born late in June or early July. There are usually 4 to 6 young at a birth, but 7 and 8 have been recorded. The mammae of fully adult females are usually in 5 pairs - 1 inguinal, 2 abdominal, 2 pectoral-but in females only a year old the anterior pair of pectoral mammae are usually undeveloped. Only one litter of young is raised in a year, and these have scant time to grow up and get fat in time to hibernate. In fact many of the later young are not fully grown and not very fat when the snow and cold weather shut them in, and if they come through the winter they are not fully grown or in breeding condition the next spring. The young usually begin to appear out of the nest when a quarter or a third grown, late in July at middle altitudes, but near Huntington in the Snake River Canyon, young were collected on May 18 and 19, while on top of the Cascade, around the base of the Three Sisters, no young were found up to July 20.

Food habits.-Voracious and almost omnivorous, these potbellied little semiground squirrels eat almost anything of an edible nature that they can find. Green vegetation, roots, bulbs, seeds, grain, nuts, fruit, berries, mushrooms, meat, fat, bread, rolled oats, or any camp food that they can find, will help to fill up their capacious stomachs 
and put under their skins the necessary store of fat for winter use. Different foods are favorites at different seasons as available. In spring much green vegetation is eaten as it appears, and roots and old seeds are dug up. Later as berries ripen they are eagerly sought, and service berries, currants, gooseberries, raspberries, manzanita berries, and others are eaten, seeds and all, or the seeds removed and carried away in the cheek pouches to be stored. Sheldon found them feeding on service berries and weed seeds, the pouches of one containing 150 and another 750 seeds of service berry and of another 410 weed seeds. Later in the season they feed more exclusively on seeds and nuts, in places getting acorns, chinquapins, hazelnuts, and numerous seeds of grasses and flowering plants.

They are fond of fresh meat of almost any kind, eagerly taking the bodies of mice and birds that have been skinned for specimens and used for trap bait. They also get into traps baited with bacon or any fat meat and pick up meat scraps around camps. At Cloudcap Inn on Mount Hood, H. D. Langille wrote that when he skinned a fat ground hog these squirrels gathered around and voraciously devoured both fat and meat, seeming to be crazed by the smell of the meat and refused to be driven away. Luther J. Goldman, near Bend, Oreg., found it necessary to visit his meat-baited carnivore traps every evening to take out the "calico squirrels" caught during the daytime.

To what extent they catch small game and insects is not well known, but apparently they are less insectivorous than are the chipmunks.

Economio status.-In places where numerous, the "Callos" are accused of doing some damage to grain crops, tearing down and carrying away the ripening heads of wheat, oats, and barley along the edges of fields in or near the woods or cliffs. This damage is rarely of serious consequence, however, and can be easily prevented by shooting, trapping, or poisoning.

Around camps and cabins they sometimes cut holes in sacks and carry off some grain and injure other camp supplies unless precautions are taken to prevent such mischief. They quickly gather at a source of food supply and become tame and bold in helping themselves. On the long freight-road grades of the Deschutes River Canyon they were numerous, picking scattered grain from the road, and reluctantly moving out of the road for horses to pass. At camps they become very tame and most companionable pets if given friendly protection, and in the parks are one of the most attractive forms of small life. Writing from Fort Klamath in 1914, Harry Telford reported that Miss Copeland had kept one as a pet for 11 years. It hibernated in winter just as in the wild state.

They are less inclined to gather tree seeds than are the chipmunks, but undoubtedly do have some effect in checking reforestation and still more effect in keeping down the grazing, both of grass and many other useful forms of vegetation. They have numerous enemies, however, from snakes to predaceous mammals and birds of prey, and generally their numbers are kept well within bounds. It may sometimes be necessary to destroy them locally in which cases the methods worked out for ground squirrels in general will be found effective. 


\title{
CALLOSPERMOPHILUS CHRYSODEIRUS TRINITATIS MERRIAM
}

\author{
Tawny-Mantled Ground Squirrel
}

Callospermophilus chrysodeirus trinitatis Merriam, Biol. Soc. Wash. Proc. 14: 126, 1901.

Type--Collected in Trinity Mountains, east of Hoopa Valley, Calif., by Vernon Bailey in 1898.

General characters.-Size of typical chrysodeirus or slightly larger; color's duller and darker. Summer pelage, crown and most of mantle tawny, becoming ochraceous tawny on sides of neck; back, rump, and hams rusty gray; two black stripes enclosing buffy stripe along each side of back; sides and lower parts buffy ochraceous; lower surface of tail dark tawny, top and margins black, long hairs tipped with ochraceous. Winter pelage grayer, less tawny. Young as in summer.

Measurements.-Average of 6 specimens from type locality: Total length, $283 \mathrm{~mm}$; tail, 100; foot, 43 ; ear (dry), 16.

Distribution and habitat.-These brown-mantled squirrels occupy the Yolla Bolly, Trinity, and Siskiyou Mountains of northwestern California and southwestern Oregon, the northernmost specimens being from the Siskiyous and a ridge near Briggs Creek west of Grants Pass (fig. 24). In 1909 Hollister reported them common all along the summit of the Siskiyous from 5,000 to 7,000 feet, and specimens were collected on White Mountain Peak.

General habits.-In no particular does there seem to be any difference in habits from typical Callospermophitus chrysodeirus, but owing to their limited range they have been much less studied. In 1897 Loring reported them as common in the Siskiyou Mountains, living under logs, rocks, and stone piles along the roads, and sitting on logs or stumps until approached within a few feet before dodging into their holes. In 1909 Hollister in the western part of the range found them very wild and hard to approach within shotgun range, but at that time they were very fat and evidently ready for hibernation.

\section{CALLOSPERMOPHILUS CHRYSODEIRUS CONNECTENS HOWELL}

\section{Copperhead Ground Squirret.}

Callospermophilus chrysodeirus connectens Howell, Jour. Mammal. 12: 161, 1931.

Type--Collected at Homestead, Oreg., June 1, 1916, by Harry H. Sheldon.

General characters. - Size and general appearance of the golden-mantled ground squirrel but slightly darker over head and shoulders, more russet and less golden yellow. Back more vinaceous, less ochraceous; lower surface of tail cinnamon brown but not so dark a brown as in Callospermophilus castanurus. In summer pelage, head, ears, shoulders, and sides of neck russet, shading on sides of face and neck to cinnamon-buff, nape and fore back more brownish; sides of body and feet pinkish buff; two light dorsal stripes creamy white, bordered on each side by shorter black stripes of the same width; tail cinnamon below, dusky above; lower parts whitish.

Measurements.- Type, adult male: Total length, $275 \mathrm{~mm}$; tail, 95 ; foot, 42 ; ear from notch (dry), 14.

Distribution and habitat.-This slightly darker form of the golden-mantled ground squirrel occupies the Blue Mountain section of northeastern Oregon and southeastern Washington but varies somewhat within this range. It may have no direct connection in range with the parent species but is not widely separated if at all. In zonal range it is mainly Transition and to some extent Canadian. 
General habits.-In no way has this form been found to differ in habits from typical chrysodeirus.

\section{AMMOSPHERMOPHILUS LEUCURUS LEUCURUS (MERTAM)}

Anteiope Squirret; White-TaIled Sand Squirrel ; Ta-watz of the Piute (L. J. G.)

Tamias leucurus Merriam, North Amer. Fauna No. 2, p. 20, 1889.

Type.-Collected in San Gorgonio Pass, Calif., by Frank Stephens, May 16, 1885.

General characters. - S i z e of a large chipmunk (pl. 28, $B)$, with shorter, heavier body, shorter tail, very short e a rs, palms naked; soles hairy up to posterior edge of plantar tubercules; claws but slightly curved; inner cheek pouches ample. In thin harsh summer pelage, upper parts grizzled cinnamon brown, becoming clearer cinnamon on rump and legs, a broad white stripe along each side of back; lower parts including lower surface of tail clear white; top and margins of tail blackish, frosted with white tipped hairs. Winter pelage fine and silky, lower

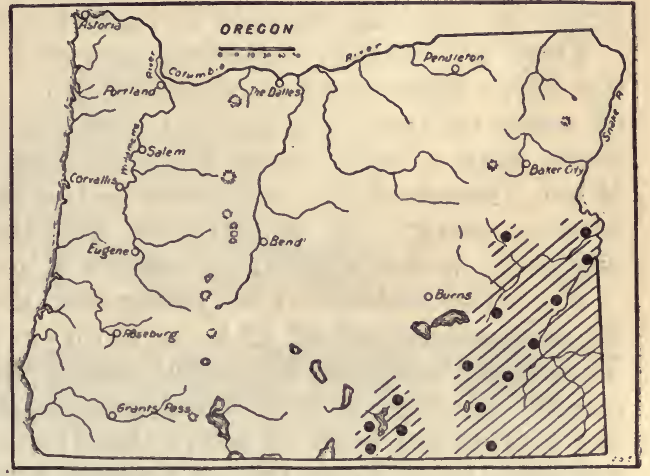

Figure 25. - Range of the antelope squirrel in eastern Oregon: Ammospermophilus leucurus leucurus. parts and side stripes silvery white; upper parts much grizzled pinkish cinnamon, brightest on legs and sides. Young as in summer adults.

Measurements.-Adult from type locallty: Total length, $220 \mathrm{~mm}$; tail, 68; foot, 40 ; ear (dry), 8.

Distribution and habitat.-With a wide range over the desert area of southeastern California and much of Nevada the antelope squirrels reach their northern limit in the Upper Sonoran valleys of southeastern Oregon (fig. 25). There are specimens from Warner, Alvord, and Owyhee Valleys, and records of occurrence in the Malheur Valley. While in the southern part of its range it is largely a Lower Sonoran Zone species, it also extends well into the arid Upper Sonoran.

General habits.-These little desert squirrels live in the open, barren valleys far from timber, but usually where tufts of greasewood, sagebrush, and low desert shrubs furnish cover, protection, and food. With their short, flat tails curled up over the rump so the white under surface shows like the white flag of the antelope, they go scampering from bush to bush over the hot, sandy valleys, running with remarkable speed and hiding in the shadows with such skill that specimens are not easily obtained. In places they take refuge among broken rocks and sit on top of the high points to watch for enemies, but more often they are out in the open, where they watch from the tops of bushes and at the approach of an enemy fly to some far-away retreat. Their homes are usually in burrows, but 
sometimes among the rocks. In a barren country where wide foraging is necessary the speed and alertness of these little sand squirrels is of vital importance.

Their voice, a shrill, prolonged chipper or bubbling whistle, is often heard during the summer when the young are out and the old females are watching for danger, or the young call back and forth, but at other times they are rarely heard.

In winter they become very fat but apparently do not regularly hibernate, as specimens are taken throughout the year. In very cold weather or deep snow, they may hibernate for a time, but their tracks are sometimes seen on the snow, and they are often found active in freezing weather in midwinter.

They are sturdy, vigorous, energetic little animals, quick to run but fierce fighters when cornered, with none of the gentle, quiet ways of some of the little ground squirrels. One kept in captivity for more than a year never became tame, nor would allow handling. When disturbed, it would rush to the vertical wheel and spin it with intense energy. It would even run the wheel at night if alarmed, although in the wild the species is wholly diurnal.

Breeding habits.-The young are usually 6 or 8 in number, but there is one record of 12 large embryos in a female collected April 1. This is evidently an abnormal number as the mammae of the females are in 5 pairs-1 inguinal, 2 abdominal, and 2 pectoral. Farther south the young are born in early April and are out of the burrows by the middle of May, but in Oregon the dates may be a little later. The young are about a quarter grown when they first come out of the burrows and remain for some time under the care and protection of the mother. When nearly full grown in the late summer they scatter out and live independent though not unsociable lives.

Food habits.-In summer these squirrels eat a great deal of green vegetation, cactus fruit, and berries and green seeds, but in autumn and winter they live largely on seeds and grain. One collected in Warner Valley by Jewett on September 26, 1915, had its cheek pouches filled with several hundred seeds of Russian-thistle, and nothing else. They are fond of all kinds of grain, also, and will gather about stacks, barns, or corrals for scattered grains.

Economic status.- In the Oregon part of their range these little squirrels are so scarce as to do no harm and are important only as objects of interest. In fact, throughout most of their wide desert range they have very little economic significance, but are always an attractive form of desert life.

\section{CITELLUS DOUGLASII (RICHARDSON)}

Douglas's Ground Squirrel; Digger Squirrel; Gray Digger; Cho-chuck of the Klamath (C. H. M.) ; WAschoI of the Wasco

Arctomys (Spermophilus) douglasii Richardson, Fauna Boreali-Amer., v. 1, p. $172,1829$.

Type.-Collected along banks of Columbia River, Oreg., by David Douglas in 1825 .

General characters.-As large or larger ( $\mathrm{pl} .29, A)$ than the eastern gray squirrel; ears about as long; tail long and bushy but less full and spreading than in the tree squirrels; claws fossorial; palms naked; soles hairy back of tubercles; cheek pouches ample. Pelage coarse and harsh; in summer, upper parts dark brownish gray, mottled and scalloped with white specks and wavy 

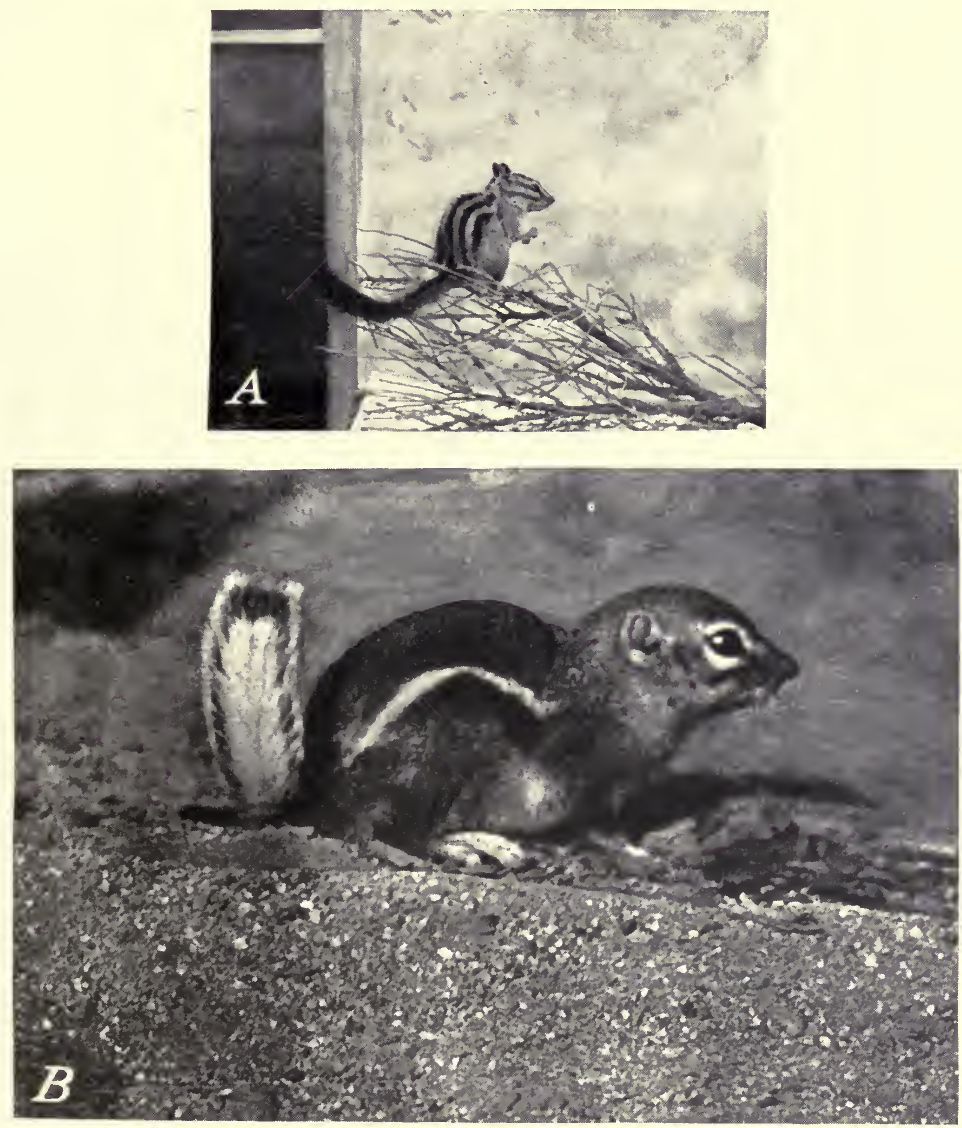

B23229; $\mathbf{B 3 3 2 1 0}$

$A$, Little sagebrush chipmunk, common over the sagebrush plains of eastern Oregon; $B$, antelope squirrel, found in the low hot desert valleys of southeastern Oregon. 

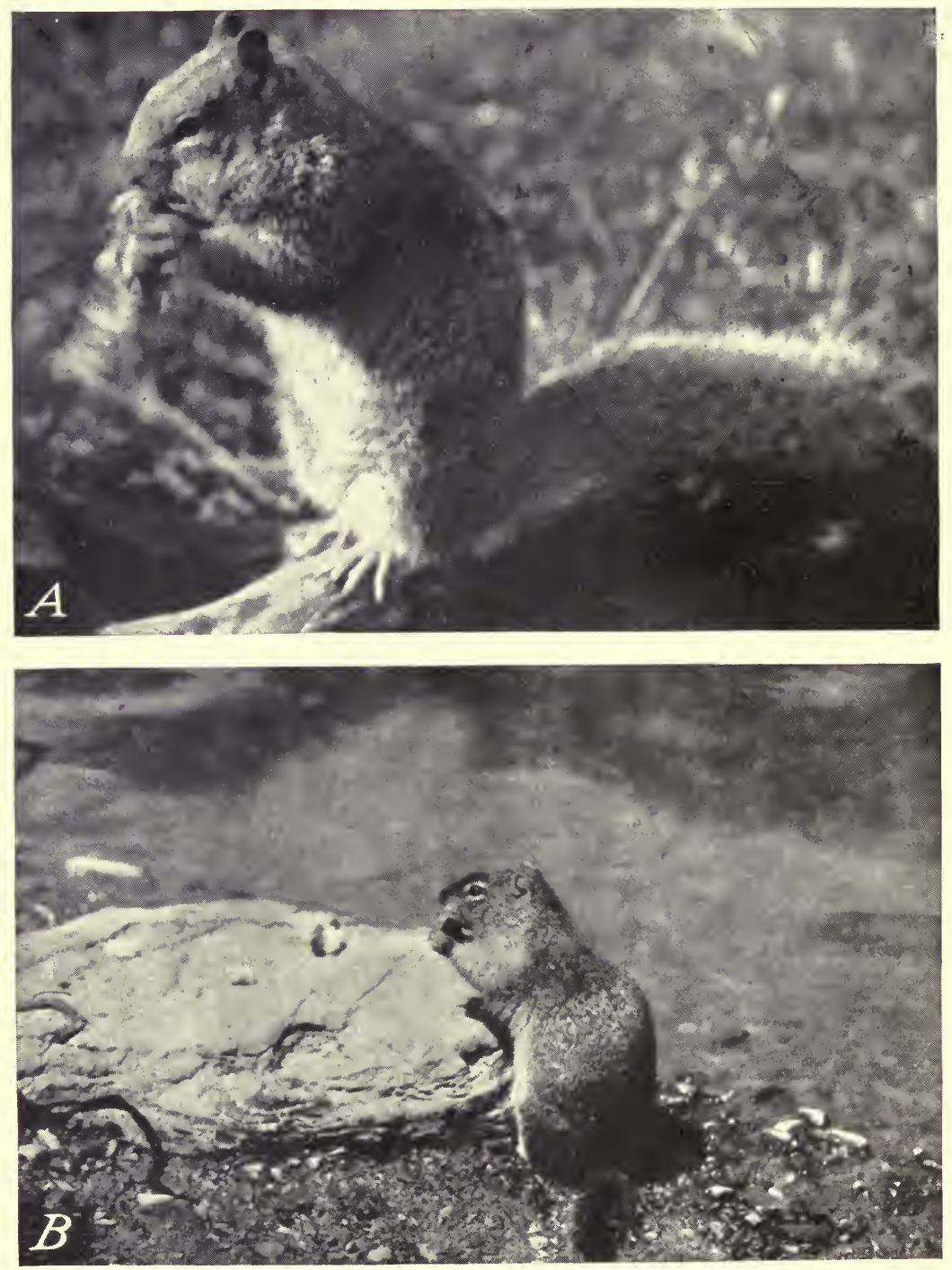

B4610M; B4609M

$A$, Douglas's ground squirrel in western Oregon (photograph by Alex Walker); $B$, Columbian ground squirrel in Glacier National Park (photograph by Walter L. Huber). 
black crosslines; middle of back with a large black or dusky $\mathbf{V}$-shaped area between posteriorly diverging light gray shoulder stripes; lower parts and feet buffy ochraceous; tail dark gray with three concealed black or dusky lines along each side and around tip. Winter pelage more gray with less conspicuous markings. Young as in summer adults or more strikingly marked.

Measurements.-Average of 10 adults: Total length, $458 \mathrm{~mm}$; tail, 200 ; foot, 60 ; ear (dry), 22. Weight about the same as the California ground squirrel, $11 / 4$ to $1 \frac{1}{2}$ pounds (Grinnell and Dixon, $1918, p .603$ ).

Distribution and habitat.-These big ground squirrels extend from the Columbia River south along both sides of the Cascades into northern California and west of the Sacramento Valley to San Francisco Bay. West of the Cascades in Oregon they cover practically all except the densely timbered areas toward the coast, but east of the Cascades only a narrow strip along the east base of the mountains, mainly in the Deschutes and Klamath Valleys, reaching their eastern limit of range in Goose Lake and Warner Valleys (fig. 26). They are most abundant in the dry interior Upper Sonoran valleys but are scattered well over the more open parts of humid Transition valleys, not usually ranging high in the mountains nor entering heavily timbered areas.

General habits.-Although squirrellike in appearance and fairly good climbers, these are true ground squirrels, liv-

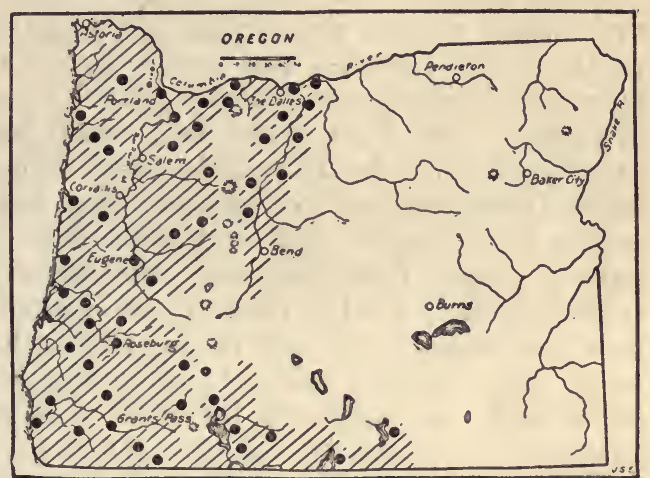

Figure 26.-Range of Douglas's ground squirrel, ing in deep burrows of their own excavation, in hollows among the rocks, or temporarily in hollow trees or logs. They often climb trees for acorns, nuts, or fruit, but if surprised in treetops always rush to the ground and away to the nearest burrow for refuge. Their burrows, if deep, are usually marked by large mounds of earth at one side, and by trails leading off through the grass and weeds to other burrows or to feeding grounds. They are often excavated under the edges of rocks, stumps, or logs, but sometimes out in the open or even in fields or meadows.

Vigilance is the price of safety, and the utilization of open ground or convenient stumps, logs, or boulders as watch towers are necessary in their home economy. In a colony the sharp, barking whistle of alarm may be heard at intervals, and is passed on from rock to rock or stump to stump as some enemy is sighted or danger threatens. It is strangely like the call note of the marmots or woodchucks, and used in the same manner as warning of danger. Sometimes at close quarters or on sudden alarm it runs into a long churrrrr or a guttural chuck as the squirrel dives for its burrow and disappears.

Hibernation.-In late autumn these squirrels become very fat and apparently hibernate for 4 or 5 months during the coldest weather, which generally includes November and February. But this period 
varies locally with the weather, the amount of fat accumulated, and the age, the smaller young of the year being the latest to enter winter quarters. Occasionally on warm days in November a few may be seen out long after general hibernation has begun, and in the Rogue River Valley warm days sometimes bring them out even in December.

Breeding habits.-The young are usually 5 to 8 in a litter, but the mammae of adult females are regularly 5 pairs-1 inguinal, 2 abdominal, and 2 pectoral. In Oregon most of the young are born in May, but they do not usually appear aboveground until the latter half of June, and for a considerable time keep close to the burrow, where they are carefully watched by the mother. It is doubtful if more than one litter of young is raised in a season, as there is only enough time for them to grow up and get fat before cold weather comes.

Food habits.-The digger squirrels have very large stomachs and are hearty eaters, in summer gorging themselves on green foliage, roots, bulbs, flowers, and green seeds, and in autumn eating more ripe seeds, grains, and nuts. Some grasshoppers and other insects are eaten, and fresh meat bait often lures them into traps set for other animals. In June 1915, near Eugene, they were digging and eating great numbers of camas bulbs, but at the same time they were eating much green stuff and some insects. Later in the season they gather acorns from the oaks, not waiting for them to fall off, and eagerly search for the nuts on the beaked hazel bushes. Some spruce and pine-cone seeds are eaten, the scales being cut off and left in little heaps on the ground, or on logs or stumps. Many grass and weed seeds are gathered for food, and grains of all kinds are eaten wherever they can be found. Much scattered grain along roads or in harvested fields is gleaned, but grain is eaten from the time it begins growing until it is ripe. Fruits, wild and cultivated, are extensively eaten, as well as a great variety of berries, cherries, plums, prunes, peaches, apples, and pears.

Economic status.-Locally these squirrels are very destructive to crops, especially as their choice of habitat is the open valley country where most of the agriculture is carried on, and where much grain is raised. They begin feeding on the seed of all grains as soon as sown in spring, then eat the sprouting grain, the growing blades and stems and the green, ripening heads, and when the kernels are ripe carry away and store them in the burrows. If the grain is cut and shocked, or stacked, the destruction often continues until it is threshed and disposed of. Many other crops are also injured by them. Apples, pears, prunes, plums, cherries, peaches, apricots, almonds, and other cultivated fruits and nuts suffer from their depredations.

Fortunately the squirrels have a potential food value that should help to keep their abundance under control. If properly prepared and cooked they are just as good eating as the tree squirrels, and their use as food should be encouraged. Sometimes it is necessary to shoot, trap, or poison them to protect crops, and very successful methods of poisoning have been perfected by the Biological Survey. The use of poison should not be left in unskilled hands, as serious damage to valuable wildlife is sure to follow. 


\section{CITELLUS COLUMBIANUS COLUMBIANUS (ORD)}

\section{Columbian Ground Squirrel; Burrowing Squirrel}

Arctomys columbianus Ord, Guthrie's Geogr., 2d Amer. ed., 2, p. 292, 1815, from description by Lewis and Clark.

Type locality.-Camas Prairie on Jim Ford Creek about 7 miles northeast of the mouth of Lolo Fork of Clearwater River, Idaho.

General characters.-Body large and heavy (pl. 29, B) ; tail short, wide and bushy; ears short; soles half naked, heels hairy; cheek pouches small and little used; fur soft and lax with coarse outer hairs. Summer pelage, upper parts coarsely grizzled brownish gray, lighter gray across top of neck; face, feet, and legs, and sometimes whole top of tail deep rufous or rusty brown; tall usually dark gray or rufous above and below with three concealed black lines along each side and around tip and with tips of long hairs frosted with white or fulvous; lower parts pale fulvous, becoming deep fulvous or rusty brown in anal region. Winter pelage and young essentially the same.

Measurements.-Average of 10 males: Total length, 375 $\mathrm{mm}$; tail, 107; foot, 54; ear (dry) from notch, 13, from crown, 6. Weight of adults about 1 pound; of very large males, $1 \frac{1}{2}$ pounds.

\section{Distribution and habi-} tat.-From northeastern Oregon and central Idaho the range of these big ground squirrels extends northward over Idaho, eastern Washington, and western Montana into British Columbia and Alberta (fig. 27). They occupy Canadian, Transition,

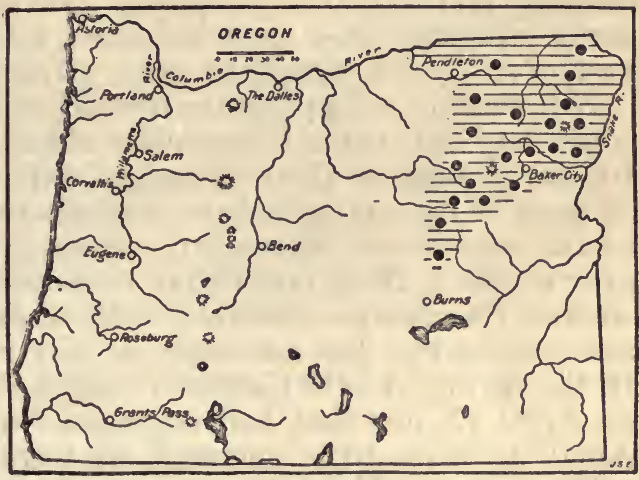

Figure 27.-Range of the Columbian ground squirrel, Citellus columbianus columbianus, in Oregon.

and Hudsonian Zones, mainly in the open country but often in brushy or sparsely timbered areas. They are rarely found in heavy timber but seem to find all the little meadows and parks scattered through the forest. As the Canadian is generally the zone of heavy forest, they are largely crowded into the more open Hudsonian above or onto the edges of the Transition plains below. In Oregon they occupy the Blue Mountain section but do not reach into the southwestern part of this plateau. Although they are numerous locally they are not generally distributed over their range.

General habits.-These burrowing squirrels were well named by Lewis and Clark, who first made them known to science, for they live the greater part of their lives underground in extensive burrows. Although almost as sociable as prairie dogs, they are less colonial in habits and are often found alone or in families, scattered far apart. In favorite sections, however, they are so numerous and so noisy in their barking, whistling, squeaking calls as to give the impression of community interdependence.

Their call note is usually a short, sharp whistle, or chirp, sometimes repeated at intervals of about 1 second for several minutes at a time, one and then another taking it up until in a populous part of their range one or several may be heard much of the time during 
the day. The note varies with circumstances, seeming at times unemotional, but in the face of imminent danger being sharp and forceful, and even crowded into a wild, blended chirrrrr as one is surprised by an enemy, or even into a shriek of alarm at a narrow escape. Each takes its turn at calling or occasionally reports its presence by a few short chirps, while feeding.

Feeding and preparing deep burrows and warm nests for winter are their principal summertime activities. New burrows are dug or the old ones deepened and extended, and before cold weather begins dry grass is carried in for big warm nests. A new burrow is generally simple, with a front door where all the earth is thrown out, and a concealed back door some 10 or 15 feet distant. The nest cavity is usually 2 or 3 feet below the surface of the ground and large enough for a big nest a little above the lowest part of the tunnel. Several smaller cavities and short side tunnels are generally dug for sanitary and unknown purposes. Old dens that have been used for many years are often more elaborate with many openings and several nest cavities and numerous other cavities and side tunnels.

Hibernation.-Apparently the old males, which are the first to become very fat, enter hibernation about the last of July; the others follow as soon as their skins are well lined with fat. By August 15 most of the squirrels have disappeared into their burrows, but up to the middle of September, especially at higher elevations, halfgrown young from late litters occasionally are found active, busily stuffing their large stomachs with seeds and forage in an effort to accumulate the fat necessary to carry them through the winter. In the spring of 1919 Cantwell caught the first one at Wallowa Lake on April 13, one that had appeared through 6 inches of snow. By April 18 they were common in warm grassy places among the yellow pines. The large ones were still very fat, but some small ones were poor, with the skin clinging tight to the flesh. On April 28 he found them abundant at Sled Springs and over the Imnaha Plateau, where they had appeared about April 20. These localities are in the middle elevations of their range. Higher and lower the hibernation dates may vary somewhat.

Breeding habits.-According to W. T. Shaw, who has made an intensive study of these squirrels, the mating season begins shortly after they come out of hibernation. The period of gestation is 24 days. The naked, blind, and toothless young grow rapidly and begin to open their eyes on the seventeenth day and to come out of the burrows when 21 to 24 days old. Shaw $(1925, p$. 108) gives 5 as the average number of young in a litter. The mammae of the females are arranged in 5 pairs -1 inguinal, 2 abdominal, and 2 pectoral-borne on 4 separate mammary glands.

Food habits.-In early spring young green plants, roots, and bulbs form most of the food of these squirrels. With the store of fat left over from the fall, these carry them through the mating season. As soon as the early flowers appear the squirrels eat them. Later the green and ripening seeds of a great variety of native, introduced, and cultivated plants form most of the food. Berries and grasshoppers, caterpillars, and other insects are eaten to a slight extent, but toward fall the ripe seeds and grains are especially sought and the large stomachs are distended with the richest food available. 
Apparently no food is stored for winter use nor do they carry food in the rather small cheek pouches.

Economic status.-In Washington, Idaho, and Montana these squirrels are among the most destructive rodents in the grainfields, causing heavy losses each year. Their limited range in Oregon, however, is fortunately not in an extensive grain-producing section. Around the edges of the Grand Ronde and Wallowa Valleys and over part of the Imnaha Plateau they do come in contact with grainfields, and locally destroy much of the growing and ripening grain, feeding on it from the time the seed is sown until the harvested crop is securely shut away from them. Their large size en ables them to pull down the standing grain and eat the heads, so that in addition to the considerable amount eaten, much is tangled and wasted. On the stock range they also consume much valuable forage, so that it is necessary to destroy them locally.

Lewis and Clark found them good food when other game was scarce, and in camp the writer has enjoyed many good

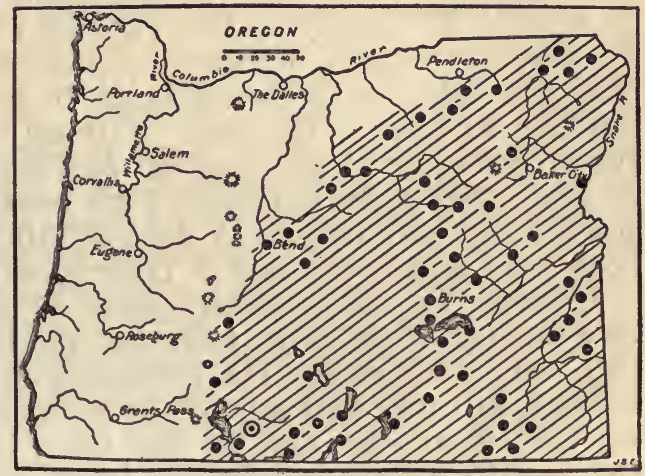

Figure 28.-Range of the Oregon ground squirrel, Citellus oregonus, in $\mathrm{Oreg} \mathrm{g}$. Type locality circled. meals from them. Their habits are exemplary as food animals, and their use for food should be encouraged.

$$
\begin{gathered}
\text { CITELLUS OREgonUs (Merriam) subspecies of } \\
\text { beldingi }
\end{gathered}
$$

Oregon Ground Squirret; Me-sas of the Klamath (C. H. M.) ; KUA-PA of the Piute at Burns

Spermophilus oregonus Merriam, Biol. Soc. Wash. Proc. 12: 69, 1898.

Type-Collected at Swan Lake Valley, Klamath County, Oreg., by Vernon Bailey in 1897.

General characters.-A medium-sized ground squirrel about half as large as Citellus columbianus and twice as large as $C$. mollis canus; ears short; tail $11 / 2$ times the length of hind foot; soles half naked; fur short and soft. Color about the same at all seasons and ages, upper parts buffy gray, becoming brownish gray on nose and back; tail clear chestnut below, with black tip and margins; top dusky gray with buffy tips to long hairs; feet and lower parts buffy gray.

Measurements.-Total length, $280 \mathrm{~mm}$; tail, 68; foot, 42; ear (dry), 10, from crown, 5. Average weight of adults, $302 \mathrm{~g}$ (about 10 ounces). (Grinnell and Dixon, $1918, p .658$.) One large moderately fat male, in eastern Oregon, weighed 1 pound on August 2.

Distribution and habitat.-These medium-sized and plain-colored ground squirrels are the most abundant and widely spread species in the State, occupying the more open parts of the Transition Zone in Oregon east of the Cascades, and extending into northeastern California, northern Nevada, and southwestern Idaho (fig. 28). They 
are not a forest or desert species, but occur most abundantly in the meadows and grassy parks and openings in or along the edges of the yellow pine timber. A few often follow down the stream courses into the edges of the valleys, but not far below their zone, except in such cases as the colony that reaches to the Snake River at Home in Baker County.

General habits.-These are typical ground squirrels, living on or under the surface of the ground, generally in the open, and depending entirely on their burrows for protection. At one moment they may all be standing up like a lot of stakes in a meadow, and the next all out of sight underground, a few short sharp whistles or squeaks having given the warning of approaching danger. The burrows are usually numerous and seem always to be close at hand. In a few minutes the heads begin to pop up from one burrow and another to inspect the field cautiously and when the danger has passed the squirrels are soon out feeding again. In tall grass, weeds, or grain they make numerous little roadways, and run from place to place under safe cover. A field of alfalfa or growing grain affords both food and cover, and a favorite site for new burrows.

Hibernation.-Fortunately these squirrels are inactive during 7 or 8 months of the year, from the middle or last of July to the first or middle of March. The beginning of hibernation varies with the seasons, altitude, and age of the animals; the old males become fat earliest, disappear first at the lower levels, some early in July; the smaller young remain out latest, but rarely beyond the 1st of August. At higher elevations they are sometimes a month later in entering hibernation, which probably means a month later in coming out in spring. At Fort Klamath, Telford reported them still securely buried under 14 inches of snow on March 9, 1914, but out of their dens at Klamath Falls on March 12.

Breeding habits.-Six or seven young in a litter seems to be the usual number, but as high as 12 and 15 have been reported (Grinnell and Dixon, $1918, p$. 658). The mammae of adult females are in 5 pairs-1 inguinal, 2 abdominal, and 2 pectoral-and 10 young would supposedly be the normal maximum.

The time of breeding varies with the altitude and time of emerging from hibernation, the mating season beginning soon after the spring awakening. The small young begin to appear out of the burrows early in May, but at higher elevations many small young are seen in June. By the first of July many of the young are scarcely full grown and apparently some are forced to hibernate before they have had time to accumulate a large supply of fat. Whether these survive the winter will not be known until the species is more closely studied, but it seems probable that the improvement of the race depends on the survival of the fattest.

There is scant time for one litter in the short season of activity and no possibility of a second.

Food habits. - The food of these squirrels in spring and early summer consists mainly of roots, bulbs, and green vegetation, including grasses, clovers, and a great variety of succulent plants, which fill the large stomach with juicy green pulp, mottled with bright colors from many flowers, and occasionally bright berries. A few bits of grasshoppers and other insects are also found in the 
stomachs, and later in summer the ripening seeds and grains form more of the food. By the time the summer is half over many of the squirrels are so fat that they fairly waddle as they run, and their feeding time is nearly over for the season. No stores are laid up, and the cheek pouches are little used.

Economic status.-These are by far the most numerous, widely distributed, and destructive ground squirrels in Oregon, generally common over the principal grain-producing area of the State east of the Cascade Range and often exceedingly numerous. Formerly they occupied the best grass area, which has now become the best wheat area.

In Swan Lake Valley in June 1897 the writer counted 30 of the squirrels standing up watching him on a quarter of an acre of pasture land, and they seemed to be no more numerous there than over the greater part of the valley. Probably 100 to the acre would be a fair estimate of their numbers in many fertile valleys in the State. In Hay Creek Valley, May 10, 1915, Jewett saw the bodies of several hundred of these squirrels on about 2 acres of alfalfa land that had been treated with poisoned grain the night before. Apparently the squirrels were about as numerous in this grain- and hay-producing valley then as when the present writer recorded their abundance there 19 years before, although poison, guns, traps, dogs, and cats had been used against them since the early settlement of the valley. In many places their numbers are temporarily reduced by poison or bounties, but they are soon back to original abundance, and it is doubtful if they are less numerous in the State today than they were 25 or 50 years ago.

They feed on the spring grain when it is first sown and while sprouting, growing, and ripening, and even after harvest if it is left in the fields. Winter wheat and rye partly escape, but the writer has seen a 30 -acre field of rye with 2 or 3 rods of the edges crumpled down and practically ruined by the squirrels in June, before it was ready for harvest as hay. Their destruction of hay and forage, alfalfa, clover, grass, and other forage plants, while less noticed, is probably as serious as their destruction of grain. Of the heavy tax laid on farm products in Oregon by rodents, these squirrels may probably claim the largest share.

There is no reason why they should not make some returns as a meat supply, however, as they are good eating, and their abundance partly compensates for their small size.

The destruction of their natural enemies-hawks, badgers, weasels, skunks, bobcats, foxes, coyotes, and snakes-probably accounts for their being able to hold their own in the face of the sporadic warfare waged against them. Only an efficient organization and the best modern methods of destruction will materially reduce the losses from these animals.

\section{CITELLUS TOWNSENDII (BACHMAN)}

Townsend's Ground SquTrRel; Speckled Ground SQuTrRer; Tetwo of the Walla Walla and Nez Percé (J. K. T.)

Spermophilus townsendii Bachman, Jour. Acad. Nat. Sci. Phila. 8:61, 1839. Type.-Collected at mouth of Walla Walla River, Wash., by J. K. Townsend in 1834. 
General characters.-Size between Citellus mollis canus and $C$. oregonus; ears and tail short; soles mainly naked; fur short and thin. Colors about the same at all seasons and ages, upper parts ashy gray, the whole back thickly dotted with small white spots; nose and hams and lower surface of tail pale rusty; lower parts and feet buffy.

Measurements.-Average of 10 adults : Total length, $222 \mathrm{~mm}$; tail, 44 ; foot, 34.5; ear (dry), 8, from crown, 2.

Distribution and habitat.-These little fat, short-tailed, gray, speckled-backed ground squirrels are abundant in the hot, dry, sandy, Upper Sonoran Zone bottom of the valley south and east of the Columbia River from near the mouth of the John Day River to Walla Walla, and north over the lower parts of the plains of the Columbia to Spokane, Wash., and east in the Snake River Valley to Lewiston, Idaho (fig. 29). They meet but rarely overlap the ranges of the

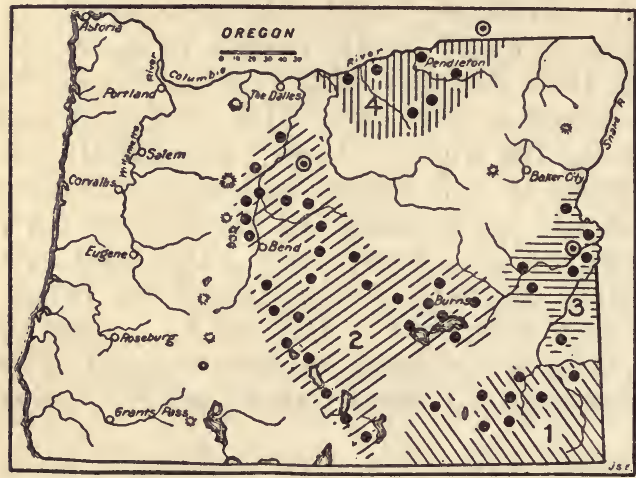

Figure 29.-Range of the sage and Townsend's ground squirrels in Oregon: 1 , Citellus mollis mollis; $2, C$. m. canus; $3, C$. m. vigilis; $4, C$. tounsendii. Type localities circled. larger Oregon and $\mathrm{Co}$ lumbian ground squirrels, which may help to determine the ir boundaries, but apparently the limits of range of all are zonal. They occupy the open sagebrush or grassland country and show a preference for sandy soil where digging is easy.

General habits.-Protected by their gray and $\mathrm{s} \mathrm{peck}$ e d colors in the gray vegetation of their somewhat arid habitat these little squirrels would be inconspicuous but for their great numbers and their lisping whistle, which sounds from one and another on all sides over the grassy prairies, from the steep hillsides, the gulch banks, and sandy bottoms. They are social in habits, but not colonial, gathering most abundantly where there is most food, living in harmony and to some extent mutually benefited by numbers, always on the watch for danger and ready to signal an alarm. When undisturbed they creep quietly about or run low over the ground. At the first suspicion of danger, they stand straight up on the hind feet, the short tail not reaching the ground, and the hands dropped at the sides, as they watch for the menace. A whistle from one will bring all within hearing to their picket-pin attitude of vigilance, and as the whistle is passed along others take it up until hundreds may be seen standing motionless. In places the ground is honeycombed with their burrows (as many as 620 have been counted on a measured acre), and in case of danger each squirrel darts down the nearest burrow. A whole field of them may disappear in a twinkling.

The burrows are generally simple, or but little branched, going down 4 or 5 feet and back several feet to a nest cavity. There seems usually to be but one opening to the surface, but this may apply only to the new or temporary burrows. No breeding or wintering dens were explored. 
Food habits.-In June these squirrels were found feeding on green leaves, tender plant stems, flowers, roots, bulbs, insects, seeds, and young grain. In places the seeds of alfilaria formed over half the contents of all the stomachs examined. Seeds of plantain, grasses, and wild mustard were also recognized in the stomachs, also a few caterpillars, cicadas, and small beetles. In a garden they were eating young cabbage plants, green peas, and young corn. In the fields they were cutting down the growing rye and eating out tender sections of the stems and the flowering heads, cutting many stems for the little food obtained. Later as the grain forms, all of the kernels are eaten, wheat, rye, and barley especially suffering from their depredations. By the middle of harvest time, however, having become excessively fat, they enter a state of hibernation. Apparently they do not lay up any stores of food, and rarely is any food found in their rather small cheek pouches.

Breeding habits.-The females have the usual arrangement of mammae in 5 pairs -1 inguinal, 2 abdominal, and 2 pectoral. The 5 to 10 young are born apparently in March and April, and appear out of the burrows in April and May, are well grown by the middle of June, and well fattened by the first of July. In the very mild climate of the Columbia Valley they keep about a month ahead of the higher country ground squirrels.

Hibernation.-During the early part of July most of these little squirrels have accumulated about as much fat as their skins can hold, and they disappear into their burrows to be seen no more until the latter part of February or early March of the following year. When first emerging from their 8 months of inactivity they are said still to be well supplied with fat, which is soon lost during the breeding season, and before food becomes plentiful. Their unusually early hibernation, or aestivation, is probably due to the long, dry summer period and scarcity of moisture.

Economic status.-The great abundance of these little squirrels in an almost exclusively grain-producing area renders them almost as serious a pest as some of the larger species. Over the most populous part of their range in 1896, their numbers were estimated at 50 to 100 to an acre and 620 of their burrows were counted on a measured acre. Small fields of grain are sometimes entirely destroyed by them before ripe enough for harvest, and every field within their range suffers to greater or less extent, according to the expense and effort put forth in destroying the squirrels.

Poisoning, trapping, and shooting are the usual methods of destruction, but the native enemies of the squirrels should, as far as possible, be protected and encouraged. Of these the badger probably stands first in importance. On 1 acre near Pendleton in 1896 62 holes were counted where a badger had dug out the burrows and evidently in most cases had feasted on a fat squirrel at the bottom. Weasels, skunks, bobcats, and coyotes help to keep down, the pest, and numerous hawks and day-hunting owls do their best to protect the crops.

The squirrels are good eating if the oily fat is removed. 


\section{CITELLUS MOLLIS MOLLIS (KENNICOTT)}

Sage Squirret; PuUte Squirrel; Koop or Goop of the Piute at Pyramid Lake (C. H. M.)

Spermophilus mollis Kennicott, Acad. Nat. Sci. Phila. Proc., p. 157, 1863.

Type Tocality.-Camp Floyd, near Fairfield, Utah.

General characters.- Small, short, and plump with short tail, short legs, and minute ears. Fur short and soft. Plain buffy gray over back and warm fulvous over head, neck, legs, and tail; feet and lower parts well up onto the sides clear buffy; winter pelage, feet and lower parts pale buffy or whitish, but with the same fulvous head, collar, legs, and tail.

Measurements.-Largest adult female: Total length, $210 \mathrm{~mm}$; tail, 46 ; foot, 34 ; ear, inside, 7 , outside, 1 . Two large and moderately fat specimens weighed 8 ounces each.

Distribution and habitat.-From a wide range over the upper Sonoran sagebrush deserts of western Utah, southern Idaho, and much of Nevada these soft little squirrels come into the Owyhee and Alvord Valleys of southeastern Oregon in their typical form (fig. 29). In 1915 Preble collected specimens at Rome and reported them all along the Owyhee Valley and up onto the slopes of the Juniper Mountains. In 1927, July 2 to 7 , the writer found them abundant throughout the Owyhee, Jordan, and Rattlesnake Valleys, up Crooked Creek and over to the Sink of White Horse Creek, over the low divide to Alvord Valley and all over the sagebrush bottom of this great basin from the Nevada line on the south to its northern end. Also they were abundant in the headwaters basin of Quinn River, north of Old Fort McDermitt on the Oregon-Nevada line, but their real connection in range with the Nevada Valley country is through the wide open southern end of Alvord Valley south of Denio, where it joins the upper Quinn River Valley.

Along more than 100 miles of desert road they were common, and many were shot for specimens, examination, and study. They seemed especially partial to sandy soil and fairly revelled in the extensive sand dunes and sandy shores of the great playas of the Alvord and White Horse Valleys. In places their little burrows were in the open and afforded almost the only cover, but generally they were under the protecting shade of sagebrush or greasewood or some of the low desert shrubs. Generally the little squirrels were seen running for the nearest burrow, but occasionally one would be seen standing erect like a stake or sitting on top of a sagebrush watching for danger.

General habits. - Their fine little squeally whistle was often heard from behind a bush, but it would give little clue to their position, and the gray sand colors were most effective in concealing them from view until they moved. Often the only glimpse of one was a mere twinkle as it scuttled into a burrow and out of sight. During the hot part of the day they were less abundant, and numerous tracks about their burrows and along the trails and roads indicated the morning and evening hours as the busy times of day.

In early July the young were nearly full grown, but they remained at the parent burrow or near by, while the adult males were getting a heavy coat of fat and the females and young beginning to show fatty deposits under the skins. 
Hibernation.-These little squirrels usually begin to hibernate about the first of August, although a few late young may be seen out a little later. Generally they reappear during March and promptly begin breeding operations.

Food habits.-The stomachs of those shot for specimens were well filled mostly with green vegetation, seeds, and flowers, with usually a trace of insect remains. The moist stomach contents could easily supply all the water necessary for their bodily needs, as little is carried off by the dry, hard pellets, and much of the food would run 50 to 75 percent of water by weight. They are thus well adapted to desert conditions and to life in dry valleys where often no rain falls for months at a time.

Economic status.-Over most of their range these squirrels are of little economic importance, and they add a bit of wildlife interest to the deserts, but in the fertile and irrigated valleys they sometimes gather along the edges of alfalfa and grain fields in sufficient numbers to do serious damage to crops and must be reckoned with accordingly.

Among the Piute Indians they have long been a source of food supply and are often hunted by the boys with bows and arrows, sticks, and buckets of water. A gallon of water poured down a burrow will often bring out the occupants; blinking and choking, to be easily killed with a stick or shot with an arrow. Their meat is very palatable, rich, and tender. No animal could be cleaner or more exemplary in its own food habits.

Townzend,

CITELLUS MOLLIS CANUS (MERRIAM)

Gray Sage Squirket

Spermophilus mollis canus Merriam, Biol. Soc. Wash. Proc. 12: 70, 1898.

Type.-Collected at Antelope, Oreg., by Vernon Bailey in 1896.

General characters. - Small and plump, ears minute, tail insignificant, fur short and very smooth. Smaller and grayer than $C$. mollis mollis. Colors much the same at all seasons and ages; upper parts clear, fine, uniform buffy gray; nose and hams dull ochraceous tawny; feet, sides, and lower parts clear buffy ; tail gray, edged with buff.

Measurements.-Average of 10 adults: Total length, $208 \mathrm{~mm}$; tail, 40 ; foot, 31 ; ear (dry), 6, from crown, 1.

Distribution and habitat.-These little soft gray ground squirrels occupy the Upper Sonoran sagebrush plains from the type locality on the high ridges between the Deschutes and John Day Rivers, south through the valleys to northwestern Nevada, and east into the Malheur Valley of Oregon (fig. 29). They are a northern form of the mollis group, which occupies the Upper Sonoran Zone of practically the whole of the Great Basin region.

General habits.-These are quiet, secretive little squirrels, soft voiced as they are soft in body, fur, and colors. They blend into the gray soil and gray sagebrush colors, and but for their abundant numbers and soft, lisping whistle, or long squeak, would be passed by unnoticed.

They burrow under sage bushes or in the open and keep close to their burrows, or, rather, seem always to have burrows close to where they are. Mellow soil is preferred, and ditch banks, which are often honeycombed by them, are a favorite site for the burrows. Plowed fields and dry meadows are also sought for homes if food is abundant. In places they seem almost colonial, but apparently 
only from gathering on suitable soils or near supplies of favorite food.

At the first alarm of danger they dive into the burrows, and it may be a few minutes or a half hour before a little black eye appears cautiously at the edge of the doorway, and the little smooth head gradually comes farther and farther out until the animal stands up and makes a careful survey to see if the coast is clear before resuming the usual occupation of gathering food.

Hibernation.-In the latter part of July or early in August these squirrels gradually disappear in their burrows, the oldest and fattest going in first, and the youngest last. They are not seen again until early in March, except by badgers that dig them out. There are no definite records of appearance in spring but the records of young out of the burrows in May would indicate that the mating season begins in the early part of March.

Breeding habits.-On May 24, 1915, Jewett found these squirrels common on the dry mesa east of Hay Creek, where he caught 21 in his traps, mostly small young. To have been out at that date, they must have been born some time in late April or early May. There seem to be no records of embryos or families of young to indicate the number in a litter, but the usual number of 10 mammae-1 inguinal, 2 abdominal, and 2 pectoral pairs-judging from related species, would indicate 5 to 10 young at a birth. There is no possibility of more than one family of young in a season and scant time for these to grow up, get fat, and be ready for hibernation by the first of August.

Food habits.-Many green plants, roots, and bulbs, a great variety of seeds and grains, and a considerable variety of insects make up the list of known foods of the species. Alfalfa, clover, and various grasses-all green and growing-as well as ripening grains and many valuable forage plants, are eaten. In places where cicadas were numerous the squirrels were found feeding quite largely on these insects. Their stomachs are very large and usually are well filled, especially late in the summer when all their efforts are concentrated on storing sufficient fat for the period of hibernation.

Economic status.-Over most of their range these little desert squirrels do not come in touch with agriculture, but in some of the wheat-growing mesa tops and in some of the irrigated valleys they are numerous and destructive to crops.

They are poisoned, shot, trapped, and generally destroyed at considerable expense of time and materials, while their principal enemies-the badger and numerous hawks and a few owls-are in many cases wantonly destroyed also.

If the squirrels are as good eating as their relative, mollis, they might be partly controlled by utilizing them as a food supply. The Piute Indians are very fond of them.

\section{CITELLUS MOLLIS VIGILIS MERRIAM}

\section{SPECKLed SAGE SquTrReL}

Citellus canus vigilis Merriam, Biol. Soc. Wash. Proc. 26: 137, 1913.

Type-Collected at Vale, Oreg., by Stanley G. Jewett, April 29, 1910.

General characters.-Small and plump; ears minute, tail insignificant, soles naked except heels; fur soft and smooth, but browner and more grizzled than 
in mollis or canus. Color, similar at all seasons and ages; upper parts finely specked or coarsely grizzled brownish gray; nose and hams touched with pale tawny; tail dark gray, bordered with buffy; feet, sides, and lower parts clear buffy.

Measurements.-Average of 10 adults: Total length, $210 \mathrm{~mm}$; tail, 38 ; foot, 34 ; ear (dry), 6 ; from crown, 1.

Distribution and habitat.-These little ground squirrels occupy the low, hot valley of the Malheur and Owyhee Rivers in extreme eastern Oregon, representing the mollis group of the whole Great Basin area in this limited area of low, hot desert country (fig. 29). They apparently blend into mollis on the south and canus on the west.

General habits.-At Vale where he collected the type and a good series of specimens in May 1910, Stanley G. Jewett reported them as common all over the valley and even up on the rocky foothills to the south. He says they make their burrows anywhere that suits their fancy from the river banks to the highest hills. When alarmed, they fairly fall over themselves in their haste to get into the burrows, uttering a shrill whistle.

When a burrowing owl flies over a field, the alarm is spread in all directions and every squirrel disappears as if by magic. In 1916 Robert H. Becker, collecting specimens at Vale and Ontario, reported them abundant in the fields, along the fence lines, on the levees and ditch banks, out among the sagebrush and boulders, and on valley slopes and hillsides-no place was free of them. They were especially numerous in grain and alfalfa fields where they were doing much damage.

Hibernation.-On July 16, at Riverside, they had mostly gone into winter quarters, but one was secured and a hawk was found eating another that was still warm. On July 19, 1896, Merriam saw them along the stage road from Westfall to Beulah. On July 28 and 29, Preble found where they had been numerous over the Cedar Mountains but had all denned up except one caught in a gopher trap and another seen but not secured. From August 4 to 6, he could find none over the valley from Riverside to Vale as they were all deep in their dens for the rest of the summer and most of the winter. Nothing definite is known of the time of appearance in spring, but it must be early, probably in February or March, as the young are appearing out of the burrows in the latter part of April and early in May.

Breeding habits.-The mammae of the females are arranged as in others of the group in 5 pairs, 1 inguinal, 2 abdominal, and 2 pectoral. The number of young in a litter is probably 5 to 10 as in other forms of the group. Small young out of the burrows on April 30 and in the early part of May would indicate that they are born early in April or throughout the month.

Food habits.-Near Huntington on May 18, 1896, a colony of several hundred of these little squirrels were living on a sandy flat just back from the river. The stomachs of those collected for specimens all contained green herbage, flowers, and unripe seeds. The yellow heads of sunflowers and other composites and the purple flowers of legumes and alfilaria were conspicuous in the food of both old and young. Even at that early date all were laying in their store of fat. At Vale, Jewett reported them feeding largely on wild 
sunflower seeds, flowers, and foliage, but eating other green vegetation and getting into traps baited with meat. Growing or ripe grain, alfalfa, and many other farm crops are extensively eaten.

Economic status.-These are the only ground squirrels in the valleys where they occur, and while small they are often so numerous as to be as destructive to crops as some of the larger species. There is much irrigated and highly cultivated land within their range, and much more that will eventually be brought under cultivation. When a new field is cleared and planted the squirrels flock in from the surrounding sagebrush and wild land, and if the field is small, they sometimes destroy the whole crop, eating the seed, the growing grain, and the ripening heads. The borders of large fields are often left in a ragged and much injured condition, and serious losses are sustained in both grain and meadow crops.

As with other species of ground squirrels poison, traps, and guns are used to keep down their numbers, and only by constant vigilance can serious losses be prevented. The protection of such natural enemies as badgers, skunks, weasels, hawks, and owls is rarely given the importance it deserves, and many of these best friends of the farmer are wantonly destroyed. Like other members of the Citellus mollis group these little squirrels could be utilized as food with a double advantage.

\section{CTTELLUS ELEGANS NEVADENSIS HowetL}

\section{Nevada Ground Squirree}

Citellus elegans nevadensis Howell, Biol. Soc. Wash. Proc. 41:211, 1928.

Type.-Collected at Paradise, Humbolt County, Nev., by Stanley E. Piper, March 3, 1908.

General characters.-Somewhat larger than the Oregon ground squirrel, and with relatively longer tail; lower surface of tail ochraceous instead of rusty; Summer pelage, upper parts buffy gray, specked with buffy and dusky; ears, feet, sides, and whole lower parts clear rich buff or ochraceous; winter pelage lighter, more grayish above and clear ochraceous below.

Measurements.-Adult male: Total length, $315 \mathrm{~mm}$; tail, 98 ; foot, 48 ; ear, inside, 13, outside, 7 . Weight, $11 / 2$ pounds (not much fat, stomach full).

Distribution and habitat.-This extreme western form of the Citellus richardsonii and elegans group reaches into southeastern Oregon on the high Transition Zone plains north of Fort McDermitt, and may well have a continuous range through the Bruneau Mountains of northern Nevada and southern Idaho to the previously known range of elegans in southeastern Idaho and Wyoming.

Three specimens were secured by the roadside on top of the divide between the headwaters of Quinn River and Rattlesnake Creek, in Malheur County, Oreg., and others were seen along the road over the top of this plateau and easily recognized by their strikingly yellowish colors.

The one old male collected on July 2 , in full summer pelage, was not very fat but was in good condition. Its stomach was well filled with green foliage, flowers, and seeds of various plants, and its cheek pouches were stuffed to their utmost capacity with ripe seeds of Collomia in 1,160 capsules, a few small seeds of Collinsia, and a little crucifer. The cheek pouches were so large as to give the head the appearance of being triple its normal size. The smaller 
male and female collected the same date were apparently young of the previous year, showing no indications of breeding.

In the broad valley near McDermitt, Preble found them living in the same meadows with oregonus and collected four specimens in early June of 1915. So far these two localities show the only Oregon records.

The specimens collected at the type locality, Paradise, Nev., by Piper, March 3, 1908, and others collected at Mountain City, Nev., by W. K. Fisher, in 1898, and by the writer at Elko and in the Ruby Mountains the same year carry the range of the form well across northern Nevada.

\section{MARMOTA FLAVIVENTRIS FLAVIVENTRIS (AUduBoN and BACHMAN)}

YexLow-Bellied Marmot; Woodchuck; Ground Hog; Rockchuck; Mo-E of the Klamath (C. H. M.); CHrk-cHrk-No of the Wasco

Arctomys faviventris Audubon and Bachman, Acad. Nat. Sci. Phila. Proc., p. 99, 1841.

Type locality.-Fixed as Mount Hood by A. H. Howell $(1915, p .40)$. Type skin in British Museum; collected by David Douglas, but no locality given.

General characters.-Large and heavy; legs short, tail short and bushy, ears low, soles wholly naked, thumb a mere rudiment with flat nail; fur long and lax, concealed by coarse outer hairs. Color approximately the same at all ages and seasons, upper parts dark brown, coarsely grizzled over back and sides with buffy white subterminal sections of coarse outer hairs ; tail plain or rusty brown, fading to yellowish; sides of neck and $\mathrm{h} \mathrm{ams}$

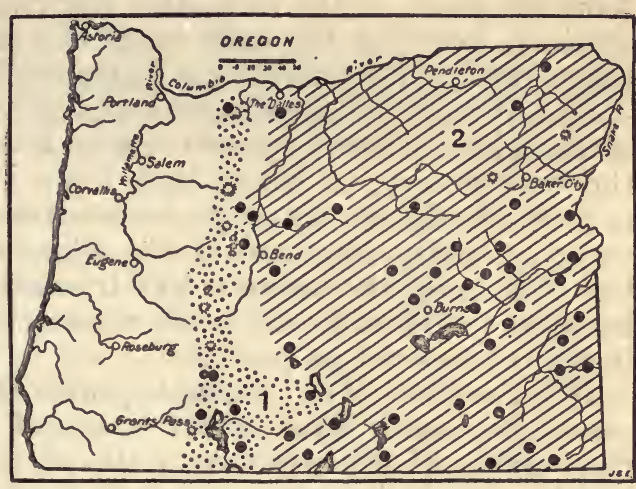

FIgure 30.-Range of two forms of woodchucks, or ground hogs, in Oregon: 1, Marmota flaviventris flaviventris; $2, M . f$. avara.

bright buffy ochraceous; legs, feet, and lower parts tawny; nose and chin whitish, and sometimes a whitish or grizzled bar across face in front of eyes. Measurements.-Adult male: Total length, $700 \mathrm{~mm}$; tail, 180 ; foot, 90 ; ear (dry), 20, from crown, 10.

Distribution and habitat.-These large, richly colored marmots inhabit the Cascades of Oregon, and extend south through the northern Sierra Nevadas to the Lake Tahoe section, mainly in Transition and Canadian Zones wherever there are extensive rock masses. Their range is very irregular and apparently not continuous, as the smaller plains form, avara, comes to the summit of the Cascades north of Three Sisters, while south of Crater Lake there are no records of marmots in the mountains until the Mount Lassen section is reached. They seem to follow the lava fields of the Klamath and Pit River country, and to have a roundabout, partial connection between the Cascades and the Sierra Nevadas (fig. 30).

General habits.-These western representatives of our eastern woodchucks are neither "woodchucks", as they rarely live in the woods, nor "ground hogs," as they rarely live in the ground. They 
are sometimes called "rock chucks", because they live usually among the rocks, but the Old World name of marmot seems best suited to them. Being heavy, slow, and to their numerous enemies defenseless and very toothsome animals, they must of necessity have secure protection, which is found among the rocks. Clefts and caves in ledges and cliffs or the deep interminable interstices of great talus slopes are their favorite haunts, and the seemingly erratic distribution of the species is due to the irregular uplifting and outcropping of rocks. A sloping mass of huge broken and angular blocks at the base of a lofty cliff is a favorite home for a family, or several families, sometimes. Such homes appear almost as a friendly colony. Some perch or lie flattened on high points to watch for enemies, while others wander out only a short distance from cover to feed on the short grass, native clovers, and other green vegetation. A short, sharp whistle, or metallic chirp, from a sentinel sends all rushing for the rocks with rolling gallop and flapping tails. They dive into the dark caverns or pause at the doorways to see if the danger is real or imaginary. Sometimes a chorus of short sharp whistles sounds from all parts of the rock slide but usually only the one or several sentinels keep up the calls until the danger is passed or all have taken refuge deep under the impenetrable mass of rocks.

So impregnable are their strongholds that little is known of their home habits, where or how their nests are placed, the appearance of the very young, or where they sleep through the long winter. It is probable that in many places burrows are dug under the rock piles, as occasionally they are at the edges or under some big boulder; but frequently the animals live in cracks and small caverns that go back into solid cliffs and walls where extension of the cavities would in many cases not be possible.

Hibernation.-The marmot provides no food stores for winter except the dense layer of fat inside of the skin, another layer over the outside of the muscular walls of the body, and as much stored inside as the body cavities can well accommodate. The full accumulation of fat must double the weight of the animal, but unfortunately actual weights are not available for comparison. Usually in August or September, with the coming of frosty nights, all disappear in their nests and sleep securely until the warm days of February or March, the time of entering and emerging from hibernation varying considerably with the weather, age, and food supply.

Breeding habits.-The females have 5 pairs of mammae-1 inguinal, 2 abdominal, and 2 pectoral-as in most of the ground squirrels. The number of young is probably as in other subspecies of the group, usually 4 to 6 but sometimes as high as 8. Half-grown young in June would indicate May as the time of birth and March as the mating season. Late in August the young are not full grown but large enough to take care of themselves and, except for late litters, are usually fat and ready to hibernate.

Food habits.-The principal native food of these marmots is green vegetation, short, tender nutritious grasses, little native clovers, stonecrops, and a great variety of tender plants. Later in summer it consists more of flowers and green or ripening seeds, always the richest food they can find. The stomachs are large and usually 
are found full to capacity, especially as the time for hibernation draws near and the storage of fat becomes of vital importance.

Economic status.-Fortunately these animals rarely come in touch with any kind of agriculture except grazing, and they are rarely found in such numbers as to be of any serious economic importance. In many of the most picturesque and inspiring mountain parks and over rugged cliffs and rock-strewn slopes, they give a wildlife thrill that has a real value beyond the mere utilitarian needs of food and clothing.

\section{MARMOTA FLAVIVENTRIS AVARA (BANGS)}

Pale Yethow-bethied Marmot; Woodohuck; Ground Hog; Ke-du of the Piute at Burns

Arctomys flaviventer avarus Bangs, New England Zool. Club Proc. 1: 68, 1899.

Type-Collected at Okanagan, British Columbia, by Allan C. Brooks, July 17, 1897.

General characters.-Slightly smaller than flaviventris; colors paler, especially the buffy underfur, and light buffy ochraceous sides of neck and hams; generally a whitish bar across face besides whitish chin and nose.

Measurements.-Adult male: Total length, $660 \mathrm{~mm}$; tail, 178; foot, 80; ear (dry), 19, from crown, 9. A half-grown young from the Mahogany Mountains weighed $41 / 8$ pounds. A yearling male from Jordan River, not very fat, on July 3 , weighed 8 pounds. Large and very fat adults would probably weigh much more.

Distribution and habitat.-These marmots of the lower country cover most of Oregon east of the Cascades wherever there are masses of rocks and extend from northern Nevada well into British Columbia (fig. 30). Over the low pass in the Cascades north of Three Sisters Peaks they come up to the summit of the range, evidently extending up in the great lava deposits that run down to the Deschutes Valley. Over wide areas of valley and prairie they are entirely absent, but generally in the rimrock, cliffs, canyon walls, and lava fields are more or less common. Most of their range lies in Upper Sonoran and Transition Zones, but little choice of habitat is shown other than safe cover of rocks and a satisfactory food supply.

General habits.-In no important respect do their habits differ from those of $M$. flaviventris except that in lower, warmer, drier country they may come out of their dens earlier, breed earlier, and hibernate earlier than at higher levels. In the Steens Mountains, however, they range in Kiger Gorge up to at least 6,800 feet, where Sheldon and Becker saw them out as late as August 23, after they had all disappeared at the lower levels about Diamond.

At Westfall, in Malheur County, Robert H. Becker found them unusually numerous, making their homes in the rocks along the edge of the valley, and some making burrows out in the alfalfa and grainfields at some distance from the rocks, where they were doing considerable damage. One of the ranchmen was obliged to poison them to protect his fields and claimed to have killed more than 90 during the spring and early summer.

Near Drewsey, where he was collecting specimens, Becker could get no marmots, as some Indians camped near there had killed them all for food. 
Near Juntura, Sheldon saw one in a meadow near the river, where it had evidently come down from the hills half a mile distant to get green plants and grasses during the dry season in July. Generally, however, they are found only in the proximity of rocks, from which they make quick journeys to the nearest grass patches for food, or sometimes to fields and gardens that have been planted close to the rocks.

At Elgin, in May, they were found feeding on green vegetation, unripe seeds, and to a great extent on the yellow flowers of a wild parsnip. In the Cascades, near Three Sisters, in July, they were feeding on green vegetation, including the leaves of elderberry bushes and squawgrass (Xerophyllum tenax).

Along the Owyhee and Jordan Rivers the writer found these woodchucks common wherever the cliffs and broken masses of lava rock afforded shelter and protection. Generally they were seen sitting on the rocks overlooking the valleys, but some were surprised in the meadows and alfalfa fields along the road. These always rushed to the nearest rocks for protection, and it was noticeable that no burrows were found in the open ground where badgers could easily dig out the occupants. Among the rocks the woodchucks could penetrate into narrow cavities where the badgers could not get them, but even then they were not safe from other enemies. Eagles and large hawks hunt them from above, and it is a wonder that any remain.

Along Cocomungo Creek, at the northern base of the Steens Mountains, many jaws and bones of young and half-grown woodchucks were found under the old nests of Swainson and red-tailed hawks and the nests of the great horned owl. The canyon was perfectly adapted to the needs of woodchucks; but they were scarce, evidently due to the numbers of their enemies.

One old male woodchuck, shot among the rocks on Jordan Creek, July 3, 1927, was moderately fat, and its stomach was well filled with green vegetation from the meadow below. Besides the green food, the skins of 55 large caterpillars were counted. They were freshly eaten and the skins, generally complete, were of black and yellow larvae about $11 / 2$ inches long and a quarter of an inch in diameter with a hornlike appendage at one end. Specimens saved and identified by Dr. Dyar of the Bureau of Entomology proved to be the larvae of the sphynx moth, Deilephila lineata Fab. Apparently a quarter of the stomach contents consisted of bodies and food of these large caterpillars.

On July 28 Preble caught a marmot at a burrow in the Cedar Mountains after all had been in hibernation for some time. It had evidently come out to get one more good meal as its stomach was entirely empty. On October 12, at Cord, near the head of Malheur River, Sheldon found one that a badger had just dug out of its burrow, where it had evidently been hiberating for some time. The stomach was empty except for the natural juices. A half inch of fat covered the body under the skin, and the intestines were almost invisible under the dense layers of fat surrounding them.

Economic status.-In a few localities these marmots prove troublesome in fields and gardens near extensive rock masses where they live, but in most cases their mischief is easily controlled by shooting 
or poisoning. In most localities they are practically harmless and could easily be made of some slight value as food. One that the writer cooked in camp at Jordan River was greatly enjoyed. The meat was dark, but rich and tender, and of very good flavor. Preble and his teamster, while camping in eastern Oregon in 1915, ate many of the nearly grown young, and on several occasions used the clear oily fat for shortening and with good success. These woodchucks are just big fat squirrels, and there is no reason why they should not be commonly utilized as food.

\section{Subfamily PTEROMYINAE: Flying Squirrels}

\section{GLAUCOMYS SABRINUS OREGONENSIS (BACHMAN)}

\section{Orfaon Flying Squirrex}

Pteromys oregonensis Bachman, Acad. Nat. Sci. Phila. Jour. 8: 101, 1839.

Type locality.- "Pine woods of the Columbia near the Sea."

General characters.-Fur long and very soft; tail wide and flat, skin of sides full and attached to wrists and ankles so as to form a broad monoplane when the feet are extended (pl. 26). This is the darkest and richest colored of the four forms of flying squirrels in Oregon, and apparently the smallest, although all are of the large northern group, and vary but little in size. Upper parts washed with rich hazel or chestnut brown over dark plumbeous underfur; tail becoming dusky towards tip; ring around eye dusky, cheeks brownish gray; under parts creamy white, washed with buffy or cinnamon, darkest on lower surface of tail. Immature specimens duller and more dusky.

Measurements. - Total length, $300 \mathrm{~mm}$; tail, 127 ; f o o t, 39; ear (dry), 17. Townsend's original description gave the length as $12 \%$ inches and spread of membranes 8 inches $(1839$, p.329).

\section{Distribution and habi-} tat.-These dark and richly colored flying squirrels occupy the

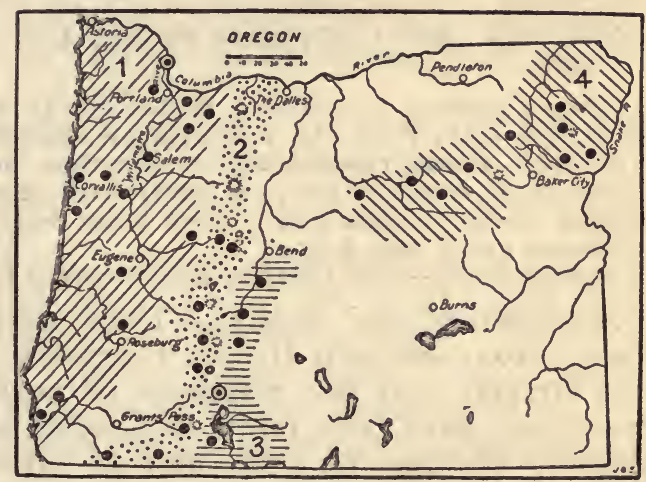

Figure 31.-Range of four forms of flying squirrels in Oregon: 1, Glaucomys sabrinus oregonen8is ; 2, G. 8. fuliginosus; $3, G .8$. klamathensis; 4, G. 8. bullatus. Type localities circled. dense forests of the humid coast region of southern British Columbia, Washington, and Oregon, south at least to the mouth of the Rogue River, and east to the base of the Cascade Range (fig. 31).

General habits.-These beautiful large-eyed, soft-furred squirrels are mainly nocturnal and hence are rarely seen and little known. Trappers find them in traps set for marten in the woods, woodchoppers see them as they soar away from falling trees in which they had their homes, and field naturalists get a few for specimens by setting traps on stumps, branches, or leaning trunks, and sometimes in old cabins and abandoned houses. They are never found far from timber and rarely on the ground. Their usual method of travel is to run up one tree and soar away to the next, always alighting at a lower level than the starting point. 
Their homes and nests are generally in hollow trees and, where these are not available, in masses of moss or old leaf nests of other squirrels, or in moss and leaf and twig nests built by themselves in forks or branches of trees. At Gold Beach, McLellan found one occupying a small spherical nest of sticks and moss in the branches of a fir tree, and some of the many nests examined in the tops of conifers undoubtedly belong to them instead of other squirrels.

The females have 4 pairs of mammae- 1 inguinal, 2 abdominal, and 1 pectoral-and the young are probably 3 to 6 in number, as in closely related forms.

The food of this form is not well known but like others of the group it undoubtedly includes a varied list of nuts, seeds, fruit, insects, and meat. Traps baited with rolled oats, bread, nuts, grain, or a bunch of cotton will catch them wherever they are common.

Economic status.-On rare occasions these squirrels get into attics, barns, or storehouses and do slight mischief, but generally they are scarce about buildings or in the open, where cats and owls prey upon them. Usually they are quite harmless and, although rarely seen, form an interesting feature of the forest wildlife.

\section{GLAUCOMYS SABRINUS FULIGINOSUS (RHOADS)}

\section{Cascade Flying Squirrer}

Sciuropterus alpinus fuliginosus Rhoads, Acad. Nat. Sci. Phila. Proc., p. 321, 1897.

Type-Collected in Cascade Mountains at 8,000 feet near Martin Station, Kittitas County, Wash., by Allan Rupert, March 1893.

General characters. - Slightly larger than oregonensis, and lighter brown. Upper parts washed with pale brown over plumbeous; tail sooty toward tip; eyering dusky; cheeks gray; lower parts soiled whitish or buffy. Immature specimens duller and darker.

Measurements.-Total length, $308 \mathrm{~mm}$; tail, 144; hind foot, 41; ear (dry), 19.

Distribution and habitat.-These squirrels inhabit the Cascade Range from southern British Columbia south through Washington and Oregon into the Siskiyous of northern California (fig. 31). Specimens have been taken in Oregon at Vida, McKenzie Bridge, Belknap Springs, 20 miles west of Crescent Lake, Fish Lake, and Crater Lake, all in the coniferous forest of the Cascades.

General habits.-At Crater Lake Preble caught one in a trap set at the base of a dead stub in open woods about a quarter of a mile south of the crater run. At Vida on the upper part of McKenzie River, Luther Goldman caught one in a trap set under a log in the spruce woods and baited with rolled oats and a bit of sausage. At McKenzie Bridge, farther up the river, a few specimens were taken in the heavy forest of conifers, alders, ash, and maples. The trunks and branches of maple and ash trees were heavily laden with tree mosses, great cushions, sheets, and streamers of deep soft old fleeces in which the flying squirrels had their nests and under which they had well-worn trails up the trunks and along the larger branches. The nests were well-lined cavities made in the middle of some hanging or resting masses of this soft moss where no hollow trees were available. A trap set at the bottom of one of these nest trees and baited with rolled oats and bits of cracker with a watermelon seed on the trigger caught an old flying squirrel the first night. 
Breeding habits.-Specimens taken have the usual 4 pairs of mammae-1 inguinal, 2 abdominal, and 1 pectoral, or, as sometimes given, 3 abdominal and 1 pectoral, because the posterior pair is so far forward as to be readily classed as either inguinal or abdominal. Although there seem to be no records of young of this form from Oregon, 3 to 6 young are common to this group.

\section{GLAUCOMYS SABRINUS KLAMATHENSIS (MERRIAM)}

\section{Kramath Flying SquirRel; KoK-Kotch of the Klamath (C. H. M.)}

Sciuropterus alpinus klamathensis Merriam, Biol. Soc. Wash. Proc. 11:225, 1897.

Type.-Collected at Fort Klamath, Oreg., by B. L. Cunningham, January 11, 1897.

General characters.-Slightly larger than fuliginosus, and paler. Upper parts washed with light brown or cinnamon drab over plumbeous; tail dusky toward tip; eyering dusky; cheeks clear gray; lower parts creamy white or buffy; soles of hind feet yellowish.

Measurements.-Total length, $319 \mathrm{~mm}$; tail, 144; hind foot, 41; ear (dry), 19.

Distribution and habitat.-This is the flying squirrel of the yellowpine forest east of the Cascade Mountains, at least from the Paulina Mountains south to the Klamath country (fig. 31). There are specimens from Paulina Lake, Davis Creek, Fort Klamath, Sun Creek, and Crater Peak (4 miles south of Crater Lake), and Upper Klamath Lake. It is probable that the form inhabits the whole length of the yellow pine east slope of the Cascades in Oregon.

General habits.-Luther Goldman, in August 1914, reported flying squirrels at Paulina Lake and along Paulina Creek and collected a specimen at a hollow tree, where it evidently came for the rain water held in a cavity of the trunk.

Harry Telford, in February and March 1914, obtained specimens from a marten trapper 8 miles north of Fort Klamath, where they proved very troublesome by getting into the marten traps. About as many flying squirrels as pine squirrels were caught. The 3 males secured showed sexual development indicating the presence of the breeding season, but the 2 females did not show signs of embryos.

\section{GLAUCOMYS SABRINUS BANGSI (RHOADS)}

\section{Bangs's Flying Squirrel}

Sciuropterus alpinus bangsi Rhoads, Acad. Nat. Sci. Phila. Proc., p. 321, 1897.

Type.-Collected at Raymond, Idaho County, Idaho, March 8, 1897, by Harbison and Benjamin.

General characters.-Slightly grayer than typical sabrinus, smaller than any other of the Rocky Mountain forms of the group. Upper parts in winter fur pale wood brown, sometimes tinged with vinaceous cinnamon, feet pale brown, shading to grayish brown, or on the toes to grayish white; tail above wood brown, more or less tinged with cinnamon and hair brown; under parts whitish, strongly washed with pinkish cinnamon; summer pelage more yellowish.

Measurements.-Average of six adult specimens from Idaho and Montana: Total length. $315 \mathrm{~mm}$ : tail, 142 ; foot, 39.5 .

Distribution and habitat.-Western Wyoming and Montana across Idaho and into the Blue Mountain section of Oregon. There are specimens from Anthony and Wallowa Lake in the Wallowa Moun- 
tains, from Bourne in the Baker Range, and from the northern part of the Blue Mountains just over the line in Washington. Near Bourne, Jewett caught one in an old cabin, and at Wallowa Lake, Cantwell took one in a trap set on an old $\log$ in the deep woods. Generally they are found in Canadian Zone forests of spruce, fir, and lodgepole pine.

General habits.-These squirrels are well known to the fur trappers who catch large numbers of them in marten traps set in the woods, and especially in those set on the side of tree trunks above the snow. Some trappers report several hundred flying squirrels taken from a line of marten traps during a winter and consider them to be as numerous and active at night as the spruce squirrels are by day.

They live in hollow trees where these are present but also make nests of soft bark fibers in the branches and forks of trees in which they sleep during the day and raise their young.

The young, usually four, are born in late May or early June, and in this cold high zone there would be scant time for more than one litter in a season.

The food, like that of all flying squirrels, is quite varied, as is shown by the different baits that attract them to traps-rolled oats, bread, biscuit, bacon, and the meat used for marten bait. They often gather around old camp sites for the scattered grain and food scraps thrown out and seem to be rather omnivorous in their tastes.

Cantwell picked up an interesting flying squirrel story near Wallowa Lake that has every indication of being authentic. In a log cabin back in the mountains where some old settlers resided, an oldfashioned spinning wheel was long stored in the attic. This wheel was sometimes heard revolving at night when no one was near it and was often found still in motion when examined. The house finally acquired the reputation of being haunted until one brave member of the family stole silently up to the dark room when the whirring of the wheel was heard and with a flashlight saw one of these flying squirrels running on top of the wheel as it spun beneath the animal's skillful tread.

\section{GLAUCOMYS SABRINUS BULLATUS HOWELL}

\section{Sawtooth Mountain Flying Squirket}

Glaucomys bullatus Howell, Biol. Soc. Wash. Proc. 28; 113, 1915.

Type-Collected at Sawtooth (Alturas) Lake, Idaho, by B. H. Dutcher, September 28, 1890.

General characters.-Similar to klamathensis but larger, with much larger audital bullae, brighter brown back, and darker tail. Upper parts washed with bright yellowish brown over plumbeous; tail dark above and dusky toward tip ; eyering dusky; cheeks and sides of neck clear ashy gray; belly soiled whitish; lower surface of tail dark buffy or dusky; soles of feet yellowish gray.

Measurements.-Total length, $336 \mathrm{~mm}$; tail 142; foot, 43; ear (dry), 21.

Distribution and habitat.-High mountains of central Idaho north to southeastern British Columbia and west throughout the Blue Mountains of Oregon in both Canadian and Transition Zones (fig. 31). It seems to show closer affinity with klamathensis in Oregon than with its nearer neighbors bangsi and latipes, in Idaho and British Columbia. 
General habits.-These large handsome flying squirrels live in both the yellow pine timber, and higher up through the lodgepole pine and spruce forests, always among the tall trees where they travel through the air from trunk to trunk or come down the trunks to gather food on the ground. They rarely get far from the trees, which are their main protection from enemies. Even the marten, which may follow them to the top of the tallest tree, is left behind as they soar away to distant trunks. The type and two others were caught in traps set for marten at the base of trees and baited with the bodies of birds and small mammals that had been skinned for specimens. The flying squirrels are always a great annoyance to trappers as they are fond of meat and constantly get into marten traps. They are rather omnivorous in taste and accept almost any camp supplies, regularly visiting camp grounds for the scraps of food to be found. At the type locality one stole a biscuit one night from the grub box, and when Merriam fired into the treetop it dropped the biscuit at his feet. The animals are fond of rolled oats, bread, nuts, seeds, or any grain used as trap bait, and like other varieties of the group probably eat many insects and insect larvae.

Economic status. - These forest dwellers rarely come about buildings or clearings and so are not likely to cause any loss of crops or property. The suspicion that they rob birds' nests may have some basis in fact but needs careful investigation before it can be accepted. Also the extent and nature of their insect food should be given careful study, as it would not be surprising to find that they contribute much to the protection of the forests and to the control of insects.

\section{Family MURIDAE: Rats and Mice}

\section{RATTUS NORVEGICUS (ERXLEBEN)}

Norway Rat; Brown Rat; House Rat; Barn Rat; Wharf Rat; Sewer Rat [Mus] norvegicus Erxleben, Syst. Regni. Anim. v, 1, p. 381, 1777.

Type locality.-Norway.

General characters.-Large and heavy; tail about as long as head and body, tapering, annulated, scantily haired; ears medium large, nearly naked; soles naked; pelage coarse and harsh. Color in adults, upper parts rusty gray, lower parts soiled yellowish white or dirty gray. Young dusky gray above, lighter gray below.

Measurements.-Good-sized adult male. Total length, $400 \mathrm{~mm}$; tail, 200 ; foot, 45; ear (dry), 18; from crown, 13. Weight 1 to 2 pounds, but very large individuals weighing more than 2 pounds have been recorded.

Distribution and habitat.-Supposedly native of Asia, these rats spread to Europe in 1730 to 1750, and to North America in 1775, and are now found over much of the inhabited earth.

They have kept close behind the vanguard of civilization in its progress across the continent of North America and were probably taken to Oregon on ships in the early part of the last century. A specimen was collected at Astoria by Lieutenant Trowbridge in 1855 (Baird, 185\%, $p .438$ ). At the present time they are common all along the coast country of Oregon, throughout the Willamette Valley, and in the Columbia River Valley. At Millers, near the mouth of the Deschutes, Jewett reported them in 1915 as a serious pest in the grain 
warehouses. Apparently they have not yet penetrated the more arid parts of eastern Oregon.

General habits.-Wharf rats usually enter a new region on vessels or railway trains and then spread rapidly from place to place, concealed in boxes, crates, or household goods on trains or freight wagons, or for short distances on foot. They are secretive animals, keeping much under cover or in burrows that they dig in banks or under buildings, rocks, or logs. From one stronghold to another they make short trips in the open, mainly at night, although they are often active in the daytime as well as in the dark. They seem to prefer the filth of stables, manure heaps, garbage, and trash piles where they can burrow and revel in dirt and decaying food. They swim well and haunt the wharves and sewer pipes, traveling thence into markets, cellars, and pantries if these are not ratproofed with concrete, brick, stone, or metal.

Breeding habits.-Rats are prolific breeders, having usually 6 or 8 , but occasionally as many as 15 or 20 , young to a litter. The mammae of the adult females are normally 12,3 pairs of inguinal and 3 pairs of pectoral on 4 distinct mammary glands, 3 mammae on each elongated gland. The period of gestation is 21 days, and many litters are produced throughout the year if sufficient food and shelter are available.

Foods habits. - Scarcely a food or food product can be mentioned that rats will not eat and many nonedible materials are cut, gnawed, and injured in efforts to get at food stores or in burrowing or making nests. They are filthy and wasteful and often destroy far more than they can eat. They kill and eat chickens or any young animals they can get, and even gnaw the feet of and injure many kinds of livestock.

Economic status.-Rats have been called the most destructive of all animal pests, not only destroying more food and property than any other animal, but being responsible for the death of more human beings than all the wars of history. They are the hosts of fleas, ticks, and other parasites that convey the germs of disease, including bubonic plague and other fatal maladies. Science and education are waging relentless warfare on the rat and many bulletins and circulars have been published giving specific directions for their control and destruction.

\section{RATTUS RATTUS RATTUS (LiNNAEUS)}

\section{BLACK RAT}

[Mus] rattus Linnaeus, Syst. Nat. ed. 10, v. 1, p. 61, 1758.

Type locality.-Upsala, Sweden.

General characters.- Somewhat smaller than the common rat, slenderer; tail much longer than head and body, slender and nearly naked; ears large and naked; soles naked; pelage in adults coarse and harsh, with long spinescent hairs. Color, black, plumbeous, or sooty, usually plumbeous over lower parts; tail, ears, and feet sooty. Young usually plumbeous all over.

Measurements.-Adult male: Total length, $390 \mathrm{~mm}$; tail, 216; foot, 38; ear (dry), 20, from crown, 15.

Distribution and habitat.-The black rat was brought to North America from Europe in ships at an early date and became abundant before the brown rat was introduced, but it has largely disappeared 
before its larger and more aggressive rival. At present it is found in localities scattered over the country, mainly near the coast, but an occasional individual may be carried to any part of the country.

The only record the writer has found for Oregon is based on a half-grown young taken in a trap set under old logs in the Sitka spruce forest near the shore at Empire. It is likely to be found near any of the shipping ports of the State and probably in the woods or among trees where it can escape from the brown rats.

General habits.-An expert climber, the black rat often makes its home in trees, thatched roofs, or any place that is inaccessible to the brown rat. In other ways it seems to be similar in habits to the brown rat, but has been given less study on account of its scarcity.

The mammae have the same arrangement as in the brown rat and the breeding habits are said to be approximately the same.

Economically the black rat is of local importance only.

\section{RATTUS RATTUS ALEXANDRINUS (GEOFFROY)}

\section{Roof RAT}

Mus alexandrinus Geoffroy, Catal. Mammif. Mus. Nat. Hist. Nat., Paris, p. 192, 1803.

Type locality.-Alexandria, Egypt.

General characters. - Similar in form and general characters to the black rat, but grayish brown above and clear white or yellowish white below. Tail very long and slender; ears small and naked; hair on back coarse and bristly.

Measurements.-A fair-sized individual : Total length, $435 \mathrm{~mm}$; tail, 230 ; foot, 37 ; ear (dry), 21.

Distribution and habitat.-While native around the Mediterranean, these rats have been carried in ships around the world and have become established in many parts of North America, especially near the coast. In Oregon there are two specimens in the Jewett collection from Netarts Bay and one in the Gabrielson collection taken at Portland.

General habits.-Apparently these smaller, lighter bodied rats are driven out or killed by the common brown rat and thus prevented from gaining a foothold over the country at large. They are found at most of the principal shipping ports and near the coast in colonies where they occasionally get a start, but usually in the woods or at some spot where brown rats do not occur. Being expert climbers, they often build nests in trees or vines or inhabit the roofs of old buildings reached by climbing vines or tree trunks. Heaps of driftwood along the shores or river banks sometimes afford shelter and protection to colonies of them.

Usually they are counted of little economic importance except on islands or in places where other rats do not occur.

\section{MUS MUSCULUS MUSCULUS LiNNaEUS}

House Mouse

[Mus] musculus Linnaeus, Syst. Nat. ed. 10, v. 1, p. 62, 1758.

Type locality.-Upsala, Sweden.

General characters.-Small, slender, with medium long tapering and halfnaked tail; ears large; soles naked; incisors not grooved; fur rather thin and 
harsh. Grayish brown above, lighter brown or buffy gray below, very similar at all ages and seasons.

Measurements.-Adults: Total length, $167 \mathrm{~mm}$; tail, 82 ; foot, 18; ear (dry), 12, from crown, 9. Weight of adult female, $23.5 \mathrm{~g}$; length, $162 \mathrm{~mm}$; tail, 75 ; foot, 17 .

Distribution and habitat.-House mice are more or less common in towns, houses, and at ranches over most of the inhabited parts of Oregon, and in the more fertile parts in the fields and meadows. Some of the widely isolated ranches in the arid part of the State may still have escaped the inroads of these pests, but eventually they probably will be invaded.

Introduced from Europe in the early days of the settlement of North America, these mice have followed so closely the advance of civilization that they now outnumber many of our native rodents over much of the continent.

General habits.-House mice are largely dependent on the works of man, occupying houses, barns, and outbuildings, feeding largely on stores of grain and foods of any kind within their reach, hiding in rooms, cellars, and boxes and making long journeys from place to place in boxes of household goods or loads of supplies. Once established they multiply rapidly, and with the protection afforded by buildings, often become so numerous as to extend out into the fields and meadows, under cover of grass and grain, until they overrun the most fertile parts of the valley country. They burrow into banks, under walls, rocks, or logs, and establish safe retreats of their own and show more skill than most of our native mice in avoiding enemies. While largely nocturnal, they are often out voluntarily searching for food in daylight and seem to see equally well in light or dark. They climb and dig and gnaw holes through boards and walls and are not easily restrained from getting at supplies.

Breeding habits.-House mice breed more or less regularly at all seasons of the year, if food is abundant and comfortable quarters assured. Six to thirteen young are recorded for the litters, and the period of gestation is given as 21 days. The 12 mammae in adult females are arranged in 3 pairs of inguinal and 3 pairs of pectoral, 3 on each of 4 separate mammary glands.

Food habits.-These mice are more than usually omnivorous for rodents, eating not only grains, seeds, nuts, and fruits, but all kinds of meat, fat, butter, cheese, milk, cream, bread, cake, vegetables, and any cooked or uncooked food they can get. They do not lay up stores for winter and are active at all seasons.

Economic status.-These are among the most annoying and destructive of mouse-size rodents, because, concentrated about buildings, granaries, stacks, and grainfields, they constantly devour and destroy valuable property. In the fields and open country they are to some extent controlled by such enemies as owls, hawks, shrikes, weasels, skunks, foxes, cats, and other predatory animals, and to some extent about buildings by house cats. Trapping, poisoning, and other methods of destruction are often necessary. Directions for the best methods of combating such pests are always available from the United States Department of Agriculture or State agencies. 


\section{NEOTOMA CINEREA OCCIDENTALIS (COOPER MS.) BAIRD}

Western Bushy-Talled Wood Rat; Cho-cho of the Klamath; Te-Ka-WA of the Piute (C. H. M.)

Neotoma occidentalis (Cooper Ms.) Baird, Acad. Nat. Sci. Phila. Proc. 7 : 335, 1855.

Type.-Collected at Shoalwater Bay, Wash., by J. G. Cooper in 1854.

General characters.-Large for a wood rat; tail bushy, wide, and almost squirrel-like; ears large and nearly naked; whiskers (vibrissae), about 4 inches long; fur long and soft; eyes rather large and prominent, appearing shiny black (pl. $30, A, C$ ). Color of upper parts dark cinnamon brown more or less clouded with dusky; feet, lower surface of tail, and lower parts white or creamy with sometimes a touch of bright cinnamon on throat. Immature more plumbeous. Winter fur darker, summer fur showing more of cinnamon.

Measurements.-Total length of large male, $440 \mathrm{~mm}$; tail, 200 ; foot, 47 ; ear (dry), 30, (fresh) 32, from crown, 20. Weight of not very large male, 12 ounces.

Distribution and habitat.-These large, dark bushy-tailed wood rats cover most of the region from southern British Columbia to northern California and Nevada, most of Idaho, and all of Washington and Oregon, except a narrow coast strip where they run into the still darker $N$. c. fusca (fig. 32). In their caves and sheltered retreats among the rocks (pl. 30, B) they have little regard for life zone lines, and while la $\mathrm{rgely}$ in Transition, they occur freely in upper Sonoran and Canadian Zones. They live mainly in cliffs or masses of broken rocks, but at

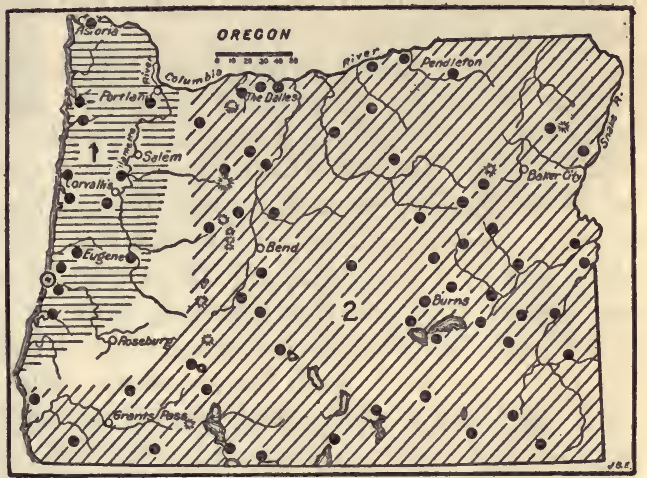

Figure 32.-Range of the two bushy-tailed wood rats in Oregon: 1 , Neotoma cinerea fusca; $2, N$. c. occidentalis. Type locality circled.

times must wander considerably, as they suddenly appear in camps, barns, or houses in either forests or in open country at a distance from rocks. They are never numerous except very locally, where unusual protection is afforded.

General habits.-Wood rats are mainly nocturnal, sleeping most of the day and working very actively at night. Occasionally, however, they move about in the daytime, and they seem to see well in either light or dark.

In Oregon their favorite haunts are the rimrock cliffs or broken lava beds and caves, where they revel in safe retreats and comfortable winter or cool summer quarters. They are noted builders and endeavor to fortify their rocky caverns by piling them full of rubbish, sticks, chips, stones, bones, thorny branches, dried manure, refuse food material, and anything they can find to carry and fill up the vacant spaces and hide or protect their nests and young. Sometimes a house is built over a hollow log or around the base of a hollow tree, or even in the branches of a tree, but houses are rarely built at a distance from the rocks, as they are by many other species of wood rats. 
Their habit of gathering material for building gives them the name of pack rat and a reputation for dishonesty, as they often carry away objects not intended for their use. Anything of a convenient size, a cake of soap, a knife, a pen, or a. watch may be taken. Mouse and rat traps and cartridge shells are often gathered up and used for building material, and around camps it is customary to look for lost objects in neighboring wood rat houses.

The nests are neatly made, cup-shaped with thick, soft walls for cold weather, always clean, even when made from shredded gunny sack or a bit of old rope or the cotton out of a quilt. Sometimes they are concealed by the heaps of sticks and rubbish and sometimes placed on a shelf in the corner of a cabin.

Wood rats are good climbers, not only in trees, but over rocks, walls. and the rough boards of outbuildings, over roofs and perpendicular or sloping surfaces. Their claws are short, but curved and sharp and are used in self-defense as effectively as those of a cat. They are quick and agile in running, dodging, and jumping. The bushy tails, like those of squirrels, are useful in climbing, balancing, steering, and turning abruptly.

Their voices are rarely heard, although an old male caught in the writer's hands and held securely against his will screamed and screeched savagely. The young make a crying or whining sound if taken from their mother. In other ways they are noisy, often making a great racket running over floors, boards, and walls, or dragging sticks, blocks, and tins over the floors. Their regular and unmistakable sounds, however, are the tapping or drumming with the sole of one hind foot on the ground, floor, rock, or any smooth surface, a slow tap, tap, tap, at about 1-second intervals. The speed and force of the taps vary with the occasion, sometimes quick and hard, again soft and slow with evident variation of expression. The sound is made by both males and females, not only when alarmed or disturbed, but often when alone and unsuspicious.

The animals have a strong musky odor emanating from an elongated abdominal gland, a thickened strip of skin that secretes a musky, oily substance that undoubtedly enables them to recognize the presence of their own species and possibly to distinguish individuals. A cave, room, or box, occupied by them is usually noticeably musky, even to our feeble noses, although not unpleasantly so. No animal could be neater, cleaner, or more sanitary in habits. The dry, black, elongated pellets are mostly placed in definite corners not used for other purposes, and the urine is deposited on the points and edges of certain rocks away from the nest or along the face of the cliffs, where it forms white calcareous encrustations on the rocks which may be seen from a distance and are always evidence of the presence of wood rats. In course of years this deposit becomes 2 or 3 $\mathrm{mm}$ thick, as hard as rock, and with every appearance of a geological formation. In some of the dry caves old deposits of the pellets have become solid, black, waxy masses with the appearance of asphalt, and might also be easily mistaken for geological deposits.

Breeding habits.-The females have 4 mammae, arranged in a quadrangle on 2 parallel mammary glands in the inguinal region. The young, generally 2, but sometimes 3 or 4 , are born usually in spring or early in summer, and are nearly full grown by autumn. 

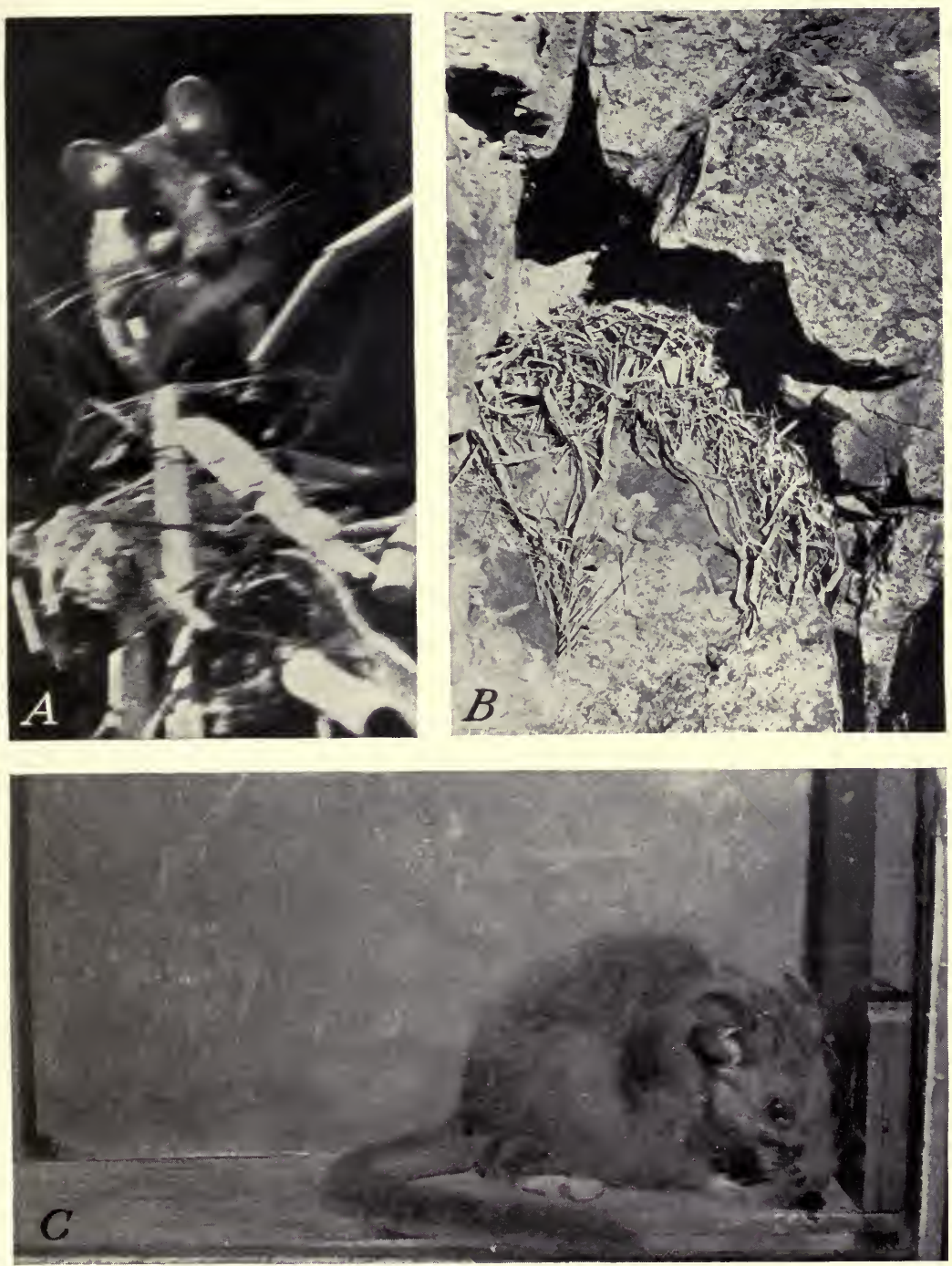

WESTERN BUSHY-TAILED WOOD RAT.

A; B17221; B23310

$A$, At its nest; $B$, typical stick house in a cleft of the rocks in eastern Oregon; $C$, captive in photographing box. 

There is no indication of more than 1 litter a year. The reproduction is less than half that of the squirrels and chipmunks, but the safe retreats of the wood rats afford partial immunity from many enemies and their numbers keep up to very limited standard. They are never abundant.

Food habits.-Wood rats are dainty feeders with small stomachs, usually containing green foliage or unripe seeds of the plants where they live. They do not become fat or hibernate, but store up food for winter; $a$ " hay" composed of numerous plants is commonly eaten. At Malheur Lake, captives kept for study of habits were fond of the leaves and tender shoots of pigweeds (Chenopodium), a herbaceous Atriplex, nettles, and Suaeda (Dondia). They ate some tips and leaves of greasewood (Sarcobatus) and rabbitbrush (Chrysothamnus), and a little grass, but were more partial to such domestic foods as cabbage, cantaloup and watermelon rinds, apple parings, rolled oats, biscuit, cheese, and such scraps from the table. They drank a little water but preferred it in the form of melon rinds or juicy fruits and plants. The writer found where they had stored leaves of the wild currant (Ribes aureum) and large quantities of nettle leaves and nettle stems loaded with seeds. Some had their stomachs filled with these seeds, which are pleasant, rich, and mucilaginous, like the seeds of elm trees. Juniper twigs and berries are often stored for food, and any seeds, nuts, and grain are eaten occasionally. Green vegetation, however, seems to be preferred.

Economic status. - Wood rats feed mainly on green foliage of weeds and worthless plants, rarely coming in contact with crops, and doing practically no damage except as one occasionally gets into a barn, shop, camp, or cabin and cuts or carries off property. They sometimes cut harness, saddles, or other leather goods; eat, carry away, or muss up food supplies; carry away small objects for building material; and cause much annoyance until destroyed. Generally it is necessary to trap or otherwise remove them from occupied buildings. The common rattrap catches and kills them quickly and mercifully, but a box set inverted on a board with a baited oval trigger under one edge will catch them alive, when they can be carried away or kept in a cage for study or as interesting pets. They are very fond of running in a squirrel wheel, and if given a wheel and good quarters are contented and happy.

\section{NEOTOMA CINEREA FUSCA TRUE}

\section{DUSky Bushy-TAILED WoOd Rat}

Neotoma occidentalis fusca True, U. S. Natl. Mus. Proc. $17: 354,1894$.

Neotoma fusca apicalis Elliot, Field Columb. Mus. Pub. 74, Zool. Ser. 3 : 160, 1903, from Gardiner, Coos County, Oreg.

Type.-Collected at Fort Umpqua, Douglas County, Oreg., by E. P. Vollum in 1859.

General characters.-Large; tall wide and bushy; ears large and nearly naked; vibrissae about 4 inches long; fur dense and almost woolly. Color much the same at all seasons, upper parts dark cinnamon brown heavily obscured with black or dusky outer hairs; tail blackish above, dark gray below; feet and belly whitish.

Measurements.-Large male: Total length, $470 \mathrm{~mm}$; tail, 217 ; foot, 48 ; ear (dry), 28, from crown, 18. 
Distribution and habitat.-These large and very dark-colored wood rats are found along the coast region of Oregon from the lower Columbia River south to Gardiner and old Fort Umpqua, on the Umpqua River below Roseburg, in humid Transition Zone (fig. 32). Generally they are in heavily timbered country, among rocks well overgrown with vegetation.

General habits.-These black wood rats, as commonly called, differ from the western wood rats only as is necessary in adaptation to a more humid and heavily forested area. They are often caught among old logs or under log piles, as well as among the rocks, and their finding and taking up quarters in any camp or cabin in the woods indicate considerable travel under shelter of logs, brush, and dense vegetation. In camps and around buildings generally they have the same reputation for noise and mischief as other wood rats, and their building and carrying habits are also the same.

At Philomath, Cantwell caught them in traps set for squirrels in the heavy timber. Near Wells, Hollister shot 1 that was driven from its nest in an old deserted house, and caught 2 others in the barn. At Mapleton, Luther Goldman found a deserted cabin in the forest where they had piled up sticks and brush in the corners and between the double walls and had stored a quantity of green alder twigs and leaves as food. At the base of Chintimini Mountain, the writer caught 1 in a vacant building. McClellan found them in old camps, cabins, stables, and vacant buildings at Florence, Gardiner, and Seton. The scarcity of rocks of the broken-cliff type, which they like, forces them to depend more on other cover and to welcome any shelter more secure than an old log.

Their food and breeding habits probably do not differ materially from those of their closest relative, $N$. c. occidentalis.

Economically, they are of little consequence, as those causing annoyance are easily destroyed by guns, traps, or poison.

\section{NEOTOMA FUSCIPES FUSCIPES (COOPER Ms.) BAIRD}

\section{DUSKY-FOOTED WOOD RAT}

Neotoma fuscipes (Cooper Ms.) Baird, Mammals North Amer., p. 495, 1857. Neotoma monochroura Rhoads, Amer. Nat. 18: 67, 1894, from Grants Pass, Oreg.

Type-Collected at Petaluma, Calif., by E. Samuels in 1856.

General characters.-Large for the round-tailed group; tail almost as long as head and body (pl. 31, A), round, tapering, and short haired; ears large and thinly haired; vibrissae about three inches long; fur not so long and soft as in the bushy-tailed species. Color much the same at all seasons, upper parts dark cinnamon brown, darkened by blackish outer hairs; tail blackish above and below; feet mainly dusky with usually whitish toes; lower parts whitish, washed across belly with buffy or pale cinnamon.

Measurements.-Large male: total length, $445 \mathrm{~mm}$; tail, 216; foot, 43 ; ear (dry), 25, (fresh), 30, from crown, 20. A large male weighed 11 ounces.

Distribution and habitat.-These large, dark, round-tailed wood rats extend from San Francisco Bay, Calif., north to the Willamette Valley, Oreg. (fig. 33). The northernmost record is of a specimen taken at Mulino, near Oregon City, by Jewett. In California they reach to the coast, but in Oregon are in the drier interior valleys of the Rogue, Umpqua, and Willamette Rivers, mainly back 
of the coast ranges. Their main distribution is in Upper Sonoran Zone, and where found they usually accompany other species characteristic of the zone.

They are chaparral dwellers over much of their range, but also enter the open forest and build their houses among the trees or even in treetops.

General habits.-These are among the most noted of wood rat builders, generally preferring their own structure to those of man, or even to the strongholds of the rocks. Their houses are generally in dense chaparral or in the underbrush of the woods, built up around old logs, hollow trees, or many-stemmed clusters of rugged shrubs. 'They are generally 4 or 5 feet high, as wide at the base, conical, well formed, with 2 or 3 rooms aboveground and 1 below the surface, aptly described as 2 or 3 stories and basement. The houses are generally made of sticks, twigs, b a r k, chips, bones, leaves, and moss, with strong, interlaced walls and supports, in a peaked form that will shed water and keep the nests and food stores dry and safe from most enemies. Doorways lead. under the houses and usually some doors and windows open out on the sides. The chambers are la rge enough for the well-formed, cup-shaped nests of soft moss and bark fibers and ample

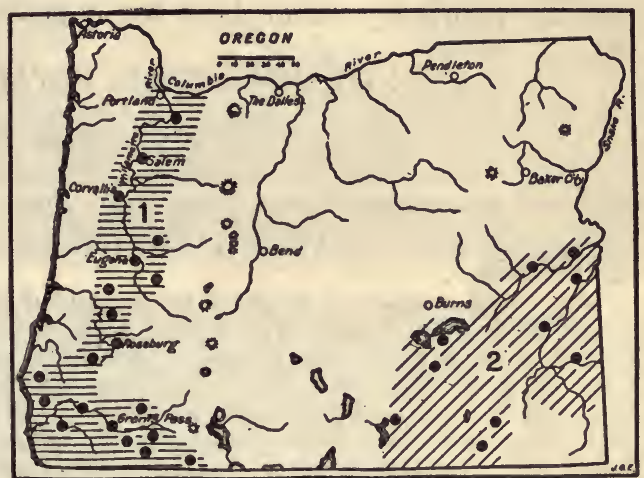

Figure 33.-Range of the two round-tailed wood rats in Oregon: 1, Neotoma fuscipes fuscipes; 2, N. lepida nevadensis.

food stores conveniently near the nests. Runways, or well-worn trails, lead away from the houses to feeding grounds, to other houses, or to the base of trees, for these rats are great climbers and not only get much of their food from the treetops, but sometimes build large houses high up among the branches.

They are active mainly at night, but if alarmed in the daytime will run from house to house or climb trees and hide among the leafy tops. They often visit barns or outbuildings, but rarely take up their residence in them. Occasionally they carry away tools or small objects for building material, but less commonly than do some of the other species. The writer often missed his mousetraps and found them on the nearest wood rat house.

Breeding habits.-Two to four embryos found in females taken for specimens indicate small families, as do also the 4 mammae arranged on 2 large glands in the inguinal region. Embryos noted in February, March, April, May, June, and . September indicate much irregularity in the breeding season or more than one litter a year. The animals are never numerous, however, and their increase is evidently not rapid.

Food habits. - While a large part of the food of these rats consists of green vegetation, they also eat many fruits, nuts, and seeds, 
storing up in their houses rose haws, cascara berries, manzanita berries, laurel fruits, acorns, and such other nuts as are available. Green and dry leaves of ferns, Ceanothus, Umbellularia, Rhamnus, and other plants are found in the storerooms, while the stomachs of the animals collected for specimens usually show much green vegetation.

Economic status.-Only in rare cases do these builders ever come in conflict with human interests. They generally prefer their own houses to ours, but sometimes explore outbuildings for any choice food or building material, and in certain places may appropriate more than a fair share of nuts, fruit, or vegetables growing near their homes. They are so easily destroyed, however, by traps or poison, or driven away by the destruction of their houses, that they cannot be considered a serious pest.

Their meat is excellent food, better in flavor and quality than squirrel, more nearly like young rabbit, and their food and general habits are wholly exemplary for a game animal.

\section{NEOTOMA LEPIDA NEVADENSIS TAYLOR}

Nevada Wood Rat

Neotoma nevadensis Taylor, Calif. Univ. Puis. Zool. 5:289, 1910.

Type.-Collected in Virgin Valley, Humboldt County, Nev., in 1909 by Annie M. Alexander.

General characters.-Slightly larger and duller colored than typical lepida or desertorum from Death Valley, but still one of the small, silky-furred, roundtailed wood rats of this group; a beautiful animal with large, almost naked, ears, large bright eyes, long trembling vibrissae, and a gentle, intelligent expression of face. Upper parts of adults rich salmon-buff, much obscured over the back by dusky tips of long hairs, sides clearer buffy; top of tail dark buffy gray to black; lower parts, feet, and lower surface of tail white or creamy, the belly sometimes tinged with delicate salmon-buff. Skull relatively wide, heavily ridged with large, quadrate interparietal when compared with that of lepida.

Measurements.-Average of 7 males from Oregon: Total length, $282 \mathrm{~mm}$; tail, 118; foot, 31.5; ear (dry), 25, (fresh) 28, from crown, 18. Weight of not fully adult male, 4 ounces; of old male, probably 6 ounces.

Three specimens from Diamond and one from Voltage are much darker than those from Watson and Vale, and have wholly black upper surface of tails.

Distribution and habitat.-These little wood rats (pl. 31, B) occupy the arid sagebrush Upper Sonoran valleys of northern Nevada and southeastern Oregon. There are specimens from Vale, Watson, Voltage, Diamond, White Horse Creek, and Warner Lake, and records from near Owyhee and Cow Creek Lakes in Malheur County (fig. 33). They live among rocks or build small houses out in the sagebrush.

General habits.-These little desert wood rats live both among the rocks and in the open. Without rocky cover they generally burrow under some bush, and among its sturdy roots, where comparatively safe from attacks; they build mounds of sticks, brush, and cow chips over the doorways of their underground homes. To save unnecessary labor they sometimes appropriate old burrows of kangaroo rats or ground squirrels, fortifying the approaches. Often a bushel or more of sticks and rubbish are piled over their doorways, but houses with nest and living chambers are rarely found. The building material is mainly for protection from enemies, the hot sun, and possible rains. 

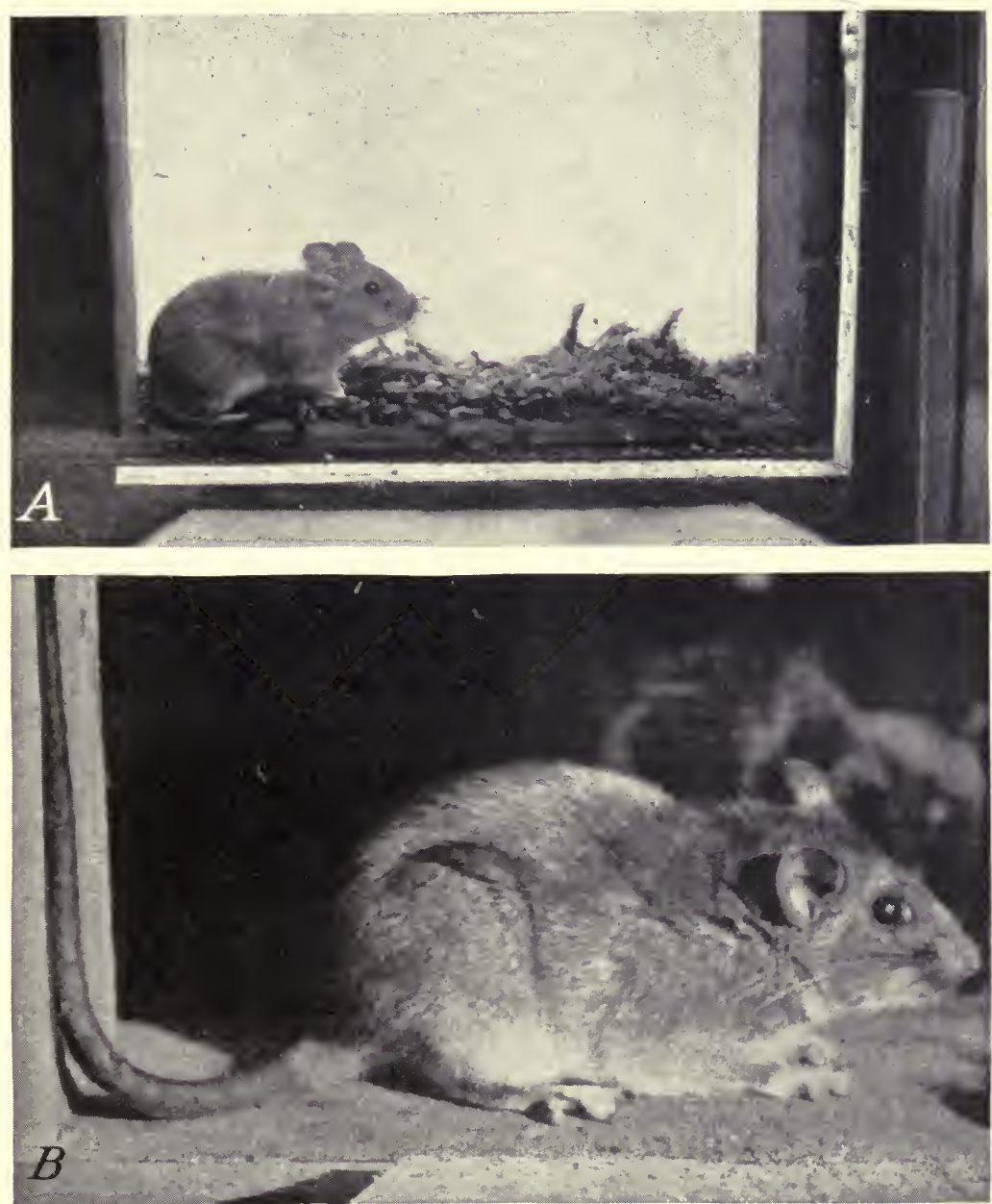

WOOD RATS.

B23306;

$A$, Brown-footed wood rat at Lagunitas, Calif., captive photographed in glass box; $\mathrm{B}$, the little roundtailed Nevada wood rat comes into southeastern Oregon in some of the lowest and hottest valleys, where it builds stick houses in the sagebrush or among the rocks. 

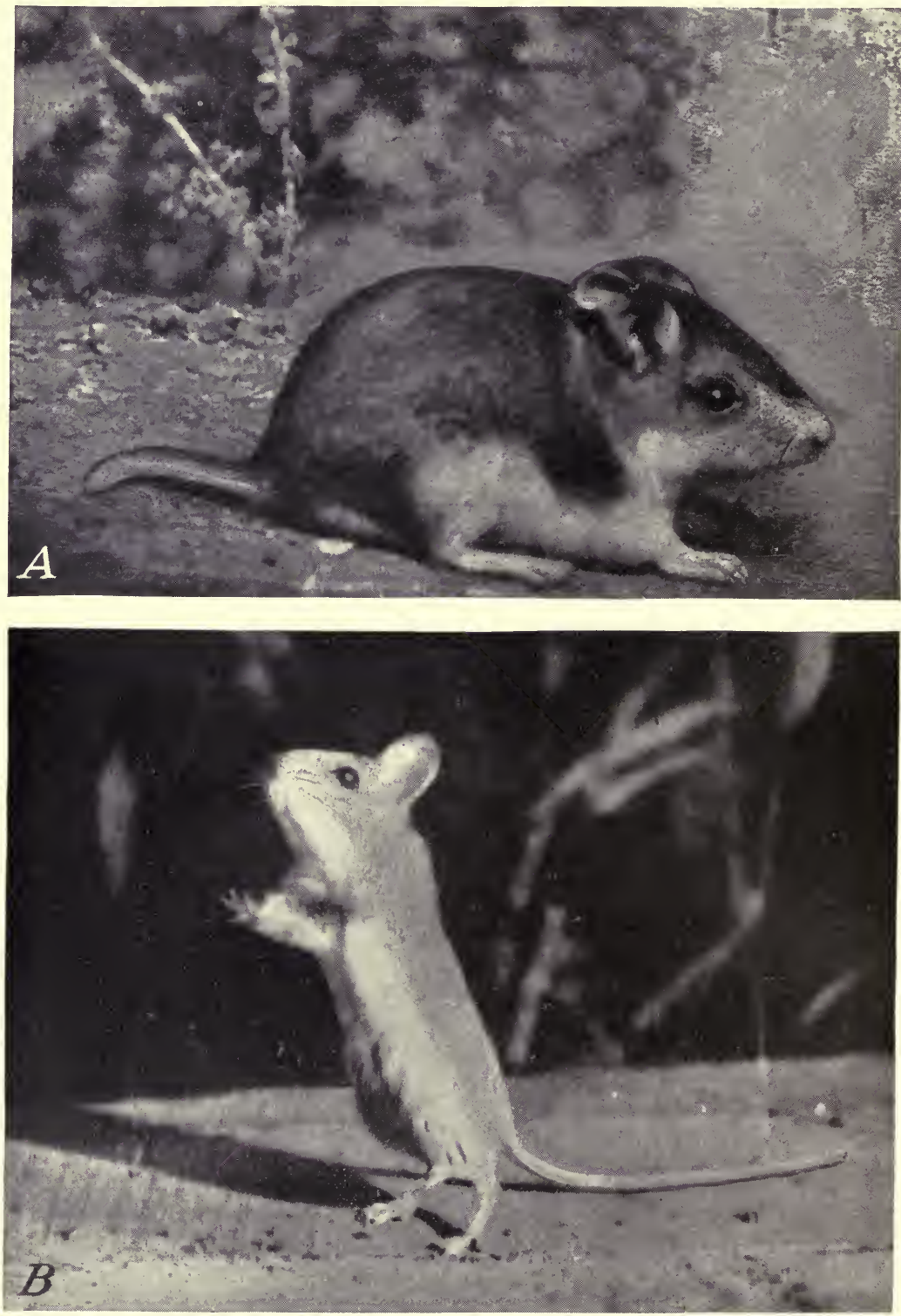

P25193; B4611M

$A$, Brown grasshopper mouse of eastern Oregon (drawing by R. Bruce Horsfall from life); $B$, Gambel's white-footed mouse, the common deer mouse over most of Oregon. 
Among the rocks the same building material is used to fill and block the passages leading back to the nest cavities. The nests of soft plant fibers are placed in cool, clean chambers deep underground or well back in cavities among the rocks. They are always neat and clean, and even those found on shelves or beams or under the floors of deserted buildings are as well made and uniform in design as many birds' nests.

One of the wood rats kept in captivity at Malheur Lake during July and August was gentle in disposition, timid but not nervous, and soon submitted to being stroked as it sat in its nest. It never made any vocal sounds, but tapped with one hind foot on the boards or in the nest with a soft thud, thud, thud, sometimes with one foot and sometimes with the other. It would spend a large part of each night running in its hollow wheel, but slept most of the daytime curled up in its soft nest. On cold nights the nest was drawn up around its neck or over the top of its head.

Breeding habits.-As in other species of wood rats, the mammae are arranged in 2 pairs of inguinal, and the young are usually 2 to 4 in number, but there are several records of 5 embryos. The young are born from February to May, and some as late as July, and in some cases more than one litter may be raised in a year.

Food habits.-In the free wild state the food of these wood rats consists of a great variety of green plants, fruit, seeds, and any scattered grain that comes their way. The captive was a dainty feeder, never eating much at a time and picking the choice bits, green leaves, tender tips, and branches of plants. Pigweeds of 3 or 4 species were eaten, as also were Atriplex, Dondia, Sarcobatus, Polygonum, nettles, dock, grasses and grass seeds, cabbage, cantaloup, apple parings, lettuce, green corn, rolled oats, bread, cheese, and many of the scraps from the table. He would not eat meat, cooked or raw, and did not kill the meadow mice or white-footed mice kept for several days in his cage.

Economic status.-Over most of the range of this species the desert valleys do not produce enough forage for stock, so the little green vegetation eaten is of no importance. In only rare cases do the rats come in contact with camps or ranches where some slight mischief might be done, and here they are so easily controlled as to prove of little economic importance.

\section{ONYCHOMYS LEUCOGASTER FUSCOGRISEUS ANTHONY}

\section{Oregon Grasshopper Mouse; Brown Scorpion Mouse}

Onychomys leucogaster fuscogriseus Anthony, Amer. Mus. Nat. Hist. Bull. 32: 11, 1913.

Type.-Collected at Ironside, Malheur County, Oreg., by H. E. Anthony in 1912.

General characters.-A sturdy little animal, with short, thick, tapering tail (pl. 32, A) ; short legs; erect ears; and a keen, bold, almost weasellike, expression of face. Color: Upper parts of adults, dark reddish brown with dusky along middle of back and on face and ears and top of tail; whole lower parts, feet, lower half and tip of tail, nose, and tuft at anterior base of each ear snow white. Immature specimens with slaty gray or plumbeous upper parts. The darkest specimens are from the Klamath region.

Measurements.-Average of several adults: Total length, $143 \mathrm{~mm}$; tail, 38; foot, 19.2 ; ear (dry), 15 . Of large female : $150 ; 40 ; 21 ; 16$. Weight of apparent subadult male when captured, $22 \mathrm{~g}$; after 2 years of captivity, $45.5 \mathrm{~g}$.

$7209^{\circ}-36-12$ 
Distribution and habitat.-The whole arid sagebrush Upper Sonoran plains of eastern Oregon are occupied by these little animals, which also extend in the same sort of country north in eastern Washington and south into Nevada and California and on the east grade into Onychomys leucogaster brevicaudus in Idaho (fig. 34). They are typical desert animals, living in the lowest, hottest, and dryest valleys they can find.

General habits.-These insectivorous and carnivorous little rodents have many of the habits of the weasel family. They are hunters, wanderers, freebooters, apparently never common, and without permanent homes of their own. They are generally caught in traps set for other animals at any kind of burrow or in trails or long marks

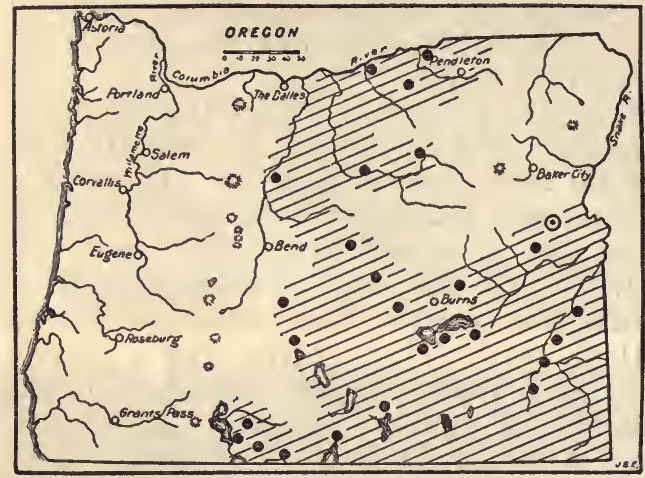

FIGURE 34.-Range of the grasshopper mouse, onychomys leucogaster fuscogriseus, in Oregon. Type locality circled.

made by running the heel or toe along the surface of the ground to be followed by inquisitive animals. They evidently frequent and probably appropriate the burrows of other small rodents, driving out or eating the owners at will. Their large front feet and claws suggest digging powers, but the writer has never found burrows that could be attributed to them and suspects that the claws are weapons rather than tools. They are much used in catching and holding their prey and also used in fighting and for defensive purposes.

In many years of trapping these animals for specimens about all that could be learned of their habits was from the contents of the stomachs of those caught and from the many species of other small animals eaten by them when caught in traps. From captive individuals, however, much concerning their habits and natures has been learned. One taken on the south side of Malheur Lake on August 31, 1920, was kept alive for nearly 3 years. He was not afraid from the first but was not so gentle and tame as others kept in captivity. He resented being handled and would bark and nip one's fingers, and if bothered too much, would on rare occasions actually bite. $\mathrm{He}$ was exceedingly quick and nimble and not easily caught in the hands, even in his cage.

While mainly nocturnal, he could see well in any light and came out of his nest box at any time when hungry, or if he heard the footfall of an insect or smelled a mouse of some other species.

He was a keen hunter and often searched his cage for any grasshopper, cricket, beetle, or scorpion that might be available. He would pounce on them and kill them, even though he did not eat them at the time. A live mouse in his cage was hunted down and cornered, if it could not be captured in the open. He would persistently follow its trail, creeping up in the grass, eager, alert, tail 
twitching, until he could pounce upon it. If he got a good hold, the struggle was short, and the mouse quickly dropped, limp and helpless, as his long sharp lower incisors penetrated its brain near one ear. If the mouse was of his own size and caught by the back end, there was a rough-and-tumble mix-up. The victim might be allowed to escape in order that a better hold might be obtained next time, but the pursuer was persistent and only awaited his chance. Whitefooted and meadow mice of his own size were regularly killed and eaten. In one case a white-footed mouse was not killed, and two mornings later it was sleeping with him in a better nest than he usually made for himself. For a couple of weeks he lived with the white-footed mouse on friendly terms, possibly waiting for a scarcity of food, or he may have been lonesome or cold, or needed a good nest builder as assistant. The white-footed mouse was then returned to his home in the sagebrush, and Onychomys accompanied his captors on a long journey.

In Arizona he was given the company of four individuals of the smaller species (Onychomys torridus) of his own genus, and from the first all were friendly and slept together in one nest. In dispositions they seemed surprisingly friendly and peaceful, in striking contrast to some of the gentler and more timid rodents.

Ony had a strong musky odor that was probably the result of a diet composed largely of insects and meat, though it did not vary noticeably with different foods. His house at first became very rank if not kept well cleaned out and sanded, but later when given a sand box for a toilet he used it exclusively and kept his house neat and clean. His fur would become mussy and rough when he did not have plenty of clean sand to roll in, but after a sand bath it was clean and fluffy. He did not usually make a good nest, but just pulled anything warm up around him when it was cold and sat on top of the nest material when the weather was warm.

His common everyday voice was a series of rapid, short, sharp squeaks, each, each, each, or chip, chip, chip, just what a little dog of his size would do in the way of barking, and it was used in the same way as a protest when annoyed, angry, or cornered.

His call note was a fine, shrill, prolonged whistle, insectlike in quality, but so thin that only keen human ears could detect it. It was heard only at night, most commonly in the spring but occasionally through the summer. It may be a sex or mating call and also a hunting call or recognition signal. The writer had occasionally heard it at night in the sagebrush country, but not until he had kept the animals in captivity did he learn its source. In Arizona, early in the spring of 1921, with no companions of his own species, Ony was evidently lonesome, and every evening when he first came out of his nest would sit on top of his nest box, lift his nose in the air, and with wide-open mouth send out his call. The howl of a wolf of his size would not be very different and the manner of giving it would be identical. The call was repeated several times each evening until he gave up the hope of calling a mate. At home in Washington, where he was kept in the library all winter, the call was not heard until the springlike days of February set the other animals to breeding while he, alone, was evidently calling for a mate.

At night he was active and energetic, darting about his cage or running at top speed on his revolving disk by the hour. In cold 
weather he slept a great deal, but showed no signs of hibernation in the coldest weather at Washington, down to $11^{\circ} \mathrm{F}$.

Breeding habits.-The mammae in this as in other forms of the group are arranged in 2 pairs of inguinal and 1 pair of pectoral, and the number of young as shown by embryos noted in specimens collected are usually 4 , occasionally 5 or 6 . A female carrying 4 embryos was taken at Klamath Falls, August 11, but throughout the group embryos have been noted in April, May, June, July, August, and September, probably indicating irregularity in the breeding season, rather than numerous litters in a season. The animals are never very abundant and reproduction is apparently not so rapid as in many other mice.

Food habits.-The names "grasshopper mouse" and "scorpion mouse" have been applied to different subspecies of this group, because of their fondness for grasshoppers and scorpions, but in no species is the diet limited to any one or even a few kinds of insects. Insects and small animal life generally form most of their food, but any kind of meat is eagerly eaten, and occasionally some seeds and a little green vegetation are taken if their chosen food is not plentiful.

During 2 years and more the captive from Oregon ate all the grasshoppers of any species he could get, up to 20 individuals a day, also crickets of many species, mole crickets, wild and domestic cockroaches, katydids, cicadas and their pupae, dragonflies, flies and fly larvae and pupae, hornets, ant eggs and larvae, beetles of almost every species offered including many large hard-shelled species, May beetles, snap beetles, lady beetles, cotton-bollweevils and other weevils, potato beetles, and such larvae as are commonly called "grub worms", "cutworms", "corn worms", and "wireworms", a great variety of moths and butterflies and their larvae, and caterpillars of the smooth kinds. He would eat angleworms but did not care much for them. He was very fond of scorpions, especially the large fat ones in southern Arizona, where he spent one winter, and also of the large praying mantis there. He refused ants, myriapods, blister beetles, hairy and spiny caterpillars, and slugs.

Lizards and salamanders were killed and eaten but were not much relished.

He killed and ate white-footed mice, house mice, pocket mice, and meadow mice, enjoying especially the newly born young meadow mice. Some of the mice killed were approximately of his own size and were nearly eaten in one night. The meat of larger animals, such as chipmunks, ground squirrels, and kangaroo rats, and of small birds, and even of a phalarope and a prairie falcon, was eaten, also beef, mutton, chicken, or any meat offered. If fresh meat was not available, he would eat cooked meat of almost any kind, and delighted in a chop bone to gnaw, putting his feet on it and tearing at it much as would a little dog on a large bone. Later, when from lack of his favorite foods he was fed mainly on rolled oats, sunflower seed, and hempseed, he grew fat and lazy and lost his appetite and much of his hunting spirit. When given the freedom of the kitchen every night for a month or more, he cleaned out the cockroaches until no more could be found except a few that lived on the shelves and did not come down to the floor. 
Economic status.-So far as known the habits of these mice are mainly beneficial to man in the agricultural field, not only in destroying insects, but in keeping down the abundance of other rodents. Undoubtedly some of the insects eaten are of predatory and beneficial species, but the check on abundance would be greatest in the numerous and usually most destructive species, such as grasshoppers, crickets, cockroaches, beetles, and beetle larvae. Some of the most abundant predatory species, such as ants and myriapods, are rejected by them, and others do not commonly come within their reach. The number of adult mice they are able to capture is probably not great, but their fondness for young mice would indicate that these might furnish a considerable item of their summer diet.

The possibility of using them in gardens, greenhouses, cellars, or other restricted areas to control insect pests has been considered but not demonstrated.

Their destruction of ground-dwelling and burrowing insects locally may be almost equal to that of the birds on insect life aboveground.

\section{PEROMYSCUS MANICULATUS GAMBELII (BAIRD)}

GaMbel's Deer Mouse; White-Footed Mouse; Meko-Ka of the Klamath (C. H. M.)

Hesperomys gambelii Baird, Mamm. North Amer., p. 464, 1857.

Type.-Collected at Monterey, Calif., by W. P. Trowbridge about 1854 .

General characters. - Size medium (pl. 32, B); tail less than half of total length; ears smaller than in rubidus, colors paler. In summer, adults, upper parts light cinnamon brown; top of tail the same; feet, lower parts, and lower half of tail white or whitish. Immature, slaty gray above, whitish below. Colors brightest in winter.

Measurements. - Average of a series of typical adults: Total length, $159 \mathrm{~mm}$; tail, 72; foot, 20; ear (dry), 15.

\section{Distribution and habi-} tat. - This is a widely distributed form, ranging from Baja California to central Washington and covering most of Oregon east of the Cascades, as well as the less heavily

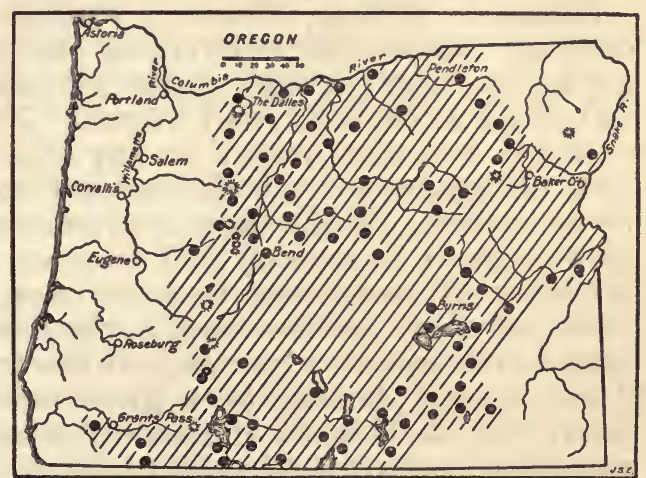

Figure 35.-Range of Peromyscus maniculatus gambelii in Oregon.

timbered part of the Cascade Range, and the upper Rogue River Valley from Grants Pass to Ashland and across to the Klamath country (fig. 35). Its place is taken in the southeastern corner of the State by $P . m$. sonoriensis, and in the northeastern corner by $P . m$. artemisiae. It belongs to the more open, semiarid area lying back from the humid coast region and reaching to the edges of the more arid interior. As it is mainly a color variety of its group, humidity, light, and shade determine its range, rather than altitude and lifezone factors. Specimens taken from sea level to timber line have 
essentially the same characters. Open timber and brush land are its main habitat.

General habits.-These mice adapt themselves to all sorts of cover and conditions, from meadows, grassland, sagebrush, chaparral, open coniferous and deciduous forests, to rocks, cliffs, and earth bankswherever they obtain safe homes and a food supply. Generally they are the most abundant mammal found within their range, causing much annoyance to collectors by filling traps set for other more desirable specimens. Even out in the sagebrush country they are often numerous where there is growth enough to hide them from owls. Many live in burrows in the ground, usually those of pocket gophers or other rodents, borrowed for the occasion, but rarely dug for themselves.

Breeding habits. - The females have normally 3 pairs of mammae2 inguinal and 1 pair of pectoral-on 4 widely separated mammary glands. The young are usually 4 to 6 in number, but in rare instances as many as 8 or 9 . They are born at all times of the year, but mostly during the spring and summer months, and in some cases probably several litters are produced during the year. The rate of reproduction depends in these as in other mammals on the nature and abundance of their food supply.

Food habits.-Seeds constitute their principal food, including almost every available kind, from acorns and hazelnuts down to the smallest seeds of grass and many other tiny plants. Berries and berry seeds are often eaten, also a little green foliage, and many insects and probably insect eggs. Almost every kind of food is acceptable to them, and in camp stores they sometimes do slight mischief.

Economic statuis.-Although exceedingly quick at running and dodging and skillful at climbing and hiding, still these little mice are an important article of diet for bobcats, foxes, coyotes, skunks, badgers, marten, mink, and weasels. Next to the meadow mice they probably feed more owls than any other mammal of their area, and their abundance and scarcity have a direct relation to the numbers of their enemies. While their destruction of insects may be of benefit to vegetation in general and to some cultivated crops, their consumption of seeds must in some cases, and especially in semiarid areas, serve as a serious check to the reseeding of the vegetation, and even to reforestation by many of the trees that scatter edible seeds. The potential damage by a great number of these mice could be heavy, but their hosts of enemies generally keep a fair balance of abundance and prevent serious losses.

The mice are easily poisoned or trapped, but it is generally better economy to protect such of their enemies as are otherwise harmless and leave the mice to natural control.

\section{PEROMYSCUS MANICULATUS RUBIDUS OSGOOD}

\section{Ruddy Deer Mouse; Western Woods Mouse; White-Footed Mouse}

Peromyscus oreas rubidus Osgood, Biol. Soc. Wash. Proc. 14: 193, 1901.

Peromyscus perimelurus Elliot, Field Columb. Mus. Pub. 74, Zool. Ser. $3: 156$, 1903. Type from Gold Beach, Oreg.

Type.-Collected at Mendocino City, Calif., by J. Alden Loring in 1897.

General oharacters.-Large for the maniculatus group, tail about as long or longer than head and body, slender, not crested; ears medium, nearly naked; 
mustaches long, reaching tips of ears; fur in summer close and dense, in winter longer and softer. Color of adults in summer, upper parts rich cinnamon brown, more or less darkened with dusky hairs; top of tail dusky brown; feet and whole lower parts and lower half of tail white or whitish; in winter slightly brighter colored; immature, plumbeous above, whitish below.

Mreasurements.-Average of several typical adults: Total length, $193 \mathrm{~mm}$; tail, 96 ; foot, 21.5; ear (dry), 16. Adult male from Lagunitas, Calif. : Total length, $178 \mathrm{~mm}$; tail, 85 ; foot, 22 ; ear, from notch, 18 . Weight, $21.6 \mathrm{~g}$.

Distribution and habitat.-This very dark colored form of the white-footed mouse inhabits the coast region from San Francisco Bay, Calif., to the Columbia River, and east in Oregon to the west slope of the Cascades, except in the upper Rogue River Valley (fig. 36). It is mainly an inhabitant of dense forest or chaparral in a humid climate.

General habits. -Whatever is known of the habits of these little forest dwellers has been chiefly gathered by collectors who find them in the morning rounds of their trap lines, usually on or under old logs, on stumps, in old camps or houses in the woods, or among broken rocks. Sometimes, however, they are caught in traps set under low vegetation, in the marshes, or even among driftwood on the o c e a $n$ beaches. While primarily woods mice, as often called, they are able to adapt themselves to almost any habitat affording cover and a food supply. To what extent they

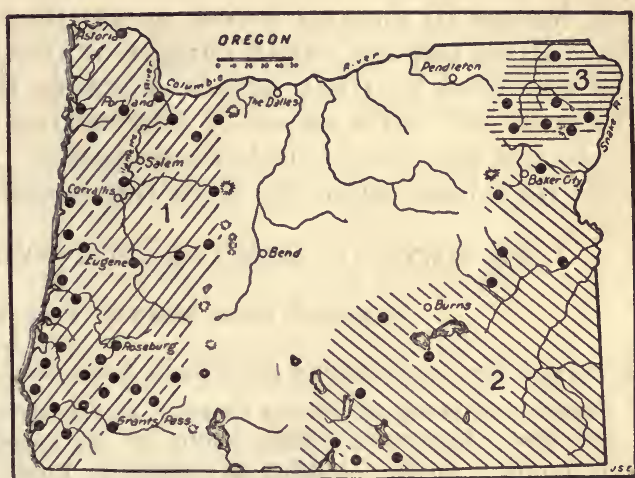

Figure 36.-Range of three subspecies of deer mice in Oregon: 1, Peromyscus maniculatus rubidus; $2, P$. $m$. sonoriensis; $3, P . m$. artemisiae.

climb the tall forest trees is not well known, but they are good climbers and are often caught well up on the branches and trunks of trees, or in the hollows of trunks where they frequently make their nests. In many cases also they build their nests under or in the great fleeces of moss that drape the trees in the coastal forests.

The mice are so strictly nocturnal as to be rarely seen except when caught in traps or occasionally surprised in their nests in camps or buildings. They can see fairly well in the daytime, but their large, dark eyes are better adapted to the night.

They do not accumulate fat or hibernate for winter and are active all the year.

Breeding habits. - In this group the females have 3 pairs of mammae-2 inguinal and 1 pectoral-on 4 widely separated glands. The young, as shown by sets of embryos usually number 4 to 6 , but on rare occasions as many as 8 or 9. They are found at all times of year, but mostly from March to October. There are a few records of embryos noted in December, January, and February. Under favorable conditions of food and protection several litters may be produced in a year, but under unfavorable conditions there may be none. Usually the mice are common but not present in great numbers. 
Distribution and habitat.-This form ranges widely over southern British Columbia, western Montana, and northern Idaho, and extends into northeastern Oregon in the Blue Mountain section (fig. 36). While found mainly in the Transition Zone in this area, it seems to have no zone limits but ranges from the lowest valleys to timber line on the mountains. These mice are more partial to a forest and brush country but adapt themselves to almost any habitat.

General habits.-In habits they show no well-marked differences from Gambel's mouse, occupying as does that form the open timbered area and brushy country, including the sagebrush from which their name is taken. In the early settlement of the Blue Mountains they were often troublesome in camps and new buildings in the timber, and even in 1916, in a forest ranger's cabin near Sheep Creek on the Wenaha Forest they kept running over the writer all night and making a great racket in the cabin. The grub box was lined with tin and the pantry well screened, however, so they could do no serious mischief.

In food and breeding habits they are practically identical with gambelii, and their economic status is essentially the same.

\section{PEROMYSCUS CRINITUS CRINITUS (MERRIAM)}

\section{IDAHo Canyon Mouse}

Hesperomys crinitus Merriam, North Amer. Fauna No. 5, p. 53, 1891.

Type.-Collected at Shoshone Falls, Snake River Canyon, Idaho, by Merriam and Bailey, in 1890.

General characters.-A rather small, slender, silky-furred mouse with long, hairy tail, medium large, very thin, and nearly naked ears, mostly naked

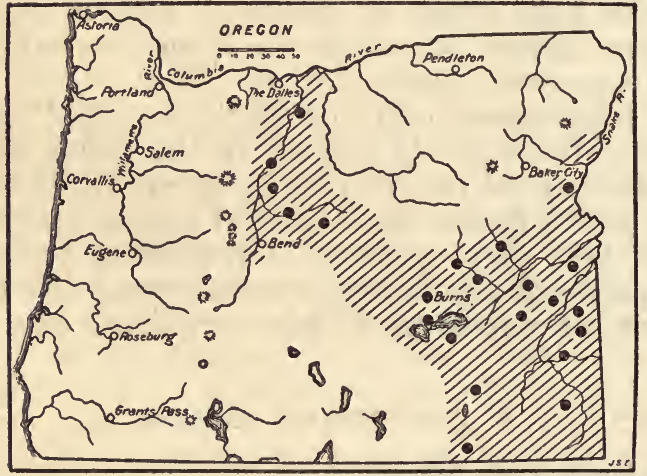

Figure 37.-Range of the silky cliff mouse, Peromyscus crinitus crinitus, in Oregon. soles, and only four mammae. Upper parts of adults dull-dark buffy gray with a touch of rich buff along sides; top of tail dark brown or blackish; feet, lower parts, and lower half of tail white or whitish. Immature, ashy or slaty gray over upper parts.

Measurements.-Average of typical adults: Total length, $176 \mathrm{~mm}$; tail, 95; foot, 20 ; ear (dry), 16.

Distribution and habitat.-These beautiful little mice are found in the Great Basin area of $\mathrm{Ne}$ vada, Utah, Idaho, and Oregon wherever deep canyons and lava-rock cliffs and rimrocks afford their favorite habitat in arid Upper Sonoran Zone (fig. 37). In Oregon they are found in the Snake, Malheur, and Deschutes River Valleys wherever there are suitable cliffs.

General habits.-Rock, cliff, and canyon dwellers, these silky little mice must be expert climbers among and over the rocks. Their long, well-haired, and almost bushy tails undoubtedly serve to steady and balance them on lofty walls, or to guide and steer them 
in long leaps through the air. Their real homes are back in cracks and little caverns of the cliffs, where their tiny tracks show on dusty shelves, and where traps baited with rolled oats get a few specimens. They seem never to be numerous and are very local in distribution. They are caught only at night and, like other members of the genus, seem to be closely nocturnal.

Breeding habits.-The females have but 2 pairs of mammae, all close together on 1 pair of mammary glands well back on the abdomen. The usual number of young is probably 2 or 4 as in other members of the group and the slow rate of reproduction may well account for the rarity of the species.

Food habits.-Little shells and husks of a great variety of seeds scattered along their rocky shelves in well-hidden holes of the rocks show the general nature of their food. Hackberry shells are often found, and chaff from grass seeds and bits of wild currant and rose seeds under the bushes at the foot of cliffs give some clue to their diet. The stomach contents show mainly a white dough from well-masticated seeds with occasional traces of insects. Rolled oats is a favorite bait, but almost any grains or seeds are eaten, also bread, meat, or other of our standard foods.

Economic status.-In their cliffs and canyons these mice fill a niche at present unoccupied by man and only in rare cases can they be considered in any way harmful.

\section{PEROMYSCUS TRUEI GILBERTI (ALLEN)}

\section{GILBERT'S WHITE-FOOTED MOUSE}

Sitomys gilberti Allen, Amer. Mus. Nat. Hist. Bull. 5: 188, 1893.

Type-Collected in Bear Valley, San Benito County, Calif., by C. H. Gilbert and W. W. Price in 1893.

General characters.-Large ; ears very large and nearly naked; tail about half of total length, long haired at tip. Skull long and narrow with especially long rostrum ; mammae in three pairs. Adults, upper parts dark rich cinnamon, considerably darkened over back by dusky; top of tail brownish black; feet, lower parts, and lower half of tail whitish. Immature, dark plumbeous over upper parts. Measurements.-Average of a series of typical adults: Total length, $200 \mathrm{~mm}$; tail, 98; foot, 24; ear (dry), 20.

Distribution and habitat.-From the interior valleys of California

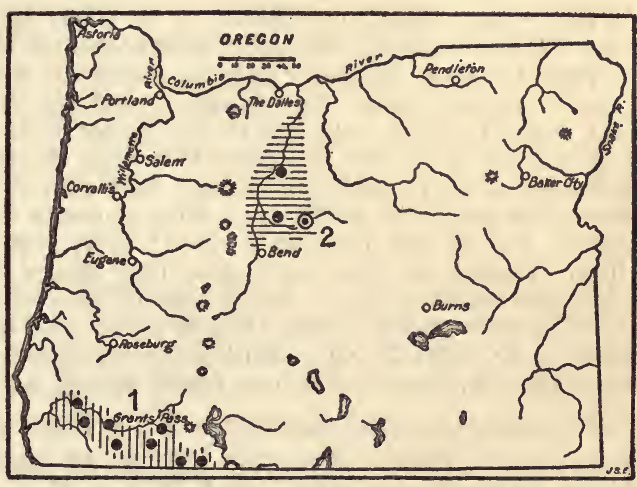

Figure 38.-Range of Gilbert's and Preble's whitefooted mice in Oregon: 1 , Peromyscus truei gil-
berti; $2, P$. t. preblei. Type locality circled.

these big-eared mice extend northward from the Klamath River Valley into the Rogue River Valley, where specimens have been taken at Grants Pass, Grants Peak, Galice, Brownsboro, and Briggs Creek (fig. 38). They occupy Upper Sonoran Zone, generally in open forest, chaparral, or cliff country. 
General habits.-Generally these mice are cliff, tree, or log dwellers; but specimens are often obtained in traps set on the ground under dense chaparral at considerable distance from their real homes, and during the dry season they may even occupy old burrows of pocket gophers and ground squirrels. More often, however, they are caught among the rocks, on or under old logs, or at the base of some old hollow tree.

They are strictly nocturnal and rarely seen, except when caught in traps or driven out of their nests. Occasionally they come into cabins or houses in or near the woods and make some racket at night, but they are rarely so common as to be much noticed.

Breeding habits.-The mammae of the females are arranged in 2 pairs of inguinal and 1 pair of pectoral, and the number of embryos found in breeding females is usually 2 to 4 with a probable maximum number of 6.

Food habits.-Like others of the genus they live mainly on seeds, nuts, berries, and a few insects, are eager for rolled oats and other grains used as trap bait, and probably have as varied a diet as other white-footed mice.

Economic status.-Not common, and rarely found in cultivated or inhabited areas these mice can do little damage. The seeds that they consume may have some slight effect on reforestation, but generally they are not in a real forest country and their effect on chaparral could not be of much consequence. They would well repay closer study in regard to the function and development of the very unusual ears.

\section{PEROMYSCUS TRUEI PREBLEI, SUBSPECTES NOVUM}

\section{Preble's White-Footen Mouse}

Type.-Male adult, no. 78660, U. S. Natl. Mus., Biological Survey collection, from Crooked River, 20 miles southeast of Prineville, Oreg., collected June 28, 1896, by E. A. Preble. Original number, 1079.

General characters.-Considerably smaller than gilberti and slightly smaller than typical truei; ears relatively larger than in gilberti, almost naked; tail long and hairy at tip; skull smaller with relatively shorter rostrum and wider braincase than in gilberti, lighter and slenderer than in truei. Color, upper parts of adults dull buffy gray with a touch of rich fulvous on shoulders and cheeks; top of tail brownish black; feet, lower parts, and lower half of tail white. Immature, light ashy gray over upper parts.

Measurements.-Type: Total length, $175 \mathrm{~mm}$; tail, 86; foot, 23 ; ear (dry), 20. Topotype, male adult, $173 ; 82 ; 23 ; 20$. A young adult male from Warm Springs, $166 ; 80 ; 23 ; 20$. Skull of type: Basal length, $24 ;$ nasals, 9.8 ; width of braincase, 13; length of upper molar series, 4.

Distribution and habitat.-This form of the truei group is known from 2 specimens taken by Preble at an overnight camp on Crooked River, 20 miles southeast of Prineville in 1896, 3 in the Jewett collection and 1 in the Gabrielson collection from Prineville, and 1 taken by Jewett near Warm Springs in the Deschutes Valley in 1915 (fig. 38). Undoubtedly they occupy the high basaltic cliffs all along the deep canyons of the Crooked and Deschutes Rivers, but there is little probability of any direct connection in range at the present time with either truei or gilberti. 
General habits.-At both localities where specimens were taken they were caught at the base of cliffs or canyon walls. This would indicate habits more nearly like those of truei, which is largely a cliff dweller, than like the timber and brush-loving gilberti.

\section{REITHRODONTOMYS MEGALOTIS MEGALOTIS (BAIRD)}

\section{Desert Harvest Mouse}

Reithrodon megalotis Baird, Mammals North Amer., p. 451, 1857.

Reithrodontomys megalotis nigrescens Howell, North Amer. Fauna No. 36, p. 32 , 1914. Type from Payette, Idaho.

Type.-Collected in northeast corner of Sonora near San Luis Spring, N. Mex., by C. B. R. Kennerly, in 1855 .

General oharacters.-Slightly smaller and paler colored. than the common house mouse, with longer and softer fur and whiter lower parts, with deeply grooved upper incisors, terete, well-haired, tail, and hairy ears. Color, upper parts buffy gray, paler on the sides; lower parts, feet, and lower half of tail white or whitish.

Measurements.-Average of several typical adults: Total length, $140 \mathrm{~mm}$; tail, 71; foot, 17.6; ear (dry), 12 to 13.

Distribution and habitat.-These mice show surprisingly little variation over a range extend-

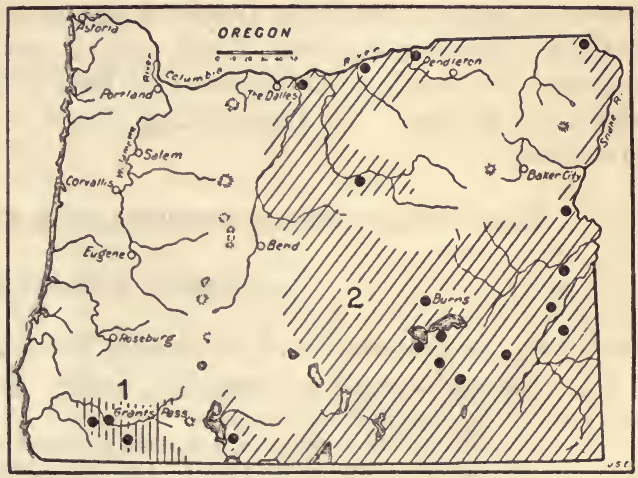

FIGURE 39.-Range of the two subspecies of harvest mice in Oregon: 1, Reithrodontomys megalotis longicaudus; $2, R$. m. megalotis.

ing from central Mexico up through the interior desert country to eastern Oregon and southeastern Washington (fig. 39). They practically fill the dry Upper Sonoran Zone area of Oregon east of the Cascades wherever there is enough moisture for a good growth of vegetation. They are partial to marshes, meadows, ditch banks, or the borders of irrigated fields. Often they, are locally abundant in suitable situations, but over the dryer parts of the region they are entirely absent.

General habits.-These little harvest mice are mainly ground dwellers, making their little roadways over the surface of the ground under cover of growing or fallen vegetation, and living in grass nests, on or under the surface of the ground. They make tiny burrows, but seem to spend much of their time in their runways or in the nearby vegetation searching for choice bits of food. They are active all winter, and seem to be almost as diurnal as nocturnal, often getting into traps during the daytime and occasionally seen darting through their runways.

Breeding habits.-The females have normally' 3 pairs of mammae-2 inguinal on 2 large mammary glands and 1 pectoral on a pair of smaller glands. The young, as indicated by sets of embryos, are usually 4 to 6 . They seem to be found at all seasons except midwinter in the North, and evidently several litters are raised in a season. 
Food habits.-About all that is known of their food is from examiration of the stomachs, which usually contain a combination of green vegetation, seeds, or grain. Grass stems are found cut in short sections on their feeding grounds, and their abundance in and around alfalfa fields would imply a fondness for the green leaves and tender shoots of these plants. They are always eager for rolled oats used as trap bait, and their very small stomachs indicate a diet of rich food, more seeds than green vegetation.

Economic status.-Too small and well hidden to be much noticed, these little harvesters of the meadows often become very numerous in the most fertile fields and meadows, where they take a small toll of the forage and a share of the seeds. Their depredations seem never to be noticed, but added to those of several other species of rodents help to swell the total of serious losses.

Clean fields, meadows, ditch banks, and borders would leave them exposed to overhead enemies and be by far the most economical and effective method of preventing their overabundance and possible mischief.

\section{REITHRODONTOMYS MEGALOTIS LONGICAUDUS (BAIRD)}

\section{Catifornia Harvest Mouse}

Reithrodon longicauda Baird, Mammals North Amer., p. 451, 1857.

Type locality.-Fixed at Petaluma, Calif. No type designated. Type series collected by E. Samuels in 1856.

General characters.- Size, color, and general appearance much as in the common house mouse, but structural characters widely different; upper incisors deeply grooved; tail well haired and not tapering noticeably; ears larger and more hairy. Upper parts rich buffy brown, darkened with dusky along median line of back and clearing to buffy orange along sides; feet, lower half of tail, belly, and chin light gray or whitish; breast buffy orange.

Measurements. - Average of a series of typical adults: Total length, $139 \mathrm{~mm}$; tail, 73; foot, 17; ear (dry), 12.

Distribution and habitat.-From a range covering practically the whole of western California these little mouselike rodents extend into southern Oregon in the upper Rogue River Valley (fig. 39). There are specimens from Grants Pass, Slate Creek (20 miles southwest of Grants Pass), and Ashland. They undoubtedly occupy the whole of the upper Rogue River Valley and connect in range with those of the Klamath Valley over the low ridge east of the Siskiyou Mountains and grade toward the paler megalotis in the Klamath Lake basin. They are mainly in Upper Sonoran Zone.

General habits.-Usually these little animals are found in meadows, on grassy or weedy uplands, or along weedy fence rows bordering fields. In dry seasons they gather on the low moist grounds, and even in wet marshes, but with the fall rains spread out over higher country. They live as do the meadow mice under the protecting cover of dense vegetation and make tiny runways over the ground and numerous little burrows below the surface. Their nests are usually placed on the surface of the ground, neat little balls of grass with soft lining.

Breeding habits.-The females have normally 3 pairs of mammae2 inguinal and 1 pectoral - on 4 distinct mamary glands. The young, 
as shown by embryos, usually number 4 to 6 . There are records of embryos in specimens taken in almost every month of the year, and it seems probable that several litters may be produced in a year by each female.

Food habits.-Like many other rodents, they live on partly green vegetation, grass, and other plants, and the seeds of grass and other grains. Their little stomachs often show mainly green food and again mainly the white starchy dough of seeds.

Economic status.-A small quantity of grass, other forage plants, and seeds are consumed by these little animals, which added to that taken by numerous other rodents causes a serious loss each year to the farmers.

\section{CLETHRIONOMYS CALIFORNICUS CALIFORNICUS (MERRIAM)}

\section{Camifornia Red-backed Mouse}

Evotomys californicus Merriam, North Amer. Fauna No. 4, p. 26, 1890.

Type.-Collected at Eureka, Calif., by T. S. Palmer, in 1890.

General characters. - The compact form, short legs , small tail, and long fur that partly conceals the ears, gives the red-backs much the appearance of meadow mice, to which they are related as a subfamily. This is one of the l a rge, dark-colored, longtailed forms in which the red of the back is much obscured or sometimes wholly concealed by black. Color of adults, deep chestnut over the back, much obscured by dusky hairs; sides dark buffy gray; belly buffy or ochraceous over dark underfur; toes white or whitish; tail indistinctly bicolor, dusky above, whitish below. Young much darker, sometimes almost black.

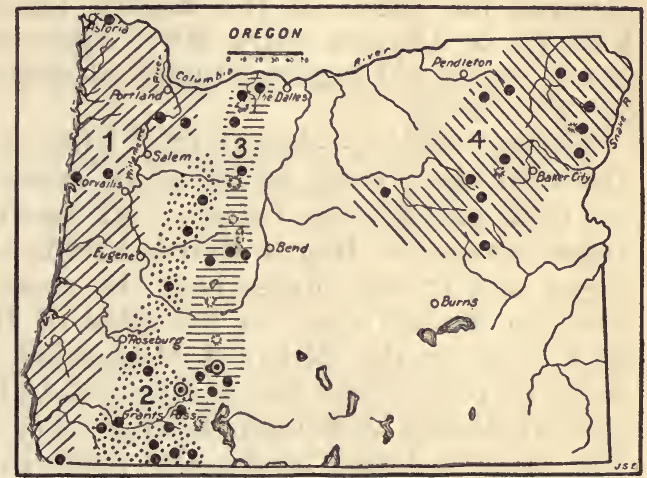

Figure 40.--Range of the four forms of red-backed mice in Oregon: 1, Clethrionomys californicus californicus; 2 , C. c. obscurus; 3, C. c. mazama; 4, C. gapperi saturatus. Type localities circled.

Measurements.-Average of typical adults: Total length, $165 \mathrm{~mm}$; tail, 53 ; foot, 20.5; ear (dry), 10.

Distribution and habitat.-The coastal area of western Oregon and northwestern California, mainly in heavy forests of humid Transition Zone (fig. 40).

General habits. - This is a scarce or rarely collected species, represented in Oregon by specimens from only four localities-Astoria, Yaquina Bay, Wells, and Oregon City. The animals live mainly on the ground, and are generally caught under old logs in the woods.

They feed largely on green vegetation, grass, seeds, and various small plants. They are eager for rolled oats or any kind of grain used for trap bait.

Little is known of their breeding or other habits. 


\section{CLETHRIONOMYS CALIFORNICUS OBSCURUS (MERRIAM)}

\section{DUsky Red-BACKed Mouse}

Evotomys obscurus Merriam, Biol. Soc. Wash. Proc. 11: 72, 1897.

Type.-Collected at Prospect, upper Rogue River Valley, Oreg., by Edward A. Preble in 1896.

General characters.-This is a smaller, lighter colored interior form of californicus, with red of back less obscured. Back of adults light chestnut brown, not much obscured by black hairs; sides dull buffy gray; belly buffy gray; feet whitish or gray with whitish toes; tail but slightly bicolor. Young darker, duller. and more plumbeous.

Measurements.-Average of typical adults: Total length, $144 \mathrm{~mm}$; tail, 44.5 ; foot, 18.2; ear (dry), 10.

Distribution and habitat.-These rather dull-colored little rodents are shown by the present series of specimens to be intermediate between californicus and mazama, not only in characters but in distribution, occupying the more open Transition Zone valleys between the heavy timber of the humid Coast Ranges and the Canadian Zone forests of the Cascades, and extending from northern California up through the edges of the Rogue, Umpqua, and Willamette River Valleys in Oregon (fig. 40). They are generally found in the woods under old logs or stumps or dense vegetation in either wet or dry situations.

General habits.-Apparently little is known to distinguish the habits of these from californicus, except that they are generally in less dark and gloomy forests. At the type locality, Prospect, on the upper waters of Rogue River, Preble took two specimens in damp mossy and grassy places near the river. At Grants Pass, Streator took one under a log in the edge of the woods back a mile from town, and in the Siskiyou Mountains, Hollister trapped a few in damp fir forests and one in a mountain beaver runway. At the west base of Mount Jefferson, Loring took a series of specimens under $\operatorname{logs}$, stumps, brush heaps, and rocks in the dry woods at some distance from streams, using rolled oats and bacon for trap bait.

\section{CLETHRIONOMYS CALIFORNICUS MAZAMA (MERRIAM)}

\section{MAzama ReD-BaCked Mouse}

Evotomys mazama Merriam, Biol. Soc. Wash. Proc. 11: 71, 1897.

Type.-Collected at Mount Mazama, south side of Crater Lake, Oreg., by C. Hart Merriam and Vernon Bailev. August 15. 1896.

General characters.-Large, but smaller than californicus, about as in obscurus, colors brighter and clearer than either. Back of adults light hazel in a fairly well-defined area; sides light buffy gray; belly washed with buffy over plumbeous; feet white or whitish; tail sharply bicolor, sooty above, whitish below. Young darker, more plumbeous.

Measurements.-Average of several typical adults: Total length, $157 \mathrm{~mm}$; tail, 52: foot, 18.75; ear (dry), 11.

Distribution and habitat.-This is a boreal mountain form, occupying apparently all the Canadian Zone area of the Cascade Mountains in Oregon and of Mount Shasta in California, grading into obscurus on the lower slopes (fig. 40).

General habits.-These bright-colored little animals are generally caught under logs or around stumps and hollow trees in the open 
mountain forests of pine, spruce, fir, and hemlock. 'They are in part diurnal, and seem to get into the traps about as much in daytime as at night. Preble saw one running in the spruce woods near Anna Creek in the early afternoon. In this, as in many other habits, they resemble the common meadow mice, except that they rarely make runways.

They feed mainly on green vegetation and seeds, the contents of the stomachs usually being dominated by green pulp of grass and other plants. They are always eager for rolled oats, which are generally used for trap bait.

There seems to be only one record of breeding for this subspecies, a female taken near the Three Sisters, July 19, containing 4 welldeveloped embryos; but the females have 4 pairs of mammae-2 inguinal and 2 pectoral-and like other forms of the genus the young probably vary from 4 to 8 in a litter.

Their abundance and scarcity probably depend on the extent to which they furnish food for the smaller carnivores and birds of prey.

\section{CLETHRIONOMYS GAPPERI SATURATUS (RHOADS)}

\section{British Columbia Red-Backmd Mouse}

Evotomys gapperi saturatus Rhoads, Acad. Nat. Sci. Phila. Proc., p. 284, 1894.

Type.-Collected at Nelson, British Columbia, by Samuel N. Rhoads, in 1892.

General characters.-Size about the same as mazama, but of the shorter tailed, brighter colored gapperi group. Whole back of adults bright chestnut, with scarce a trace of black-tipped hairs; sides buffy gray, belly washed with whitish or very pale buffy; feet and lower surface of tail whitish or light gray. Young duller and darker colored.

Measurements.-Average of several typical aduits: Total length $149 \mathrm{~mm}$; tail, 45; foot, 18.2; ear (dry), 12.

Distribution and habitat.-From a wide range over British Columbia, Washington, and northern Idaho, this form of the eastern group of red-backed mice comes into northeastern Oregon in the Blue Mountain section, filling the Canadian Zone and coming down cold slopes and gulches into what seems to be Transition (fig. 40).

General habits.-They are forest dwellers, but in Oregon are found mainly in the open pine and spruce forests of the Rocky Mountain type, living around the trees and logs and under cover of low vegetation in the driest parts of the forest as well as along streams and the edges of meadows. They are to a great extent diurnal, and where abundant are often seen in the daytime, running over the ground or on logs, and occasionally up the trunks of trees. They have larger eyes and ears, and are much more active and keen, than the meadow mice and less restricted to cover and runways. In fact they rarely make noticeable runways but burrow under the mellow surface of the woods earth and leaves, and in part live in hollow logs and trees or under loose bark of logs.

Occasionally they are as abundant as meadow mice and are the most abundant animal of their habitat. At Sled Springs, 25 miles north of Enterprise, in April and May 1919, Cantwell reported them taken every day in 75 percent of his traps, and in several of the traps 1 every day for a period of 10 days. More often, however, they are rather scarce and very irregular in distribution, seeming to find existence possible only where there is especially favorable cover. 
The females have 2 pairs of inguinal and 2 of pectoral mammae, and the young, as shown by embryos, are usually 4 to 6 . Probably 8 is the maximum number, as occasionally recorded in related forms.

Their stomachs are usually filled with green pulp, and many bits of cut grass and small plants, cut and drawn under cover to be eaten in safety, are found under the logs where they feed. Traces of grass and other plant seeds are also found in the stomachs, and rolled oats or other grains are eagerly taken as trap bait.

Very little mischief can be ascribed to these beautiful little forest dwellers, and their value as food for fur-bearing mammals may well overbalance any destruction of vegetation.

\section{PHENACOMYS LONGICAUDUS True}

\section{RED Tree Mouse}

Phenacomys longicaudus True, U. S. Natl. Mus. Proc. 13: 303, 1890.

Type-Collected at Marshfield, Coos County, Oreg., by Aurelius Todd, in 1890.

General characters.-Next to the largest of the genus; tail hairy, about as long as body without head; legs short, toes long, and claws sharp and well curved; eyes small; ears low, nearly concealed in fur; fur long, fine, and soft; upper parts uniform light rusty or cinnamon rufous; lower parts washed with buffy white over plumbeous underfur; tail dark brown or blackish above and below.

Measurements.-Average of 5 adult females: Total length, $182 \mathrm{~mm}$; tail, 73 ; foot, 21; ear (dry), 11. Weight, $27 \mathrm{~g}$ (A. B. Howell, 1926, p. 52).

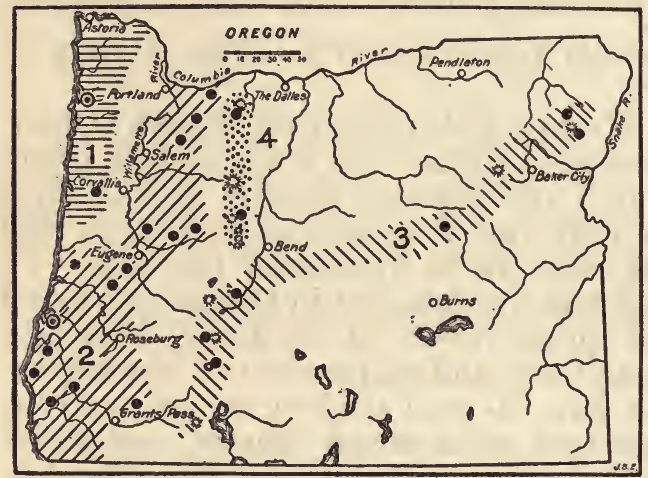

Figure 41.-Range of four forms of the genus Phenacomys in Oregon: 1, Phenacomys silvicola; 2 , $P$. longicaudus; $3, P$. intermedius intermedius; 4 , P. . olympicus. Type localities circled.

Coquille River, in Coos County; on Elm Creek and at Melrose in Douglas County; on the Willamette, at Cottage Grove, and at Vida, in Lane County; on the upper Clackamas River, in Clackamas County; and near Bonneville, in Multnomah County.

These localities indicate a range over most of the timbered parts of western Oregon, from the foothills to the coast, unless, as seems probable, its place is taken west of the Willamette Valley by the darker colored dusky tree mouse. To the south the species ranges down the timbered coast region of northwestern California as far as Mendocino County. 
With their homes in the treetops, they naturally occupy only the areas of extensive forest or areas of recently isolated forest. They are found mainly in the branches of Douglas fir, but occasionally also in Sitka spruce and grand fir. A few years ago they were considered one of the rarest mammals in North America, known only from two specimens, but when their tree-dwelling habits became known, they were found to be common over a wide extent of country and are now better known than most of the small mammals.

History.-The red tree mouse was first made known to science by its discoverer, Aurelius Todd, of Eugene, Oreg., when he sent a specimen to the National Museum in 1890. It was collected near Marshfield, in August, and was described in the Proceedings of the United States National Museum of November of the same year, by $\mathrm{F}$. W. True, curator of mammals, with a letter from Todd giving the first information regarding the habits of the species. For several years he had known of them in southern Douglas County and knew of their tree-dwelling habits, but the type from Marshfield, Coos County, was the second specimen he had seen. Their nests on the branches of the Douglas spruce had been found in considerable numbers not only in Douglas, Coos, and Curry Counties, but in Lane County, a considerable range being thus indicated in this first account of the species.

In 1907 William Bebb, of Los Angeles, Calif., showed several specimens that he had taken the previous year at a lumber camp near Marmot, Oreg. When the tall Douglas spruce trees were felled for lumber these mice were found stunned or killed by the crashing of their nests, often located 100 feet up in the treetops.

In 1914 Alfred Shelton, while at the University of Oregon, secured two specimens of this rare mouse and learned to recognize their bulky nests in the treetops. He found the nests on Spencer Butte, and together he and the writer alternately climbed a lot of tall trees and examined many nests but secured only one of the mice at that time.

In 1917 Jewett found them abundant along the lower Rogue River Valley in Curry County, where their bulky nests were seen in the spruce trees from 15 to 80 feet above the ground. He secured a couple of the mice alive but they failed to survive a long, hard pack trip.

Meanwhile the tree mice had been found in several places in northwestern California and very carefully studied by H. E. Wilder, Walter P. Taylor, and A. B. Howell, so at present few of our small native mammals are better known.

In July 1927 a piece of dried skin with the unmistakable red fur of the tree mouse was picked up by Jewett, who was on his way up Salt Creek in northwestern Jackson County, which establishes a new locality record in the Rogue River Valley.

General habits.-These mice are well named, for, so far as known, they live almost entirely in the treetops, often at a height of 100 feet or more from the ground. In young forests, of low branching trees they are sometimes found on lower branches, but in old forests of tall trees they are generally 60,80, or 100 feet up in the green branches, where they travel freely from treetop to treetop. They climb well, although not rapidly, and follow the slender branches with ease and security, the long and well-haired tail serving some- 
what the function of a squirrel's bushy tail in enabling them to keep their balance.

In California Wilder has discovered several of the males living in burrows under logs and woodpiles on the ground under the trees where their food is obtained, but this is where they live in comparatively low trees with nests in the branches often not far above the ground. In Oregon the mice have not as yet been found on the ground, although tracks in snow at the base of the trees were thought by Todd to have been made by tree mice. Hundreds of traps set on the ground on logs and low branches have failed to secure any specimens, but this may in part be due to the fact that the mice refuse the ordinary trap baits used.

The nests of the tree mice are of various sizes from the new or freshly built nests of the males, the size of ordinary mouse nests, to the old breeding nests in large trees that have been used and built up for many years until they attain the size of a peck or half-bushel measure. In fact, some would apparently fill a bushel basket and have the appearance of permanent houses on as elaborate a scale as a wood rat or muskrat house. The smaller nests are often well out on the branches away from the trunks and at first are a mass of clean dry twigs and leaf fibers with a hollow cavity inside where the mouse sleeps and eats the leaves from fresh green twigs brought in nightly for food. The nests are largely built up from the leaf fibers left as food refuse and slowly grow in size and solidity, those on firm and broad foundations eventually becoming large and solid, while those in young timber are smaller and fresher in appearance. The nests built high up on large limbs or forks of old trees, 60 to 100 feet from the ground, are the oldest and largest. They are usually close to the trunk and in some cases surround the tree trunk and rest on a whorl of 5 or 7 limbs.

These large structures are really houses, containing in some cases as many as five nests in excavated cavities connected by burrows or tunnels, winding spirally up and down through the mass and opening out on the top of the supporting branches or close to the tree trunk. The main mass of these old houses consists of packed and settled leaf fibers and twigs with which the mouse pellets of years have become compacted into an earthy mass more or less solid and substantial. There is no reason why one of these houses should not continue for hundreds of years, or as long as the tree lives, and some already have the appearance of great age. Usually they are rounded above and more or less dome shaped and apparently shed water during the rainy season and keep the inmates dry and comfortable.

Some of the larger houses have been started on old hawks' or squirrels' nests as shown by large sticks at the base which the mice could not have brought together. Such strong foundations have undoubtedly been a factor in the size and endurance of the tree mouse houses.

When the house is disturbed the mice usually slip out quietly along the branches or up the trunk of the tree and if possible escape to the next tree, but they rarely come down the trunk to the ground unless forced to. They run slowly but securely along the tops of the branches and from one tree to another over the interlacing tips, hid- 


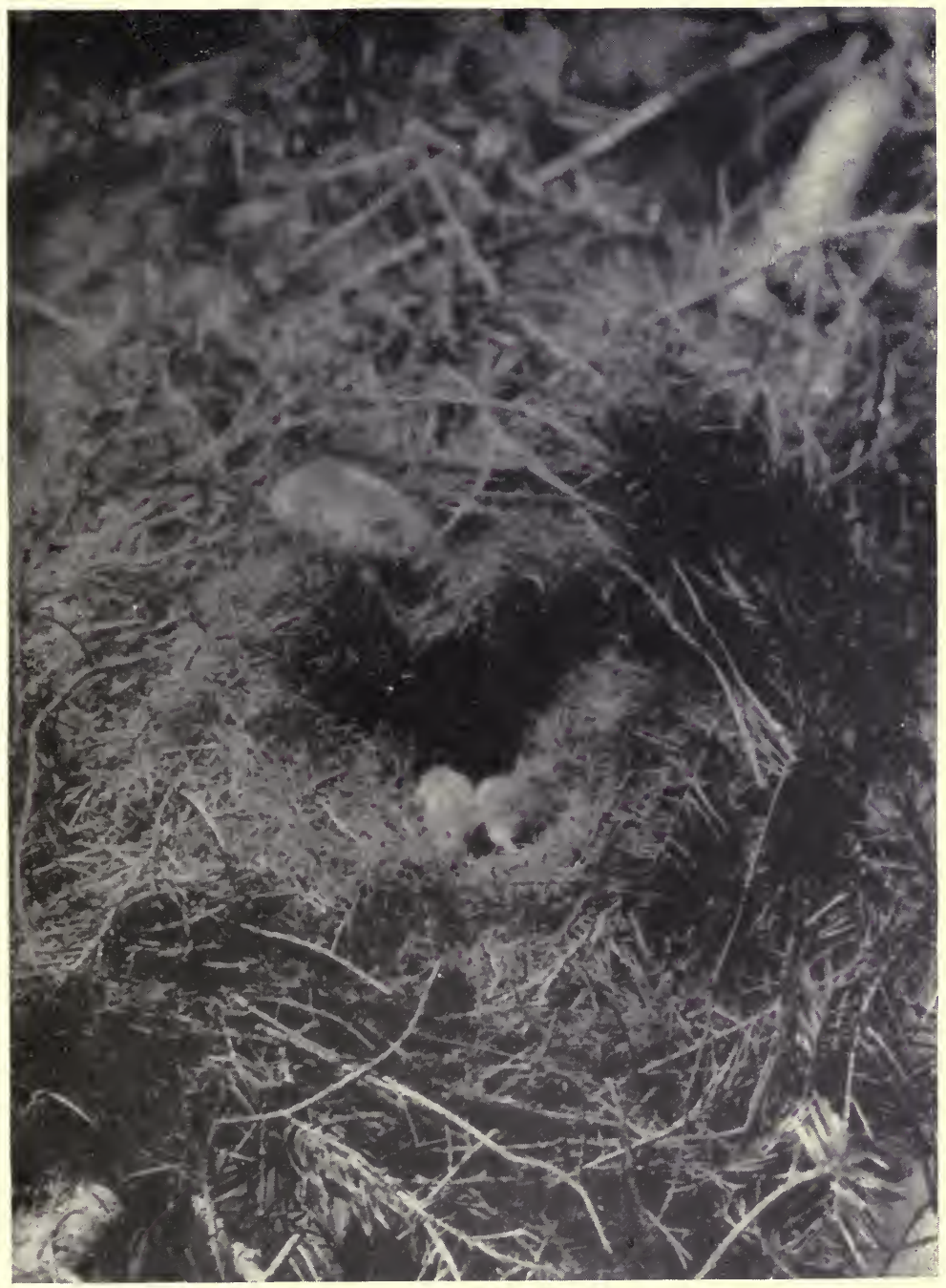

RED TREE MOUSE.

B4612M

Mother and two young in an opened nest on spruce bough (photograph by A. Brazier Howell). 

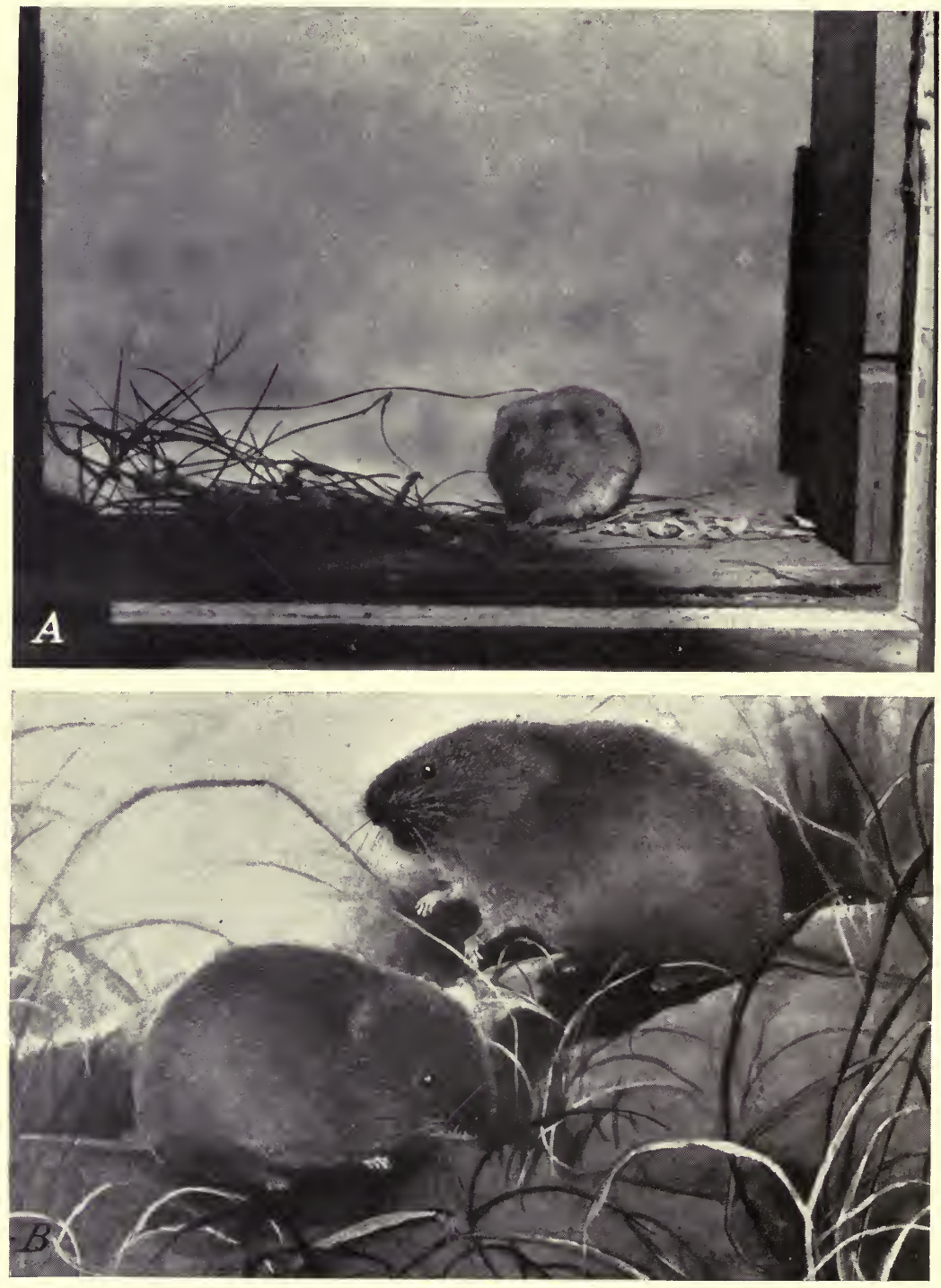

COMMON MEADOW MOUSE OF EASTERN OREgON.

$A$, Live mouse in captivity at Malheur Lake; $B$, from a drawing by Kako Morita. 
ing among the leaves or against the trunks of trees or in the forks of the branches.

Breeding habits. - The females have but 2 pairs of mammae, on the posterior part of the belly. Sets of 1,2 , and 3 embryos have been noted in those taken for specimens. Four is probably the normal maximum number of young for fully adult females, about half the number of most microtines. On September 14 Jewett took a female in Curry County that contained 3 embryos, and Shelton took 2 young from a nest on Spencer Butte near Eugene on February 21. In California, Wilder found young in the nests in January and February, and Taylor records young found in the nests at Mendocino City on July 15 and 17 and half-grown young in Humboldt County in July $(1915, p .151)$. From these dates it would seem that breeding may occur at any time of year, but it is probable, as believed by Wilder and Clay, who have had unusual opportunity for observing these mice, that the main breeding season is from early spring until late summer.

Howell found the young at birth in about the same helpless and primitive condition as young meadow mice, but with the difference that the eyes did not open until the young were 19 days old and that they showed no inclination to leave the nest until 29 days old. For the first 2 weeks they were generally found attached to the mother's teats, and when the family was disturbed the young clung so tightly that she would drag them all around the cage and could even be lifted if one took hold of one of the young. This habit and the slow development of the young are excellent adaptations for the protection of arboreal species. The slow development is almost squirrellike, and the small number of young in a litter in comparison with ground-dwelling microtines is paralleled by the corresponding conditions in the tree squirrels as compared to the large litter's of ground squirrels.

Food habits.-The stomach and intestines of one collected near Eugene were full of the green pulp of Douglas fir leaves, and the fresh pellets in numerous other nests examined in that part of Oregon were all of pure green material, indicating that their food was all, or mainly, derived from these leaves. None of the rolled oats placed in their nests or on the feeding platforms was eaten, and no trace of food other than the millions of leaf fibers containing in some cases the central vascular bundles and in others the marginal resin ducts were found on or around the houses. Apparently the animals are active throughout the year and a permanent supply of their evergreen leaves is always available.

Howell in a careful study of their food habits in captivity could not induce them to eat anything but the leaves of conifers, of which Douglas fir was preferred. Grand fir (Abies grandis) was also eaten, as well as the leaves of the large cone fir (Pseudotsuga macrocarpa), of an exotic fir from the Caucasus (Abies nordmanniana), and of the deodar cedar (Cedrus deodara).

Their usual method of feeding is to cut off the terminal twigs of green branches and eat the leaves or carry them to the nest or house each night to provide enough to last through the day, placing them within easy reach of the nest. These are eaten at frequent intervals as determined by Howell, averaging about 100 leaves an hour for 
both night and day, or about 2,400 Douglas fir leaves weighing about $18 \mathrm{~g}$ in 24 hours.

Normally these green leaves must furnish both food and moisture as the mice refused water except when forced to eat dried leaves.

Economic status.-In a large number of tree nests examined in Oregon no trace of injury to the trees or foliage was found and no complaints of injury have been reported. It is possible that the tree mice may have a slight value as food for martens and fishers, the two species of tree-climbing fur-bearing animals of the region, and they have certainly added a feature of living interest to these magnificent forests of the Pacific slope.

\section{PHENACOMYS SILVICOLA A. B. HOWELL}

\section{DUSKY Tree Mouse}

Phenacomys silvicolus A. B. Howell, Jour. Mammal. 2: 98, 1921.

Phenacomys silvicola Miller, U. S. Natl. Mus. Bull. 128: 400, 1923.

Type.-Collected 5 miles southeast of Tillamook, Oreg., by Peter P. Walker, October 25, 1916 (collection of Alex Walker).

General characters. - Slightly larger and much darker than Phenacomys longicaudus but with the same general proportions of total length, tail and foot, the same hairy tail and long soft fur; ears small, not projecting much beyond the fur; skull long, narrow, ridged, and with heavy molar teeth. Color dark brown; upper parts sayal brown of Ridgway, the long hairs sparsely tipped with black; lower parts washed with whitish; nose dusky; tail blackish; feet dark gray.

Measurements.-Total length, $191 \mathrm{~mm}$; tail, 81; foot, 22; ear (dry), 10.

Distribution and habitat.-The type was found dead on a log on a ridge covered with first-growth Douglas fir near Tillamook (fig. 41). Other specimens from near the type locality were later collected by Alex Walker, and one other adult and four young were taken by H. M. Wight from a nest in a tree near Corvallis.

The limits of its range remain to be established. At present it is one of the rarest and most interesting of Oregon mammals, presenting problems to baffle as well as tempt the most daring naturalists.

Walker contributes the following notes:

The type specimen of Phenacomys silvicola was taken near Tillamook, Oregon, October 25, 1916, and remained unique until 1924 when a female and four small young were taken from a nest in a tree near Corvallis, Oregon, and recorded by H. M. Wight (Journ. of Mammalogy, vol. 6, p. 282, 1925). I am now able to record two more specimens of this rare species.

On February 1, 1926, my brother, Peter P. Walker, who secured the type of Phenacomys silvicola, presented me with another specimen in the flesh, taken 6 miles south of Tillamook under the following circumstances. Employees of the Coates Driving and Boom Co., in the course of their logging operations, removed by blasting a hemlock snag about 2 feet in diameter and 20 feet high. Quite a hole was blown in the earth under the stump, and immediately after the blast workmen saw 4 or 5 mice in this excavation. My brother, who was employed by the company, captured one of the mice but the others escaped. Fragments of what was unquestionably the nest were noted at the time. On the following day I visited the place but the shattered pieces of the snag had been removed and no trace of the nest could be seen. However, while examining the debris in the pit, the somewhat mangled remains of another tree mouse was found, this one undoubtedly having been killed by the blast.

On examination the hemlock snag was found to be hollow, and the cavity, though small, extended the entire length. Now from the fact that immediately after the explosion several of the mice were noted alive in the pit, it is apparent that they must either have had a nest underneath the stump, or, as 
seems more probable, low down in the cavity, and not, as in the case of the only other nest of this species that has been discovered, on, or in, the broken-off top of the snag. The snag stood on a hillside, and the surrounding country was very rugged and clothed with first growth Douglas fir and hemlock of large size. In the immediate vicinity of the place where the mice were taken the timber, which was exclusively hemlock, had recently been cut and still lay upon the ground.

The first of the two specimens here recorded was a male, and the measurements are : total length, $177 \mathrm{~mm}$.; tail vertebrae, $\mathbf{7 1}$; hind foot, 22.5. The other, a female, measured: $174 ; 71 ; 22$. This, I am informed by Mr. A. B. Howell, is the first time that a fully adult pair of either species of tree mouse has been found in one nest. $(1928, p$. 254.)

At later dates, March 4 and June 1, 1929, live dusky tree mice were captured not far from Tillamook and kept by Alex Walker for some time in captivity and much information on their habits obtained. He found them in nests usually 40 to 50 feet from the ground in Sitka spruces, but one only 15 feet up in a hemlock tree. None was over a foot in diameter, all were placed on the branches close to the tree trunks and made of branch tips and food refuse.

Walker says further:

It is probable that the habits of this species do not differ greatly from those of Phenacomys longicauda. My captive specimen proved very gentle and was often given the liberty of a large hemlock bough where it seemed perfectly happy and at home, running back and forth and out to the tips of the smallest branches, occasionally stopping to cut off a twig and eat it on the spot. Though sure-footed it was extremely cautious and never attempted to leap from one branch to another in the manner of other mammalian dwellers of the tree tops. Often it would dangle by one hind foot from a tiny twig at the end of the branch, only to recover itself if another branch could not be reached with its fore feet.

Experiments in feeding convince me that it is utterly futile to attempt the trapping of these mice by the use of bait. Rolled oats, meat and other such materials used for bait were completely ignored by my specimen, as were plants and parts of the foliage of deciduous shrubs and trees commonly found in the woods. A few clover leaves were eaten on one occasion, but an acquired fondness for apples constituted the only real departure from a straight diet of conifer leaves. Hemlock was preferred at all times and neither spruce nor fir would be touched when hemlock was available, though they were eaten at other times. In season, the tender new growth at the ends of the branches of the evergreens mentioned seemed to be particularly appreciated and was taken in preference to the older leaves. As previously noted, hemlock twigs were found on the nest examined in the hemlock tree and only spruce twigs on the nests in spruce trees. It seems probable that the young are fed entirely on the twigs of the tree in which they live and when fully grown still have a decided preference for the same kind of food. My captive animal was provided with a dish of water, which it rarely touched, and then only in an awkward sort of way as though it had not yet learned to drink. A small wad of moss saturated with water was readily accepted, however, and this led to the use of a water soaked sponge in the cage until the animal learned to eat apples, which seemed to supply all the water necessary. $(1930, p$. 233.)

\section{PHENACOMYS ALBIPES MerRIAM}

\section{White-Footed Phenacomys}

Phenacomys albipes Merriam, Biol. Soc. Wash. Proc. 14: 125, 1901.

Type.-Collected in the redwoods near Arcata, Humboldt County, Calif., by Walter K. Fisher, May 24, 1899.

General characters.- Slightly smaller than longicaudus; tail almost as long relatively but sparsely haired and sharply bicolor; nails not much curved, of the digging rather than climbing type; fur rather short and smooth; skull long, narrow, and smooth; upper parts and top of tail snuff brown, darkened 
with black hairs; lower parts washed with buff; feet and lower half of tail white.

Measurements. - An adult male: Total length, $168 \mathrm{~mm}$; tail, 62; foot, 19; ear (dry), 10.

Distribution and habitat.-These rare mice are known only from a few adult specimens-the type from Arcata, another specimen from Orick, and 7 from Trinidad, Calif. Others were taken in Oregon by Stanley G. Jewett and Alex Walker; 1 at Vida on the McKenzie River, 3 at Netarts on the coast near Tillamook, 2 at Blaine in Tillamook County, and 1 at Gardiner, Douglas County. All were taken in densely forested areas and all on or near the ground. The type was taken in a trap set on an old rotten $l o g$ beside a redwood tree near Humboldt Bay, and the 7 Trinidad specimens at the edge of a little forest stream. The Vida specimen was caught among rocks under the bank of a small stream flowing through a dense forest of spruce and fir with an undergrowth of salmonberry and sword ferns. Those from Netarts were in a thicket of salmonberry bushes among the Sitka spruces, and the Gardiner specimen on the brushy bank of a small stream. All were taken in small traps baited with rolled oats. Evidently they are ground dwellers of the dense coastal forests, either very scarce in numbers and scattered in distribution or, more probably, of peculiar habits that are not yet sufficiently known to enable collectors to locate their homes or hunt for specimens with any certainty of success.

General habits.- The first real clue to habits of these little animals was obtained by A. B. Howell from the specimens collected at Trinidad, Calif., in July 1926. Of the seven specimens collected in a densely shaded gulch under the redwoods, bay, and maples, and back about half a mile from the sea, three full stomachs were saved and the contents examined by C. C. Sperry, of the Biological Survey. The stomach contents showed entirely the finely masticated pulp from underground roots of some unidentified herbaceous plant. This food preference may well explain the difficulty in securing specimens and their rarity in collections, and when the plant they feed upon is known they may be found to be a common and wideranging species.

\section{PHENACOMYS INTERMEDIUS INTERMEDIUS MERRIAM}

\section{Mountain Phenacomys}

Phenacomys intermedius Merriam, North Amer. Fauna No. 2, p. 32, 1889.

Phenacomys orophilus Merriam, North Amer. Fauna No. 5, p. 65, 1891. From Salmon River Mountains, Idaho.

Type-Collected 20 miles north-northwest of Kamloops, British Columbia, by Geo. M. Dawson, October 2, 1888.

General characters.-Small; tail short and slender, with little taper, thinly halred; toes short; nails not much curved, of the digging type; ear's conspicuous above fur; fur long and soft but not so fine as in longicaudus; side glands of males large and elongated, in front of hips; skull relatively short and wide; upper parts and top of tail buffy gray, lower parts washed with whitish; feet and lower half of tail whitish.

Measurements.-Average of several adults: Total length, $152 \mathrm{~mm}$; tail, 34; hind foot, 18.

Distribution and habitat.-These obscure little mice have a wide range over the Rocky Mountain region from northern British Colum- 
bia to New Mexico, and into the Blue Mountains and Cascades of Oregon (fig. 41). In Oregon they are represented by specimens from Wallowa Lake and Aneroid Lake in the Wallowa Mountains, from north of Harney in the Blue Mountains, and from Diamond Lake and Crater Lake, in the Cascades, but by only 1 or 2 specimens from a locality. These localities are in Canadian and Hudsonian Zones, but the main range of the species is generally considered to be Hudsonian. Beds of heather and dry slopes of short grass are the more general habitat, but any open, grassy ground, not too wet, suits their purpose. They are rarely found in the dense timber, which occupies most of Canadian Zone, and for this reason are sometimes crowded down to the more open grassy places in the upper edge of Transition Zone, but are more generally found in the parks and meadows of the Hudsonian.

General habits.-Although widely distributed and doubtless far more common than the scattered records indicate, these little gray grass-colored mice are not well known. They burrow in the ground and hide under cover of grass and heather and old logs, so that they are rarely seen alive. Those caught in traps by collectors indicate both nocturnal and diurnal activity and in summer a mainly underground residence except when out foraging for food. As the spring snow melts, the winter nests are often found on the surface of the ground where their trails and runways have been covered and protected by deep snows, while the mice ranged for food over the surface of the ground. Their nests are made of fine dry grass, thick walled and clean with soft warm central cavities. Little heaps of winter pellets nearby show good sanitation and also indicate a purely vegetable diet.

Breeding habits.-The adult females have 4 pairs of mammae2 inguinal and 2 pectoral-and the number of embryos recorded in those taken for specimens is usually 4,5 , or 6 . The dates of these embryos range from May to August, and it is probable that even in the short summer at high altitudes more than one litter of young may be raised in a season.

Food habits. -Like most of the microtines, they feed mainly on green grass and low vegetation, bark, leaves, twigs, and seeds of such plants as grow in their vicinity, and are fond of rolled oats used as trap bait. They usually show no trace of fat but seem to find abundance of food of satisfactory quality at all seasons of the year.

Economic status.-While too small and scarce and scattered to seem to be of any serious economic importance, these little mice fill a niche in the scheme of adjustment in plant and animal life that may be of more importance than we now realize.

\section{PHENACOMYS INTERMEDIUS OLYMPICUS ELIOT}

\section{Olympic Phenacomys}

Phenacomys olympicus Elliot, Field Columb. Mus. Pub. 30, Zool. Ser. 1:225, 1899.

Type-Collected at Happy Lake, Olympic Mountains, Clallam County, Wash., at 5,000 feet altitude, by D. G. Elliot, August 14, 1898.

General characters. - Slightly larger than typical intermedius, colors duller and darker; upper parts dark buffy gray or dusky gray; lower parts washed 
with dull buffy; feet and lower half of tail whitish in sharp contrast to the dark colors of body.

Measurements.-Average of 10 adult topotypes: Total length, $150 \mathrm{~mm}$; tail, 43; foot, 20; ear (dry), 13.

Distribution and habitat.-This large, dark form from the Olympic Mountains extends down the Cascades from Mount Rainier to Mount Hood and the Three Sisters Peaks in Oregon (fig. 41). Some of the specimens from the Three Sisters are almost as large and dark as typical olympicus, while others could as well be referred to intermedius. One small female from the mouth of Davis Creek on the Upper Deschutes could be referred to either form, while farther south at Crater Lake they are all clearly referable to intermedius.

\section{MICROTUS MONTANUS MONTANUS (PEALE)}

Peale's Meadow Mouse; GiL-Wa of the Klamath (C. H. M.) ; Pa-mota of the Piute

Arvicola montana Peale, U. S. Explor. Exped., v. 8, Mammalogy, p. 44, 1848.

Type.-Collected on headwaters of Sacramento River near Mount Shasta, Calif., by Titian R. Peale, October 4, 1841.

General characters. - Size medium (pl. 34), about as in Miorotus pennsylvanicus; tail about twice as long as hind foot, slightly tapering; hip giands

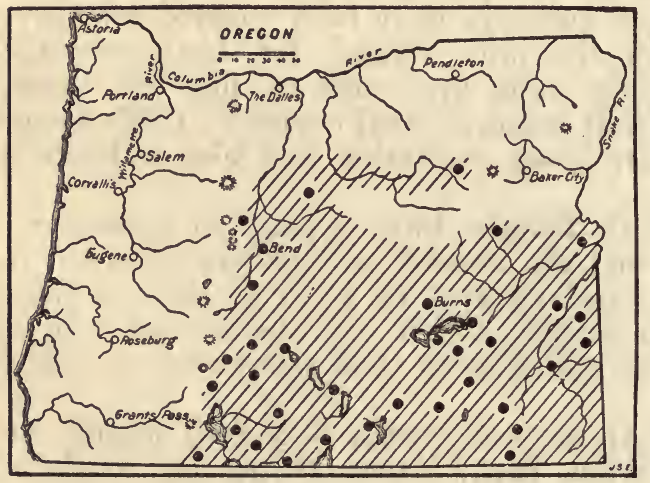

Figure 42.-Range of Peale's meadow mouse, Microtus montanus montanus, in Oregon. conspicuous in aduit males; upper in $\mathrm{c}$ is ors projecting more than in most species; color of upper parts sooty gray, smoky gray, or dusky, sometimes blackish; lower parts lightly washed with whitish; feet plumbeous ; tail indistinctly bicolor, blackish above, gray below.

Measurements.-Average of a series of topotypes: Total length, $175 \mathrm{~mm}$; tail, 52 ; foot, 21.5; ear (dry), 12. Weight of adult, but not large, female, from Malheur Lake, $48 \mathrm{~g}$. Her measurements in the flesh were $164 ; 39 ; 20 ; 14 \mathrm{~mm}$.

Distribution and habitat. - This is a wideranging species in the Great Basin area and in northeastern California. In Oregon it occupies almost every marsh, slough, and stream valley east of the Cascades and south of the Blue Mountains, in both Transition and Upper Sonoran Zones. The mice are most abundant in and around the large tule marshes, so extensive in some of the otherwise arid valleys (fig. 42).

General habits.-These little, long-furred "woolly bears" of the meadows are often called "moles" or "meadow moles" by the ranchers in the desert country where no real moles occur. They appear to be black as they run through the grass or stubble in their little roadways over the surface of the ground and keep in the shadows of protecting grass and dense vegetation. They are rarely seen except after the meadows are mowed and are most often sighted when the hay is being hauled or sledded to the stacks with buck rakes. On the big hay meadows around Malheur Lake the writer 
caught 36 of the mice alive in his hands in a few minutes by following the buck rake, while the men were stacking. Usually 2 or 3 and sometimes a dozen would run from their nests as a haycock was slid from over them and in the confusion they were easily picked up and dropped into a tin can until more than enough were obtained for study of habits in captivity. Hundreds more could have been caught just as readily. Out in the uncut grass and tules their tiny roadways were easily found and traps set across them yielded all the specimens needed, while cut grass and fragments of food showed where and on what they had been feeding. In places they were more numerous than others, and on one spot in a dry meadow where the hay had been cut the writer counted 169 open burrows on a rectangle of 10 by 12 feet. This was in September, the season when the mice were most abundant, and in such places there were certainly 100 mice to an acre. In other places there were probably not more than 1 to an acre and for the whole 40,000 acres, roughly estimated, of marsh and grassland in the Malheur Valley 10 mice to an acre should be a fair estimate of abundance.

They are good swimmers and like to live along the edges of water but also occupy dry meadows, where no water is available except from rain or dew and what they get in their green food. They are active all the year and about equally so in the daytime or at night, are sociable and friendly with one another and with many other species of native mice, but will fight savagely anything from their own size up to a hayrake, biting severely with their keen incisor teeth. One placed in a cage with a grasshopper mouse of about his own size fought off this predacious species all the evening, but in the morning there was only a bit of skin and bones left to show that he had been unequal to his antagonist.

Breeding habits.-The females have 8 mammae arranged in 2 pairs of inguinal and 2 pairs of pectoral, 2 on each of 4 distinct mammary glands. The young usually number 4 to 8,8 being the full normal complement for fully adult females. The number of litters in a season or a year is not known and probably varies greatly with abundance and nature of food and congenial environment, but normally there evidently are several litters during the summer. There are records of embryos in specimens collected in every month from March to October, and on August 17 young of 5 different ages were found under a few adjacent haycocks. Apparently they do not breed during the winter months, as a large number of females examined during November in Nevada showed no signs of embryos.

Food habits.-Grass is the principal food of these mice, but with it are included the sedges, tules, and a great variety of meadow plants, including the edible parts of the green leaves, stems, roots, and seeds. These are obtained by cutting off the base of the stem or plant and drawing it down, often repeating the operation until the seeds are reached and a little pile of sections $11 / 2$ to 2 inches long lie in a heap. Usually not half of the plant cut for food is eater, and sometimes all but the seeds or a very small portion is wasted. Also the roots, bulbs, and running rootstallss are dug up and eaten, and the stomachs examined usually show a portion of well-masticated root pulp and seeds with the green tissue. Those kept in captivity are especially fond of rolled oats or any grain or seeds, grass, tule, 
nettle, pigweed, Atriplex, Dondia, and such vegetables and fruits as cabbage, spinach, cantaloups, and apples. They do not care much for potatoes but do eat them extensively when other food is scarce. They are especially fond of all the clovers and alfalfa.

Economic status. - In captivity one of these mice which weighed $34.5 \mathrm{~g}$ reduced the weight of its bundle of green grass $27 \mathrm{~g}$, almost an ounce, in 24 hours, but this was not choice food, and related species have been found to eat an average of their own weight in green food every 24 hours. Allowing 1 ounce a day to a mouse and 10 mice to an acre over the 40,000 acres of meadowland in the Malheur Valley, they would eat about 4,400 tons of green grass, or approximately 2,200 tons of hay, in a year. Even 1 mouse to an acre, the lowest possible estimate at any season, would at this rate consume 220 tons of hay in a year, an item of considerable importance in one valley.

In Nevada in 1907 these mice devoured practically all the alfalfa and most of the other crops, and killed many of the fruit and shade trees in the lower Humboldt Valley, causing a loss to the ranchmen estimated at $\$ 250,000$. In this case their numbers in some of the alfalfa fields were estimated at several thousand to an acre, far more than a heavy crop of alfalfa could support for any considerable length of time. Such conditions are possible anywhere under circumstances favorable to the rapid increase and complete protection of the mice from their natural enemies.

The remedy for much of the loss due to these mice is simple and inexpensive: Clean fields and meadows, clean borders, ditch banks, roadsides, and waste places so the hawks, owls, ravens, crows, magpies, gulls, herons, foxes, skunks, badgers, and numerous other enemies can see and capture these, their favorite prey. Only under protecting cover can the mice become seriously harmful.

\section{MICROTUS NANUS NANUS ${ }^{\circ}$ (MERRIAM)}

\section{DWarf Meadow Mouse}

Arvicola (Mynomes) nanus Merriam, North Amer. Fauna No. 5, p. 62, 1891.

Type.-Collected in Pahsimeroi Mountains, Idaho, at 9,300 feet altitude, September 16, 1890 , by Merriam and Bailey.

General characters.- Small; tail short; ears short and rounded; hip glands conspicuous in old males; incisors slightly protruding, not curved abruptly downward. Upper parts uniform sepia gray; lower parts washed with white; tail distinctly bicolor, dusky gray above, whitish below; feet gray.

Measurements.-Average of several typical adults: Total length, $143 \mathrm{~mm}$; tail, 37; foot, 19; ear (dry), 11.

Distribution and habitat.-These little gray meadow mice have a wide range over the Rocky Mountain region from New Mexico to Canada and reach their western limit in Oregon, occupying practically the whole Blue Mountain section and west to Hay Creek on the ridge between the John Day and Deschutes Rivers (fig. 43). A specimen from the high ridge north of Crane, on the southernmost spur of the Blue Mountains, marks their southern limit in the State. Generally they are found in Transition and Canadian Zones in open

- Some of the specimens along the lower edges of the Blue Mountain section are grading toward the grayer subspecies, canescens, but none seen from the State is typical of that form and all are here referred to nanus. 
grassland or dry meadows. Sometimes they are in wet places or along creek banks, but generally are in drier situations than those occupied by the larger, darker Microtus montanus from the lower meadows.

General habits.-Except for their smaller size, grayer colors, and ability to live in drier situations, these little mice are strikingly similar to Microtus montanus. They are ground dwellers, with summer homes mainly underground in burrows and nest cavities, while their little roadways mark the surface in all directions under cover of grass and concealing vegetation. Often they are numerous in meadows and fields, but rarely so excessively numerous as to do conspicuous damage to forage or crops, or to be frequently seen except in harvest time.

Breeding habits.-The mammae are in four pairs, and embryos show the young to number usually 6 to 8 . Breeding continues throughout a long season, and reproduction is rapid if conditions are favorable.

Food habits. - The ir food consists mainly of green vegetation, roots, bulbs, and seeds. Sections of cut grass and fragments of plants cut for food and remains of grass tops are found scattered about on their feeding grounds, and the stomachs usually contain green food, mainly, with smaller quantities of white dough from seeds,

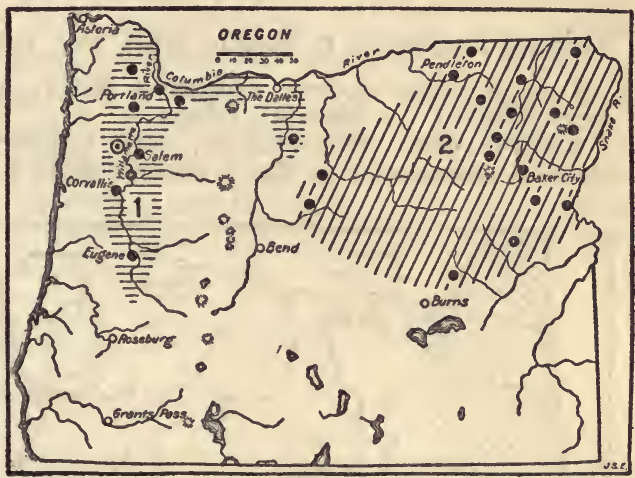

Figure 43.-Range of gray-tailed and dwarf meadow mice in Oregon: 1 , Microtus canicaudus; $2, M$. nanus nanus. Type locality circled. or soft gray root tissue or sometimes traces of bright-colored flowers. They will eat others of their own kind found dead in traps, and seem fond of fresh meat, but apparently do not eat insects.

Economic status.-Owing to their ranging over the dry grassy uplands as well as in the meadows these little mice, when numerous, must do considerable damage to the stock range, reducing its carrying capacity in direct ratio to their abundance. They rarely become very numerous, however, as cover is usually not very dense and they are steadily preyed upon by a host of bird and mammal enemies.

\section{MICROTUS CANICAUDUS MIII.ER}

\section{Gray-talled Meadow Mouse}

Miorotus canicaudus Miller, Biol. Soc. Wash. Proc. 11: 67, 1897.

Type.-Collected at McCoy, Polk County, Oreg., by B. J. Bretherton, in 1895.

General characters. - About the size and general appearance of nanus but more yellowish with grayer tail. Upper parts in summer bright yellowish gray; lower parts grayish white; feet grayish; tail mainly light gray or whitish with a half concealed dusky dorsal line.

Measurements.-Average of typical adults: Total length, $141 \mathrm{~mm}$; tail, 35; foot, 20; ear (dry), 12. 
Distribution and habitat.-Long known in the lower Willamette Valley in the open country where there were originally grassy prairies but now are fields and the best of the farming land, and recently found in the Deschutes Valley, east of the Cascades (fig. 43). There are specimens from McCoy, Albany, Sheridan, Beaverton, Portland, Hillsboro, Banks, Gresham, Corvallis, and Eugene, and on the east side of the Cascades from Warm Springs in the Deschutes Valley and in Washington in the Yakima and Wenatchee Valleys.

General habits.-These little gray-tailed mice are so scarce and local that few specimens have been taken and little is known of their habits, other than that they are found in fields, pastures, or grassy situations, where they make runways under the old grass and such cover as they can find.

\section{MICROTUS TOWNSENDII (BACHMAN)}

\section{TOWNSEND's MEadow Mouse}

Arvicola townsendii Bachman, Acad. Nat. Sci. Phila. Jour. 8: 60, 1839.

Type locality.-Lower Columbia River, near mouth of Willamette, on or near Wapato (or Sauvie) Island.

General characters.-Large; ears conspicuous above thin harsh fur; hip glands conspicuous in adult males; skull compared with that of californicus

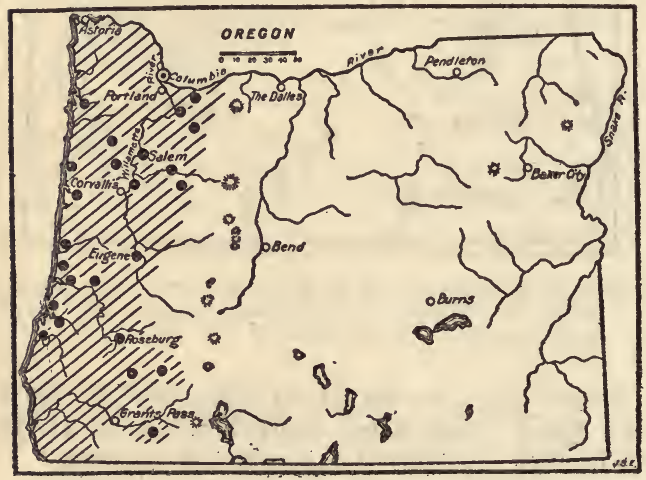

Figure 44.-Range of Townsend's meadow mouse, Microtus townsendii, in Oregon. Type locality circled. longer and less arched with posteriorly constricted incisive foramen. Upper parts dark brown ; lower parts grayish brown or smoky over plumbeous; feet plumbeous or blackish; tail blackish, but little $\mathrm{lighter}$ below than above.

Measurements. - Of typical adult male: Total length, 225 $\mathrm{mm}$; tail, 66; foot, 26; ear (dry), 15.

\section{Distribution and habi-} tat. - These $\mathrm{mice}$ are found in the coast area of Was h ing to $n$, Oregon, northwestern California, and southwestern British Columbia (fig. 44). In Oregon they occupy the Willamette, Umpqua, and Rogue River Valleys, but keep entirely west of the Cascade Range. They are marsh and meadow dwellers of the low country, preferring wet ground and dense cover of vegetation such as rank grass and tules.

General habits.-These are typical meadow mice with habits very much like the eastern Microtus pennsylvanicus. They live under cover of growing or dead and fallen vegetation, where their numerous little roadways may be found leading from one burrow to another, or away to their feeding grounds, and often through shallow water or to the edges of ditches or streams where the mice swim from bank to bank. Their nests are balls of dry grass placed on the surface of the ground under cover of protecting plants or in nest chambers in the underground tunnels. 
The mice are abroad throughout the year and seem to be about equally active day and night.

Breeding habits. - There is little on record of their breeding habits. The mammae are in 4 pairs, and the young, as in other species with this arrangement, probably number 4 to 8 . One old female taken at Albany on October 2 contained 5 small embryos.

Food habits.-In food as in other habits they resemble $M$. montanus, cutting and eating the tender parts of grass and tule stems and roots, or drawing down the seed-laden tops for food. In the grainfields they cut the stems in sections as the heads are drawn down and eaten with sometimes considerable damage to the crop. They are especially fond of clovers and alfalfa and are always eager for rolled oats or grain with which the collector baits his traps.

Economic status. - There have been few complaints of damage by these mice, but they have great possibilities for crop destruction. On Government Island, in the Columbia River near Portland, in 1911, Jewett reported them as "simply swarming in the alfalfa fields." The farmers had done nothing to check them but were becoming alarmed and asked for instructions for poisoning them. On one farm they had already killed about 80 young fruit trees.

Such outbreaks, however, are insignificant in comparison with the unnoticed but steady drain on farm products by even the normal numbers of such mice over a wide extent of rich agricultural land like that of western Oregon valleys.

\section{MICROTUS CALIFORNICUS CALIFORNICUS (PEALE)}

\section{California Meadow Mouse}

Arvicola californica Peale, U. S. Explor. Exped., v. 8, Mammalogy, p. 46, 1848.

Type.-Collected at San Francisco Bay, Calif., by Titian R. Peale, on the United States Exploring Expedition, 1838 to 1842.

General characters.-Large; ears conspicuous above fur; hip glands in adult males well concealed under fur; pelage relatively coarse and harsh; skull wide and angular with incisive foramina widest posteriorly, incisors abruptly decurved. Upper parts dull buffy brown or clay color, slightly lined with dark hairs; belly buffy gray or soiled whitish; feet gray; tail bicolor, brown above, buffy below.

Measurements. - T у p i c a 1 adults : Total length, $171 \mathrm{~mm}$; tail, 49 ; foot, 21 ; ear (dry) , 15.

Distribution and habitat.-From a wide range

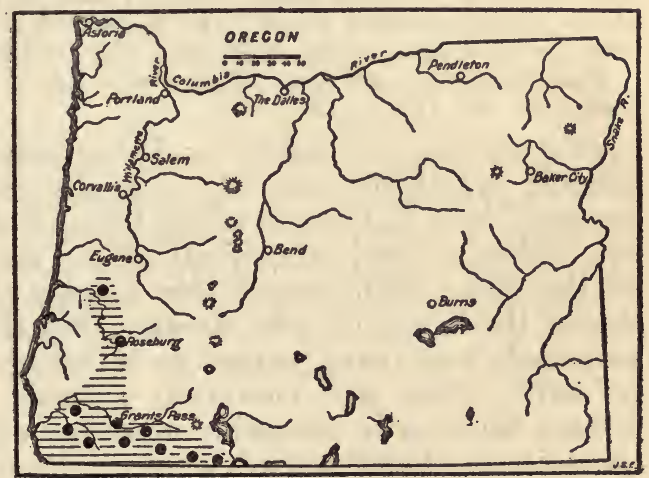

Figurn 45.-Range of California meadow mouse, Microtus californicus californicus, in Oregon. in California these mice extend into Oregon in the Rogue River and Umpqua Valleys, reaching their northernmost points of known distribution at Roseburg and Drain (fig. 45). They are found mainly in the dry upland meadows and grassy slopes of the open valleys, and belong primarily to Upper Sonoran Zone. 
General habits.-These rather large, coarse-furred mice, while occasionally found in marshes and wet places, seem to prefer the drier uplands and to require less cover than the regular marsh species. Often their little roadways may be seen through the short dry grass or their little heaps of fresh earth where thrown out of their burrows on dry ground. In other respects they are similar in habits to Microtus montanus and townsendii.

Breeding habits.-The mammae of females are arranged as usual in this group in 4 pairs, and the young are usually 4 to 8 . Breeding apparently continues throughout the year, since embryos are noted in specimens collected in winter as well as at all other seasons.

Food habits.-Green vegetation, grass, tules, young or ripe grain, roots, bulbs, bark, and a great variety of vegetable foods are eaten. Rolled oats or any grains are eagerly taken as trap bait, and frequently the mice caught in traps are eaten by their more fortunate relatives.

Economic status.- In Oregon these mice are not very widely distributed nor generally very numerous, so their economic importance is slight, but they inhabit fertile valleys where favorable conditions of food and cover might at any time result in great increase of numbers and serious injury to crops and fruit trees.

\section{MICROTUS MỌRDAX MORDAX (MERRIAM)}

Rocky Mountain Meadow Mouse

Arvicola (Mynomes) mordax Merriam, North Amer. Fauna No. 5, p. 61, 1891.

Type-Collected at Sawtooth (or Alturas) Lake, on east slope of the Sawtooth Mountains, Idaho, (altitude 7,200 feet), by Merriam and Bailey, 1890.

General characters.-Size medium; tail long; ears conspicuous above fur; hip glands rarely noticeable even in old males; fur long and soft in winter pelage, thin and harsh in summer; color in summer coat, back brownish gray, sides olive gray; lower parts whitish; feet gray; tail indistinctly bicolor, dusky above, soiled whitish below. In winter lighter gray above, with clear gray sides; whiter below with light gray feet and sharply bicolor tail.

Measurements.-Average of typical adults: Total length, $182 \mathrm{~mm}$; tail, 66 ; foot, 22; ear (dry), 13.

Distribution and habitat.-These long-tailed meadow mice, which inhabit practically the whole Rocky Mountain region, reach their western limit in Oregon along the east slope of the Cascades and in the Siskiyous and occupy all of the mountains of the eastern part of the State high enough for a trace of Canadian Zone (fig: 46). Along the banks of cold streams they descend with other species of mammals and many plants as intrusions into Transition Zone, but primarily they are mountain animals. They live mainly along stream banks or in mountain meadows where for most of the summer there is an abundance of water.

General habits.- While partial to creek banks and cold water when available, these little mountain dwellers will remain for considerable time in grassy places that have become thoroughly dried out in summer. In winter they scatter out under cover of snow without regard to water and seek their food in the thickets and woods and seem to delight in the cover and protection of old logs and brush 
heaps. Each winter sees a spreading out over the mountain slopes and each summer a retreat to the meadows and brooks with the dry weather. When the spring snows disappear their old runways mark the surface of the ground in all directions and food refuse and little heaps of pellets show where and how they have lived. Nests of dry grass on the surface of the ground-thick-walled balls with-1 or 2 side entrances-that have kept the occupants warm through the winter are now abandoned for new nests in chambers of the underground burrows.

Breeding habits.-Like other species of the group these mice have four pairs of mammae, and usually bear 4 to 8 young. The young are born at irregular times from May to September, and possibly for the rest of the year under cover of deep snow. There are few data of actual breeding habits.

Food habits. - During the summer these $\mathrm{mice}$ feed largely on green grass and sedges, roots, bulbs, and the green or ripening seeds of numerous mountain plants, always finding abundance of food and keeping in g o o d condition, though never fat. In winter when green vegetation is scarce they feed more on roots, dormant bases, or

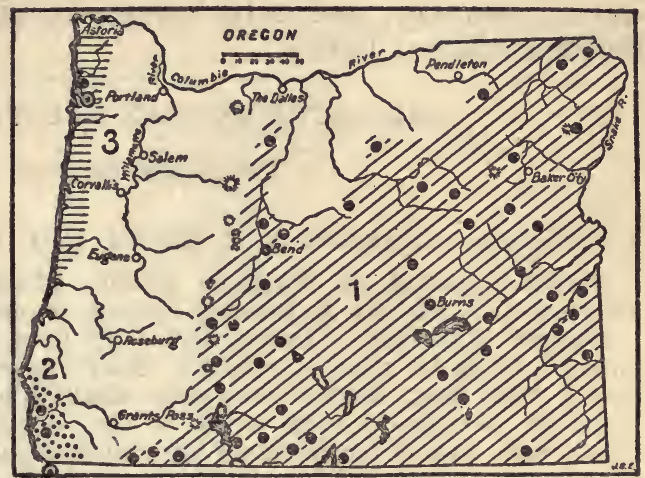

Figure 46.-Range of three long-tailed meadow mice in Oregon: 1 , Microtus mordax mordax; $2, M . m$. angusticeps; $3, M$. m. abditus. Type localities circled.

shoots of perennial plants, and the bark of bushes, trees, or fallen branches. Where green timber has been cut, they often strip the branches clear of bark before spring up as far from the ground as the depth of snow affords cover. Traps baited with rolled oats, other grains, or meat, and set in their runways, catch them readily, and occasionally one of those caught is eaten by the others.

Economic status.-Fortunately these mice do not often become excessively numerous, and they live mainly above the zones of successful agriculture. They do, however, occupy the areas of most valuable summer range for domestic stock and live largely on the grasses and forage plants of the region. Their present abundance must somewhat reduce the carrying capacity of the range but to what extent can be determined only by careful tests in field and laboratory.

\section{MICROTUS MORDAX ANGUSTICEPS BAILY}

\section{Coast Mradow Mouse}

Microtus angusticeps Bailey, Biol. Soc. Wash. Proc. 12: 86, 1898.

Type.-Collected at Crescent City, Calif., by T. S. Palmer, in 1889.

General characters.-Smaller and darker colored than typical mordax, with narrow, slender skull and small audital bullae. Summer pelage, upper parts dark bister, lined with black hairs, darkest on face and nose; sides slightly $7209^{\circ}-36-14$ 
paler; belly washed with creamy white or smoky gray; feet plumbeous; tail blackish above, grayish below.

Measurements.-Average of adult topotypes: Total length, $177 \mathrm{~mm}$; tail, 64; foot, 22; ear (dry), 12.

Distribution and habitat.-This brown form of the long-tailed meadow mice occupies a narrow strip along the coast of southwestern Oregon and northwestern California, usually in the marshes or low fields, only little above high tide level (fig. 46).

General habits.-In no important manner do the habits of these mice appear to differ from those of typical mordax. The animals are numerous in the little marshes just back of the coast and sometimes extend into the fields and meadows and brush land. At the mouth of Rogue River the writer's line of 13 traps caught 11 of these mice during the day, and only 5 more at night, which indicates rather decided diurnal habits.

\section{MICROTUS MORDAX ABDITUS A. B. HownL}

\section{Thlamook Meadow Mouse}

Microtus mordax abditus A. B. Howell, Jour. Mammal. 4:36, 1923.

Type-Collected at Walker's Ranch, Pleasant Valley (8 miles south of Tillamook), Oreg., by A. Brazier Howell, September 8, 1920.

General characters.-Large with very long tail and large hind feet, distinguished from its nearest relative, Microtus mordax macrourus by relatively larger hind feet, longer, narrower skull, and generally browner coloration. From M. townsendii with which it may occur it is distinguished by slightly longer tail, lack of conspicuous hip glands in adult males, and by radical group characters shown in the skulls. September pelage, upper parts dark sepia brown; lower parts light cinnamon or buffy gray; feet dusky; tail blackish above, brownish below. Skull longer, narrower and more slender than in macrourus, with narrower, more elongated audital bullae.

Measurements.-Type, adult male : Total length, $221 \mathrm{~mm}$; tail, 93 ; foot, 28.5 ; ear (dry), 14. Skull of type: Basal length, 28; nasals, 8.5 ; zygomatic breadth, 16; mastoid breadth, 12.5; alveolar length of upper molar series, 7.2.

Distribution and habitat.-Ten specimens of this species are recorded by Howell from the type locality near Blaine, and from $\mathrm{Ne}$ tarts on the coast west of Tillamook (fig. 46). Two were caught in a small roadside ditch filled with cattails, and others in salal thickets bordering a small creek near the sea. Evidently they are scarce or rare over western Oregon or others would have been taken by some of the numerous collectors who have worked along the coast.

\section{MICROTUS RICHARDSONI ARVICOLOIDES (RHOADS)}

\section{Cascade Meadow Mouse; Water Vole}

Aulacomys arvicoloides Rhoads, Amer. Nat. 28:182, 1894.

Type.-Collected at Lake Keechelus, Kittitas County, Wash., at 8,000 feet, by Allan Rupert, September 1893.

General characters.-Largest of our meadow mice; tail long; incisors projecting; side glands conspicuous on flanks in old males; tubercles on soles of hind feet only five; fur long and rather coarse. Upper parts dusky or smoky gray; lower parts thinly washed with whitish over plumbeous underfur; feet dark gray; tail bicolor, dusky above, grayish below.

Measurements.-Average of typical specimens: Total length, $234 \mathrm{~mm}$; tail, 81 ; foot, 29.3 ; ear (dry), 13. Large old male, $261 ; 92 ; 30 ; 14$. 
Distribution and habitat.-This large form of the Richardson meadow mouse inhabits the Cascade Range of Washington and Oregon south to Crater Lake, mainly in Boreal zones (fig. 47). In places they come down into Transition Zone but only along streams of cold water from the mountains. They are rarely found far from water and generally inhabit creek banks or flooded marshes.

General habits.-More than any other species of American meadow mice these large, long-tailed, large-footed water voles are semiaquatic in habits, being excellent swimmers and divers, and depending in part on the water for protection. They generally live in burrows along the banks of the streams or in wet places not far away, and are often seen in daytime swimming across the streams. Their large trails are conspicuous in the grassy places, and are often strewn with stems of grass and sedges cut for food. High up at timber line and along the edges of permanent s n o w banks they often live in the beds of mountain heather or any scant cover that affords concealment. In winter they spread out under the cover of snow over slopes that are dry in summer and make bulky nests of dry grass on the surface of the ground in addition to those in the burrows.

Breeding habits. - The $\mathrm{m}$ a $\mathrm{m} \mathrm{m}$ a $\mathrm{e}$ are arranged in 4 pairs - 2 inguinal

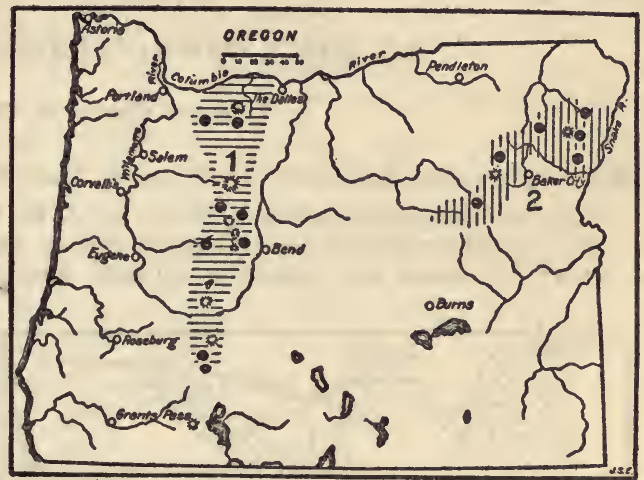

Figure 47.-Range of water voles in Oregon : $1, \mathbf{M i}$ crotus richardsoni arvicoloides; $2, M$. $r$. macropus.

and 2 pectoral. Embryos found in females usually number 4 to $7 ; 8$ is probably the normal maximum. The length of breeding season is not known.

Food habits.-Most of their food consists of the green leaves and stems of grasses, sedges, mountain clovers, and numerous native plants, including the seeds during the short seedtime of the mountain summer. Roots and bulbs and bark form a part of their food, especially under the deep winter snows. Sometimes they are eager for rolled oats used as trap bait and again they will not touch any bait and can be caught only by concealing traps in their runs.

Economic importance.-Fortunately these big mice are not very widely distributed nor more than locally abundant, as they might otherwise do serious damage to the stock range of the higher mountain slopes. The open nature of their country generally exposes them to numerous enemies, and their increase is restricted to a point of little consequence.

\section{MICROTUS RICHARDSONI MACROPUS (MERRIAM)}

LARGe-FOOTED MEAdow Mouse; Water Vole

Arvicola (Mynomes) macropus Merriam, North Amer. Fauna No. 5, p. 60, 1891.

Type.-Collected in the Pahsimeroi Mountains, Idaho, at 9,700 feet, by Merriam and Bailey, 1890. 
General characters.-Slightly smaller than arvicoloides; upper incisors less projecting; colors much the same or slightly grayer.

Measurements. - Type, an adult female: Total length, $220 \mathrm{~mm}$; tail, 71; foot, 26 ; ear (dry), 12. Of adult male topotype: $218 ; 68 ; 29 ; 12$.

Distribution and habitat.-These large mice are found in the higher Rocky Mountains of Montana, Wyoming, Utah, Idaho, and northeastern Oregon, in the Blue Mountain section. There are specimens from the Wallowa Mountains, the Baker Range, and Strawberry Butte, all from Canadian and Hudsonian Zones (fig. 47). They live mainly along mountain streams and in mountain meadows or marshes.

General habits.-In no important manner do their habits differ from those of arvicoloides, from which they are at best barely distinguishable. Their economic importance is not great and relates mainly to mountain grazing problems.

\section{MICROTUS OREGONI OREGONI (BACHMAN)}

\section{Oregon Creiping Mouse}

Arvicola oregoni Bachman, Jour. Acad. Nat. Sci. Phila. 8: 60, 1839.

Type.-Collected at Astoria, Oreg., by J. K. Townsend, in 1836.

General characters. - Small, form rather slender; ears short; tail medium length; fur short and smooth, without long hairs; side glands inconspicuous

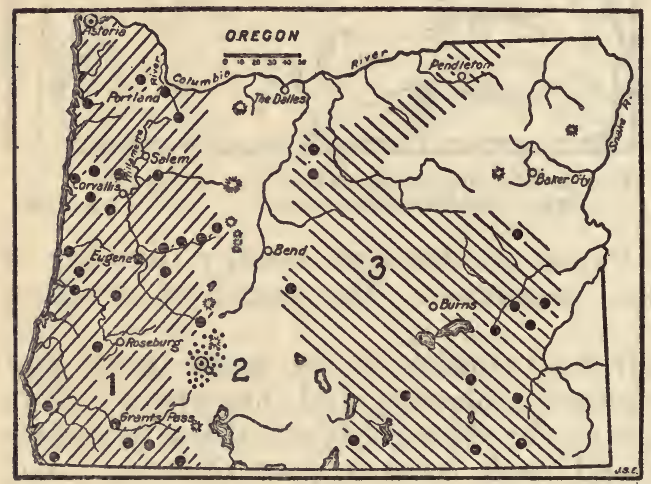

FIGURE 48.- Range of creeping and pygmy, mice in Oregon: 1, Microtus oregoni oregoni; $2, M$, o. in males; tubercles on soles only five; color of upper parts dusky brown from a mixture of black and yellowish hairs; lower parts dusky, lightly washed with dull buffy; feet dusky; tail bla ckis h, but slightly lighter below.

Measurements.-Adult male topotype: Total length, 140 mm; tail, 42; foot, 17; ear (dry), 9.

Distribution and habitat.-These little ground mice range west of the Cascades from Puget $\mathrm{S}$ o und to northwestern California and cover all of Oregon west of the higher part of the Cascade range (fig. 48). They occupy the dense forests as well as the brushy and open grassy areas of the uplands and dry slopes, seeming to avoid the marshes and wet bottoms.

General habits.-As the smooth fur, short ears, and little eyes suggest, these mice are largely burrowers, with habits similar to those of the eastern pine mice. In the mellow woods soil where they seem most at home they burrow just below the surface in long tunnels, often pushing up the surface in little ridges similar to those made by moles, but smaller. Under a dense cover of old grass and leaves they often merely push up the plant layer and make their tunnels as trails over the surface of hard ground but in all cases insist upon ample protection from above. Some of their little burrows are 
left open in places where the mice come out to feed or where a hard trail cuts across their line of progress, but so well hidden are the runs that few specimens are taken by inexperienced collectors, even where the animals are fairly common. They are easily caught, however, by digging down and setting the trap across the burrow a little below the bottom level.

Breeding habits.-The females have normally 4 pairs of mammae -2 inguinal and 2 pectoral -2 on each of 4 distinct mammary glands. The young as shown by embryos usually number 3 to 5, and the records indicate May to August as the main breeding season. This season may be only apparent, however, as comparatively few specimens have been taken in winter, and the breeding season may be more or less continuous throughout the year.

Food habits.-Comparatively little is known of the food habits of these mice beyond what is gathered from the few bits of green grass and other little plants found scattered about their burrows or along the lines of their surface trails. The abundance of camas and other underground bulbs and roots in their territory would suggest a diet mainly from subterranean sources, varied in times of scarcity by any green vegetation available. At times they will take rolled oats as trap bait but again refuse to touch them, and the traps must be set so they will be sprung without regard to bait.

Economic status.- There are few complaints of damage by these little burrowers, but they will bear watching and merit a much closer study of habits than has thus far been made. Injury to root crops, shrubbery, vines, and trees attributed to other rodents may be due in part to them.

\section{MICROTUS OREGONI BAIRDI MERRIAM}

\section{Batrd's C'Regiping Mouse}

Microtus bairdi Merriam, Biol. Soc. Wash. Proc. 11: 74, 1897.

Type.-Collected on Glacier Peak, northwest side of Crater Lake, Oreg., at 7,800 feet altitude, by Merriam and Bailey, in 1896.

General characters. - Similar to oregoni but colors lighter, brighter, and mainly clear yellowish bister above; lower parts lightly washed with whitish; feet and nose dusky ; tail slightly bicolor, dusky above, dark gray below.

Measurements.-Type specimen, adult female: Total length, $131 \mathrm{~mm}$; tail, 33 ; foot, 17.5; ear (dry), 9.

Distribution and habitat.-As yet no typical specimens of this form have been taken beyond the type locality on an open timberline ridge northwest of Crater Lake, where in the open exposed Hudsonian Zone they were living under beds of heather (fig. 48). Undoubtedly they have a more extended range along the higher levels of the Cascades, where the light and exposure have modified them into a recognizable form.

Nothing is known of their habits except from the two specimens trapped in the beds of short grass, sedges, and heather close to extensive snow banks that were lying late in August on the wind-swept north slopes of. Glacier Peak. 


\section{MICROTUS PAUPERRIMUS (COOPER)}

Pygmy Mouse

Arvicola pauperrima Cooper, Amer. Nat. 2: 535, 1868.

Microtus (Lagurus) curtatus artemisiae Anthony, Amer. Mus. Nat. Hist. Bull. 32: 14, 1913. Type from Ironside.

Type-Collected on Plains of the Columbia, near Snake River, Wash., by J. G. Cooper, in 1860 .

General characters.-A small, short-tailed, light-gray mouse with lax fur; soles of hind feet with only five tubercles; side glands in males on flanks; skull short, wide, and rectangular. Upper parts uniform buffy gray; ears and nose tinged with clear buff; lower parts and feet pale buffy; tail buffy, with darker upper surface. Browner in summer and grayer in winter.

Measurements.-Average of three immature from Antelope, between Deschutes and John Day Rivers: Total length, $115 \mathrm{~mm}$; tail, 20; foot, 16; ear (dry), 8. Of adult female from Waterville, Wash., on the Plains of the Columbia northwest of the type locality, $128 ; 27 ; 17 ; 9$.

Distribution and habitat.-There are specimens of these little gray mice from Bakeoven, Antelope, Steens Mountains, Cedar Mountains, Skull Spring, McDermitt, Disaster, Creston, Ironside, Fort Rock, and Rock Creek (north of Hart Mountain) (fig. 48). Undoubtedly they occupy all of the sagebrush country of eastern Oregon that lies within Transition Zone or upper edge of Sonoran but are very irregular in distribution and abundance. Also their habits are such as to shield them from observation and even render them difficult to locate. They live usually on dry ground among the sagebrush where trails and signs do not show and in burrows well hidden under the bushes.

General habits.-More than any other members of the genus Microtus, these little mice are adapted to desert conditions, usually living where no permanent water supply is within reach and where infrequent rains, snows, and dew must leave them for months at a time without available moisture, other than that obtained from succulent food. They live mainly in burrows, coming out to gather green plants for food and generally carrying them into the burrows to be eaten. To what extent they burrow for roots and underground vegetation is not fully known. They rarely make noticeable runways but run over the barren surface of the ground from one burrow to another, merely leaving lines of tiny footprints in sandy or dusty spots.

They seem to be largely diurnal as more are usually caught in the daytime than at night, and they are often seen running through the sagebrush even in bright sunlight. At three different localities in Malheur County, Preble caught them in his hands in the daytime. He and Anthony each found one in the stomach of a rattlesnake, and as these snakes are mainly diurnal the mice were probably taken during the warm part of the day.

Breeding habits.-The females have the common microtine arrangement of 8 mammae in 2 pairs of inguinal and 2 pairs of pectoral. The young are probably 4 to 8 , as in the closely related curtatus; 5 to 7 embryos have been recorded.

Food habits.-Apparently their food consists largely of green vegetation, grass, lupines, and other small plants found growing under or among the sage bushes. The little dry pellets scattered along the trails or on the feeding grounds are usually green in color but give no further clue to the nature of the food. Roots and bulbs 
are undoubtedly eaten when obtainable and may furnish an important part of the food within the tunnels.

Economic status.-In a desert country with scant cover and food these mice can rarely attain even local abundance. They are not likely to come in contact with agricultural interests and can have but little effect on abundance of native forage plants.

\section{FIBER ZIBETHICUS OSOYOOSENSIS LORD}

\section{Rocky Mountain Muskrat; Pamúse of the Piute}

Fiber osoyoosensis Lord, Zool. Soc. London, Proc., p. 97, 1863.

Type.-Collected at Osoyoos Lake, British Columbia, by J. K. Lord, in 1861 or 1862.

General characters.-Large; ears and eyes small; hind feet large and heavily margined with bristles; front feet small; tail long, laterally compressed and nearly naked; fur dense and soft when prime, half concealed by long, coarse, shiny guard hairs. Upper parts in fresh pelage, glossy dark brown; hips blackish; sides russet brown; belly cinnamon, paler on throat and anal region. In worn pelage often faded and much paler. Young more sooty brown than adults.

Measurements.-Average of 10 adults: Total length, 589 $\mathrm{mm}$; tail, 271 ; foot, 83 ; ear (dry), 18. Weight of adults approximately 2 to 3 pounds.

Distribution and habitat. - This large, dark, northern muskrat ranges from southern British Columbia to northern New

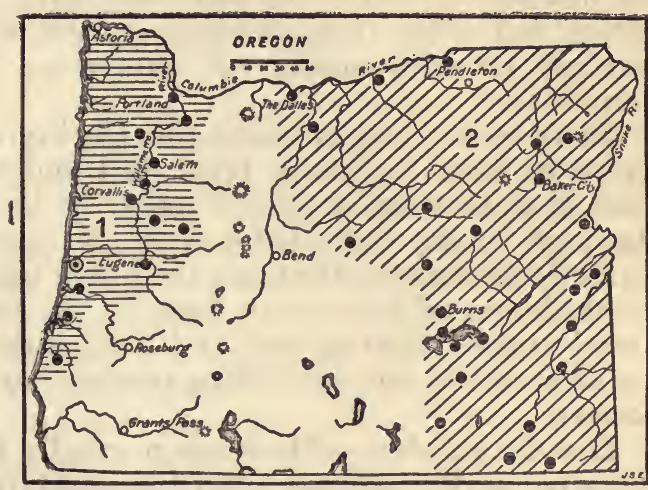

FIgure 49.-Range of two subspecies of muskrats in Oregon: 1, Fiber zibethicus occipitalis; 2, F. $z$. osoyoosensis. Type locality circled.

Mexico, including in its range northeastern Oregon east of the Cascades (fig. 49). Specimens from the Malheur Valley are clearly referable to it rather than to mergens of Nevada, while those south of the Malheur Valley are perhaps nearer to the paler mergens, although not typical. For present purposes, all of the specimens examined from east of the Cascades in Oregon can be treated under the single form osoyoosensis, rather than to include only intermediates in a form not typical in the State.

Muskrats are more or less common in the Columbia, Snake, Deschutes, John Day, Malheur, and Owyhee drainages and also in the isolated Malheur Lake Basin, and one was taken in 1896 by C. P. Streator at Shirk, west of the Steens Mountains. They have not been taken in the Klamath or Pit River Valleys nor in Summer, Abert, or Warner Lake Valleys, although these great lakes and tule marshes seem admirably adapted to their requirements and very similar to the Malheur Lakes where they abound. Altitude and zonal conditions seem to have little influence on these aquatic mammals, while food supply and suitable habitat are the main factors in their original distribution and abundance.

General habits.-Muskrats are mainly aquatic in habits, swimming and diving with great skill, getting most of their food from under 
water or along shores, building houses surrounded by water, or living in bank burrows opening into the water. They are famous builders, constructing conical or dome-shaped houses of plant stems, roots, sods, and mud rising usually 3 or 4 and sometimes 5 feet above the surface of the water, with broad bases resting on the bottom of shallow lakes or ponds. A single room occupies the center of the house just above the water level with usually 2 or 3 doorways opening downward through the water and out under the house into the lake or pond. The heavy walls, often a foot thick, keep out the winter cold and many of their enemies, and the room within often accommodates a whole fámily of 6 or 8 animals in the moist bed of water plants close to the water level. Even in the coldest weather the inside of the house is kept warm and the water is prevented from freezing by the body warmth of the muskrats, while the porous walls admit sufficient ventilation to afford them healthy existence. In case of danger or alarm the muskrats dive quickly through the water holes and swim long distances under water before coming to the surface, or swim under the winter ice to other houses or to bank burrows.

In deep streams or lakes the muskrats usually live in bank burrows, or tunnels leading from well under water back into the banks and upward until a nest chamber is formed above the water level. In high banks these bank dens are usually well hidden and even safer from enemies than are the house nests, and in many places both bank dens and houses are used by the same animals. There is evidently much visiting back and forth among the houses and dens, but to what extent the sociability reaches beyond the family circle is not known.

Breeding habits.-Muskrats normally have 4 pairs of mammae-2 inguinal and 2 pectoral - and the usual numbers of embryos recorded are 6 to 8 . One large old female containing 13 embryos evidently was abnormally fertile. The first young of the season are born in May and June, but later litters born during July and August may be second litters, or the first litters of young females. The number of litters produced in a season by one mother has not been satisfactorily determined.

The young are born blind, naked, and helpless and do not come out of the house until well furred and old enough to swim and dive and take care of themselves. They mature rather slowly and apparently do not reach full size during the first season, or until a full year old.

Food habits. - The food of muskrats consists principally of roots, tubers, bulbs, and the tender basal portion of tules, sedges, cattails, grasses, and other marsh plants. The long rhizomes of cattails, rich in starch and gluten, furnish much food, while the blanched tender basal portion of the stems of both cattails and tules are extensively eaten. Waterlily roots and leaves are a favorite food. The tender young shoots of grasses, sedges, wildrice, and numerous other green plants are eaten, while clover and alfalfa are always acceptable food. Rolled oats are eagerly eaten as are carrots and many cultivated crops, but in wild lands, grains and seeds, except wildrice, are not often obtained. Small turtles, muscles, and crawfish are sometimes 
eaten, but there is no evidence that fish are ever captured for food. Muskrats rarely show much fat but are generally plump and well muscled. Their flesh is excellent food if properly cooked and brings a good price in the large city markets.

Economic status.-At present muskrats are kept scarce in most of the waters of eastern Oregon by vigorous trapping for their fur, but in Malheur Lake, where given special protection on the national bird refuge they have at times become normally abundant. In 1908-9, from November to March, 3 trappers took 5,600 skins around Malheur Lake, and other trappers took an unknown number. The next winter 22 trappers secured only 1,500 skins. The next winter 2 trappers secured 2,000 skins and the following winter 2,258 skins, but the next winter (1912-13), only 890 skins. The season was then shortened to 4 months, November to February, and for the 3 years following, the 2 trappers took 1,480,1,736, and 1,399 skins, respectively. There were a few other trappers but none making a regular business of it for the whole season as did these 2. The number of skins taken at this lake probably averaged 2,000 to 3,000 a year for the ' 8 years.

In the winter of 1914-15 for some unknown cause most of the muskrats left the lake as soon as it froze over and scattered out for miles over the sagebrush valley where they died and were killed by hundreds. They were poor and possibly diseased, but more probably starving, as their regular food supply had been destroyed by unusually high water that summer. Many of the ranchers killed 100 or more of the animals around their places and found others dead in the sagebrush, on the ice, and even in Spring Creek, which never freezes. Many thousands were estimated as killed outside of the lake, and many more died that were not recovered. The next summer the writer saw their carcasses in the sagebrush over the valley and the animals were scarce in the lake. Still with a couple of years' suspension of trapping they increased again to normal numbers and in 1920 were abundant in the lake.

A much fuller knowledge of the habits and requirements of muskrats is necessary before they can be intelligently controlled, but on private or public land where they can be kept at a maximum abundance they afford a profitable fur industry. This large dark-brown variety yields an especially beautiful and valuable pelt. There are other lakes in Oregon that could undoubtedly be stocked with muskrats to advantage, but it should be borne in mind that under certain conditions, especially in irrigated areas, muskrats are capable of serious injury to ditch banks and to crops along the ditches. In such localities more thorough trapping and a long open season usually afford all the protection necessary and the value of the fur amply pays for the control.

\section{FIBER ZIBETHICUS MERGENS HoLLISTER}

\section{Nevada Muskrat}

Fiber zibethicus mergens Hollister, Biol. Soc. Wash. Proc. 23:1, 1910.

Type-Collected at Fallon, Nev., by S. E. Piper, in 1908.

General characters.-Slightly smaller than osoyoosensis and much larger than pallidus. Typical specimens from the Great Basin valleys somewhat paler than osoyoosensis in comparable pelage; upper parts dark grayish brown; 
sides rusty; lower parts creamy white with central area pale cinnamon or russet. In worn pelage often pale yellowish brown.

Measurements.-Average of adults from type locality: Total length, $554 \mathrm{~mm}$; tail, 253 ; foot 80.

Distribution and habitat.-Mainly the inland lakes and streams of Nevada and the Great Basin generally. S S ecimens from southeastern Oregon have been referred to mergens, but are more or less intermediate in characters and have been treated under osoyoosensis.

\section{FIBER ZIBETHICUS OCCIPITALIS ELLIOT}

\section{Oregon Coast MUSkrat}

Fiber occipitalis Elliot, Field Columb. Mus., Zool. Ser. 3:162, 1903.

Type.-Collected at Florence, Oreg., by Edmund Heller, in 1901.

General characters. - About the size of $F$. $z$. osoyonsensis but slightly paler and more reddish; skull with narrower interpterygoid space.

Measurements.-Average of 4 specimens from type locality: Total length, 589 $\mathrm{mm}$; tail, 271 ; foot, 83.5.

Distribution and habitat.-This seems to be a well-marked local form occupying the Willamette Valley and a limited section of the coast from Florence to Coquille (fig. 49). It inhabits the streams and marshes of the more open country but not the streams of mountain and forest. The animals are rather scarce, and very few specimens have found their way into museum collections.

Family CASTORIDAE: Beavers

\section{CASTOR CANADENSIS PACIFICUS RHOADS}

\section{Pacific Coast Beaver; Gannok of the Wasco}

Castor canadensis pacificus Rhoads, Amer. Phil. Soc. Trans. 19:422, 1898.

Type. -Collected at Lake Keechelus, Kittitas County, Wash., by Allan Rupert, in 1893.

General characters.-Large, form heavy and compact (pl. 35); hind feet large and fully webbed; tail broadly flattened, naked and scaly; ears and eyes small; incisors large and chisellike; fur deep and soft, under cover of long, coarse guard hairs. Fresh winter pelage, dark chestnut brown over upper parts; duller more sepia brown over lower parts; cheeks yellowish brown. Spring and summer pelage fades out to rusty or yellowish brown. Young about the same color as adults. Skull large and long with heavy rostrum, long and medium width nasals and heavy dentition.

Measurements.-Type specimen, adult female: Total length, 1,143 mm; tail, 330 ; foot, 185 . A medium-sized male from Bear River, 12 miles east of Woodruff, Wash.: Total length, $1,016 \mathrm{~mm}$; tail, 280 ; foot, 185 . Weight $481 / 2$ pounds.

Distribution and habitat.-These fine large beavers seem to occupy the whole drainage of the lower Columbia River Basin and the Snake River Valley (fig. 50). Specimens from the headwaters of the Deschutes, La Grande, Pine Creek, near Pine in Baker County, Oreg., from 5 miles south of Walla Walla, Wash., from Boise River west of Boise, Idaho, are typical pacificus, while those from the Owyhee River and Jordan Creek near Rome, in Malheur County, are near pacificus in external characters but show skull characters clearly grading toward the Nevada form. Specimens from western Oregon in the Rogue River Valley, the McKenzie and Willamette 
Valleys and two skins and skulls from Nehalem in Tillamook County, can be referred to pacificus, although showing considerable variation.

A century ago beavers were abundant in almost every lake and stream in Oregon, so abundant that the first trapping expeditions brought back rich returns in fur from the least-inhabited parts of the State. In the vicinity of extensive Indian settlements the beavers were less numerous, or even scarce, in those days, and in a comparatively few years of vigorous trapping they became scarce over the whole State, and later, while unrestricted trapping was allowed, they were reduced to the verge of extermination.

In 1805 Lewis and Clark reported beavers along the Lower Columbia. In 1812 Franchere, on a 20-day trip up the river from Astoria, brought back " 450 skins of beaver and other animals of the furry tribe." In December 1825 Peter Skene Ogden, with his large party of trappers, found beavers scarce along the Columbia and lower Deschutes, but east of the Deschutes on Hay Creek, Trout Creek, and Crooked River they began to get from 15 to 29 beavers a day. Still farther east on the branches of John Day River, they took generally 20 to 28 a day, and in January took 215 beavers

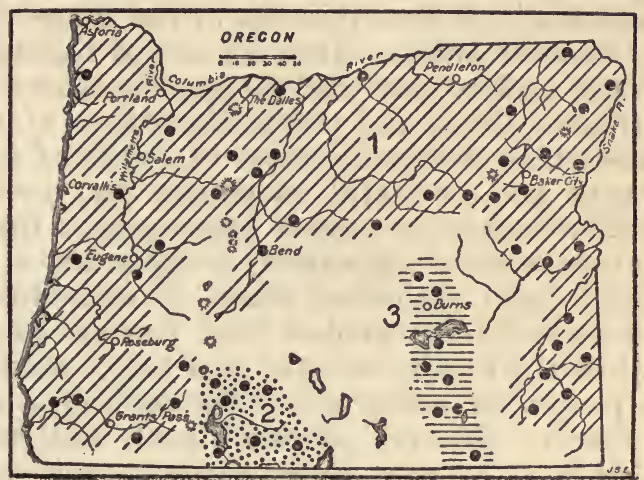

Figure 50.-Range of three forms of beavers occurring in Oregon: 1, Castor canadensis pacificus; 2, C. c. shastensis; 3, C. c. baileyi.

and 16 otters. On Burnt River they took but 54 beavers but blamed the cold weather and thick ice for their not getting the 3,000 skins expected in planning this midwinter trip across new territory.

A small party of Ogden's trappers was sent up the Owyhee the following winter, and although attacked by Indians and robbed of their horses, they brought back 650 beaver skins, while another party took 81 beavers in a brief time on the Malheur River. In this season's round, his trappers over the State from October 1826 to March 22,1827 , took 2,230 beavers and otters (only a few of the latter) (1910, p. 217).

West of the Cascades beavers were reported as plentiful along the Willamette River in 1811-17 (Cox, 1832, p. 101), but in 1824 Douglas (Hooker, 1836, p. 101) reported them as "now scarce" although the valley had at one time been considered the finest hunting ground for beaver west of the Rocky Mountains. In 1827 Ogden first reached the Rogue River, only to be informed by the Indians that the trappers from the Willamette had visited the river and taken all the beavers $(1910, p$. 217).

In 1860 Lord, traveling northward along the headwaters of the Deschutes River, reported "every stream thronged with beavers" and trees up to 4 feet in circumference cut down by them $(1866, p$. 
294). At their lowest ebb a few remained in the larger rivers, however, and during the past quarter century under the awakened interest in wildlife and the most rigid legal protection that could be given them in an area of extensive wilderness they have come back to some of their old haunts and increased locally until they now may be found in many of the streams and lakes of the State. In fact, they are apparently more common now in the Grand Ronde and Walla Walla Valleys than they were a hundred years ago when these valleys were occupied by settlements of Indians who depended largely on the native animals for food and clothing.

In recent years beavers have been reported as more or less common locally in Clatsop, Columbia, Tillamook, Benito, Lane, Hood River, and Jackson Counties west of the Cascades, and in Wasco, Sherman, Crook, Wheeler, Gilliam, Umatilla, Wallowa, Union, Baker, Grant, and Malheur Counties east of the range.

General habits.-Beavers are so highly specialized for life in the water and so slow and clumsy on land as to be closely restricted to streams, lakes, and ponds, the shores of which they rarely leave for more than a short distance in search of food. In the water they are rapid and powerful swimmers and great divers, often remaining under water for several minutes at a time and swimming long distances without appearing at the surface, digging, cutting roots and sticks, and gathering much of their food under water. The very large and fully webbed hind feet are powerful swimming members, while the broad, flat muscular tail is used in steering and diving, for a prop in standing up, or for striking a signal blow on the water or ground. Beavers are intelligent, skillful, and industrious workers, building extensive dams across streams to hold back sufficient depth of water in ponds to protect their houses and winter stores of food, and building large, strong, and comfortable houses in which to live and raise their young. They cut trees and bushes for food and building material and show great skill and industry in getting material and carrying on their building and food-storing operations. When much hunted and trapped for their valuable fur they become very shy and difficult to catch, but when protected for a time become gentle and unsuspicious. They are easily tamed and make interesting pets if properly handled. Often in their native haunts they can be baited with favorite food plants, such as the aspen and cottonwood branches, thrown in the water or laid on the shore every day until they come regularly for the food. In this way they may be kept in localities where desired, and even induced to come out before dark to feed in places where they may be observed at close range. While largely nocturnal in habits, and strictly so when persecuted by much trapping, they usually come out and begin work before dark and continue their activities until after daylight if unmolested.

Breeding habits.-Female beavers have normally 4 pectoral mammae on 2 large breast mammary glands, and 4 seems to be the usual number of young in a litter. In yearling females breeding for the first time there are often only 2 young, while in older females the number is sometimes 6 and there are a few records of 8 embryos in old females. The young are nursed by the mother in the houses or bank dens until old enough to dive through the 
long waterway to the open water and begin to get a part of their own food from tender plants, twigs, and leaves. They remain with the mother during at least the fall and first winter, and if undisturbed probably longer if the food supply is ample. The relation of the males to the family life is not fully known, but they are sometimes found with the mother and larger young and are probably on friendly terms with their various families.

Food habits.-Beavers are purely vegetarian, feeding mainly on bark, twigs, leaves, roots, and a great variety of water and shore plants. Aspens, cottonwoods, and willows are their principal tree food; these are cut along the shores, and the bark is eaten from the branches and the small trunks. In autumn the branches and sections of small trunks are cut and stored in masses in deep water near the houses or bank dens, where they are accessible all winter under the ice, but much winter food is also obtained from roots and water plants along the banks and on the bottoms of ponds and streams. During the summer much of the food is from green vegetation in the water or on the shores and few trees are cut except as needed for building. Coniferous trees are rarely cut and not generally used for food.

Beavers eat large quantities of coarse food and under favorable conditions become moderately, and sometimes extremely, fat.

Economic status.- In past years the beaver has been the most valuable fur animal of North America, and with proper control and management might well take again that place among fur bearers. While in many places beavers do serious damage and ought not to be encouraged, in suitable localities on public or private lands where they can be fenced and supplied with the right kind of food they should afford profitable returns in fur and meat. Great care should bo taken, however, to stock areas with animals producing the darkest, most valuable fur, as it is just as easy to raise high-priced as low-priced beaver fur, and there is a wide range of prices between, the pale and the very dark beaver skins. As a private industry beaver farming promises to be a complete success, but many of the details have not yet been worked out, and if undertaken it should be at first on a small scale with careful experimental advances (Bailey, 192\%').

Since 1924 only partial protection has been given beavers in Oregon, and most of the animals have been destroyed.

The report of the district forester for Oregon, dated February 14, 1930, says :

The open season on beavers in Oregon has proved an expensive mistake and every effort should be made to repeal the law. The present law allows trapping everywhere except on the national-forest land. However, the patented land is so intermingled that this restriction has no effect. A check on the raw furs shows that most of the beaver were caught before the fur was prime. This was because every trapper was afraid every other trapper would get in ahead of him. The number of beaver in the State has been reduced almost to the vanishing point and this has affected stream flow, fish, grazing, and erosion to a serious degree. The beaver dams originally held back the run-off on the heads of streams, supplying the irrigation sections of eastern Oregon. The dams are now gone. These dams originally formed rearing ponds for the small fish and helped to restock the streams. * * * Erosion followed and many of our best grazing areas have changed in type from wet meadows of high carrying capacity to a dry, rapidly eroding type of extremely low or no carrying capacity. 
The following notes in the Portland Oregonian of June 1, 1931, by Ranger Ralph Elder of the Ochoco National Forest in semiarid northeastern Oregon give some idea of the beaver in conservation of water:

The removal of beaver has been a large factor in the shortage of water during the drought through which we are passing. Streams have dried up below former beaver dams to an alarming extent and water for stock has been reduced. * * * During 1914, as forest guard, I assisted Forest Ranger Anderson and Homer Ross, supervisor, to survey a road across a virtually dry draw just below the Cold Springs ranger-station cabin. It was decided that a bridge was unnecessary, as not enough water ran across the proposed road location to justify building one. During 1920 beaver moved into this draw and constructed a dam just above the proposed road location, near a large spring. Since that time these dams have been increased, and at present approximately 2 acres are wet beaver meadows and swamps, and springs have developed 300 yards below this. During the past season, the driest on record, water was plentiful for a distance of a quarter mile below the beaver dams, and springy places were increased all down the draw. **** The actual improved area is hard to estimate and the increase in water for the dry part of the season can only be guessed at, but there is plenty of water for a band of sheep at all seasons and at least 20 acres of land that were dry in the very wet season of 1914 are kept fairly moist.

Another example of more recent date is at Little Summit ranger station. This area was formerly full of beaver, but the last, as far as we could tell, were trapped out about 1925. From that date to 1929 the old ditch and the entire meadow were fast becoming a dust bed. During 1928 and 1929 no water ran out at the lower end of the station. *** Some beaver moved back in 1929 and by the fall of 1930 the meadow in the pasture was 75 percent irrigated. The old ditches were full of water and a nice stream was running at the lower end of the station. While hardly sufficient handily to water a band of sheep this much had been accomplished during two summers. I believe, from the evidence of a number of dams, that several beaver are there, which is probably the result of moving in rather than of natural increase. I have every reason to believe that by 1932 this entire meadow will be irrigated and that there will be plenty of water for a band of sheep at all seasons, below the station fence. * * * Water stored in this ground during the earlier part of the season will go a long way toward raising the water table for a considerable distance below, and, as the country is flat, it will undoubedly improve the forage on an area of at least 40 acres, in addition to the land actually surface irrigated. It will also provide water for sheep one-half mile farther down the stream than has existed before.

\section{CASTOR CANADENSIS SHASTENSIS TAYLOR}

\section{Shasta Beater; Pome of the Klamath (C. H. M.)}

Castor subauratus shastensis Taylor, Calif. Univ. Pubs., Zool. 12: 433, 1916.

Type (skull only).-Collected at Cassel on Hat Creek, near Pit River, in Shasta County, Calif., by H. E. Williams, in 1893.

General characters.-External characters from two skins collected at Thomas Creek, Lake County, Oreg., by H. J. Roosa, October 19, 1921. Externally scarcely distinguishable from pacificus, unless slightly brighter chestnut about head and tail in fresh October pelage. Skull readily distinguished by shorter, wider outline, short, wide, posteriorly pinched in nasals and heavy rostrum.

Measurements.- Medium-sized female from Thomas Creek, Lake County, Oreg.: Total length, 1,046 mm ; tail, 300; foot, 185; ear (dry), 25 . Weight, 42 pounds.

Distribution and habitat.-Known only from the Pit and Klamath River drainage in northern California and southern Oregon, from specimens taken at Cassel, Calif., and from Thomas Creek, a small branch of Cottonwood Creek, which flows into the northwestern 
corner of Goose Lake, Oreg. (fig. 50). It is probably safe to assume that the beavers of the Klamath section, Lost River, Sprague River, and the Yamsay Mountains, are also of this form.

In January 1827 Ogden and his party of trappers in the Klamath Lake section nearly starved because they could not find enough beavers to furnish food for the party, but a few days later Ogden met McKay's party of trappers with " 735 beaver skins taken on two small rivers that discharge into Klamath River." Still later, in February, he found beavers abundant along the Pit River, his trappers bringing in large numbers every day, and on February 22, completing their first 1,000 skins. On March 9, he says: "It is a sin to see the number of small beavers we destroy. Some females have no less than five young." On March 11, his trappers came in with 72 beavers and 1 otter (1909, $p p$. 212-217).

On May 19, 1860, Lord on his way from California to British Columbia with a drove of horses and pack mules crossed the Klamath River just above Lower Klamath Lake, which he described as a great tule marsh with open patches of water, which seemed to be the "head center" of the beaver population of Oregon. This beaver colony of many acres in extent was so populous that in some of the ponds there seemed "no room to jam in even a tiny beaver cottage" among those already occupying the area. Back from the lake shores "the trees had been felled for a good half mile from the water" as if busy emigrants had been making a clearing. The branches had been cut from the trees and dragged along well-beaten roads to the rushes, through which roads had been cut to gain easy access to the open water $(1866, p .273)$.

On Drew's Creek west of Goose Lake in 1897 there were several dams and ponds, a small beaver house in one of the ponds, and many trees and bushes cut for food and building material. In 1915 Jewett reported two dams freshly built of aspens and willows on Drew's Creek. In 1914 L. J. Goldman reported them on the west slope of the Yamsay Mountains, on Sprague and Yamsay Rivers, and in the Klamath Marsh. In 1896, Preble reported them along Wood River and Diamond Creek, and in 1914, Harry Telford reported them on the head of Wood River and Diamond Creek, and near the mouth of Anna Creek Canyon. Evidently they have held their own or increased in this section in recent years.

In July 1927 there were still a few beavers in Sprague River and its branches north and east of Bly, but the old colony on Drew's Creek that had been visited in 1897 was gone.

In no noticeable way do the habits of these beavers differ from other species in similar type of country. They now live mainly in creeks or small rivers, where they build dams and houses and often live in bank burrows.

\section{CASTOR CANADENSIS BAILEYI NELSON}

Nevada Beaver; Hak-NE-sha of the Piute

Castor canadensis baileyi Nelson, Biol. Soc. Wash. Proc. 40: 125-126, 1927.

Type.-Collected in Humboldt River, 4 miles above Winnemucca, Nev., by J. H. Bunch, October 13, 1917. 
General characters.-Relatively small; form slender; colors dull and pale; upper parts rusty brown; lower parts drab brown; under fur uniformly pale brown or drab; skull very long and narrow, with long slender rostrum and narrow nasals; dentition light.

Measurements.-Adult male from type locality : Total length, 1,046 mm; tail, 254 ; foot, 183 ; ear $(d r y), 24$. Weight not given. Young adult, a 11/2-year-old female (Oct. 11), from same place measured $946 ; 368 ; 190 ; 24 \mathrm{~mm}$; and weighed 32 pounds.

Distribution and habitat.-In 1826 one of Ogden's beaver trappers, Sylvailles by name, discovered the river flowing into Malheur Lake from the north, since called Silvies River and reported it rich in beavers. The following year the party again visited this river in June, when they took 300 beavers in about a month, but complained that the natives of this section had destroyed upwards of 6,000 beavers, not 1 of which had reached their trading pasts $(1910, p p$. 221). In 1828 Ogden and his party of trappers struck south across Alvord Valley onto the headwaters of streams flowing south, probably the headwaters of Quinn River and the North Fork of the Humboldt, near the Nevada line, into country where "there were great numbers of Indians and abundance of beavers." Here in November his 6 trappers brought in as high as 52,58 , and 60 beavers a day, and before the month was over they had taken 800 skins. In April of the following spring he returned to this "unknown river" with a larger party to complete the fur harvest and on May 8 reported 1,700 beaver skins taken and said "in no part have I found beaver so abundant".

These desert-valley beavers are still found in the Great Basin drainage of northern Nevada along the Humboldt River, and its tributaries and in the Malheur Lake and Steens Mountains drainage of southeastern Oregon (fig. 50). Two skulls from Fish Creek, a branch of the Blitzen River, which flows into Malheur Lake from the south, are typical baileyi. There are a few beaver all along the Blitzen from its headwaters down to near Malheur Lake, and George Benson reports one shot at the edge of Malheur Lake in 1909. In 1916 they were found in Big Fish Creek, McCoy Creek, and Kiger Creek. It is fair to assume in the absence of specimens that the beaver in the Silvies River and its branches on the north of Malheur Lake are also of this subspecies. In 1920 they were still common in many places along the Silvies and Blitzen Rivers, and while in places they were doing some damage by flooding the meadows, more often they were merely holding up the water to a better depth and improving the meadows by subirrigation.

On the other hand they sometimes dam the irrigation ditches or locate in the banks of streams near fields and orchards where they do serious mischief and have to be removed, driven away, or destroyed. With intelligent handling and the introduction of a darker and more valuable fur variety they could become a valuable asset on many of the eastern Oregon ranches. 


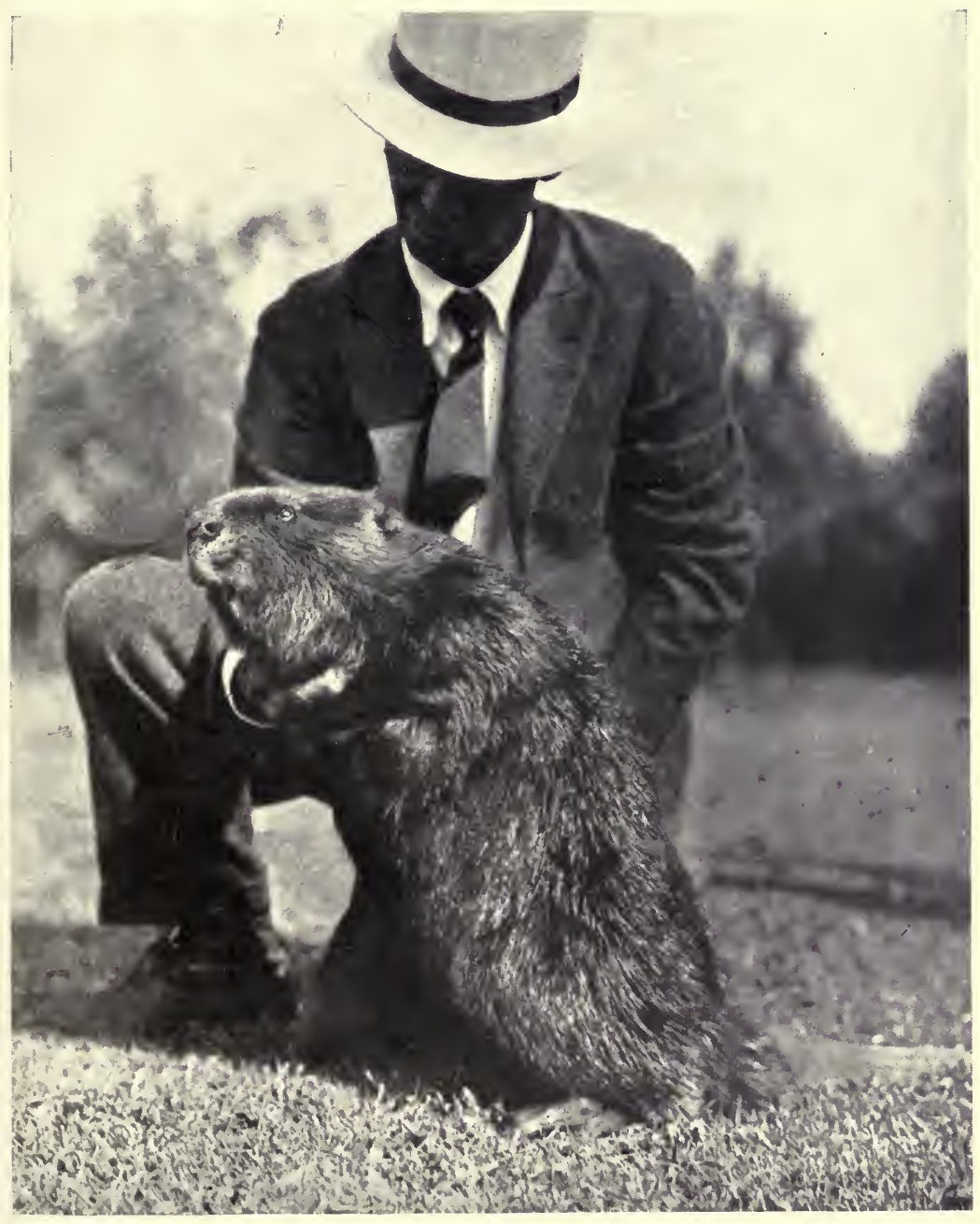

Old Male Beaver.

B4616M

Just taken from a wire cage trap in Maine, and as easily handled as any domestic stock (photograph by W. B. Campbell). 

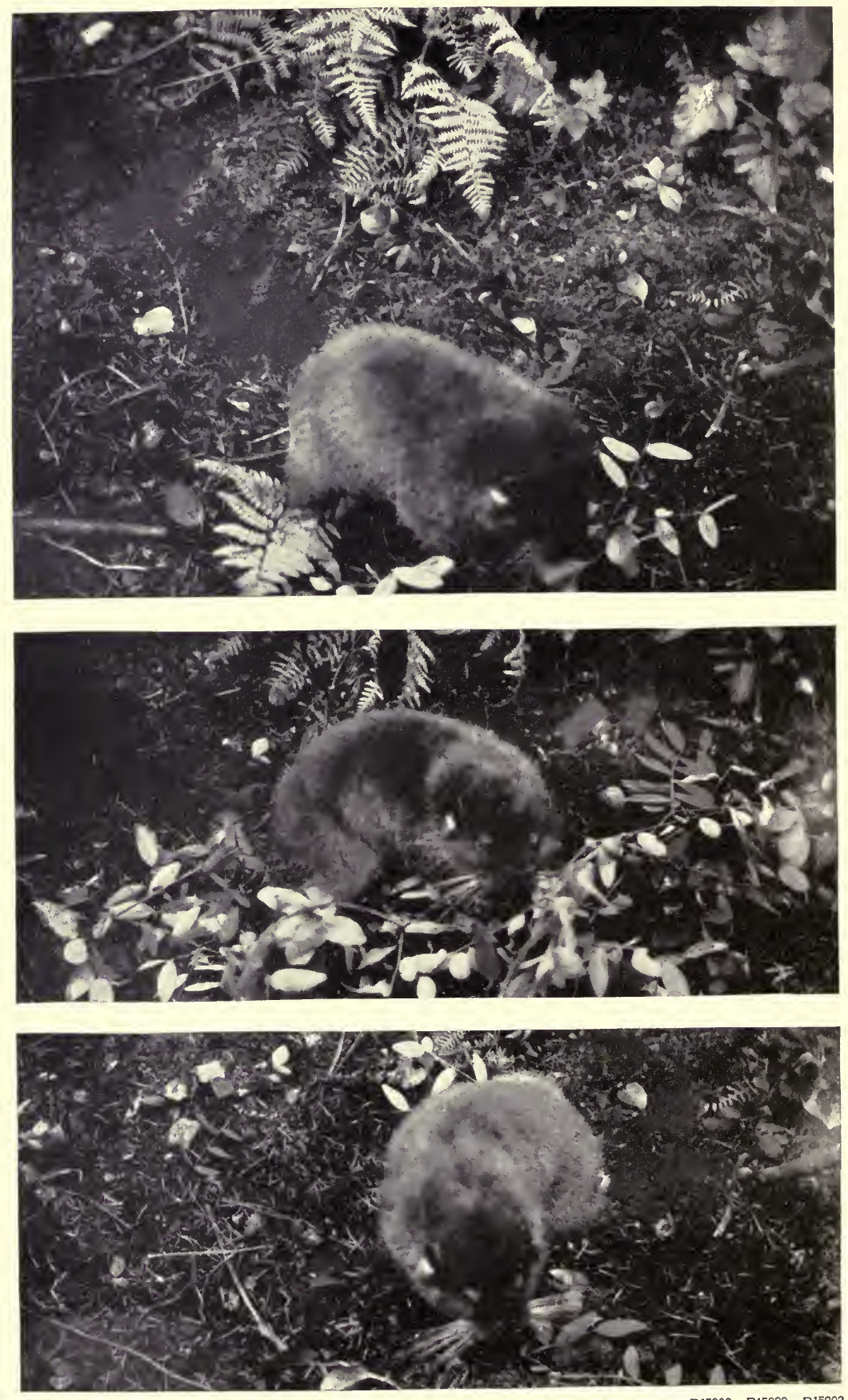

CAPTIVE MOUNTAIN BEAVERS.

B15906; B15899; B15902

Near burrow at Vida, on the McKenzie River, Oreg. (photograph by Luther J. Goldman, 1916). 


\section{Family APLODONTIIDAE: Mountain Bearers}

\section{APLODONTIA RUFA RUFA (RAFINESQUE)}

Brown Mountain Beaver; Mountain Burrowers; Sewelleet (Indian name); Netate (Tolowa of Crescent City, Calif.) (C. H. M.)

Anisonys ? rufa Rafinesque, Amer. Monthly Mag. 2: 45, 1817.

Type region.-Neighborhood of the Columbia River, Oreg. Restricted to the Mount Hood section. Original description based on Lewis and Clark, from skins obtained from the Indians.

General characters.-Size about the same as a very large muskrat (pl. 36) ; form heavy compact; legs, tail, and ears short; eyes small; feet large with wholly naked soles and strong claws; mustaches long and bristly; fur short and dense, with short, coarse, shiny guard hairs; upper parts dark rusty brown with dusky nose and ears and a small white spot at anterior base of each ear; lower parts clear buffy brown with conspicuous dark brown nipple spots in the females.

Measurements.-Old female from Marmot, west of Mount Hood: Total length, $330 \mathrm{~mm}$; tail, 34 ; foot, 55 ; ear in dry specimens, 16 . Weight about 2 pounds.

Distribution and habitat.-This large form of the mountain beaver extends along the lower slopes of the Cascade Range from southern $\mathrm{B}$ rit is h Columbia to northwestern California (fig. 51). In O regon there are specimens from M a r mot, Bissel, Eagle Creek, Vida, McKenzie Bridge, Mount Mazama, Anna Creek, Fort Klamath, Siskiyou, and north base of Ashland Peak. There are also records of their occurrence at Hood River, west base of Mount Jefferson, west base of Three Sisters, 20 miles east of Drew, near head of Rogue River, and at base of Mount McLough-

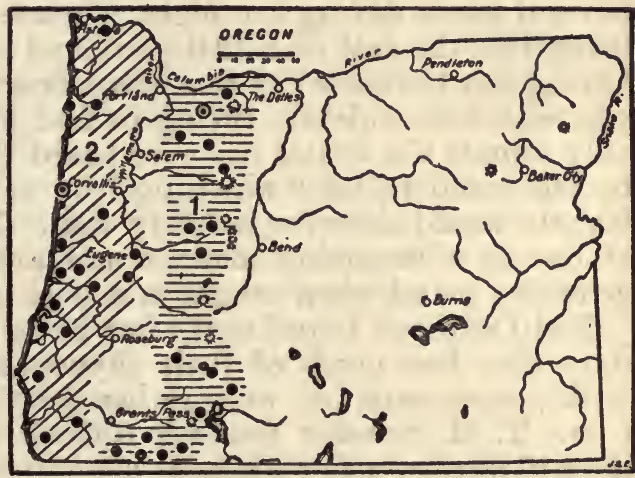

Figure 51.-Range of the two forms of the mountain beaver in Oregon: 1 , Aplodontia rufa rufa; $2, \boldsymbol{A}$. $r$. pacifica. Type localities circled. lin (Pitt). Generally they are in Transition Zone timber country in the gulches and ravines, where there is considerable moisture and dense growth of vegetation. Their range is irregular, interrupted, and to some extent colonial. Locally they are often abundant, but they occupy only a small part of the range assigned to them.

General habits.- In many ways the habits and actions of mountain beavers suggest pocket gophers, as does also their general appearance, for if the big camas pocket gopher (Thomomys bulbivorus) were twice its present size its longer tail would be the only convenient means of distinguishing the two. The burrowing habits and similar mode of life are evidently responsible for this superficial resemblance. Mountain burrowers would have been a better name for Aplodontia and especially for this mountain-dwelling species. The animals are almost never seen except when caught in traps, but 
the burrows, the size of woodchuck holes, are in places so numerous and so well hidden under ferns and low tangled vegetation that one traversing the home of a colony is constantly falling into them. Unlike gopher burrows they usually are left open and will readily allow a man to slump in up to the boot top. The burrows often go straight down for a foot or two and strike the main tunnels which extend for long distances underground, and often run through wet ground and springy places or carry small streams of water.

The animals are mainly nocturnal, generally silent, and very shy, but when caught in traps they fight savagely anything that comes within their reach, biting sticks and jumping at any object that moves near them. Their eyes are small and watery, sometimes milky, and their vision is short and poor. One that the writer caught uninjured in a trap was taken to camp with a firm grasp around the back of its neck and kept all day and part of the night before it escaped. It was extremely vicious when touched and tried to get hold of the captor's hands or feet but succeeded only in biting a hole in his heavy leather boot. It cut strings tied around its neck or to its foot. It was finally caged under a telescope top from which it escaped in the night but not until it had given up a few of its secrets. Several times during the night it made a long quavering cry something like the call of a little owl and several times during the following day the same cry was heard from the fern beds back of camp, where it was evidently trying to find its way home. These are the only sounds the writer has ever heard these animals make, and may be the sound called "whistling" by various authors. A quavering whistle would describe it fairly well. They also chatter their teeth at one in a menacing manner and are said sometimes to make a growling sound when caught in a steel trap.

Ned Dearborn found that after being kept in captivity for several days they lost much of their shyness and could be handled safely with proper care, but were rather deficient in intelligence and affection. T. H. Scheffer found it difficult to keep them alive for more than 10 days or a few weeks at most in captivity, even when supplied with abundance of their favorite foods and with living conditions as nearly normal as possible. Even when caught in box traps they would be found dead in many cases after a few hours of confinement.

H. E. Anthony kept one for a week, and it became tame enough to eat from his hand. It swam readily when put in water.

R. Bruce Horsfall told the writer that in Wahtum Lake, on the north slope of Mount Hood, the mountain beavers swam out into the lake and from place to place along the shores, like muskrats, for which they were at first mistaken.

At the lower levels they seem not to hibernate in winter, but are more or less active under the snow, sometimes coming out on the snow to cut branches and bushes for food. Near Hood River and Parkdale on the north slope of Mount Hood, G. G. Cantwell, in March 1919, found their old tunnels leading 20 feet or more under the snow, but could not catch any of the animals and thought they might be hibernating. Other records of inactivity in winter may indicate partial hibernation or merely the quiet utilization of food stores in their underground storehouses. The animals are never fat enough to suggest possible hibernation. 
Breeding habits.-The females have an unusual arrangement of mammae, 2 pairs of pectoral and 1 pair of anterior abdominal, all conspicuously marked by large round spots of dark brown. Even the nipples of the males are sometimes indicated by small brown spots in the fur. Scheffer gives the number of young as generally 2 or 3, scantily haired and blind at birth, but there are other reports of 5 or 6 . He thinks that but one litter is raised in a year and says the young are born about the middle of April in well-sheltered nests in the burrows under logs, stumps, or upturned roots of trees.

Food habits. - Aplodontias are purely vegetarian with a wide range of food plants. One brought into camp alive would eat almost any plants offered him. A little lily (probably Vagnera sessitifolia) seemed to be its favorite, but vetch, lupine, salal, and ferns were eagerly eaten. Willows, alders, maples, thimbleberry, salmonberry, dewberry, fireweed, valerian, and in fact most of the shrubs and plants available are cut and eaten on the spot or carried into the burrows for future use. The habit of leaving bunches of cut plants around the mouths of the burrows, on logs or stones to dry, has given the animals credit for making hay; but green as well as dry plants are carried into the burrows, and some of the dried plants are left outside until they become well bleached. The haymaking is not thorough or systematic but is evidently a part of the preparation for winter for either food or nest material. Scheffer reports bark eaten from the roots and bases of tree trunks in winter, and many lower branches of conifers cut for food.

Economic status.-Generally these are harmless little animals of the forest, thickets, and waste places, rarely noticed unless a trail goes through one of their colonies or a place is cleared where their burrows are already located. While these occurrences are rare they usually occasion some annoyance and in case of fields a possible injury of crops. The animals quickly disappear, however, before clearings and cultivation of the soil and are of no permanent consequence to agriculture. Locally it may be necessary to trap or poison them at the edges of fields or where they burrow across trails; but they are easily trapped and readily poisoned.

They are said to be used as food by the Indians, but one cooked in the writer's camp was strong, tough, and dark colored. No one seemed to enjoy it, and even the dog would not eat the meat.

Apparently they are preyed upon by many of the fur-bearing carnivores and thus help to convert some of the abundant vegetation of the mountain slopes into the valuable and varied fur crop of the State.

Among the Northwest coast Indians the skins of these little animals seem to have been in general use for fur robes and blankets in the days of Lewis and Clark, in 1805, and of Douglas, in 1827, and for clothing, according to Suckley, in 1860. The fur is short, but soft and when prime fairly dense and of an attractive neutral brown. The skins are strong and light and would seem well suited for linings or for light outer garments. Camp says the skins of the California species bring only 8 or 10 cents in the fur market, and Jewett reports sales of Oregon skins at 10, 15, and 20 cents each. If taken when fully prime these skins should have a much greater value. 
APLODONTIA RUFA PACIFICA MERriam

\section{Pacifio Mountain Beaver}

Aplodontia pacifica Merriam, Biol. Soc. Wash. Proc. 13: 19, January 31, 1899.

Type-Collected at Newport, on Yaquina Bay, Oreg., by B. J. Bretherton in 1896.

General characters.-Noticeably smaller than rufa with conspicuously narrower, slenderer skull, and slightly darker colors; generally more dusky on head and back and the basal ear spots mainly or wholly dusky instead of white.

Measurements.-Adult male at Astoria: Total length, $303 \mathrm{~mm}$; tail, 20 ; foot, 53 ; ear in dry specimens, 16 to 20.

Distribution and habitat.-This is a coast form, extending practically the whole length of the Oregon coast and inland to the open valley country (fig. 51). Specimens from Eugene show characters intermediate between mufa and pacifica, but seem to be nearer to pacifica. Over the heavily timbered and densely brush-covered slopes of this humid area they are more generally distributed than are those of the mountain form of the drier interior range, but even here they are more or less colonial or localized in the areas occupied, and often absent for wide intervals.

General habits.-Only as modified by the type of country are their habits different from those of the larger rufa. More often they are located on the broad slopes of the mountains and hillsides, where in the long rainy season there is abundance of water to trickle through their burrows. In places the slopes are fairly honeycombed by the burrows. A group of burrows may have 20 openings scattered over a few square rods of ground, some with considerable mounds of earth thrown out and others without a trace of earth around the mouth. Surface trails often lead from one burrow to another or out into brush or fern patches nearby. Many of the shallow tunnels have been broken into from above and often the line of a burrow may be traced for considerable distance.

Food habits.-In the coastal region their favorite or most generally available food plants seem to be salmonberry, thimbleberry, huckleberry bushes, and the abundant ferns about their burrows. They also cut the branches from alders, vine maples, hemlocks, and cedars, and carry them to their burrows, supposedly for food. Many other plants are eaten and sometimes all of the bushes around their colonies are cut down until only stumps remain, but as these are mainly unimportant growth and spring up again with the next growing season, the food supply is perennial and abundant. In examining large numbers of colonies the writer has not found where any number of young or larger trees had been injured by them.

Family EREThIzontidaE: American Porcupines

\section{ERETHIZON EPIXANTHUM EPIXANTHUM BRANDT}

YeLLOW-HAIRED PorCUPINE

Erethizon epixanthus Brandt, Mem. Acad. Imp. Sci., St. Petersbourg (6) $3: 390,1835$.

Type locality.-California.

General characters. - Next to the beaver our largest rodent; form short and broad, with short legs and short muscular tail; feet fully plantigrade, with 


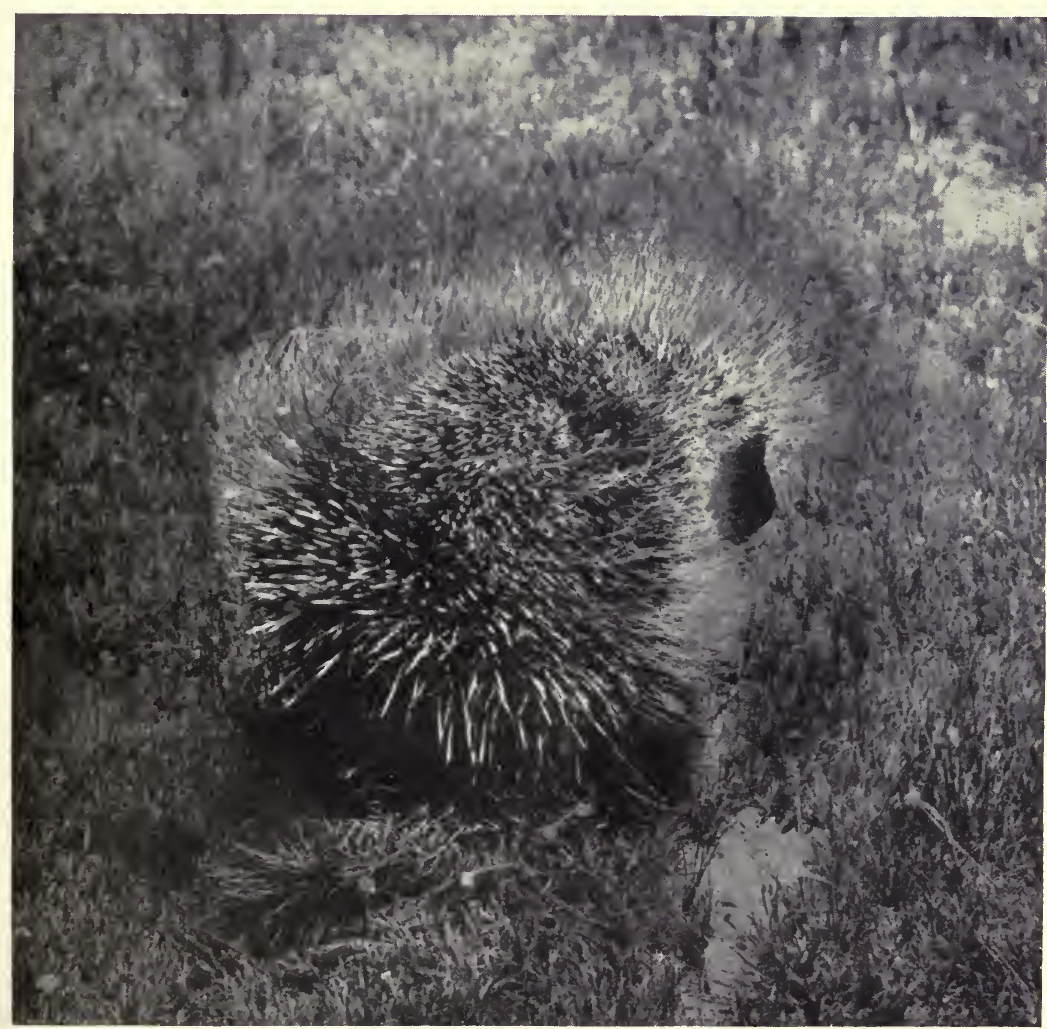

B4614M

REAR VIEW OF YELLOW-HAIRED PORCUPINE.

When alarmed the porcupine draws the skin of its back forward and exposes the armor of quills from tip of tail to eyebrows (photograph by C. Hart Merriam, in Tuolumne Meadows, Calif.). 


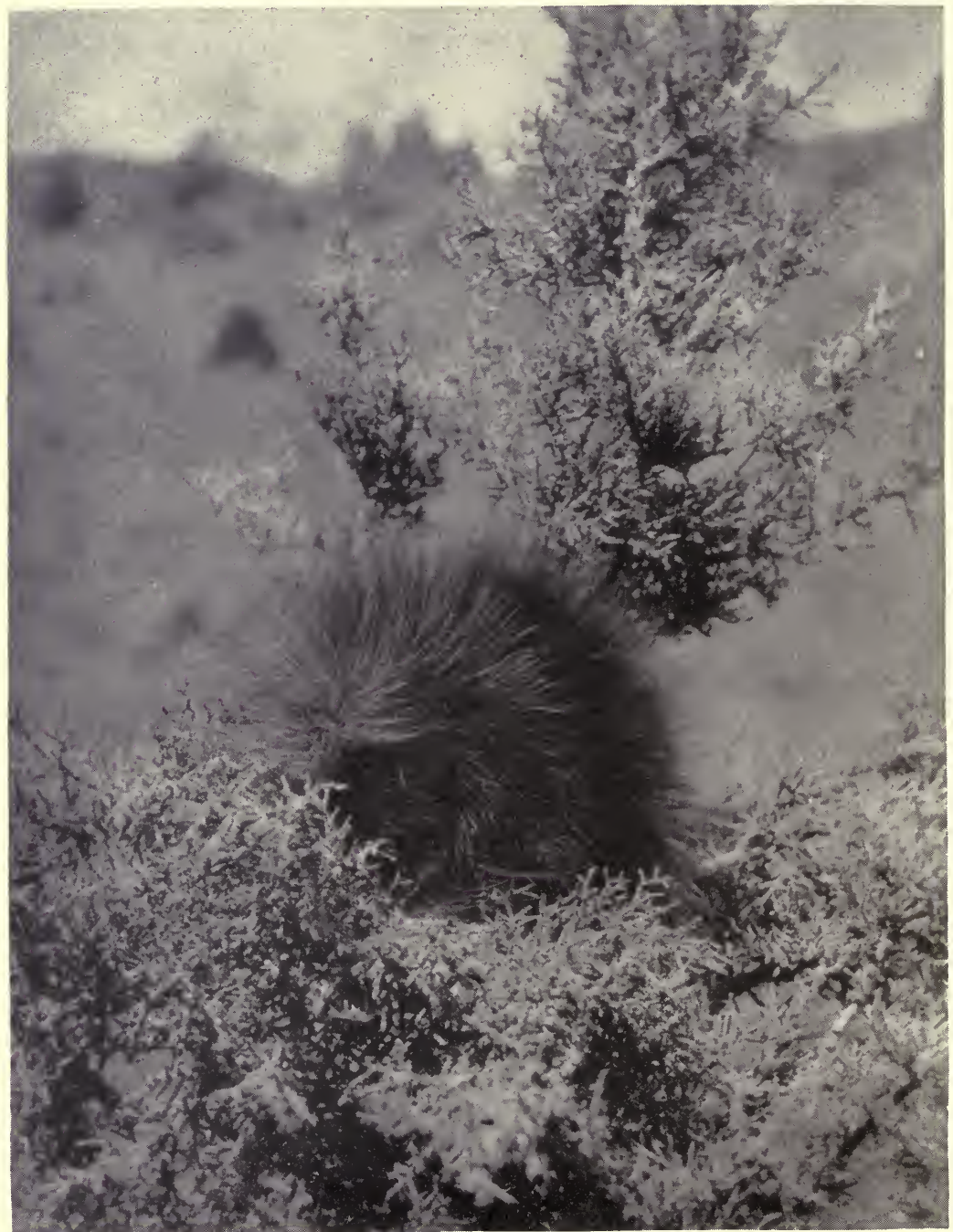

YELLOW-HAIRED PORCUPINE IN JUNIPER TREE.

B4613M

Front view of animal at rest in treetop, eastern Oregon (photographed by Alex Walker). 
oval, denticulate soles, and heavy, curved claws; ears small and hidden, in the fur; eyes small; nose soft and furry. Pelage in winter a dense coat of long, soft, blackish fur, thickly set over upper parts with stout, sharp, and terribly barbed quills from 1 to 4 inches long, partly concealed over back and sides by a loose outer coat of coarse, erectile yellow or yellow-tipped hairs 6 to 10 inches long; lower parts covered with fur and coarse hair, and lower surface of tail with rigid bristles that help it to serve as a prop in climbing. Summer pelage with but little fur, mainly naked quills and long outer hairs, the black-tipped white quills fully exposed when erected. Young, black all over.

Measurements.-Adult male: Total length, $765 \mathrm{~mm}$; tail, 211; foot, 105: ear (dry), about 20. Weight of large males generally estimated at 20 to 30 pounds. One taken in Yellowstone Park, Wyo., weighed $331 / 2$ pounds. Weight of 7 males from Oregon, excluding young of the year, given by Gabrielson as 18 to $221 / 2$ pounds; of 8 females, as 12 to 14 pounds. This series evidently included no very old animals.

Distribution and habitat.-The yellow-haired porcupine occurs over most of the western United States from the edge of the Great Plains to the Pacific, but the areas where it grades into the more northern and southern forms have not been fully determined. In Oregon it covers almost the whole State from desert valleys to the coast and from the hottest upper Sonoran Valleys to timber line on the mountains, seemingly with no regard to well-established life zones. It is much less common in the humid coast region, however, than in the dry interior of the State, and the writer has seen no specimens from west of the Cascades.

General habits.-Porcupines are slow, rather stupid, timid animals, depending mainly on their spiny armor for protection, but always eager to get under cover or up a tree, or into a cave or cleft in the rocks for additional safety. Their only method of defense is to present the back with erect spines (pl. 37) to the enemy and to strike upward and sideways with the powerful, spiny tail, but in most cases this is ample defense. The quills are not thrown, as is commonly believed, but may be driven deep into an enemy by a blow of the tail, and if only lightly imbedded will work their way by means of their barbed points in through skin and flesh.

These animals are slow but industrious travelers, often leaving their lines of oval tracks in dusty trails for miles in a single night, wandering at random over deserts or open valley country, finding an abundance of plant food wherever they are, and taking advantage of any available cover for places to sleep during the day.

They have squeaky, querulous voices, with many modifications to express anger, fear, or pain, and softer little squeaks and grunts for friendly feelings or entreaty. A treetop song has been reported in the mating season, but this needs further study. Generally, however, they are silent and by many are supposed to be voiceless.

They are excellent climbers and spend much of their time among the branches of large trees (pl. 38), where they are comparatively safe and where much of their winter food is obtained. They do not hibernate even in the coldest winter weather and the deeper the snow the more easily available becomes their food of twigs and bark.

Breeding habits.-The females have four mammae in a large rectangle on the abdomen, but often only the anterior pair is developed. The young are sometimes 2 , but more commonly only 1 , born usually in 
Gemeral characters.-Large for a Zapus; tail rery long and slender and almost naked; hind feet long with long slender toes and naked soles; ears long and narrow; upper incisors deeply grooved, dark orange in color; pelage appressed, harsh, and bristly. Color with strong pattern, back from nose to tail dusky with but a trace of yellow; sides deep rich orange with coarse black bristles scattered through; whole lower parts white or creamy white.

Measurements.-Large typical adult female: Total length, $235 \mathrm{~mm}$; tail, 135 ; foot, 33 ; ear (dry), 13. Weight of adult male, $27.5 \mathrm{~g}$.

Distribution and habitat.-This large, dark, richly colored, and beautifully marked form occupies the coast country from southern British Columbia to southern Oregon and extends inland to include in its range the Willamette, Umpqua and lower Rogue River Valleys

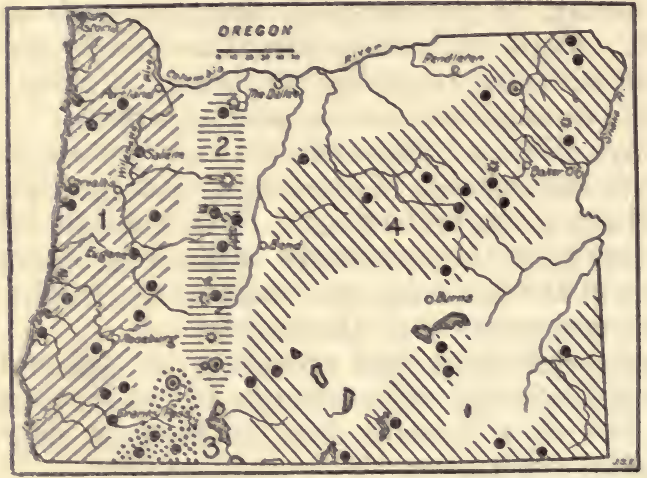

Figers 52. - Range of the four forms of Jumping mice in Oregon: 1.Zapus trinotatus trinotatus; 2 Z. $t$. montanus; $3, Z$. t. pacificus; $4, Z$. princeps oregonus. Type localities circled. (fig. 52). S p e c i m en s from Eugene are fairly ty p i a l but show a slight tendency to w a $\mathrm{r} d$ montanus from the Cascades, while others from Grants Pass are grading toward pacificus of the upper Rogue River Valley. Humid Transition Zone in Oregon seems to be fully occupied by them. They are largely marsh and meadow dwellers but are often caught along the creek banks or under ferns and weeds in the woods. In places they are

occasionally aburidant but more generally they are scarce in numbers and scattered in distribution.

General habits.-Although of mouse size, these graceful little animals in disposition and habits have little in common with ordinary mice. Naturally quiet and phlegmatic, they are easily captured alive in the hands and if gently handled rarely bite and seem not much afraid. When startled they progress rapidly in long leaps but usually after 3 or 4 jumps they stop and sit motionless to see if they are pursued, and then if closely watched may often be approached stealthily and captured under the hollowed hand. In dense vegetation such as ferns or marsh grass or weedy cover their method of escape is generally successful.

While mainly nocturnal they are occasionally seen in daylight when frightened from their grassy nests on the surface of the ground. They do not make runways nor leave any trace of their presence except the little heaps of grass stems where they feed. These are 2 to 3 inches long and are readily distinguished from the shorter, more scattered cuttings found in the runways of meadow mice.

The animals burrow into the ground to make their winter nests, become very fat in autumn and hibernate long and closely during the cold winter weather, remaining unconscious for about half the year in the colder parts of their range and apparently also in that part of Oregon where the winters are comparatively mild. 
Breeding habits.-The females have 4 pairs of mammae-1 inguinal, 1 abdominal, and 2 pectoral. The number of young ranges from 4 to 8 in a litter; apparently but one litter is born in a season. In some cases the young have scant time to get their growth and lay in a stock of fat before winter.

Food habits.-These mice are dainty feeders, living mainly on small seeds of grasses and other plants which they reach by cutting off the stems, drawing them down and biting off the lower sections until the seed-laden heads are reached. The small grains-wheat, barley, rye, and oats-are treated in the same manner and are also farorite foods. Many other plants are also cut for their seeds, and rolled oats used for trap bait are eagerly eaten.

In the early autumn the animals accumulate an excessive amount of fat in thick layers under the skin, over the muscles and especially in the abdominal cavity. In the case of other subspecies this oily fat will more than double their weight and supply ample food material to carry them through the long winter's sleep.

Economic status.-Generally these little animals are not numerous enough to be of any serious economic importance, but where they are unusually numerous the meadows suffer in spots from the amount of grass that they cut to get the seeds. In places an acre or more of the best grasses may be found noticeably thinned by them. The loss of seed locally may also prove a serious check on the reproduction of the grasses. Potentially they are thus capable of serious injury to grain and forage crops, and every encouragement should be given to their natural enemies, owls and other nocturnal birds, weasels, skunks, badgers, and beasts of prey.

\section{ZAPUS TRINOTATUS PACIFICUS MERRIAM}

\section{Pacific Jumping Mouse}

Zapus pacificus Merriam, Biol. Soc. Wash. Proc. 11: 104, 1897.

Type.-Collected at Prospect, Rogue Rirer Valley, Oreg., by Edward A. Preble, August 29, 1896.

General characters.-Small; form slender; skull narrow and slender; colors bright, with much yellowish in dorsal area and unusually clear yellow sides, lightly lined with black hairs; belly and lower surface of tail white; feet gray; ears slightly or not at all edged with yellow.

Measurements.-Type, adult male: Total length, $225 \mathrm{~mm}$; tail 141; foot, 31; ear (dry), 12.

Distribution and habitat.-This mouse is found in the upper Rogue River Valley in Oregon and extends southward into northern California, in semiarid Transition Zone (fig. 52).

General habits. - No peculiarities of habits have been observed for this form except the habit of swimming, which is probably common to all. On the side of Preston Peak, Calif., N. Hollister, in 1909, gave the following interesting note:

While I was walking around the grassy border of a small pond one jumped out at my feet and struck in the water like a frog, which at first it was thought to be, until it was seen swimming across the pond on the surface of the water, when it was shot for a specimen. The animal may not have intentionally jumped into the water but he certainly handled himself as if perfectly at home and swam with little effort and great speed over the still surface of the pond. 


\section{ZAPUS TRINOTATUS MONTANUS MERRIAM}

\section{Mountain Jumping Mouse; Kangaroo Mouse}

Zapus trinotatus montanus Merriam, Biol. Soc. Wash. Proc. 11:104, 1897.

Type.-Collected at Crater Lake, Oreg., by Edward A. Preble, August 21, 1896.

General characters.- Slightly smaller and lighter colored than trinotatus; skull slenderer and more delicate; back dusky, lightly grizzled with orange; sides light orange, lined with black hairs; lower parts creamy white; feet gray; tail whitish below.

Measurements.-Average of eight topotypes : Total length, $228 \mathrm{~mm}$; tail, 135 ; foot, 31; ear (dry), 12.

Distribution and habitat.-This is a mountain form inhabiting mainly Canadian Zone for the whole length of the Cascade range in Oregon. Specimens from McKenzie Bridge are clearly intermediate between trinotatus and montanus, and intergradation between the two may be expected all along the west base of the Cascades (fig. 52).

General habits.-These mountain jumping mice, as do other forms of the group, live in meadows and marshes or near mountain brooks and streams, feeding on grass seeds and such other seeds as are available, even the fiery seeds of western skunkcabbage, becoming very fat in autumn and sleeping soundly during the long winter period of cold and deep snows. Actual dates of entering and emerging from hibernation are not available and it is not known if the period is longer in the high mountains than in the lowlands.

\section{ZAPUS PRINCEPS OREGONUS PREBLE}

\section{Blue Mountain Jumping Mouse}

Zapus princeps oregonus Preble, North Amer. Fauna No. 15, p. 24, 1899.

Zapus major Preble, North Amer. Fauna No. 15, p. 24, 1899, from Hart Mountain (Warner Mounțain), Oreg.

Type.-Collected at Elgin, Blue Mountains, Oreg., by Edward A. Preble, in 1896.

General characters.-Large, about the same as Zapus princeps of the Rocky Mountains, but less sharply marked, with graser head and obscurely margined ears; back and head dusky, lightly flecked with yellow; sides and cheeks broadly dark ochraceous or light orange yellow, lined with coarse black hairs; lower parts white; feet and lower surface of tail whitish.

Measurements.-Average typical adult: Total length, $132 \mathrm{~mm}$; tail, 138; foot, 33 ; ear (dry), 12.

Distribution and habitat.-The Blue Mountain jumping mice cover practically all of the Transition and Canadian Zone areas of Oregon east of the Cascades, including such scattered desert ranges as the Yamsay, Hart, Steens, and Mahogany Mountains and the high country at the headwaters of the Owyhee River (fig. 52). Being lovers of meadows and brooks, they are not found in the desert valleys, which are also below their zone level, hence their range is more or less broken and scattered. Zapus major from Hart Mountain (Warner Peak) proves, on comparison with abundant material, to be typical oregonus, while those from the southeastern corner of the State are grayer and may be grading toward nevadensis, but at present are better referred to oregonus.

General habits.-In no way have the habits of these little animals been found to differ from those of other subspecies. They are locally 
common in the grassy and flowery mountain meadows and under the fringing willows along the creeks, and are often taken in considerable numbers by collectors.

In August they become fat, and none are taken between the early part of September and May. They hibernate for 6 or 7 months in underground nests, laying up no food but depending entirely on their accumulated fat to carry them through the winter. In food and breeding habits they show no subspecific peculiarities.

\section{Family HETEROMYIDAE: Kangaroo Rats and Pocket Mice}

\section{PERODIPUS ORDII COLUMBIANUS MERRIAM}

Columbian five-toed Kangaroo Rat; Wapota Pitsua of the Piute

Perodipus ordi columbianus Merriam, Biol. Soc. Wash. Proc. 9: 115, 1894.

Type.-Collected at Umatilla, Oreg., by Clark P. Streator, October 18, 1890.

General characters.-A small, five-toed, buff-colored kangaroo rat, with long crested tail (pl. 39, A) ; long hairy soled hind feet; small hands; wide head; large eyes; small hooded ears ; and very long mustaches. Skull with inflated mastoids and broad antorbital arches; upper incisors narrow, equally grooved and strongly recurved. Upper parts d a r k buff with dusky ears, sides of nose, heels, and soles, and plumbeous stripes along top and bottom of tail; lower parts, feet, sides of tail, hip stripes, brow and ear patches and lining of cheek pouches white. The white side lines of the tail are broad and usually meet below just back of the tip of tail.

Measurements. - Type: Total length, $254 \mathrm{~mm}$; tail, 148; foot, 40; ear (dry), 11 . Adult female from Malheur Lake: $242 ; 135 ; 42$; ear in flesh, 13 . Weight $50 \mathrm{~g}$.

Distribution and habitat.-These are the common kangaroo rats of eastern Oregon, occupying practically all of the Upper Sonoran sagebrush valleys east of the mountains, except in the Klamath section (fig. 53). They prefer sandy or mellow soils, but are occasionally found on firm or even hard soils on the uplands, but never in such numbers as in the sandy areas. They prefer the open and avoid dense vegetation.

General habits.-The name "kangaroo rat" is wholly inappropriate and misleading for these beautiful little rodents. The large hind feet and legs and long tails are the only points of superficial resemblance to kangaroos and these are structurally entirely different from those of any marsupial. Neither are they closely related to rats or in any way ratlike in appearance. Still the name seems hopelessly fastened upon them.

They are beautiful little animals with short, arched bodies, large heads, large black eyes; short rounded ears; fur-lined cheek pouches; long, slender, tasseled tails; long hind feet and legs; and small hands. 
In ordinary travel they go hop, hop, hopping over the ground on the two hind feet or in rapid flight skimming over the surface with tail straight out behind and used as a rudder for keeping their course or making quick and devious turns.

The use of the long tail always raises a query. It is not powerfully muscular as in the kangaroos but has many uses besides that of an eificient steering apparatus. It balances every motion of the animal and at rest lies partly on the ground. At other times as the animal reaches up for seeds or leaves from plants, the tail serves as a prop or with the two hind feet makes a firm tripod, while the delicate hands reach up for food. In climbing among the branches of tall weeds or sagebrush the animal presses the tail against the stems and steadies itself, and even when sitting on a man's arm or fist one will press its tail down over the side to keep its body in a stable position.

The long hind feet and heavily muscled thighs are powerful aids to speed and are also used in digging and fighting, while the tiny hands are used with great skill in gathering and holding food and tucking it into the cheek pockets, in making nests, and in loosening up the earth to be kicked far back by the hind feet. Running is accomplished entirely on the hind feet, by long leaps, the tracks in the sand often showing 20,24 , and 28 inches from toe to toe.

The ample, elastic fur-lined cheek pouches, extending back under the skin of the cheeks and sides of neck, when well filled with seeds or grain or rolled oats, hold about a tablespoonful each of food, enough to last the animal for 1 full day and enough to make the storage of an excess food supply a rapid process. They are filled rapidly with the hands and emptied instantly with a single motion of both hands at once, pressing forward from the rear on the outside.

A little warty gland on the back between the shoulders appears to serve at least two purposes. It has a faint musky odor that may have recognition purposes very useful to the individuals of the species. It also yields an oily substance that may serve as an important hair dressing. If kept in a clean box or cage for a few days the animals become very rough, mussy, and oily in appearance. Given dry sand or dust for a vigorous bath, which they greatly enjoy, they again become sleek and fluffy with removal of excess oiliness from the fur.

The animals are so strictly nocturnal that people rarely see them or even know of their presence. Even tame individuals kept in the house would not come out of their nest boxes until long after dark, and all would retire for the day before the first signs of daylight. Still they did not sleep through all of the 15 hours spent in the nest boxes, for they carried in at least their pockets full of food, or more than one load if a supply was available, and ate it during the day; they also moved about considerably inside the boxes, and repaired their nests. Behind closed doors in their burrows they apparently do some digging and considerable moving around during the day, and if a closed door is opened from the outside they usually soon replug it with earth. They see well in the dark and in a moderately lighted room, but sunlight or any bright light causes them to blink and half close their eyes. Their eyes are always closed in sleep, but when awake in a dim light they are 

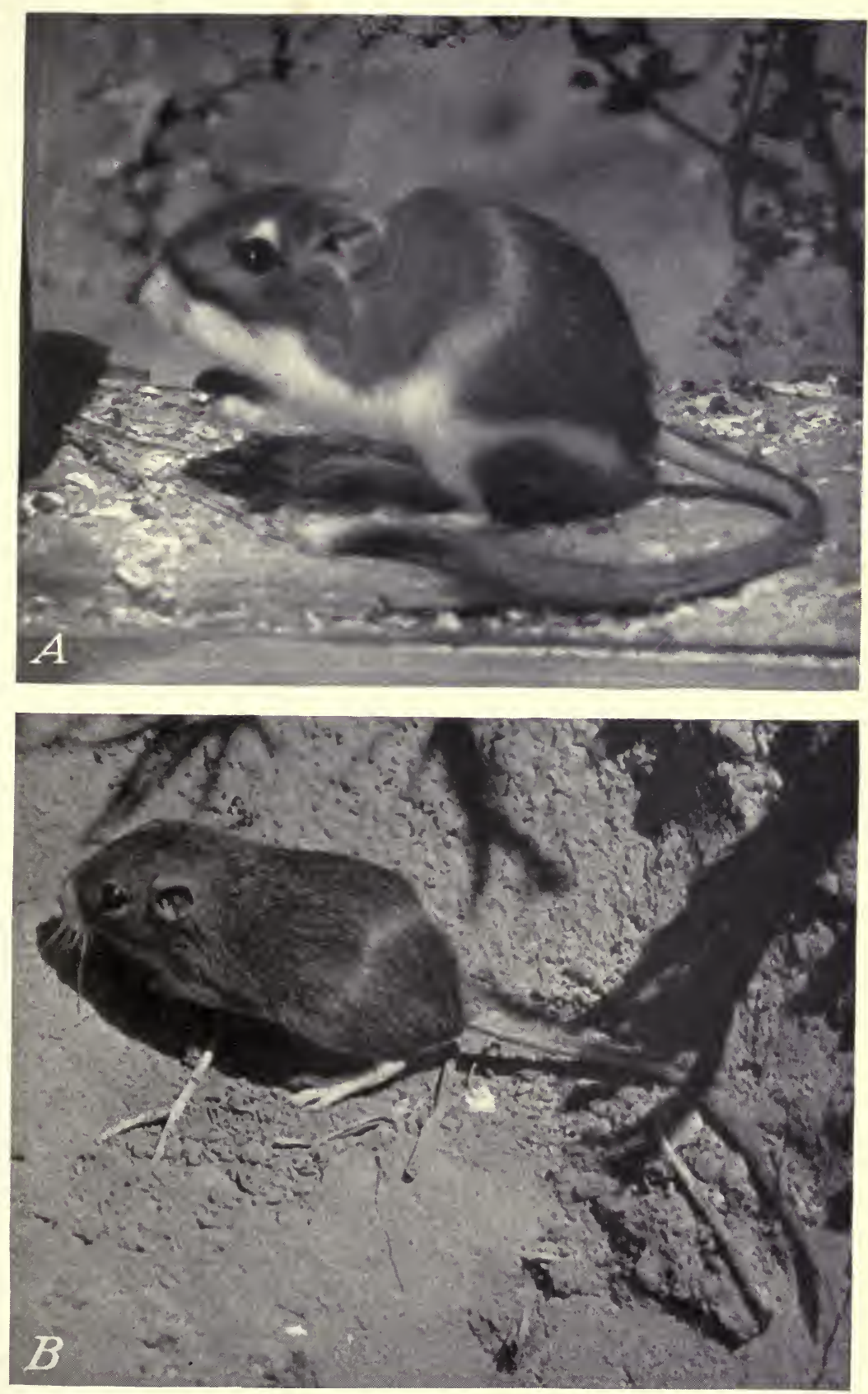

$A$, Columbian kangaroo rat in glass photographing box at Malheur Lake; $B$, pocket mouse dug out of its burrow in the sagebrush near Malheur Lake. 

wide open and very large. In the dark they shine with reflected light as two glowing yellow balls just the color of the full moon well above the horizon.

In disposition the animals are surprisingly gentle and tame with man and to a limited extent social and friendly with each other in a family or colony. With others from different dens they are savagely unfriendly. Seven were caught alive at one group of burrows and kept in a two-room cabin. When put in a box together they all fought like cats and dogs, but given the run of the house they selected separate quarters in boxes, tin cans, boots, the stuffing of a lounge, and in a corner of the wood box. They did much chasing and fighting around the rooms at night and several were killed by the others, but finally several became wonted to the wood box and slept together or in different corners of it.

Dens and burrows that were dug out and mapped were often found to be elaborate and complicated. One large den in an old barren field covered about 12 by 20 feet, with 4 main entrances where considerable earth had been thrown out, but each entrance kept closed during the day. An elaborate system of connected burrows led to several nest and food chambers a foot to $11 / 2$ feet below the surface, and 10 blind burrows were traced to points near the surface where, in case of danger, an animal might easily break through and escape. Two main and five smaller storage chambers contained a little food and food refuse. At least 2 , and probably a family of 5 or 6 animals, occupied this den. Other burrows examined were much simpler in nature, some with only a single burrow with a main entrance and blind exit and a small nest and food chamber at the bottom. Usually the occupant escaped by breaking out through the back door and making off at a flying pace to some other burrow.

Climbing.-Those in captivity have shown unexpected skill in climbing, in running through branches of sagebrush in the wood box and through the slender branches of large weeds and bushes, and in balancing on edges of boxes and thin boards. They will hop to the top of a 15-inch box, sit on the edge of the thin board, hop across to the other edge, or to the edge of another box, swarm up a big dry mustard plant and sit on the branches with tails pressed against the branches or stems to keep a balance, climb to the tops of screen doors and then jump down, and climb up a bed blanket that reaches near the floor and find their way into bed in a friendly fashion. The wild mustard plants, often 4 or 5 feet high, from which much of their food is gathered, are evidently climbed as the small branches are cut off and the seeds stored for food.

Fighting.-When two strangers meet there is sure to be trouble. One will jump on the other, or both will sit up and spar with their hands each trying to get hold of the other with its teeth. Sometimes they will clinch and bite and kick each other until one breaks away with a bloody nose or torn skin or broken tail and runs for its life, with the other in hot pursuit. One was found dead in the morning on the floor with its nose and tail bitten and dozens of little holes through the skin of the back and into the flesh, where the sharp toe nails of the hind feed had been driven in with great force. Later two other dead ones were found behind the wood box, torn and 
punctured, and others had bloody noses and damaged tails. Old Hopsy, the first one taken and the gentlest of the lot, was twice rescued from combats with a bloody nose, and between sniffles she kept up a belligerent undertone of chur, chur, chur, and had to be held and comforted for some time to be kept from going back on the warpath.

There seems to be no age or sex distinction in the fighting, both males and females being attacked indiscriminately by the other. The younger and weaker animals suffer most. In the open where escape is easy the fighting is probably not often serious, but occasionally specimens are taken with ragged ears or injured tails. The fighting instinct is evidently an outcome of the storing habit, each animal being of necessity compelled to protect and defend its food supply.

$V$ oices.-Generally the animals are silent, but close association shows that they have many little sounds and notes that mean different things. When disturbed in a nice warm nest, they often make a complaining note. Again, when hopping about the floor at night, a low birdlike chirp, chirp, chirp is occasionally heard, or when on the warpath this note becomes an angry chur, chur, chur, and if two come to blows there are sharp squeaks and squeals, sometimes frantically shrill in pain or anger.

Breeding habits.-The females have normally 3 pairs of mammae, 2 inguinal on a pair of elongated glands and 1 pectoral on short glands. In 1 female there were also 2 pairs of pectoral mammae. Three and four embryos have been found in females taken for specimens in June and July, but the breeding season is probably as irregular and uncertain as in other desert mammals. Apparently no small young have ever been found, and little is known of the breeding habits.

Food habits.-Their food consists largely of seeds of a great variety of plants, including grasses, grains, pigweeds, wild mustards, capers, shadscale, Dondia, wild sunflowers, lupines, and the small desert star Mentzelia albicautis. In captivity they are fond of rolled oats and any seeds or grains but also eat green leaves of weeds, fresh cabbage, and the rinds of ripe cantaloups. At first they would not touch water but were eager for juicy cabbage and cantaloup, but after a week or more in the house they were noticed drinking the drops of water spilled on the kitchen floor, and when some water was given them in shallow dishes they drank eagerly but in a peculiar way, dipping it up and licking it from the hands, usually both hands together and not from one hand as does Perognathus. In the desert they evidently obtain their water from succulent vegetation, and in the dry season they were found carrying both ripe and green seed capsules of Mentzelia in their pockets. Each of these little green capsules, half an inch long and a tenth of an inch in diameter, contains a good-sized drop of clear green juice, not unpleasant in flavor and affording an ample supply of water during the hottest, driest part of the summer.

Economic status. - In the warm, arid valleys where most of these little kangaroo rats are found there is generally no form of agriculture for them to interfere with, but occasionally where dry farming 
is attempted they feast on the sown seed and later on the growing and ripening grain. In irrigated sections they may do some mischief around the edges of the fields. On the stock range, which in eastern Oregon has been almost ruined by overgrazing, they have doubtless done their share to exterminate many of the grasses and forage plants by consuming the few remaining seeds. In fact there are now not enough seeds to support them over wide valleys where there is nothing for stock to eat. Wild mustard and shadscale were the only seeds they were getting in some localities. Their numbers are not sufficient to do serious harm in a more fertile region, but in places they can now take all the seed that is left.

As pets they are gentle, cleanly, inoffensive, interesting, and amusing. They are contented in captivity and are fond of running on revolving wheels or inclined disks, thus getting good exercise.

\section{PERODIPUS MICROPS PREBLEI GOLDMAN}

\section{Preble's Kangaroo Rat}

Perodipus microps preblei Goldman, Jour. Mammal. 2: 233, 1921.

Type.-Collected at the Narrows, Harney County, Oreg., by Edward A. Preble, July 23, 1896.

General characters.-In external characters scarcely distinguishable from columbianus but slightly larger, with relatively longer, darker tails, and dusky lining of cheek pouches; skull slender, with narrower antorbital arches; upper incisors unequally grooved, not recurved, set approximately at right angle to plane of palate.

Measurements.-Of type, female: Total length, $263 \mathrm{~mm}$; tail, 154; foot, 41 ; ear (dry), 11 . Of female topotype: $168 ; 156 ; 42 ; 11$. Weight of adult female topotype $65.5 \mathrm{~g}$.

Distribution and habitat.-There are specimens from Narrows, Tumtum Lake, White Horse Creek, and Summer Lake in southern Oregon, and from Granite Creek in northwestern Nevada, all from the sandy bottoms of low, hot desert valleys in Upper Sonoran Zone.

General habits.-The only striking peculiarity of habits of this species observed to differ from those of columbianus is that of building mounds over the den or group of burrows. In the light sandy soil and mellow sand dunes around Harney Lake and extending along the side of the valley to Narrows their mounds are common, often a foot high by 5 or 6 feet across, with several openings into the sides. In the White Horse Creek Valley some of the mounds are 10 or 12 feet across with a dozen openings. Part or sometimes all of the doorways are closed if the occupants are inside. The earth from the burrows is thrown out and then kicked back onto the mounds, and thus with age and use the mounds increase in size. Some become almost as well developed as those of Dipodomys spectabilis in Arizona, but never so large.

Trails and runways lead from mound to mound or off to the feeding grounds, and the paired tracks of the hind feet show in the sandy or dusty trails in short or long hops according to the speed of the animals. Feeding and breeding habits seem to be the same as in cotumbianus, while the economic importance in these sandy desert areas is negligible. 


\section{DIPODOMYS HEERMANNI CALIFORNICUS MERRIAM}

\section{Northern California Kangaroo Rat}

Dipodomys californicus Merriam, North Amer. Fauna No. 4, p. 49, 1890.

Type.-Collected at Ukiah, Mendocino County, Calif., by T. S. Palmer, May 4, 1889.

General characters.-Largest of the kangaroo rats found in Oregon; form compact, with large head and hooded ears; tail very long and slender, with welldeveloped terminal white-tipped brush; hind legs and feet very long; feet with four toes and sharp, nearly straight nails; hands small, with short thumb and slightly curved nails; cheek pouches ample and fur-lined; skull broadly triangular, with inflated mastolds and grooved upper incisors. Upper parts dark rich buff, heavily clouded with dusky, becoming blackish on nose, ears, hams, soles, and along top and bottom of tail; lower parts, feet, the tip, sides, and base of tail, stripe across hams, and ear and brow spots, pure white.

Measurements.-Average of typical adults: Total length, $312 \mathrm{~mm}$; tail, 184; foot, 46 ; ear (dr. $), 14$.

Distribution and habitat.-These large, dark kangaroo rats occupy the interior valleys of northern California from near San Francisco Bay north into southern Oregon in the Klamath Valley (fig. 53). There are specimens from Klamath Falls, Tule Lake, and Swan Lake Valley in Klamath County. The specimen from Swan Lake Valley was collected by Elmer Applegate in 1898. They occupy upper Sonoran Zone valleys, usually in the open but in places among the chaparral on lower slopes of the foothills.

General habits.-Like other kangaroo rats these animals are nocturnal burrowers, usually keeping the doorways of the burrows closed during the day, and preferring mellow or sandy soil, but sometimes burrowing in hard clays or gravels. The long, paired tracks of the two hind feet are often seen in dusty trails or sandy places near their haunts. In sand or soft ground they make conspicuous trails from one burrow to another or from the burrows away among the grass and small plants, but often they live where the ground is so hard that trails are not conspicuous.

Breeding habits.-The females have 3 pairs of mammae-2 inguinal and 1 pectoral-and sets of 2 and 4 embryos have been recorded in April and September.

Food habits. - The ample cheek pouches of these little animals yield some light on the food habits. Berries and seeds of the manzanita, seeds of buckbrush (Ceanothus creaneatus), rabbitbrush (Chrysothamnus), lupines, bur-clover, wild oats, and some small tubers have been found in the pockets, and there is usually much chaff and refuse from seeds of many wild grasses and other plants scattered about the burrows. The animals are fond of rolled oats and are said to do some damage in grainfields by cutting down the stalks of grain for the seeds. During the long, dry season they must depend on green vegetation, roots, and tubers for their moisture, as usually no water is available where they range.

Economic status.-Owing to their general scarcity these kangaroo rats are of very little consequence, but locally they may do slight mischief in grainfields or cause a slight check on reproduction of grass and other forage plants by the consumption of seeds. With the destruction of their natural enemies, foxes, coyotes, owls, and snakes, they may at some future time become numerous and require artificial control. 


\section{DIPODOMYS HEERMANNI GABRIELSONI GOLDMAN}

Gabrielson's Kangaroo Rat

Dipodomys heermanni gabrielsoni Goldman, Biol. Soc. Wash. Proc. 38: 33-34, 1925.

Type.-Collected at Brownsboro, Jackson County, Oreg., by Ira N. Gabrielson, June 21, 1924.

General characters.-Similar to Dipodomys heermanni californicuis but silghtly darker, and with broader maxillary arches and smaller mastoid inflations of the skull. Tail long and white-tipped. Upper parts dark buff, heavily overlaid with black over top of head and back; face marked with black; soles of hind feet, and top and bottom of tail blackish; lower parts, sides and tip of tail, stripe across hams, and ear and brow spots, white.

Measurements.-Type, male adult: Total length, $294 \mathrm{~mm}$; tail, 188; foot, 46.

Distribution and habitat.-All of the specimens examined are from the vicinity of Brownsboro, some 15 miles northeast of Medford, where they were collected by Gabrielson, Jewett, Moore, and Heckner, but the tracks and trails may be seen in the open chaparral parts of practically all of the Upper Sonoran area of the Rogue River Valley from Grants Pass to Ashland (fig. 53).

General habits.-In a letter of June 25, 1923, Ira N. Gabrielson wrote that these kangaroo rats were found in the Brownsboro country below 4,000 feet altitude where they inhabit the chaparral, making their burrows at the base of the bushes and around old stumps. They were not abundant, and while no specimens were secured in traps, several were picked up where poisoned grain was put out for rodents. In June they were feeding mainly on foxtail grass, which in places forms a solid cover for the ground. The refuse where the seeds had been removed from the grass was often found scattered on the ground where they fed, and its seeds along with some of the poisoned wheat were found in the one nest burrow dugout.

\section{MICRODIPODOPS MEGACEPHALUS OREGONUS MERRIAM}

\section{Oregon Gnome Mouse}

Microdipodops megacephalus oregonus Merriam, Biol. Soc. Wash. Proc. 14: 127, 1901.

Type--Collected on Wild Horse Creek, 4 miles northwest of Alvord Lake, Oreg., by Clark P. Streator, August 18, 1896.

General characters. - Size of a large mouse; body short and wide; head large and wide with large eyes, short rounded ears, and ample fur-lined cheek pouches; skull with greatly inflated mastoids and audital bullae; hind feet long with densely hairy soles and five well-developed toes; tail thiclrest in the middle, tapering to a point, and a little longer than head and body, not crested or tufted; fur long, lax, and silky. Upper parts buffy gray with white ear patches; sides of nose, edges of ears, and narrow border along sides clear buff; lower parts white or creamy; feet gray; tail dark buff above with dusky tip, light buff below. Immature pelage darker and grayer.

Measurements.-Of type, male adult: Total length, $153 \mathrm{~mm}$; tail, 88 ; foot, 24 ; ear (dry), 8. Of a larger male, $163 ; 96 ; 25 ; 9$. Another male measured 167; $97 ; 25 ; 10$, and weighed $13.9 \mathrm{~g}$.

Distribution and habitat.-There are specimens of these quaint little animals in the Biological Survey collection from near Alvord Lake, near Tumtum Lake, head of Crooked Creek, White Horse Sink, and the Narrows, all in extremely arid Upper Sonoran Zone $7209^{\circ}-36-16$ 
valleys of eastern Oregon (fig. 54). In the collection of the late Donald Dickey, of Pasadena, Calif., are 2 specimens from Oregon, 1 collected by Gabrielson near Beatys Butte in Harney County, and 1 by Jewett near Powell Butte, Crook County, in arid, sandy, Sonoran desert country.

General habits.-Like their relatives, the kangaroo rats and pocket mice, these quaint little gnomes are desert dwellers, lovers of sandy or mellow soil among the sagebrush, and able to live where there is little rain and long periods of drought. They are nocturnal burrowers, sleeping underground during the day and rarely seen except when taken in traps at night. The little paired tracks of the two hind feet, too large for pocket mice and too small for kangaroo rats, are easily recognized in the dusty trails, but the closed burrows, well hidden under the sagebrush, are not easily found. Like many other

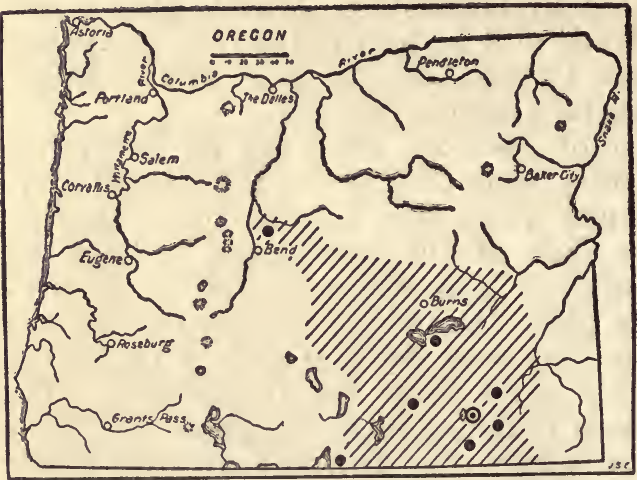

Figure 54.-Range of the gnome mouse, Microdipodops megacephalus oregonus, in Oregon. Type locality circled. small animals they will follow a long mark made with the foot in the soft soil and may be caught in $\mathrm{traps}$ set delicately across these artificial trails and baited with rolled oats.

They run in little short hops on the two hind feet, rarely leaving a print of the little hands, which are generally folded on the breast and used mainly for feeding, digging, and all the general purposes of hands rather than feet. Their speed is so great that when frightened they disappear like a flash of light over the sandy soil of their own color. In captivity, if quietly handled, they are gentle and unafraid. They are closely like the kangaroo rats in disposition and habits.

Near the Narrows, where Preble found them in 1896, the writer camped overnight on July 13, 1927, to collect more specimens. In a sandy sagebrush spot near a point of lava rocks about 2 miles southwest of Narrows tracks of the gnome mouse were found and a line of 66 mousetraps set in the most promising localities. The next morning the traps contained the usual numbers of pocket mice, kangaroo rats, white-footed and grasshopper mice, but only one gnome. Their tracks were around many of the traps, and they had taken the bait from several without being caught, but they seemed not to care much for rolled oats. Their tracks in the early morning before the wind and ants had obliterated most of them were easily followed and generally led from the burrows out into patches of the abundant little desert weed, Mentzelia albicaulis, then well laden with flowers and green and ripe seed capsules on which they were feeding. This plant, only 5 to 7 inches high, was loaded with little capsules, half an inch long and half filled with tiny seeds, that, before they are ripe, are full of clear green watery juice. A 
drop of good water could be squeezed out of each capsule between the thumb and finger, and half a dozen of these would furnish a good drink for a gnome, besides a good lunch on the ripening seeds. The cheek pockets of the one specimen taken were empty but its stomach contained, besides a bit of rolled oats and some other seeds, some of the green pulp and black seeds of these Mentzelia capsules; bits of the refuse of the capsules were also found in one of the burrows; and it was evident that this was one of their principal foods at that season, as it was also of the kangaroo rats and pocket mice. One of the kangaroo rats had its pockets stuffed full of the ripe and green capsules. Many other little plants were full of seeds, and many tender shoots, bulbs, and tubers were to be found just below the surface of the ground. There was no lack of food and water for these desert dwellers, even if it did not rain again all summer.

Living in the dry, hot, sandy desert they might be supposed to be very thirsty animals, but as they are out only at night when the air close to the ground is moist and cool, and spend the daytime in closed burrows a foot below the surface in a cool, moist atmosphere, they probably do not require a great amount of water and the little they need can be readily secured at any time from their food. Several burrows were dug out in the hope of learning more of the habits of the occupants; but in only one was the owner at home, and it ran with such lightning speed from bush to bush' that only a buffy streak on buffy sand marked its course. The burrow entered the ground, beside a bunch of sagebrush, had several pockets or little rest rooms a foot below the surface, and came out on the other side about 4 feet away. The doorway was securely closed from within by fresh sand pushed out after the animal entered, and the occupant escaped by merely breaking out through the thin crust on the other side as the writer dug in along the line of the burrow. In this case there was no nest material, and the clean, soft sand may be pleasanter to the furry feet and soft fur coat of the gnome in its cave than would be a soft warm winter nest. Neither were any food stores found, for the ample cheek pockets provided enough storage room for 1 day's lunches, and the season was too early for the winter storing to have begun.

Two other burrows dug out did not have closed doors and contained no occupants, but were of the same simple plan, one about 4 and the other 6 feet long, and dipped about a foot below the surface. It is probable that more elaborate burrows are provided for winter.

In trapping for specimens it often happens that few of these little animals are taken even where they are fairly abundant, and this is due to two causes. (1) It often seems that they do not care for the bait offered them as they are getting an abundance of certain seeds, which they prefer to anything else. (2) They are so light, so skillful, and delicate in touch, and such dainty feeders, that they may not spring the traps even when they take all the bait. Their bodies are so light and the soles of the feet so soft and hairy that only the most delicate trap will be sprung as they step on it, in case they do not entirely avoid it. Before good series of specimens are readily secured it will be necessary to modify some small trap, to 
give it a more delicate support for the trigger and also to extend and lower the trigger or pan so that the trap can be set across the artificial runway in the sand in such a way that the lightest step on an invisible trigger will spring it.

Breeding habits.-Practically nothing is known of the breeding habits of these rare little animals, except that the females have 3 pairs of mammae -2 inguinal and 1 pectoral-as do the kangaroo rats.

Food habits.-Little is known of the food of these mice beyond the few seeds that have been found in the fur-lined cheek pouches, and the rolled oats and other grains available as trap bait or fed to them when in captivity. Seeds of Eriogonum, lupine, little burs (Krintakia), and the little desert plantain (Plantago purshii), and the seeds and green capsules of desertstar (Mentzelia albicaulis) are eaten. In captivity they eat rolled oats or any small seeds, and stuff their pockets so full that their cheeks stick out in a grotesque manner, then carry it to a corner of the cage, dig a hole in the sand, and quickly empty the pockets and go back for more. Evidently they are regular storers, laying up food in times of abundance to last through times of scarcity. Their stomachs are small and usually contain a clean, white mass of starchy material from the carefully shelled seeds.

There is no trace of fat even in cold weather and no indications of hibernation. In Nevada the typical form, Microdipodops megacephatus, was found active well into November in freezing weather at altitudes above 5,000 feet.

Economic status. - It would be difficult to accord any commercial or economic value to these dainty little denizens of the desert nor can any serious sins of omission or commission be laid to them. Still they have a value sufficient to warrant many in making a long journey into the desert to gain a few specimens of a unique type and to learn a little of the causes that have guided its development along lines different from all other forms of life. As the writer looks back more than 45 years to the capture of the type of this genus and the first thrill of realizing its remarkable characters, so different from even its nearest relatives and opening up a whole new field of possibilities for the multiform kinds of desert life, it is no wonder that the hardships of bitter winter and scorching summer camps should have vanished before the fascination of this first-hand study of desert life. With all our intelligence and versatility of adaptation we are still far behind such animals in the perfection of physical mechanism for our needs, and we can surely learn humility if not wisdom from many of our inferior mammalian brothers.

\section{PEROGNATHUS PARVUS PARVUS (PEALE)}

\section{Oregon Pocket Mouse}

Cricetodipus parvus Peale, U. S. Expl. Expd., 8, pp. 52-54, 1848.

Perognathus monticola Baird, Mammals North Amer., Pacific R. R. Rept. 8: 422,1857 . Type probably from the region of The Dalles.

Type locality.-Given as Oregon, assumed to be The Dalles, Oreg.

General characters.-Rather large for a pocket mouse (pl. $39, B$ ) ; tail long and slightly crested toward the tip; ears small with distinct inner lobe at 
base; cheek pouches well developed and lined with short hairs; upper incisors deeply grooved as in all of the family; skulls with mastoids and audital bullae moderately inflated; pelage long, appressed, and very silky. Upper parts buffy gray with clear buff along sides; ears dusky inside with buff spot at lower base; lower parts buffy with usually white on breast; feet buffy gray; tail clear buff below, buffy brown above with dusky tip. Young grayish buff.

Measurements.-Average of adult specimens: Total length, $172 \mathrm{~mm}$; tail, 92 ; foot, 22.4 ; ear (dry), 7. Adult male at Voltage, Oreg.: Total length, 170; tail, 97 ; foot, 24 ; ear, 8 . Weight $18 \mathrm{~g}$.

Distribution and habitat.-These pocket mice occupy practically the whole Upper Sonoran area of eastern Oregon and extend into southern Washington as far as North Yakima and slightly into Idaho along the Snake River Valley (fig. 55). In the sandy or mellow soil of the arid valley bottoms they are often abundant and so easily taken as to be well represented in collections by large series of specimens. One specimen was taken by Jewett at about 7,600 feet on the Steens Mountains, in aspen country, where the ground was barren and much sheeped over.

General habits. - In tho dry. sagebrush valley south of Malheur Lake. these beautiful, silky little pocket mice were as common as the writer ever found them anywhere,

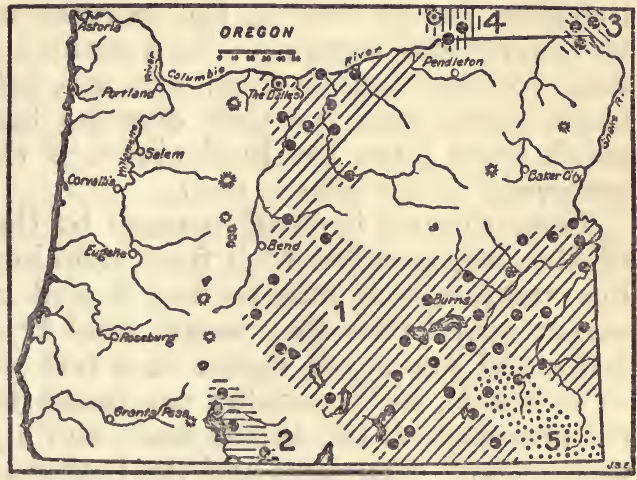

Figurn 55.-Range of the five species and subspecies of pocket mice in Oregon: 1, Perognathus parvus parvus; $2, P$. p. mollipilosus ; $3, P$. lordi lordi; $4, P$, $l$. columbianus; $5, P$.' nevadensis. Type localities circled.

ranking next to the white-footed and meadow mice in abundance. Some mornings as many as 5 or 6 were found alive in his line of a dozen tin-can traps placed near their burrows where the slender tracks and tail marks were noticed.

Their burrows are generally placed under sagebrush in mellow soil where the scattered vegetation furnishes food and some concealment, but still leaves open spaces for free travel. Usually a little heap of fresh sand marks the main entrance, which is securely closed during the daytime. Half a dozen other doorways may be standing open under the bushes, but these are unmarked by earth and are used only as exits. Still others come close to the surface but are not opened except in case of danger when the animals burst out and flee to other burrows. Several escaped in this manner as the writer dug out their dens and kept a careful watch for them. Usually the burrows run 2 or 3 feet deep, with many branches and winding shafts, one or more storage chambers, and a nest cavity.

The animals are strictly nocturnal and spend the daylight hours in their closed underground retreats, but if a closed burrow is opened up at any time of day they soon close it again with earth from within. They are dazed by bright sunlight when driven out of their burrows, but in the house or in the shade of bushes they see well. 
They run on all fours like other mice, and are quick and difficult to capture as they flash from bush to bush. Their tracks are in fours, the large hind feet showing in front of the smaller front feet. In feeding, the hands are used to hold the food and to fill and empty the pockets. They are also used in digging and are provided with strong claws.

Like all storing animals they are not sociably inclined, and usually but one adult is found in a den. The litter apparently disbands as soon as full grown and each begins storing for itself. In captivity the animals prefer to be solitary, but for a week or more 5 were kept together in a box. They quarreled much of the time and even fought occasionally, and as far as possible each made a separate nest. Sometimes on cold mornings 2 or 3 would be found cuddled up together, but as soon as the weather warmed up they would begin to quarrel and separate. Two males that were taken in a box on a long journey fought until one was killed, its nose and feet being much bitten and the skin over its back punctured with so many small holes from the hind claws of the other that the skin, when removed, looked like a sieve.

Their discord is clearly caused by the storage habit. Each would fill its cheek pouches with food, then hunt for a safe place to store it, but another was sure to find it and carry it away to some other corner. And thus they would steal from each other all night. One large and one small mouse in a box were given a cup with a hole in each side, so the smaller one could not be cornered in its nest. In the morning all the choice seeds and a grape were stored in the cup and covered with sand and the larger animal was guarding it, while the other had to content itself with rolled oats in a far corner. The storage habit, the selfish greed of gain, seems to destroy all better sentiments of these little animals.

They show no signs of playfulness with each other, but each greatly enjoys a hollow wheel or an inclined disk, running it by the hour with evident signs of exhilaration. If two got into the wheel together they would quarrel until one got out.

Their voices are rarely heard when alone, unless one becomes cold or hungry, is held too closely, or is in some way hurt or injured. The complaining squeak, or que, que, que, is made, varying from a faint whimper to a whine or a shrill squeal, according to circumstances. When two or more are together their que, que note is often heard as they meet and scold, threaten, fight, or try to get each other's stores or as one disturbs another in his nest. They seem to have no pleasant conversational notes.

Hibernation.-The pocket mice do not become excessively fat in autumn, but with the aid of their stored food supply they seem to keep within their burrows during the cold winter weather, and not improbably spend a part of the time in partial or complete hibernation.

Breeding habits.-The females have 3 pairs of mammae-2 inguinal and 1 pectoral. The number of embryos recorded varies from 3 to 5 . The young are born at irregular times during summer, but there seems to be no data to indicate more than one litter in a season. 
Food habits.-They feed mainly on seeds of a great variety of plants, including grasses, little wild beans, borages, wild sunflowers, and other composite plants, pigweeds, nettles, docks, Solanum seeds, and even wild plants of the mustard family. Generally they are fond of rolled oats but sometimes, when more acceptable seeds are available, refuse to touch the rolled oats used for trap bait. One taken by R. H. Becker at Ontario, May 17, 1917, had 960 seeds of Solanum (sp. ?) and 3 of Amaranthres in its pouches. At The Dalles, Streator dug open many burrows and in each found small stores of wild mustard seed, varying up to half a pint in a chamber.

In captivity they accepted almost every kind of native seed offered them, also mixed birdseed, grain, and many green plants and juicy vegetables, such as cabbage, lettuce, and apple, but ate only a little, evidently just for the moisture it contained. They occasionally drank a little water, using their hands to dip it up or eating the drops scattered on plants in their cages. In a wild state they must go long periods with only the moisture obtained from vegetation.

Economic status.-Over most of their arid range these mice could do little damage to crops or grazing because there is neither, but locally they might gather a little seed grain along the edges of fields or possibly cut some of the ripening grain for the seed-laden heads. On owned and protected grazing lands they might, in connection with many other species of rodents, place a serious check on the reseeding of grasses and other forage plants and thus do serious injury to the grazing industry.

At Diamond one was taken from the stomach of a small rattlesnake, and at Malheur Lake the tame grasshopper mouse killed and ate as many as were put in its cage. Burrowing owl pellets are generally well filled with their bones and fur, and other owls undoubtedly get many. Badgers dig out their burrows and probably catch some of the occupants. As with many other rodents the most economical means of control is a wise protection of their not too harmful enemies,

\section{PEROGNATHUS PARVUS MOLLIPILOSUS COUES}

\section{Coues's Pocket Mouse}

Perognathus mollipilosus Coues, Acad. Nat. Sci. Phila. Proc., p. 296, 1875, under $P$. monticola.

Type-Collected at Fort Crook, Shasta County, Calif., by John Feilner, in or about 1860.

General characters.-Very little smaller than parvus; slightly more dusky over back; ears noticeably larger with white or buffy spot at base more conspicuous.

Measurements.-Average of three adults from type locality: Total length, $163 \mathrm{~mm}$; tail, 88; foot, 22.3; ear (dry), 8.

Distribution and habitat.-These little mice extend northward into the Klamath Valley from northeastern California but are not typical, and all of the Oregon specimens might almost as well be referred to parvus, as mollipilosus (fig. 55). There are specimens from Tule Lake, Lost River, Swan Lake Valley, and Williamson River, all in Klamath County.

In habits they seem not to differ from parvus. 


\section{PEROGNATHUS LORDI LORDI (GRAY)}

\section{Northwest Pocket Mouse}

Abromys lordi Gray, Zool. Soc. London Proc., p. 202, 1868.

Type-Collected in southern British Columbia, Canada, by John Keast Lord, probably in 1860.

General characters.-Largest of Oregon pocket mice, a little larger than parvus with relatively larger audital bullae and narrower interparietal. Duller and darker, more grizzled brownish over upper parts and ear spots scarcely noticeable; lower parts mainly dark buff with generally a white patch on breast and sometimes another on back part of belly; tail strongly bicolor, dusky above, buffy below.

Measurements.-Typical adults: Total length, $183 \mathrm{~mm}$; tail, 98; foot, 23.2 ; ear (dry), 7.

Distribution and habitat.-From Ashcroft and the Okanagan country in southern British Columbia this species ranges down through the Okanagan Valley to Wenatchee, diagonally across the plains of the Columbia to Snake River, and up the Grand Ronde Valley into the extreme northeast corner of Oregon (fig. 55). A specimen taken by Cantwell near Paradise, Wallowa County, Oreg., is the only record for the State, and this is labeled 15 miles north of Paradise, which would put it back in Washington. Assuming that Cantwell knew in which State he was working and merely exaggerated the distance from Paradise down a steep and tiresome grade, the species may be provisionally accepted for the State list until other specimens are taken on the Oregon side of the Snake River Canyon, or the lower valleys of Joseph Creek or the Imnaha River.

General habits.-In habits these mice seem to differ but little from parvus to which they are closely related, but generally they occupy a more fertile and grassy country.

Breeding habits.-A female taken by L. R. Dice at Prescott, Wash., July 7, 1914, contained eight small embryos, while half-grown young were taken at the same time, implying more than one litter in a season or an irregular breeding time.

\section{[PEROGNATHUS LORDI COLUMBIANUS MERIAM ${ }^{\text {a }}$}

\section{Columbian Pocket Mouse}

Perognathus columbianus Merriam, Acad. Nat. Sci. Phila. Proc., p. 263, 1894. Perognathus lordi columbianus Osgood, North Amer. Fauna No. 18, p. 40, 1900.

Type locality.-Pasco, Franklin County, Wash. Inasmuch as the Columbian pocket mouse has been collected south of the Columbia River in the State of Washington close to the boundary of Oregon, it probably occurs also in Umatilla County. Since, however, specimens have not yet been taken in Oregon, this subspecies is not here definitely included in the list of Oregon mammals.]

\section{PEROGNATHUS NEVADENSIS MERriam}

\section{Nevada Pocket Mouse}

Perognathus nevadensis Merriam, Acad. Nat. Sci. Phila. Proc., p. 264, 1894.

Type.-Collected at Halleck, Nev., by Vernon Bailey, July 4, 1893.

General characters.- Smallest of the Oregon species; ears small without inside lobe at base; tail slender, not crested, longer than head and body; cheek pouches thinly lined with hair; pelage silky; color of upper parts buffy gray

9a Hypothetical. 
with dusky tips of hairs and clear buff margin along each side; ears dusky with white specks at upper and lower base; feet and lower parts buffy with white on breast; tail buffy gray above, clear buff below except dusky tip.

Measurements.-Average of typical adults: Total length, $133 \mathrm{~mm}$; tail, 72; foot, 18.7; ear (dry), 6.

Distribution and habitat.-Found in the Upper Sonoran sagebrush valleys of central and northern Nevada, northwestern Utah and southeastern Oregon (fig. 55). Three specimens taken by Streator at Tumtum Lake in 1896 and one by Preble at Rome on the Owyhee River in 1915 are the only records for Oregon.

General habits.-In habits these tiny pocket mice seem to be much the same as parvus, which is twice as large and lives in the same localities. Even their tracks and burrows are easily recognized by their small size, the burrows sometimes being mistaken for those of the mole cricket, Stenopalmatus. They are found under sagebrush or greasewood on mellow soil, but the main entrance is usually kept closed during the daytime and only a tiny mound of earth is seen to mark the place. Where common the animals are readily caught in traps baited with rolled oats and set near their burrows, or in long smooth lines made by scraping the foot over the surface of the ground and with the traps set across these lines.

Breeding habits.-One taken by H. C. Oberholser at Stillwater, Nev., May 7, 1898, contained 4 embryos, and another recorded by Taylor from Big Creek ranch, Nevada, on June 10, 1909, contained 3 embryos.

\section{Family GEOMYIDAE: Pocket Gophers}

\section{THOMOMYS BULBIVORUS (RICHARDSON)}

\section{Camas Pocket Gopher}

Diplostoma bulbivorum Richardson, Fauna Boreali-Amer., v. 1, p. 206, 1829.

Type.-From banks of the Columbia River, Oreg., probably near where Portland now stands. Collector unknown.

General characters.-Largest of the genus; compact and robust; ears small, merely thickened rims; eyes small; incisors protruding; tail weak and tapering, almost hairless; winter coat long and furry; summer thin and harsh; color dark sooty brown, nearly the same above and below; chin and anal spot usually white.

Measurements.-Average of adult males: Total length, $300 \mathrm{~mm}$; tail, 90; foot, 42 ; ear (dry), 5. Average of females: $271 ; 81 ; 39 ; 5$.

Distribution and habitat.-Willamette Valley, Oreg., from Portland and Forest Grove south to Eugene, west to Grand Ronde Valley (fig. 56). Generally common in the more open parts of the valley country but not entering the coniferous timber.

General habits.-These big pocket gophers have relatively rather weak claws for an underground life, but by the use of their protruding incisors they are able to loosen up the hard-baked earth through which they tunnel, and in consequence their large mounds thrown out on the surface of the ground are often a mass of small cakes and lumps of well-baked clay. 'The burrows are large and extend in endless labyrinths a foot or two below the surface of the ground, coming to the top at intervals of a few feet to a few rods where the surplus earth is pushed out in little heaps called "gopher hills." The entrance is then securely packed full of earth and the tunnel continued until it is necessary to open a new doorway or one of the 
old doors through which to dispose of the refuse. Except for these occasional visits at the surface, almost the whole life of the gopher is passed in the utter darkness of its tunnels. No wonder its eyes are small and weak and rarely opened, and its vibrissae, naked nose, and naked tip of tail well sensitized for work in the dark. No wonder its disposition is morose and savage and that each works alone for most of its life.

Breeding habits.-Little is actually known of the breeding habits of these rodents except that the females have 2 pairs of inguinal and 2 pairs of pectoral mammae, arranged on 4 widely separated mammary glands, indicating 4 to 8 young. Before they are half grown the young have left the parental burrow and each is extending its own tunnel and getting its own living in happy solitude that continues for the rest of its life except during brief mating periods.

Food habits.-Most of

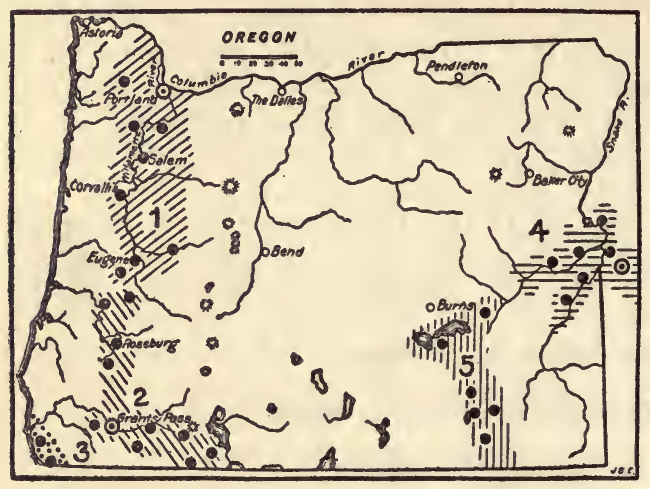

Figure 56.-Range of five forms of pocket gophers in Oregon: 1,Thomomys bulbivorus; $2, T$. bottae leucodon; $3, T$. $b$. laticeps; 4, T. townsendii townsendii; $5, T . t$. nevadensis. Type localities circled. the food of these pocket gophers is obtained from roots, bulbs, and tubers encountered in extending their tunnels, but when they come to the surface they usually fill the capacious cheek pouches with green vegetation gathered near the opening, preferring clover, alfalfa, dandelions, thistles, and succulent vegetation, but also taking grasses, grains, and a great variety of crops and vegetables as they are encountered. The roots of many plants are eaten, and the bark from the woody roots of bushes and trees is sometimes eaten so persistently as to destroy the plants. The roots of apple and pear trees unfortunately are a favorite food, but many other fruit or ornamental trees and many shrubs and vines are injured by the gophers. The original name of camas rat was undoubtedly based on their fondness for the bulbs of the camas, which grows in great abundance in their valley but is generally scarce where the gophers are common.

Economic status.-For unknown ages these pocket gophers have been plowing the ground, burying vegetation with their mounds, enriching and improving the soil for the use of man, but when the white man arrives they must go for they like his crops and thrive and multiply in his fields and orchards, and even in his dooryards and along his streets. On Council Crest, the scenic section of Portland, in 1914 their big mounds, a bushel of black earth in a place, were seen on some of the best-kept lawns and again were thrown out overnight on the concrete sidewalks so that pedestrians had to go around or jump over them. Again on the grassy campus of the agricultural college at Corvallis long lines of pocket-gopher hills added more biological interest than beauty to the closely mown turf. The 
farmer and orchardist, however, have a more serious grievance, for the gophers regularly reduce their incomes unless persistently destroyed by every possible means.

Ordinary-sized pocket-gopher traps are not large enough to hold this species, and special large-size traps have to be made for them. These rodents are easily poisoned, however, by dropping pieces of sweetpotato or carrots containing strychnine into their burrows. Green leaves of clover or alfalfa moistened and dusted over with strychnine and pushed well down into the burrow would probably kill these as well as it does other pocket gophers.

\section{THOMOMYS TOWNSENDII TOWNSENDII (BACHMAN)}

\section{TOWNSEND's POCKET GOPHER}

Geomys towonsendii Bachman (from Richardson's Manuscript), Acad. Nat. Sci. Phila. Jour. 8: 105, 1839.

Thomomys nevadensis atrogriseus Bailey, Biol. Soc. Wash. Proc. 27: 118, 1914. Type from Nampa, Idaho.

Type.-Erroneously labeled "Columbia River" but evidently from southern Idaho and probably from near Nampa where Townsend, who collected it, camped to trade with the Indians on August 22, 1834.

General characters.-Large, next to bulbivorus; ears small but pointed ; mammae in four pairs; skull wide and angular, with slightly protruding incisors; dichromatic, a dark gray and a black phase; in the gray phase upper parts dark buffy gray or sooty gray; nose and face blackish; ear patches black; feet and tail gray; lower parts washed with rich buff. In the black phase dull slaty black all over except white patches on chin and toes and usually on lower part of feet.

Measurements.-Adult male: Total length, $305 \mathrm{~mm}$; tail, 100; foot, 38; ear (dry), 7. Female: $276 ; 75 ; 35$.

Distribution and habitat.-These very large and dark-gray or black pocket gophers occupy the fertile valley bottoms of the Snake River in Idaho and the Malheur, and Owyhee Valleys in Oregon, a rather restricted range in Upper Sonoran Zone (fig. 56). They do not extend into the dry sagebrush country beyond the moist and fertile bottom lands and usually do not overlap the range of the smaller forms of the surrounding country. In favorable locations they are abundant, and their large hills of mellow sand sometimes cover nearly half the surface of the ground.

General habits.-Like all pocket gophers these animals live mainly underground in endless tunnels, throw up numerous earth mounds, or "gopher hills", and travel only as fast and as far as their burrows carry them. This is sufficient, however, to bring them into choice fields of alfalfa or other crops affording favorite food, and new fields in the irrigated valleys often suffer severely until the gophers are caught, poisoned, or driven out. On well-irrigated lands the water fills their burrows and soon drives them out but only to the edges of the fields where they soon work back if not destroyed, or into other fields where the water has not flooded the ground.

Breeding habits.-These pocket gophers breed early in the spring as shown by Everett E. Horn in experiments near Vale, Oreg., in 1921. On March 27, a female and 5 young not yet weaned were taken from one burrow, and the old female was found to contain 6 well-developed foetuses. Nine other females taken in the few days following were suckling young, and 4 of these also contained 
foetuses, so that at least 2 litters are produced in rapid succession in the early spring, and the fact that half-grown young are taken in traps all summer would indicate that under favorable circumstances of food supply a considerable number of litters are produced each summer. The specimens recorded by Horn contained generally 6 to 8 embryos, with one set of 3 and another of 10 . The females have normally 8 mammae in 2 pairs of inguinal and 2 of pectoral, and 8 young evidently is the normal maximum.

Food habits.-Their native food consists of a great variety of roots and green vegetation gathered in the burrows or about the openings made for throwing out earth. In places the blanched running root stalks of saltgrass are a staple food, but all grasses are eaten-tops and roots, especially the tender bases. Leguminous plants seem to be favorite foods and the gophers take eagerly to alfalfa, eating tops, roots, and all. Most of the cultivated crops, including grains, vegetables, and especially potatoes and other root crops are eaten.

Economic status.-Locally these rodents do serious injury to crops and prove very annoying by running their big burrows through the banks of irrigation ditches and causing serious breaks, with waste of water and injury to flooded crops. It is thus often necessary to eradicate them locally, and for this purpose efficient and economic methods have been worked out by the Biological Survey.

\section{THOMOMYS TOWNSENDII NEVADENSIS MERRIAM}

\section{Nevada Pocket Gopher}

Thomomys nevadensis Merriam, Biol. Soc. Wash. Proc. 11: 213, 1897.

Type.-Collected at Austin, Nev., by Vernon Bailey, November 11, 1890.

General characters. - Similar to townsendii but slightly smaller, paler, more buffy gray in the gray phase, and more plumbeous black in the dark phase.

Measurements.-Type, adult male: Total length, $275 \mathrm{~mm}$; tail, 90 ; foot, 38 ; ear (dry), 6. Female : $255 ; 82 ; 35$.

Distribution and habitat.-The fertile valleys of northern Nevada and north into Alvord and Malheur Lake Valleys, Oreg., are occupied by this Upper Sonoran, Great Basin form of the townsendii group (fig. 56). Its present-day connection in range with townsendii is interrupted by many arid stretches of desert country where none occur, but in a series of rainy years some of these gaps could be passed over easily.

General habits.-In no noticeable way do the habits of this pocket gopher differ from those of its close relative townsendii. The country occupied is more generally uninhabited desert, but in places the gophers are abundant in cultivated grounds, where their large size renders them especially destructive.

\section{THOMOMYS BOTTAE LEUCODON MERRIAM}

\section{WhITE-TOOTHED PoCkET Gopher}

Thomomys leucodon Merriam, Biol. Soc. Wash. Proc. 11: 215, 1897.

Type.-Collected at Grants Pass, Rogue River Valley, Oreg., by Clark P. Streator, December 17, 1891.

General characters.-Rather larger than oregonus; ears very small; incisors slightly protruding and white tipped; upper parts dark rusty ochraceous; lower 
parts bright buffy ochraceous; feet, cheeks, chin, and often spots on belly white.

Measurements.-Average of typical males: Total length, $233 \mathrm{~mm}$; tail, 70 ; foot, 30.5 ; ear (dry), 6 . Females: $188 ; 60 ; 28$.

Distribution and habitat.-From a wide distribution in Upper Sonoran valleys of northern California these pocket gophers extend up the Klamath Valley west of Lower Klamath Lake and into the Rogue River and Umpqua Valleys in western Oregon, reaching their northern known limit of range at Cottage Grove in the upper Willamette Valley (fig. 56).

General habits.-These pocket gophers burrow extensively in hard clay or volcanic soil, a habit that seems to account for the protruding and white-tipped incisors, the tips showing scratches and wear that have removed the yellow enamel surface and indicate much use as digging tools. The animal's mounds are often composed of lumps of baked clay, and the burrows extend through hard ground as well as in the mellow soil areas in the open valley country. Rarely are they found in the timbered areas. Little mounds mark the lines of underground tunnels, and the animals are rarely seen except as trapped in the burrows. Often they are difficult to catch because they so frequently push a load of clay lumps into the trap and spring it ahead of themselves.

Breeding habits.-Like other members of the bottae group, they have 4 pairs of mammae, and the regular number of young seems to be 4 to 8 .

Food habits.-The food of these pocket gophers includes a great number of the roots and plants encountered in their excavations, and in a fertile and well-settled valley country they find native plants scarce and introduced and cultivated plants abundant and often very acceptable food. All of the clovers and alfalfa are eaten, root and branch, with great relish. In a district especially noted for its fine fruit they do considerable damage and have to be destroyed in every possible way.

\section{THOMOMYS BOTTAE LATICEPS BAIRD}

\section{Humboldt Bay Pocket Gopher}

Thomomys laticeps Baird, Acad. Nat. Sci. Phila. Proc. 7 : 335, April 1855.

Type.-Collected at Humboldt Bay, Calif., by W. P. Trowbridge, February $21,1855$.

General characters.-Size and general appearance of bottae but colors warmer and brighter brown, less clouded with black tipped hairs; skull averaging slightly wider and nasals especially wider; incisors less projecting than in leucodon and without white tips. Upper parts rusty ochraceous or almost snuff brown; lower parts light buffy ochraceous in strong contrast to upper parts; feet and usually half of tail, lips, and chin whitish. Summer and winter colors the same.

Measurements.-Average of five adult males from type locality : Total length, $264 \mathrm{~mm}$; tail, 88; foot, 33.

Distribution and habitat.-Transition Zone coast section of northwestern California from Eel River north to the Oregon line. In the year 1927 Jewett took some specimens on the Oregon side of the line near Chetco on the coast, adding this second subspecies of the bottae group to the Oregon list (fig. 56). 


\section{IIHOMOMYS DOUGLASII DOUGLASII (RICHARDSON)}

\section{Dougras's Pocket Gopher}

Geomys douglasii Richardson, Fauna Boreali-Amer., v. 1, p. 200, 1829.

Type-Collected "near the mouth of the Columbia" at Fort Vancouver, Wash., by David Douglas, probably in 1825.

General characters.--Size medium, claws rather heavy, ears medium with rounded tips, skull long and narrow with flat top and abruptly decurved incisors minutely grooved along inner margins; interparietal small; pterygoids

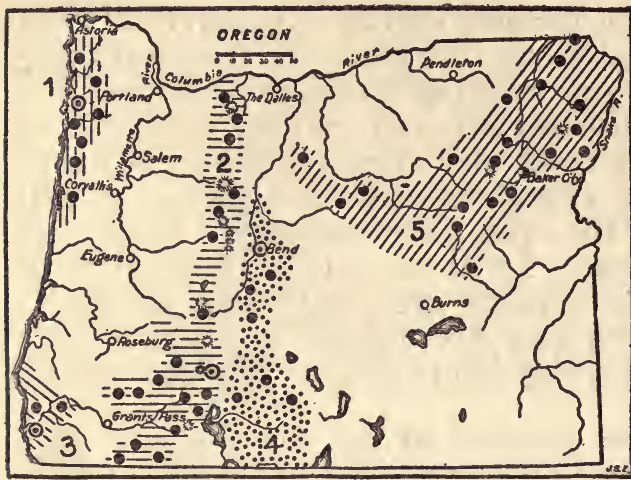

Figure 57.-Range of five forms of pocket gophers in Oregon: 1, Thomomys douglasii douglasii; $2, T$. $d$. oregonus ; $3, T$. niger ; $4, T$. quadratus quadratus ; 5, T. columbianus. Type localities circled.
U-shaped. Upper parts uniform dull hazel, slightly paler on sides; lower parts lighter, more ochraceous, with usually a white spot on breast; nose gray; feet and tail soiled whitish; usually no black ear patch.

Measurements.-Average of typical males: Total length, $215 \mathrm{~mm}$; tail, 64; foot, 30 . Average of females : $200 ; 58$; 28.6.

Distribution and habitat.-Previously known only from the vicinity of Vancouver, this old species has been recently added to the Oregon list by A. W. Moore, who in 1926 and 1927 collected a series of specimens at Scapoose, on the Oregon side of the Columbia River, some 20 miles northwest of Portland (fig. 57). These specimens are almost typical and certainly nearer to douglasii than to oregonus.

\section{THOMOMYS DOUGLASII OREGONUS MERRIAM}

\section{OREGON POCKeT GOPHER}

Thomomys douglasii oregonus Merriam, Biol. Soc. Wash. Proc. 14: 115, July $19,1901$.

Type.-Taken at Ely, near Oregon City, Oreg., by Clark P. Streator, October 24, 1893.

General characters.-Size medium, not half as large as bulbivorus; ears short and rounded; incisors abruptly decurved; fur long and soft in winter, short and harsh in summer; yellowish or bright hazel with dusky nose and cheeks and black ear patch; lower parts more ochraceous; feet and tail soiled whitish or gray.

Measurements.-Average of typical adult males: Total length, $216 \mathrm{~mm}$; tail, 67; foot, 29.5; ear (dry), 5. Females smaller. Weight 4 to 5 ounces (A. W. Moore).

Distribution and habitat.-For many years these little yellow pocket gophers were known only from the type locality, near Oregon City, where a good series of specimens were taken by Streator, in 1893; but in 1921, Ira N. Gabrielson sent for identification specimens collected near Canby and Sherwood and later others were taken by A. W. Moore near Hillsboro, Forest Grove, Falls City, Pedee, and Summit (fig. 57). A series of specimens taken by G. G. Cantwell 2 miles west of Parkdale, Hood County, are not typical, but are best referred to oregonus. 
General habits.-The original series of 28 specimens collected by Streator were taken in orchards and gardens in October when heavy rains had washed away the mounds and all external traces of the gopher's work, so the burrows were located by his feet breaking through into them or by thrusting a cane into the ground until a burrow was penetrated. In August 1922, A. W. Moore secured specimens near Canby, Forest Grove, and Hillsboro, considerably extending the range of the species and learning that the pocket gophers were doing damage on one of the farms. He found them mainly in cultivated fields where the mounds were destroyed by cultivation and the burrows were not easily located. The farmers complained of their destruction of potatoes. Theo. H. Scheffer found them in grain and clover fields as well as on the waste land outside.

\section{THOMOMYS HESPERUS MERRIAM}

\section{West CoAst POCKet Gopher}

Thomomys hesperus Merriam, Biol. Soc. Wash. Proc. 14: 116, 1901.

Type.-Collected at Tillamook, Oreg., by J. Ellis McLellan, November 9, 1894.

General characters.--Small, with the small pointed ears of the fuscus group; color of upper parts dark rich auburn; nose and cheeks dusky; large ear patches black; lower parts lighter, more ochraceous; lining of cheek pouches white; feet and tip of tail whitish. About 10 percent of the individuals are partly or wholly black.

Measurements.-Of large old male: Total length, $222 \mathrm{~mm}$; tail, 64; foot, 30 ; ear (dry), 6. Of adult female : $205 ; 60 ; 28 ; 6$. (Type, immature female: 175; $54 ; 24 ; 6$.)

Distribution and habitat.-These little richly colored pocket gophers are found in the open valley spots in Tillamook County, and in southern Clatsop County (fig. 58). They are reported from 8 or 10 miles east of Tillamook in the Wilson River Valley and some 20 miles south in the Nestucca RiverValley. Specimens have been examined from Tillamook, Blaine, and Mount Hebo in Tillamook County, from Alsea in Benton County, and from Elsie in Clatsop County. A specimen from the top of Chintimini Mountain and one from Philomath, west of Corvallis, are not fully

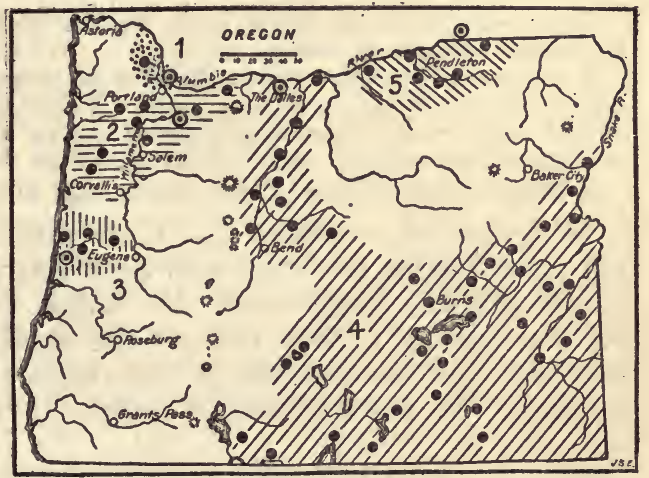

FIGURE 58.-Range of five forms of pocket gophers in Oregon: 1, Thomomys hesperus; 2, T. monticola mazama; 3, T. m. helleri; 4, T. m. nasicus; 5, T. fuscus fuscus. Type localities circled. typical of this species and probably have no connection with it in range, but can be referred to it better than to any other form.

The range of this, as of many other species of pocket gopher, is interrupted by soil and forest conditions, and each isolated colony shows some slight peculiarities recognizable by the critical student but not worthy of recognition by name.

General habits. - These little pocket gophers make very small burrows and throw out small mounds of earth in the old fields, pastures, 
and waste places, and they would be practically harmless if they did not also enter the cultivated areas. They are not very active or energetic burrowers, evidently because the rich, mellow soil is so full of bulbs and roots, and so covered with dense vegetation, that little work is necessary to procure abundance of food. Their doorways are lightly closed and often can be pushed open with the fingers.

Food habits.-Grass and clover are the plants most commonly cut about the doorways of the pocket gophers, merely because they are the most abundant plants. Over many of the little native prairies where they occur the wild blue-flowered camas grows in great abundance. In pastures where there was no camas, their stomachs contained only green vegetation, but the camas is undoubtedly their native food.

Economic status.-The county clerk at Tillamook said that $\$ 4,000$ had been paid out in bounties on moles and pocket gophers during 1914 , and over half of it on gophers, at 25 cents each. One man, he said, had made as high as $\$ 100$ a month catching them, and one little girl had earned $\$ 80$ in a month. Then the boys all got busy and the bounty fund was soon exhausted, while the pocket gophers remained numerous. In this mild climate where dairying is the principal industry and clover is the most important crop, these rodents, even though small, are capable of doing considerable damage.

\section{THOMOMYS NIGER MERRIAM}

Bracik Pocket Gopher

Thomomys niger Merriam, Biol. Soc. Wash. Proc. 14 : 117, 1901.

Type.-Collected at Seton, near mouth of Siuslaw River, Oreg., by J. Ellis McLellan, October 6, 1894.

General characters. - About the size of oregonus and similar in general characters, but with short, heavy skull. Upper parts uniform glossy black, with purple and green iridescence; lower parts duller and more plumbeous; feet and tip of tail white. One albino specimen was taken at Scottsburg.

Measurements.-Type: Total length, $225 \mathrm{~mm}$; tail, 81 ; foot, 30 ; ear (dry), 6.

Distribution and habitat.-Known only from near the mouth of the Umpqua River, at Seton and Scottsburg, and in the Siuslaw Valley at Mapleton, Deadwood, 10 miles northeast of Deadwood, and Mercer (fig. 57), they occupy the small open spaces near the coast but have not been found in the dense timber covering most of that country. No peculiarities of habits have been noted.

\section{THOMOMYS MONTICOLA MAZAMA MERRIAM}

Mazama Pocket Gopher; Mo-NANA-TAM-Has of the Klamath (C. H. M.)

Thomomys mazama Merriam, Biol. Soc. Wash. Proc. 11: 214, 1897.

Type.-Collected at Anna Creek, near Crater Lake, Oreg., by Edward A. Preble, September 3, 1896.

General characters.- Size medium, about as in oregonus; rather light and slender; ears well developed and pointed, about $6 \mathrm{~mm}$ in dry skins: upper incisors not protruding, curved downward at right angles to axis of skull; upper parts bright russet brown; ear patch blackish; nose plumbeous; lower parts rich buff or ochraceous; feet and tail whitish; tail usually gray above at base. 
Measurements.-Typical males: Total length, $209 \mathrm{~mm}$; tail, 66; foot, 28; ear dry), 6. Females: $202 ; 66 ; 28$.

Distribution and habitat.-These are mountain pocket gophers inhabiting the Cascades, Siskiyou, and Trinity Mountains of Oregon and northern California, mainly in Canadian Zone, but in places reaching into Hudsonian (fig. 58). While living mainly in the meadows and open parklike places, they are often found scattered through the more open timber.

General habits.-The small size of these pocket gophers is generally compensated by the greater abundance of individuals in the mountain parks and meadows, where they burrow actively, not only during the short summers, but all winter under the deep snows. In spring when the snow disappears long snakelike plugs of earth lie over the surface of the ground, where the excavations from deeper down have been pushed into snow tunnels on the surface and left to freeze and harden. In melting and disintegrating in spring these earth coils show all the bits of bark, stems, wood, and refuse of the underground food pushed out with the earth and help to explain how the gophers can keep active during the winter. They sometimes store food in the burrows but do not become fat in the fall and evidently do not regularly hibernate.

Breeding habits.-These pocket gophers have normally the usual number of 8 mammae, but occasionally an extra pair of pectoral, making 10. Little is known from actual observation of their breeding habits, but young of various sizes are taken in traps all through the summer, which would indicate several litters during a season. Judging from other species 4 to 8 would be the probable number of young in a litter.

Food habits.- In summer their large stomachs are generally found filled with both green vegetation and the white pulp from roots, bulbs, and tubers, with occasionally spots of bright colors that serve to identify local flowers or bright-colored roots. The surface vegetation is gathered at the openings of their burrows before the earth is thrown out, or at openings made merely to reach the plants and then closed without throwing out a mound. In camp near Three Sisters one came up in the middle of the tent where the writer was at work, quietly preparing specimens. There was a muffled gnawing or scratching, then an aster stem began to move, and soon the tip of a little brown nose showed in the middle of a tuft of short grass, and the hole was quickly enlarged to allow the pocket gopher's head to protrude. The aster stem was cut off and drawn down into the burrow; then some wide leaves and some grass blades were cut and stuffed into the pockets. Within a minute a good meal was thus gathered and the hole securely plugged from within. The pocket gopher safely enjoyed its morning meal below.

Economic status. - These mountain pocket gophers are often so numerous in the mellow-soil parks that their mounds cover from 5 to 10 percent of the surface, and the burrows- 6 inches to a foot below the surface-are so numerous that one's feet keep breaking into them, while cattle, sheep, and deer tracks often make so many openings that the gophers are kept busy closing them. The mounds are usually small, a few quarts to a half bushel of earth in a place at $7209^{\circ}-36-17$ 
intervals of 3 feet to 1 rod apart along the line of each tunnel. The tunnels are constantly extended and gradually fill up as they are abandoned and the old nests, food refuse, and excrement are buried well below the surface, while the mounds are constantly burying the surface vegetation deeper and deeper underground. The soil is kept mellow and porous, and a great part of the rainfall is held in the ground instead of running quickly from the surface in destructive floods. The meadows are enriched, the forests are benefited, and soil erosion, the menace of the mountain ranges, is largely checked. To be sure, many plants are eaten that would make forage for sheep, but every bit of vegetation taken is eventually returned to the soil in such a manner that fire cannot reach it and some of the disastrous effects of overburning and overgrazing of the mountain parks is thus prevented. In very few places does this species range down into valleys to the level of any agriculture.

One day in camp the cook, armed with a few traps, caught 20 of these little animals near the tent and dressed and cooked 16 of them for a supper for five. They made a good meal and were enjoyed by all, the meat being somewhat like squirrel, but more tender and rather better flavored. Broiled on the coals they are especially good, and they provide an always available source of meat supply in the mountains when game is out of season.

\section{THOMOMYS MONTICOLA HELLERI ELIOT}

HELLLR's POCKET GOPHER

Thomomys helleri Elliot, Field Columb. Mus., Zool. Ser. 3 : 165, 1903.

Type.-Collected at Gold Beach, mouth of Rogue River, Oreg., by Edmund Heller, in 1901.

General characters.-About the size and general appearance of $T$. mazama, but darker and richer in coloration, and with slenderer skull; upper parts dull chestnut or mars brown; sides and under parts becoming ochraceous; ear patches intense black; nose and face blackish, rarely a trace of white on lips; tip of tail usually white.

Measurements.-Average of typical males: Total length, $203 \mathrm{~mm}$; tail, 55; foot, 29 ; ear (dry), 6 . Females: $195 ; 57 ; 27 ; 6$.

Distribution and habitat.-This very dark and richly colored form of the monticola-mazama group is common on both sides of the mouth of the Rogue River, at Gold Beach and Wedderburn, and their hills were seen back a couple of miles from the coast along the river bottoms (fig. 58). One set of pocket-gopher hills was also found on the open ridges north of the river, about 20 miles inland. Other hills at Port Orford and Pistol River, and several places south of the Rogue River near the coast, may also be made by this species. They occupy the sandy bottoms and grassy ridge tops only in the openings, which are scarce and isolated along this coast section.

General habits.-The pocket-gopher burrows are but lightly closed and easily dug open with one's fingers, or a small stick. With only 2 gopher traps 8 gophers were caught in 1 day by going around frequently to examine the traps. The animals were active all day and soon came to close the openings of their burrows and were caught. Some had a little wild mustard, grass, and other plants stuffed in their pockets, showing that they had been feeding during the day. 


\title{
THOMOMYS MONTICOLA NASICUS MERRIAM
}

\author{
Deschutes Pocket GOPHeR
}

Thomomys nasicus Merriam, Biol. Soc. Wash. Proc. 11: 216, 1897.

Type.-Collected at Farewell Bend on the Deschutes River, west of Prineville, Oreg., by Edward A. Preble, August 4, 1896.

General characters.- Size and general characters of mazama but lighter and more yellowish in coloration; skull long and narrow with long, spreading nasals; upper parts bright yellowish hazel, with plumbeous nose and ear patches; lower parts rich buff; feet, most of tail and chin, usually whitish.

Measurements.-Type, adult male: Total length, $214 \mathrm{~mm}$; tail, 69 ; foot, 27 ; ear (dry), 6.

Distribution and habitat.-This is the pocket gopher of the yellow pine forest east of the Cascades, from Farewell Bend on the Deschutes to Fort Klamath, and in the Paulina and Yamsey Mountains (fig. 58).

General habits.-In the open yellow pine forest country these pocket gophers live among the trees as well as out in the meadows, fields, and cleared pastures. In habits they differ little from mazama except that at lower levels they more often come in direct conflict with agriculture and in many places prove so troublesome that their destruction in the fields and among the irrigation ditches becomes necessary.

\section{THOMOMYS FUSCUS FUSCUS MerRIAM}

\section{Brown Pocket GopHer}

Thomomys ciusins fuscus Merriam, North Amer. Fauna No. 5, p. 69, 1891.

Thomomys quadratus vallowa Hall and Orr, Biol. Soc. Wash. Proc. 46: 41, 1933. Type from Catherine Creek, 7 miles east of Telocaset, Wallowa Mountains, Oreg.

Type.-Collected in mountains at head of Big Lost River, Idaho, 8,000 feet altitude, by B. H. Dutcher, September $23,1890$.

General characters. - Small, relatively light and slender; ears small but pointed; incisors not protruding; upper parts light brownish or dull walnut brown, not so bright as in nasicus or mazama; ear patches blackish; nose plumbeous; lower parts buffy; feet and tail soiled whitish or buffy.

Measurements.-Average of typical adult males: Total length, $203 \mathrm{~mm}$; tail, 70 ; foot, 27 ; ear (dry), 5.

Distribution and habitat.-This is a small mountain pocket gopher of the northern Rocky Mountain region, extending west into eastern Washington and the Blue Mountains of northeastern Oregon, mainly in Transition and Canadian Zones (fig. 58).

General habits.-These little pocket gophers live in the meadows, parks, and open woods of the Blue Mountain section and range down into only the higher of the agricultural valleys. Their small "gopher hills" are often thickly scattered over the most beautiful and fertile parks and open places where they bury some of the growing vegetation, and, in course of time, thoroughly plow the parks and mountain slopes, stirring, mixing, and mellowing the soil as well as enriching it, and providing mellow spots for the seeds of such plants as could not grow in a crowded turf.

Breeding habits.-The mammae are in four pairs, and young of various sizes are found throughout the summer months. Little is on record, however, of their actual breeding habits. 
Food habits.-In places they feed extensively on the great tuberous roots of Balsamorhiza, the broad-leaved compass plant of the mountains, and some of those caught have a strong odor of wild onions. A great variety of green plants also are eaten, and any grains and many other crops where raised on gcpher-infested ground.

Economic status.-In unsettled country these little pocket gophers may be considered beneficial rather than injurious, but in fields and gardens, and especially in orchards and yards, where flowers and shrubbery are grown, they should be destroyed.

\section{THOMOMYS QUADRATUS QUADRATUS MERRIAM}

Dalles Pocket Gopher; YA-ze-bA of the Piute

Thomomys quadratus Merriam, Biol. Soc. Wash. Proc. 11: 214, 1897.

Type.-Collected at The Dalles, Oreg., by Clark P. Streator, November 2, 1893.

General characters.-Size medium, about as in mazama; ears small; skull relatively short and wide, with posterior tip of nasals truncate; mammae normally in five pairs. Upper parts light russet brown; ear patches black; nose dark plumbeous; lower parts dark buff; tail brownish except at tip; feet whitish.

Measurements.-Average of typical adult males: Total length, $210 \mathrm{~mm}$; tail, 64 ; foot, 27 ; ear (dry), 5. Females: $195 ; 62 ; 26 ; 5$.

Distribution and habitat.-These light-brown pocket gophers are more or less common over most of the sagebrush plains of eastern Oregon, and extend slightly into northwestern Nevada, northeastern California, and into southern Washington, mainly in Upper Sonoran Zone (fig. 57). They are most abundant along streams or in valley bottoms, where there is some moisture and green vegetation, and are absent from wide stretches of arid or barren uplands. In the Steens Mountains and some other desert ranges they reach high into the Transition Zone without sufficient variation for subspecific separation.

General habits.-In habits these pocket gophers do not differ much from fuscus except in their adaptation to more open and arid country, where they burrow, often in great numbers, along the more fertile stream valleys and in the native meadows. As these are the choice lands for agriculture, the gophers are now mostly occupying fields, pastures, or meadows on farm or ranch lands. On the stock ranches they generally do as much good as harm, but in fields, gardens, and orchards they have to be destroyed to prevent loss of crops.

\section{THOMOMYS COLUMBIANUS BAILEY}

\section{Columbia Pocket Gopher}

Thomomys fuscus columbianus Bailey, Biol. Soc. Wash. Proc. 27 : 117, 1914.

Type.-Collected at Touchet, Walla Walla County, Wash., by Clark P. Streator, September 10, 1890.

General characters.-Slightly larger than quadratus; skull heavier; mammae normally in six pairs; colors pale, upper parts light wood-brown or buffy gray; ear and postocular patch blackish; nose slaty gray; tail gray with white tip; feet whitish.

Measurements.-Type, adult male: Total length, $209 \mathrm{~mm}$; tail, 60 ; foot, 28 ; ear (dry), 5. Female topotype: $208 ; 68 ; 27$. 
Distribution and habitat.-The low, hot arid sagebrush country around the Great Bend of the Columbia in northern Oregon and southern Washington and up the Snake River Valley to Lewiston, Idaho (fig. 57).

General habits.-These large valley pocket gophers, occupying the sandy bottoms of the Columbia River Valley, are now found mainly in cultivated fields of alfalfa and grain. At Umatilla, Peck found them common in alfalfa fields and along irrigation ditches. Near Willows, or Heppner Junction, Jewett found them common throughout the cultivated valley in alfalfa fields and orchards and in the ditch banks, where they are often forced to take refuge to escape being drowned out by irrigation of the level fields. On April 2 he caught a well-grown young of the year, and on April 5 took a male and female in the same burrow. Evidently in this mild climate they begin breeding early, and the large number of 12 mammae would indicate a prolific species. Only in adult females are all of the mammae usually developed, and some variation is shown even in adults.

Unless controlled, this large, prolific pocket gopher in an irrigated district of intensive agriculture is potentially a serious menace to crops.

\section{ORDER CARNIVORA: FLESH EATERS}

\section{Family FELIDAE: Cats}

\section{FELIS CONCOLOR OREGONENSIS RAFINESQUE}

Oregon Cougar; Mountain Lron; Panther; Dos-Lotch of the Klamath (C. H. M.) ; Swo-WAH of the Nisqually (G. S.)

Felis oregonensis Rafinesque, Atlantic Jour. 1: 62, 1832.

Type locality.- "Western Oregon Mountains."

General characters.-Largest of Oregon cats (pl. 40, B), almost as great as that of the Rocky Mountain cougar, but colors darker and richer with more black on tail; upper parts dark tawny, or rusty brown, becoming bright cinnamon brown on sides; top of tail darker brown than back, darkening into the long black terminal part; back of ears and spot on each side of nose black; lower parts whitish on chin, chest, and belly; throat tawny. Young light tawny, coarsely and irregularly spotted over upper parts; legs and tall dusky or dark tawny.

Measurements.-A large cougar killed in Josephine County measured 71/2 feet from tip to tip and weighed 150 pounds (Oreg. Sportsman $2: 15,1914$ ). Others have been recorded up to 8 and 9 feet in length, but the largest skulls do not equal some from the Rocky Mountains.

Distribution and habitat.-The Oregon mountain lions inhabit the western part of the State (fig. 59) and extend southward into California and northward into Washington to an unknown distance, as the group has not yet been monographed and limits of range are not definitely known. There are specimens from numerous localities in Oregon in and west of the Cascade Mountains, all of which are referable to this dark, richly colored form. They are mainly deepforest animals and are generally most abundant where the greatest number of deer are to be found, without much regard to type of country.

Abundance.-Apparently they have been common in Oregon since the earliest explorations as they have been mentioned by most of the 
naturalists since the days of Lewis and Clark, David Douglas, J. K. Townsend, Cooper, Suckley, and Gibbs. In 1884 Cope reported them abundant throughout the Cascade Range and said fresh tracks were seen daily. In 1896 Merriam, Preble, and the writer found tracks common along the Cascades. In 1910 reports from the Forest Service gave them as common on most of the national forests in western Oregon, and the supervisor estimated 250 cougars in the Crater Lake National Forest. In 1908 the Forest Service reported 14 killed on the Fremont National Forest. In recent years better statistics have shown more nearly the actual abundance of these animals. Records show that for the period from October 1, 1913, to December 31, 1914, bounties were paid on 269 mountain lions in Oregon, the highest number from one county being 85 from Douglas County. Of the

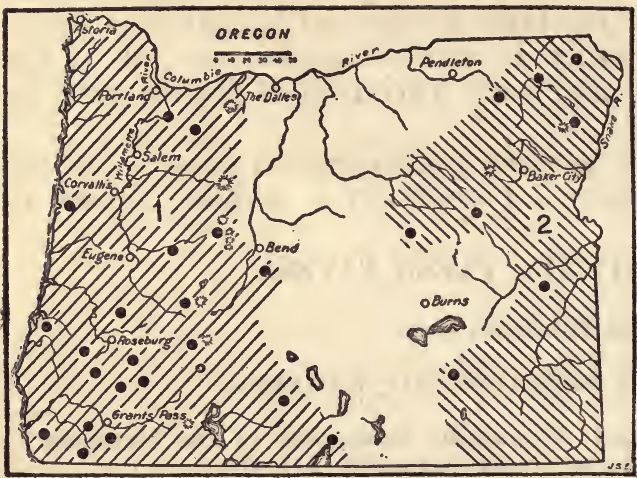

Figur 59-Range of two forms of mountain lions in Oregon: 1 , Felis concolor oregonensis; $2, F$. $c$. hippolestes. remainder on which bounty was paid, 60 were killed in Curry County, 28 in Jackson County, 24 in Lane County, 18 in Coos County, 11 in Josephine County, 10 in Linn County, and 1 to 5 in 14 other counties. The total amount of bounty paid on these animals for that period was $\$ 4,035$. (Oreg. Sportsman, 3: 40, 1915.)

In the fiscal year 1930 Jewett reported 17 cougars killed by Biological Survey hunters in Oregon, where they had been reported killing stock or game. While the number is insignificant, it shows a marked decrease in these big cats during recent years and that their destruction of livestock and game is being well curbed.

General habits.-Few animals are more stealthy and secretive than mountain lions as they hunt through the shady forests and dense undergrowth or lie in wait near the deer trails for their prey. Softfooted and silent they sneak away at the approach of hunters and are rarely seen even by those much in the woods and accustomed to catching every motion and sound of the forest. While largely nocturnal in their hunting they also under stress of hunger or necessity hunt in broad daylight and apparently can see equally well in daylight or the darkest night. They are great wanderers and except in the breeding season while the young are small rarely remain for long in one locality. For this reason they are not easily trapped, especially where their game is abundant and easily captured. They are generally hunted most successfully with dogs. Their lack of fighting courage is strikingly shown by the ability of any little cur to drive one up a tree. In rare cases a lion will refuse to tree for a considerable time and will fight off even a pack of hounds and keep running from place to place as it is overtaken. The animals are swift but not long-winded runners and rarely pursue their game if it cannot be captured with a few quick bounds. Though usually 
cowardly before man and dogs they are bold in attacking large game animals. Apparently no choice is made between small or large deer or those with or without horns, and they are known to attack and kill a large bull elk or the largest horse if other game is not available. They rarely attack full-grown cattle, however, but will kill calves and yearlings without hesitation.

Voice.-That much-discussed subject, the "scream" of the mountain lion, is a delicate one because of some confusion in the interpretation of the scream. Generally the animals are silent, but they are by no means without vocal powers. When treed or cornered they have a repelling growl and snarl and hiss, and at times when they are free and alone they utter a loud call or cry that suggests a fair compromise between the caterwaul of a tomcat and the roar of a lion. It is heavy and prolonged, slightly rising and falling and fairly well indicated by the letters $o-o-W-O-U-H-u-u$. On two occasions, in the woods, on dark nights the writer has heard this cry repeated several times at frequent intervals, and once from a cage in a zoological park. There was no mistaking its catlike quality in any of these cases, but it could hardly be called a scream. Still, if the animals have the vocal range of some other felines, it is not improbable that they make sounds that could be called screams. The most common mistake in regard to mountain lions is in attributing to them the shrill "woman-in-agony scream" of the full-grown young of the great horned owl, which is often heard, and when close on a dark night is fully as terrifying as any sound a real mountain lion could possibly produce.

Breeding habits.-Mountain lions usually have from 2 to 6 young, 4 being the common number. The period of gestation is about 3 months, and the young are born irregularly from April to August, and by the following autumn may be half-grown cubs able to travel with the mother and eat a large share of the venison killed. By the following spring they are generally large enough to kill game and to take care of themselves under favorable circumstances. Whether they breed when a year old seems not to be known, but it is doubted that they do. The male assumes no family duties or responsibility after the young are born and is rarely found in company with the female except at the brief mating time late in winter or early in spring.

Food habits.-So far as is known, mountain lions live entirely on meat and almost entirely on game that they kill. Occasionally one will return to its kill for a second meal, but in a country of abundant game another animal is usually selected for the next meal. A mother and 3 or 4 well-grown young of the year will fairly well pick the bones of a deer at one sitting, and during the time when the young are following the mother game is killed almost daily. Just how often it is necessary for them to eat is not known, but evidently they can go for several days without eating and lose no flesh. Generally they are lean and muscular; but sometimes the immature animals, especially in a good game country, will be found with considerable excess fat under the skin. They do not hibernate and require food more or less regularly throughout the year.

Economic status.-No other predatory animal, unless it be the wolf, compares in its destruction of game and livestock with the mountain 
lion. The estimate that has been sometimes made of 50 deer a year to each mountain lion is undoubtedly far too small except in a country where deer are scarce and it is necessary for the animals to consume each kill entirely and help out its menu with stock and small game. A hundred deer a year to each lion would seem more nearly the probable destruction of these game animals. If deer are abundant domestic stock is usually not seriously molested, except colts, which are often killed in preference to deer. Calves, pigs, and sheep are taken wherever they are available, and in a district where game is scarce and domestic stock is common the financial losses caused by even a few mountain lions are intolerable. For this reason it has been found good economy to employ experienced mountain-lion trappers and hunters to destroy as many of the animals as possible. At the present time the mountain lions have been so reduced over most of Oregon that they are no longer a serious menace to livestock industries.

Generally the cougars are cowardly and much afraid of man, but there are many authentic cases of their voluntarily attacking men and children. A man was attacked by one in 1883 near Mount Hood (Anonymous, 1884, p. 1161).

The Oregon Sportsman gives credence to an account of one that attacked a little girl in Curry County and was killed as it sprang at her mother, who had come to the rescue (Oreg. Sportsman 4:61, 1916).

More recently, in December 1924, a 13-year-old boy was killed and partly eaten by a mountain lion in Okanogan County, Wash., and the facts fully verified and widely published at the time (Finley, 1925).

\section{FELIS CONCOLOR HIPPOLESTES MERRIAM}

Rocky Mountain Cougar; Mountain Lion; Panther; To-Qua-To-hoo-oo uf the Piute

Felis hippolestes Merriam, Biol. Soc. Wash. Proc. 11: 219, 1897.

Type.-Collected in Wind River Mountains, Fremont County, Wyo., by John Burlingame, November 1892.

General characters.-Largest of the cougar group; dull tawny with less black above and more white below than in oregonensis. Upper parts, including top of tail, dull tawny ; tip of tail, back of ears, and spot on each side of nose, black; lower parts whitish on chin, breast, and back part of belly, the tawny reaching across throat and sometimes middle of belly.

Measurements. - A large male measured in Colorado by Theodore Roosevelt was 8 feet from tip of nose to tip of tail, and weighed 227 pounds, and a large female measured 6 feet 9 inches and weighed 124 pounds.

Distribution and habitat.-These large, dull-colored mountain lions range over the Rocky Mountain region from northern New Mexico to Montana and western Idaho, and probably over eastern Oregon, although there are no specimens from the State east of the Cascades (fig. 59). Hunter's skins seen in the Blue Mountains were certainly not of the dark west-coast form. There are records from many localities in the Blue Mountains and from the Steens and Mahogany Mountains, but apparently none from the open-plains country. The animals inhabit mainly forested country or canyons and cliffs where there is cover and concealment for them as well as for the large game animals on which they feed. 

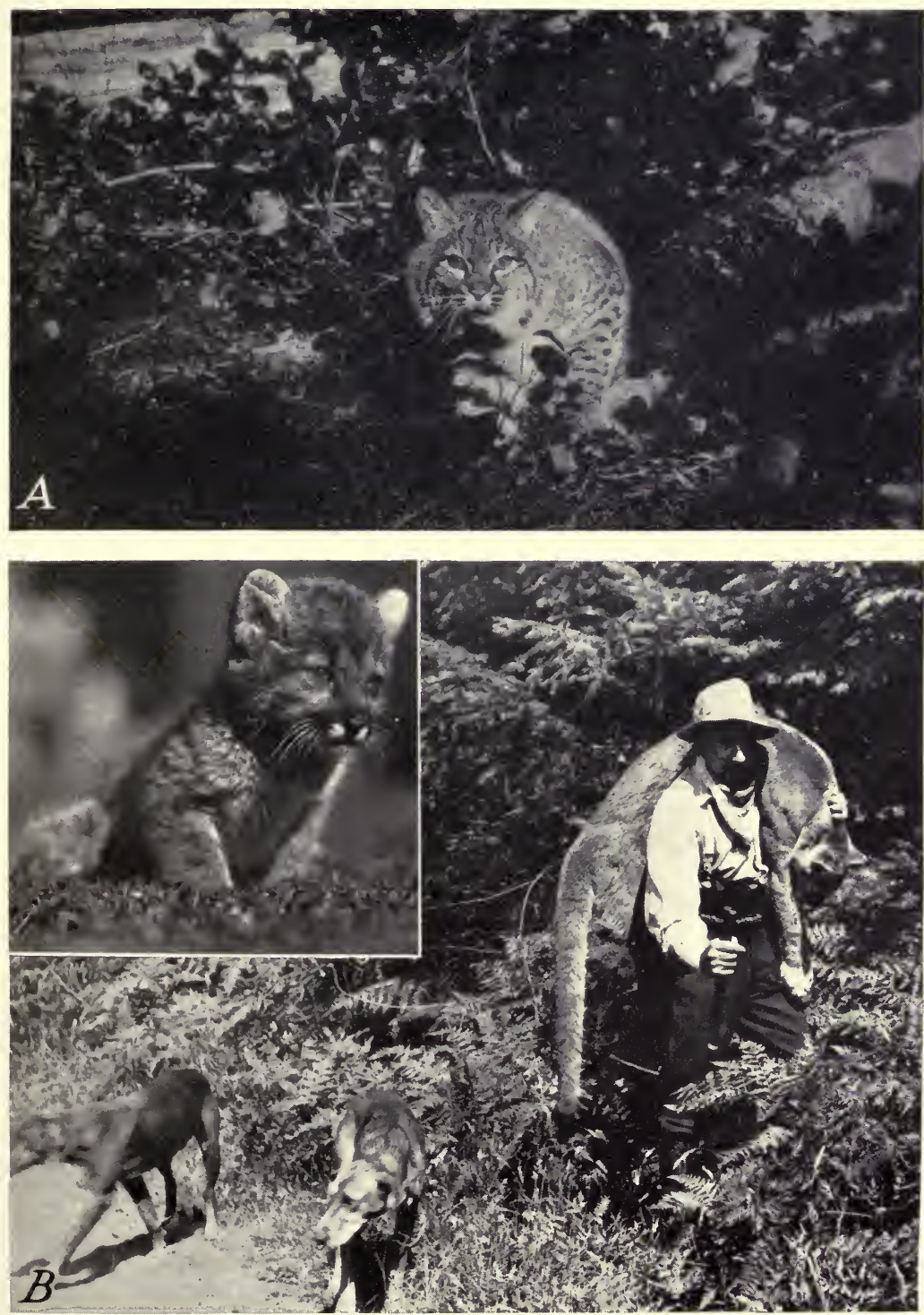

B4617M; B4618M

$A$, Oregon bobcat in Olympic Mountains (photograph by O. J. Murie); B, Oregon mountain lion killed in Lane County by C. A. Bartell-1 of the 4 young, inset in corner. 

On September 1, 1834, J. K. Townsend in his camp in the Blue Mountains of Oregon heard "as we thought, a loud halloo, several times repeated and in a tone like that of a man in great distress." Early next morning a large panther was seen prowling about camp and the hallooing of last night was explained. The panther is said to inhabit these mountains in considerable numbers and has not infrequently been known to kill the horses of a camping party. It has seldom the temerity to attack a man unless sorely pressed by hunger or infuriated by wounds $(1839, p .149)$.

In 1896 mountain lions were reported as occasionally met with along the canyon of the Grand Ronde River. In 1897 one was seen freshly killed near the Wallowa River, and in the Wallowa Mountains near Aneroid Lake, at about 7,600 feet altitude, Merriam and the writer saw one walking leisurely across an open meadow in the lodgepole pines in bright sunlight in midafternoon. The new snow was about 5 inches deep, and the cougar was evidently starting out to catch its supper. Before a shot could be fired between the trees, the animal had entered a willow thicket and was not seen again. Apparently it had slipped out through a little gulch and returned across its pursuers' tracks, past their horses, and up over the mountain side, where the horses could not go. The animal was followed for several miles on foot at a rapid pace, but could not be overtaken, although its tracks showed only a steady, long, swinging walk.

In 1908 Supervisor H. Ireland reported to the Forest Service six mountain lions killed on the Blue Mountain National Forest. In 1914 Jewett reported one killed near Strawberry Lake in the mountains east of Prairie City. In 1916 a few mountain lions were reported in the Steens Mountains; H. H. Sheldon saw fresh tracks in the trail from Diamond up to the Kiger Gorge; and one of the predatory-animal trappers caught one in a small trap from which it escaped. In $1917 \mathrm{~L}$. J. Goldman reported them as occurring rarely in the Mahogany Mountains in Malheur County. In 1920 G. G. Cantwell reported them as seldom seen in the Wallowa country, but one with only 3 feet had quite a reputation in the district about Flora.

In the Wenaha National Forest E. F. Averill in 1916 reported a small bear that had been caught in a trap by A. B. Ballard killed, partly eaten, and buried, trap and all, under leaves, pine needles, and earth at some distance from where it was caught, evidently by a mountain lion.

\section{FELIS CATUS LinNaEUS}

\section{House Cat; Domestic Cat}

Type from Europe introduced into North America in early days.

General characters.-About half the size or weight of a bobcat, with short legs and long tail. Colors variable, black, white, gray, yellow, spotted, striped, and mottled. Too well known to need description and too variable in color and characters to fit any description. Weight usually about 6 to 12 pounds but occasionally up to 22 pounds.

Distribution and habitat.-Found on almost every ranch and farm in Oregon, as well as in city homes and in the back yards, streets, and alleys. Also found commonly in forests, around fields, 
and in waste places, generally where there is cover and protection, but not in wide open places, for here coyotes and bobcats range and take especial delight in killing these smaller competitors in their own field of depredation.

General habits.-Tame cats are generally kept on the theory that they kill mice and rats, and some of them do to some extent. More often, however, they prefer birds and find it easier to catch young birds just out of the nest than mice or rats. In the woods and fields they prey upon many young game birds, such as quail, grouse, and partridge; upon young squirrels and rabbits; and, where abundant, they become a serious menace to the increase of small game. Their depredations are mainly at night or under cover, where they are rarely seen, but there seems little doubt that the half-wild domestic cat is one of the most abundant and destructive of the predatory animals in the State. In future years as larger predatory species are destroyed the problem of controlling these introduced felines will certainly become more acute, as it has in other older States.

The menace of pet cats as disease carriers, especially among children, is becoming better understood than formerly, and this has banished these night prowlers from the family circle in many homes.

Control methods.-The spread of house cats into the woods and open country is in large part due to a careless and unfeeling system of leaving pets to shift for themselves when houses or camps are abandoned, or of carrying supernumerary cats or kittens to some lonely place in the woods and abandoning them instead of humanely ending their careers and giving them decent burial. To the credit of the cats they are not too far removed from the wild state to maintain a successful existence in any mild climate where birds and small game abound, and as they multiply rapidly the woods are soon well stocked with them up to the limit of available food supply. In Pennsylvania where their destruction of useful birds and small game has been appreciated at its actual significance the Department of Conservation has requested hunters to kill all cats found in the woods and report the number killed with their reports of game. As a result 6,000 to 7,000 cats have been reported destroyed in a year, which in part accounts for the relative abundance of small game in that State. The intelligent cooperation of the people of a State is all that is necessary to control this and many other local problems.

It is well to see that pet cats are well fed and cared for and as far as possible restrained from wandering at night or hunting birds. A superabundance of kittens should be guarded against, and preferably only emasculated male cats should be kept. When it is necessary to kill a tame cat, drop it into a tight can or box (a metal trash can with tight cover is the best); pour in an ounce of ether, carbon bisulphide, or gasoline; and keep the cover on tight for half an hour. The cat inhales the gas and becomes fully anesthetized, goes to sleep in about 1 minute, and by being kept in the gas for a long time never wakes up. With carbon bisulphide or gasoline gas it will usually not revive after the first 10 or 15 minutes. A blow on the head while the animal is totally unconscious will save time in 
waiting for the fatal results of the anesthetic and will cause no pain to the cat. Care must be taken with any of these gases not to use them near a fire or light as they are highly explosive.

\section{LYNX RUFUS UINTA MERRIAM}

\section{Rocky Mountain Bobcat; Too-Hoo-oo of the Piute at Burns}

Lynx uinta Merriam, Biol. Soc. Wash. Proc. 15: 71, 1902.

Type--Collected at Bridger's Pass (18 miles southwest of Rawlins), Wyo., by Vernon Bailey, May 11, 1890.

General characters.-A large, long-legged, short-tailed cat with small feet, erect, slightly tufted ears, conspicuous side whiskers or throat ruff, skull short, wide, and high. Perhaps the largest of all the bobcats, skull large, heavily crested, and with narrow rostrum, colors pale, considerably paler than pallescens. In winter pelage, upper parts light tawny or rich buff, heavily frosted with white-tipped outer hairs, obscurely mottled with brown or dusky spots, and often striped along center of back with blackish; face striped and lined with black and white; back of ears black with large gray central spot; lower parts white, heavily spotted with black and buffy throat band; tail tawny above with one wide subterminal crossbar of black and 2 or 3 narrow crossbars of brown back of it; tip and lower surface white. Summer pelage light tawny above without gray frosting. Young at first finely spotted and striped with dusky or blackish.

Measurements.-Of type, large adult male: Total length, 1,030 mm; tail, 195; foot, 200 ; ear (dry), 60; ear tuft, 25; whiskers, 60 . Skull : Basal length, 114 ; zygomatic breadth, 94 . Weight of type $31 \frac{112}{2}$ pounds. An old male at Baker, Oreg., after remaining 2 days in a trap, being shot and bleeding profusely, weighed $271 / 2$ pounds; normally it probably weighed 30 pounds.

Distribution and habitat.-These large, light-colored bobcats fill the Transition Zone area of the Rocky Mountain region west to the east base of the Cascades and north into southern Alberta and southeastern British Columbia.

In Oregon they cover all the sagebrush country east of the Cascade Range in both Transition and Upper Sonoran Zones (fig. 60). Their greatest abundance is along the numerous lava-rock cliffs and canyons, the rimrock country so generally distributed over eastern Oregon.

General habits.-In the open sagebrush country where they abound these big bobcats find safe and comfortable homes in

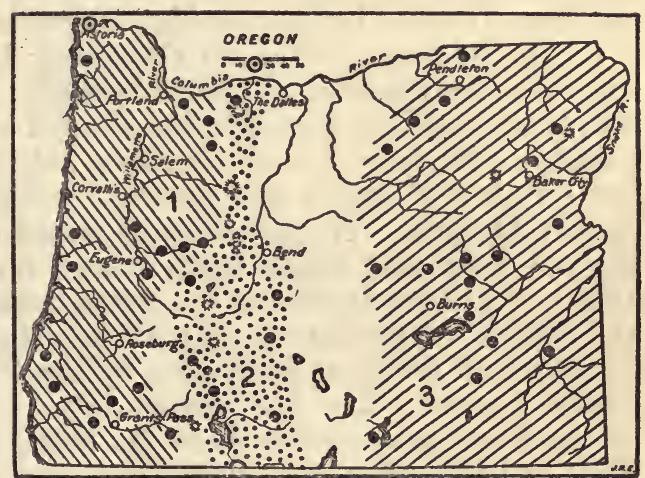

Figure 60.-Range of three forms of bobcats in Oregon: 1 , Lynx rufus fasciatus; $2, L$. $r$. pallescens; $3, L$. $r$. uinta. Type localities circled. caves and caverns of the broken lavas. From these strongholds the cats at night prowl in the gray sagebrush, which they match so perfectly in color as to be almost invisible, even by daylight, and hunt for such small game as mice, gophers, kangaroo rats, rabbits, and grouse. Also along the shelves and walls of the cliffs and canyons they catch wood rats and other small rodents or slip through the tules and tall vegetation of the lake shores in search of game birds and smaller prey. The whole surface of the country is covered and 
combed for their food supply which often includes sheep, deer, and antelope, where such game is to be found. They hunt mainly at night and are silent and little noticed, even where they are as numerous as the more conspicuous coyotes.

Breeding habits.-Four seems to be the usual number of young to a litter, but sometimes there are only 2 or 3 , and again 5 or 6 , born generally in May or June in dark caverns of the cliffs.

Food habits. - In the examination of 200 stomachs of bobcats from eastern Oregon by the Biological Survey predatory-animal hunters, 95 contained rabbits of the 4 common species; 27 contained sheep meat; 23 , sage hens; 13 , mice of various species; 12 , ground squirrels; 8 , pine squirrels; 3 , deer meat; 3 , wood rats; 1 , woodchuck; 1 , chipmunk, 3, quail; 3, small birds; 2, pheasants; and 1, sharp-tailed grouse. Seven others contained bird feathers and 1 grasshopper. This gives only a part of their food, however, as they are known to take pocket gophers, kangaroo rats, and practically every rodent of the region, besides any kind of poultry whenever it can be obtained. One of the common complaints is that they kill all of the domestic cats introduced at some of the isolated ranches, and it has been generally observed that these Old World cats do not thrive where coyotes and bobcats occur.

Economic status.-Next to the coyote these big cats are the greatest menace to the sheep herds of eastern Oregon, and their destruction of poultry and game birds and mammals makes it necessary to wage constant warfare against them. On the other hand they serve as an important check on overabundance of rodents and wandering house cats, so that total extermination is not desirable, even if it were possible. Their fur value serves in part to limit their abundance, but in the sheep and ranch country it is necessary to reduce their numbers further by employing expert hunters and trappers.

From October 1, 1913, to December 31, 1914, bounties of $\$ 1$ each were paid by the State on 5,425 bobcats: 1,039, from Harney County; 595, from Malheur County ; 452, from Lake County ; 409, from Crook County; 182, from Grant County; 144, from Wallowa County; 104, from Baker County; and smaller numbers from other counties in eastern Oregon. These were additional to those taken by the Biological Survey and State hunters and represent but a part of those killed by private individuals. State bounties were then discontinued, and control of predatory animals has since been carried on by expert hunters and trappers employed by the State and the Bureau of Biological Survey. The 410 bobcats taken by Biological Survey hunters in the fiscal year ended June 30,1930, would indicate sufficient reduction in numbers to obviate any serious losses to game, livestock, or poultry.

\section{LYNX RUFUS PALLESCENS MERRIAM}

CASCAde BobCat; WAL-Kot-SKa of the Klamath (C. H.M.); EŕqUA of the Wasco

Lynx fasciatus pallescens Merriam, North Amer. Fauna No. 16, p. 104, 1899.

Type-Collected at Trout Lake, south base of Mount Adams, Wash., by D. N. Kaegi, January 10, 1895.

General characters.-Size and skull as in Lymx rufus fasciatus but general coloration paler, with less black on face, ears, and tail. Winter pelage, upper parts frosted with long white tips of outer hairs over pale tawny, faintly dappled with dusky and brown spots, striped and spotted along middle of back with 
black; stripes above and below eyes and spot on back of each ear whitish; lower parts, except buffy band across throat, whitish, heavily spotted, and blotched with black or dusky; legs tawny, thickly spotted and specked; tail brownish above with 1 or 2 narrow and 1 wide subterminal bars of black; tip and lower surface white. Summer pelage more reddish and less gray. Young, finely spotted and striped.

Measurements. - Of type, well-made skin of adult male: Total length, $930 \mathrm{~mm}$; tail, 130 ; foot, 170 ; ear, 50 . Shelton in his field report gives the weight of a large male as 22 pounds 12 ounces, and another male as 23 pounds.

Distribution and habitat.-This mountain bobcat is a transition form, ranging between typical fasciatus and uinta, and occupying both slopes of the Cascades from southern Oregon north to British Columbia (fig. 60). The specimens from the yellow pine forest country seem to be most nearly typical. They are rarely found in the spruce and fir country of the Canadian Zone summit of the range.

General habits.-Only as their type of range differs from that of the more western and more eastern forms of the bobcat do these intermediate animals differ in habits from the other Oregon subspecies. Generally they find abundance of lava-rock cliffs and caverns for homes and strongholds, and do part of their hunting in the forest and part in the open. Rabbits, squirrels, chipmunks, gophers, mountain beavers, small birds, game birds, and deer are their regular prey, while the sheep herds that come into the mountains in summer suffer from their depredations.

\section{LYNX RUFUS FASCIATUS RAFINESQUE}

\section{Oregon Bobcat ; Northwest Coast Bobcat}

Lynx fasciatus Rafinesque, Amer. Monthly Mag. 2: 46, 1817.

Type locality.- " Northwest Coast", based on Lewis and Clark's description of specimens obtained near the mouth of the Columbia, on "Netul" River (now Lewis and Clark River) near Astoria, December 13, 1805.

General characters. - A large, long-legged, short-tailed cat with small feet, erect, slightly tufted ears, conspicuous side whiskers or throat ruff, and dark rich coloration ( $\mathrm{pl}, 40, \boldsymbol{A}$ ). Skull short and wide with wide muzzle and heavy dentition. Winter coat, upper parts dark rich tawny or hazel brown, finely speckled with darker or blackish, obscurely striped with black on face and crown and sometimes along nape and back; sides and legs more or less frosted with white-tipped hairs; top of tail rusty brown with 2 narrow and 1 broad subterminal bar of black, extreme tip and lower surface of tail white; chin, breast, and back of belly whitish; throat and middle of belly light tawny; whole lower parts and inside of legs coarsely spotted with black. Summer fur thin and harsh and more reddish brown. Young at birth finely striped and blotched above, coarsely spotted on sides and belly and striped on throat and cheeks.

Measurements.-Large male from Blue River, Oreg., measured by hunter: Total length, $915 \mathrm{~mm}$; tail, 178; foot, 203; ear (dry), 63; tassel, 15; sidie whiskers, 65 ; in inches, length, 36 ; tail, 7 ; foot, 8 . A well-made skin of male from Estacada measures $36 ; 6 ; 7$ inches, Weight of large males said to be from 20 to 23 pounds.

Distribution and habitat.-This most richly colored of all our bobcats occupies the humid and heavily forested area west of the Cascade Mountains from southern Oregon and northwestern California to southern British Columbia (fig. 60). It is mainly a forest dweller, living and hunting under the deep shade of tall timber, or in the dense tangle of west-coast chaparral.

General habits.-While largely nocturnal in habits, these cats occasionally hunt in the daytime. On a clear day in midafternoon 
one was surprised eating a rabbit on the side of Mount Chintimini, but the cat disappeared so suddenly that it left the warm and bleeding rabbit in the trail. Owing to the dense cover, their highly concealing coloration, and secretive habits, they are rarely seen alive except when treed by dogs or caught in traps. Their tracks are occasionally seen in trails or on sandy beaches, and the fur of a rabbit or feathers of a bird often show where they have dined in the forest. They are primarily hunters of small game, from mice and small birds to rabbits and game birds, but do not hesitate to kill sheep and deer when hunger demands and opportunity offers. They climb trees readily and quickly take refuge in the tops when chased by dogs. Only when trapped or cornered will they fight, and while no match for a good-sized hunting dog they will severely punish with teeth and claws any dog so rash as to attack them.

Breeding habits.-The young, as shown by examination of pregnant females caught in spring, range in number from 3 to 6 , and are generally born in April or May. They are kept in hollow logs, trees, or among the rocks until old enough to follow the mother and take part in the hunt. The male apparently assumes no responsibility in the family affairs.

Food habits.- Stomachs examined by predatory-animal hunters have been found to contain remains of red squirrels, gray squirrels, snowshoe rabbits, brush rabbits, deer, sheep, and blue grouse. The bobcats' droppings along the trails often contain mouse hair, bones of gophers, Aplodontia, and feathers of birds. Generally the animals are able to catch plenty of game, which they prefer fresh and warm, but at times they will eat cold meat when used as trap bait. More often they are attracted to traps by tufts of rabbit or squirrel fur, or by bird feathers hung above or scattered about the traps.

Economic status.-Besides the sheep and poultry killed by these invisible prowlers, the small game suffers severely wherever they are numerous, and they occasionally kill even deer, especially fawns. The extent of damage depends on their abundance, which is best shown by State records. From October 1, 1913, to December 31, 1914 , a $\$ 1$ bounty each was paid on 5,425 bobcats; these included 327 in Douglas County, 271 in Coos County, 269 in Jackson County, 258 in Lane County, 139 in Lincoln County, 121 in Clatsop County, 111 in Josephine County, 101 in Clackamas County, 97 in Tillamook County, 86 in Columbia County, 78 in Linn County, 68 in Curry County, 38 in Washington County, 21 in Yamhill County, 20 in Multnomah County, and 19 in Benton County (Oreg. Sportsman 3 (2) : 40, 1915).

The destruction of mice, pocket gophers, chipmunks, ground squirrels, and mountain beavers affords an important check on overabundance of these rodents, while the fur value of the bobcat skins taken each year by hunters and trappers brings considerable money into the State. When the high prices of fur have prevailed the reduction of these, as other fur-bearing animals, has been evident, but during low prices they increase and in areas where sheep are raised and there is relatively little trapping, it has been necessary to keep hunters employed all the year to reduce the number of such preda- 
tory animals. During the year 1929, the Biological Survey and State hunters turned in skins of 410 bobcats from the State. This was in addition to those taken by private parties.

\section{LYNX CANADENSIS CANADENSIS KERR}

\section{Canada Lynx}

Lynx canadensis Kerr, Animal Kingdom, 1: 157, 1792.

Type locality.-Eastern Canada.

General characters. - Size about as the bobcat, but with much larger feet, longer legs, shorter tails, longer ear tassels, longer side whiskers, and longer fur, giving them in winter the appearance of a much larger animal. Skull wider interorbitally than that of the bobcat, with heavier dentition, smaller audital bullae, and $U$-shaped instead of $W$-shaped interpterygoid fossa.

Winter pelage, upper parts light frosted gray, the buffy brown underfur being almost concealed by the white tips of the long, soft outer hairs; back of inner edges of ears, ear tassels, tufts in side whiskers, and whole tip of tail black; lower parts, legs, and feet light buffy gray, with generally little trace of spotting. Summer pelage, upper parts dark brownish gray with dusky line along back; ear tips and tassels, tufts in side whiskers and tip of tail black; legs and tail yellowish gray; lower parts buffy gray to soiled whitish, faintly spotted along sides with dusky. Young more yellowish and more spotted and striped than adults.

Measurements.- Of large male: Total length, $954 \mathrm{~mm}$; tail, 100 ; foot, 203 ; ear, (dry), 60; tassel in wintèr, 60 ; whiskers in winter, 100 . Skull of adult male: Basal length, 110; zygomatic breadth, 94. Largest weight 28 pounds.

Distribution and habitat.-The Canada lynx is scarce in Oregon, but specimens have been taken at Fort Klamath, Bend, North Fork John Day River, near Pendleton, at Granite in Grant County and on Kiger Creek in the Steens Mountains (fig. 61). There are also a couple of records for northern Nevada, which seems to be the southern limit of this boreal species in the Great Basin country. There are several verbal reports of their occurrence west of the Cascades in Oregon, but these are unsupported by specimens. The general range of the species is across boreal North America and south in the moun-

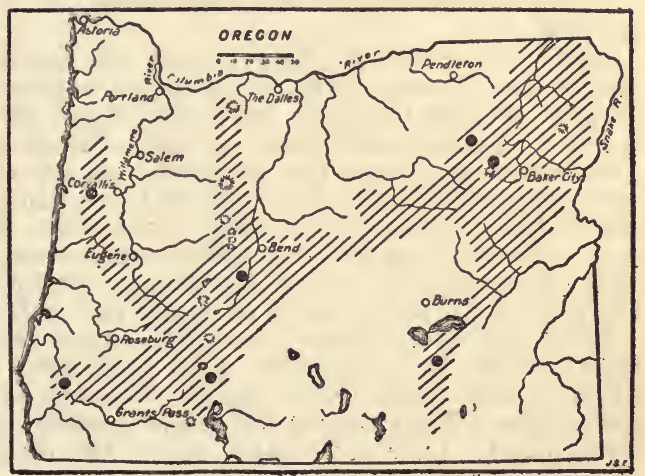

Figure 61.-Range of the Canada lynx, Lynx canadensis canadensis, in Oregon. tains to Pennsylvania and Colorado. Subspecies have been described from Labrador and Alaska, but the characters remain surprisingly constant over an enormous area, perhaps due to the wandering habits of the animals. Primarily they belong to Canadian and Hudsonian Zones, but in times of scarcity of food, they wander long distances into lower zones. The Cascades and Blue Mountains are probably their real home, and other records are of wanderers from these boreal areas.

General habits.-Peculiarly adapted to life in the forest and to cold weather and deep snows, these big-footed cats remain in the 
forests as long as snowshoe rabbits and grouse are sufficiently abundant to furnish them food. Hunting by stealth, soft footed, silent, and invisible, they pounce upon their prey or wait by the trails until game comes their way. If the game proves undesirable or a man appears, they vanish like ghosts, and many hunters who have been for years in their country have never seen one alive except one trapped or treed by dogs. Their shadowy-brown summer coats and frosty gray winter coats afford remarkably perfect concealing coloration at all seasons, a protection they certainly do not need except in stalking their prey. In the presence of man they are usually as timid as rabbits, but there are records of their attacking man when desperate with hunger.

Food habits.-Generally their food consists of snowshoe rabbits, grouse, and such other small game as they can capture, but in Alaska Charles Sheldon found them killing mountain sheep in winter, and there is good reason to suspect them of killing deer and other large game animals when opportunity offers. Although the lynx is a valuable fur animal, yielding a light, fluffy fur of unusual beauty and value, it is perhaps fortunate that it is not more abundant in the State.

Family CANIDAE: Wolves, Foxes, and Dogs

CANIS LYCAON GIGAS (TOWNSEND)

North Western Timber Wolf; Gray Wolf; Black Wolf; Eskmox of the Wasco

Lupus gigas Townsend, Jour. Acad. Nat. Sci. Phila. 2 : 75, 1850.

Type.-Collected near Fort Vancouver, Wash., by J. K. Townsend, December 19, 1835.

General characters.-Larger than the eastern timber wolf, colors generally darker and richer. Size about as in nubilus of the Great Plains but much darker. Pelage long and dense in winter, thin and coarse with little fur in summer; a long coarse mane on back of neck, a triangular cape over shoulders, and narrow glandular line of bristles on top of tail near base. Normal winter coat dull ochraceous, heavily clouded over back and tail with black tips of long coarse hairs; lower parts buffy ochraceous, sometimes whitish on throat and back of belly; legs and feet bright ochraceous; occasionally black or dusky all over. Summer colors much the same or slightly darker and more rusty. Young black at birth, paling later to dusky and dull ochraceous.

Measurements. - Taken from well-tanned skin from Estacada, Oreg.: Total length, $1,610 \mathrm{~mm}$; tail, 420 ; hind foot, 245 ; ear, inside, 94, from crown, 84 . Skull of adult male: Basal length, 230 ; zygomatic width, 145 . Skull of Townsend's type: Total length, 273 [10.70 inches], greatest width, 150 [5.90 inches], from Baird. Weight probably about 100 pounds.

Distribution and habitat.-A few of these large, dark gray wolves are still found in the timbered country west of the Cascades in Oregon, and locally northward to British Columbia and Alaska (fig. 62). In recent years they have been found mainly along the west slope of the Cascade Range, but before extensive white settlements were made in the State they seem to have been common in the Willamette Valley and west to the coast. In 1805 Lewis and Clark reported them at the mouth of the Columbia, and in 1835 Townsend secured the type of this subspecies near Fort Vancouver, just north of the Columbia River. In 1834 Wyeth reported several killed along the Deschutes River, and in 1854 Suckley collected specimens near The Dalles. In 1897 Captain Applegate reported them as formerly common, but at that time extremely rare in the southern Cascade region. 
From October 1, 1913, to May 10, 1914, bounty was paid on 30 wolves in Oregon-from Douglas County, 10; Crook County, 6; Clackamas County, 6; Linn County, 6 ; Lane County, 1, and Jackson County, 1 (Oreg. Sportsman $2(6): 19,1914$ ). These records probably represented at that time the areas of greatest abundance of wolves in the State, and the high bounty of $\$ 25$ each for timber wolves- $\$ 20$ paid by the State Game Commission added to the regular $\$ 5$ paid by the State-brought in an unusual number. As they were submitted to Finley and Jewett for determination, the skins were unquestionably of wolves and not coyotes.

Jewett reports one large male wolf taken by Fred R. Sankey, August 20, 1930, near Balm Mountain on the Umpqua National Forest, where it had recently killed several of Winlock Hendrick's sheep. The animal was very old with teeth much worn. Another old male wolf was taken by Charles Anway on the shore of Crescent Lake in Klamath County, where it seemed to be the only wolf ranging through the previous winter. $\mathrm{T}$ wo other wolves were killed in Douglas County and 1 in Lane County during 1930, and 1 near McKenzie Bridge in Lane County, January 1, 1931.

General habits.-These large, dark-gray wolves are forest dwellers and forest hunters, rarely seen except when caught in

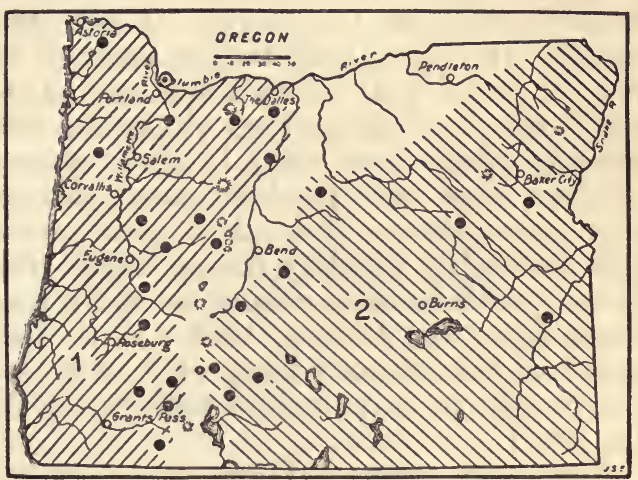

Figure 62.-Range of the two forms of the big wolves in Oregon : 1 , Canis lycaon gigas; $2, C$. l. nubilus. Type locality circled.

traps and rarely caught except by the most skillful trappers. Usually silent, shy, and stealthy, they follow the game trails or slip through the deep shadows of the forest, disappearing at the first sign of danger. The long musical howl of the wolf cannot be mistaken for the yap-yap of the coyote. They are exceedingly intelligent in recognizing and avoiding danger and have only man to fear, either as a competitor in the hunt, or as a deadly enemy. Originally their game was the black-tailed deer and powerful Roosevelt's elk, but now it is mainly deer and any domestic cattle or sheep that come within their reach. Usually they catch their prey by the ham or flank, tearing out the flesh and sinews, often hamstringing the larger animals and rendering them helpless to be torn and eaten at leisure. Bloodthirsty in their hunting methods and terribly destructive to game and livestock, they are nevertheless among the most intelligent of our native animals and most difficult to trap or hunt successfully.

Breeding habits. - The Oregon Sportsman reports a female containing four foetuses taken near Estacada the last week in March and cites other records of young or mothers suckling young in summer, but these give little data regarding breeding season. However, there seems no reason for supposing that the breeding habits differ from the better-known gray wolves of the Great Plains, which, $7209^{\circ}-36-18$ 
when fully adult, usually have from 7 to 11 young at a litter in March or April, and remain associated as a family, or pack, led by the old male through summer and fall to the beginning of the next breeding season. The breeding dens are usually large holes in banks, under rocks, log jams, or in hollow logs where the little black puppies are guarded with great care until they are large enough to come out and follow the parents to the kill and later to join in the hunt. Apparently the first litter of young is small, often only 3 or 4 pups. The male and female mate for one or more seasons. The male devotes all his time and energy to protecting, feeding, and leading his family until the young are full grown and able to kill their own game.

Food habits.-The wolves are hunters, and, where game is plentiful kill as they need food and usually more than is eaten. If large game is scarce, they will kill rabbits or any small animals, or attack domestic stock on the range. Their diet is almost entirely meat, usually freshly killed, but in case of hunger any old carcass that can be found will furnish a meal. Among the Olympic Mountain elk herds, wolf droppings along the trails are generally composed entirely of elk hair, while in areas where there are no elk and plenty of deer, deer hair predominates. Stomachs examined by trappers show deer, sheep, and rabbit meat, accompained by enough of the hair to readily identify the animals. Deputy Game Warden Ben S. Patton, of Estacada, caught an old female wolf on the upper Clackamas River on June 6, 1914. With her family of young, she had eaten all the skinned body of a recently killed bear. The old wolf was caught in traps baited with fish heads (Oreg. Sportsman 2 (7): $16,1914)$.

Economic status.-These large wolves are so destructive that neither game nor domestic stock can be successfully maintained where they are present in any considerable numbers. Fortunately, however, they keep as far as possible from settlements and civilization, and owing to this restricted range are more easily controlled than are the coyotes. In Oregon, at the present time, they are so nearly under control that their damage is negligible, but a careful watch must be maintained to keep them from getting a fresh start.

\section{CANIS LYCAON NUBILUS SAY}

Buffalo Wolf; Gray Wolf; Plains Wolf; Lobo; Hohni of the Cheyenne (Wied)

Canis nubilus Say, Long's Exped. to Rocky Mountains, v. 1, p. 169, 1823.

Type locality.-Engineer Cantonment, near Blair, Nebr.

General characters.-Larger than the eastern timber wolf with heavier skull and paler coloration. About the same size as gigas, but with longer, lighter skull and general coloration much lighter gray, some individuals becoming almost white. In winter fur light gray from the combination of creamcolored underfur overlain with the black tips of long outer hairs; back of ears and top of nose buffy; face clear gray; feet and legs creamy white, nose pad, lips, and eyelids black. Summer coat darker and more yellowish gray. Young black at birth, soon fading to dusky and buffy gray.

Measurements.-Adult male from Colfax County, N. Mex., measured in the flesh by E. T. Seton: Total length, $1,575 \mathrm{~mm}$; tall, 406 ; weight, 102 pounds. Well-tanned skin of large male from Miles City, Mont.: 1,750;400;245; ear, 95. Skull of large male from Montana: Basal length, 230; zygomatic breadth, 145. Skull of large male from Fort Kearney, Nebr.: Total length, 258 (10.15 inches); greatest width, 137 (5.4 inches). 
Distribution and habitat.-These large, light-gray wolves of the Great Plains region still extend westward into central Idaho and supposedly belong to the form once found with the buffalo in eastern Oregon (fig. 62). In $1916 \mathrm{Wm}$. F. Schnabel, of Caldwell, Idaho, wrote to the Biological Survey that, about 1889, "Old Chief Yakima Jim told me that when he was a boy there were lots of wolves in the Cow Creek Lakes Country" in extreme eastern Oregon. The age of Yakima Jim was then supposed to be about 110 years, which carries the record back to perhaps 1789 , the time when the buffalo were common there. In most of the records of "wolves" killed by trappers of the early expeditions in eastern Oregon no distinction was made between large wolves and coyotes. In 1854 Suckley reported them very numerous in Oregon and Washington from the Cascades to the summit of the Rocky Mountains, and especially in the Blue Mountain country. In 1915 Jewett reported a large wolf killed in Logan Valley, Grant County, near the Strawberry Mountains in the Blue Mountain Plateau, the skin of which he saw. This is the only recent reliable record of a wolf killed in that section.

On June 27, 1927, Elmer Williams, one of the Biological Survey predatory-animal hunters, trapped an old male wolf on the Sycan Marsh, east of Fort Klamath, that had been credited with killing a great number of cattle and some horses over a period of 12 years in that section. It was almost white, possibly owing to age, as the much-worn teeth showed it to be an old wolf. It had the heavy muzzle of gigas but less thickened carnassial tooth and a low, wide coronoid process of the lower jaw that suggest a variation from either typical gigas or nubitus, possibly a remnant of the form that occupied the sagebrush country when the buffalo were there in abundance.

The lower jaws, some extra teeth, and a part of the skeleton of a wolf taken from the South Ice Cave, about 40 miles south of Bend, in December 1927, by W. J. Perry of the Forest Service, show the same tooth and jaw characters as the Sycan specimen, possibly even more strongly marked. These bones are old, but probably only a century, or such a matter, as the cave is not very dry and bones would probably not have lasted for a great length of time in it. Until more material is obtained from caves or otherwise it is not advisable to recognize a separate form on such slight characters as are shown in the present scanty material, and for the present these specimens seem best referred to the plains wolf.

Joseph Mailliard's (1927, p. 358) reports of two large wolves seen near Straw, Modoc County, Calif., just southeast of Tule Lake, by Game Warden Courtwright in October 1922, would suggest the possibility of a few wolves then ranging in the Klamath section or possibly the Sycan wolf and his mate may have wandered down there at that time. The importance of obtaining specimens, even any old skulls, from this region or anywhere east of the Cascades cannot be too strongly emphasized.

Senior Forest Ranger George O. Langdon reports a wolf track seen in the fall of 1930 near Desolation Butte on the Whitman National Forest in the Blue Mountains, probably the latest record of this species of wolf in Oregon. 


\section{CANIS LATRANS LESTES MERRIAM}

Mountain Coyote; Northwestern Coyote; EJa aH of the Piute; Ko-LA-A WAS of the Klamath (C. H. M.)

Canis lestes Merriam, Biol. Soc. Wash. Proc. 11: 25, 1897.

Type.-Collected on Toyabe Mountains, near Cloverdale, central Nevada, by Vernon Bailey, November 21, 1890.

General characters.-Large but slightly smaller than latrans, about the size of nebracensis, but darker and with lighter dentition. Wolflike in appearance (pl. 41), with erect, pointed ears, bristling mane on back of neck, and triangular cape of long hairs back of shoulders; elongated, bristle gland on top of tail near base; long, soft fur in winter; thin harsh hair in summer. Winter pelage: Upper parts light brownish gray over buffy underfur, the long coarse outer hairs heavily tipped with black on mane, cape, back, top, and tip of tail; back of ears rusty brown; muzzle, crown, outside of legs, and lower surface of tail bright yellowish brown; lower parts, except gray throat band, buffy or creamy white; nose pad, eyelids, lips, claws, and soles of feet black. Summer pelage thin and harsh, darker and more brownish than in winter. Young dusky or dark brown at birth, becoming buffy gray later. Skull of medium size with heavy dentition when compared with southern forms, lighter dentition than in latrans and nebracensis.

Measurements.-Type, adult male, measured in flesh by collector: Total length, 1,116 mm; tail, 320; hind foot, 200 ; ear (dry), 85. Skull of type: Basal length, 170; zygomatic breadth, 102. Weight estimated at about 30 pounds.

Distribution and habitat.-Coyotes cover most of the State, except the coastal slope west of the Willamette and Umpqua Valleys. In the southwestern corner of the State they occasionally reach almost

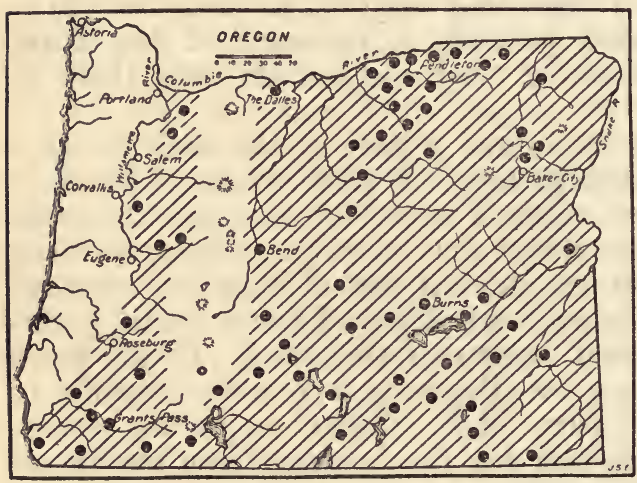

FIGURE 63.-Range of the coyote, Canis latrans lestes, in Oregon. to the coast on the lower Rogue River and on Pistol River (fig. 63). They are scarce west of the Cascades and in the higher part of the range but abundant and generally distributed over the sagebrush plains east of the mountains. A large number of specimens, including both skins and skulls, from over the State show little constant variation except slightly darker colors west of the Cascades. However, the size and skull characters are near to those of lestes, to which they are all referred. Until the coyotes are more fully studied it seems best to refer all specimens from central Nevada north to Alaska to this large, northern form.

General habits.-Coyotes are far more adaptable to varied conditions and environment than are the large wolves, but seem to prefer the open country and especially the arid sagebrush areas. Bold and cunning, they have little fear of man or dogs and thrive among farms and often up to edges of towns. Though mainly hunters of small game, they will boldly attack and kill deer, antelope, sheep, goats, and calves, or feast on old carcasses of any game or stock found dead, proving somewhat useful scavengers as well as most destructive predatory animals. 


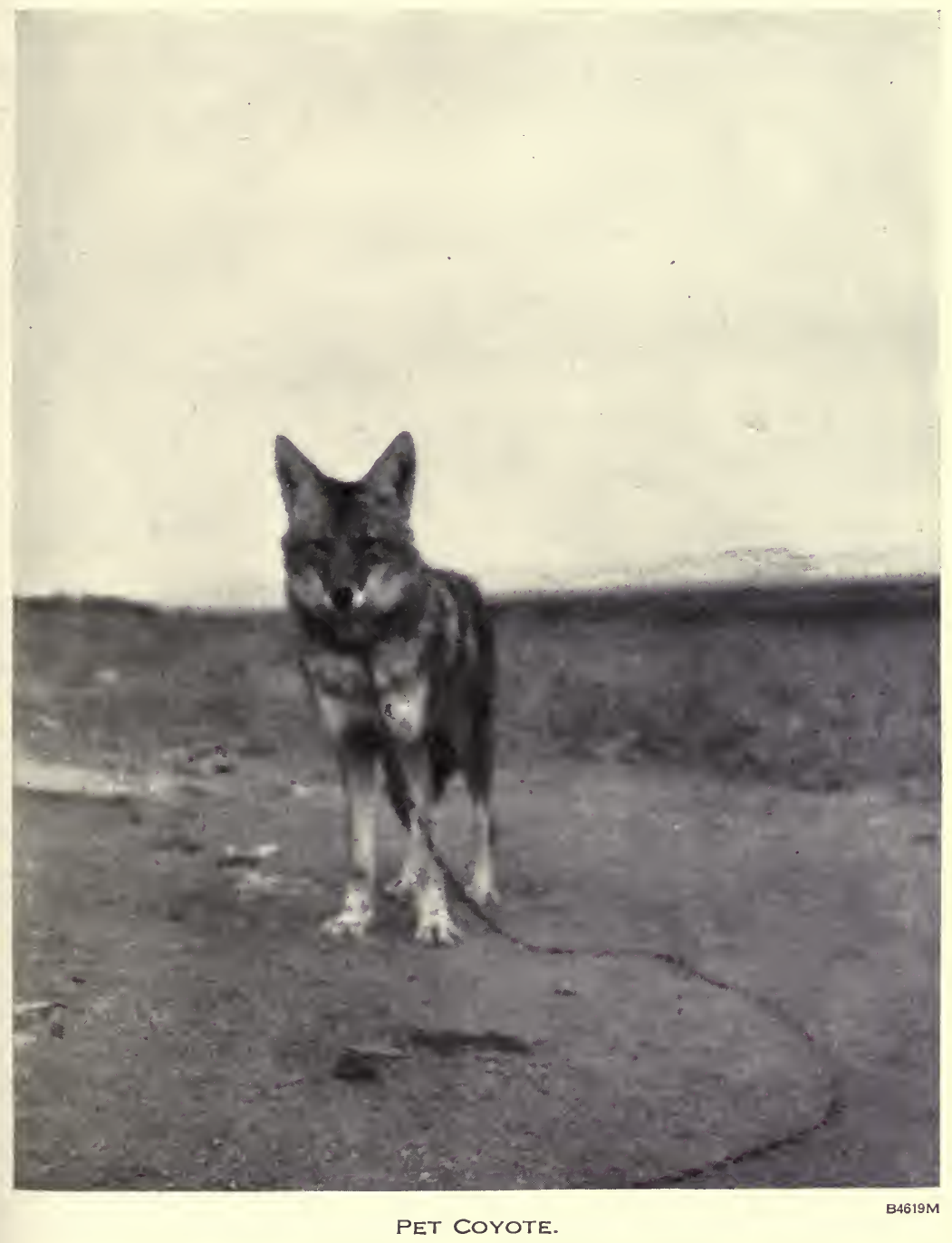

Photographed at Guano, Oreg., by Stanley G. Jewețt. 

To a great extent they are wanderers, moving from place to place in search of food, following the sheep and game herds high into the mountains in summer and back to the valleys in winter, or, in time of scarcity, seeking new ranges in quest of food. Still they seem to have a strong home instinct and apparently return to their home breeding grounds when possible. Easy and rapid travelers, they cover a wide nightly range, but are often seen abroad in daylight, gliding through the sagebrush, loping across meadows, or hunting for mice and ground squirrels in the fields. At times they are bold and inquisitive, coming close to unarmed humans, or actually into dooryards for poultry; but usually they are shy and wary, keeping well out of rifle range during daylight.

Noisiest of all our wolf tribe, they are more often heard than seen. Their yap, yap, yap, yi, yi, yi, followed by a long shrill ou, ou, ou, ou, ou, rings far in a still night, so fast and jumbled that the voice of 1 often sounds like 2 , and 2 in chorus sound like 6 , in a real call of the wild, and a neighboring cliff sometimes doubles or quadruples these sounds. On special occasions they are heard in the daytime, but most commonly in evening or early morning, at the opening or closing of the night's hunt.

Breeding habits. - Four years' records of the predatory-animal hunters in Oregon show January as the mating time and April in most instances as the month of birth. Females containing foetuses have been taken as late as April 29, while newly born young have been found in the dens as early as April 5 and 6. The period of gestation is about 65 days. Some of the females may not breed when a year old, but others apparently do, producing a small number of 3 or 4 young. The number of young in a litter, as shown by examination of embryos and litters of young in the dens in 110 cases in Oregon, runs as follows: One litter of 12 young; 7 of $10 ; 10$ of 9 ; 22 of $8 ; 11$ of $7 ; 26$ of $6 ; 22$ of $5 ; 10$ of 4 ; and 1 of 3 . The average in this series is $62 / 3$ young to a litter.

At birth the young are very dark brown or sooty black, and almost invisible in the darkness of deep burrows, caves, or hollcws of badland banks, or under masses of broken rocks. When old enough to toddle out of the den and play about the entrance, they are a yellowish-gray or clay color, harmonizing well with the bare ground or clay banks.

Coyotes breed but once a year and the family, including the male, usually remains together well into the autumn, the old male doing much of the hunting and killing of game for the young. Often, however, the family is broken up and scattered by hunters or dogs, and only occasionally are they seen together after the young are full grown. Whether the same male and female remain as a pair year after year is not definitely known, but early in January they are found running in pairs and when the young are small the male is generally on guard near the den. In July when the half-grown pups are out of the den both parents are exceedingly active and anxious in guarding and leading them and will often risk their lives to attract hunters away from the young.

Food habits.-While mainly meat eaters, coyotes have a wide range of food besides the flesh of mammals and birds, including snakes, lizards, salamanders, frogs, insects, and a great variety of fruits and berries. The following list of foods noted in the field examina- 
tion of 450 stomachs of coyotes trapped, shot, or poisoned by the Biological Survey predatory animal hunters in Oregon, 1917 to 1920 , give a rough idea of prevailing food. Many of the stomachs of animals long in the traps were empty or contained only sticks and earth, and some of the meat may have been from trap bait, but on the whole a fair range of food is shown. ${ }^{10}$ Of these 450 coyote stomachs, 177 contained rabbits, including the two species of jack rabbits, cottontails, and snowshoe and pygmy rabbits; 172 contained sheep meat, easily recognized by the wool; 77 disclosed ground squirrels, including several species; 38 contained mice; 8 contained porcupine; 5 , woodchuck; 5 , deer; 4 , cattle; 3 , pigs; 3 , pine squirrel; 2 , antelope 2 , chipmunks; 2 , wood rats; 1 , gray squirrel; 1 , pocket gopher, and 1, badger. One stomach contained a rattlesnake, and $1 \mathrm{a}$ green frog. Thirty-seven contained remains of sage hens; 9 , of poultry; 5 , ducks; 2 , prairie chickens; 2 , quail; 2 , meadowlarks; 1, pheasant; 1 , owl, and 4, bird feathers. Ten stomachs contained grasshoppers; 1, beetles, and 1, angleworms. Fourteen stomachs contained juniper berries; 3 , chokeberries; 3 , apples; 2 , rose haws; 1 , prunes, and 7, green grass.

Other stomachs examined in the field have shown the shells of $\epsilon \mathrm{ggs}$ of ducks, sage hens, and other ground-nesting birds, garter snakes, lizards, horn toads, salamanders, and greater numbers of pocket gophers and wood rats than are indicated in the foregoing list. The large number of stomachs containing remains of sheep may be explained partly by the fact that the efforts of the predatory-animal hunters have been concentrated in areas where coyotes were doing most damage to the sheep industry of eastern Oregon. Otherwise the bulk of coyote food generally consists of game, rabbits, ground squirrels, meadow mice, and gophers.

Economic importance.-Because of its abundance and wide distribution, the coyote is the most destructive predatory animal in Oregon, if not in the whole continent of North America. The animals' depredations are most serious to the sheep industry, and in places, without some check or control, they would render the industry unprofitable. They occasionally kill calves, pigs, goats, and poultry, and are very destructive to game, killing many deer, antelope, mountain sheep, young elk, sage grouse, prairie chickens, pheasants, quail, ducks, geese, and other small game, besides eating the eggs of ground-nesting game and other birds. The remarkable increase in certain localities of ell, deer, antelope, and sage hens in recent years can be credited largely to reduction in abundance of coyotes.

On the other hand, they may serve a useful purpose in checking overabundance of jack rabbits, cottontails, ground squirrels, woodchucks, gophers, meadow mice, and other small rodents. Even their insectivorous tastes may at times be useful in grasshopper and cricket plagues, while their destruction of house cats that have taken to the wilds has a value of growing importance. Still, in times of greatest abundance of these pests they have not prevented serious plagues of rabbits, meadow mice, and ground squirrels.

\footnotetext{
10 Horse meat used for poison bait was reported in many stomach examinations but is not included in this list. Most of the trapping is done with scent bait, so that only in rare cases can any of the food be attributed to trap bait.
} 
Absolute extermination of the coyotes over any considerable area is practically impossible and is undesirable, but a wise control of their abundance locally is necessary for the best interests of stockmen, farmers, and all concerned. Fortunately their fur has a value which partly checks their numbers and pays a considerable share of the expense of systematic and organized control.

Highly efficient and economical methods of trapping and poisoning coyotes have been worked out and put into practice by Biological Survey experts, and full directions have been published, so as to enable others to cooperate in a wide-spread campaign for their control. Directions for trapping and poisoning can be had by applying to the Biological Survey. Improved methods are given from time to time as they are discovered and tested.

Hydrophobia became very prevalent among the coyotes of eastern Oregon in 1914 and continued up to about 1920, causing great loss of domestic stock and many human lives. Many dogs were bitten. These conveyed the disease to stock and people, and a serious epidemic of one of the most dreaded diseases ensued. The force of animal hunters was increased and concentrated in the localities where rabies was most prevalent until the number of coyotes was so reduced that the disease was checked and finally put under control, but not until serious losses of life and property and heavy expenses had been suffered. In future such outbreaks can be controlled much more promptly from the experience gained in this case, and if carefully watched need not spread over such extensive areas.

\section{CANIS FAMILIARIS LINNAEUS}

\section{Domestic Dogs}

\section{Canis familiaris Linnaeus, Syst. Nat., p. 56, 1766-99.}

\section{Type locality.-Sweden.}

General characters.-Varying widely from pug and poodle to bulldog, greyhound, mastiff, great dane, and innumerable other varieties of unknown origin. Distinguished from our large wolves by generally smaller size, lighter dentition, relatively shorter, wider, higher skulls, and from the coyotes by less slender and elongated skulls and by lack of well-developed inner cusp, or protocone, of upper carnassial tooth. In this, as in other characters, they show closer affinity with the wolves of some ancient forms from which they are supposed to have originated, than with our modern wolves.

Varieties.-No attempt will be made to define or even list by name the domestic varieties of dogs in Oregon, as probably most of the well-known forms of the world would be included. A brief list of the varieties noted among the aborigines during the days of early settlement of the State may, however, serve a useful purpose in bringing to light further information and possibly the preservation of additional specimens and records for a later and more comprehensive study of the Canidae. Any skulls or skeletons of dogs from caves or ancient burial sites should be preserved for study in local collections or museums, or sent to the United States National Museum, at Washington, D. C., accompanied by full data.

To Suckley and Gibbs (1860, pp. 89-139) of the Pacific Railroad surveys, the writer is especially indebted for important notes on dogs found among the Indians of Oregon in 1853 to 1855 , and more recently to Glover M. Allen $(1920, p .431)$ of Cambridge, Mass., for bringing together in the Proceedings of the Museum of Comparative Zoology for 1920 the scattered information on the aboriginal dogs of North America. 


\section{Plains Indian Dog}

Canis familiaris canadensis Richardson, Fauna Boreali-Amer., v. 1, p. 80, 1829.

Wolflike dogs, with erect, pointed ears, drooping tails, and yellowish gray, black, white, or spotted coats, were kept in great numbers by most of the Plains Indians and reported among the Indians at The Dalles in 1854 by Suckley and Gibbs. These animals were generally considered to be a mixture of $\mathrm{dog}$ and coyote. This opinion, however, seems to have been based on general appearance, size, and on the well-known fact that they were often crossed with wild coyotes.

These dogs were generally used by the Indians for hunting and packing and over much of the West were an important source of food for the natives. Suckley and Gibbs, however, state positively that none of the Oregon Indians ate their dogs, but that they used them for driving elk and deer.

\section{Short-Legged Indian Dog; Carrier Indian Dog}

Canis familiaris novacalidoniae Richardson, Fauna Boreali-Amer., v. 1, p. 82, 1829.

A small, long-bodied, short-legged dog of the Turnspit kind, with large head, erect ears, fur short and sleek, longer on tail, was reported by Richardson from British Columbia, and by Suckley and Gibbs from The Dalles, Oreg., and Eel River, Calif. Usually white or spotted with black and white or liver color and white, these were kept by the Indians as playmates for the children and pets for the women. But even in the 1850 's Suckley says that throughout Oregon the native dogs were intermingled largely with imported dogs. Some of the purebred original stock may still be found among certain Indians, but skulls from caves and old burial places and shell heaps will probably prove more satisfactory for study.

\section{Klamath Indian Dog}

Canis familiaris klamathensis, New name.

Suckley $(1860, p .112)$ says:

"On the Klamath is a dog of good size, with a short tail. This is not more than 6 or 7 inches long and is bushy, or rather broad, it being as wide as a man's hand. I was assured they were not cut and I never noticed longer talls on the pups. They have the usual erect ears and sharp muzzle of Indian dogs but are (what is unusual with Indian dogs) often brindled gray."

This seems to be the only mention of such a dog among any Indians, and unfortunately there are no specimens from which to amplify this meager description. Some day, when the numerous lava caves of the Klamath country are carefully explored, there will undoubtedly be brought to light considerable numbers of skulls of dogs of unquestionable aboriginal origin, and these should be preserved with the greatest care.

\section{Crallum Indian Dog}

Canis laniger Hamilton Smith, Jardine's Nat. Library, v. 10, p. 134, 1840.

Described as a medium-sized dog with erect, pointed ears, sharp nose, and bushy tail, hair thick and woolly, white, or perhaps brown 
and black, the Clallum dog has the hangdog, thievish appearance of other Indian dogs. First reported by Vancouver, later by Suckley and Gibbs, and by Lord as abundant in the Puget Sound section among the Chinook Indians and at the mouth of the Columbia, this dog is now apparently extinct (Douglas Leechman, 1929, p. 176).

Large numbers of these dogs were kept by the Indians and sheared for wool to be woven into blankets and rugs. Gibbs says that in his time (1855) the fur, or hair, was generally intermixed with ravellings of old English blankets to facilitate twisting with yarn. These were stretched over a frame and then interwoven, leaving when finished a fringe where the ends were separated. One of these dog's wool blankets made of this material and one made of dog's wool and duck's feathers mixed were sent to the Smithsonian. Suckley says the native dogs of Oregon subsisted well upon fish which they did not hesitate to eat raw, though it would make any blooded dog from the East sick and scarcely 1 out of 10 would recover (Suckley and Gibbs, 1860, p. 112).

While the dog is often man's closest and most devoted friend, capable of deep and lasting affection, devoted service, and useful in a thousand ways, it is quite possible to accumulate so many dogs that they become a curse instead of a blessing. This seems to have been too often the case among the Indians, especially those who did not use them as food. Among the white races a great number of dogs is often considered a sign of poverty, varying in direct ratio to the number of dogs. Under such conditions there is a tendency to let the dogs live on the wildlife of the country as far as possible. In parts of Oregon in past years this has caused a heavy drain upon the game resources of the State, and various means of checking the abuse have been tried. Also with an unnecessary number of dogs there is always the great danger from the dread disease of hydrophobia, or rabies; and in special cases there have been considerable losses of domestic stock, sheep, pigs, and cattle through the depredations of neglected, half-starved, and half-wild curs. In some cases dogs have become entirely wild and proved even worse stock killers than wolves or coyotes.

Thus the problem of dogs in their human relations is closely akin to that of the native animals of the State and is one that requires as careful study and intelligent consideration as any of the economic animal problems of the country.

\section{VULPES FULVUS CASCADENSIS MERRIAM}

Casoade Red Fox; Yellow Fox; Wan-Na of the Klamath (C. H. M.) ; Wa-Nie of the Piute

Vulpes cascadensis Merriam, Wash. Acad. Sci. Proc. $2: 665,1900$.

Type-Collected at Trout Lake, south base of Mount Adams, Wash., by $\mathbf{P}$. Schmid, March 3, 1898.

General characters.-Form slender and light with large, erect ears, long bushy tail, small furry feet, light skull with medium crest, small teeth, very long, soft fur, and conspicuous white tip to tail. Color varying from light yellow to dark gray or silver tipped and black. Yellow phase in winter, upper parts bright buffy yellow, richest on sides of neck and back of shoulders, palest on face and cheeks, slightly brownish on back and legs, and grayish on tail ; back of ears and feet mostly black; tip of tall white; lower parts bright yellow or orange, with more or less white on throat and hinder part of belly. In gray or "cross 
fox" phase, upper parts largely black or dusky, overlaid with whitish or strawcolored tips of long hairs, the clear yellow usually appearing on sides of shoulders, neck, and face ; back of ears, nose, tail, and feet black or blackish; tip of tail always white; lower parts yellow, with black throat and belly. In silvergray phase all black, upper parts frosted with white-tipped hairs; tip of tail white. In black phase all black, except white tip of tail. Young at birth dark brown or black, with tip of tail white.

Measurements.-Average of three males from type locality: Total length, $1,070 \mathrm{~mm}$; tail, 412 ; foot, 178 ; ear (dry), 83 . Skull of type : Basal length, 133; zygomatic width, 70. Weight about 8 to 12 pounds.

Distribution and habitat.-These yellow foxes inhabit the Cascade Range in Washington and Oregon, and extend south into the northern Sierra Nevadas, but the limits of their range are not well defined

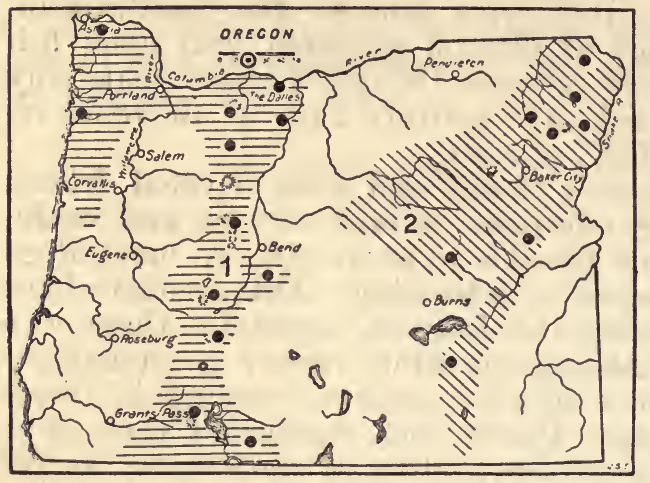

Figure 64.-Range of the two forms of red foxes in Oregon: $1, V$ Vilpes fulvus cascadensis; $2, V$. $t$. macrourus. Type localities circled. Biological Survey by H. D. Langille at Cloudcap Inn, near timber line on Mount Hood, on October 10, 1896, and another in the Wood River Mountains near Fort Klamath by B. L. Cunningham on December 24, 1897.

In 1855 Suckley and Gibbs $(1860, p .113)$ collected specimens and reported them common at Fort Dalles, Oreg. (The Dalles), where large numbers of skins of all four forms-red, cross, silver, and black - were reported among those brought in to the fur traders. The great variation in color was very confusing to the settlers there, as every shade of intergradation was shown among the four color phases.

In addition to the specimen records there are reports of foxes by Suckley and Gibbs from the Klamath Lakes country in 1855, by Lewis and Clark at the mouth of the Columbia in 1805, and by A. K. Fisher near Tillamook in 1897. In more recent times they have been reported from Swan Lake Valley, Yamsay Mountain, Klamath Lake, Crater Lake, Mount McLoughlin, Paulina Mountains, Cascade range west of La Pine, and about the Three Sisters Peaks. Also Cantwell in April 1919, reported seeing four very pale skins that had been taken at 6,000 feet on Mount Hood. Usually these foxes are absent from the densely timbered or brushy areas west of the Cascades, as well as from the arid sagebrush valleys east of the range. Open grassy parks and meadows afford their favorite hunting grounds, and the greatest abundance of mice and small rodents on which they largely subsist. 
General habits.-Alert, cautious, cunning, swift, and quick to take alarm, these graceful and beautiful animals generally hold their own, even among settlements and where hunting and trapping is prevalent. They live largely in the open where their speed saves them from most enemies except men and dogs, and even from these their intelligence and cunning usually saves them. To a great extent they occupy the areas where coyotes are not common, either because these are rival hunters of mice and small game, or because they are old-time enemies with the size advantage all in favor of the coyote. Apparently there is little difference in speed of the two, but the big brush of the fox gives him a decided advantage in turning and dodging. It is a noticeable fact that in the range of coyotes red foxes live and breed mainly among or near rocks where they find safe retreats for their dens and young, while in the Eastern States they live mainly in earth burrows. Otherwise the habits of red foxes are much the same across the continent.

Stealthy hunters of small game, they pounce upon mice, chipmunks, ground squirrels, birds, and rabbits, or catch them in quick runs and sudden turns. The great brush of a tail is not only ornamental, but extremely useful in pursuit of prey as well as flight from enemies. Few animals are so quick and agile or so light and graceful in motion.

They are more often heard than seen, their short, sharp little bark, like that of some small dog but more rapid and prolonged, being heard in the evening or morning. Usually the long lines of delicate tracks in the snow, the prints of the narrow, furry feet in dusty trails, or the pungent almost musky odor greeting one's nostrils in the dewy morning, furnish the only evidence that a fox has passed along in the night.

Breeding habits.-A litter of red foxes usually numbers 5 to 9 , born in April or May in eastern localities. There seem to be no Oregon records of breeding. The young are raised in carefully hidden dens under rocks or in holes dug under or near a rocky cover.

Food habits.-To their staple diet of mice, gophers, ground squirrels, chipmunks, rabbits and other small game, are added, in their seasons, birds, birds' eggs, poultry, insects and many berries and fruits. Meadow mice usually furnish a large item of their food, but whatever small game is most abundant and most easily captured seems to predominate in the animal's food. Their droppings scattered along the trails furnish a good index to their food, and hair, bones, teeth, feathers, and often the skins and seeds of fruit can be recognized in the old dry pellets. Their well-known fondness for poultry often gives them a bad reputation among the farmers, and a trail of scattered feathers is generally attributed to the work of a fox.

Economic status.-Red foxes serve as an effective check on overabundance of mice and small rodents, but they also destroy much small game and the eggs of game and song birds, poultry, and probably some young fawns and lambs. They are not sufficiently abundant or generally distributed to do serious damage, and their value as fur bearers probably adds to the wealth of trappers about as much as their depredations take from the resources of the farmers. On the other hand their destruction of rodents may increase the 
wealth of the farmers about as much as their destruction of game diminishes the bag of the sportsmen. It is difficult to balance these accounts to the satisfaction of all, and it is perhaps well that foxes are not more numerous in the wild state. In captivity the silver, black, and cross foxes are proving profitable fur producers, and fox farms are increasing in number in the Northern States and would be well suited to the Canadian and Transition Zone areas of Oregon.

\section{VULPES FULVUS MACROURUS BAIRD}

\section{Rocky Mountain Red Fox}

Vulpes macrourus Baird, Rept. Stansbury Exped. to Great Salt Lake, p. 309, 1852. Mamm. North Amer., p. 30, 1857.

Type.-From Wasatch Mountains, bordering Great Salt Lake Valley, Utah. A hunter's skin purchased by the Captain Stansbury Expedition in 1849 or 1850. Cataloged in 1860 .

General characters.-Larger and longer tailed than the eastern red fox, and paler fulvous or more yellowish, in the light phase, but more inclined to be dark or of the cross fox phase. Larger with heavier skull and teeth than the very similar cascadensis. In light phase it is pale buffy yellow along sides, sides of neck and cheeks, but always with darker fulvous across shoulders and along back, rump, and base of tail straw yellow, tail buffy gray or dusky with white tip, lower parts whitish or dusky gray, back of ears and feet black, a black line running half way up leg. In the cross fox phase it is yellowish fulvous on sides and belly, and over rump, dusky or black along middle of back, and across shoulders, and on throat, breast, and most of tail except white tip; feet, legs, and nose are blackish or somewhat grizzled with whitetipped hairs. Silver phase has all black except white tip of tail and white subterminal bands on long hairs over back. Black phase is glossy black all over except white tip of tail.

Measurements.-Young male from Wind River Mountains, Wyo.: Total length, $1,015 \mathrm{~mm}$; tail, 461 ; foot, 172 . Weight about 8 to 12 pounds.

Distribution and habitat.-The Rocky Mountain region from New Mexico to Montana and west to Idaho and the Blue Mountains, usually in open parks and meadows of the mountain ranges but in places down in meadow valleys along streams (fig. 64). Not found in deserts or arid valleys. Several skulls and summer skins from the Blue Mountains are clearly of this more robust Rocky Mountain form and not the light, slender Cascade fox. The skin of a breeding female taken by Elmer Williams on July 25, 1923, in Big Sheep Basin, 16 miles south of Joseph, Oreg., is in the typical cross fox phase, with much black on back, over shoulders, and along throat and breast, with light yellow cheeks and lower base of tail, rich fulvous sides and belly, and black feet, legs, and face. The belly shows a pinkish tinge of fur, as usual in nursing foxes, coyotes, and wolves. Another skin from Big Sheep Basin and one from Wallowa are both in the light-red phase, typical of macrourus.

Red foxes were reported from the country about Elgin when Preble and the writer were there in 1896, and in 1919 Cantwell reported them in the Sled Springs and Grand Ronde section of Wallowa County, and as occasionally taken about Wallowa Lake. In 1920 a few red foxes were reported in the Blue Mountain and Steens Mountain Valleys north and south of Malheur Lake, but none in the sagebrush valley.

General habits.-The general habits of the Rocky Mountain red fox in no way differ from those of the Cascade red fox except as 
their habitat affords them other species of small game, fruits, and berries on which to feed. Often they make their homes among broken rocks, where safe retreats protect them from various enemies. From these they go forth to hunt their food in the meadows and open woods where mice, gophers, and chipmunks abound, or lie curled up on the rocks to watch for the approach of enemies. Occasionally in the vicinity of the breeding dens or even at other times their sharp little staccato bark is heard, but usually they are silent, shy, and secretive.

Trapping for fur has greatly reduced their numbers. From 25 cents in the days of Suckley and Gibbs their skins have increased in value at times to $\$ 20, \$ 50$, and $\$ 100$ each, but so cunning, cautious, and intelligent have the animals become in recognizing and avoiding traps that their extermination over any great area has not been accomplished.

Now that the value of black and silver foxes, which was due to their scarcity in nature, has been destroyed by the production of large numbers of these choice-color varieties in captivity, there is likely to result a tendency to level the price of all of the color phases of foxes, as the prime skins of red and cross foxes are wonderfully beautiful in their native colors, and after all the value of furs is a matter of fashion and fancy based on real beauty and harmony of colors.

\section{VULPES MACROTIS NEVADENSIS GOLDMAN}

\section{Nevada Long-Eared Fox; Nevada SwifT}

Vulpes macrotis nevadensis Goldman, Jour. Wash. Acad. Sci. 21:250, 1931.

Type.-Collected at Willow Creek Ranch near Jungo, Humboldt County, Nev., December 14, 1915, by Mike Gill.

General characters.-A little, slender buffy-gray fox with large ears; round, puffy, black-tipped tail; and small, furry feet. Fur long, soft, and beautiful in winter; short and harsh in summer. Upper parts buffy gray, becoming clear buff and ochraceous on sides, legs, lower surface of tail, and back of ears; throat, back of belly, and inside of ears white; tip and sides of nose, base and tip of tail, blackish. Skull small and slender with smoothly rounded brain case, large audital bullae, and very light dentition.

Measurements. - Somewhat smaller than typical macrotis, which measures: Total length, $770 \mathrm{~mm}$; tail, 300; foot, 128; ear, 68. Weight about 4 pounds.

Distribution and habitat.-These graceful little foxes have been found in the valleys of northern Nevada, southwestern Idaho, and southeastern Oregon, not far beyond the limits of Lower Sonoran Zone valleys, where the species generally ranges. One skin and skull from the Owyhee Valley between Rome and Pollock and several other skins reported by Jewett from the Owyhee Valley are the only actual specimens from Oregon, but the species may be looked for in the Alvord and adjoining valleys that open out into northern Nevada.

General habits.-These smallest of our foxes are among the most graceful and beautiful of the group. They are so swift and quick in their motions that they have little fear of enemies. They live and burrow in the open valleys, where they catch kangaroo rats and small rodents, dig ample burrows in sandy banks, or borrow old badger holes to live in. They are so gentle and unsuspicious that they quickly melt away before settlements and frontier civilization with its dogs, traps, guns, and poison. Only in wide areas of extreme 
deserts can they be found today, and tomorrow they will be gone. Gentle intelligent, and affectionate as any dog, they have a brightness and keenness that should make them most attractive pets. The two that the writer has had in captivity for brief periods have thrilled him with their expressive eyes and their quick confidence, alertness, and intelligence. Why not keep such animals instead of cats and dogs and save a few from extermination?

\section{UROCYON CINEREOARGENTEUS TOWNSENDI MERRIAM}

Oregon Gray Fox; Treel Fox; Sketch-LOO-IS of the Klamath (C. H. M.)

Urooyon californicus townsendi Merriam, North Amer. Fauna No. 16, p. 103, 1899.

Type-Collected at Baird, Shasta County, Calif., by C. H. Townsend, November 11, 1893.

General characters.-Slightly smaller than the red fox, with relatively shorter legs, smaller ears, longer and more curved claws, and shorter, coarser fur. Skull with conspicuous widely separated temporal ridges. Tail laterally compressed and with dorsal crest. Winter pelage, upper parts dark pepper and salt gray, the white and black-tipped outer hairs obscuring the wood-brown underfur; muzzle and top and tip of tail black; back of ears, sides, legs, and under surface of tail bright tawny or hazel brown; throat, breast, and back of belly white. Summer pelage, lighter gray with brighter, more orange sides and legs; nursing females have pinkish fur on belly. Young, black or dusky at birth, soon showing buffy bellies and pattern of adults; tip of tail always black.

Measurements.-Adult male from type locality: Total length, $1,030 \mathrm{~mm}$; tail, 390 ; foot, 145; ear (dry), 65 . Skull: Basal length, 118; zygomatic width, 70. Weight $4 \frac{1}{2}$ to $101 / 2$ pounds.

Distribution and habitat.-The gray fox ranges the Upper Sonoran Zone valleys of northern California and north through the interior valleys of western Oregon to the Columbia (fig. 65). It is

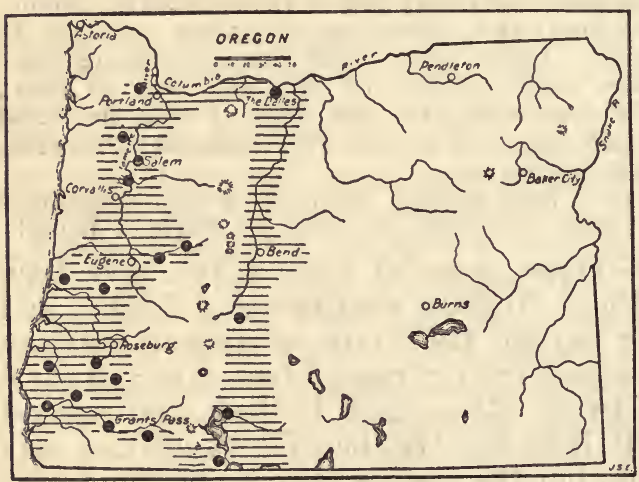

Figure 65.-Range of the gray fox, Urocyon cinereoargenteus townsendi, in Oregon. common in the Rogue River and Umpqua Valleys, and a few are recorded as far north as Portland. In 1855 Suckley and Gibbs reported them as common on the Klamath River and as occurring at The Dalles $(1860, p .113)$, and recently some bones were found in Skeleton Cave near Bend on the east side of the Cascades. A few skins were found in a closet of the fur house at Fort Vancouver, Wash., but these were thought to have come from southern Oregon. Usually the gray fox is found in open timber or chaparral valleys and especially in rocky situations in Upper Sonoran Zone.

General habits.-In motions these little foxes are exceedingly quick at dodging and turning but not very swift in a race, so they must of necessity take advantage of rocky or brushy cover, or when hard pressed, even take refuge up the first tree that offers escape 
from their enemies. Their curved nails enable them to climb readily, even up the straight trunks of moderate-sized trees, and hide among the branches, out of reach, and often out of sight, of the hounds. They have a sharp little bark much like that of a very small dog.

Their dens are usually among broken rocks or in hollow logs or trees where entrance is barred to any larger animal. A favorite situation is some crack or narrow opening well up the side of a ledge or cliff that promises comparative safety from molestation.

Breeding habits.-Breeding females have 6 or 8 mammae, and 6 and 7 young have been recorded in litters. The young are born in April or May, and both parents are said to take part in caring for them.

Food habits.-Like other foxes, these animals are hunters of small game, rodents, rabbits, game birds, and such small birds as they can catch, but even more than other foxes they depend on berries and fruit for a large part of their food. Berries of manzanita, juniper, cascara, and blueberries form a large part of their food, as shown by the droppings along the trails where they travel, but many other fruits, and feathers, hair, and bones are found in their pellets. They feed on mice, gophers, kangaroo rats, wood rats, ground squirrels, chipmunks, brush rabbits, and often trouble the mammal collector by robbing his traps of small rodents. On occasion they feast also on birds, grasshoppers, beetles, grapes, figs, prunes, cherries, apples, or any accessible cultivated fruits and capture poultry that is not protected.

Economic status.-These foxes undoubtedly have considerable value in rodent control, but this is perhaps balanced by their destruction of useful birds and small game. Their destruction of poultry, and possibly of lambs is probably also balanced by their value as fur-bearing animals. Fortunately trapping usually keeps their numbers down to a harmless minimum and few complaints of damage are received.

Family MUSTELIDAE: Weasels, Minks, Martens, Wolverines, Otters, Skunks, and Badgers

\section{MUSTELA LONGICAUDA ARIZONENSIS (MEARNS)}

Mountain Weaser; Arizona Weasel; KetCH-Ketch of the Klamath (C. H. M.)

Putorius arizonensis Mearns, Amer. Mus. Nat. Hist. Bull. 3:234, 1891.

Type.-Collected 10 miles south of Flagstaff, Ariz., by E. A. Mearns, June 20, 1886.

General characters.-Rather small (pl 42, A), form long and slender, with short legs, long tail, low, wide ears, and small bright eyes. Claws sharp and moderately curved for climbing; fur thin and harsh in brown summer coat, soft and even in white winter coat; tip of tail with brush of long stiff hairs always black; skull short and wide with short, deep audital bullae. Anal glands well developed and secreting a strong musky fluid. Summer pelage, upper parts light snuff brown, darkest on face and nose; lower parts broadly rich buffy yellow, paler on chin and toes; tip of tail black for about $1 \frac{1}{2}$ inches. Winter pelage pure white except for black tip of tail and a slight yellowish tinge to belly, and usually a buffy strain on tail and hind feet.

Measurements.-Adult male from Springerville, Ariz.: Total length, $363 \mathrm{~mm}$; tail, 140 ; foot, 41 ; ear (dry), 20 . Of female, type : $302 ; 109 ; 32 ; 19$. Weight of large female 6 ounces, of male 12 ounces.

Distribution and habitat.-These weasels, with considerable local variation, occupy the Rocky Mountain and Great Basin country 
from Arizona and New Mexico to southeastern British Columbia, and west to the eastern slope of the Sierra Nevada and Cascade Ranges (fig. 66). In the Columbia and Snake River Valleys they are as small or smaller than typical arizonensis, while in the higher valleys of the Great Basin they are almost as large and as pale as longicaudus of the Great Plains region. In fact the specimens from eastern Oregon could be sorted into longicaudus, arizonensis, and oribasus with many intermediates between these forms. Until more thorough study of the group can be made it seems best to refer the weasels of this group in eastern Oregon to arizonensis. They range from the lowest valleys to high up in the mountains, wherever food is available.

General habits.-These bold and savage little hunters cover much of the country in search of prey, ranging widely until good hunting is found and then killing and feasting on the fat of the land until

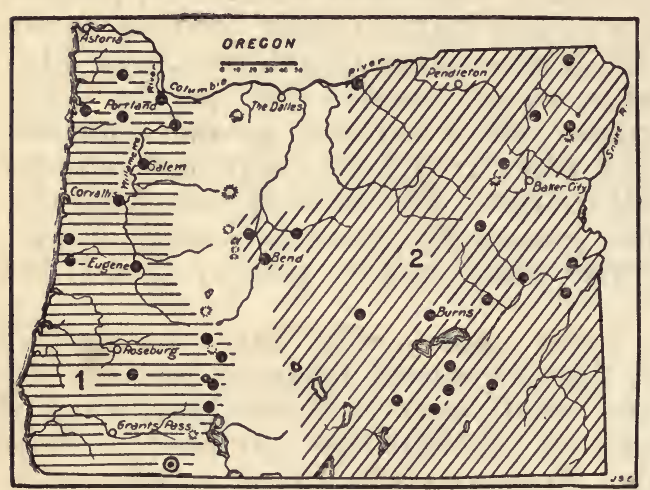

Figure 66.-Range of Cascade and Arizona weasels in Oregon: 1 , Mustela longicauda saturata; $2, M . l$. arizonensis. Type locality circled. game becomes scarce and they are urged by hunger or wanderlust to move on. Usually they are seen running from one burrow to another in the open, or along fences or logs where small mammals live, or are caught in traps in the burrows of ground squirrels, pocket gophers, kangaroo rats, wood rats, mountain beavers or in winter in traps set and baited for marten and mink. Their little paired tracks, widely spaced over the snow, are unmistakable and, either in long curving lines or intricate network of cross lines, show a well-written record of the hunt for small game.

Breeding habits.-Fortunately for other forms of small animal life weasels are not very prolific. The females have 5 or 6 pairs of mammae close together on the posterior part of the abdomen, and the litter probably numbers 5 or 6 . When about half grown the young are sometimes found following the mother. More often, though, weasels are found alone even in the breeding season, and it seems probable that they do not breed with much regularity; otherwise there would be a greater increase in numbers.

Food habits.-The food of these weasels consists largely of mice, gophers, ground squirrels, wood rats, young rabbits, and occasionally birds. When game is abundant they eat the blood and some choice parts and often kill far more than they can make good use of, apparently for the pleasure of killing. Their slender form enables them to enter burrows of such small animals as ground squirrels and pocket gophers and capture the occupants, feast upon them, and then use their nests and burrows as comfortable homes. The young of such animals as well as the adults, trapped without possibility of escape, 

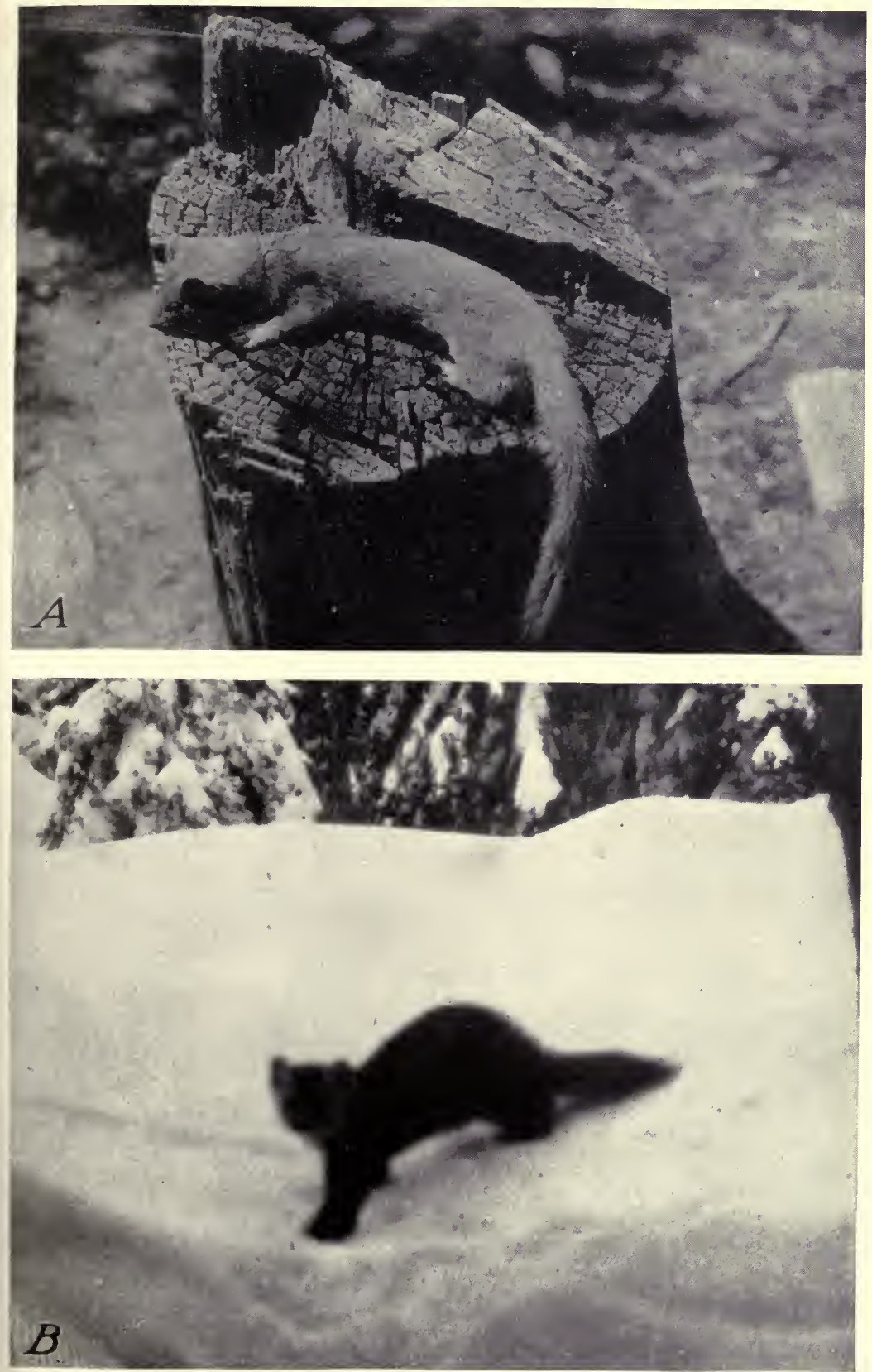

B4621M: B4620M

A, Arizona weasel in Yellowstone Park (photograph by C. O. Schneider, July 12, 1924); B, Rocky Mountaín marten in full winter fur, Glacier National Park, Mont. (courtesy of Ranger James Brooks). 

are killed and eaten. With all their abundance of easily procured food the weasels rarely show any signs of fat, being usually very thin and muscular.

Economic status.-Occasionally a weasel gets into an unprotected chicken house and kills young chickens or even some of the old hens. This is remembered for a whole generation, while their constant check on the overabundance of destructive rodents is unknown or little noticed. Their destruction of poultry is usually preventable, however, and should not be given undue importance. To what extent they destroy quail, grouse, or other ground-nesting birds is not well known, but it is certain that they do kill some young rabbits, which locally are counted as game. As fur bearers they have a small value, good white winter skins usually bringing the trappers about 50 cents to $\$ 1$ each, sometimes forming an important part of his catch. The greatest value of weasels, however, is their holding in check the rapid increase of numerous rodent pests, thus helping to maintain an important and long-established check on abundance of meadow mice, ground squirrels, and other small rodents.

\section{MUSTELA LONGICAUDA SATURATA (MERRIAM)}

\section{Cascade Weasel}

Putorius saturatus Merriam, North Amer. Fauna No. 11, p. 21, 1896.

Type-Collected at Siskiyou, near southern boundary of Oregon, by Clark P. Streator, June 6, 1894.

General characters.-Slightly larger than typical arizonensis, colors darker and richer, skull relatively short and wide with short, deep audital bullae. Summer pelage, upper parts dark snuff brown, darkest on face with occasionally a white spot or specks between eyes; lower parts rich clay or ochraceous buff; tip of tail always black. Winter pelage pale wood brown with lighter underfur, darker face, and black tip of tail; lower parts whitish or tinged with pale yellowish posteriorly. If a white winter pelage occurs locally, it has not been recorded.

Measurements.-Adult male, type: Total length, $402 \mathrm{~mm}$; tail, 154; foot, 46 ; ear (dry), 20. Female from Anchor, Oreg.: $339 ; 123 ; 39 ; 16$.

Distribution and habitat.-The Cascade weasel ranges over northwestern California to southwestern British Columbia, west of the Cascades (fig. 66). Specimens from Hornbrook, Fort Klamath, and Mount Mazama are intermediate and could almost as well be referred to arizonensis. The darkest specimens are from Salem and other localities in the coast country.

General habits.-The type of this weasel was taken in a trap set in an Aplodontia burrow, a favorite run for all weasels in this region. At the type locality in June 1897, A. K. Fisher called 3 of them out of the thick brush by squeaking, and shot 1 of them with his cane gun, but they would not come to his traps set and baited especially for weasels. In the timbered country where they live, relatively few specimens have been taken and their habits have been but rarely observed. There is no reason to suppose that their habits differ greatly from those of the more widely distributed and better-known arizonensis except as the animals have adapted themselves to a mild climate and humid habitat of timber and brush land.

$7209^{\circ}-36-19$ 
where dense cover and dark soil have left their indelible stamp of color intensity. Ranging from southwestern British Columbia to southern Oregon west of the Cascades, they are typical only in the low country (fig. 68).

General habits.-Like other weasels the Puget Sound weasels are wanderers and hunters of small game, the size of the game being limited only by their power to overcome and kill it. Mice, gophers,

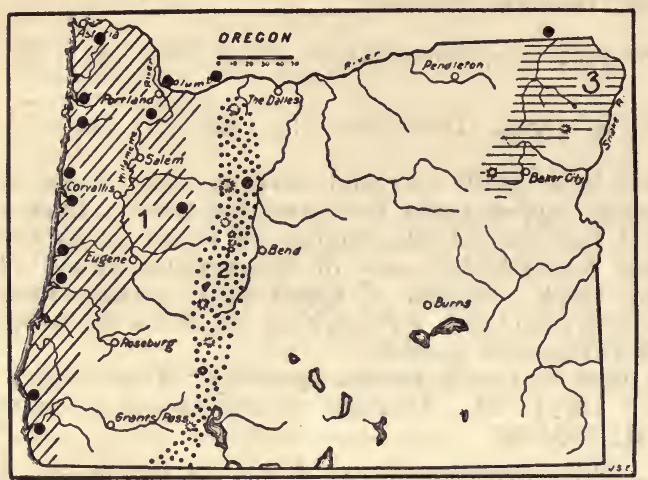

FIGURD 68.-Range of the three small weasels in Oregon: 1, Mustela cicognanii streatori; $2, M . c$. muricus; 3, M. c. leptus. chipmunks, and the young of larger species of rodents evidently constitute most of their prey and usually are to be found in abundance. If game is scarce in one locality the weasels hurry away to other and better hunting grounds, or add more energy and speed to their search until blood and meat satisfy their rapacious appetites. Too small to be a menace to poultry or game, or to be of value for fur, they can go on destroying small rodents with little danger of interference by man. However, many are caught in traps set for the more valuable fur bearers, and perhaps in this way their abundance may be seriously curbed.

\section{MUSTELA CICOGNANII MURICUS (BANGs)}

\section{Sierra Least Weaset}

Putorius (Arctogale) muricus Bangs, New England Zool. Club Proc. 1: 71, 1899.

Type.-Colfected at Echo, El Dorado County, Calif., adult male, by W. W. Price and E. M. Nutting, July 15, 1897.

General characters.-Very small, the smallest weasel at present known in Oregon; skull long and narrow, bullae long and continuous with inflated squamosals; tail rather short; lower parts broadly white. Summer pelage: Upper parts light chocolate brown (close to natal brown of Ridgway); lower parts broadly white, including upper lips, toes, and inside of legs; tip of tail for about 1 inch black. Winter pelage unknown but probably all white except black tip of tail.

Measurements.-Of adult male type from Echo, Calif.: Total length, $220 \mathrm{~mm}$; tail, 60 ; foot, 31 . Adult male from Warm Springs, Oreg.: $235 ; 68 ; 30$. A female from Siskiyou County, Calif., recorded by Kellogg, measured 210; 55; 27. Weight of male 54.5 g (Grinnell, Dixon, and Linsdale 1930, p. 463).

Distribution and habitat.-The only specimen of this little weasel from Oregon was taken at Mill Creek about 20 miles west of Warm Springs, on the east slope of the Cascades, by Stanley G. Jewett, May 7, 1915 (fig. 68). It is in brown summer coat, slightly larger and darker than typical muricus, suggesting the first step of gradation toward streatori. Two specimens from Siskiyou County, Calif., were identified by Kellogg as muricus, and an unsexed skull from Fort Klamath if a male, is muricus; if a female, streatori. 
General habits.-Little is known of the habits of these little weasels, but it is fair to infer that they do not differ greatly from those of streatori or cicognanii. Because of their small size it is probable that their prey is chiefly mice, as was assumed by the author of the name muricus-a mouser. At present it is not known that they turn white in winter, but from the high altitude of their habitat this seems probable.

\section{MUSTELA CICOGNANII LEPTUS (MERRIAM)}

\section{Rocky Mountain Least Weasei}

Putorius streatori leptus Merriam, Biol. Soc. Wash. Proc. 16: 76, 1903.

Type.-Collected at Silverton, San Juan County, Colo., by J. Alden Loring in 1893.

General characters.-Very small; tail short with well-developed pencil; skull light and smooth, relatively shorter and wider than in muricus or streatori, with inflated bullae and mastoids. Summer pelage, upper parts drab brown, lacking the reddish or hazel; tip of tail black; toes and whole lower parts white, or yellowish white posteriorly. Winter pelage pure white or greenish white all over except black tlp of tail.

Measurements.-Type, male: Total length, $243 \mathrm{~mm}$; tail, 64 ; foot, 31 . Female: $195 ; 50 ; 26$.

Distribution and habitat.-Ranging the Rocky Mountain region of the United States, south to northern New Mexico and west to the Blue Mountains of southeastern Washington, these weasels usually are found in Canadian Zone (fig. 68). There seems to be no definite record for Oregon; but a specimen taken by L. R. Dice on Butte Creek, Walla Walla County, Wash., was within a few miles of the Oregon line, and undoubtedly the species occurs throughout the Blue Mountain section, where tracks of a tiny weasel are reported.

\section{LUTREOLA VISON ENERGUMENOS (BANGS) ${ }^{11}$}

Western Mink; Pahuna-Ah of the Burns Piute; Adete of the Wasco; KLA-PA of the Klamath (C. H. M.)

Putorius vison energumenos Bangs, Boston Soc. Nat. Hist. Proc. 27 : 5, 1896.

Type.-Collected at Sumas, British Columbia, by Allan C. Brooks, September $23,1895$.

General characters.-Form long and low, somewhat weasellike but heavier bodied; feet fully webbed for swimming; ears low and wide; eyes small; nose pointed; outer hairs coarse and lax; underfur dense, soft, and fine; tail about one-third of total length, heavily furred and without long terminal pencil or brush as in the weasels; anal glands secreting unmistakable mink odor. Nearly uniform dark brown all over. Adults in summer pelage, dull chestnut brown, fading to almost rusty brown, sometimes with white streaks on chin, breast, or belly; tail blackish toward tip. Young dark chocolate brown or blackish. Winter pelage full and soft, bright chestnut brown with blackish tail and the same white markings as in summer.

Measurements.-A large male near Mount Jefferson: Total length, $615 \mathrm{~mm}$; tail, 211; foot, 72; ear from basal notch to tip of upper rim, measured dry, 20. Adult female from Beaverton: $503 ; 157 ; 61 ; 18$. Weight of males about 2 to 4 pounds, females considerably less.

11 In retaining the genus Lutreola Wagner, 1841, rejected by recent authors on the ground that the minks are not generically separable from the weasels of the older genus Mustela, the writer is not passing final judgment on the value of generic characters beyond our North American species of the two genera. Such a decision must wait a final thorough revision of the Mustelidae of the world, which may show radical changes necessary in the nomenclature of the group. Such studies may even reveal intermediate characters in some remote part of the earth, between the two genera. In our own species, however, the differences between the minks and weasels are certainly as great as those separating many other of our recognized genera. 
where dense cover and dark soil have left their indelible stamp of color intensity. Ranging from southwestern British Columbia to southern Oregon west of the Cascades, they are typical only in the low country (fig. 68).

General habits.-Like other weasels the Puget Sound weasels are wanderers and hunters of small game, the size of the game being limited only by their power to overcome and kill it. Mice, gophers,

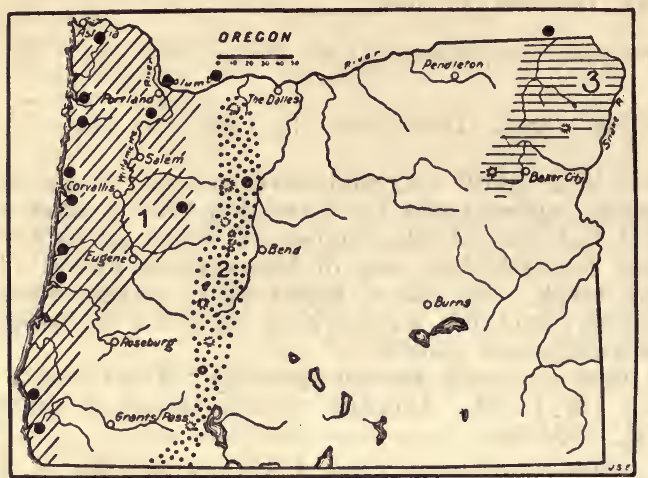

Figure 68.-Range of the three small weasels in Oregon: 1, Mustela cicognanii streatori; 2, M. c. muricus; 3 , M. c. leptus. of interference by man. However, many are caught in traps set for the more valuable fur bearers, and perhaps in this way their abundance may be seriously curbed.

\section{MUSTELA CICOGNANII MURICUS (BANGB)}

\section{Sterra Least Weaset}

Putorius (Arctogale) murious Bangs, New England Zool. Club Proc. 1: 71, 1899.

Type.-Collected at Echo, El Dorado County, Calif., adult male, by W. W. Price and E. M. Nutting, July 15, 1897.

General characters.-Very small, the smallest weasel at present known in Oregon; skull long and narrow, bullae long and continuous with inflated squamosals; tail rather short; lower parts broadly white. Summer pelage: Upper parts light chocolate brown (close to natal brown of Ridgway); lower parts broadly white, including upper lips, toes, and inside of legs; tip of tail for about 1 inch black. Winter pelage unknown but probably all white except black tip of tail.

Measurements.-Of adult male type from Echo, Calif.: Total length, $220 \mathrm{~mm}$; tail, 60 ; foot, 31 . Adult male from Warm Springs, Oreg.: 235 ; 68; 30. A female from Siskiyou County, Calif., recorded by Kellogg, measured $210 ; 55 ; 27$. Weight of male $54.5 \mathrm{~g}$ (Grinnell, Dixon, and Linsdale 1930, p. 463).

Distribution and habitat.-The only specimen of this little weasel from Oregon was taken at Mill Creek about 20 miles west of Warm Springs, on the east slope of the Cascades, by Stanley G. Jewett, May 7, 1915 (fig. 68). It is in brown summer coat, slightly larger and darker than typical muricus, suggesting the first step of gradation toward streatori. Two specimens from Siskiyou County, Calif., were identified by Kellogg as muricus, and an unsexed skull from Fort Klamath if a male, is muricus; if a female, streatori. 
General habits.-Little is known of the habits of these little weasels, but it is fair to infer that they do not differ greatly from those of streatori or cicognanii. Because of their small size it is probable that their prey is chiefly mice, as was assumed by the author of the name muricus-a mouser. At present it is not known that they turn white in winter, but from the high altitude of their habitat this seems probable.

\section{MUSTELA CICOGNANII LEPTUS (MERRIAM)}

\section{Rocky Mountain Least Weased}

Putorius streatori leptus Merriam, Biol. Soc. Wash. Proc. 16: 76, 1903.

Type.-Collected at Silverton, San Juan County, Colo., by J. Alden Loring in 1893.

General characters.-Very small; tail short with well-developed pencil ; skull light and smooth, relatively shorter and wider than in muricus or streatori, with inflated bullae and mastoids. Summer pelage, upper parts drab brown, lacking the reddish or hazel; tip of tail black; toes and whole lower parts white, or yellowish white posteriorly. Winter pelage pure white or greenish white all over except black tip of tail.

Measurements.-Type, male: Total length, $243 \mathrm{~mm}$; tail, 64 ; foot, 31 . Female : $195 ; 50 ; 26$.

Distribution and habitat.-Ranging the Rocky Mountain region of the United States, south to northern New Mexico and west to the Blue Mountains of southeastern Washington, these weasels usually are found in Canadian Zone (fig. 68). There seems to be no definite record for Oregon; but a specimen taken by L. R. Dice on Butte Creek, Walla Walla County, Wash., was within a few miles of the Oregon line, and undoubtedly the species occurs throughout the Blue Mountain section, where tracks of a tiny weasel are reported.

\section{LUTREOLA VISON ENERGUMENOS (BANGS) ${ }^{11}$}

Western Mink; Pahuna-AH of the Burns Piute; Adete of the Wasco; Kra-PA of the Klamath (C. H. M.)

Putorius vison energumenos Bangs, Boston Soc. Nat. Hist. Proc. 27 : 5, 1896.

Type.-Collected at Sumas, British Columbia, by Allan C. Brooks, September 23,1895 .

General characters.-Form long and low, somewhat weasellike but heavier bodied; feet fully webbed for swimming; ears low and wide; eyes small; nose pointed; outer hairs coarse and lax; underfur dense, soft, and fine; tail about one-third of total length, heavily furred and without long terminal pencil or brush as in the weasels; anal glands secreting unmistakable mink odor. Nearly uniform dark brown all over. Adults in summer pelage, dull chestnut brown, fading to almost rusty brown, sometimes with white streaks on chin, breast, or belly; tail blackish toward tip. Young dark chocolate brown or blackish. Winter pelage full and soft, bright chestnut brown with blackish tail and the same white markings as in summer.

Measurements.-A large male near Mount Jefferson: Total length, $615 \mathrm{~mm}$; tail, 211; foot, 72; ear from basal notch to tip of upper rim, measured dry, 20. Adult female from Beaverton: $503 ; 157 ; 61 ; 18$. Weight of males about 2 to 4 pounds, females considerably less.

if In retaining the genus Lutreola Wagner, 1841, rejected by recent authors on the ground that the minks are not generically separable from the weasels of the older genus Mustela, the writer is not passing final judgment on the value of generic characters beyond our North American species of the two genera. Such a decision must wait a final thorough revision of the Mustelidae of the world, which may show radical changes necessary in the nomenclature of the group. Such studies may even reveal intermediate characters in some remote part of the earth, between the two genera. In our own species, however, the differences between the minks and weasels are certainly as great as those separating many other of our recognized genera. 
Distribution and habitat.-Mink are fairly common along most of the streams, lakes, and coast lines of Oregon and absent only from the high mountains and deserts or waterless areas (fig. 69). Semiaquatic in habits, they follow streams, getting much of their food from the water, and hence are mainly restricted to areas of permanent water supply. They show no preference for timber or open country, as marshes with tall grass, reeds, and tules afford ample shelter and protection. They are equally at home though in the forests or wherever a satisfactory food supply is found. Their abundance depends largely on the price of fur and the energy with which trapping is carried on. No matter how thoroughly trapped out, they seem always to return and to increase slowly. Few of our fur bearers have held their own so successfully against the inroads of civilization.

General habits.-Mink

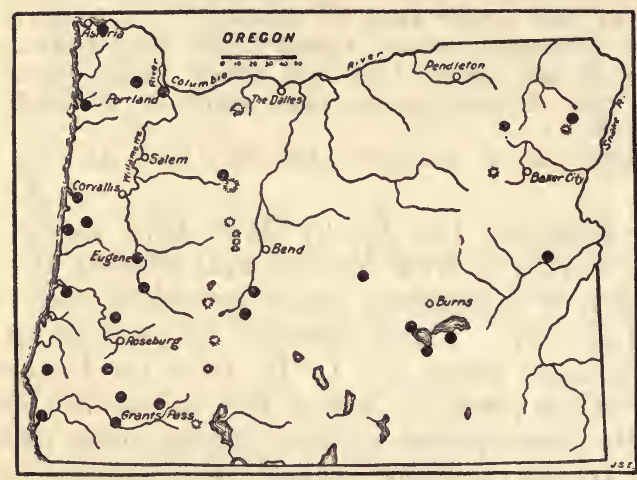

Figure 69.-Range of the minls, Lutreola vison energumenos, in Oregon. are well adapted by their dense fur and webbed feet to a semiaquatic life. 'Their robust form and unusual fighting powers fit them also for life on land. Their keen, well-curved nails enable them to take refuge or pursue prey into the treetops. Often they are treed at night by dogs hunting raccoons, and only with difficulty dislodged from the topmost branches of the tree. They are great travelers overland, but usually follow along the banks of a stream or on the ice or snow above its frozen surface, where they hunt under the banks and in hollow trees and logs for the small game that makes up much of their food. In the water they are nearly as much at home as the otter, swimming rapidly, diving, and remaining under to pursue and capture fish, frogs, and crustaceans or to escape from enemies by keeping below the surface until well out of sight. If pursued they always take refuge in the water, if possible, unless a deep burrow or hollow log or tree is available close by. In a burrow or hollow log or tree they are "bad medicine" for any dog that tries to get hold of them, for, of the weasel family, they are far quicker than any dog and always get the first hold, usually of the dog's nose or lip, in a way to fully command the situation. As fighters they perhaps have no superiors of their own size, and even in the open, a mink will often severely punish a dog of many times its size and send the dog home with a bloody face and a sad heart. The mink has a savage scream with which it threatens a dog or even a person coming near its retreat, and in the cruel jaws of a steel trap a mink will scream and fight to the last, never yielding its valuable pelt without a fierce struggle for life. Hunters and merciless killers themselves, they seem to have little sense of fear and great confidence in their own strength and skill. In domestication they are said to be gentle and affectionate pets, running at large on friendly terms with the dogs, cats, and poultry. 
Breeding habits.-Apparently the mink breeds but once a year, the 6 or 8 young being born in April or May and attaining maturity during the following winter. The young are kept in some burrow or hollow under rocks or logs until old enough to follow the mother, who hunts and brings them food before they are old enough to travel. The polygamous male apparently takes no interest in his family or is kept away by fear of the keen teeth of the mother mink.

Food habits.-From the water minks obtain fish, frogs, and crustaceans, the latter being apparently their favorite food, and where abundant, as in western Oregon, their principal food for the year around. Other small game such as muskrats, mice, ground squirrels, chipmunks, and birds in varying numbers form a part of the bill of fare. Undoubtedly some game birds are killed and some nests destroyed, as poultry is occasionally attacked and on rare occasions ruthlessly killed and left lying. In case of a raided poultry yard or any unusual supply of such food, apparently the blood only is taken, but normally the game is eaten-bones, feathers, fur, scales, shells, and all-as shown by the traces left in the droppings near the dens or along the shores.

Economic status.-On rare occasions there are complaints of serious destruction of poultry by mink, but these are of local and infrequent occurrence, and in most cases could be easily prevented. Some game birds and nests and such small game as rabbits and squirrels and some fish are undoubtedly destroyed by them, but a constant check on the abundance of destructive rodents serves to counterbalance in part these losses, while the value of the fur far outweighs all losses through their depredations. During the trapping season of November 1 to February 28, 1913-14, 2,466 mink were taken in Oregon, according to the records of the State Game Commission. These at an average price of $\$ 3.25$ would bring into the State more than $\$ 8,000$. The mink is one of the most permanent and valuable fur bearers of the State, and the least likely to be exterminated. Still they require careful protection to keep the numbers up to the maximum, and to insure that they are taken only when prime, in the 3 winter months.

\section{MARTES CAURINA CAURINA (MERRIAM)}

Pacifio Marten; American Sable; Pap of the Klamath (C. H. M.)

Mustela caurina Merriam, North Amer. Fauna No. 4, p. 27, 1890.

Type.-Collected near Grays Harbor, Wash., February 4, 1886, by L. C. Toney.

General characters.-In size about the same as the mink, but apparently larger because of longer legs, tail, and ears, longer fur, and especially more bushy tail ; upper teeth 18 , lower 20 , instead of 16 and 18, as in the mink and weasels ; nails, slender, sharp, and well curved for climbing; toes webbed only at base; males with elongated gland on belly; summer pelage thin and harsh, winter fur long, fine, and silky. Color about the same in summer and winter, upper parts light or dark yellowish brown, near snuff brown or raw umber, slightly paler on head and shoulders, darker or blackish on tail and feet; throat and breast and sometimes back of belly varying from yellow to rich orange.

Measurem'ents.-A large male: Total length, $600 \mathrm{~mm}$; tail, 203 ; foot, 92 ; ear, (dry ), 38. Female: $597 ; 206 ; 83 ; 35$. Basal length of skull, 76 ; zygomatic breadth, 72. Weight of one male, from Three Sisters, 2.5 pounds. 
Distribution and habitat.-This western form of the marten ranges from southern British Columbia to northern California through the Cascades and coastal area of Washington and Oregon (fig. 70). Specimens from southern Oregon are included but are grading toward Martes caurina sierrae characterized by Grinnell and Storer from the Sierra Nevada. In Oregon they are found mainly in Canadian and Hudsonian Zones of the mountains, and in the humid mixed zones of the coast and Coast Ranges.

General habits.-Martens are primarily forest dwellers, ranging mainly in the dense coniferous forests where they travel widely in search of small game. They are expert climbers and will leap from tree to tree in pursuit of their prey, or stalk it on the ground among the logs and undergrowth, or even range among the bare rocks high

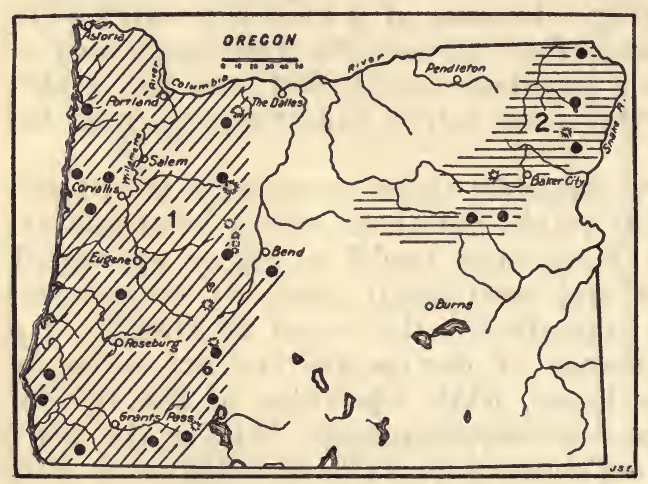

FIGURE 70.-Range of the two forms of martens in Oregon: 1 , Martes caurina caurina; $2, M . c$. origenes. above timber line in search of conies. While mainly nocturnal they are often active during the day and seem to see well even in bright sunlight, and consequently do their hunting by night or day whenever they feel the urge of hunger. Where really common they are occasionally seen running over logs or up trees inalarmat passersby, but generally they are so scarce as to be rarely seen, except when caught in traps. Their nests and such temporary homes as they may claim are in hollow trees or logs, or among the rocks, but outside of the breeding season they seem to be wide wanderers with many temporary camps and shelters. In winter their unmistakable diagonally paired tracks, much larger than those of the mink, are occasionally seen leading from grove to grove or through brush patches where rabbits and grouse might be found, over hilltops or through deep woods in the manner of foxes or weasels rather than along the watercourses where the mink and otter hunt.

Breeding habits.-Female martens have usually 2 or 3 pairs of well developed mammae on the posterior, abdominal or inguinal region, and there are records of $2,3,4,5$, and 6 embryos or young. The young are born generally in April, May, or June. On June 19, 1889 , T. S. Palmer secured a young one only a few days old near Crescent City, Calif., taken from its mother by a farmer as she carried her young in her mouth, one at a time, across the road. The young are said to develop slowly but are half grown and out of the nest by the middle of July.

Food habits. - Martens might be called omnivorous carnivores, for they capture a great variety of small game, largely mice, chipmunks, squirrels, wood rats, conies, and rabbits, as well as any birds that come in their way, and they even feast on some insects and berries if these are numerous. The stomachs of two caught in August 1896 at 
Crater Lake were filled with big brown, wingless crickets (Cuphodirris piperi) which were also found in one collected near Three Sisters Peaks in July 1914. Feathers of birds and fur conies and other small rodents were also found in their stomachs, and birds, squirrels, chipmunks, rats, and mice are excellent bait for marten traps. Traps set in the runways and burrows of mountain beaver sometimes catch martens, and it is probable that the mountain beaver and pocket gophers are on their bill of fare. Fish are said to be good trap bait for martens, but it is doubtful if fish are caught or taken from the water by them. Food is generally abundant, but martens rarely show any signs of fat and are generally as lean and muscular as the mink or weasel.

Economic status.-According to the Oregon Sportsman for June 1914, 518 martens were taken during the previous winter, November 1 to February 28, by the registered trappers in Oregon. Of these, 88 skins were taken in Klamath County; 87 in Union County; 82 in Grant County; 60 in Curry County; 41 in Baker County; 23 in Umatilla County; 22 in Douglas County; 21 in Lane County; 19 in Crook County; 18 in Multnomah County; 15 in Lincoln County; 14 in Wallowa County; and smaller numbers in other counties in the State. At the current price of trappers' skins, about $\$ 25$ each, these brought into the State nearly $\$ 13,000$, about the same as was received for the greater number of skins of mink.

Martens are not destructive to poultry and not seriously so to game. The beauty and high price of their fur make them one of the most important fur-bearing animals of Oregon.

\section{MARTES CAURINA ORIGENES (RHOADS)}

\section{Rocky Mountain Marten}

Mustela caurina origenes Rhoads, Acad. Nat. Sci. Phila. Proc., p. 458, 1902.

Type.-Collected at Marvine Lodge, Garfleld County, Colo., Sept. 16, 1901, by E. T. Seton.

General characters.-Size and proportions about the same as in caurina but colors generally lighter, more drab brown with more distinctly gray head, lighter yellow or occasionally white throat patch, and light yellow traces along median line of belly ( $\mathrm{pl} .42, B$ ). Skull relatively wide with slender rostrum and the same heavy molar teeth and wide heel of back upper molar as in caurina.

Measurements.-Adult male from Colorado: Total length, $610 \mathrm{~mm}$; tail, 170; foot, 95; ear (dry), 30. Skull: Basal length, 76 ; zygomatic breadth, 49.

Distribution and habitat.-These beautiful fur bearers range from northern New Mexico through Colorado, Utah, Wyoming, and Idaho into the Blue Mountains of Oregon (fig. 70). There are specimens from Strawberry Butte and vicinity in the Biological Survey collection, and one from Cornucopia in the University of Oregon collection. In 1897 the writer found their tracks on the snow far above timber line on the Wallowa peaks, and in 1915 Jewett reported them as becoming scarce in the Wallowa Mountains, although during the previous winter of 1913-14 one trapper had taken $\$ 800$ worth of their skins in the lodgepole pine forest near Olive Lake, and the winter before that two trappers had taken 12 skins near Bourne in the Baker City Range. In 1896 a fine old male was collected on Strawberry Butte, and in 1915 Jewett took 4 specimens near there 
at Strawberry Lake. In 1919 Cantwell reported them as rare but occasionally taken by trappers in favorable places in the Sled Springs district north of Enterprise, and in the Wallowa Mountains. In the Rocky Mountains these animals are found mainly in Canadian and Hudsonian Zones of the mountain ranges.

General habits.-The habits of the martens everywhere seem to be much the same; they are boreal forest hunters of small game, expert climbers, and great travelers over the winter snow fields, and keep generally in the shelter of the forests and away from the water or open country. They are to some extent weasellike in their methods of hunting over the ground, along logs, and even up the trees after squirrels or birds. They climb rapidly and hunt Richardson's squirrels in their tree homes. Chipmunks, ground squirrels, and various mice are common prey. At Strawberry Lake, where Jewett caught a whole family of martens, the old male had a water ouzel in its stomach. Rabbits and grouse are about the largest game on their list, but mice and insects are their "daily bread" in summer, and berries in their" season are said to be a favorite food.

\section{MARTES PENNANTI PACIFICA (RhoAdS)}

\section{Pachio Fisher; Pekan; Agabastam of the Wasco}

Mustela canadensis pacifica Rhoads, Amer. Phil. Soc. Trans. (n. s.) 19: 425, 1898.

Type.-Collected at Lake Keechelus, Kittitas County, Wash., by Allan Rupert, 1892.

General characters.-Much larger than the marten, with longer tail and heavier build, nearly as large as a fox but with shorter legs, tail, and ears; tooth and cranial characters as in martens, but with heavier skull and teeth; high sagittal crest; feet heavily furred in winter; toes webbed at base only; nails sharp and curved for climbing; without the conspicuous abdominal gland of the male martens. Summer pelage thin and harsh, the coarse outer hairs hiding thin underfur. Winter fur long, light and wavy, much obscured by very long, sparse outer hairs; tail heavily furred to tip with long shiny black outer hairs. Color much the same at all seasons; upper parts variable, buffy gray or snuff brown, coarsely grizzled with black-tipped white hairs over shoulders and becoming darker or blackish over back and rump; tail, feet, nose, and back of ears black or blackish; lower parts mostly black or - blackish with often white spots on throat, breast, and in axils of front and hind legs.

Measurements._Large male: $1,013 \mathrm{~mm} ; 395 ; 128 ; 41$. Weight 10 pounds 2 ounces. Other weights given up to 12 and 18 pounds.

Distribution and habitat.-The fisher of the Cascades extends from British Columbia south through Washington and Oregon to northern California and also through the Coast Ranges (fig. 71). No specimens have been seen from the Blue Mountain section, but provisionally the records are included under this name. Like the martens, they are boreal in habitat, but in Oregon they occupy also the cool humid Coast Ranges and coniferous coastal forests. They are forest dwellers and are rarely found far from cover of spruce and pine.

General habits.-Fishers are similar to the martens in habits, being great climbers and hunters, pursuing their prey on the ground or to the tops of the tallest trees, and even making long leaps from tree to tree in pursuit of squirrels or to escape their enemies. Their nests and breeding dens are said to be in hollow trees or hollow 
logs. They cover much country in tireless pursuit of small game but keep well concealed and are rarely seen except when caught in traps.

Breeding habits.-Seton records one litter of 3 young fishers that were taken from a hollow tree about 40 feet from the ground, and says that the number varies from 1 to 5 , born about the first of May.

Food habits.-In food habits they are similar to the martens, capturing a great variety of small game up to the size of rabbits and grouse, but depending largely on squirrels and smaller animals. They are said to be especially fond of porcupines.

Economic status.-During the trapping season of 1913-14, 9 fishers were reported to the State Game Commission by the registered trappers of the State; 3 from Lane County; 2 from Curry County; and 1 each from Douglas, Josephine, Marion, and Umatilla Counties. At that time prime

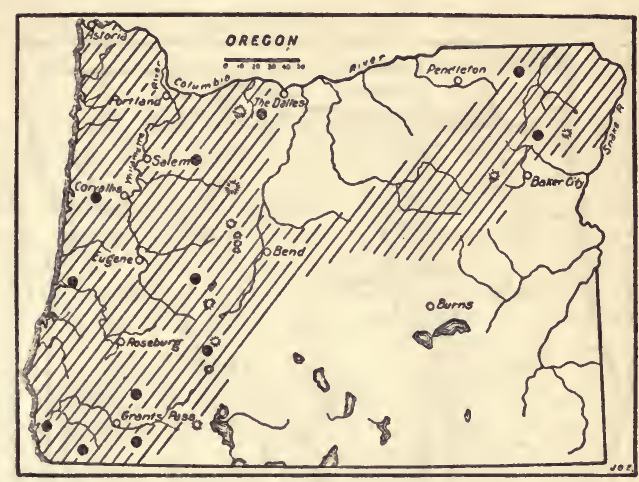

FIGURE 71.-Range of the fisher, Martes pennanti pacifica, in Oregon.

fisher skins were quoted at $\$ 25$ each, but in 1920 to 1925 they went up to $\$ 100$ and $\$ 150$ for prime skins. They form beautiful and durable garments and are sufficiently rare to be highly desirable furs.

\section{GULO LUSCUS LUSCUS (LINNAEUS)}

Wolverine; Glutton; Carcajou; Mountain Devil; Skunk Bear; Maneater

[Ursus] Iuscus Linnaeus, Syst. Nat. ed. 12, v. 1, p. 71, 1766. (Subspecies uncertain-no specimens from Oregon available for study.)

Type locality.-Hudson Bay.

General characters.-Form robust; body short and wide with powerful head, neck, and legs; ears low; legs short; tail short and bushy; toes short and webbed at base only; nails sharp and curved for climbing; skull massive and powerful; pelage long and coarse with wholly concealed short dense underfur. Pelage long and dense in winter, thin and stringy in summer. Color approximately the same at all seasons; back dark brown or blackish, almost encircled by a broad yellowish band along sides and across hips; shoulders yellowish brown or gray; crown gray back of eyes; face, nose, feet, and tail black; lower parts dark brown or blackish except throat and breast, which are usually heavily mottled with white or salmon.

Measurements.-A large male from Alaska, collected by Charles Sheldon, measured $1,070 \mathrm{~mm} ; 218 ; 190$, and weighed 36 pounds. One brought to the National Zoological Park from Cordova, Alaska, in March 1928, weighed 28 pounds. One recorded from Labrador by George Cartwright weighed 26 pounds. A large male from the Sierra Nevadas, of California, recorded by Joseph Grinnell and Storer (1924, p. 85), weighed 25 pounds.

Distribution and habitat.-Wolverines once occupied the boreal zone across the northern part of the continent and southward in the mountains to Colorado and California (fig. 72). At present they are rare in the United States, but probably are not yet extinct in the 
Cascades and Sierra Nevadas. Adolph Aschoff reported them in the Mount Hood section in 1896, and George Moody caught one in the upper McKenzie Valley west of the Three Sisters Peaks, Oreg., in 1912.

General habits.-Although of the weasel family, wolverines have much the build and habits of little bears. They are great wanderers, hunters, and scavengers, always searching for meat, and killing any kind of game that their short legs enable them to catch or corner, but actually feeding largely upon offal or the carcasses of game animals killed by hunters or found dead. Of powerful strength and

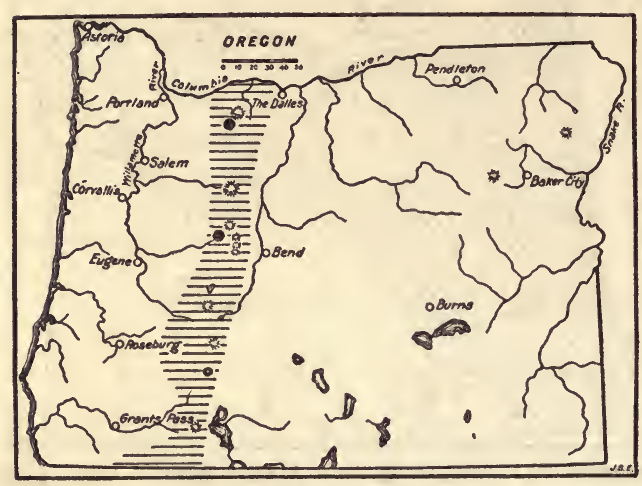

FiguiRD 72.-Range of the wolverine, Gulo luscus luscus, in Oregon. build, they do not hesitate to attack any animal, even to the caribou and moose, that they can steal upon and get a death grip upon with their powerful jaws. They seem to have no fear, even of man, but are cunning and suspicious in stealing food and avoiding traps and are bold and dangerous fighters when c ornered or captured. Fortunately for other animals of the woods and for man, their legs and bodies are short and their best

speed is but slow. Great strength and tireless energy enable them to secure food, even where it is scarce and widely scattered.

Breeding habits.-Litters of from 2 to 5 young wolverines have been recorded, born in April, May, and June. Seton says the site chosen for the young ones' home is almost any sheltered hollow in the ground or under rocks, and that in October they appear in families, the young still following their dam, though not much inferior in size. The mother is said to be savage in defense of her young and to bring them food before they are old enough to leave the nest.

Food habits.-While hunters of any large or small game which they can capture, the wolverines are credited with enormous appetites not always satisfied by the fresh kill and largely depending on dead carcasses of game found under the winter's snow or summer's sun. With keen noses they scent a feast from a distance and locate the meat or food cache of the hunter and even devour his cache of furs if by any device of skill or strength it can be broken into. Martens or any other fur-bearing animals found in traps are eaten until the trapper is sometimes obliged to move his trap line if he cannot catch the thief. The trap bait is also eaten along the trap line and the traps either avoided or sprung or broken up. A no. 4 steel trap is said to be required to hold securely a wolverine, and the no. 1 traps set for marten and mink only educate him to greater caution in avoiding such devices.

Economic status.-Wolverine skins have never brought high prices for fur, the 1923 quotations for prime skins being only $\$ 6$ to $\$ 8$ 
each. They are in great demand by the Eskimo for trimming hoods but among whites are used mainly for sleigh robes and heavy overcoats in the coldest parts of the Northern States. Occasionally a beautiful muff made from a single skin is seen. The fur is warm and durable, and the long glossy hairs and unique color pattern give it a distinguished appearance.

\section{LUTRA CANADENSIS PACIFICA RHOADS}

Western Otter; Pahtsugo of the Piute at Burns; Nannocks of the Wasco; Kolta of the Klamath (C. H. M.)

Lutra hudsonica pacifica Rhoads, Amer. Phil. Soc. Trans. (n. s.) 19:429, 1898.

Type.-Collected at Keechelus Lake, Kittitas County, Wash., by Allan Rupert in 1892 or 1893.

General characters.-Appearance somewhat minklike but in size many times larger than the mink; body long and low with short legs; long, tapering, flattened tail; small head; small eyes and ears; hind feet large and fully webbed; front feet half webbed, soles mainly naked; fur dense and silky, wholly concealed by short glossy guard hairs. Color, dark chestnut brown, slightly paler below and with grayish-brown throat and cheeks. In summer pelage fading to lighter, more hazel brown. Young much the same as adults. Larger than typical canadensis with heavier skull and more gray on throat and cheeks.

Measurements.-Of old female from Birch Creek, Idaho: Total length, 1,150 $\mathrm{mm}$; tail, 463 ; foot, 137 ; ear, 21 . Weight 19 pounds. There are other records of otters weighing $20,23,25$, and 28 pounds, but not all of these can be verified.

Distribution and habitat.-Otters formerly occupied practically all permanent streams and lakes in Oregon and after 100 years of trapping are still found sparingly in many of them (fig. 73). Climate, altitude, and life zones are wholly ignored by these aquatic hunters and fishers, fresh water and an abundant food supply being all they ask anywhere between the Tropics and Arctic regions.

General habits.Adapted to life in both the water or on land, otters seem to prefer the water. They swim with the graceful motions of a fish or seal and with great speed, capturing most of their prey, fish, frogs, or

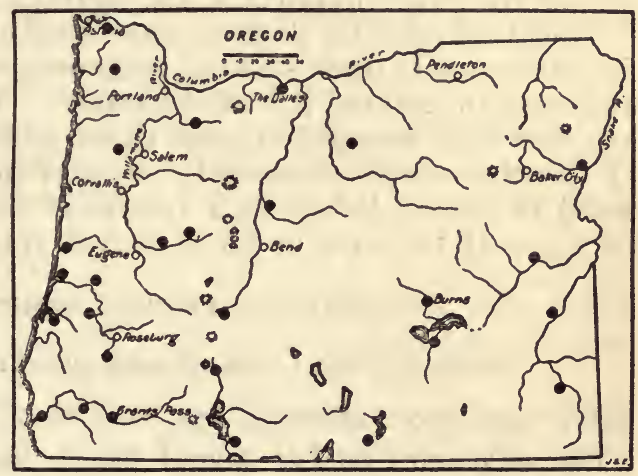

Figure 73.-Range of the western otter, Lutra canadensis pacifica, in Oregon.

crustaceans, in the water and eating them on the shore or on rocks and logs. They are great travelers, making long rounds up one stream and down another, or short trips overland to lakes or other streams. On bare ground they have a slow awkward gait and rarely go far from the water, but in soft snow they travel rapidly in long slides on their glossy bellies and sometimes strike off for several miles across country to some little-frequented stream or lake. They are gentle, playful animals with little of the savage disposition of the weasels and are easily tamed and make affectionate pets. They are savage fighters when cornered and more than a match for most dogs. 
Breeding habits.-Female otters have 4 mammae arranged in 2 pairs on the posterior part of the abdomen, and the young are usually 2,3 , or 4 , the normal litter of fully adult females numbering 4 . In the far north the young are born in April (Richardson 1829, p. 58), but the time is much earlier in southern latitudes. Overton Dowell. Jr., of Mercer, Lane County (Oreg. Sportsman, 1917, p. 15), says that otters have 2 to 4 young in May.

Food habits.-Otters feed on fish, frogs, crustaceans, snakes, birds, small mammals, or almost any small game they can catch. Fish and crawfish generally form most of their food, as shown by fish scales and bits of crawfish shells in the droppings along otter slides, or on the banks of streams where they come out to feed and roll. As their food is generally abundant and easily procured, they have ample leisure for sleep and play.

Economic status.-In 1805 Lewis and Clark reported otters plentiful along the "Multnomah" [Willamette] River, and in 1825 Ogden $(1909, p .344)$, recorded in his journals the frequent capture of otters by his beaver trappers in eastern Oregon. Next to the beaver they were perhaps the most important fur animal of that time. In 1914 (Oreg. Sportsman, 1914, p. 20), it was reported that 143 otters were taken in the State by licensed trappers during the open season, November 1 to February 28, of the preceding winter; of these, 37 were taken in Douglas County; 21 in Coos County; 12 in Klamath County, and lesser numbers in other parts of the State. At that time prime skins of Pacific coast otters were quoted at $\$ 11$ to $\$ 17$ each. The fact that otters have so long been able to maintain considerable numbers in the face of persistent trapping leaves them among the more important fur bearers of today.

They undoubtedly destroy some food and game fish but apparently feed extensively upon suckers, minnows, and nonfood fishes, and other unimportant animal life of the water. No serious charge of mischief has ever been brought against them, and such numbers as the waters of the State will reasonably support should be maintained. This could be accomplished by a system of limited licenses providing for taking only the surplus from each drainage system.

\section{ENHYDRA LUTRIS NEREIS (MERRIAM)}

\section{SOUTHERN SEA OTTER; E-LUCK-KE of the Clatsop (L. and C.)}

Latax lutris nereis Merriam, Biol. Soc. Wash. Proc. 17 : 159, 1904.

Type.-Collected on San Miguel Island, Santa Barbara Islands, Calif., by Geo. M. McGuire, 1904.

General characters.-Size large (pl. 43, A), form low and heavy, almost seallike; tail flattened, club-shaped, about a foot long; legs short; hind feet large, fully webbed and paddlelike ; front feet small ; ears small and low down on side of head; eyes rather small; mustaches of stiff bristles; skull weasellike, but teeth 16 above and 16 below, the molars heavy and rounded for crushing instead of cutting; fur deep and soft with short even guard hairs. Color very dark brown or blackish over body, with gray head and throat; nose pad and lips black; in prime fur of adult animals long white-tipped hairs are scattered through the dark fur, giving a beautiful frosted appearance.

Measurements. - The type of nereis, an adult male, is a disarticulated skeleton; the total length of the animal in the flesh is given as 6 feet. Measurements of adult given by Audubon: Total length, 5 feet 2 inches; tail, 1 foot; hind foot of young about 2 years old, 61/4 inches; "helght of ear", 3/4 inch. (These are presumably measurements of California specimens.) Hoover 
(Forest and Stream 71: 488, 1908) gives the weight as 50 to 75 pounds. Lewis and Clark $(1893, p .853)$ say that the animal is the size of a large mastiff dog, and give measurements of 5 feet to tail and tail 10 inches.

Distribution and habitat.-Sea otters were originally abundant about the northern shores and islands of the Pacific Ocean from the Kurile Islands to Alaska and on down our coast to the Gulf of California. Sufficient specimens have not been brought together to show the area of intergradation with the subspecies nereis, but all available specimens from the coast of California, Oregon, and Washington can be safely referred to this form, rather than to Tutris of Kamchatka (fig. 74).

In 1805 Lewis and Clark found sea-otter skins commonly worn as robes or blankets, among the Clatsop Indians near the mouth of the Columbia. One Indian was " dressed in three very elegant sea-otter skins" which he refused to sell for less than 3 fathoms of blue beads for each skin. As the supply of blue beads was down to 4 fathoms, and white beads, knives, and all other articles of trade were refused, the skins remained with the Indian and probably kept him warmer than the blue beads would have done, for this was on January 17. Two days

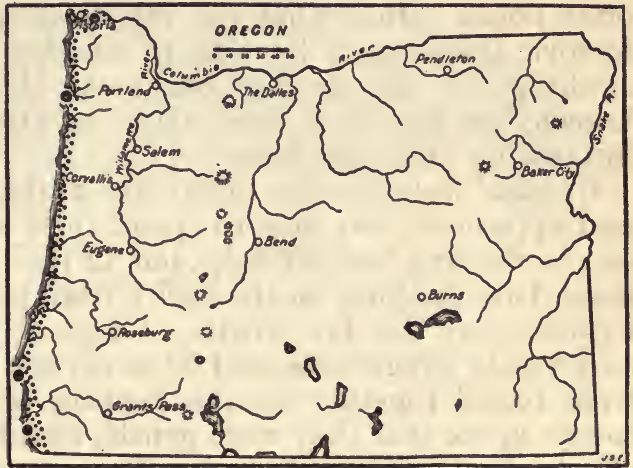

Figure 74.-Range of the southern sea otter, Enhydra lutris nereis, on the coast of Oregon. later, however, they purchased a single sea-otter skin from another Indian for 4 fathoms of blue and 4 of white beads, and a knife.

Later, on March 29, 1806, the explorers bought a robe of two seaotter skins from Indians near Wapato Island for a belt of blue beads.

The "sea otters" reported by Lewis and Clark as numerous in the Columbia near The Dalles on October 23 and 25, 1805, were later referred to by them as seals, and the authors state that the sea otter resides only on the coast or in the vicinity of salt water.

In 1811 at the mouth of the Columbia, Franchere (1904, p. 229) said the Clatsop Indians came every day to the sides of the vessel to trade beaver and sea-otter skins. J. K. Townsend listed sea otters among the mammals found in Oregon in 1839; George Gibbs reported them as abundant at Port Orford; and as found at the mouth of the Columbia in 1855 and 1856. George Suckley obtained a skull of one at Port Orford about 1856 (received at U. S. National Museum in 1857), and R. W. Dunbar sent in a skull from there in 1859. There is another skull in the collection labeled Oregon, 1874, and one from Pistol River, 1875. A femur of a sea otter in a good state of preservation was picked up by Jewett in a shell mound at the mouth of Pistol River in Curry County in 1930 and sent to the Biological Survey for identification. Its bleached and weathered condition does not indicate prehistoric origin. 
Scammon (18\% , p. 69) gives Cape Blanco, Oreg., as one of the principal hunting grounds for sea otters from 1852 to 1872 , and Allen $(1898, p$. 356) reported many taken in Oregon as late as 1876. Since that time there has been only sad silence as to their occurrence on the coast of the State, although there are evidently a few left on the coasts of Washington and California, and if absolute protection over the whole world could be enforced for this most valuable fur bearer there would be a possibility of its increase to abundance.

During the summer of 1928, Mrs. Stanley G. Jewett and her son, Stanley G., Jr., made a considerable collection of bones from the shell heaps at Netarts, on the coast in Tillamook County, and sent them to the Biological Survey for identification. Among the great number of bones of sea lions and seals are a few fragments of seaotter bones. Just what the relationship of these animals to a prehistoric people may have been, whether they were used as food and clothing, or merely for ornament, is not evident from present knowledge, but their association in Oregon with primitive man is interesting and significant.

General habits.-Sea otters are highly adapted to an aquatic life and apparently are able to spend their whole time in the water, and on the floating beds of kelp, but in their early abundance they spent much time basking on the rocky islands of our coasts or the floating ice cakes of the far North. Originally they were very abundant and highly gregarious, and 50 to several hundreds or even thousands were found together on the feeding or sleeping grounds. All accounts agree that they were gentle, timid animals, rarely making any efforts at self-defense except in the case of mothers in defense of their young, their only desire being to get into the water where escape by diving and swimming long distances below the surface was possible. They are said to swim on their backs but to turn over in diving. In their early abundance they were unafraid and were easily slaughtered by the thousands with clubs and spears, but after being brought to the verge of extermination by years of ruthless slaughter they have become extremely wary and difficult to shoot even at long range, thus showing a degree of intelligence that may yet rescue the species from extinction.

Breeding habits.-Sea otters have 1 pair of mammae located on the posterior part of the abdomen, and normally they have but one young at a time. The young are said to be generally brought forth on the beds of floating kelp, but Steller speaks of them on the islands where the herds were in the habit of resting or out at sea with the mother, playing on or about her body as she floated on her back in the water. The mother will not desert her young and often sacrifices her life in protecting it. The young are found with the mothers at all seasons of the year, and most writers agree that there is no particular breeding season.

Food habits.-Only the statements of early writers are available as to the nature of the food of sea otters, and they generally agree that crabs, clams, and other forms of crustaceans and bivalves form most of their food. Other foods generally referred to are sea urchins, squids, small fishes, and some kelp. Scammon says they bring up their food to the surface and instantly resume their habitual atti- 

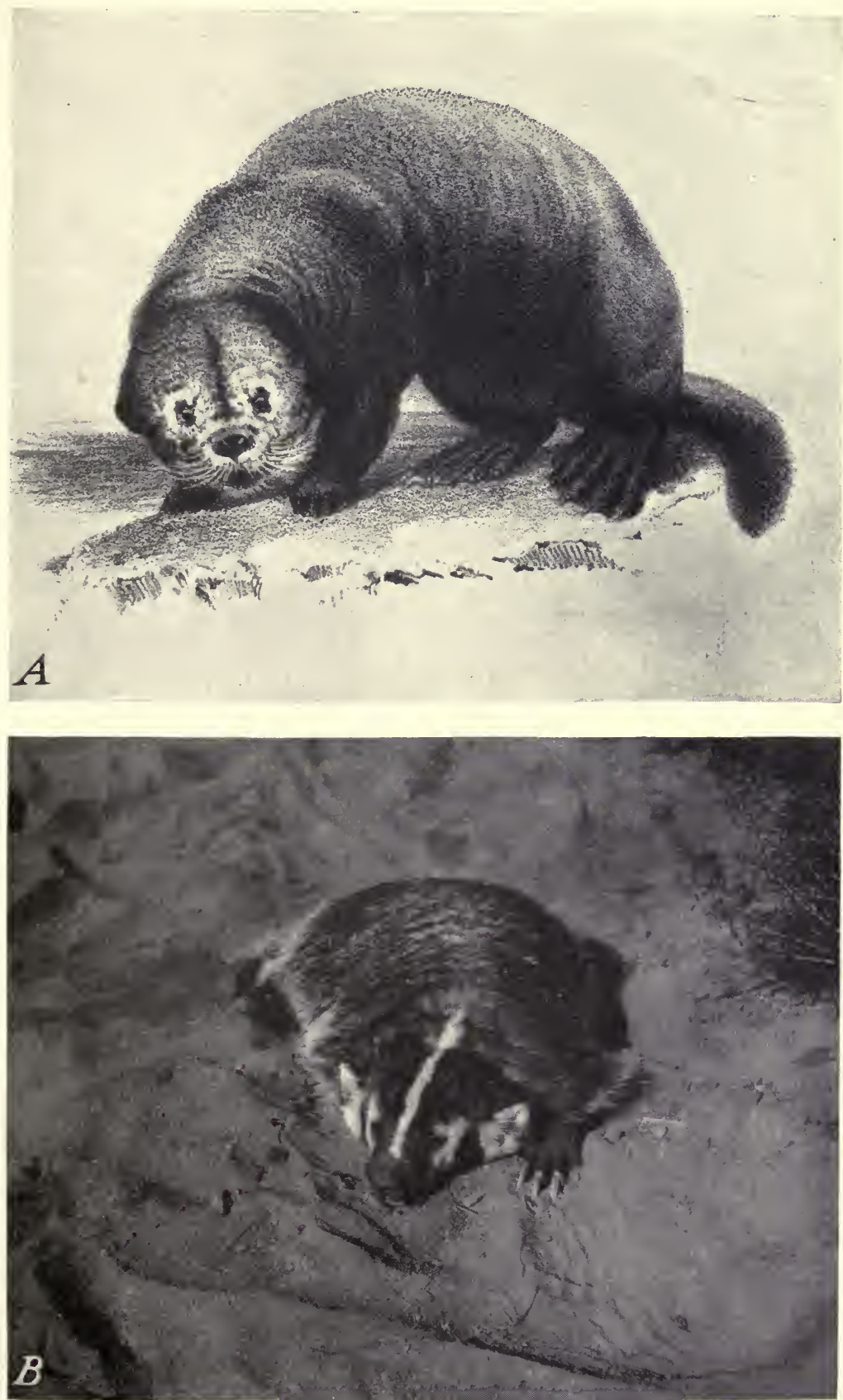

$A$, Sea otter (from drawing by Wolf, in Scammon's Marine Mammals); $B$, western badger (from photograph by Luther J. Goldman, taken at Fremont, Oreg.). 

tude-on the back-to devour it. The character of the molar teeth, with rounded, crushing surfaces, would indicate their use in crushing shells rather than catching fish or tearing and cutting any kind of flesh. The kelp which they are said to eat may be accidentally included with the crustaceans, mollusks, and other inhabitants of the kelp beds. The abundance of their favorite food in the past was undoubtedly a very important factor in determining their distribution and abundance.

At times they become very fat and are reported by some to be good eating and by others as not fit for human food.

Economic status. - Sea-otter fur has been generally considered the most beautiful and valuable fur in the world, and has brought the highest price, even up to several thousand dollars each for choice skins. Their high value brought about almost complete destruction of the species during a time when no international protection was possible. Now with the help of international laws and a partially awakened world conscience, it would seem to require mainly the efficient local enforcement of the laws to bring back gradually a fur bearer that under proper care would be worth more to the State than all of her present yield of fur.

\section{TAXIDEA TAXUS NEGLECTA MEARNS}

Calffornia Badger; Hoonah of the Burns Piute; Akowa of the Wasco; KoLTz of the Klamath (C. H. M.)

Taxidea americana neglecta Mearns, Amer. Mus. Nat. Hist. Bull. 3 : 250, 1901.

Type.-Collected at Fort Crook, Shasta County, Calif., by John Feilner in 1859.

General characters.-Body heavy, low, and wide (pl. 43, B); tail short; legs short and powerful, with long digging claws on front feet; soles mostly naked and partially plantigrade; ears low and wide; eyes small; skin thick and tough, especially over head and neck, and muscles of head, neck, and shoulders powerful; fur in winter long and loose, with very long coarse hairs projecting along the sides; in summer short, harsh, and hairy; skull heavy, triangular, with 34 teeth. Color, in summer pelage, upper parts coarsely grizzled buffy brown, from black and white tips of long hairs showing over clear buff underfur; top of head, back of ears, a spot on each cheek, feet, and legs blackish; a narrow stripe from nose to back of neck or shoulders white; lower parts buffy, paler on throat and sides of face around black spot and inside and edges of ears; a white stripe generally along middle of belly. Winter fur paler, more frosted with the long white tips of the hairs which partly obscure the dusky subterminal zones.

Measurements.-A large male from Antelope, Oreg., measured in the flesh: Total length, $800 \mathrm{~mm}$; tail, 120; foot, 130; ear from notch to tip, measured dry, about 30 . A female from Yamsey Mountain measured $780 ; 154 ; 108 ; 30$. Weight of a large male from North Dakota 25 pounds. Weight of average animals when lean about 16 to 20 pounds.

Distribution and habitat.-This form of the genus, characterized by slightly smaller size, darker colors and more inflated audital bullae than typical taxus from Saskatchewan, occupies the Great Basin region, including Oregon east of the high part of the Cascades (fig. 75). There is one record for the upper Rogue River Valley where many of the desert species cross over the low pass west of Klamath Lakes. They are primarily animals of the sagebrush plains with no zonal restrictions wherever a convenient food supply may lead them. Their apparent aversion to forest country $7209^{\circ}-36-20$ 
as rare as the marten and fisher if they are not given better protection than fur bearers usually get. Raising choice light-colored badgers for fur has proved a successful enterprise in some parts of the country and will perhaps be developed into a real industry.

\section{MEPHITIS OCCIDENTALIS OCCIDENTALIS BAIRD}

California Skunk; Chaw-sis of the Klamath (C. H. M.)

Mephitis occidentalis Baird, Mamm. North Amer., p. 194, 1857.

Type.-Not designated; description based on two specimens from Sonoma County, Calif.; collected by E. Samuels in 1856 or earlier.

General characters.-About the size of a house cat, with heavy body, short legs, a large bushy tail, short ears, pointed nose, and small eyes; feet fully plantigrade, with naked soles and long front claws for digging; teeth 16 above and 18 below; fur full and soft with long, coarse guard hairs; a pair of large glandular musk sacs at the sides of the anus, surrounded by a broad band of muscle that may be contracted, forcing fine streams of amber liquid of powerful odor through two nipplelike ducts at the edge of the anus. Color, fur dark brown and outer hairs black all over except a narrow white stripe through forehead, a broad white band from top of head to shoulders, then dividing along sides of back and tail, and meeting across top of tail near the middle, leaving the tip of tail black; long tail hairs white at base, mostly with long black tips; the white hairs of nape, back, and tail longer than the black hairs and forming a sort of crest. White often tinged with creamy buff or salmon; pattern the same at all seasons and ages, but with varying proportions of white.

Measurements.-Average of adult males from type region: Total length, $693 \mathrm{~mm}$; tail, 303; foot, 78; ear (dry), about 20. Females slightly smaller. Grinnell and Storer give the weight as $3 \frac{1}{3}$ to $81 / 3$ pounds, but large fat individuals may probably run even higher.

Distribution and habitat.-California and Oregon valley country, west of the Sierra Nevada, and the Cascades from the vicinity of Monterey Bay north to the Willamette Valley, in mainly Upper Sonoran and Transition Zones (fig. 76). Although valley rather than

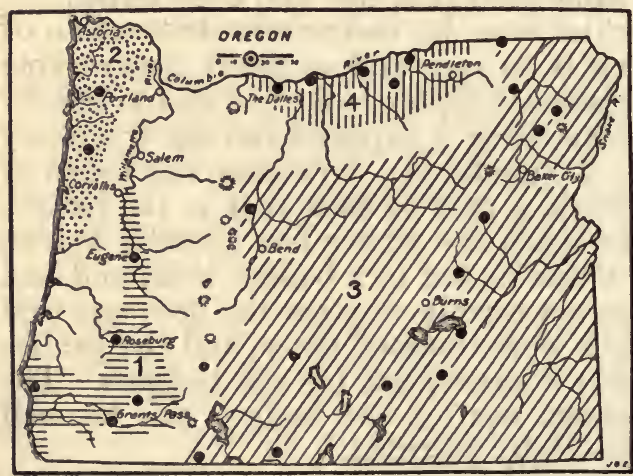

Figure 76.-Range of four forms of the common skunks in Oregon: 1 , Mephitis occidentalis occidentalis; 2 , M. o. spissigrada; $3, M$. o. major; $4, M$. 0 . notata. Type locality circled.

ers and great diggers, depending on their long, strong claws not only for digging out much of their food but for construction of numerous deep burrows in which they generally make their homes. In places they live under or among the rocks, in small caves, or even in hollow in places go well up into foothills and high valleys. They generally preferopen country with brush land and wood lots but sometimes penetrate well into partially ti m be red regions. In southern Oregon this form reaches to the coast, but in the northwestern part of the State it gives place to the broader striped Puget Sound skunk.

Generalhabits.-Skunks are entirely ground dwellmountain animals, they 
logs, but their winter homes are generally deep under ground. They are mainly nocturnal but are not infrequently seen abroad in the early evening, hunting for grasshoppers, or in the morning hours, racking along with a sideways gait toward home. Their best speed is but a sorry pace for escaping danger, and if pursued, they quickly face about with threatening attitude, knowing well their powers of defense.

On such occasions, with tail erect and black and white plume strikingly spread, the skunks make little runs at the enemy, which generally keeps beyond the enchanted circle, but if not, jets of amber liquid are thrown with surprising accuracy to a distance of 10 or 15 , or possibly 20 feet, filling the air with the most stifling odor. An experienced hunting dog will usually keep beyond the danger limit and merely bark at a skunk, but one without experience or with a reckless disposition often rushes in and grabs the skunk, usually by the wrong end, and shakes the life out of it, greatly to his own and his master's sorrow. Often the dog becomes violently sick and loses his supper and would like to die, but cannot. If water is near he will plunge in and wash his mouth and his fuming coat, but to little purpose. If there is no water he will chew up the ground and leaves and roll and wallow in the grass or sand, but with little relief or improvement of his condition. Many a dog, however, never gets nearer than the first barrage, and the skunk safely reaches home before the enemy recovers from its surprise and discomfort. Under similar circumstances men, bears, mountain lions, and railroad trains are treated like dogs, with a full discharge of the weapons of skunkly warfare, and with varying but rarely enjoyable results.

The skunk's weapon is the simplest of squirt guns, two glandular sacs at the sides of the anus, surrounded by a broad band of muscle which, contracted, forces the yellow fluid secreted by the gland through two nipplelike ducts in a straight line with considerable force. The strange part of it is that from the rear the skunk can aim and shoot with such precision. With a quick twist of the body it will fire over one shoulder or the other at an enemy directly in front or aim at an object at one side or the other, or in the rear, or even directly above, and generally with astonishing accuracy. The only really safe place is beyond the animal's range.

However, the skunk is naturally a gentle, timid animal, fairly intelligent, and if met halfway in gentleness and wisdom, will prove harmless and exceedingly interesting. By moving slowly and talking softly to one, it is generally possible for a person to enter the charmed circle without unpleasantness. It is quite possible for one to coax a skunk into a box, a joint of stovepipe, a tile, or any dark retreat, cover the openings, pour in an ounce of ether, and after a few minutes take the animal out and handle it safely as long as it is under the anesthetic. If the skunk is placed in a good light and allowed to revive without being excited, 1 or 2 good photographs can usually be obtained. If kept in captivity, the animals become gentle and make good pets, even without the removal of the scent glands.

Breeding habits.-The female skunks of this group have normally 5 or 6 pairs of mammae-2 inguinal, 2 abdominal, and 1 or 2 pectoral-arranged in two parallel rows the whole length of the belly. The young-6, 8,10 , or possibly a dozen in a litter-are born in 
May or June and begin to follow the mothers in July or August while still small.

Food habits.-Skunks are fond of meat, grasshoppers, crickets, beetles, beetle larvae, fly larvae and pupae, ant and hornet larvae, mice, rats, ground squirrels, birds and birds' eggs, frogs and crayfish, and in fact, practically any small game that they can dig out or catch. Skunks have large stomachs and in times of abundance, as during a grasshopper or cricket year, stuff themselves to the limit on such choice food. They are fond of ripe prunes that have fallen on the ground, and of other fruits and berries, especially blueberries, on which they sometimes gorge themselves. In captivity they will eat a great variety of foods, such as bread, milk, mush, fruit, and berries.

Economio status.-Skunk fur forms an important part of the trapper's harvest each year, and while the price is not high, usually, in recent years, $\$ 2$ or $\$ 3$ for prime skins, the abundance of the animals and the ease with which they are caught give them an important place on the list of fur bearers.

Farmers sometimes complain of damage to their poultry by skunks, but this is rarely serious and in most cases could be easily prevented by giving the poultry a safe place to sleep. The enormous consumption of insects, mainly injurious species, and destruction of rodent pests, give the skunks an economic value that generally outweighs their occasional killing of poultry and their local destruction of eggs and young of both poultry and game birds.

\section{MEPHITIS OCCIDENTALIS SPISSIGRADA BANGS}

\section{Puget Sound Skunk}

Mephitis spissigrada Bangs, Biol. Soc. Wash. Proc. 12 : 31, 1898.

Type.-Collected at Sumas, British Columbia, by Allan C. Brooks, 1895.

General characters.-Like occidentalis but with broader white stripes and long white hairs usually extending beyond black at tip of tail; skull shorter and broader than in occidentalis. The white stripes generally tinged with cream, buff, or salmon below the surface.

Measurements.-Average of 3 adult males from the type locality : Total length, $653 \mathrm{~mm}$; tail, 246; foot, 79; ear (dry), about 24. Females: 625; $235 ; 75$. Weight of a large fat skunk taken by A. J. French, of Carlton, Oregon, 14 pounds.

Distribution and habitat.-Puget Sound section of southern British Columbia, western Washington, and south to the coast country of northwestern Oregon (fig. 76). One specimen from McCoy in Polk County seems to be the only substantiated record for Oregon.

General habits.-Not known to differ from those of $M$. o. occidentalis.

\section{MEPHITIS OCCIDENTALIS NOTATA (HOWELL)}

\section{Columbia Valley Skunk; Apiscus of the Wasco}

Chincha occidentalis notata Howell, North Amer. Fauna, No. 20, p. 36, 1901.

Type-Collected at Trout Lake, Skamania County, Wash., by Peter Schmid, 1897.

General characters.-Size about as in occidentalis, but tail shorter, white stripes narrower and often incomplete, usually divided to back of neck or back of head; tail sometimes without long white hairs, but if present reaching to near tip. 
Measurements.-Average of adult males from type locality : Total length, 633 $\mathrm{mm}$; tail, 249 ; foot, 76 . Of adult females: $659 ; 286 ; 69$.

Distribution and habitat.-This well-marked but restricted form occupies the Columbia River Valley from the south base of Mount Adams eastward on both sides of the river to near the Great Bend. On the Oregon side specimens are referred to it from The Dalles, from Millers (near the mouth of the Deschutes), Willows, Umatilla, and Lena, all in semiarid Upper Sonoran Zone of the Columbia River Basin (fig. 76). The name "Cascade skunk", which has been applied to it, is misleading as its range is entirely in the Columbia Valley, east of the Cascades.

\section{MEPHITIS OCCIDENTALIS MAJOR (HowELL)}

\section{Great Basin Skunk; Poonúche of the Piute at Burns}

Chincha occidentalis major Howell, North Amer. Fauna, No. 20, p. 37, 1901.

Type.-Collected at Fort Klamath, Oreg., by B. L. Cunningham, January 5, 1898.

General characters.-Size slightly larger than occilentalis; underfur darker brown and outer hairs more shiny black; white stripes pure white, dividing nearer to neck and continuous along sides of back and tail and across top of tail well back of black tip.

Measurements.-Average of 5 adult males from type locality: Total length, $705 \mathrm{~mm}$; tail, 306 ; foot, 84 .

Distribution and habitat.-The Great Basin skunks occupy the desert region from Utah, Nevada, and northeastern California to eastern Oregon, southeastern Washington, and southern Idaho (fig. 76). They cover most of Oregon east of the Cascades in Upper Sonoran and Transition Zones, and all of the low country except the immediate valley of the Columbia River.

General habits.-In adaptation to arid and open environment these big skunks of the Great Basin area are mainly restricted to the vicinity of streams, lakes, canyons, or areas where water and cover are to be found, and where insects and small rodents or birds are abundant. The skunks often travel long distances in roads or trails, but never beyond reach of water and cover; consequently they are not found over wide spaces of desert country, but often rather abundant in restricted areas. In canyons or along cliffs they live under or among rock masses, or burrow in the dense growth of weeds and bushes near the rocks. Near lake shores they will burrow anywhere within reach of the tule-bordered breeding grounds of water birds or mouse-infested meadows. In a mouse year they gather about the fields and feast on meadow mice. In a grasshopper year or a cricket year they fatten on these wholesome and nutritious insects; in a rabbit or ground-squirrel year they aid in keeping down the surplus, capturing the young or even pulling down the sick jack rabbits in times of epidemic. On the breeding grounds of waterbirds around some of the great tule-bordered lakes of eastern Oregon, they are a possible source of danger to eggs and young, and in some cases are evidently responsible for some broken eggs and small broods of young ducks. This, the most serious mischief of which skunks are sometimes convicted, is, however, almost wholly preventable by allowing or encouraging more thorough trapping in areas where they are likely to prove destructive. Fortunately their 
fur is always of sufficient value to keep their numbers reduced to a harmless minimum without any expense for artificial means of control. On the whole this skunk is thus a valuable animal, from both the economic and commercial viewpoints.

\section{SPILOGALE GRACILIS SAXATILIS MERRIAM}

Great Basin Spotted Skunk; Hydrophobia Skunk; Phoby Cat; Civet Cat; Crvet; Wapolapissa of the Piute at Burns

Spilogale saxatilis Merriam, North Amer. Fauna No. 4, p. 13, 1890.

Type.-Collected at Provo, Utah, by Vernon Bailey, November 13, 1888.

General characters.-A slender, graceful little skunk, with short legs; plantigrade feet; naked soles; climbing claws; short rounded ears; a large plumelike tail (pl. 44, A); and a weasellike expression of face; fur very soft and full when prime, and colors dazzling in their intricate pattern of black and white. Scent glands almost as highly developed as in Mephitis, and used in the same way in self defense. Color, clear black, or sooty black all over except four white shoulder stripes and two side stripes; a white spot on forehead and one on each cheek; eight white spots on rump and a large white tip to the tail, including half its length. Pattern the same at all ages and seasons.

Measurements.-Average of 2 males from type locality: Total length, 436 $\mathrm{mm}$; tail, 170 ; foot, 47 ; ear (dry), about 20 . Average of three females from Oregon: $360 ; 129 ; 40$.

Distribution and habitat.-The Great Basin area from Utah and Colorado through northern Nevada and southern Idaho to northeastern California, Ore-

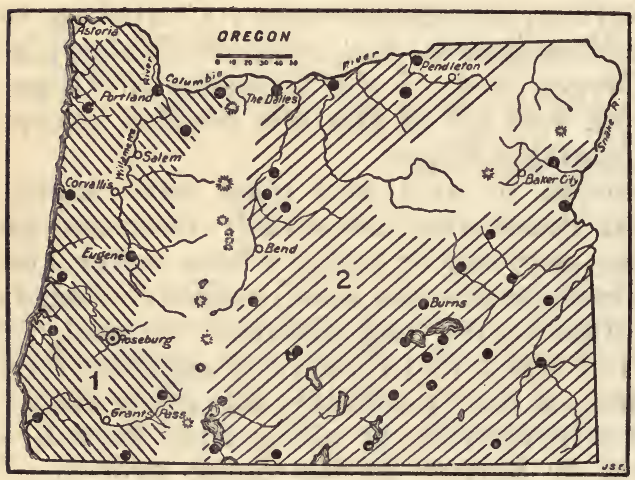

Frgure 77.-Range of the two forms of little spotted skunks in Oregon: 1, Spilogale phenax latifrons; 2, S. gracilis saxatilis. Type locality circled. gon, east of the Cascades, and southeastern Washington in Upper Sonoran Zone (fig. 77 ).

General habits.-These beautiful little spotted weasel skunks are more or less wanderers in their desert range, along the lines of cliffs, canyons, and rimrocks, or in the arid valleys of eastern Oregon in the broken and cavernous lava fields. There is some doubt as to whether they follow the cliffs and canyons for shelter and protection, or merely because these are also favorite haunts of numerous small rodents and many forms of insect life on which they prey. They are great climbers, both among the rocks and in trees and bushes, and seem to be able to capture the most active of the small rodents, many of which are also good climbers. They often take up temporary residence about barns, sheds, or even under houses where, if unmolested, they do good work in destruction of rats, mice, insects, and reptiles. They are so fully nocturnal as to be little noticed, even when living under the doorstep of a dwelling. At the warden's cabin near Malheur Lake, one lived under the house and came out at night and ate up some of the meadow mice from a box where they were kept under the window for study and ate part of a prairie fal- 

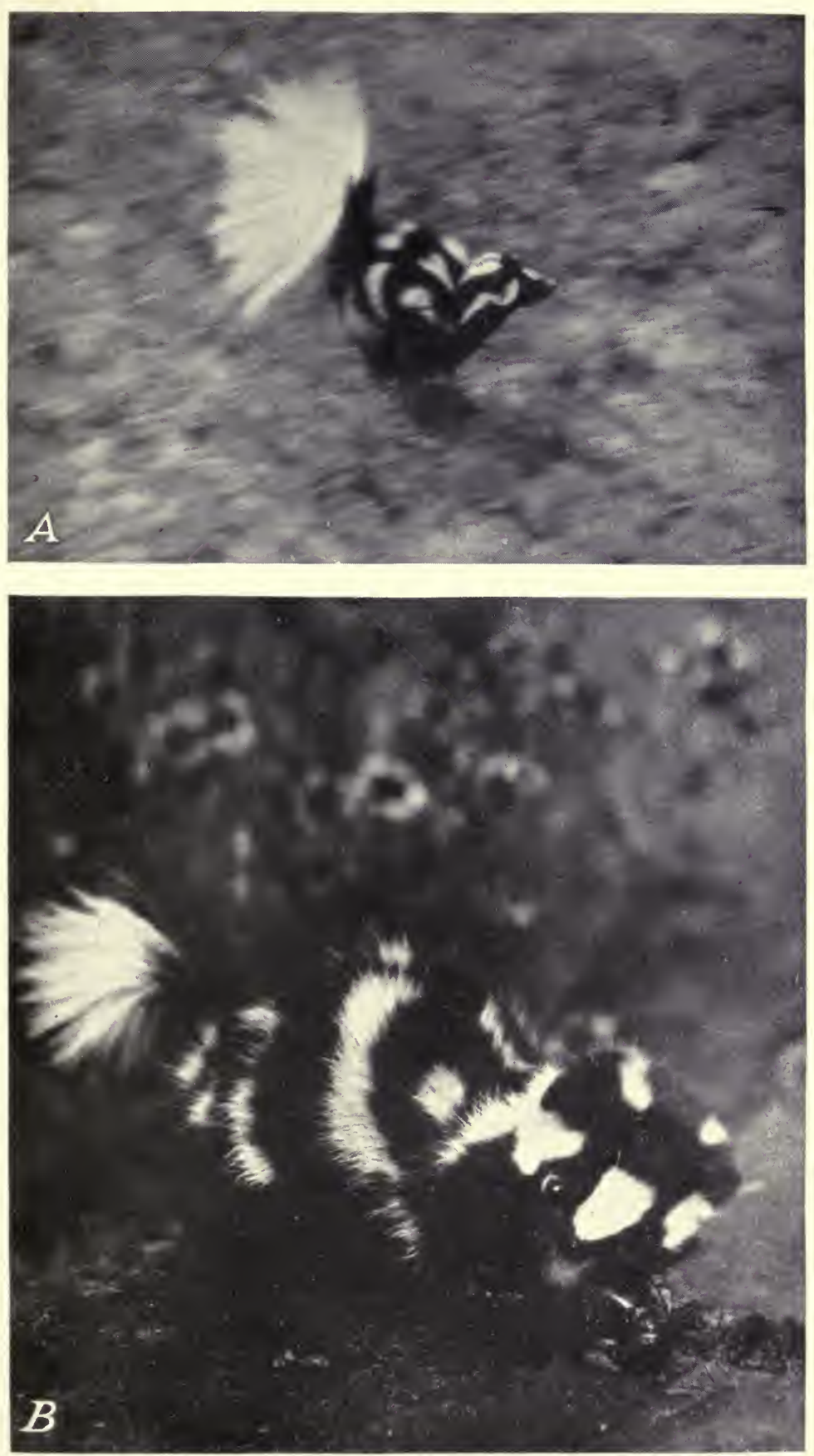

SPOTTED SKUNKS.

B23506; Е622AM

$\dot{A}$, Great basin spotted skunk on the run (from photograph taken at Malheur Lake, Oreg.); $B$, Oregon spotted skunk (from photograph taken at Tillamook, Oreg., by Alex Walker). 


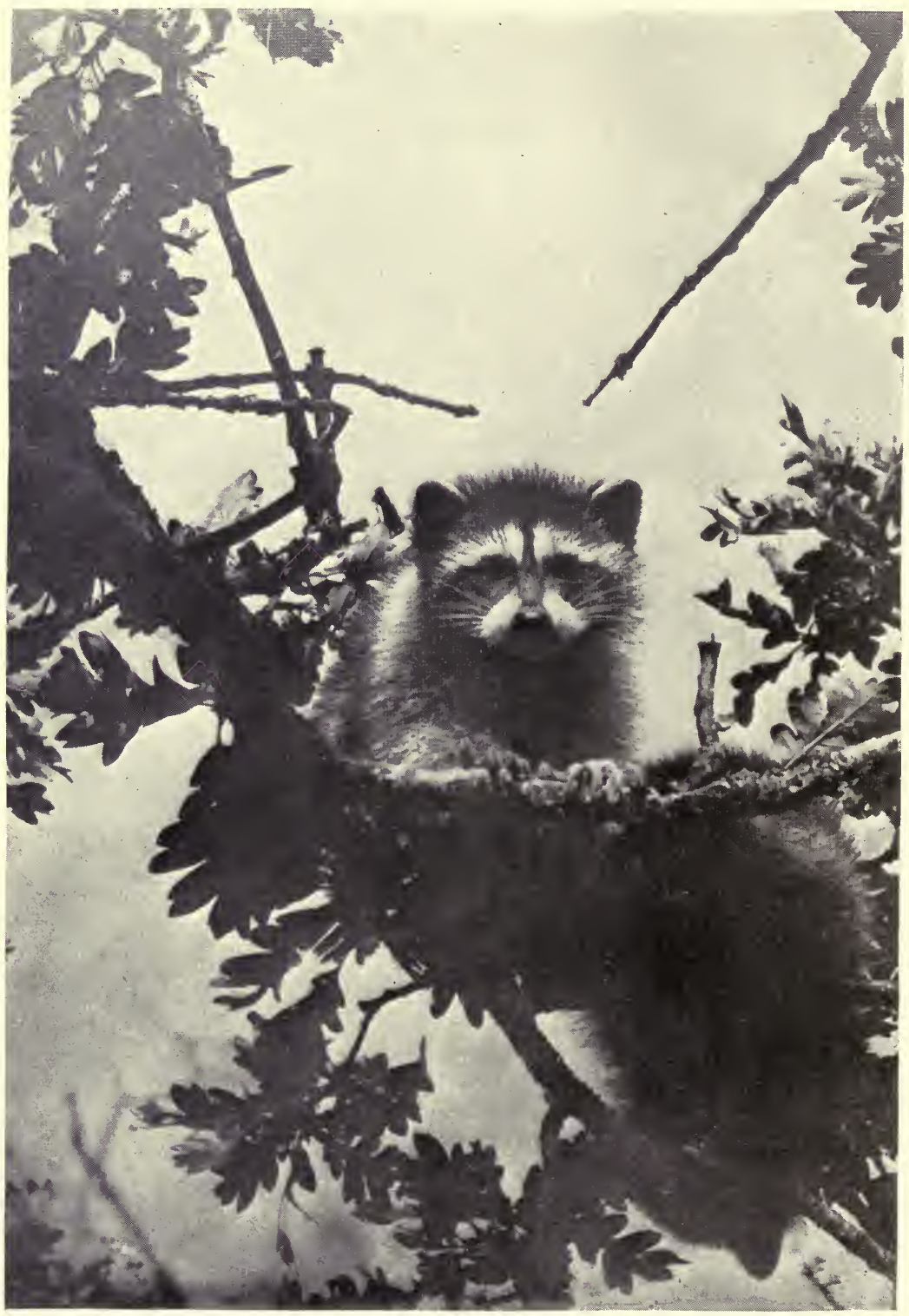

NORTHWESTERN RACCOON.

Photograph by O. J. Murie. 
con that had been shot for a specimen. An inverted soap box was set on the steps with a trigger under one edge, baited with meat, which the skunk smelled and tried to get as soon as the writer turned away. A large gunny sack was slipped under and over the box and the little skunk transferred to it; the sack was dropped gently into a tin can and carried out to the middle of a clean pasture, where the skunk was released and photographed as it ran, sometimes away from and sometimes toward the writer. It was no trouble to keep near the animal and take pictures at a 6-foot focal distance. Through all this unusual excitement the skunk did not throw its scent or become unpleasant in any way, except that while under the box it would stamp its feet in a fury. The next night it was back under the house and in response to friendly advances only stamped its feet in a threating manner. It seemed able to express much of its feelings in various forms of stamping with both front feet at once.

At the next cabin out in the sagebrush valley one was caught at the side of the house, under a tin can set for wood rats. At the ranch beyond, a dog was kept and there were none of these interesting little animals about.

In 1915 Jewett found one prowling about his room at night on the Hay Creek ranch. When the light was turned on it showed no alarm but continued its search until it found the bodies of three birds that had been skinned for specimens the day before. These were quickly appropriated and carried under a box to be eaten at leisure.

Other specimens of these little skunks were obtained along the canyon of the Deschutes River by using the bodies of birds for bait, but at that time the animals had become scarce through years of persistent trapping for fur. The collector gets more of these animals in traps set for wood rats than in any other way, as they are always hunting for and following the runways of these rodents, but they are also attracted to any traps baited with meat and set for other skunks, foxes, coyotes, bobcats, or mink.

They have a pair of scent glands, arranged as in the large skunks at the sides of the anus and operated by surrounding bands of muscle that on contraction force two streams of powerfully pungent amber liquid to a distance of 10 or 12 feet. Its odor is scarcely distinguishable from that of Mephitis, but when not too strong has a little sug. gestion of the red-fox odor. It is used only in self-defense, and then only as a last resort when escape seems hopeless. When the animal is killed by a sharp blow across the back the rear muscles are paralyzed and no scent is thrown, or if an ounce of carbon bisulphide or gasoline is poured into a small box or burrow where they are, they soon become unconscious without ejecting their fluid and may be handled freely without unpleasant results or kept under the influence of it until the heart has ceased to beat. Ether can be used in the same way but does not result in death unless its application is long continued.

The popular belief that the bite of these little skunks will always produce hydrophobia has no foundation in fact. These and other skunks, as well as dogs, coyotes, and other animals, may convey the disease when they have contracted it, but at no other time, and there are very few authentic records of hydrophobia following the bite of skunks. 
Breeding habits. - The mammae of adult females are arranged usually in 5 pairs - 1 inguinal far back, 2 abdominal, and 2 pectoralor in two parallel rows of 5 each. There are records of 4 and 5 young in a litter, but the number of mammae would indicate the possibility of larger families up to perhaps 8 or 10 in some cases.

Food habits.-The food of these little skunks is largely insects and small rodents, but as in the case of others of the group probably includes lizards, snakes, salamanders, small birds, and crayfish, any kind of meat that becomes available, and some berries and wild fruits. There are many records of their clearing out the rats and mice around barns and houses where they have taken up their abode, but very few records of any destruction of poultry. However, it is not improbable that they may sometimes kill young chickens or other small poultry found roosting in unprotected places.

At times they become very fat, but it seems doubtful that in the mild climate of their zone they should hibernate for long periods, if at all.

Economic status.-In recent years the fur of these little animals has become fashionable and is often seen in ladies' coats, collars, and muffs. It is very light and soft and fairly durable. The price per skin is not very high, but the considerable number of skins taken each year adds to the value of the trapper's harvest. On the other hand the animals may have considerable value as destroyers of insect and rodent pests, and might well be given a degree of protection that would insure their perpetuation in reasonable abundance.

SPILOGALE PHENAX LATIFRONS MERRIAM

Orbgon Spotted SkunK; Hydrophobia Skunk; "Crvet Cat"

Spilogale phenax latifrons Merriam, North Amer. Fauna No. 4, p. 15, 1890.

Type-Collected at Roseburg, Oreg., by T. S. Palmer, July 13, 1889.

General characters.-Much larger and heavier than S. gracilis saxatilis (pl. $44, B)$; white areas much less extensive than the black and usually tinged with buffy or salmon; white tip including less than half of tail.

Measurements.-Average of 6 males: Total length, $408 \mathrm{~mm}$; tall, 127; foot, 47.7; ear (dry), 20. Average of 11 females: $373 ; 122 ; 42.8$. Weight of $S$. phenax 16 to 28 ounces (Grinnell, Storer, and Linsdale, 1930, p. 465).

Distribution and habitat.-Coast section of Oregon and Northern California in Upper Sonoran and Transition Zones (fig. 77).

General habits. - In the absence of rocks in much of the low country of western Oregon, these little spotted skunks live commonly in the timber among old logs and in such cover as the forest affords. Near the coast they find abundance of logs and dense growth, in which to hide away and are usually more numerous than in the interior valleys. In food, breeding, and general habits, they differ but little from the Great Basin species, except as they adapt themselves to different cover and to different types of food. They come more in contact with agriculture and human affairs and thus seem more often to do the only mischief of which they are accused, occasionally killing young poultry that is left unprotected at night. On the other hand their destruction of small rodents and insects on farms is of greater economic importance than in a country of little agriculture.

Their value as fur is not great but adds considerably to the trapper's returns. The following notes from the Oregon Sportsman for April 1914 give an idea of their local importance. John Vaughn of 
Eugene brought in 2 cougars, 7 bobcats, 3 raccoons, 2 fishers, 2 martens and 28 "civet cats." Another trapper brought 14 bobcats, 1 coyote, 3 mink, 5 fishers, 20 martens, 5 white weasels, 5 skunks, and 55 "civet cats." Another brought in a coyote, 6 wildcats, and 30 "civet cats." While the skins of "civet cats", the trade name for the little spotted skunks, were quoted at that time at only 50 to 65 cents each, the numbers of skins taken gave them considerable importance in the fur yield.

\section{Family PROCYONIDAE: Raccoons}

\section{PROCYON LOTOR PACIFICA MERRIAM}

\section{NoRTHWEstern RaCcoon}

Procyon psora pacifica Merriam, North Amer. Fauna, No. 16, p. 107, 1899.

Type.-Collected at Lake Keechelus, Kittitas County, Wash., by C. Hansen, January 15, 1898.

General characters.-Size of a badger or a small dog (pl. 45) ; body heavy ; face short with pointed nose, erect ears, and crossed by a black mask; feet fully plantigrade with naked soles; claws curved for climbing; teeth 40 in number; tail round and bushy, encircled by black and gray rings; fur full and soft, mainly obscured by long coarse outer hairs. Color, upper parts dark coarse gray, produced by brown under-fur, white or yellowish subterminal portions and black tips of long guard hairs; top of head blackish and a broad black band across face and eyes, connecting with brownish black throat patch; a narrow band of whitish crossing forehead and cheeks, and three white spots covering chin and sides of nose; tips of ears whitish; tail tipped with black and encircled by 6 or 7 gray and 6 or 7 black rings; top of hind feet dusky; lower parts light brown, more or less silvered with scattered long whitish hairs; throat dusky; chin whitish; nose pad and naked soles black.

Measurements.-An immature male from Easton, Wash., measured in the flesh: Total length, $780 \mathrm{~mm}$; tail, 275; hind foot, 120 ; ear (dry), 40 . An adult female from Steilacoom, measured $830 ; 270 ; 129$; ear (dry), 40 . Skull of adult male from Lake Cushman, Wash.: Greatest length, 120; zygomatic breadth, 85 ; interorbital constriction, 26 ; alveolar length of upper molar series, 35.

Distribution and habitat.-These large raccoons of the Northwest range from southern British Columbia south to northern California, in and west of the Cascades (fig. 78). They are common along the coast and foothill streams and lakes in mainly Transition Zone, but absent from the higher parts of the mountains. Generally animals of forest and timbered areas, they are also much at home where cliffs and canyons afford safe retreats, in which they may sleep during the daytime, or take refuge when pursued by enemies at night.

General habits.-Rac-

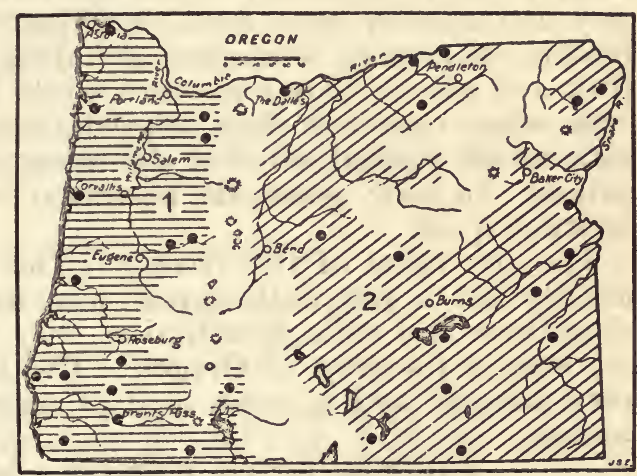

Frgure 78.-Range of the Northwestern and Snake River Valley raccoons in Oregon: 1, Procyon lotor pacifica; $2, P$. l. excelsus. coons are mainly nocturnal, but when urged by hunger sometimes come out of their dark retreats in hollow logs, trees, or caves before dark or on cloudy days, to catch a meal of frogs or crayfish. At night they wander far and wide along the creek or river banks, the lake shores, or ocean beaches, 
or through the woods from one stream or marsh to another, or to some field of roasting ears, thicket of choke cherries, or orchard of prunes or other sweet fruit. Except in the fruit and nut season their food is largely obtained from or near the water and they are fond of wading, and even swimming, to get it. They have the wellknown habit of washing or soaking their food or dipping it in water before eating it, but if no water is near they do not wait for this formality. They often make well-worn trails along the shores, and the babylike tracks of their long hind feet, found in the sand or mud where they have been searching for food, are unmistakable.

Breeding habits. - Adult females have 3 pairs of mammae-1 inguinal, 1 abdominal, and 1 pectoral. Two to five young have been reported in the litters. The mating season appears to be immediately after the awakening from hibernation, which varies from January to March, and young are born apparently in April and May, according to the local climate. The period of gestation has been determined as about 65 days.

Food habits.-Raccoons are about as omnivorous as the bears, eating any kind of meat or small game they can capture or find dead, but usually subsisting largely on frogs, fish, crayfish, clams, mussels, berries, and any sweet fruits, acorns, nuts, and green or ripe corn. In autumn they are especially eager for nuts and grain on which they fatten for a long winter's sleep. In the mild climate of the low country they do not hibernate for long periods or necessarily at all, but where snow lies deep and the weather is cold they often remain dormant for 3 or 4 months, coming out with the warm days of March when the snow begins to melt, even before its disappearance affords a remnant of the previous year's food. At such times they must depend largely on the store of fat left over from fall, on an occasional mouse or rabbit that may be surprised and captured, or on some animal found dead under the snow.

Economic status.-On rare occasions raccoons have been known to catch poultry, especially when the latter roosts in the trees, and they undoubtedly catch some small game and eat the eggs of waterfowl found nesting in marshes and along lake shores. They eat some fruit and also destroy some corn while in the roasting-ear stage, or even when ripe, but these depredations are usually overlooked in view of the general value of the raccoon as a game and fur-bearing animal. In many places the nocturnal "coon hunt" with dogs is an exciting sport.

The fur value of the raccoon is not great, the prices reaching usually but a few dollars per skin, but because of their general abundance and wide distribution, they form an important part of the annual fur crop of Oregon. The fur is attractive, warm, and very durable, and is much used in winter coats for both men and women.

\section{PROCYON LOTOR EXCELSUS NELSON AND GOLDMAN}

Snake River Valley Raccoon; Canyon Coon

\section{Procyon lotor excelsus Nelson and Goldman, Jour. Mammal. 11: 458, 1930.}

Type-Collected on upper Owyhee River near mouth of North Fork in southeastern corner of Oregon, by J. W. Fisk, April 15, 1920.

General characters.- Size largest of the raccoons; color light gray; skull large and angular, with elongated brain case, broad frontals, and high sagittal 
crest. Color of upper parts light buffy gray, darker along the back where the brown underfur is heavily overlaid with black-tipped hairs; sides clearer gray; lower parts light buffy gray; face with the usual black mask and whitish markings; ears gray with black patches at posterior base; throat patch dark brown; hind legs grayish with brown patches near heels; tail with six black bands and black tip, alternating with broader buffy rings.

Measurements. - No body measurements available. Skull of type: Greatest length, $136.5 \mathrm{~mm}$; zygomatic breadth, 89 ; interorbital constriction, 30 ; alveolar length of upper molar series, 37. Other skulls from eastern Oregon and southern Idaho are larger than any seen from Minnesota or North Dakota, where the raccoons run large, and where fat individuals weighing 24 to $301 / 2$ pounds have been recorded.

Distribution and habitat.-These large raccoons are common only locally along some of the streams of eastern Oregon, southern Idaho, and northern Nevada, where they find ideal conditions in some of the deep lava-rock canyons (fig. 78). The canyon walls, full of clefts, cracks, and small caves afford the safest kind of shelter and protection close to the water where an abundant supply of food is generally available on the brushy bottoms or in the water along the edges of streams and ponds. In such places along the Snake River and its branches they are found in considerable abundance and are so close to safe retreats that many individuals reach full maturity or very old age. This is evidenced by some of the skulls that show excessive development of ridges, processes, and massive bony structure as well as much worn teeth.

Food habits. - Abundance of crayfish, frogs, minnows, mussels, and other small water life attracts them to the river banks, while numerous mice and small rodents, berries, and grapes afford a variety of foods along the canyon bottoms. In favorite spots the raccoon tracks are seen on every sandbar and mud flat, and the droppings scattered along the trails show the nature of their food.

Economio status.-Most of the range of these big raccoons is away from settlements, and little damage to crops or poultry is charged to them, but where cornfields are accessible these are likely to be raided for the juicy ears, and poultry is never safe from them if left within their reach. They are not inclined to come about ranches, however, especially where there are dogs, and their value for fur keeps their numbers reduced to a safe minimum.

In recent years many choice dark varieties of raccoons have been raised for their fur, which is beautiful and brings high prices when the black and gray strains are properly blended.

Family BASSARISCIDAE: Cacomistles

\section{BASSARISCUS ASTUTUS RAPTOR (BAIRD)}

Ringtail; Cacomistle; Civet Cat

Bassaris raptor Baird, Mammals, Mex. Boundary Survey, p. 19, 1859.

Bassariscus flavus oregonus Rhoads, Acad. Nat. Scl. Phila. Proc. 1893: 416, 1894. Type from Grants Pass, Oreg.

Type.-From California. A captive animal found on the street of Washington, D. C., in 1852 and supposed by Baird to have been brought from Callfornia. Later identified by J. A. Allen and by Merriam as the form occupying Callfornia and Oregon. A comparison of the more ample material now available clearly proves this view to be correct.

General characters. - Size of a small house cat but slenderer, with larger ears, and very long bushy tail, marked with black and white crossbars. Skull light, comparatively flattened with widely separated sagittal ridges and 40 teeth. 
Color, upper parts dark yellowish gray, heavily clouded with black-tipped, long hairs; face dusky gray with whitish spots above and below eyes and in front of ears; tail flattened, wide, with 7 transverse bars of white and 8 of black including the tip, the black predominating above and the white below; lower parts buffy or creamy white, approximately the same at all seasons.

Measurements.-Adult male from Glen Ellen, Calif.: Total length, $742 \mathrm{~mm}$; tail, 346; foot, 76; ear (dry), 40. Of adult female from Prospect, Oreg.: 745; $361 ; 72 ; 40$. Weight 28 to 39 ounces (Grinnell and Storer, 1924, p. 81).

Distribution and habitat.-The California ringtail inhabits western California and southwestern Oregon, mainly in Upper Sonoran Zone. There are specimens from Prospect, Grants Pass, and Gold Beach, Oreg., all in the Rogue River Valley, and reports of occurrence at Riddle, in the Umpqua Valley, and along the west side of Upper Klamath Lake. The description by Mr. Winans of Follyfarm, east of the Steens Mountains, of a long-tailed cat with rings around its tail, killed there in 1915, apparently adds a record for eastern Oregon and possibly another form, Bassariscus astutus nevadensis Miller $(1924, p .113)$, to the State. Ringtails, however, are so often kept as pets and escape after being carried long distances, that such isolated records are questionable.

Near Prospect, on the upper part of Rogue River, Preble caught one of these animals in 1896 in a trap set at the base of a tree near a cliff of the canyon wall and baited with fresh meat, the bodies of small birds and mammals skinned for specimens. In 1910, A. B. Cameron wrote to the Biological Survey that he had caught several "ring-tailed cats" in 1896 near Crater Lake. He described them as about the size of a marten, with long tails ringed with black and white, and head, eyes, and ears resembling a small fox. In 1914 Harry Telford of Klamath Falls, found tracks near Crater Lake that he "was pretty sure" were made by these animals, which he considered common on the west side of the Cascades. In $1916 \mathrm{Mr}$. Wampler, at Pelican Bay, told the writer that he had caught several ring-tailed cats along the west side of Upper. Klamath Lake, where he usually trapped for fur in winter.

Near Grant's Pass, Clark P. Streator in 1891, and Luther Goldman in 1914, reported them as well known to hunters and trappers in that vicinity and usually found in the mountains and canyons. At Gold Beach, in 1909, the writer saw one skin brought into the store and was told that the animal was common in Rogue River Canyon near there.

General habits.-Over a wide range in the southwestern United States the ringtails inhabit mainly canyons, cliffs, and caves, but in western California and southern Oregon, under cover of forest and chaparral, they range also to some extent over the lower mountain slopes at a distance from protecting rocks. They are strictly nocturnal animals, hunting at night or in dark caves and rarely seen except as caught in traps, or when they come into camps and cabins at night to hunt for mice and rats. They are excellent climbers, both over cliffs and in trees, and are noted for their quickness and skill in catching small animals for food. They have gentle dispositions and in the early days were often tamed and kept instead of cats to catch the mice and rats about the miners' cabins.

Breeding habits.- The females have usually two pairs of mammae arranged in a quadrangle on the posterior part of the belly, and the young are, in the few instances known, 3 or 4 in number. 
Food habits.-Small mammals, largely mice and wood rats, are said to furnish most of their food, but like other closely related species the ringtails undoubtedly capture some small birds and eat insects and fruit when other game is scarce. They are readily attracted to traps by any kind of meat, fur, or feathers, and are easily caught.

Economic status.-As fur-bearing animals ringtails have but little value and often are not considered worth skinning when caught. Still their fur is fine and soft and when prime rather pretty, as well as light and warm. Perhaps the fur value, however, makes up for their occasional meal on poultry or small game, while their greatest value lies undoubtedly in their check on overabundance of wood rats, mice, and other rodents. To what extent they destroy insects and such small animal life is not known.

Family URSIDAE: Bears

\section{EUARCTOS AMERICANUS CINNAMOMUM (AUDUBON AND BACHMAN)}

Idaho Black Bear; Cinnamon Bear; Yackxah of the "Chopunnish" Indians (L. and C.) ; TOKA'KUACHA of the Piute at Burns; WE-TAM of the Klamath (C. H. M.)

Ursus americanus var. cinnamomum Audubon and Bachman, Quad. North Amer., v. 3, p. 125, 1854.

Type locality.-Lower Clearwater River, Camp Chopunnish, near mouth of Jim Ford Creek. western Idaho. Description based on skin purchased from Indians by Lewis and Clark on May 31, 1806 (1893, v. 3, p. 1030).

General characters.-Bears are heavily built and powerful animals with mere rudiments of tails, very strong limbs, plantigrade feet, strong claws, and heavy carnivore dentition. The black-bear group differs from the grizzlies in generally smaller size, relatively as well as actually lighter dentition, and in short well curved rather than long relatively straight claws on the front feet. Nose with large naked pad; eyes small; ears well haired, prominent in summer, almost buried in the long fur of winter; teeth normally 38 , but some of the small premolars usually lacking.

This subspecies averages larger than the eastern americanus, with higher, more arched outline of skull, relatively heavier canines and lighter molars. The skull is similar to that of amblyceps, of the southern Rocky Mountains, but molar teeth larger and thicker. Color varying from black to dark and light brown and often fading in summer to yellowish or whitish in the old winter coat, sometimes with a white spot or patch on throat or breast; nose usually brown or yellowish. Judging from specimens examined and field reports there are about one-third more brown than black bears in eastern Oregon, and about four times as many black as brown west of the Cascades. There are several records of twin cubs, 1 brown and 1 black, with either a black or a brown mother.

Trustworthy measurements and weights of bears are greatly needed for all parts of the country, including Oregon. A well-tanned skin of a large male from the Blue Mountains measures in total length 6 feet; hind foot, 7 inches; tail, 3 inches; ear, 4 inches. Skull of old male from Wallowa: Basal length, $275 \mathrm{~mm}$; zygomatic breadth, 185. Published weights of from 200 to 500 pounds rarely specified whether the animal was actually weighed or the weight merely estimated.

Distribution and habitat.-The black bears still occupy much of their original range in Oregon, but generally in greatly reduced numbers (fig. 79). They were once common throughout the Blue Mountain section and along the east slope of the Cascades. Apparently they never occupied the arid southeastern part of the State, or any part where water and timber were not within easy reach. 
The Forest Service reports of large game animals on the national forests of Oregon give the total number of black bears estimated as 6,272 for the year $1930 ; 6,457$ for $1931 ; 6,143$ for 1932 ; and 6,240 for 1933. This would naturally include the greater part of the bears of the State, although in western Oregon there is much good bear country outside the national forests.

General habits.-Black bears are especially forest animals, enjoying shade and cover and many of the fruits and other foods found in the woods. They are timid animals, and the mere presence of trees that can be quickly climbed in the absence of no other means of escape from their few but powerful enemies, probably gives them confidence, especially so with young bears, which are quick to take to trees if danger threatens or the mother gives the climb-a-tree-quick signal. After a long and busy night searching for the large quantity of food

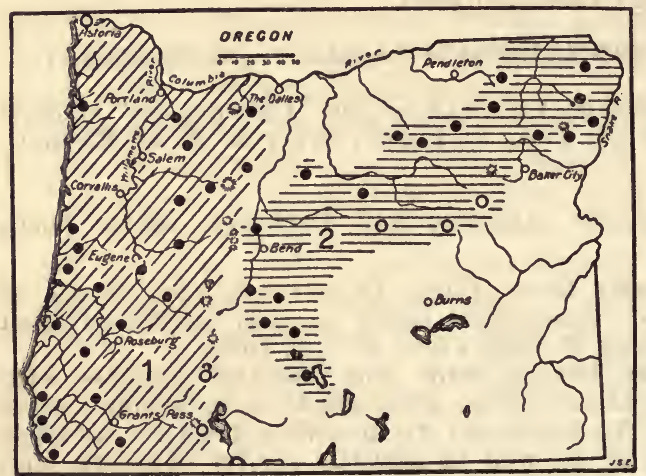

Figure 79.-Range of black bears in Oregon: 1, Euarctos americanus altifrontalis; $2, E$. $a$. cianamornum. required to satisfy their appetites they like to find some densethicket, swamp, or wooded canyon where they can sleep without danger of disturbance through the day or until hunger urges them to continue the food search. They also love the water and in hot weather swim and wallow in it for sheer enjoyment. They do not hesitate to swim across rivers or lakes and in places find much of their food along the shores or in the water. They are endowed with great strength and endurance but are not swift runners compared with a dog or horse, or even a grizzly bear. They are usually not dangerous to people unless wounded or cornered, but an old bear with cubs will sometimes fight to protect her young.

Breeding habits.-The black bear usually has two young, born in January or February while the mother is in her winter den. The young, small and helpless when born, are nursed in the den through the winter and spring, when the mother brings them out, and then far into the summer. By the middle of June they are about the size of a raccoon, and by fall are very competent little bears, though still accompanying the mother.

J. T. Jardine, of the Forest Service, wrote to the Biological Survey an account of the killing of a large black bear by J. K. Casper, near Promise, in Wallowa County, Oreg., and the capture of her 2 small cubs, 1 black and 1 brown, sometime in January 1909. The young, thought to be only a few hours old, measured 7 inches in total length.

Economic status.-Opinions in Oregon differ widely as to whether black bears are valuable game and fur-bearing animals to be preserved, or destructive predatory animals to be destroyed. Both opinions seem to be well supported under different conditions and in 
different parts of the State. In many places, such as uninhabited wildernesses and mountains, the bears can do no serious harm to stock, game, and crops and should be considered a valuable and interesting form of game. In farming, fruit-growing, and stock-raising districts they may do serious harm, principally on the sheep ranges where they sometimes acquire the habit of killing and feasting on sheep. They rarely kill larger stock or game, except sick or crippled animals, but a bear that has formed the habit of killing stock is generally killed to prevent serious losses. The evidence should be fairly considered, however, and the bears should not be destroyed because they merely clean up carcasses of animals killed by wolves, coyotes, mountain lions, or by hunters. Prime bearskins in winter fur usually have a value of $\$ 10$ to $\$ 20$ each, which added to the value of the meat and oil gives them a value about equal to that of a deer. As game animals they also rank high for the chase as well as for fur and trophies.

\section{EUARCTOS AMERICANUS ALTIFRONTALIS (ELIOT)}

OlyMPIC BLACK BeAr; Eskinkua of the Wasco at The Dalles

Ursus altifrontalis Elliot, Field Columb. Mus. Pub., Zool. Ser. 3: 234, 1903.

Type.-Collected at Lake Crescent, Clallum County, Wash., by D. G. Elliot expedition in 1898.

General characters.-Size large, about as in the Rocky Mountain black bears; color mainly black, often wholly black, including nose, the brown form much less common. Records show about 4 black to 1 brown west of the Cascades. Skull generally short, wide, and high, the frontal region in old males often abruptly and conspicuously elevated. Dentition rather heavy and upper molars generally wider if not longer than in cinnamomum, its nearest associate on the east.

Measurements.-No reliable skin measurements are available. The skull of an adult male from Hoodsport, Wash., measures: Basal length, $265 \mathrm{~mm}$; zygomatic breadth, 190.

Distribution.-Specimens of black bears from the Olympic Mountains, western Washington and Oregon and northwestern California show more or less typical characters of this form, but along the eastern slope of the Cascades in Oregon they combine the characters of cinnamomum with those of altifrontalis so completely that often they could as well be placed with one as the other (fig. 79). From Dufur at the east base of Mount Hood, the skulls go more nearly with altifrontalis, but from Paulina Lake, La Pine, Fort Rock, and Silver Lake they are clearly intermediate or nearer to cinnamomum. No specimens have been examined from the Klamath country where black bears were once common and where californianus might be expected to occur, if anywhere in Oregon.

General habits.-In the densely forested range of these west-coast black bears there was and still is a wealth of food and cover to support large numbers, and probably nowhere in North America were bears originally more numerous. In 1909 , on a trip down the coast of Oregon the writer found them still abundant all along the way, although that part of the State had been well settled for many years. On one sheep ranch on Chetco River in southern Curry County more than a hundred bears had been killed within the year without much apparent impression being made on the general supply. In 1929 the Forest Service credits the Siskiyou National Forest in that same $7209^{\circ}-36-21$ 
general section as harboring 910 black bears, a fairly generous supply for even this extensive area of wild rough land. The dense cover of forest and undergrowth of the Coast Ranges has not only furnished protection but abundance of choice food for bears, so for actual numbers they have been less destructive to livestock, sheep, and pigs than in the more arid parts of the State where at times food becomes scarce.

Hibernation.-In the late fall or early winter the bears generally become very fat, and in the mountains go into hibernation after the first deep snow in some cave, hollow tree, or log, or burrow under a $\log$ or brush pile, or in any secluded place. In the Fort Klamath country Harry Telford said they had not yet emerged from hibernation on March 9, 1914. In the mild climate of the coastal slopes the bears apparently hibernate for only short and irregular periods during the coldest weather and may be found active at any season of the year. To what extent they become torpid is not well known, but the rest period seems generally to be utilized, even where the weather conditions do not make it necessary.

Breeding habits.-A pparently the breeding season varies somewhat over the State. J. C. Warner killed an old female bear near Myrtle Point in Coos County on February 28, 1914, and took her two cubs, only a few days old. He fed them on the bottle until their eyes opened, after 6 days (Oreg. Sportsman 2 (4) : 8, 1914).

On February 14, 1914, Alva Addington killed an old female black bear with two cubs. Their eyes were not yet open (ibid).

Apparently the breeding season is later or less regular in the coast country than in the mountains where hibernation begins at an earlier date.

Food habits.-Few carnivores are more nearly omnivorous than bears. Their food consists largely of berries, roots, green vegetation, bark, acorns, nuts, grain, insects, crayfish, fish, small animals, or the meat of any animal they can catch, kill, or find dead. On emerging from their winter dens in the mountains before the snow has all gone they apparently fill their empty stomachs with dead grass, leaves, pine needles, or anything filling, without regard to food value. Then there is a vigorous search for carcasses of animals that have died during the winter, or have been preserved under the snow from the previous year's hunting or trapping season. Often this supply carries them up to the sprouting time of new plants or until roots, insects, and rodents can be dug from the ground to yield a food supply until the first berries are ripe.

Thistles, cow-parsnip, hellebore, skunkcabbage, flower stalks of beargrass (Xerophyllum tenax), camas bulbs, wild onions, and the inner bark of pines, spruce, balsam, tamarack, and hemlock all contribute to their summer food as shown by their droppings and the traces of food along their trails. These bears are especially fond of blueberries, salal, blackberries, raspberries, salmonberries, cascara berries, elderberries, and apparently all sweet fruits. A. G. Ames reports apples, mushrooms, pea vines, and grass in a number of stomachs examined. In autumn they feed extensively on acorns and any nuts, seeds, or grain they can find. They also dig out fat ground squirrels that have denned up for the winter and transfer the store of fat from the squirrels to their own supply. Where salmon or 
any kind of fish become numerous in shallow water, the bears wade in and catch them or feast on dead fish found along the shores. In places they find crayfish so abundant that they apparently yield an important food supply. At Paulina Lake, where crayfish are excessively abundant, Luther J. Goldman caught a bear by baiting his trap with crayfish, but the bear pulled his foot out of the no. 4 trap. Bears are fond of meat whenever they can get it, but domestic sheep and pigs are probably the only large animals they are able to capture unless the animals are young, crippled, old, or sick.

Economic status.- Nature draws few hard and fast lines, and one is often in doubt whether to class the bears as game, fur-bearing, or predatory animals. They combine the characteristics of all three categories. A series of full and interesting statements from the forest supervisors of Oregon in 1910 showed about an equal division in favor of killing black and brown bears as predatory animals on one hand and protecting them as game animals on the other. The recommendation of the district forester in letter of June 13, 1910, was that the Forest Service issue orders to its officers that no bears be killed when the fur was not prime unless they were actually killing stock.

The policy of the Biological Survey has been to kill bears only when necessary to protect stock or other agricultural interests, and the number thus killed is relatively small. In 1929 the Survey reported 48 bears killed in the State for the protection of stock. The Forest Service in their game census of the national forests in Oregon for that year reported the number of black and brown bears estimated on the Cascade National Forest as 350; Crater, 290; Deschutes, 200; Fremont, 50; Malheur, 140; Mount Hood, 400; Ochoco, 49; Santiam, 325; Siskiyou, 910; Siuslaw, 480; Umatilla, 700; Umpqua, 500; Wallowa, 455; Whitman, 655; total, 5,504, of which 538 were reported killed by all hunters. The national forests do not hold all of the bears of Oregon, but they do harbor the major portion, probably about three-quarters of the total.

Black bears are intelligent animals, naturally playful, and goodnatured, but temperamental and somewhat uncertain in disposition. Tame bears that have lost their natural fear of man are often dangerous and should be avoided by those not familiar with their psychology, for it should be remembered that they are quick and powerful animals, well able to kill a person with a single bite of their powerful jaws or a blow from their heavily armed paws. Their eyes are small and their vision not very keen, but their senses of hearing and smell are unusually quick and far-reaching. Few animals are more difficult of capture without the use of traps or good hunting dogs that will trail and tree them or delay them for the hunter.

\section{URSUS KLAMATHENSIS MERRIAM}

Klamath Grizzy; LoK of the Klamath (C. H. M.)

Ursus klamathensis Merriam, Biol. Soc. Wash. Proc. 27 : 185, 1914.

Type.-From eastern end of Siskiyou Mountains, near Beswick, Calif.; old skull presented to the Biological Survey by Charles F. Edson in 1912.

General characters.-In size rather large, larger than idahoensis; but not equaling californicus; skull high with broad flat frontal shield, long rostrum, heavy canines and short wide upper molars; back upper molar narrowed to 
a point posteriorly. Nearest in skull characters to idahoensis of the Rocky Mountain region, not closely related to other California forms. Skin characters unknown.

Measurements of type skull, large old male: Basal length, $331 \mathrm{~mm}$; zygomatic breadth, 223.

Distribution and habitat.- Unfortunately there is not known to be even a skull of this huge bear from Oregon, although the type was killed so near the Oregon line that a large part of its life may well have been lived within the State. Merriam gives the species as ranging in the Siskiyou Mountains of northern California and southern Oregon, north in recent times to Fort Klamath section and Rogue River Valley; in earlier days to lower Willamette Valley (presumably the same species) ; south in the Sierra Nevada an unknown distance (fig. 80). A skull from the lower McCloud River he refers

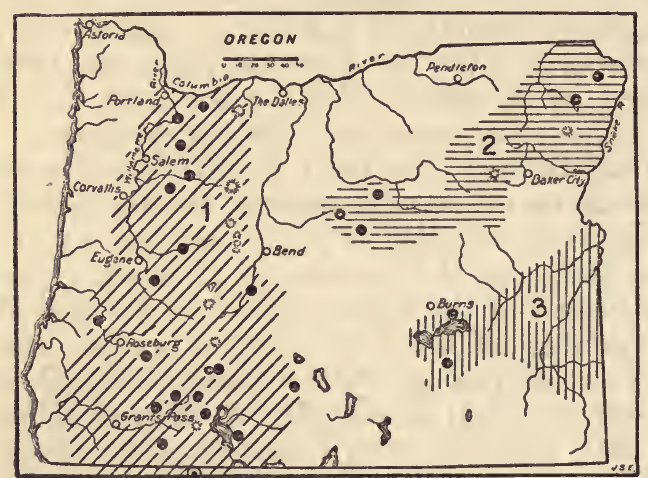

FIGURE 80.-Range of grizzly bears in Oregon: 1 , Ursus klamathensis; 2 ,U. idahoensis; $3, U$. mirus. Type locality circled. to this species (1918, $p$. y2). There are many old records of grizzly bears from the Klamath country, Rogue River, Umpqua, and Willamette Valleys, but no recent records.

In 1927 W. J. Perry, of the Forest Service at Bend, made a collection of bones in the South Ice Cave, some 40 miles south of Bend, and sent them to the Biological Survey for identification. Among these bones was found one tooth, next to the back lower molar, of a grizzly bear agreeing almost perfectly with the heavy, wide, quadrate molars of corresponding position in the type skull of klamathensis but sufficiently smaller to suggest a female of the species. It is an almost perfect tooth of a young bear with unworn cusps, but well blackened with age, and may date back for considerable time, although all of the bones with which it was associated are of present-day species. In fact it may not be more ancient than the time when Lord followed the track of a grizzly in the same general location in 1860 .

From 1811 to 1813 Franchere reported grizzly bears in the Willamette Valley as extremely ferocious (1904, p. 323).

In 1826 Douglas encountered grizzlies near the head of the Willamette, and one of his companions was attacked and had much of his clothing torn off as he escaped up a tree. On the upper Umpqua an old grizzly with 2 cubs was encountered, and Douglas killed 1 of the cubs (Hooker, 1836, pp. 126, 131).

In 1827 Ogden (1910, v. 11, no. 2, p. 21\%), in the Rogue River Valley, records an encounter with a large grizzly bear that was wounded by the trappers and then attacked by their Indian guide, armed with only a bow and arrow and a small ax. The Indian was seriously and probably fatally injured, but the bear remained in the bushes. 
Wilkes $(1845, p .348)$ reported that grizzlies were common in the vicinity of the Willamette Falls and that their flesh was esteemed for food.

On May 25, 1860, Lord $(1866, p$. 299) struck the trail of a large grizzly bear on the upper Deschutes River and followed it for some distance but failed to come up with " his large-clawed friend."

In 1894 Powell (1894, p. 182) published an account of killing a grizzly on the South Fork of McKenzie River and showed a photograph of the dead bear.

In 1916 Chris Beale, an old-time game warden and hunter at Snowshed Camp, about 8 miles west of Mount McLoughlin (Pitt), pointed out where, many years before, he had killed a famous old grizzly (Oreg. Sportsman 4 (1): 40, 1916).

A right posterior upper molar of a grizzly bear picked up on a sand bar of the Santiam River by Stanley G. Jewett and A. G. Ames, in August 1920, does not show positive specific characters but can be most reasonably referred to klamathensis.

Oliver Applegate, of Klamath Falls, reported to Dr. Merriam (189\%, p. 225) a grizzly killed in 1894 or 1895 on the west slope of the Cascades, but said that very few were then found north of the Umpqua Mountains and none north of the Calapooya Mountains, while east of the Cascades they had ranged not many years before as far north as Crooked River.

In December 1930 Oliver Applegate told the writer of experiences with grizzlies in the early days of southern Oregon. When he was a young man, some time in the sixties, his people kept the toll road over the Siskiyou Mountains between Oregon and California. He said that bears, panthers, and big wolves were numerous and that the grizzlies took a heavy toll of the cattle. He and his brothers built scaffolds in the trees, at points frequented by the bears, to watch for the marauders in the night, usually near the carcass of one of their victims, and they killed enough bears to make the stock industry possible in that vicinity. Later, on December 20, 1874 , on the ranch in Swan Lake Valley near Klamath Falls, he shot and killed a large grizzly that got in the habit of killing his cattle. The pasture was enclosed by a rail fence, made of split cedar rails not intended to hold a 1,000-pound bear. The bear would climb onto the fence, break it down, come into the pasture and kill a fat cow or steer, eat a good square meal of beef, and when hungry return for another. After 12 valuable cattle had been killed, the bear was tracked in the snow and shot on the Mountain Mahogany Ridge, north of the valley, since known as Grizzly Hill. The third generation of Applegates, well-known pioneers of Oregon, are still raising cattle in that valley, and they express no regrets at the passing of this species of grizzly.

Captain Applegate says that there was a big brown bear not quite so large as the grizzly in the Rogue River Valley that was powerful and savage enough to be a terror to the early settlers and regarded as more aggressive than the grizzly. It was so aggressive in fact that its duration in the pioneer settlements was brief. The Klamath and Modoc Indians (the Lutuanis) have three names for the bears, Wetam for the black bear, Loke for the grizzly, and Kanocka for 
the big brown bear. Unfortunately there are no specimens known to show what this bear was, whether another species of brown grizzly or merely large, morose, and uneducated individuals of the cinnamon- or black-bear group. The general keenness of Indians in recognizing specific differences would seem to indicate another species of grizzly with no name but the one they give it.

Captain Applegate, with a California hunter named Morenus P. Crapo, killed the last one of these bears that he knows of just north of the Lake of the Woods about 1868. It was a large reddishbrown male, but the length of claws was not noted. He thinks, however, that these bears did not climb trees. Twice on previous occasions bears of this species had apparently attempted to attack him. Once in 1862 on a peak in the Siskiyou Mountains when he was without a gun, one attempted to climb up some rocky peaks to get at him despite his vociferous protests but was finally dissuaded by stones rolled down about it. On another occasion four of these bears that he followed on crusted snow turned and came toward him when he shouted at them, but whether hostilely inclined or through mistaken identity was never learned.

John B. Griffin (Oreg. Sportsman, January 1918, p. 35), gives an account of a fight between two grizzly bears witnessed by Fred Barneburg, an early settler in the Rogue River Valley. It was on Hoxie Prairie near Medford; but no hint of the date is given, except that Barneburg was one of the early settlers in the valley who hunted deer where Medford now stands and hunted bears on Dead Indian Creek and around Grizzly Mountain. From his camp on the edge of Hoxie Prairie he came out of the timber one morning armed with an old muzzle-loading rifle and was surprised to see two large grizzlies fighting savagely in the open. They would rear up, claw each other, bite and growl, and roll over and over on the ground, oblivious to anything around them. Having only a single-shot muzzleloader, he wisely decided not to attempt to settle difficulties between the bears but to return quietly to camp.

Griffin adds that grizzlies in those days were dangerous. They were plentiful and not hunted much, and it took a man with plenty of nerve to attack one with only an old muzzle-loading rifle, or even with the earlier improved guns. He goes on to describe his own experience in killing a large grizzly in the Siskiyou Mountains at close quarters with the bear coming on until it dropped within 20 feet of him, after receiving several fatal shots.

In 1910 M. J. Anderson, supervisor of the Siskiyou National Forest, reported grizzly bears as very scarce.

In 1914 Luther J. Goldman was told of a grizzly killed in the Yamsay Mountains by an Indian about 1911, but he had no means of verifying the report.

In $1916 \mathrm{Mr}$. Wampler, an old hunter and trapper living west of Upper Klamath Lake, told the writer that he had on two occasions in previous years seen bear tracks too large for any black bear, and he was confident there were still grizzlies in the Mount Pitt section.

In 1924 and 1925 the Forest Service reported 1 grizzly bear on each of the Cascade and Siskiyou National Forests, and in 19312 and in 19321 on the Wallowa Forest, and in 19331 on the Williamette. 
It is to be hoped that there are a few left in the State today and that when their wanderings are finished their bones and skins may be immortalized in some good museum collection so that we may know positively what species originally roamed over western Oregon.

General habits.-Grizzly bears in the early days of muzzle-loading guns had little fear of man and were justly considered dangerous animals to encounter, but with the development of repeating and high-power rifles and the filling up of the West with hardy pioneers, these lordly animals have yielded to civilization and have all but disappeared.

Probably half of the recognized forms of grizzlies are extinct and others are rapidly going. Moreover, their natures have changed through persecution, and they are now the most wary and difficult of our large game animals to hunt, using their keen senses and intelligence for protection and escape rather than for aggression. Even where a few are known to reside in the wildest parts of the country they can rarely be found or seen unless caught by expert trappers.

Hibernation.-In early winter the grizzlies become very fat if the food supply has been at all ample, and with the first snows usually move upward into the higher mountain slopes to find winter dens in caves or hollow spaces among the rocks or to some dense cover where they can dig out a huge cavity under brush, logs, or stumps for a winter nest. Here they sleep or remain in a deep torpor, sometimes from October to March, but apparently for varying times in different localities according to climate.

Breeding habits.-The 2 to 4 young are born while the mother is in her winter den, sometimes as early as January; but apparently more often in February or March. They are not brought out until the warm days of spring, sometimes not until April or May, when, the size of house cats (Wright, 1909, $p$. 204), they follow the mother as she searches for food. They are said to nurse until late summer or early fall and to remain under the care of the mother through the winter and for the second summer. The mother then deserts them and brings forth another family of young the following winter.

Food habits.-Grizzlies are as wholly omnivorous as are the black bears, but apparently better hunters and more capable of capturing game and livestock. Meat is undoubtedly their favorite food, and it need not be freshly killed or fresh in any sense of the word. Any old carcass will give them a meal. Fish, and especially salmon, are eagerly sought and captured in the shallow streams or found dead along the shores, but for most of the year green vegetation, roots, bark, berries, or any fruit, nuts, grain, insects, or small animal life which they can find in rotten logs, under stones, or in the ground help to appease their appetites. In autumn they devote much time and effort to digging out fat rodents, ground squirrels, woodchucks, and such animals as go into hibernation earlier than they do.

Economic status.-Over most of their original range the grizzly bears must of necessity disappear and give place to farms and livestock. Some individuals become habitual cattle killers and must be hunted down to protect the livestock industry, but in some of the very steep and rugged mountain areas where grazing is not possible a few might well be spared to keep alive one of our most interesting forms of wildlife. Such areas, however, are few outside of national 
parks and are steadily growing more restricted. A limited number of grizzlies on the national parks do little harm and are always a great interest and attraction to visitors.

\section{URSUS IDAHOENSIS MERRIAM}

IDaho GrizzLy; Hohost of the "Chopunnish" (L. and C.) ; Sonaha of the Piute at Burns

Ursus idahoensis Merriam, North Amer. Fauna No. 41, p. 54, 1918.

Type.-Collected on North Fork Teton River, eastern Idaho, by Richard Leigh (Beaver Dick) in 1874. Preserved by C. Hart Merriam.

General characters. - Size medium, much less than horribilis; skull of old male well arched in outline; frontal region elevated and frontal shield slightly convex; rostrum long; canines rather light; molars heavy; posterior upper molars long and widely rounded posteriorly. Skull of female long, low, slender, with narrow zygomatic arches, and very small teeth. External characters not known.

Measurement of type skull, fully adult male: Basal length, $317 \mathrm{~mm}$; zygomatic breadth, 206.

Distribution and habitat.-The skull of an old female grizzly killed near Billy Meadows, on the Imnaha National Forest in 1908, by Joseph K. Carper, is considered by Merriam as typical idahoensis. This would naturally imply that the form of grizzly bear once common throughout the Blue Mountain section of Oregon (fig. 80) was also of this species, but the skull of another old female grizzly from the same locality, killed by the same hunter a year later and presented to Merriam for the Biological Survey collection, by J. T. Jardine, then of the Forest Service, cannot reasonably be referred to the same form. This skull, with slightly dished or concave frontal region, is considered by Merriam as probably representing the female of some form of the Ursus horribilis imperator group of the Rocky Mountain region. So much confusion and uncertainty still exists as to the relationship of female specimens to the several well-marked species of grizzly occupying the Yellowstone Park section, and represented only by male specimens, that more material is required for satisfactory determination of the females. These two skulls of females, one not perfectly identifiable, were until recently the only specimens known from Oregon of her once abundant and now almost vanished largest carnivore. There are doubtless still old trophies in skin rugs, or old skulls at ranches or homes of early settlers that would throw much light on the original distribution of grizzlies in Oregon if they could be made available for study. The tanned skin upon Jardine's floor from which the previously mentioned skull was taken, was of a dark-brown grizzly, with light-yellow tipping of the long hairs, with long slightly curved claws, but the uncertainty of its identification render these characters of little significance at present. It was later presented to the agricultural college at Corvallis, Oreg., and the skull is in the Biological Survey collection in the United States National Museum.

In 1915 the forest supervisor of the Imnaha National Forest reported grizzly bears as scarce, and the same year in the Wallowa Mountains the writer could get no recent records of occurrence. In 1919 G. G. Cantwell reported them from the Imnaha country on hearsay, but could find no trace of their presence, and the same year 
Stanley G. Jewett could get no recent reports from the Howard and John Day River country. He was told of a grizzly bear killed near Lookout Mountain, east of Prineville, in 1885, and one seen by some hunters on the head of Badger Creek, northeast of Prineville in 1891.

\section{URSUS MIRUS MERRIaM}

Small Yellowstone Park Grizzly; Sonaha of the Piute at Burns

Ursus mirus Merriam, North Amer. Fauna No. 41, p. 40, 1918.

Type-Collected at Slough Creek, Yellowstone National Park, Wyo., by Henry Anderson, March 27, 1915.

General characters. - Size, medium, much less than horribilis, imperator, klamathensis, or idahoensis, still somewhat larger than texensis or nelsoni. Skull long, narrow, and flat with light dentition for a grizzly ; posterior upper molar small and triangular with narrow posterior point. Color from life and from a few skins seen in and around Yellowstone Park, dark brown, fading to yellowish brown in summer.

Measurements.-Of type skull : Basal length, $315 \mathrm{~mm}$; zygomatic breadth, 220 ; interorbital breadth, 77; alveolar length of upper molar series. 75. Measurements of skull from bed of Malheur Lake; Basal length, 324; zygomatic breadth, 210; interorbital breadth, 78; alveolar length of upper molar series, 77.

Distribution and habitat.-The only specimen of this small brown grizzly from Oregon is a sikull picked up on the dry bed of Malheur Lake on October 15, 1930, by Frank and Mack Thompson, and given to G. N. Jameson, of Burns, Oreg. (fig. 80). Jameson kindly lent it to the Biological Survey for comparison and identification but wished to keep it in a local museum of Harney County material at Burns as a representative of the animal life once indigenous to the Malheur Valley. Later, however, through the efforts of Merriam, and with Thompson's consent, it was acquired by the United States National Museum as a part of the Biological Survey collection.

The skull was found on the dry bed of Malheur Lake a few miles south of Lawn and east of the mouth of the Silvies River, about a mile from the shore line. During the summer of 1930 the water of the lake receded for several miles from shore, leaving exposed many old skulls of buffalo and some elk, as well as this bear skull. All are in a fairly good state of preservation but show evidence of age and loss of some of the mineral matter of the bones but no deposit of silica or evidence of petrifaction. The bones are brittle and the thin edges are somewhat eroded or receding, but otherwise the skulls are quite normal.

The written history of this valley goes back for more than 100 years, and it is probable that the skulls of the buffalo in the lake all date still further back. This grizzly skull shows evidence of about the same antiquity and may be a contemporary of the bison in the tragedies of the lake bed. In fact its presence there may have some relation to the buffalo also trapped in the oozy mud of the lake bottom.

While far from the previously known range of Ursus mirus this specimen suggests a very logical range for the species from the lower levels of the Yellowstone Park country down the Snake River Valley over southern Idaho, and the lava-bed country of eastern Oregon. It seems highly probable that old records of grizzlies in the gorges of Steens Mountains are referable to this species. Up to 
recent years a small grizzly has occupied southern Idaho, and possibly the species may still be represented in some of the great lavabed country stretching between Oregon and Yellowstone Park.

In 1916 William F. Schnabel sent the Biological Survey some notes from an old Piute chief, Yakima Jim, who told him that long ago there were so many bears in the Steens Mountains that the Indians did not dare to go into the mountains alone, but always two or more together. In 1896, when Merriam and the writer were first in the Steens Mountains, and since then, it has been impossible to learn of any trace of grizzly bears there, and they were probably killed out at an early date. Whether they were the Idaho grizzly or the Yellowstone Park grizzly, or neither, will probably never be known.

\section{ORDER PINNIPEDIA}

\section{Seals, Sea Lions, Sea Elephants, and Walruses}

Family OTARIIDAE: Eared Seals

\section{EUMETOPIAS JUBATA (SCHREBER)}

Steller's Sea Lion; Northern SEA LroN; KLE'-UH-UN of the Kwakiool (G. M. D.)

Phoca jubata Schreber, Saugthiere, v. 3, p. 300, 1776.

Eumetopias stelleri True, U. S. Nati. Mus., Proc. (1884) 7: 607, 1885.

Type locality.-North Pacific Ocean.

General characters. - Size large (pl. 46) ; neck long and heavy; form highly modified for life in the ocean; external ears small and pointed; front feet broad paddlelike flippers without nails or distinct digits; hind feet flipperlike but reversible and useful on land, with 5 distinct terminal lobes and small straight nails on top of 3 middle digits; rostrum broad; skull with low sagittal crest in males, none in females; molars $5 / 5$, small and pointed, with wide space in front of posterior premolars; eyes large; vibrissae few but very coarse and rigid; tail rudimentary; hair short and coarse without underfur. Color uniform brown or yellowish brown all over when dry, dark brown when wet, without spots or markings. Young darker brown than adults. Voice a heavy, prolonged roar, or deep bass growl.

Measurements.-Length of old male, said to be 12 to 13 feet; tail, 3 or 4 inches; ear, $1 \frac{1}{2}$ inches. Length of female, 8 to 9 feet. Weight of old male estimated 1,500 to 2,000 pounds; of female 600 to 1,000 pounds.

Distribution and habitat.-Shores of the North Pacific from Bering Strait south to the Santa Cruz Islands, Calif., and to Japan. Along the coast of Oregon, Steller's is the common sea lion seen in the surf or lying on the rocky islands and points. In 1814 Alexander Henry reported one seen in the mouth of the Columbia and several very large individuals seen and five killed in the Columbia near Oak Point, some 40 or 50 miles above the mouth of the river (189\%, vol. 2, p. 850).

On the complaints that great numbers of salmon were destroyed by seals and sea lions, the Oregon Legislature in 1900 passed a bill authorizing the payment of a bounty of $\$ 2.50$ on the scalp of each seal or sea lion killed along the coast of Oregon, or within 1 marine league off shore. A tax on fishing gear was levied to finance the bounty system, and later the bounty was raised to $\$ 5$ and even $\$ 10$ a scalp. Official records show that from 1921 to 1926 bounties were paid by the State on scalps of 8,965 sea lions and hair seals, of which the greater number seems to have been seals (Scheffer, 1928, p. 12). Most of these animals were killed with dynamite or shot with rifles, 
and the hunters estimated not more than 60 percent of those killed recovered for scalps. In addition hunters were employed by the State to shoot or otherwise destroy as many of the animals as possible. In 1926 the bounty was reduced to 50 cents a scalp and the wholesale killing of these animals for bounty practically ceased, but it was evident that the numbers were greatly reduced.

In 1908 Warden George W. Phelps, of Three Arch Rocks Reservation, near Netarts, stated in a letter to the Biological Survey that the sea lions "were very plentiful, the rocks being covered by them wherever they can get."

In 1917 Warden John Larson, of Astoria, tells of shooting 60 sea lions in about 3 hours on the Ecola Rocks, near Tillamook Head, where about a thousand were sunning themselves on the outside reef (Oreg. Sportsman, 5 (3) : 205, 1917).

On the Rogue River Reefs and at Cape Blanco the crews of gasoline boats were killing 300 to 400 sea lions a month for their skins, and making considerable profit from them (Greenwood, Newcombe, and Fraser, 1918, p. 24).

On June 10, 1923, United States Game Warden Ray C. Steele visited the sea lion rocks near Cape Blanco in company with W. M. Hunter, employed by the State Fish Commission to destroy the sea lions. Large numbers of the animals were seen on the rocks, and 106 were killed by Hunter that day.

General habits.-These huge sea lions are generally seen swimming in the surf or resting on the rocky islands off the coast, where their loud and almost continuous roaring carries above the roar of waves and wind. Clumsy and slow on land, they are powerful and graceful swimmers, even in the roughest water. When alarmed on their rocky resting places they struggle and flop to the edge and plunge into the water, sometimes from considerable heights. They are timid and when approached by man seek only to escape into the water, but rival bulls on the breeding grounds fight savagely among themselves and keep at a distance all young and less powerful males during the breeding season. They are highly social animals and often gather on favorably located rocks or islands in large numbers, formerly sometimes many thousands in a herd. At present, however, their numbers have been greatly reduced by killing for skins, oil, and bounty, and the large herds are found no more.

Breeding habits.--Steller's sea lion is polygamous, the old bulls taking up favorite stations on the rocks in May, fighting for their positions and keeping the less powerful males at a distance until the females join them a few weeks later, about the first of June. Elliot says there are usually 10 to 15 cows to a bull. The single large young is born soon after the arrival of the cow and is nursed and cared for by the mother on the rocks until old enough to go into the water. Ray C. Steele, in his report on the sea lion herd near Cape Blanco, says the animals mate when the pups are only a few days old; the period of gestation is therefore nearly a year.

Food habits. - Sea lions are known to feed on squids, starfishes, crustaceans, clams, and various kinds of sea food. The stomach contents of many animals examined along the coasts of California, Oregon, Washington, and British Columbia by various naturalists have disproved the oft-repeated statement that they live largely or entirely upon salmon and were responsible for the growing scarcity 
of these valuable food fishes. Besides salmon the remains of halibut, herring, flatfish, sea bass, and dogfish have been found in their stomachs, and it is evident that they feed upon whatever small animal life is most abundant and at hand (Greenwood, Newcombe, and Fraser, 1918, p. 17). There is still some question as to whether they are seriously detrimental to the fishing industries, except as they occasionally get entangled in the fish nets and cause some trouble and annoyance and much antipathy on the part of the fishermen. Scientists like Evermann, Starks, and Rowley, who have made careful studies of the evidence, have expressed grave doubts of the injurious effects of sea lions on the supply of food fishes.

Economic status.-There has long been controversy between commercial fishermen and those interested in the preservation of all harmless wildlife, but the evidence of serious destruction of food and game fishes has not been produced to convict these interesting animals of high crime against man's best interests. Still they have been destroyed in such numbers as to greatly deplete the herds and wipe out many large breeding colonies.

Sea lions have a commercial value for skins and oil, and in many places where they are in the habit of lying on islands near shore, they are of great interest to the public. Thousands of dollars are spent to have a few in a zoological park, but the interest there is insignificant compared with that of a roaring herd on their native rocks.

\section{ZALOPHUS CALIFORNIANUS (LESSON)}

\section{California Sea lion}

Otaria californiana Lesson, Dict. Class. Hist. Nat. 13: 420, 1828.

Type locality.-California.

General characters. - Size much less than that of Steller's sea lion, but form and general appearance about the same; rostrum narrow; skull with high arched sagittal crest in old males, none in females; molars $5 \%$, small and pointed and evenly spaced; hair short and coarse without underfur. Color dark brown, fading to light brown or yellowish brown, blackish in appearance when wet. Voice a shrill, far-reaching howl or hoarse bark, often heard for a long distance above the roar of the surf.

Measurements.-Adult male: Total length (nose to tip of tail, not flippers), about 7 to 8 feet; tail, 2 to 4 inches; ear, $11 / 4$ inches. Adult female: Total length about 6 feet. Weight of bulls 800 to 1,000 pounds; of cows 500 to 700 pounds.

Distribution and habitat.-Pacific coast from Mexico north to British Columbia. Common on many points and islands along the California coast and recorded on the coast of Washington and southern British Columbia (Greenwood, Newcombe, and Fraser, $1918, p .10)$, but there are few records and no recent specimens from the coast section of Oregon. Still it is probable that they are more common here than is generally supposed, but have been overlooked, and that some of the records attributed to Steller's sea lion are really based on the California species.

A few bones of this species appear among the greater number of Steller's sea-lion bones in the shell mounds on the beaches near Netarts in Tillamook County, Oreg., and a further examination of these prehistoric kitchen middens will doubtless throw more light on the relative abundance of such animals along the coast. A peck of bone fragments gathered by Mrs. Stanley G. Jewett and son, Stanley 


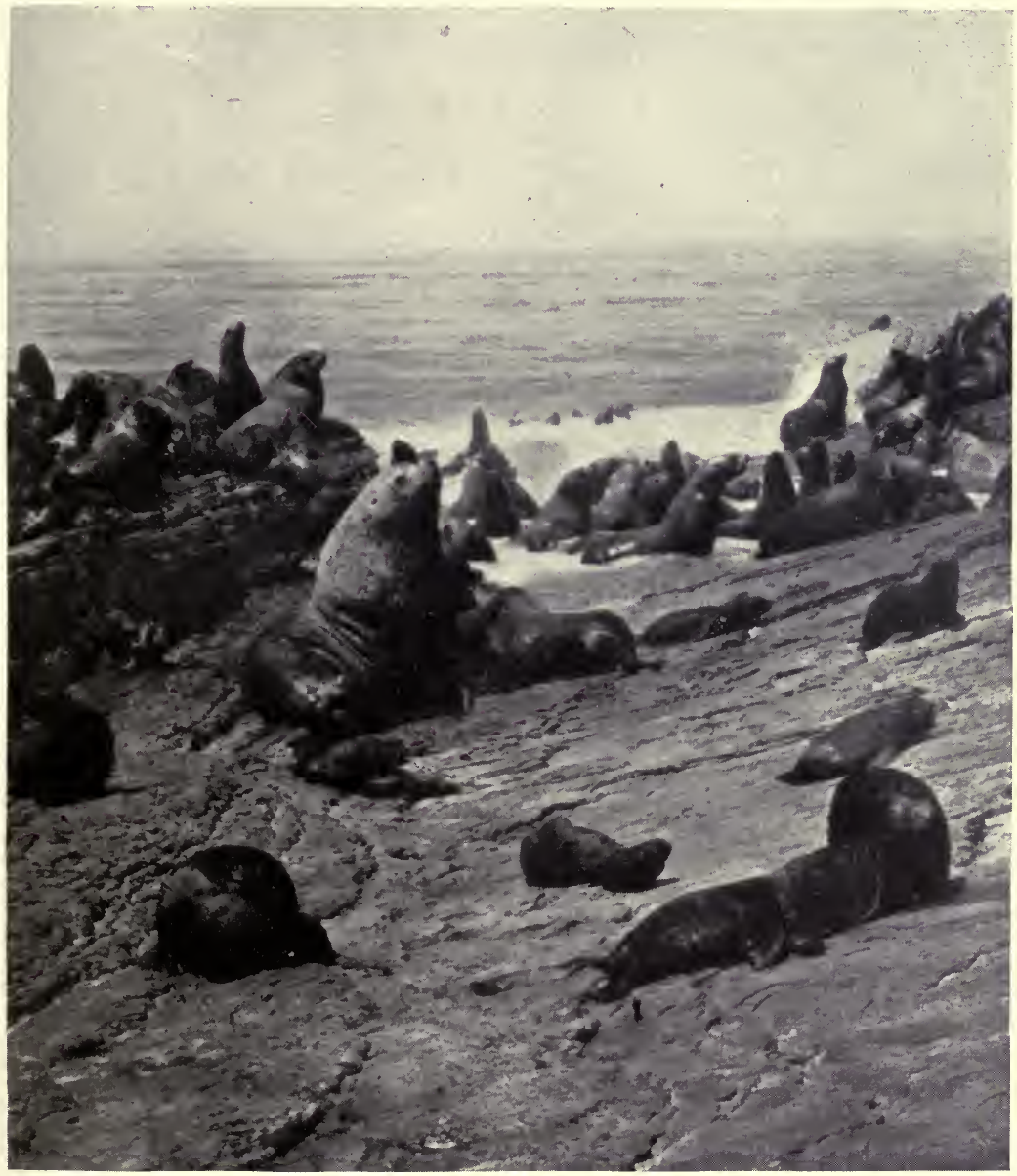

STELLER'S SEA LIONS ON ANO NUEVO ISLAND, CALIF.

A rookery in the breeding season, July 1, 1921 (photographed by the late John Rowley; courtesy of the American Society of Mammalogists). 

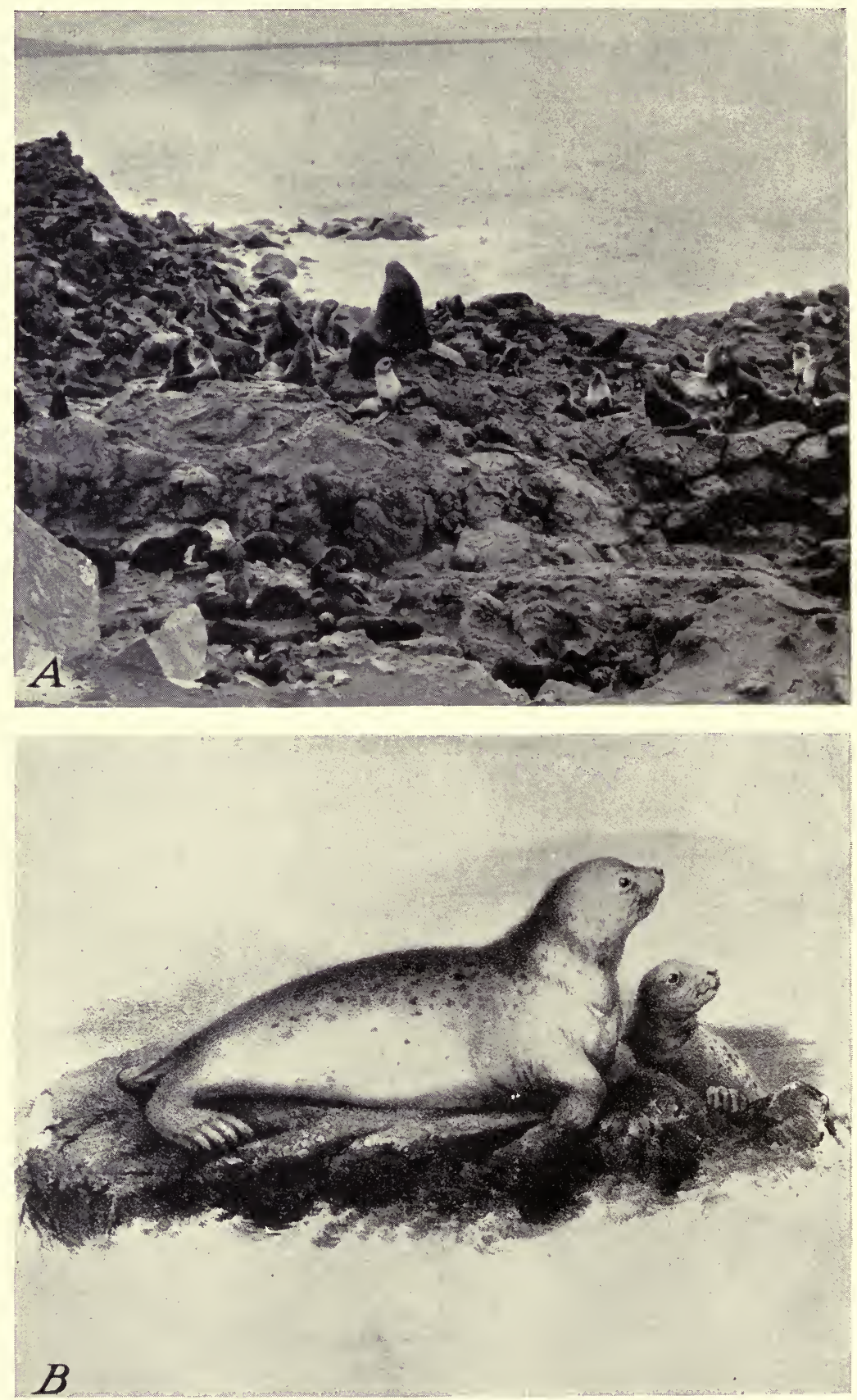

$A$, Fur-seal rookery, a bull, cows, and pups, on St. Paul Island, Alaska (courtesy Bureau Fisheries); $B$, harbor seal, spotted seal, or hair seal (from drawing by C. M. Scammon, in his Marine Mammals). 
G. Jewett, Jr., during their 1926 vacation at the beach, contained only a few pieces that could be reliably referred to this species.

General habits.-California sea lions are generally seen in the surf along shore, or lying on the rocky points or islands. They are wonderful swimmers, graceful and powerful in the water. On the coast near Cape Mendocino, in northern California, on September 5, 1899, Merriam and the writer sat on the bank above the beach for half an hour admiring a few of these animals sporting in the high running surf, gliding evenly along, often 3 or 4 abreast, on their backs, in the green-walled front of the oncoming breakers. By swimming diagonally they would keep pace with the waves and so close to the front that while many feet below the surface, they showed as in a glassfronted aquarium. As one wave broke on the beach they disappeared to reappear in the front of the next. When tired of this sport they dashed off between the waves, leaping clear of the surface in long graceful arches.

On the rocks they lie for hours basking in the sun, or sit up barking and yelping in noisy chorus. When it is necessary for them to move they flop and hitch along with great effort.

Breeding habits.- Toward the end of May the old males are said to resort to regular breeding places on rocky islands where they are soon followed by the females. The single pup is born in June and mating takes place about a month later according to Heinroth, who gives the period of gestation as averaging about 11 months. The females remain with the pups, nurse and care for them for a long time until they are able to swim and accompany their mothers in quest of more substantial food.

Food habits.-Evermann reports the stomachs of 13 of these sea lions examined in August 1901 by a special commission appointed for investigation of their food habits as showing small fish in 5 stomachs and squid in 11 stomachs. * * * "The quantity of fish was trivial, 17 small fish being the maximum, while the remains of 100 to 300 squid were found in each of 5 stomachs" (1921a, p. 16). He further says that, while the investigations of the commission were not sufficiently comprehensive or prolonged to warrant a final decision, they show rather definitely that sea lions cause very little damage to the fisheries, and the little injury done is caused by Steller's sea lion, the California sea lion being almost entirely guiltless.

Economic status.-Rowley (1929, pp. 1-36), after a full account of distribution, habits, breeding, food, and relation to fishing industry, based on years of close study, considers the California sea lions practically harmless to commercial interests and of great value to the State in their general interest to the public. He urges adequate. sanctuaries for their preservation and laws to protect them and control their abundance.

\section{CALLORHINUS ALASCENSIS JORDAN and CLARK}

\section{NORTHERN Fur SEAL}

Callorhinus alascensis Jordan and Clark, The Fur Seals and Fur Seal Islands of the North Pacific, pt. 3, p. 2, 1899.

Type locality.-Pribilof Islands, Alaska.

General characters.-Adult males large; females about one-fifth the size of males; neck long and in old bulls large; ears small and pointed; front feet 
modified as swimming flippers without distinct digits or nails; hind feet reversible and useful in walking as well as swimming; toes indicated by terminal lobes, the three middle toes with small subterminal nails; skull light with slight crests and long, narrow interorbital ridge; molars $6 \%$, small and sharp pointed; hair short, densely filled with soft underfur. Color dark umber brown or blackish, with gray tips to the outer hairs and buffy brown base of underfur; females and young more grayish (pl. $47, A$ ).

Measurements.-Adult males: Total length, 7 to 8 feet; tail, 2 inches; ear, 2 inches. Females: Total length, 4 feet; tail, 2 inches; ear, 2 inches. Weight of old males, when fat, 500 to 700 pounds; females 70 to 100 pounds; young at birth 12 pounds.

Distribution and habitat.-American coastal region of the Pacific Ocean, breeding on the Pribilof Islands and migrating south and eastward, some of the females wandering as far down the coast as southern California. Charles Bryant speaks of their abundance along the coast of Oregon and Washington Territory in 1869 (Allen, $18 \% 0, p .88)$. C. H. Townsend's map, in part 3 of the Sea Investigations Report (1899, opposite p. 234), shows great numbers of records of capture of fur seals by pelagic sealers along the coast of Oregon in January, February, March, and April. They are still of common occurrence along the coast of Washington and California, but little is heard of them on the Oregon coast. This may be due to the fact that no one is hunting them and that they are never seen on shore and are not generally distinguished in the water from the harbor seal and sea lions.

On February 1, 1921, an immature fur seal in badly emaciated condition came ashore on the beach at Netarts Bay, and a few hours later was found dead on the sand just above the breakers (Jewett, 1921, p. 235). Again on February 28, 1925, a young Alaska fur seal was captured in Tillamook Bay by a fisherman and the skin sent to Stanley G. Jewett for identification (Jewett, 1925, p. 200). These seem to be the only recent records of fur seals on the coast of Oregon.

General habits.-Apparently all of the Alaska fur seals gather on the Pribilof Islands during the summer, the old males returning to the islands in May, the adult females in June and July, the 2-yearolds mainly in July, and the yearlings in August and early September. After the prolonged breeding season, all leave the islands by the end of November and scatter to their feeding grounds in the open ocean and along the shores. They do not come on land again until the following spring.

Breeding habits. - The fur seals are highly polygamous. The old males gather as many females about them as they can protect from rivals, sometimes 100 or more. The females begin to arrive on the breeding grounds soon after the first of June and give birth to a single pup within a few days, or sometimes within a few hours, of their arrival. The majority of the pups are born between June 20 and July 20, but a few births occur up to the first week in August. The female accepts the male a few days after the pup is born, but does not leave the island to feed for some days later. The pups are nursed on shore for several weeks longer before they go into the water and learn to swim, but apparently are weaned before they leave the islands for the season.

Food habits.-Only in case of the nursing pups is any food found in the stomachs of seals while on land, but the stomachs of those killed while feeding in Bering Sea contain mainly squid, pollock, 
and a small fish known only by its bones in seal stomachs. Occasionally, Mr. Lucas says, salmon, herring, and rockfish are eaten. For full accounts of the fur seals refer to the History of North American Pinnipeds (J. A. Allen, 1880), Reports of the Fur Seal Commission, United States Treasury Department, and numerous bulletins of the United States Bureau of Fisheries.

Family PHOCIDAE: Hair Seals

PHOCA RICHARDII RICHARDII (GRAY)

Hair Seat; Harbor Seat; Spotted Seal; leopard Seal

Halicyon richardii Gray, Zool. Soc. London Proc., p. 28, 1864.

Type locality.-Vancouver Island, British Columbia, Canada.

General characters.-Form prostrate; body tapering both ways from the middle; neck short; no external ears (pl. $47, B$ ) ; molars $5 / 5$, small and serrate; feet modified for swimming; anterior finlike and held at sides; posterior paddlelike, not reversible, and projecting permanently backward beyond short tail; five nails on each foot; eyes large; hair short and coarse, but smooth and glistening. Color varying, from mainly whitish to almost black, but usually much spotted and mottled with brown and black on a gray or yellowish base, darker on back, paler below; young at birth woolly, whitish, or yellowish.

Measurements.- Total length of adults said to be 5 to 6 feet; sexes not very different in size. Weights are given as 60 to 100 pounds.

Distribution and habitat.-The Pacific coast from California to Alaska, limits of range not well established. Formerly abundant and still common along the coast of Oregon, in the bays and well into the mouths of the larger rivers. Found by Lewis and Clark in 1805 and 1806 and by many subsequent travelers in the Columbia River up to The Dalles and still occasionally seen in the lower part of the river.

General habits.-In summer the hair seals spend much of their time basking on the beaches, close to the water's edge, but little is known of their migrations and movements from place to place in the ocean. They are intelligent and very shy and difficult to approach on land and quickly disappear in the water if alarmed. They are, to a slight degree, social in habits but do not gather in large colonies nor emit loud sounds. Still, according to Captain Scammon, they have considerable vocal range among themselves. It is generally believed that they gather where the fish are most abundant, but there is a great lack of definite information as to food and breeding habits.

Breeding habits.-These seals are reported by Ernest P. Walker as breeding along the coast of southeastern Alaska, but there seem to be no records of their breeding on the Oregon coast.

Food habits.-It is generally supposed that the food of these seals is mainly fish, but more definite data should be gathered by actual examination of their stomach contents after feeding and under varying conditions. On St. George Island, Alaska, Lucas found crabs, squid or cuttlefish, and bones of codfish in their stomachs. Digestion is rapid, however, and generally their stomachs are found to be empty.

Of 35 stomachs of this seal examined by Scheffer from various points in Puget Sound, Wash., 8 were empty and 13 stomachs of young contained only milk. Fourteen of the adults contained solid 
food. Of these 1 contained salmon, 1 some small salmon or trout, and 12 contained traces of herring, tomcod, sculpin, flounder, shiner, skate, starfish, squid, octopus, shrimp, and crab. This meager contribution to our knowledge of the food habits of the seal is important, as it gives actual data on which to base some conclusions as to their economic status. Scheffer $(1928, p$. 10) concludes that instead of the food of these seals being entirely or largely salmon, as is so often claimed, it is largely of a harmless or possibly a beneficial nature, and may well be an advantage to the salmon industry.

Economic status.-Undoubtedly the harbor seals feed extensively on fish, but we should know what kinds and in what amounts the fish are eaten at various seasons of the year, as well as amount and kind of other food eaten, before the seals are destroyed, for they have certain values also worth considering. In many places they add an interesting form of wildlife to the shores and beaches, and they would be far more attractive if more abundant and less timid. Locally they have furnished an important staple of food and clothing, and commercially they have a money value in their beautiful skins, considerably used as rugs, couch covers, and to some extent as furs.

\section{ORDER CETACEA: WHALES AND PORPOISES}

\section{Suborder MYSTICETI: Toothless Cetaceans}

Family BALAENIDAE: Right and Bowhead Whales; Whalebone Whales

\section{EUBALAENA SIEBOLDII (GraY)}

\section{Pacific Right Whale}

Balaena sieboldii Gray, Ann. and Mag. Nat. Hist. (3) 14: 349, 1864.

Type locality.-Coast of Japan and northwest coast of North America.

General characters.-A large whale with very large arched head and wide mouth (pl. $48, A$ ), no teeth but two great slabs of whalebone with fringed edges for straining out the minute water animals for food. No back fin nor throat grooves; front feet modified as side paddles, or flippers for steering and balancing; tail broadly expanded into powerful flukes for swimming; head about one-third of total length; eyes very small, close to angle of mouth; no external ears; spiracles or nostrils two, separate on top of head about 16 feet back of tip of upper jaw; whalebone about 8 feet long, blackish in color; skin thick and hairless, over heavy layer of fat; color mainly black or blackish all over.

Measurements. - Total length about 60 to 70 feet, sexes varying but little in size; side flippers about 8 feet long; tip of snout to spiracles (blowholes) about 16 feet (Scammon); baleen 7 to $8 \frac{1}{2}$ feet long.

Distribution and abundance.-In former years, according to Scammon, the right whales were found on the coast of Oregon and occasionally in large numbers, but their chief resort was farther north among the islands along the coast of British Columbia and Alaska, in Bering and Okhotsk Seas, and south to Japan on the west and occasionally along the coast of California and Baja California on the east side of the North Pacific. There is no record of their passing south of the Tropics. Their migrations and breeding grounds are little known, and their numbers have been greatly reduced through long years of commercial whaling.

General habits.-These great whales are entirely pelagic, with seasonal migrations not well defined; in spring they resort in considerable numbers to the shores of the North Pacific and in winter 
are occasionally found at the southern limits of their known range. They are found at sea singly or in pairs or late in the season in large numbers crowded together in herds or gams, indicating the beginning of the migrations.

Their manner of respiration is to "blow" 7 to 9 times at the surface, sending up each time a spout or spray of exhaled air and vapor, often mixed with the surface water, which is conspicuous from considerable distance, and then to go down for 12 or 15 minutes. Some believe that they can remain under water for an hour or more, but proof of this is lacking. They are warm-blooded mammals and require the usual amount of oxygen for the blood.

Breeding habits.- So far as known the right whale does not come to sheltered bays or shallows to bring forth her single young, but gives birth to it wherever she happens to be in the open ocean. The period of gestation is not definitely known, but is thought by the whalers to be about a year. The frequency of breeding and rate of increase are not known.

Food habits.-With their great fringed mouths these whales scoop up vast quantities of plankton from the water and with a rising motion of the tongue force the water out between the fringes of whalebone at the sides of the mouth and swallow the plankton. Much of this consists of a great variety of forms of plant and animal found floating at or near the surface of the ocean.

Economic status. - Scammon states that the yield of oil by one of these whales averages about 130 barrels, but that individuals have yielded as much as 200 to 280 barrels, worth in the early days $\$ 10$ to $\$ 20$ a barrel. The yield of whalebone ranges from 1,000 to 1,500 pounds per whale, worth in $1911 \$ 5$ a pound. A large whale of this species taken at San Simon, Calif., in 1883, was estimated in value of oil and whalebone as worth $\$ 4,000$ (Starks, 1922, p. 8). A vast world industry has been maintained for centuries by the whales, and it would seem the part of wisdom to devise methods by which the industry should be made permanent, and that none of the species be exterminated or the valuable byproducts wasted.

The whole group of whales, including the killers, porpoises, dolphins, blackfish, and grampuses, are greatly in need of further study, both of specimens to show relationship and specific characters and of the living animals to obtain more reliable data on migrations, habits, breeding, food, and general economic value. Perhaps no other great group of mammals is so little known or so difficult to study, and for this reason every available bit of knowledge regarding them should be carefully recorded and every specimen that will give a clue to the species should be saved. Of course it is not possible to collect many skulls or skeletons of the larger whales, but of the porpoises and smaller cetaceans the skulls in many cases and the whole skeletons in a few cases can be saved and sent to some of the State or National museums, or information may be given that will lead to securing such specimens.

With the larger whales found stranded on the beaches or floating near shore it is always important to report the animal with such description as will lead to recognition of the species, and if desirable to. securing the important parts of the specimen. If possible the information should be telegraphed to the nearest public museum or 
to the United States National Museum so that prompt steps may be taken to obtain the specimen if desirable.

Occasionally old skeletons of whales are found on the beaches, and where the whole or a large part of a skull cannot be saved it is often possible to learn the identity of the species and obtain a desirable museum specimen by cutting out one or both of the ear bones from underneath the base of the skull. The ear bones consist of an outer shell-like bulla, and the more important inner ear bones to which it is attached. Any species of whale can be positively identified by these bones.

Family RHACHIANECTIDAE: Gray Whales

\section{RHACHIANECTES GLAUCUS (COPE)}

California Gray Whale

Agaphelus glaucus Cope, Acad. Nat. Sci. Phila. Proc., p. 160, 1868.

Type locality.-Monterey Bay, Calif.

General characters.- Size smaller and form more slender than in the right whale (pl. 48, $B$ ) ; no dorsal fin; 2 or 3 longitudinal grooves on throat; head relatively slender and flat; baleen short, yellow in color; eye above corner of mouth; ear a mere opening in skin about 18 inches back of eye; spiracles on top of head about 6 feet from tip of nose; no dorsal fin, tail broadly expanded; side flippers well developed, about 6 feet long; teeth entirely absent in adults and baleen (whalebone) light and coarse. Color mottled gray, lighter in some individuals and in others almost black, most of the mottling on the upper surface.

Measurements.-Length of large males, 42 to 44 feet; pectorals, about 6 feet; spiracles (nostrils or blowholes), about 6 feet back of tip of rostrum; baleen, 14 to 16 inches long.

Distribution and abundance.-The California gray whales spend the winter along the coast of California, Baja California, and Mexico, where the young are born in the shallow gulfs and bays, and in spring they pass northward along the coast and spend the summer in Bering Sea, the Arctic Ocean, and Okhotsk Sea. According to Scammon they again appear off the coast of Oregon and upper California in October and November on their way south to their tropical winter haunts.

In 1853 to 1856 the number of these whales visiting the southern California coast in winter was estimated at 30,000 or 40,000 individuals, and in 1874 about 8,000 or 10,000 individuals (Scammon, 18\%4). In April 1927, Huey (1928, p. 17) saw 5 of this species, "reported on the verge of extinction" in San Ignacio Lagoon on the west coast of Baja California, and in August 1926, saw and photographed 1 taken at the California Sea Products Co.'s plant at Trinidad, Calif. This was taken near shore at Crescent City and was the only one of the species taken by the company's fleet at this point during 6 years of operation.

General habits.-These migratory whales follow the general shore line of the continent and come into the shallower waters of the bays to feed and breed. Hence their capture for oil and for other uses has been more rapid than in some of the more strictly pelagic species. Among the whalers they are counted dangerous animals as they are quick and powerful and will sometimes attack their pursuers and smash the boats and kill or cripple the occupants. The mother whale will savagely pursue and attack the boats if her calf is injured or separated from her. 
Breeding habits.-The young are brought forth in the spring in the warm, shallow waters of southern bays where they can be carefully guarded by the wary and intelligent mothers. Scammon gathered some evidence that the period of gestation was about a year and that the females bred at intervals of about 2 years. Huey (1928, p. 72 ) found 1 bull mating with 2 cows on April 18, 1927, off Baja California, and with each of the cows was an 18- to 22-foot calf. The cow's length was estimated at 40 to 45 feet.

Food habits. - Apparently little is known of the food habits of the gray whales. Green vegetation found in their stomachs may have been swallowed accidentally in collecting their regular food of small animal life, zoophytes, mollusks, crustaceans, and small fish.

Economic status.-The yield of oil from one of these small whales is given as usually 20 to 25 barrels, and the baleen is of small amount and coarse quality. Still there has been sufficient incentive to all but destroy the species. To the native hunters along the coasts of Oregon, Washington, British Columbia, and Alaska the hunting of these shore-frequenting whales has furnished food and many useful byproducts of the chase and has developed hardy and vigorous tribes of native hunters.

Family BALAENOPTERIDAE: Finback Whales, Whalebone Whales

\section{BALAENOPTERA PHYSALUS (LiNNAEUS)}

Compon Finback Whale; Set Whale

Balaenoptera relifera Cope, Acad. Nat. Sci. Phila. Proc., p. 16, 1868 . Type from coast of Oregon.

[Balaena] physalus Linnaeus, Syst. Nat., ed. 10, v. 1, p. 75, 1758.

Type locality.-Spitzbergen Seas.

General characters.-The finback whale, or "finner" is intermediate in size between the right whale and the blue whale, but is distinguished from the former by a well-developed finlike dorsal projection on the back toward the tail, and from both by the large number of deep grooves on throat and belly. It is one of the whalebone group with 2 well developed slabs of baleen some 2 feet long, of a light lead color, sometimes streaked with whitish; throat and belly heavily ridged longitudinally; eyes close to corners of mouth; pectoral fins and tail about as in the California gray whale, but top of head less arched, much more flattened. Color of upper parts plain blackish or sometimes brown, lower parts, including lower surface of tail flukes white.

Measurements. - Total length, about 60 to 75 feet; tip of nose to tip of side fins, 15 feet; width of tail flukes, 14 feet (Scammon).

Distribution and abundance.-These whales have been recorded along the coasts of California, Oregon, and Washington, but their wider range seems lost in the uncertainty of relationship with forms to the north and south and in the Atlantic bearing other names. The type of Balaenoptera velifera described by Cope from the coast of Oregon is the only definite record for the State. The type specimen (a section of the baleen) seems to have been lost, and until other specimens are collected or the animals are carefully observed and described it will not be known whether to use Cope's name velifera, or the older name of the Atlantic finback physalus.

Apparently these whales are not abundant along our coast of the Pacific and never have been in such numbers as some of the other species.

General habits.-Scammon says these whales frequently gambol about vessels in mid ocean as well as close into the coast, darting 
under and around the ships, singly or in groups of 15 or 20 , as if enjoying a spirited race with the ship dashing along under press of sail. Their uncertain movements and great speed render them difficult of capture.

Breeding habits.-There is little on record of the breeding habits of this species except the observance of the single young accompanying its mother, and in one case Andrews (1909 p. 225) notes that a calf refused to leave its mother after she was killed but followed the boat until it also was killed.

Food habits.-Scammon says their food is of the same nature as of other rorquals and the quantity of codfish found in them is truly enormous. Andrews (1909, $p$. 225) reports the stomachs of Vancouver and Alaska animals containing only Euphausia (minute crustaceans) with the exception of one individual, taken August 18, which contained in addition about 4 barrels of herring.

Economic status.- The yield of oil from one of these whales is given by Scammon as about 75 barrels and the baleen is only about 28 inches long. Their relatively low commercial value, and the difficulty of capturing these swift whales, as well as their scattered distribution, may save some of them for future generations.

\section{BALAENOPTERA BOREALIS LESSON}

Pollack Whale; Sei Whale; Sardine Whale; Rudolphi's Rorqual

Balaenoptera borealis Lesson, Hist. Nat. Gen. et Partie. Mamm. et Oiseau, Cetaces, p. 342, 1828.

Balaenoptera velifera borealis Dall, Scammon's Marine Mammals, p. 303, 1874.

Type locality.-Gromitz, Lubeck Bay, Schleswig-Holstein, Germany.

General characters.-Differing from the common finback according to Captain Scammon, by a larger and higher dorsal fin. Whalebone dark with fine curly white hairs over inner surface. Body dark blue or brownish above, generally spotted; tail flukes usually not white below, and little white on belly.

Meusurements. - Total length recorded up to 52 feet.

Distribution.-Once common along our northwest coast. - Dall, who observed many of them in the summer of 1872 in the Shumagin Islands, Alaska, says those of Oregon seem to have a dorsal intermediate in size between the northern and small-finned southern forms. These whales are regularly taken off the coast of Vancouver Island, and there is one record for Monterey Bay, Calif. (Starks, 1922, p. 31). It seems probable that they still reach to the coast of Oregon, even if not in the typical form.

\section{BALAENOPTERA DAVIDSONI SCAMMON}

Little Piked Whale; Sharp-headed Finner Whale; Lesser Robqual

Balaenoptera davidsoni Scammon. On a new species of Balaenoptera. Calif. Acad. Sci. Proc. 4: 269-270, 1873. Advance publication October 4, 1872.

Type sloull.-Collected at Admiralty Inlet, Washington Territory, October 1870 , by C. M. Scammon, who measured and wrote a description of the whale while it was being cut up by the Indians on the beach of Port Townsend Bay.

General characters. - Smallest species of the whalebone whales known on the Pacific coast, 30 to 33 feet in length; the type, a 27 -foot female containing a $5 \frac{1}{2}$-foot foetus, was slender in form with pointed head, well-developed and curved dorsal fin, and small pointed pectoral fins or flippers; baleen pure white, the longest laminae only 10 inches long; throat and belly marked by 70 longitudinal folds or ridges. Color, upper parts dull black, lower parts, including lower surface of flukes and pectorals, white. 
Measurements.-Of type: Total length, 27 feet; greatest depth, 5 feet 4 inches; length of pectorals, 4 feet; breadth of tail flukes, 2 feet 1 inch.

Distribution.-Scammon says that in the course of 12 years' observations, during which time he had traced these whales from the coast of Mexico to Bering Sea, they had generally been considered by the whalers as young of one of the finback or one of the larger whales, but finding the type, an evidently adult breeding female, convinced him of the distinctness of the species.

General habits.-In habits they are said to be like the finbacks, swift and active, frequently seen gamboling about vessels under way, or darting underneath from one side to the other, usually solitary, or rarely, in pairs. They wander along the whole continental coast of the North Pacific occasionally visiting the large estuaries about the shores. They often shoot along the shallow borders of the bays, in search of the myriads of small fry on which they mainly sustain themselves. They cannot be considered as objects of pursuit by whaling vessels but are occasionally taken by the natives at Cape Flattery. The yield of oil from the type specimen was estimated to be about 300 gallons.

\section{SIBBALDUS MUSCULUS (LINNAEUS)}

\section{Blue Whale; Sulphur-bottom Whale}

Sibbaldins sulfureus Cope, Acad. Nat. Sci. Phila. Proc., p. 20, 1869. Type from northwest coast (Pacific Sulphur-bottom Whale of Grinnell in Distributional List of Mammals of California, p. 374, 1913).

[Balaena] musculus Linnaeus, Syst. Nat. ed. 10, v. 1, p. 76, 1758.

Type locality.-Firth of Forth, Scotland.

General characters. - Largest of the known whales, reaching slightly more than 100 feet in length and estimated as weighing as much as 147 tons, the largest mammal ever known on our earth. Head flat above (pl. $48, C$ ) ; body relatively more slender than in the California gray whale with smaller dorsal fin and small pectorals; eyes close to corner and below level of mouth; throat and belly thickly ridged longitudinally with narrow folds; baleen in two heavy series, broad at base but not long, usually black. Upper parts bluish black, gray, or mouse brown, or in some cases light brown or whitish; lower parts yellowish or sulphur color, or speckled with white.

Measurements.-One large individual taken by Captain Roys: Total length, 95 feet; length of jawbone, 21 feet; longest baleen, 4 feet. Yield of baleen, 800 pounds; yield of oil, 110 barrels. Weight of whole animal estimated at 147 tons. (There are reports of 100 and 105 feet $1 n$ length.)

Distribution and abundance.-The sulphur-bottom whales are found in the Atlantic as well as in the Pacific but whether identically of the same species is not positively known. In the Pacific they are widely distributed and apparently occur at all seasons off the coast of California and northward; but according to Allen (1916, p. 225) seem to avoid the tropical seas.

General habits.-Less common than the finbacks and usually solitary or in pairs; swift and powerful swimmers and rarely captured by the ordinary whaling methods. They usually inhabit deep water where they quickly sink when shot with the powerful bomb guns. Breeding habits.-Little is known of the breeding habits of whales, but Guldberg says the mating takes place in summer on the coast of Finmark and Lapland, where he once saw a pair in the act of copulation on July 15, 1883. The period of gestation is supposed to be about a year, and the single young is born the following summer. There 
are records of two young with a mother and one record of two foetuses taken from a female. The young at birth are about 20 feet in length.

Food habits.-Glover M. Allen says the blue whale is not known to feed on fish but appears to subsist largely if not entirely upon minute crustaceans, which it engulfs in great quantities and sifts out from the water by means of its matted bristles of whalebone. Twelve bushels or more of these crustaceans have been recorded in the stomach of one of these whales.

Economic status.-Despite the large yield of oil and whalebone these great whales have not in the past contributed greatly to the profit of the whaling industry, owing to the difficulty of their capture, but now they are being sought from floating factories in the Antarctic seas, and with improved machinery for capture their ultimate extinction seems threatened.

\section{MEGAPTERA VERSABILIS COPE}

\section{Pacific Humpback Whale}

Megaptera rersabilis Cope, Acad. Nat. Sci. Phila. Proc., p. 15, 1869.

Megaptera nodosa (Bonaterre) of G. S. Miller and G. M. Allen. Described from coast of New England, 1789. ${ }^{12}$

Type locality of versabilis Cope.-North Pacific.

General characters. - Size medium, length about 50 feet; form short and thick, with lower jaw projecting well beyond upper (pl. 48, D); eye near corner and well below level of mouth; pectorals very long and large, scalloped on lower edge; tail flules broad; dorsal fin low and humplike; numerous knobby protuberances scattered over posterior line of back, top of head, and on chin and edges of pectorals; throat and belly heavily ridged with longitudinal folds; baleen small and of inferior quality. Color variable, generally black or rarely gray above, gray below with pale or whitish throat, often mottled or sometimes pure white under the fins and flukes, and on belly.

Measurements.-Male from Bering Sea: Length, 49 feet, 7 inches; pectorals, 13 feet, 7 inches; spread of flukes, 15 feet, 7 inches; tip of snout to nostrils, 9 feet, 4 inches. Young at birth, about 12 to 15 feet in length. One captured in Puget Sound near Tacoma on August 22, 1930, was reported as measuring 55 feet in length, and estimated as weighing 35 tons (Murrelet, 11 (3): 75 , 1930 ).

Distribution and abundance.-The humpback whales are said to roam through every ocean in all latitudes between the Equator and the frozen seas, both north and south. Whether the Atlantic and Pacific individuals are specifically the same has not yet been conclusively shown, but the name for the Pacific form described by Cope is used in preference to the name of the Atlantic species. In the North Pacific they seem to have a more or less regular migration from their winter breeding grounds on the coast of Mexico north along the coast of the continent to summer feeding grounds in Bering Sea and the Arctic Ocean, running the gauntlet of the whaling industry all the way, but especially in their northern and southern resorts. Formerly they were one of the abundant and valuable products of the fisheries all along the western coast of the continent.

General habits.-In actions as well as form the humpbacks are so characteristic as to be easily recognized at a distance by the whalers. The large fins or pectorals are used in making graceful turns and curves at or below the surface of the water, and the enormous lungs

12 Megaptera versabilis Cope given as synonym in Miller's Check-List. 
often throw the spout of vapor and water to a height of 20 feet or more. The females when nursing young appear to use up most of their fat and sometimes yield only a few barrels of oil. When killed these whales promptly sink to the bottom of the ocean unless secured by the harpoon and line before being shot in a vital spot with the bomb gun. The Indians and Eskimos hunt them in their open boats with air-inflated sealskins fastened to the harpoons as floats to retard the speed of the wounded whale and eventually to keep it afloat when killed.

Breeding habits.-The females resort to favorite localities to bring forth their young. On the west coast of Mexico Scammon (18\%.4, $p .43)$ reports numbers of females with calves only a few days old during December, and other females accompanied by large calves, probably yearlings. The calf at birth is about one-fourth the length of the cow-some 12 or 15 feet-and Scammon says they nurse much as do other mammals but under water as the cow lies at the surface partly exposed. As in other whalebone whales, the one nipple on each side is located well back on the side of the abdomen.

Food habits.-Scammon $(18 \%, 4, p$. 44) reports their food as consisting mainly of small fish and the lower orders of crustaceans. G. M. Allen (1916, p. 303), in writing of the Atlantic form, says they feed chiefly on pelagic crustaceans, engulfed in quantities as they swim about in the plankton currents. He also gives records of their feeding on small fish and squid.

Economic status.-Although relatively low in yield of oil and whalebone, these whales have been considered an important product of the whaling industry, and great numbers have been taken during the early days of the industry. The yield of oil is variable, from only 8 or 10 barrels in some nursing females to 30 or 40 barrels in animals in good condition. There are records of 85 and 145 barrels of oil from unusually large and fat individuals. The whalebone is of poor quality and low value, and the yield is usually not over 100 pounds to a whale.

\title{
Suborder ODONTOCETI: Toothed Cetaceans
}

\author{
Family PHYSETERIDAE: Sperm Whales
}

PHYSETER CATODON LINNAEUS

SPERM Whale

[Physeter] catodon Linnaeus, Syst. Nat. ed. 10, v. 1, p. 76, 1758.

Physeter macrocephalus Linnaeus (Grinnell, in Distrib. List of Mamm. Calif.), 1758.

Type locality.-Kairston, Orkney Islands.

General characters. - Largest of all the toothed whales, with an enormous head and full set of 40 to 50 teeth in slender lower jaws (pl. 49, A); upper teeth absent or rudimentary; nostril, or single blowhole, located near tip of heavy truncate rostrum; eyes well above corners of mouth; pectorals small; tail flukes broad; no dorsal fin; a knob or bunch on top of head and several along small of back; general color blackish above, becoming grayish below.

Measurements.-Large old males reach a length of 64 feet, but the females are much smaller and more slender, rarely exceeding 40 feet. The pectoral fins are only about 6 feet long, and the caudal flukes spread 12 or 15 feet.

Distribution and abundance.-Sperm whales were said to inhabit every ocean not bound with icy fetters during the winter, and 
formerly to range in the Pacific from $56^{\circ}$ north latitude to $56^{\circ}$ south, but that was in the early days of the whaling industry from 1853 to 1874 , when this most valuable of all whales was being eagerly pursued. At present their numbers are greatly reduced.

General habits. - Sperm whales are wide ocean wanderers and are often found in schools numbering 15 to 20 and even up to hundreds, sometimes a mixture of cows, calves, and bulls, or sometimes a band of old bulls or young bulls together. Generally the young bulls are timid and wary, but the old bulls will sometimes savagely attack the whalers' boats or even the ships, while the cows will fight for their calves and follow the boats if their young are captured. They are supposed to be deep-sea divers, and are known to stay under water for a longer time than any other whales, having been timed from 50 to 80 minutes while submerged.

Breeding habits.-Owing to their pelagic range little is on record of their breeding habits. The single calf is usually found with the cow whale and is born "at any time or place that nature may demand."

Food habits.-Their food consists principally of squid or cuttlefish, captured while swimming or possibly snapped up with the wellarmed jaw from their hiding places on the ocean floor. Also, according to Scammon, an occasional codfish, albicore, or bonito contributes to their bill of fare.

Economic status.- Scammon says the fully matured whales of this species rank with, if they do not exceed, the bowhead or great polar whale in magnitude and commercial value. The yield of oil is giver: as 75 to 85 barrels, while the sperm oil and spermaceti from the oil tank of the head, will sometimes yield as much as $15^{\circ}$ barrels of these valuable products. In less imminent danger of extinction than some whales of more local range, there seems great danger that this valuable species will not long be found in paying abundance.

\section{Family ZIPHIIDAE: Beaked Whales}

\section{BERARDIUS BAIRDII StejNEger}

\section{BAIRD'S BEAKED WhALE}

Berardius bairdii Stejneger, U. S. Natl. Mus. Proc. 6: 75, 1883.

Type.-Skull collected on eastern shore of Bering Island, by Leonhard Stejneger, in 1881.

General characters.-A small whale about 40 feet long with small head, slender beaklike mandibles, and 1 or 2 large teeth near tip of each lower jaw; pectorals small and close to head; dorsal fin small and far back; tail flukes broad. Black over most of body, gray or whitish on belly posteriorly in some individuals.

Measurements.-A large male stranded on the beach at Ferndale, Calif., measured 41 feet in total length and 16 feet in circumference around the middle of body.

Distribution and habitat.-Known from a few individuals cast up on shores of the North Pacific, the type skull and a few others from Bering Island, 2 from St. George Island of the Pribilof Group, and 1 from the outer beach near Ferndale, Calif. There seems to be no record of a living individual of the species, hence nothing of their habits is known. 

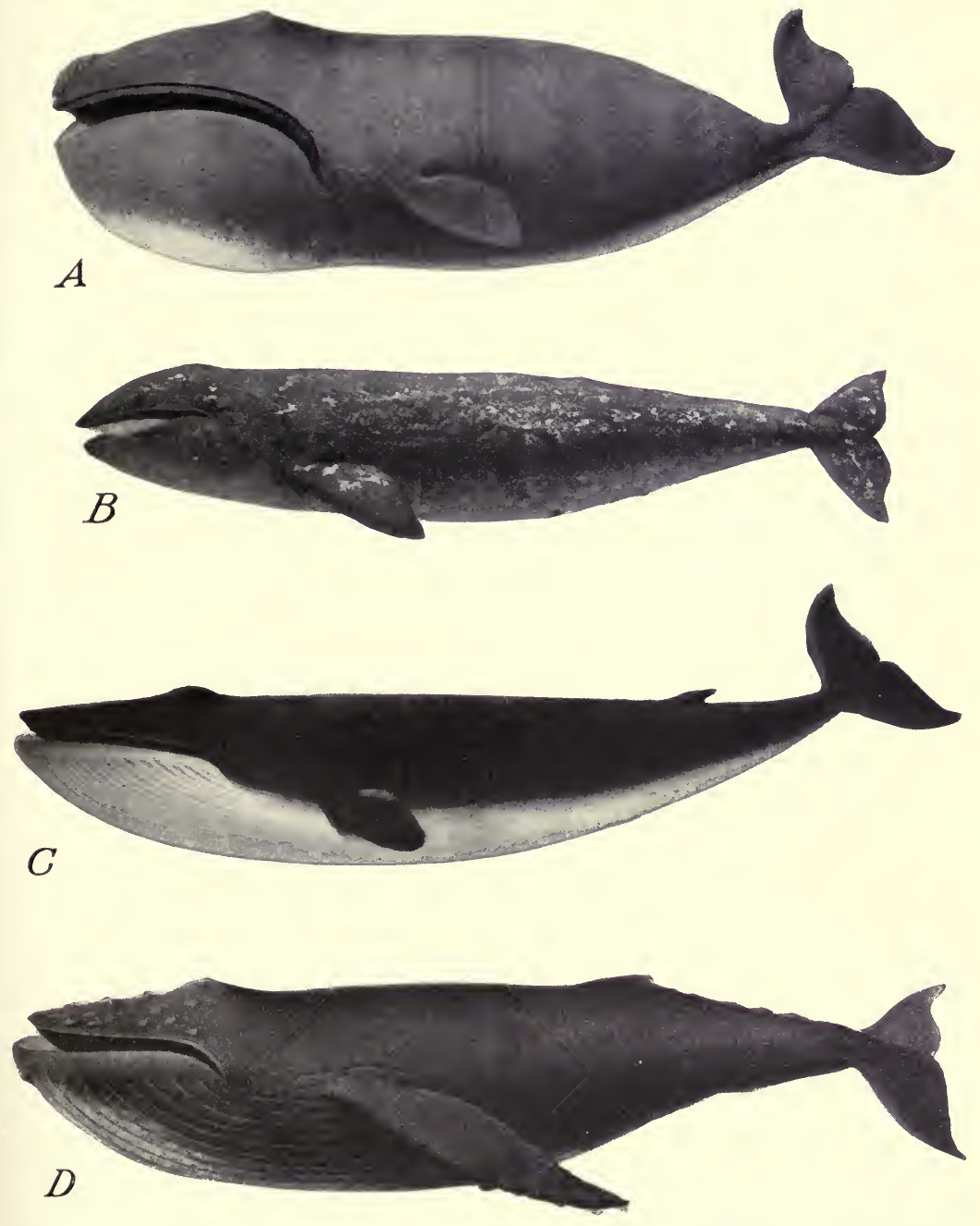

B2869M; В3867M; В3870M; В3868M

SOME WHALEBONE, OR BALEEN, WHALES OF THE NORTHWEST COAST. INCLUDING THE COAST OF OREGON.

$A$, Pacific right whale; $B$, California gray whale; $C$, Pacific sulphur-bottom whale; $D$, Pacific humpback whale. (All reduced from Scammon's Marine Mammals.) 

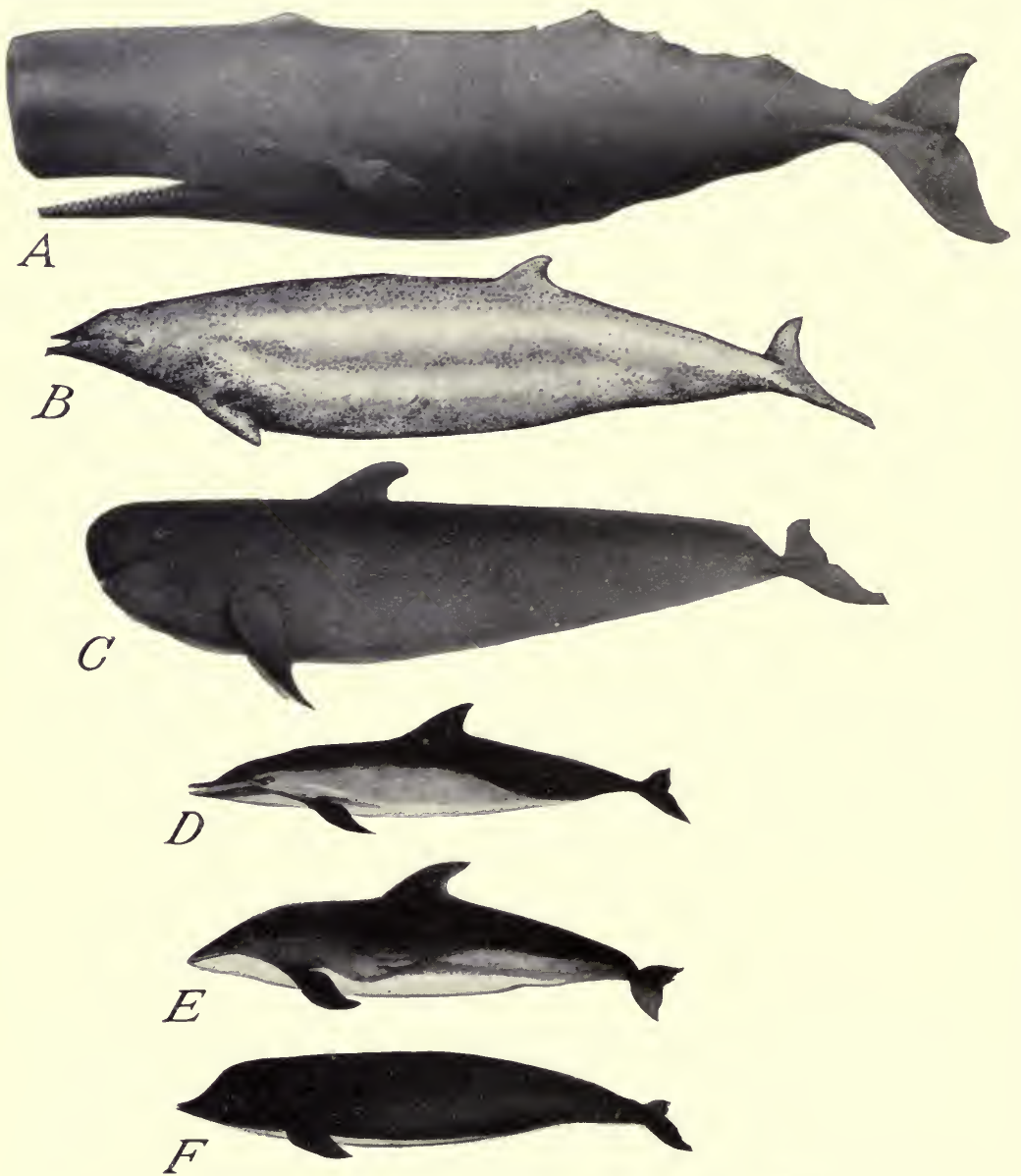

B3871M: B3834M; B3865M; B3875M (3)

SPERM WHALE AND OTHER TOOTHED WHALES AND PORPOISES.

A. Sperm whale (from Scammon's Marine Mammals); $B$, Stejneger's beaked whale (from drawing by J S. Elliott, from True); $C$, the blackfish (from Scammon); $D$, common dolphin, or Baird's dolphin (from Scammon); $E$, striped porpoise (from Scammon); $F$, right whale porpoise (from Scammon). 


\section{MESOPLODON STEJNEGERI TRUE}

\section{STEINBGER's BEAKED WHALE}

Mesoplodon stejnegeri True, U. S. Natl. Mus. Proc. 8: 585, October 19, 1885.

Type.-Skull collected on Bering Island, Commander Islands, Bering Sea, by Leonard Stejneger; cataloged February 2, 1884.

General characters. - Size small, about 17 feet long; body thickest in middle (pl. $49, B$ ), head small with slender beak or mandibles, the lower longest; pectoral fins small and near head, dorsal fin small and well back; tail flukes broad; mandibles narrow; upper toothless, lower with one large flat tooth or tusk about the middle of each ramus, no other teeth; eyes small, low on sides of head.

Measurements.-Total length, about 17 feet; head, 32 inches; anterior edge of teeth $61 / 2$ inches from tip of jaw; width of tooth, 3 inches; thickness of tooth, three-quarters of an inch; height of tooth along anterior edge, about 6 inches.

Distribution and habitat.-Known only from the type skull from Bering Island and from one complete individual washed ashore on the beach near Newport, Yaquina Bay, Oreg., about February 15, 1904.

Through J. G. Crawford, of Albany, Oreg., David Starr Jordan, of Stanford University, and F. W. True, of the United States National Museum, were promptly informed of a strange little whale that had washed ashore on the beach at Yaquina Bay. The description and photographs furnished by Crawford indicated that the whale belonged to this rare species, previously known only from a skull, and aroused great interest among students of marine mammals. Measurements and many of the external characters of the species were obtained, and the skull was finally secured for the United States National Museum collection.

As yet there is no record of the living animal, and nothing is known of its habits or range beyond these two records, but it belongs to a world-wide group or family of the rarest and least known of the cetaceans.

\section{Family DELPHINIDAE: Porpoises; Dolphins}

\section{DELPHINUS DELPHIS LINNAEUS}

\section{COMMon DoLphin; BaIrd's DoLPhIN}

[Delphinus] delphis Linnaeus, Syst. Nat. ed. 10, v. 1, p. 77, 1758.

Delphinus bairdii Dall, from Point Arguello, Santa Barbara County, Calif., 1873.

Type locality.-European seas.

General characters. - Form slender with long narrow beak or jaws, each well set with a row of 80 to 120 slender, conical teeth (pl. $49, D$ ); pectoral fins nariow; dorsal triangular; tail flukes broad. Top and sides of head black; hack, fins, and flukes greenish black; sides gray; belly and throat white. Length of adult 6 or 7 feet; weight 100 to 160 pounds.

Distribution and habitat.-If the Pacific form bairdii proves separable from the Atlantic delphis, as seems highly probable, its range as given by Scammon (18\%4, p. 99) would be the Pacific coast of North America.

\section{TURSIOPS GILLII DALL}

CowFISH

T'ursiops gillii Dall, Calif. Acad. Scl. Proc. 5: 13, 1873.

Type.-One mandible only collected at Monterey, Calif., by C. M. Scammon in 1871 . 
General characters.-Larger than the right whale porpoise; form slender; snout contracted and beaklike; teeth in type 48 above, 46 below; dorsal fin in middle of back. Color mainly black, a little lighter below.

Measurements.-Skull: Total length, 21 inches; rostrum, 113/4 inches.

Distribution.-Range given as North Pacific Ocean, but there seems to be no definite record north of Monterey, and its inclusion in the Oregon list is merely tentative.

\section{GLOBICEPHALUS SCAMMONII COPE}

\section{SOAMMON'S BLACKFISH ; DOLPHIN}

Globicephalus scammonii Cope, Acad. Nat. Sci. Phila. Proc., p. 21, 1869.

Type.-Collected off coast of Baja California, lat. $31^{\circ}, 10$ miles from land, by C. M. Scammon, cataloged October 25, 1869.

General characters. - These large sea-going dolphins reach a length of 15 feet, have large rounded heads with oblique mouth (pl. $49, C$ ), overhanging muzzle, and long low dorsal fin just back of head; teeth 8 to 10 in each side of lower and 10 to 12 in each side of upper jaw, rather large and mainly in posterior part of jaws. Color black all over.

Measurements.-A large male: Total length, 15 feet, 6 inches; nose to dorsal fin, $41 / 2$ feet; dorsal fin 28 by 12 inches; length of pectorals 2 feet, 10 inches; width of tail flukes 3 feet, 6 inches (Scammon 1874, p. 86).

Distribution.-Scammon says they are found where the sperm whales resort but in many instances range in large numbers nearer the coasts. Their favorite resorts are along the Pacific coasts of North America and South America off Guatemala, Ecuador, and Peru, yet their geographical distribution is occasionally extended to high northern and southern latitudes. True gives their range as the North Pacific Ocean. Osgood (1901, p. 25) reports them in the Queen Charlotte Islands and Dall $(1869$, p. 333) in Bering Sea.

General habits.-The blackfish collect in schools of 10 or 20 up to hundreds, and when going along the surface of the sea do not rise and fall so much as the porpoise, and the time and number of spoutings are more irregular. In fact their habits are more like those of the sperm whale, with which they are more or less associated.

Breeding habits.-Breeding habits of the blackfish are little known, but Scammon says the young are apparently brought forth at any time in any part of the ocean.

Food habits. - The food of this species is said to consist almost entirely of squid or octopus, but in the bays and shallow waters it also feeds on small fish. The animals have little commercial value for oil and are not often hunted by the whalers except as a supply of fresh meat, which is said to be like beef in texture and flavor.

\section{LISSODELPHIS BOREALIS (PEALE)}

\section{Northern Right Whale Porpoise}

Delphinapterus borealis Peale, U. S. Exploring Exped., v. 8, Mamm. and Ornith., p. 35, 1848.

Type locality.-North Pacific Ocean, Lat. $46^{\circ} 6^{\prime} 50^{\prime \prime}$ N., Long. $134^{\circ} 5^{\prime}$ W. (west of the mouth of the Columbia River).

General characters.-No dorsal fin; size small, length given as 4 feet, form slender (pl. 49, $F^{\prime}$ ) ; " snout slightly produced; color black with a white lanceolate spot on breast, which is extended in a narrow line to the tail" (Peale, $1848, p$. 35).

Measurements.-Total length of type, 4 feet. Model in United States National Museum of specimen from Japan about 8 feet. 
Distribution.-Described and drawn by Peale from specimens taken in the North Pacific Ocean about 500 miles off the coast of northern Oregon and from others observed in the water about the ship.

\section{LAGENORHYNCHUS OBLIQUIDENS GILL}

Striped Porpoise; Common Porpoise

Lagenorhynchus obliquidens Gill, Acad. Nat. Sci. Phila. Proc., p. 177, 1865.

Type.-Collected in the Pacific Ocean near San Francisco, Calif., by W. P. Trowbridge, United States Army. Cataloged in United States National Museum, October 24, 1855.

General characters. - Size medium for a porpoise, length 7 to 8 feet; snout blunt (pl. $49, E$ ) ; teeth small, 44 to 46 in each jaw; dorsal fin falcate or curved; pectoral fins and tail flukes wider than in Baird's dolphin. Color of upper parts greenish black, with variable longitudinal stripes of dull black, gray and white along sides; lower parts, throat, and belly, pure white.

Measurements. - Total length of adult male, 7.5 feet; weight about 400 pounds (Higgins, 1919 p. 15\%).

Distribution and habitat.-Abundant along the Pacific coast and more numerous in the larger bays and lagoons than in mid ocean. Specimens in the United States National Museum collection from near San Francisco and Puget Sound would indicate regular occurrence along the Oregon coast.

General habits.-Gregarious, often found in schools of a dozen to several hundreds; active at night as well as day, swift in the water, swimming around ships at full speed, jumping clear of the surface or diving in graceful curves that expose the backs and curved dorsal fins.

Food.-Largely small fish, sardines and other of the smaller kinds that collect in schools near the surface.

Economic status.-When fat they yield considerable oil; the flesh is considered excellent food, tender and of delicate flavor, somewhat like beef.

\section{ORCINUS RECTIPINNA (COPE)}

\section{Pacific Killer}

Orca rectipinna Cope, Acad. Nat. Sci. Phila. Proc., p. 22, 1869.

Type locality.-Coast of California.

General characters.-One of the largest of the dolphin family (pl. 50, A) ; dorsal fin anterior to middle of back, high and nearly straight; head short and heavy; teeth strong, sharp, and conical, 12 above and 13 below in two specimens recorded by Scammon $(18 \%$, p. 88). Color usually jet black above and lighter below, but some of smaller size pure white below and varlously marked with white stripes and spots.

Measurements.- Scammon says the males may average 20 feet and the females 15 feet in length, the dorsal fin in large individuals rising 6 feet from the back (ibid).

Distribution.-Killers, probably including several forms, are said to range in all oceans. In the Pacific they occur in both north and south latitudes over the ocean, and in the bays and lagoons of our western coasts. Along the shores of British Columbia and Washington the Indians hunt them in canoes.

General habits.-These great dolphins have been called the "wolves of the sea", the hunters and killers among the whales. While their food consists in part of fish and seals and young sea 
lions and walruses, it also includes the smaller dolphins and porpoises, usually swallowed whole, often several at a meal. The killers attack and kill and devour not only the white whale and smaller whales and the young of the great whales but also the largest whales of all, biting and tearing their jaws, striking them from above and below, and tearing out pieces of flesh until their helpless victims become paralyzed with fear and pain and yield without resistance to their bloodthirsty attacks. Fortunately they are not so numerous, nor do they go in such large schools as the porpoise and blackfish. They are rarely taken by the whalers as they yield comparatively little oil, but Scammon says the Makah Indians pursue and take them about Cape Flattery as they consider their flesh and fat more luxurious food than that of the larger balaenas and rorquals.

\section{ORCINUS ATER (COPE)}

\section{Black Kiluter; OrCa}

Oroa ater Cope, Acad. Nat. Sci. Phila. Proc., p. 22, 1869.

Orcinus orca (Linnaeus) of Miller, from European Seas. U. S. Nat. Mus. Bull. 128, p. 511, 1924.

[Delphinus] orca Linnaeus, Syst. Nat., ed. 10, v. 1, p. 77, 1758.

Type locality.-Northwest coast.

General characters.- Size smaller than in rectipinna with lower, more falcate dorsal fin, less white on lower parts, and with white spot or stripe back of eye and brown crescent back of dorsal fin $(\mathrm{pl} .50, B)$.

Range.-Given by Cope as Oregon to the Aleutian Islands.

\section{GRAMPUS GRISEUS (CUVIER)}

\section{Common Grampus}

Delphinus griseus Cuvier, Ann. Mus. Hist. Nat., Paris 19: 14, 1812. Grampus stearnsii Dall, 1873, from Monterey Bay, Calif.

Type locality.-Brest, coast of France.

General characters. - Scammon says the average length of the grampus may be 10 feet and that it has a rounded muzzle like that of the haroor porpoise. In the high and narrow dorsal fin it resembles the black killer, Orcinus ater, and in its movements in the water it also resembles that species. It has a small number of teeth, 4 to 6 in each jaw, and varies greatly in color and markings, some being almost black all over and others with white head and anterior part of body, and others more or less mottled with white and gray (pl. 50, $C$ ).

Measurements.-One adult female from the Atlantic coast: Total length given as about 12 feet (True, 1889, p. 126) ; length of pectoral fin, 21 inches; height of dorsal fin, 13 inches.

Distribution.-A species or group of species so little known that the application of names is doubtful, as the general characters are largely drawn from observation of the animals at sea. Whether one species ranges along the coasts of several oceans or whether two or more forms occupy the western coast of North America is not entirely settled. Apparently in one form or another they occupy the whole western coast of the United States, wandering along the coasts or in the bays in large schools or occasionally 2 or 3 together, or more rarely singly.

Their food is said to consist of fish and several varieties of crustaceans. They are extremely wild and shy and rarely taken. 


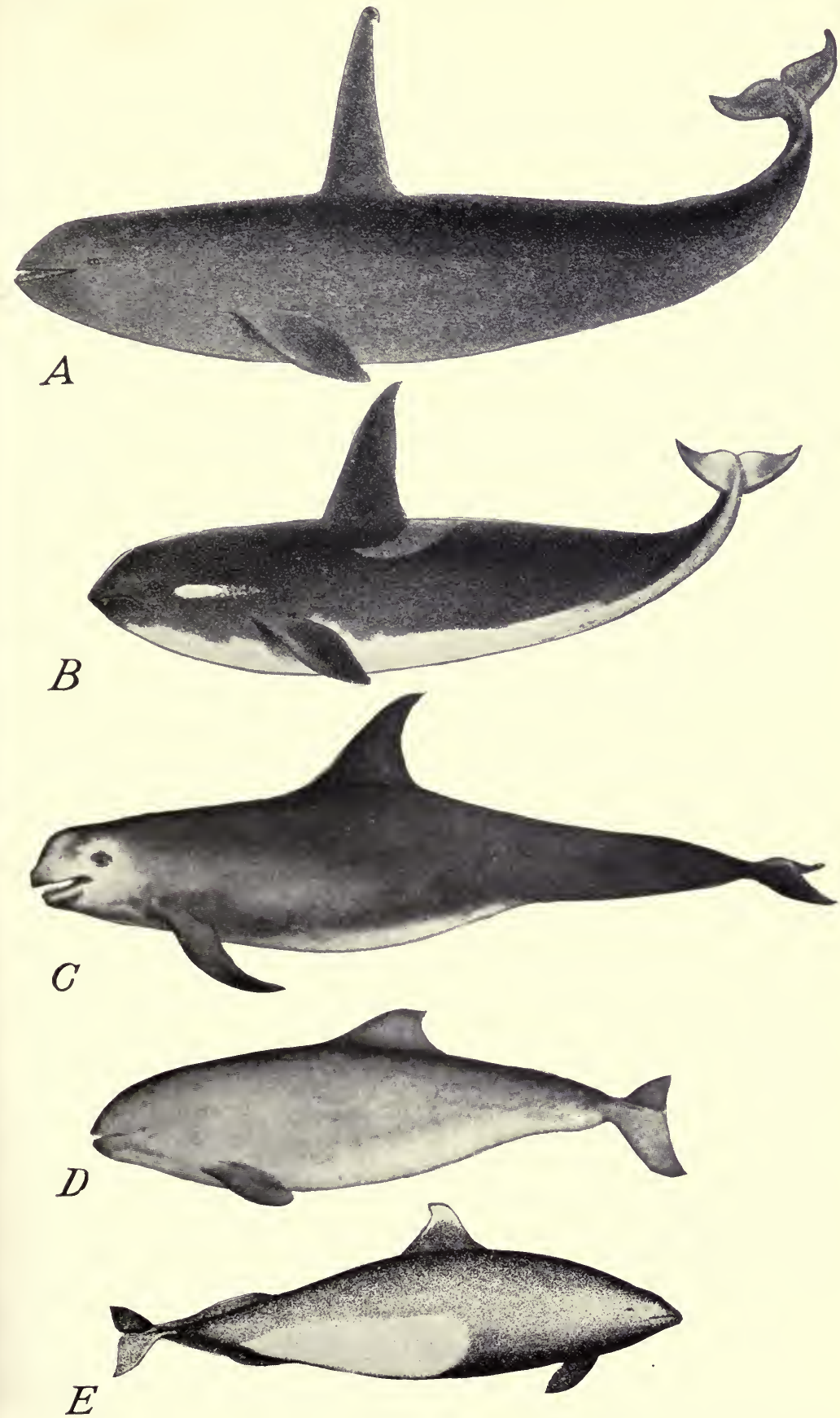

B3873M (2): B3864M; В3862M; В3863M

KILLERS, GRAMPUS, AND PORPOISES.

$A$, Pacific killer (from Scammon); $B$, black killer (from Scammon); $C$, common grampus (from Flower, P. Z. S. London); $D$, harbor porpoise (from U. S. Nat. Mus., Bull. 36); $E$, Dall's porpoise (from U. S. Nat. Mus., Bull. 36). 

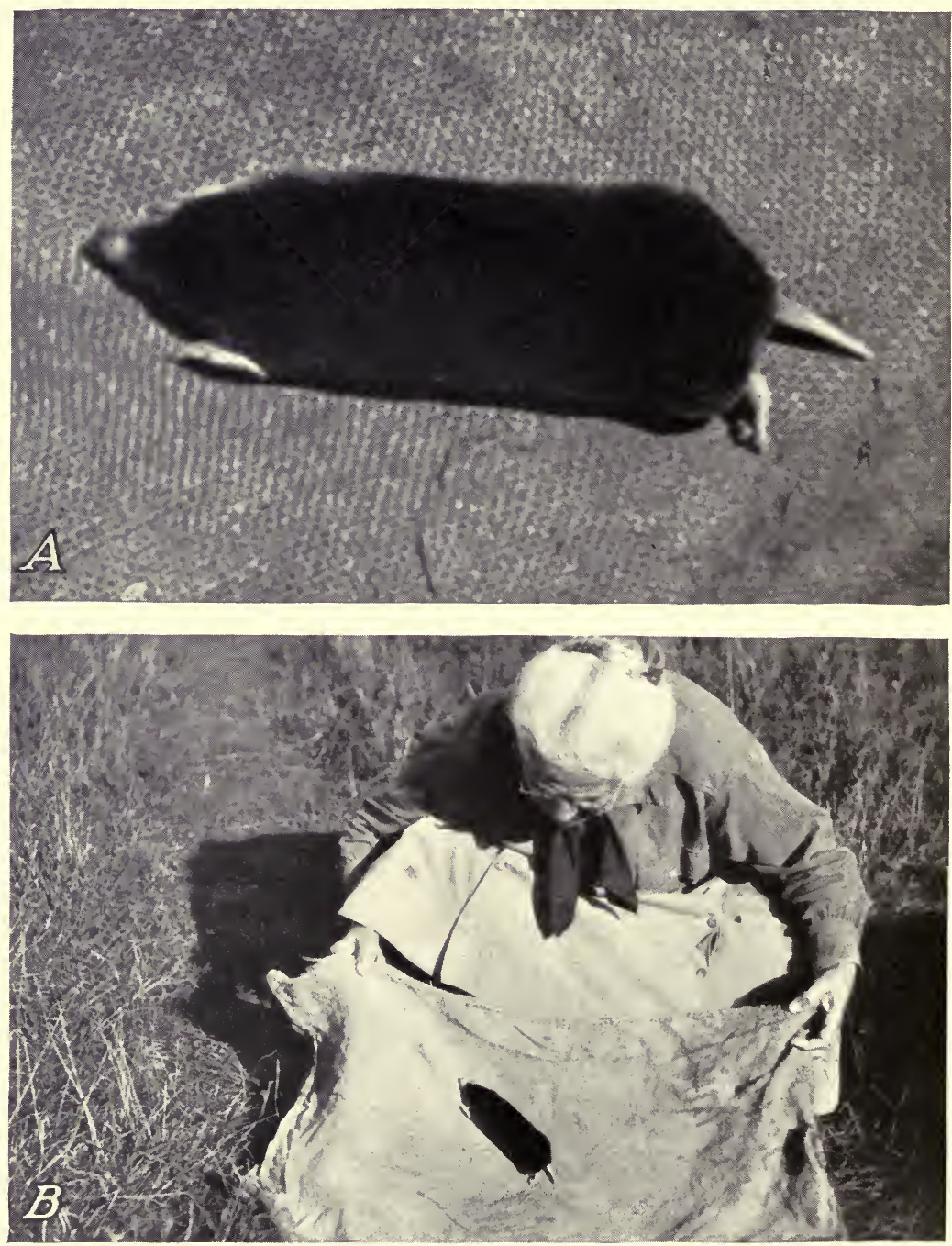

TOWNSEND'S MOLE.

A; $\mathbf{B 2 3 5 1 4}$

Photographed at Carlton, western Oregon. 


\section{PHOCAENA PHOCOENA (LinNaEUs)}

\section{Harbor Porpotse; Bay Porpotse}

[Delphinus] phocoena Linnaeus, Syst. Nat., ed. 10, p. 77, 1758. (Synonyms: Phocaena communis Lesson; Phocaena vomerina Gill).

Type locality.-Swedish seas.

General characters. - Size small, less than 6 feet in total length; form short and thick (pl. 50, D) ; head short; dorsal fin small, triangular, and about middle of back; teeth thin and flat, in two from San Francisco Bay, Calif., 26 above and 24 below and 21 above and 24 below (Scammon, 1874, p. 95). Black above, paler, gray or white below, sometimes with white markings on tail and pectorals.

Measurements.-Of male from Port Townsend, Wash., April 28, 1869 (Scammon) : Total length, 4 feet, 8 inches; length of pectorals, 8 inches; width of tail, 14 inches; height of dorsal fin, $3 \frac{1 / 2}{2}$ inches; thickness of blubber, 1 inch.

Distribution and habitat.-Inhabits Atlantic and Pacific coastal bays and harbors, possibly including many forms. Noted by Scammon along the Pacific coast from Mexico to Puget Sound and in the lower waters of the Columbia River, in Cathlamet Bay, and off Astoria. He says they are never found in large schools, but occasionally 6 or 8 may be seen together, appearing at the surface singly or 2 or 3 together. They make a quick puff and quickly disappear below the surface, seeming to prefer the darkness below and never making playful gambols as do the larger porpoises (Scammon, 1874, p. 97$)$.

They feed upon small fish and are occasionally taken in nets hauled by the fishermen. The Indians frequently shoot or capture them in the sheltered coastal waters and regard their flesh as a great delicacy.

\section{PHOCOENOIDES DALLI (TRUE)}

Dali Porpoise; KUd-AH' -TikH of the Aleut (W. H. D.)

Phocaena dalli True, U. S. Natl. Mus. Proc. 8: 95, 1885.

Type--Skull from Strait west of Adak Island, Aleutian Group, Alaska.

General characters. - Size small, length about 6 feet; dorsal fin moderately high and falcate; head sloping (pl. $50, E$ ) ; lower jaw slightly protruding; true teeth very small, 23 above, 27 below, alternating with a secondary set of gum teeth or hardened serrations of the gums which function as teeth. Color of upper parts, black; lower parts and lower half of sides, white.

Measurements.-Total length, 6 feet; height of dorsal fin, 6 inches; length of pectoral fin, 8 inches.

Distribution.-Coasts of Alaska and south to Santa Cruz Island, Calif.

\section{ORDER INSECTIVORA: INSECT-EATING MAMMALS}

Family TALPIDAE: Moles

\section{SCAPANUS TOWNSENDII (BACHMAN)}

Tow NSEND's MoLe

Scalops townsendii Bachman, Jour. Acad. Nat. Sci. Phila. 8: 58, 1839.

Type locality.- "Banks of the Columbia", probably the vicinity of Fort Vancouver, Wash. Type specimen not known to exist, but a cotype, now in the Academy of Natural Sciences, Philadelphia, was collected by J. K. Townsend on May $9,1835$.

General characters.-Largest of our moles; form compact and subcylindrical, tapering to the elongated naked-tipped snout in front and to small nearly naked tail in the rear (pl. 51); legs greatly reduced and invisible; front feet 
large, broad and armed with straight, stout nails; hind feet relatively small and weak, with slender claws; teeth 44 in total number; eyes minute and hidden in the fur; ears a mere auditory opening under the fur; fur dense and velvety without guard hairs; color of fur at surface dark plumbeous purple or almost black, with a metallic luster when smoothed down, paler and plumbeous at base.

Measurements.-Average of 7 adult males from Humboldt County, Calif.: Total length, $224 \mathrm{~mm}$; tail, 41 ; hind foot, 26-27. Adult male from Fort Vancouver, Wash.: $202 ; 41 ; 27$; weight $51 / 4$ ounces. Adult female from Fort Vancouver, Wash. : $215 ; 42 ; 26$; weight $45 / 8$ ounces.

Distribution and habitat.-Extreme northwestern California, Oregon, and Washington west of the Cascades, mainly in the low country and open valleys (fig. 81 ).

General habits.-These beautiful big furry moles are abundant in most of the open rich valley country of western Oregon, where their presence is easily recognized by the ridged runways and large

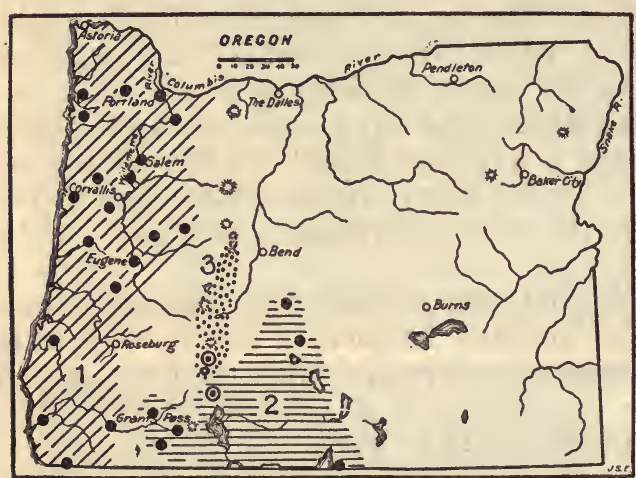

Figure 81.-Range of three forms of moles in Oregon: 1 , Scapanus tounsendii; 2 , S. latimanus dilatus; 3, S. l. alpinus. Type localities circled. black mounds of earth. Occasionally their ridges and mounds are found in the more open woods but always are more abundant a nd conspicuous in meadows, fields, and lawns. The animals are rarely seen except by some prying naturalist, as they spend most of their lives below the surface of the ground. Unlike the eastern moles, however, their minute eyes can be opened and seem to be functional, and there is some evidence that the moles occasionally come out upon the surface of the ground at night. Occasionally one is seen when a board is suddenly lifted from the ground, or a log rolled over, but most of their active lives they spend underground, extending long tunnels just below the surface in search of insect food, or digging deeper burrows a foot or two below the surface, and from these burrows pushing out the loose earth in the little rough mounds so familiar to all. These mounds vary from 6 inches to 2 feet in diameter, and 4 inches to a foot in height, and are easily distinguished from those of the pocket gopher by the absence of any trace of a closed doorway.

The mole does not appear at the surface even while pushing up the earth but remains safely hidden below, and when through with one mound leaves the terminal part of the burrow closed as it goes on to extend the tunnel and throw out the next mound of refuse at a distance of 2 to 6 feet from the last. Often these mounds extend in an irregular line of 10 or 20 rods across a field, but more generally they wind about and crisscross each other until sometimes the surface of the ground is half covered with the black earth recently brought up from below.

Theo. H. Scheffer, who has made a close study of these animals and their habits, says that much of the real life of the moles is lived 
in the deeper burrows, while the hollow ridges near the surface are mainly feeding runs and passageways, sometimes used but once as the animal pushes by while in search of food. Others are used regularly, not only by the moles but by many small rodents that take advantage of this cover to penetrate fields and gardens and feed upon the farmers crops.

Breeding habits. - Scheffer says that Townsend's mole mates in February and that the young are born in the latter part of March, and develop with astonishing rapidity. By the last of May they are scarcely distinguishable from the adults. There are usually 3 in a litter of young, but sometimes only 2 , and still more rarely 4 . They are found in rudely constructed nests of grass and stubble, leaves, and rootlets in hollowed-out chambers along the runways. Apparently there is but one litter of young a year, as the wellprotected life of the mole insures a sufficient abundance of individuals to balance the food supply. Nearly blind as they are, they would never be so shortsighted as to exterminate or reduce too greatly the abundance of the insect life on which they feed.

Food habits.-Moles are primarily insectivorous. According to Scheffer, Wight, and Moore, they subsist mainly upon earthworms, ground-inhabiting insects and insect larvae, spiders, and centipedes, and occasionally eat a small amount of sprouting grain and seeds, such as corn, peas, wheat, and oats. In captivity they ravenously eat fresh meat, beefsteak, birds, fish, or almost any kind of meat, but soon starve if given only grain and roots (Scheffer, 1922, $p .11$; Wight, 1928, p. 31; Moore, 1933, p. 38).

Their activity and strength are astonishing and their appetites almost insatiable. If given food to their liking they will eat more than their own weight each day, and without abundance of food they quickly starve. They drink freely and soon die if deprived of water.

Economic status.-While the food habits of these moles show them to be almost wholly beneficial to man, they are often the unintentional cause of great annoyance by scattering their mounds of earth over the surface of the ground, in fields and meadows and golf links and on well-kept lawns. They also loosen up the surface of the ground with numerous burrows that allow the soil to dry out and in midsummer to kill or injure the grass and growing crops, and also afford cover to rodents that come in to feed upon the crops. Fortunately, however, their beautiful velvety fur has a value sufficient to make their trapping profitable where they are abundant, and thus lead to control of any overabundance of the species.

\section{SCAPANUS LATIMANUS DILATUS TRUe}

\section{Kramath Mole}

Scapanus dilatus True, U. S. Natl. Mus. Proc. $17: 242,1894$.

Scapanus truei Merriam, Biol. Soc. Wash. Proc. 2: 102, 1897. Type from Lake City, Modoc County, Calif.

Type--Collected at Fort Klamath, Klamath County, Oreg., by Charles E. Bendire in 1883.

General characters.-Size smaller and colors paler than in townsendi; larger than orarius, with heavier feet and claws and more hairy feet and tails. Fur very soft and silky, colors pale silvery drab or brassy brown, the underfur pale plumbeous or maltese. Compared with typical Scapanus latimanus, which 
reaches north to Beswick, Calif., and may come into the southern edge of Oregon, it is slightly smaller and much paler.

Measurements.- Two adult males from McCloud, Calif., measure: Total length, 178 and $170 \mathrm{~mm}$; tail, 36 and 32 ; foot, 21 and 21 . One adult male from Fremont, Oreg., measures $166 ; 31 ; 22$. Weight of male $83 \mathrm{~g}$, of female $78 \mathrm{~g}$ (Grinnell, Dixon, and Linsdale, 1930, p. 446).

Distribution.-South-central Oregon, northeastern part of California, and adjacent parts of Nevada, in Transition and Upper Sonoran Zones (fig. 81). They are found generally in the mellow soil of the open valley country of this semiarid region but do not extend into the real desert country.

General habits.-In the Klamath section mole ridges are occasionally found near the edges of the meadowlands, and even in the yellow pine timbered bottoms along the shores of Upper Klamath Lake. In 1896 Preble found fresh ridges near Lost River and at Fort Klamath the ridges were seen in the sandy flats. In 1897 they were found common on the Applegate ranch in Swan Lake Valley, a few around Christmas Lake, and on sandy ridges 35 miles farther north. At Fremont in 1914 Luther J. Goldman reported them as not common, but 1 specimen was secured from a fresh burrow at the edge of the foothills, where it was throwing up little heaps of earth. Another was obtained by Stanley G. Jewett at Fort Rock, near there, in 1923. Near Ashland, in the Rogue River Valley, in 1914, Goldman caught 1 in a wet place near the valley bottom, and 2 others in pocket-gopher burrows on dry ground.

In habits there seems to be little difference between the different species of moles in this western group, except as the type of country varies, and with it the animal's relations to various soil and food conditions. Mole hills are generally found on heavy, moist land, while on mellow-soil land the ridges are generally all there is to indicate the presence of the little burrowers. In many if not most of the localities this subspecies is found occupying light or sandy soil.

\section{SCAPANUS LATIMANUS ALPINUS MERRIAM}

\section{Mazama Mole}

\section{Scapanus alpinus Merriam, Biol. Soc. Wash. Proc. 2: 102, 1897.}

Type.-Collected at Crater Lake, Mount Mazama, Oreg., August 18, 1896, by Vernon Bailey.

General characters.-About the size of large specimens of latimanus but much paler in coloration, indistinguishable in color from dilatus, but larger and with relatively long and narrow skull. Color of type specimen in worn pelage, drab gray with a slight buffy or brassy tinge along the back and on the throat.

Measurements.-The type and only known specimen, an adult male, measured: Total length, $188 \mathrm{~mm}$; tail, 38; foot, 24.5.

Distribution and habitat.-The type and only known specimen was collected on August 18, 1896, on the south slope of Mount Mazama at an altitude of 7,000 feet, and a few hundred feet below the present site of the hotel at the rim of Crater Lake (fig. 81). On this steep warm slope of half barren pumice sand the mole runways were fairly common at the time the type specimen was taken, but no general distribution could be more than assumed from this one locality. Mole ridges were common on the pumice slopes north of Crater Lake, and Preble found burrows a few miles west of the summit on the Medford road. Others were found around Mount McLoughlin 
(Pitt), but without specimens they throw little light on the range of the subspecies.

General habits.-The type specimen was caught in a trap set in a shallow burrow where a pocket gopher had been caught the day before, but in the loose soil of the mountain slope it was not always possible to distinguish between the mole and the pocket-gopher burrows. Both species apparently used the same tunnels.

\section{SCAPANUS ORARIUS ORARIUS TRUE}

\section{Coast Mole}

Scapanus orarius True, U. S. Natl. Mus. Proc. 19 : 53, 1896.

Type.-Collected at Shoalwater Bay, Pacific County, Wash., August 30, 1855, by J. G. Cooper.

General characters.-Size medium, much smaller than in tounsendii; form slenderer, with relatively as small or actually smaller and slenderer front and hind feet, tail, snout, and feet almost naked; fur shorter and finer than in townsendii and of almost the same shade of color, purplish black at the surface and plumbeous underneath. Skulls strikingly different in size but very similar in general characters.

Measurements.-Average of three adult males from Eureka, Humboldt County, Calif.: Total length, 167 (163-175) $\mathrm{mm}$; tail, 33.7 (31-35) ; foot, 20.7 (20-22). Adult male from Puyallup, Wash.: $160 ; 36 ; 21$. Weight 2 ounces. Adult female from Puyallup, Wash.: $15.7 ; 37 ; 21$. Weight 1 15/16 ounces.

Distribution and habitat.-Humid coast section of northwestern California, western Oregon and Washington, entirely west of the Cascades (fig. 82). The range overlaps that of the large Townsend's mole almost completely, and both are taken on the same ground, but the small form. is usually much less common than the large one.

General habits.-So far as known the habits of the coast mole seem not to differ from those of other moles of the genus Scapanus. Economically these moles are of importance mainly in the destruction of ground-dwelling worms

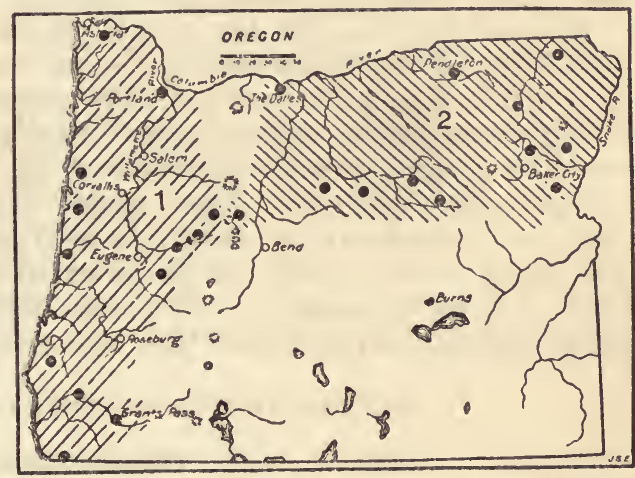

Figure 82.-Range of the two smaller moles in Oregon: 1 , Scapanus orarius orarius; 2 , s. 0.8 chefferi. and insect larvae. Their small ridges and mounds are of little consequence in cultivated ground, and their small size prevents any important fur value attaching to their skins.

\section{SCAPANUS ORARIUS SCHEFFERI JACKSON}

SCHFFFER'S MOLE

Scapanus orarius schefferi Jackson, North Amer. Fauna No. 38, p. 63, 1915.

Type-Collected at Walla Walla, Wash., August 8, 1914, by Theo. H. Scheffer.

General characters. - Slightly larger and with heavier feet and claws than in typical orarius; skull relatively shorter and wider; colors paler, more $7209^{\circ}-36-23$ 
coppery brown in typical specimens, but grading westward into the purplish black of orarius. Specimens from the west base of the Cascades could be referred to orarius on color alone, but they show a slight increase in size over the strictly coast form. Two specimens from the top of the Cascade Range at the north base of Three Sisters Peaks are clearly referable to this form, but others from McKenzie Bridge and Vida are apparently nearer to orarius.

Measurements.-Type specimen, adult male: Total length, $170 \mathrm{~mm}$; tail, 35 ; foot, 23 . Adult male topotype: $165 ; 34 ; 23$. Weight $2 \frac{1}{2}$ ounces. Adult female topotype: $163 ; 35 ; 22$. Weight: 2 ounces.

Distribution and habitat.-From the Blue Mountains and Cascades of northern Oregon through central Washington to extreme southwestern British Columbia, mainly in Transition Zone, except at the type locality and some places along the Columbia near The Dalles that are in Upper Sonoran (fig. 82). They are absent from the really arid sagebrush soil but keep to the moist valleys or the more humid plateau tops.

On top of the Cascades at the north base of the Three Sisters Peaks two of these little silvery moles were caught at 5,000 and 5,500 feet at the lower edge of Canadian Zone, and a few other runways were seen lower down on the slope. At the east base of the range near the town of Sisters their ridges were often seen in the open yellow pine forest and near the moist banks of irrigation ditches. In the Blue Mountains country near Prineville Jewett secured a specimen that was drowned out of its burrow in an irrigated alfalfa field, and he caught two more along the banks of Ochoco Creek about 6 miles above Howard. Specimens have been collected at Cornucopia, Halfway, and near Baker, and unmistakable mole signs have been noted near Meacham and Palmer.

General habits. - So far as at present known the habits of this pale form of the little coast mole are not different from those of its dark western relative, unless in the generally more sandy and mellow soil of the semiarid region it more rarely makes mounds, and its long ropelike ridges over the surface of the ground are generally more conspicuous. Like the other moles they live underground, where they find abundance of small life to supply their ravenous appetites. Too small to have any fur value or to disturb noticeably the green turf of lawn or meadow, they are little noticed, and while of no great economic importance they are mainly beneficial.

\section{NEUROTRICHUS GIBBSII GIBBSII (BAIRD)}

\section{GIBBs's MoLd}

Urotrichus gibbsii Baird, Mamm. North Amer., p. 76, 1857.

Type.-Collected at White River Pass, north of Mount Rainier, Wash., by George Gibbs, July 15, 1854.

General characters.-Size small, nose long and pointed, naked only at tip; tail moderately long and thickened in middle, bristly haired; legs short and feet moderately stout; eyes and ears minute and generally invisible; skull slender and shrewlike in appearance; teeth 36 in total number; fur dense and velvety, flecked with short, shiny hairs; color blackish all over, with purple iridescence.

Measurements.-Adult male from type region: Total length, $115 \mathrm{~mm}$; tail, 44 ; foot, 16.5. Apparently no sexual difference in size. Weight of largest male $12 \mathrm{~g}$ (Grinnell, Dixon, and Linsdale, 1930, p. 452).

Distribution and habitat.-Northwestern California to southwestern British Columbia and west of the Cascades in Oregon and Washington (fig. 83). In the Fort Klamath section they cross over to the 
east side of the Cascades, but generally they belong to the humid coastal slope or "web-foot" country, in mainly Transition Zone. They are generally found in swampy places, marshes, meadows, or sometimes under logs in the dry woods.

General habits.-These tiny moles are apparently shrewlike in habits, living partly underground in their own little tumnels but also pushing about under the leaves and grass on the surface of the ground, or through the soft mold of old decaying logs. Occasionally they are caught in mousetraps set in runways of meadow mice and other ground-living rodents and shrews, indicating a life lived partly on the surface of the ground. Their small eyes are probably of some service in their quest for insect food, and the long flexible nose is well fitted for detecting food under cover of the soft earth where they hunt.

Food habits.-The nature of their food can be guessed from the highly specialized insectivore teeth and from the finely masticated remains of worms and various insects found in the stomachs of those collected for specimens.

At Crater Lake, Preble caught one in a mousetrap baited with fresh meat and

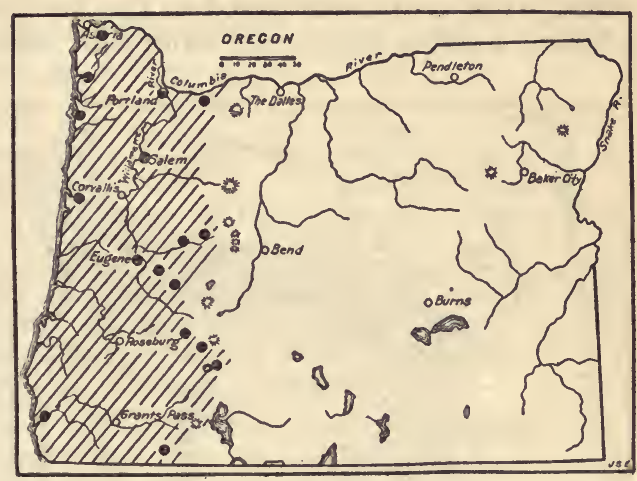

FraURE 83.- - Range of Gibbs's mole, Neurotrichus set in a hollowed-out place under an old log. At Fort Klamath he caught four in a patch of willows and alders on the bank of Wood River by baiting his traps with bacon. They were evidently attracted from their burrows by the odor of the bait.

Economic status.-Like the shrews these little moles are entirely harmless, and may even be highly beneficial from their help in controlling the abundance of ground and underground insects and other small life.

\section{Family SORICIDAE: Shrews}

\section{SOREX PALUSTRIS NAYIGATOR (BAIRD)}

\section{Rocky Mountain Water Shrew}

Neosorex navigator Baird, Mamm. North Amer., p. 11, 1857.

Type-Collected at Yakima River, Cascade Mountains, Wash., by J. G. Cooper, August 31, 1853.

General characters. - Size large, tail about as long as head and body; feet large; sides of feet and toes heavily fringed with silvery bristles for swimming; nose long and pointed; eyes minute; ears short and wide and almost concealed in fur; body covered with dense, soft, velvety fur; feet and tail thinly haired. Color: Above blackish or plumbeous, finely flecked with hoary; below light gray or whitish over plumbeous underfur; feet plumbeous gray with silvery margins; tail blackish above, whitish below.

Measurements.-Adult male from Mount Rainier: Total length, $152 \mathrm{~mm}$; tail, 78; foot, 19. Weight of 12 males 8.3 to $15 \mathrm{~g}$ (Grinnell, Dixon, and Linsdale, 1930, p. 452). 
Distribution and habitat.-Mountains of Oregon as well as the whole Cascade and Sierra Nevada and Rocky Mountain systems of North America from Alaska to central Arizona, generally in Canadian Zone, or along streams of cold water just below the zone (fig. 84).

General habits.-These beautiful large long-tailed shrews are more than any other of our North American species adapted to aquatic life and are almost invariably found along the margins of small streams, springs, or ponds. They live in holes in banks, under logs, or under any cover where it is moist and cool and convenient to the water, from which their food is largely obtained. With the large bristle-margined feet and toes they can fairly run over the top of the water or dive and swim with great speed and skill, while their velvety fur is as waterproof as the feathers of a diving duck. At the edge of a little clear cold mountain lake near the north base of the

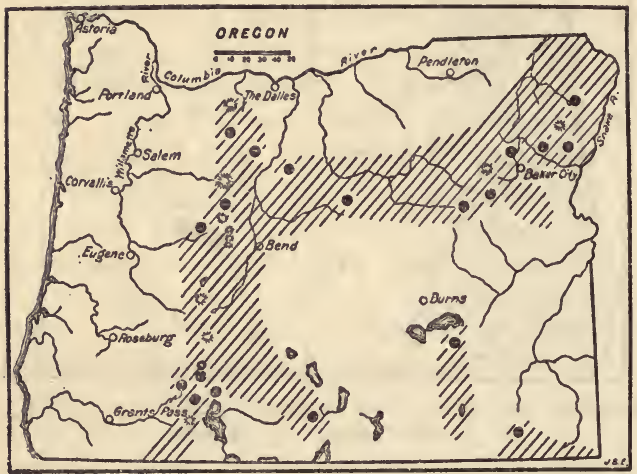

Figure 84.-Range of the water shrew, Nepsorex palustris navigator, in Oregon.

Three Sisters Peaks one of these little animals was seen as it ran under an old $\log$ near the water. The $\log$ was rolled over and the shrew was caught in the hands, to which act it showed vigorous and futile objection by trying to bite. To facilitatefurther observations a thread was looped around one leg and the shrew was let go in the edge of the lake. At first it puffed its fur and sat on top of the water like a duck while it tried to bite the thread from its leg. Soon abandoning this endeavor, it swam along the surface to a log and climbed on it, shook itself dry, ran along a little way and dived into the water again, darting about under and over submerged logs and sticks as rapidly and gracefully as a fish. In fact, from its motions and the shining layer of air which clung to the surface of the fur it strongly resembled a silvery fish. The otter had always seemed the most graceful and skillful aquatic mammal, but this tiny creature surpassed any 4-footed creature of the writer's acquaintance in its relative speed and skill in the water.

The fact that these shrews are not often seen except when collected for specimens in traps set along the water's edge is due in part to their being largely nocturnal in habits and partly to the observer's failure to recognize them in the water. 'They are not uncommon in suitable country as shown by good series of specimens from numerous localities over the State.

Breeding habits.-Data on this subject are meager. One female collected at the north base of Three Sisters Peaks on July 17, 1914, contained 7 very small embryos. There are other records of 5 and 6 embryos at varying seasons during the summer. The regular number of mammae is 6,2 pairs of inguinal and 1 pair of abdominal. 
Food habits.-The stomachs of these water shrews generally contain finely chewed remains of insects and other forms of small animal life, but in many examined in the field no trace of fish scales or bones could be detected. They often contain bits of fresh meat or bacon used as trap bait and many are caught in mousetraps baited with rolled oats. This may have been in part accidental or in pursuit of insects or slugs attracted by the bait, for there seems to be no record of any oatmeal found in their stomachs. Occasionally a meadow mouse in a trap at the water's edge is found half eaten by one of these large shrews.

They have been accused of eating salmon eggs and small fish, but apparently none of these charges has been proved by actual examination of stomach contents.

\section{SOREX BENDIRII BENDIRII (MERRIAM)}

BENDIRE'S SHREW

Atophyrax bendirii Merriam, Linn. Soc. N. Y. Trans. 2: 217, 1884.

Type-Collected at Williamson River, 18 miles southeast of Fort Klamath, Oreg., August 1, 1882, by Charles E. Bendire.

General characters.- Size large, tail long, feet large and but slightly fringed or bristle-margined; nose long and pointed; eyes minute; ears mainly concealed in fur; fur dense and velvety over whole of body; feet and tail thinly haired. Blackish or sooty brown all over, slightly paler below, summer pelage more brownish; feet grayish brown; tail brownish black all around.

Measurements.-Adult male from Fort Klamath: Total length, $155 \mathrm{~mm}$; tail, 71; foot, 20. One taken at Puyallup by Scheffer weighed $12 \mathrm{~g}$.

Distribution and habitat.-The Klamath section of Oregon, a narrow strip of the coast of western California, and the Cascade section of Washington and southwestern British Columbia (fig. 85). There are specimens in the Biological Survey collection from Williamson River, Fort Klamath, and Prospect, and two in the Gabrielson collection from Rustler Peak and Camp 76 , on the Crater National Forest north and west of Mount McLoughlin. All of the localities are in Transition Zone.

These large dark shrews are probably no better adapted to aquatic life than are most other shrews, although all seem to be good swimmers and

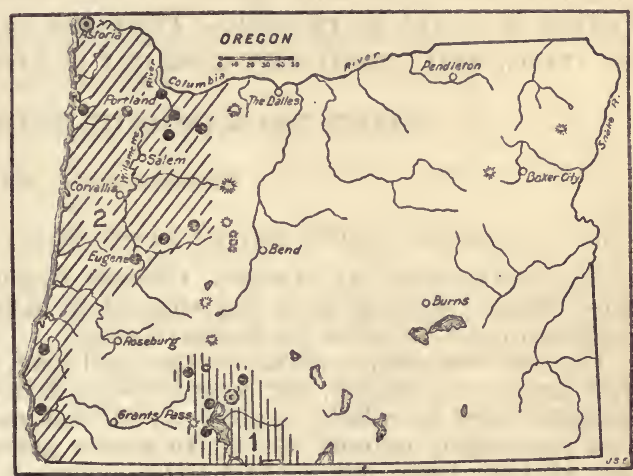

Figure 85.-Range of Bendire's and Palmer's shrews in Oregon: 1 , Sorex bendirii bendirit; $2, S .6$. palmeri. Type localities circled. not afraid of the water. They are generally found in low, moist, or muddy places where they live under old logs or such cover as is available, often in the shade of deep forests but also along the edges of low, open ground. They are mud shrews rather than water shrews and probably find an abundance of food in the black ooze of moist ground.

Of their actual habits nothing is known beyond what is shown by the specimens secured by collectors from small traps set in suitable 
places, and the contents of a few stomachs examined. So far as shown their food consists of insects, snails, and other forms of small animal life.

\section{SOREX BENDIRII PALMERI Merriam}

PALMer's SHrew

Sorex (Atophyrax) bendirii palmeri Merriam, North Amer. Fauna No. 10, p. $97,1895$.

Type.-Collected at Astoria, Oreg., by T. S. Palmer, July 29, 1889.

General characters. - Size largest of Oregon shrews, slightly larger and darker than bendirii; skull conspicuously larger and heavier. Color: Upper parts black or blackish, lower parts scarcely if at all lighter; feet dark biown; tail blackish all round.

Measurements.-Adult male, type: Total length, $165 \mathrm{~mm}$; tail, 73 ; foot, 20.5 .

Distribution and habitat.-The coast region and low country west of the Cascades of Oregon and the extreme northwest corner of California, in the coast and valley country west of the Cascades, except the upper Rogue River Valley (fig. 85). A Transition Zone species of the most humid part of the State.

General habits.- In the humid region where these shrews live they may be found under logs in the dense forest, in muddy places around springs, under stream banks, in thickets of alder, or in tall grass wherever there is cover and food. Near Eugene they were caught under logs and in Microtus runways in tall grass, on the side of Spencer Butte and at McKenzie Bridge in the heavy forest, often at a distance from any water. At Oregon City Streator caught one near a spring and at Astoria A. K. Fisher took one in thick vegetation on the bank of a stream. Near the top of Chintimini Mountain one ran down the trail ahead of the writer but escaped into a burrow before it could be caught. They are rarely seen except when taken in traps, and practically nothing is known of their habits.

\section{SOREX TROWBRIDGII TROWBRIDGII BAIRD}

\section{TrowbrmaE's SHrew}

Sorex trowbridgii Baird, Mamm. North Amer., p. 13, 1857.

Type-Collected at Astoria, Clatsop County, Oreg., received from W. P. Trowbridge; without date but entered in museum catalog July 1855 . Cotype collected June 10, 1855, by James Wayne.

General characters. - Size medium, tail long, nearlỳ as long as head and body ; feet small and slender, not conspicuously fringed; nose long and pointed ; eyes minute; ears not wholly concealed; fur soft and fine over whole body; feet and tail very thinly haired. Color: In winter pelage dull blackish or sooty plumbeous all over body, but slightly paler below; in summer pelage more brownish; feet pale; tail dark brown above and whitish below.

Measurements.-Adult female from type locality: Total length, $130 \mathrm{~mm}$; tail, 59 ; foot, 14 . Another, $115 ; 56 ; 13$.

Distribution and habitat.-West of the Cascades from southwestern British Columbia to northwestern California, covering practically all of Oregon west of the Cascades (fig. 86). They are most abundant in the low-timbered country of humid Transition Zone, where they are often caught in considerable numbers.

At the type locality T.S. Palmer caught three specimens in July 1889 , in a grassy spot under overhanging alders near the beach, and back in the spruce woods under fallen logs. They were much less 
common than the brown bairdi, with which they were associated. In 1897 A. K. Fisher trapped for them at the type locality and caught one at the entrance of a small hole near a stream.

At Vida and McKenzie Bridge the writer found them one of the commonest small mammals in the woods, obtaining sometimes a dozen specimens in a line of small traps set under logs and banks, or around old stumps and roots of trees. They seemed to be attracted by the rolled oats used as bait for meadow mice and other rodents, but many of the traps were baited also with bits of fresh meat.

On Mount Hood, Cantwell collected several specmens at 1,500 feet altitude in the dry forest above the lava beds. One found under a flake of bark was caught in his hands, but it put up a lively fight with much squealing and

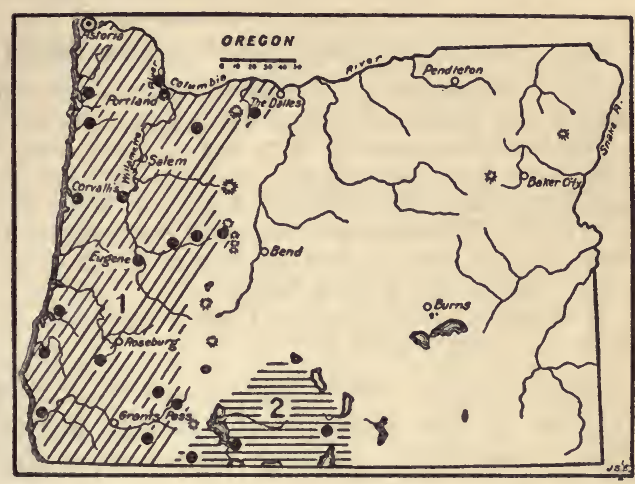

Figure 86.-Range of Trowbridge's and Yosemite shrews in Oregon: 1 , Sorex trowbridgii trowbridgii; 2, S. t. mariposae. 'Type locality circled. finally squirmed out and escaped as if by magic. The strength of the little creature was surprising. At Philomath, Cantwell took several specimens on hillsides in heavy timber but did not find them on the lowlands.

\section{SOREX TROWBRIDGII MARIPOSAE GRINNELL}

\section{Yosemite SHREW}

Sorex montereyensis mariposae Grinnell, Calif. Univ. Pubs., Zool. 10:189, 1913.

Type.-Collected in Yosemite Valley, at 4,000 feet altitude, Mariposa County, Calif., May 27, 1911, by H. W. Grinnell.

General characters. - Size medium, slightly smaller than typical trowbridgii, with paler more grayish coloration. Upper parts of adults sooty or dark brownish gray, lower parts distinctly paler, or silvery gray; feet pale, tail long, sharply bicolor. Summer and immature specimens decidedly brown.

Measurements.-Type specimen, adult female from Yosemite: Total length, $121 \mathrm{~mm}$; tail, 51 ; foot, 14 . Adult male topotype: $120 ; 53 ; 15$.

Distribution and habitat.-Extreme south-central Oregon and south through the Sierra Nevadas to Kaweah River and through the inner Coast Ranges to Mendocino County, Calif. (fig. 86). There are Oregon specimens from Swan Lake Valley, Klamath County; Lakeview, Lake County; and Beswick, just below the Oregon line in California. All of these are from Transition Zone localities, and the whole range of the subspecies seems to be largely in this zone.

At Swan Lake Valley, just over the ridge east. of Klamath Falls, in June 1889, two of these little long-tailed dark-colored shrews were taken on the bank of the little spring brook that comes out above the ranch, and Elmer Applegate told the writer that he had often caught them in the irrigated meadow below. This seems to be the only Oregon note on the species, but farther south specimens have been collected along streams, in meadows, and in various locations 
in the forests. Some are caught in traps baited with fresh meat, and others in traps baited with rolled oats into which they may have blundered in following runways of meadow mice.

\section{SOREX OBSCURUS OBSCURUS MERRIAM .}

Dusky SHRew

Sorex obscurus Merriam, North Amer. Fauna No. 10, p. 72, 1895.

Type-Collected at Timber Creek, Lemhi Mountains, Lemhi County, Idaho, August 26, 1900, by Vernon Bailey and B. H. Dutcher.

General characters.-Size small, tail less than length of head and body; nose long and pointed; eyes minute, ears mainly hidden in the fur; feet slender and not noticeably fringed; fur over body in summer short and rather harsh, in winter long and lax; feet and tail thinly haired. Color: In summer pelage dull tobacco brown over upper parts, lower parts buffy gray; in winter darker above and more silvery below.

Measurements.-Average typical specimen: Total length, $110 \mathrm{~mm}$; tail, 47; foot, 13 . Type: $111 ; 46 ; 13$.

Distribution and habitat.-From a wide range extending from central Alaska through the Rocky Mountains to central New Mexico this little brown shrew comes into the Blue Mountains of north-

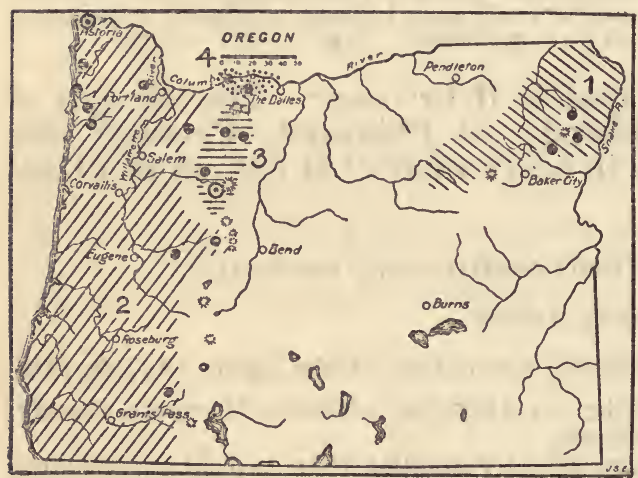

FIGURn 87.-Range of four shrews in Oregon: 1, Sores obscurus obscurus; 2,8 . o. bairdi; 3 , S. 0 . cled. eastern Oregon, where specimens have been taken at WallowaLake, Wallowa Mountains, and Anthony (fig. 87). Generally a Canadian Zone species, it sometimes comes down along cold mountain streams to lower levels.

General habits.-These little brown, long-nosed, soft-furred animals are generally common in wet, grassy places along streams or under the cover of logs, rocks, bushes, and leaves in the dry forest of the mountains. They keep well under cover and are rarely seen, but occasionally one crosses a trail or some open spot and gives the observer a glimpse of its tiny form or pokes its long flexible snout out of a burrow and waves it rapidly about in an inquiring way as if depending more on scent and feeling than on eyesight. In the mellow woods earth around and under old logs their tiny burrows often honeycomb the ground, or a network of tiny runways may be found between the soft cover of fallen grass and leaves and the surface of the ground. Most of these seem to be mere plowings for food and not regularly used as are the runways of rodents, but the shrews are great wanderers and are frequently caught in traps set across the runways of meadow mice, or in small burrows of other rodents. In winter their lines of tiny tracks are often seen over the soft snow, usually ending in little burrows where they readily return to the surface of the ground. 
Their fine little squeaking voices are rarely heard except in captivity and close up but evidently are used to indicate their feelings toward each other and the world at large.

Breeding habits.-Adult females have 6 mammae arranged in a double row of 3 each, well back on the lower parts. They are generally given as 2 pairs of inguinal and 1 pair of abdominal, but are so far back and close together as to be sometimes given as 3 pairs of inguinal. The embryos vary from 4 to 8 in number, 6 apparently being normal for adults. Embryos are found in June, July, and August, but probably only one litter of young a year is raised. Little is known of the young after birth, and few naturalists have ever seen a young shrew.

Food habits.-While true insectivores in dentition and habits, the dusky shrews are also fond of any fresh meat and certain kinds of vegetable food. Field examination of their stomachs and the intestinal tracts usually show mainly insect remains, bits of exoskeleton, legs and other hard parts floating in a mass of soft material that evidently represents the internal organs and fluids of insect bodies, of insect larvae and eggs, or of the soft body parts of worms and other low forms of animal life. Occasionally a stomach will be found well filled with the recently eaten flesh of some small animal with a few hairs that may serve to identify the species, and many of the small rodents caught in traps for specimens by the field collector are found half eaten by these voracious little beasts. To what extent they kill such prey will not be known until someone studies their habits in captivity in an intelligent and systematic manner, but it is probable that their destruction of young rodents in the nests is one of the incentives accounting for their being so often found associated with rodent runways. To some extent they appear to eat plant food, and are often caught in traps set for mice and baited with rolled oats or nuts, the bait being found in the mouths and stomachs of the shrews as evidence of the acceptance of such food. Still more rarely traces of green plants are found in the stomachs, but this is not usual and may be accidental.

Like all shrews these animals are voracious feeders and die in a short time if food is not available. They do not become fat and do not hibernate, but are active all winter, finding abundance of food in underground burrows and cavities.

Economic status.-On general principles insectivorous animals are supposed to be beneficial in their economic relations to man, but so little is known as to the species and quantities of insects consumed by these shrews that we cannot say whether they protect the trees, grass, or crops in general, nor how much of their food is neutral and of no direct benefit to us.

\section{SOREX OBSCURUS BAIRDI MERRIAM}

BAIRD'S DUSKY SHREW

Sorex bairdi Merriam, North Amer. Fauna No. 10, p. 77, 1895.

Type.-Collected at Astoria, Clatsop County, Oreg., August 2, 1889, by T. S. Palmer.

General characters.-Larger than typical obscurus, and more uniformly brown above and below. In summer pelage, upper parts rather bright tobacco brown, lower parts but little lighter, tail scarcely bicolor. Winter pelage not seen. 
Measurements.-Adult topotype: Total length, $125 \mathrm{~mm}$; tail, 55; foot, 15. Type: $130 ; 57 ; 15$.

Distribution and habitat.-Western Oregon from the mouth of the Columbia southeast to Prospect on the head of Rogue River, Jackson County, in humid Transition Zone (fig. 87). Four specimens not perfectly typical collected by Luther J. Goldman at the north base of Three Sisters Peaks at 6,000 feet, were actually in Canadian Zone, but near the lower edge. At Astoria Palmer found them abundant along the beach under driftwood shaded by alders, as well as under fallen logs in the spruce woods well up on the ridge back of town. At Netarts Jewett collected a series of specimens, and others were taken near Tillamook by Alex. Walker. At Vida and McKenzie Bridge they were found common all through the heavy forest, where they were caught in traps set under old logs and stumps, and in burrows in the mellow woods earth.

General habits.-These large brown shrews have essentially the same habits as their smaller relatives, except that they live in a milder, more humid region with dense vegetation and probably a more abundant food supply. No peculiarity of habits has been noticed.

\section{SOREX OBSCURUS PERMILIENSIS JACKSON}

\section{Cascade Dusky Shrew}

Sorex obscurus permiliensis Jackson, Biol. Soc. Wash. Proc. 31: 128, 1918.

Type-Collected at Permilia Lake, west base of Mount Jefferson, Marion County, Oreg., October 2, 1897, by J. Alden Loring.

General characters.-In size slightly larger than typical obscurus and smaller than bairdi. In summer pelage scarcely distinguishable from bairdi in color, the upper parts being bright tobacco brown and lower parts but little lighter. In early winter pelage the upper parts darken to sooty brown and the lower parts are slightly more grayish brown.

Measurements.-Type, adult male: Total length, $117 \mathrm{~mm}$; tail, 51; foot, 14.

Distribution and habitat.-Known only from around Mount Jefferson and Mount Hood in the northern Cascades of Oregon, mostly in Canadian Zone (fig. 87). At Permilia Lake near the west base of Mount Jefferson Peak in October 1897, Loring took a large series of these shrews, but lower down, near Detroit, he obtained only one specimen from a line of 70 traps set especially for them.

At Mount Hood in September 1896, 1 specimen was taken on the summit of the Cascades, just south of the base of the mountain and 2 more on the west side of the peak near timber line at the head of Sand Creek, localities representing the lower and upper edges of Canadian Zone. These four localities seem to constitute all the existing data on the range of the species, and of habits nothing more is known than what was shown by the dead specimens taken from the traps.

\section{SOREX OBSCURUS SETOSUS ELIIOT}

\section{OLYMPIC DUSKY SHREW}

Sorex setosus Elliot, Field Columb. Mus. Pub. 32, Zool. Ser. 1: 274, 1899.

Type.-Collected at Happy Lake, Olympic Mountains, Clallam County, Wash., August 18, 1898, by D. G. Elliot.

General characters. - Size slightly larger than typical obscurus, about as in S. o. permiliensis, but colors darker, more nearly seal brown in summer and 
darker brown, sooty or plumbeous in winter pelage. Side glands covered with short stiff hairs as in other shrews.

Measurements.-Type, adult male: Total length, $120 \mathrm{~mm}$; tail, 54; foot, 13. Topotype, adult male: $115 \mathrm{~mm} ; 50 ; 14$.

Distribution and habitat.-Southwestern British Columbia, western Washington, and northwestern Oregon-one record for Oregon at Parkdale, northeastern base of Mount Hood (fig. 87). Found in mainly humid Transition and Canadian Zones in forests, thickets, marshes, and meadows.

The two specimens taken by Cantwell at Parkdale were at an altitude of only 1,500 feet, but they reach to timber line on Mount Rainier and in the Olympics.

In habits they are apparently nearest to bairdi, since they occupy the same general type of country.

\section{SOREX PACIFICUS PACIFICUS CouES}

\section{PACIFIC SHREW}

Sorex pacificus Coues, U. S. Geol. and Geogr. Surv. Terr. Bull., v. 3, p. 650, 1877.

Type-Collected at Fort Umpqua, mouth of Umpqua River, Oreg., by E. P. Vollum, no date on label, but cataloged in National Museum collection on March 8, 1858.

General characters.-Largest of the small shrews, next in size to the water shrews; tail not quite as long as head and body; nose long and pointed; feet slender and not conspicuously fringed; eyes minute; ears rather conspicuous; fur dense and soft over body; feet and tails thinly haired. Color uniform bright snuff brown all over, scarcely paler below and about the same on feet and tail; tail not bicolor. Immature specimens slightly lighter and brighter brown.

Measurements.-Adult female from Marshfield, Oreg.: Total length, $151 \mathrm{~mm}$; tail, 65 ; foot, 18 (about average size, no difference in sexes). Another, from Gardiner: $160 ; 54 ; 17.5$.

Distribution and habitat.-Coast strip of southwestern Oregon from the mouth of the Umpqua River south to Mendocino, Calif. (fig. 88). There are Oregon specimens from Fort U m p q u , Gardiner, Marshfield, Myrtle Point, Gold Beach, and the State line in Curry County.

General $h a b i t s$.-At Myrtle Point in Coos County, McLellan caught these large red shrews about old decayed logs in damp, marshy and brushy places. Farther south along the coast section of northern California they are more or less common in the redwood and dense spruce forests as well as

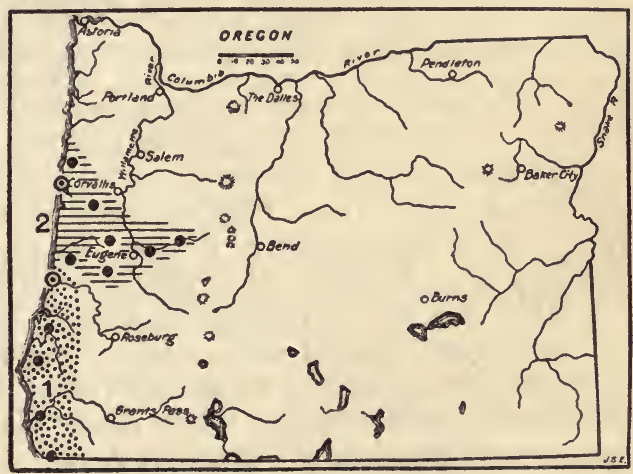

Figure 88.-Range of Pacific and Yaquina shrews in Oregon: 1, Sorex pacificus pacificus; 2 , S. p. yaqui nae. Type localities circled.

in the marshes and swamps of the Humboldt Bay section, being generally taken under old logs or stumps in dense chaparral or in the marshes and muddy bottoms. They are easily caught in traps baited 
with rolled oats, peanuts, bacon, or fresh meat. Their stomachs generally show insect remains and their food habits are probably as varied as those of other shrews.

\section{SOREX PACIFICUS YAQUINAE JACKSON}

\section{YAQUINA SHREW}

Sorex yaquinae Jackson, Biol. Soc. Wash. Proc. 31: 127, 1918.

Type.-Collected at Yaquina Bay, Lincoln County, Oreg., July 18, 1895, by B. J. Bretherton.

General characters.-Slightly smaller than pacificus, colors slightly darker brown, but general appearance much the same.

Measurements.-Type: Total length, $137 \mathrm{~mm}$; tail, 59 ; foot, 16 . Adult male from Philomath: $145 ; 60 ; 15$.

Distribution and habitat.-Coast section of central Oregon (fig. 88). There are specimens from Yaquina Bay, Newport, Mercer, Elk Head, Mapleton, Philomath, Eugene, and Vida, all in the low humid Transition Zone.

At Philomath Cantwell reports a pair of these large brown shrews taken near a creek on low ground strewn with rotten logs. At Mapleton, Luther Goldman found them along streams in timbered canyons, and at Gardiner, McLellan caught one in a cool ravine and another on the dyke along the river front.

So far as our limited information goes there seems to be no difference in the habits of yaquinae, pacificus, and bairdi from this low, humid coast section of the State.

\section{SOREX VAGRANS VAGRANS BAIRD}

\section{VAGRANT SHREW}

Sorex vagrans Buird, Mamm. North Amer., p. 15, 1857.

Type.-Collected at Shoalwater Bay, Pacific County, Wash., by J. G. Cooper ; date of collection unknown, but cataloged October 23, 1856.

General characters.-Very small, general appearance as in the obscurus group. Color, upper parts tobacco brown in summer pelage with distinctly grayish belly and bicolored tail. In winter pelage seal brown above and silvery gray below, tail dark brown above and buffy below.

Measurements.-Average of typical adults: Total length, $104 \mathrm{~mm}$; tail, 42; foot, 12. Adult female from Eugene, Oreg.: $102 ; 41 ; 12$. Weight about $7 \mathrm{~g}$.

Distribution and habitat.--Southwestern British Columbia, western Washington and Oregon and northwestern California, south along the coast to Point Reyes. In Oregon they range east to the Yamsay and Paulina Mountains, well beyond the east base of the Cascades, but not across the sagebrush plains (fig. 89). Over mucl. of western Oregon these are the commonest small shrews and often the commonest small mammal found in the woods, dry uplands, meadows, and marshes. They occur mainly in Transition Zone, but to some extent also in Canadian Zone.

General habits.-These little brown shrews are generally caught in traps set under old logs, around loose rocks, or under the fallen grass or other vegetation, which affords a shady cover and protection from light and enemies. To some extent they burrow in the mellow woods earth but more commonly push up little tunnels between the 
leaves and the surface of the ground or occupy burrows of meadow mice and other rodents, or the hollow banks and ridges along streams and gulches. They are often caught in traps set in runways of meadow mice, or at holes made by other small animals, sometimes by accident as they run across the trap triggers and sometimes while eating the bait prepared for them or for other species. They appear to be as active and as often caught in daytime as at night, and are abroad throughout the year.

Breeding habits.-The regular number of mammae in breeding females is 2 pairs of inguinal and 1 pair of abdominal, and the number of embryos found in females trapped for specimens varies from 5 to 7. At Crescent City, Calif., W. K. Fisher took 2 females on July 5, each containing 6 embryos. At McKenzie Bridge Luther Goldman took 1 on July 2 containing 7, and at Crater Lake on August 14 a female was taken with 6 embryos. The uniformity of the dates and the comparatively few records of embryos would indicate but one litter of young a year.

Food habits.-Field examination of stomachs usually shows traces of insect remains, well masticated and unidentifiable by superficial methods. Apparently soft-bodied larvae and eggs, worms, and other small earth-dwelling animal forms are included in the bill of fare. Occasionally traces of animal flesh are found in the stomachs, either from trap bait or from trapped animals which they frequently devour. They are often caught in traps baited with rolled oats or nut meats, and a trace of these foods is sometimes found in their mouths or stomachs, but vegetable food seems not to be commonly eaten. Digestion is evidently rapid, and the stomachs are often found empty while the food has all passed along to the intestines.

Economic status.-If, like other shrews, these little fellows eat almost continuously, and consume twice their weight of insects, larvae, and eggs every 24 hours, they might well fill a very important place in the economy of nature, a place comparable with that of the wrens, warblers, or hummers among birds. Fortunately they are unpleasantly musky and seem not to be generally relished by carnivorous birds or mammals and with their habits of seclusion are in little danger.

\section{SOREX VAGRANS MONTICOLA MERRIAM}

\section{ROCKx MOUNTAIN SHREW}

Sorex monticola Merriam, North Amer. Fauna No. 3, p. 43, 1890.

Type.-Collected on San Francisco Mountain, Ariz., 11,500 feet altitude, August 28,1889 , by C. Hart Merriam and Vernon Bailey.

General characters.-Small, summer pelage short. Similar to vagrans in size and general appearance, but color more grayish brown; upper parts in summer pale sepia brown, lower parts ashy gray; tail brownish above, whitish beneath except at the dark tip.

Ireasurements.-Average of four specimens from type locality: Total length, $108 \mathrm{~mm}$; tail, 44 ; foot, 12-13. Type, male adult: $107 ; 45 ; 12.5$.

Distribution and habitat.-Rocky Mountain region from southern British Columbia to Mexico and westward over eastern Washington and Oregon (fig. 89). They are the commonest little shrews of the Blue Mountains and Steens Mountains in Canadian Zone, and often 
range along cold mountain streams down into Transition Zone. While found all through the forests they are also taken in open brushy or grassy places wherever

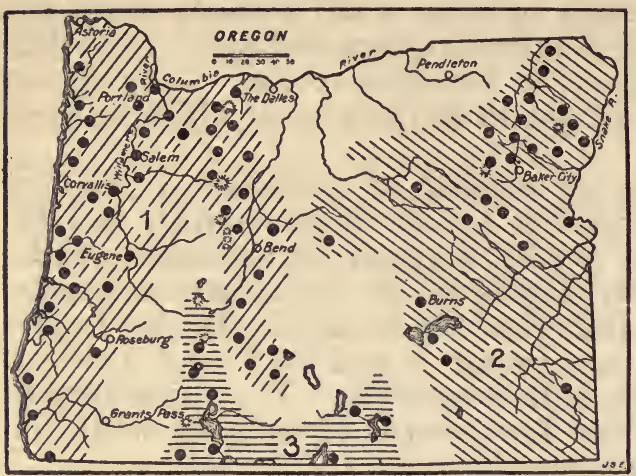

FigURE 89.-Range in Oregon of: 1 , Sorex vagrans vagrans; 2 , S. v. monticola; 3 , S. v. amoenus. there is plenty of moisture and vegetation, especially along the margins of watercourses.

General habits.-In no known way do the habits of this little gray shrew differ from those of typical vagrans exceptas modified by a more open and elevated range and a change of cover and food species of insects and other small animal life. The breeding habits are apparently much the same.

\section{SOREX VAGRANS AMOENUS MERRIAM}

\section{Sierra SHrew}

Sorex amoenus Merriam, North. Amer. Fauna No. 10, p. 69, 1895.

Type.-Collected near Mammoth, altitude 8,000 feet, near head of Owens River, Mono County, Calif., July 22, 1891, by E. W. Nelson.

General characters.-Much like vagrans, but tail shorter, and color darker. In summer pelage, upper parts dark grayish brown, lower parts smoky gray; feet and lower surface of tail buffy gray; top of tail dark brown, becoming dusky at tip. Winter pelage, back sooty gray; sides grayish brown, lower parts smoky gray.

Measurements.-Of type specimen, male adult: Total length, $103 \mathrm{~mm}$; tail, 38 ; foot, 12 . Of adult female topotype: $103 ; 36 ; 12.5$.

Distribution and habitat.-Klamath and Warner Mountain country of south-central Oregon south in the mountains to Owens River, Calif., and reappearing in the Ruby Mountains of Nevada (fig. 89). Found in mainly Transition and Canadian Zones, under logs or rocks or banks in moist situations, often along the margins of cold mountain streams or springs of cold water where local conditions of plant and animal life are similar to that of higher levels.

General habits.-So far as observed similar to those of the Rocky Mountain form, monticola, with which they agree more nearly in habitat than with typical vagrans, of the humid region.

One female, collected by E. W. Nelson at 8,000 feet in the Sierra Nevadas on July 22, 1891, contained 9 embryos.

\section{SOREX ORNATUS TRIGONIROSTRIS JACKSON}

\section{SISKIYOU SHREW}

Sorex trigonirostris Jackson, Wash. Acad. Sci. Jour. 12: 264, 1922.

Type.-Collected at Ashland, Oreg., May 5, 1914, by Luther J. Goldman.

General characters. - Size small, tail relatively short, similar to Sorex ornatus californicus in appearance but distinguished by broader skull and shorter rostrum, giving a more triangular outline, especially to the front part of the skull. Color: In summer pelage grayish brown; lower parts smoky gray; feet buffy gray; tail buffy white below, grayish brown above. 
Measurements.-Of type, adult female: Total length, $95 \mathrm{~mm}$; tail, 34 ; foot, 12. Adult male from west slope of Grizzly Peak : $106 ; 36 ; 14$.

Distribution and habitat.-Known only from the type locality near Ashland, north base of Siskiyou Mountains, at 1,900 feet, and one specimen from the west slope of Grizzly Mountain, a few miles farther north at 3,500 feet (fig. 90). Nothing is known of its further distribution or habits except that it evidently represents the Sorex ornatus group of California.

\section{SOREX MERRIAMI DOBSON}

\section{MERRIAM'S SHREW}

Sorex merriami Dobson, Monograph Insectivora, pt. 3 , fasc. 1 , pl. 23 , fig. 6,1890 .

Type-Collected at Little Bighorn River, near Fort Custer, Mont., December 26, 1884, by Charles E. Bendire.

General characters.- $\mathrm{S}$ i z e small, skull short and wide. with fourth upper unicuspid tooth smaller than third;

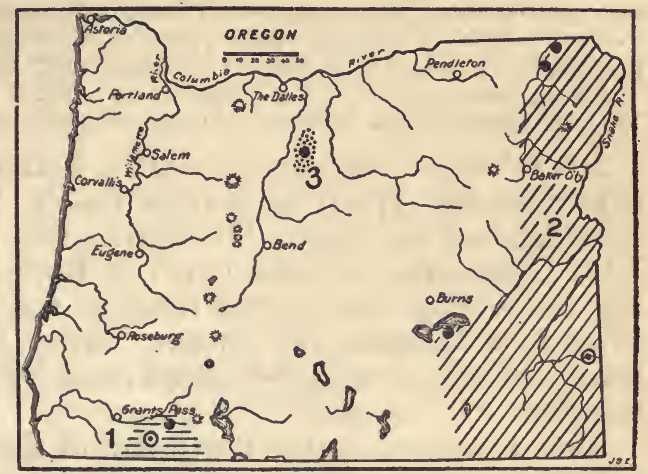

Figurm 90.-Range in Oregon of: 1, Sorex trigoniros tris; 2, S. preblet; 3 , S. meriami. Type localities circled.

color gray above, white below; upper parts light brownish gray or warm drab, whole lower parts, feet, and lower surface of tail white or whitish; top of tail grayish brown to tip.

Measurements.-Of type specimen from alcohol: Total length, $90 \mathrm{~mm}$; tail, 36 ; foot, 11.

Distribution and habitat.-Known by one specimen each from Montana, North Dakota, Nevada, Washington, and Oregon at localities in semiarid Upper Sonoran Zone valleys (fig. 90). One specimen from near Antelope, Oreg., 1 from Starbuck in southeastern Washington, and 1 from Desert Ranch, 100 miles northeast of Golconda, Nev., and near the southeast corner of Oregon, suggest a range over the whole sagebrush valley country of eastern Oregon. The Oregon specimen was found in a creek valley about 7 miles southeast of Antelope June 23, 1896. It was dead and dried up when found and may have been brought from a little distance by cat, weasel, or hawk, but probably was near where it was killed. It was in semiarid sagebrush country where burrows of kangaroo rats were common. The Nevada specimen was collected by Heller in the fall of 1914 in an arid sagebrush locality and was taken away from a house cat that brought it in. The North Dakota specimen, collected by Jewett, June 13, 1913, was found, partly eaten and left probably by some hawk or owl, on top of a badland butte near Medora, also in arid sagebrush country.

Unlike any other known species of the genus Sorex, these little gray, white-bellied shrews seem to be adapted to desert conditions in a hot, dry zone. As yet nothing is known of their habits, as all of the specimens have been picked up or secured through accident. When a clue to their habits is obtained, they may be found to be locally common over parts of their wide range. 


\title{
SOREX PREBLEI JACKSON
}

\section{Preble's SHREW}

Sorex preblei Jackson, Wash. Acad. Sci. Jour., v. 12, p. 263, 1922.

Type.-Collected at Jordan Valley, Malheur County, Oreg., July 3, 1915, by Edward A. Preble.

General characters.-Smallest of known Oregon shrews, only known representative in the State of the Sorex cinereus group, and the only one found there except merriami with the fourth unicuspid upper tooth smaller than the third. Color in summer pelage, upper parts dark brownish gray or hair brown; lower parts silvery gray; feet buffy ; tail light buff below, dark brown above.

Measurements.-Of type, adult male: Total length, $95 \mathrm{~mm}$; tail, 36 ; foot, 11. Of female from Diamond, Oreg. : $77 ; 28 ; 10$.

Distribution and habitat.-The 3 known specimens of this little shrew are the type from Jordan Valley, 1 from near Diamond at the north end of the Steens Mountains, and 1 from Sled Springs, in the Blue Mountains, 25 miles north of Enterprise (fig. 90). It probably has a somewhat interrupted range in the mountains and high country of eastern Oregon. In Jordan Valley Preble collected the type in a trap set near a willow-fringed creek out on the big Transition Zone meadows.

Near Diamond, at the north end of the Steens Mountains, Sheldon caught one in the marsh not far from the cold stream that comes out of the Kiger gorge. The meadow plants indicated Transition Zone with a mixture of Canadian Zone species, although the surrounding dry slopes were pure Upper Sonoran. The specimen taken by Cantwell at Sled Springs in the northern part of the Blue Mountains was without notes, but probably came from the little marsh among the yellow pines of that vicinity.

\section{ORDER CHIROPTERA: WINGED MAMMALS-BATS}

\author{
Family VESPERTILIONIDAE: Common Northern Bats
}

\section{MYOTIS LUCIFUGUS ALASCENSIS MILLER}

\section{ALASKa Litwle Brown Bat}

Myotis lucifugus alascensis Miller, North Amer. Fauna No. 13, p. 63, 1897.

Type.-Collected at Sitka, Alaska, by Clark P. Streator, August 5, 1895.

General characters. - Size of typical Myotis lucifugus but very much darker in coloration, often appearing sooty or blackish brown. Underfur blackish at base but tips of outer fur glossy dark brown, mummy brown of Ridgway; ears and naked membranes blackish. Immature specimens dullef and more sooty in coloration.

Measurements.-Adult male from McKenzie Bridge: Total length, $85 \mathrm{~mm}$; tail, 38 ; foot, 10 ; ear (dry), 12 . Adult female from Blue River : $89 ; 39 ; 10 ; 12$.

Distribution and habitat.-Humid Northwest coast country from southern Alaska to northwestern California and extreme northwestern Montana. In Oregon mainly west of the Cascades or along the east base. There are specimens from Mohler, Blaine, Tillamook County, McKenzie Bridge, Blue River, and La Pine (fig. 91). Three from Bend are slightly paler than typical. One listed from Butte Creek, in the Blue Mountains of southeastern Washington, close to the Oregon line, has not been seen by the writer.

This dark Northwest coast form of the wide-ranging little brown bat is generally found in a forested country and apparently is not 
widely migratory or specimens would be taken outside of its breeding range.

General habits.-At McKenzie Bridge specimens were secured in the evening twilight as they flew rapidly across the open spaces in the forest, catching their insect prey on the wing among or near the treetops. They also flew about the houses in the settlement but seemed more a part of the forest life and apparently came from among the trees. Still, there were rocks and cliffs not far away, and old cabins in the forest may have afforded shelter during the day. Near Bend L. J. Goldman shot them around his camp fire in the evening and saw them catching insects around the arc lights in

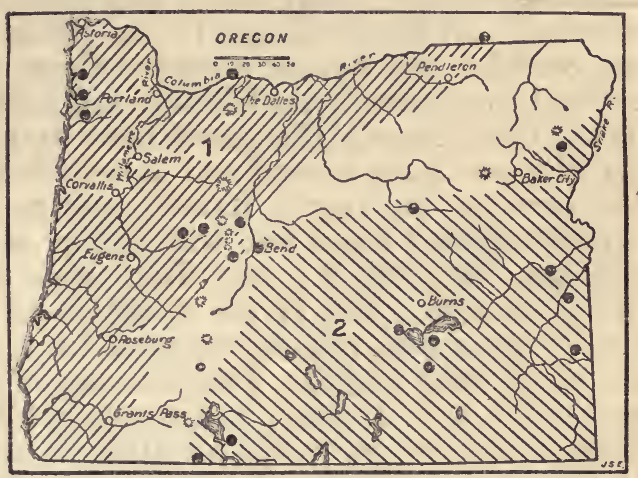

Figure 91.-Range in Oregon of : 1, Myotis lucifugus alascensis; 2 , M. $l$. carissima. town.

In general their habits are very similar to those of their near relative, the Yellowstone bat, a more widely distributed and betterknown form.

MYOTIS LUCIFUGUS CARISSIMA THOMAS

\section{Yed lowstone Bat; Pejahana of the Piute at Burns}

Myotis (Leuconoe) carissima Thomas, Ann. and Mag. Nat. Hist. (7) 13: 383, 1904.

Type-Collected at Yellowstone Lake, Yellowstone Park, Wyo., by J. ffolliott Darling, September 1903.

General characters.-Slightly larger and paler in coloration than typical Myotis lucifugus, with paler membranes and often with whitish margins of the posterior edge of tail membranes; upper parts glossy pale cinnamon buff or light brown; lower parts with silvery whitish wash over dusky underfur; ears, feet, and membranes sooty or blackish, the posterior edges of tail and part of wing membranes generally pale or whitish. Immature specimens often more sooty and less glossy.

Measurements.-Adult female from Malheur Lake: Total length, $85 \mathrm{~mm}$; tail, 35 ; hind foot, 10.5; ear (in flesh), 14, (dry), 12 . Weight (fat and with full stomach) $9.8 \mathrm{~g}$. Another female from the same place: $85 ; 31 ; 10 ; 14$. Weight $0.75 \mathrm{~g}$. Spread of wings, about $260 \mathrm{~mm}$.

Distribution and habitat.-Rocky Mountain and Great Basin region from southeastern Montana, Wyoming, Colorado, Utah, Nevada, and west to the Cascades and Sierra Nevada Mountains. Oregon specimens referred to this form are from Riverside, Watson, Sheaville, Malheur Lake, Voltage, The Narrows, Steens Mountains, Crooked River, East Pine Creek, Paulina Lake, and Klamath Falls (fig. 91). These rather small, pale brown bats are generally common over the open sagebrush country of eastern Oregon, and in many places are the most abundant species seen during the early dusk of evening flying around the ranch houses and barns, or along the streams and canyon walls, in both Upper Sonoran and Transition Zones. 
Gemeral habits.-At Watson, July 21, 1915, Preble says that among the large number of bats seen flying evenings there were always a few that seemed referable to this species. On July 13 he shot one at the head of the canyon about 5 miles north of Sheaville, where bats were numerous. At Riverside, Sheldon and the writer shot two of these bats among many others that flew swiftly about the barns every evening. In Kiger Gorge, in the Steens Mountains, August 24 and 25, Sheldon and Becker collected three specimens among the aspens around their cabin. At Paulina Lake, Goldman shot one August 16, 1914, from among the small bats flying over the lake and creek. At Malheur Lake a dead and mummified specimen was picked up on the porch at Springers Ranch, and on August 12, Watson and the writer knocked down two with gunny sacks as they flew about in an old shop at about 8 p. m. Both were adult females and fat, with full stomachs. The larger weighed $8.8 \mathrm{~g}$, and its stomach full of finely masticated insects, weighed $2.4 \mathrm{~g}$, or approximately one-quarter of its total weight. This amount of food merely represented one meal-the bat's supper, and another full meal, and probably some lunches in between, would certainly be eaten before it retired to roost in the morning. The bat would thus consume at least half its weight in insects each night, even when fat and heavy, or near its own weight when lean and light. Both of these bats were fat enough to hibernate at the first cold weather, but where they go to pass the winter is not yet known.

Breeding habits.-In the Devils Kitchen, a large warm cave near the Mammoth Hot Springs in Yellowstone Park, these bats gather in a colony for breeding. On July 11, 1915, several hundred were found in the cave, all of those collected being females, and each containing one large foetus nearly ready for birth. They were gathered in bunches of sometimes 50 or more in a place, in the crevices of the cave wall, clinging to the rocks or to each other, and the writer could easily put out his hand and take as many as he wished. They would bite fingers as hard as they could, but without breaking the skin or doing any harm.

This was evidently only a breeding colony, as on September 18, when the cave was again visited, the bats were all gone, evidently for cooler winter quarters where hibernation would be possible.

\section{MYOTIS YUMANENSIS SOCIABILIS H. W. GRINNELL}

\section{TeJon Bat}

Myotis yumanensis sociabilis H. W. Grinnell, Calif. Univ. Pubs., Zool. v. 12, p. 318, 1914.

Type.-Collected at Old Fort Tejon, Calif., by Joseph Grinnell, July 23, 1904.

General characters.-Size small, color between that of the very pale Myotis yumanensis of the Colorado Desert region and the dark $M$. yumanensis saturatus of the Northwest coast region. Upper parts "tawny-olive" or sepla; lower parts dull whitish or buffy ; ears and membranes pale brownish in color, posterior edges of membranes sometimes whitish.

Measurements.-Adult female from Eagle Lake, Calif.: Total length, $87 \mathrm{~mm}$; tail, 37; foot, 10; ear (dry), 12; forearm, 37; spread of wings, 240 (Bunnell). Average of five adult males (Grinnell) : 81; 33; 8 ; forearm, 34. Weight of adult female $6.4 \mathrm{~g}$ (Grinnell, Dixon, and Linsdale, 1930, p. 455).

Distribution and habitat.-Southeastern British Columbia and southward east of the Cascades and west of the Sierra Nevadas to 
southern California; eastward to the Bitterroot Valley, Mont. (fig. $92)$.

Eight skins and skulls from Klamath Falls, Oreg., from the University of California collection, and 2 alcoholics from Lone Rock east of the lower John Day River, are referred to this form by Miller and Allen $(1928, p .69)$. In the Jewett collection are 3 males taken at Molin, Klamath County, on September 27, 1926, and 9 specimens taken from a large colony in an old cabin at Springers Ranch, close to Malheur Lake, on June 10, 1922. They undoubtedly range all over eastern Oregon in the semiarid part of the State. Near Lone Rock, in the valley bounded by lava cliffs, they were common and after some waste of ammunition 2 specimens were secured in the evening of June 16, 1896.

General habits.-Practically nothing has been recorded on the habits of this species in Oregon, but at the type locality in Kern County, Calif., Grinnell, July 21-25, 1904, secured a series of 61 specimens in and around the ruins of Old Fort

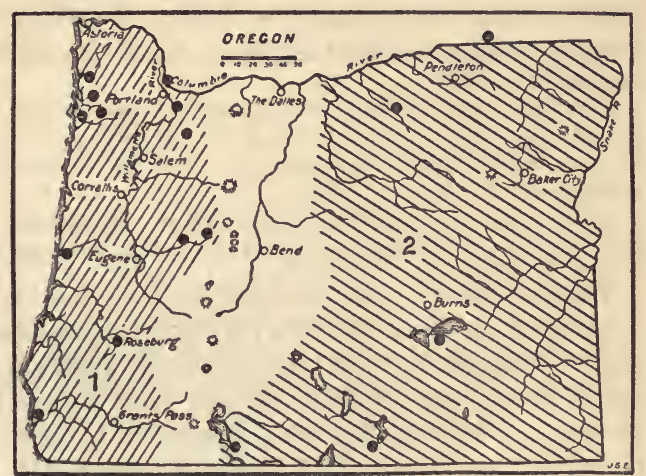

Figure 92.-Range in Oregon of: 1, Myotis yumanensis saturatus; $2, M$. $y$. sociabilis.

Tejon. Of these 33 were adult females, the rest nearly grown young of the year of both sexes, indicating a breeding colony (Grinnell, 1918, p. 278). On September 3, 1920, Howell (1920, p. 173) estimated at least 1,000 of these bats under the iron roof of an old adobe storehouse at Old Fort Tejon, but in the series of specimens collected no adult males were found. On September 23 he found only 200 left in the colony and on December 16 all had departed. He says "beyond doubt this form is entirely migratory."

Grinnell records one of these bats taken in the San Bernardino Mountains June 28, 1905, but does not give the sex (1908, p. 158). Glover M. Allen reports a male taken at 11,000 feet on Mount Whitney on July 16, 1919, and another male at Lone Pine a few days later $(1919, p p .1-2)$. The males, free from family cares probably wander widely in summer.

Their winter resorts are not known but probably both sexes gather in large numbers in caves for hibernation.

Breeding habits.-Little is known of the Tejon bats' breeding habits except that they breed in considerable colonies and have one young each. Large breeding colonies have been found in buildings or bridges at Old Fort Tejon, Tulare, and Eagle Lake, Calif., and at Corvallis, Mont.

At Eagle Lake, in northeastern California, on June 24, 1906, Sterling Bunnell found a colony of these bats in an attic where he estimated 1,000 or 2,000 individuals, but found no young. If this was a breeding colony the young were probably not yet born.

At Corvallis in the Bitterroot Valley, Mont., Bernard Bailey found a breeding colony of several hundred of these bats between the tim- 
bers at the top of a large wooden bridge. The breeding females arrived in April. A few young were born as early as June 1, and a few females still contained foetuses as late as July 7. In every case there was but 1 young or 1 embryo to a female, and some of the bats shot for specimens had small young clinging to them. In 1910 all of the bats had deserted the bridge by September 2 , nearly 2 weeks earlier than on the previous year.

\section{MYOTIS YUMANENSIS SATURATUS MILLER}

DUSKY BAT

Myotis yumanensis saturatus Miller, North Amer. Fauna No. 13, p. 68, 1897.

Type.-Collected at Hamilton, Skagit County, Wash., by T. S. Palmer, September 13, 1889.

General characters.--Size small, color dark; upper parts dull sepia; lower parts buffy on belly, washed on throat and sides with sepia; ears and membranes dark brown or blackish. Young of the year duller and more dusky than adults.

Measurements.-Adult male from McKenzie Bridge: Total length, $85 \mathrm{~mm}$; tail, 38 ; foot, 10 ; ear (dry), 11 . Adult female from same place: 83 ; $35 ; 10 ; 12$.

Distribution and habitat.-The humid coastal slope west of the Cascades from southern British Columbia to northwestern California and down the coast to San Luis Obispo County. In Oregon specimens have been taken at the Columbia River, Wilson River, Hope, Mohler, Blaine, Netarts, Mercer, Wedderburn, Roseburg, McKenzie Bridge, and Vida (fig. 92). Apparently this is one of the commoner small bats in the Transition forest area west of the Cascades. It is resident throughout the summer, specimens having been collected at various dates from June 24 to October 24, but where they spend the winters no one seems to know. At Blaine, Tillamook County, Alex Walker has collected specimens from July 19 to September 28.

General habits.-At Vida, on the upper McKenzie River, the writer secured one of these little bats on June 24, but found them so quick and erratic in flight that in the deep shadows of the forest no more specimens could be brought down. At Wedderburn near the mouth of Rogue River, on October 24, they were found flying in and out of an old barn rather early in the evening, and one was shot in the early twilight before it had secured a meal of insects. Its stomach was found to be quite empty, a rare condition with bats shot on the wing, as they quickly acquire a full stomach.

Breeding habits. - Apparently there is nothing on record regarding the breeding habits of this common and wide-ranging form, a sad reflection on the state of knowledge of a highly useful mammal.

Food habits.-Most or all of the food is taken on the wing and consists of flying insects found among the trees or around buildings, but not easily identifiable as to species. Probably many or most of these are injurious species.

\section{MYOTIS EVOTIS EVOTIS (H. ALLEN)}

\section{LITTLE BIG-EARED BAT}

Vespertilio evotis H. Allen, Monograph Bats of North America, Smithsn. Misc. Collect., no. 165 , p. 48, 1864.

Type locality.-Puget Sound; no type specimen.

General characters. - Size slightly larger than that of Myotis yumanensis or lucifugus, and ears very much larger, longer, and wider. Color yellowish 
brown or buffy brown with black ears and membranes; upper parts uniform yellowish brown or dull clay color; lower parts pale buffy; ears black, wing and tail membranes black or dusky.

Measurements.-Male from Fremont, Oreg.: Total length, $84 \mathrm{~mm}$; tail, 38; foot, 11; ear (dry), 18; humerus, 37. Another male from McKenzie Bridge: $95 ; 41 ; 11 ; 17 ; 37$.

Distribution and habitat.-The humid coast region from southern Alaska to northern California (fig. 93). One skin from Fremont, Oreg., is referred to this species by Miller and Allen, but is paler than typical specimens and approaches chrysonotus, while 1 from McKenzie Bridge and 2 from Tillamook County, are dark and rich in color and near typical evotis. In the Jewett collection are $2 \mathrm{fe}-$ males from Salem, collected by Elmer Griepentrog on June 5 and August 13, 1927, and in the University of Oregon collection are 1 from Eugene collected in the fall of 1919, 1 from McKenzie Bridge taken July 4, 1914, and 1 from Fish Lake, Jackson County, July 30 , 1920. In the Alex Walker collection are an adult female taken at Blaine, August 10, 1921, and an adult male from Tillamook, September 8, 1924.

A series of specimens from the Blue Mountains just over the Washington

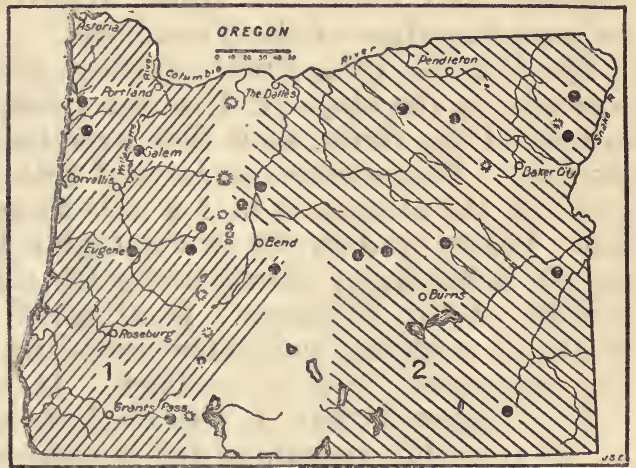

Figura 93.-Range of the little long-eared bats in Oregon: 1 , My,tis evotis evotis; 2 , M. e. chrysonotus. line at Godman Spring, Columbia County, are mainly intermediate but are referred by Miller and Allen to evotis.

While at present represented in Oregon by only a few specimens, the species may be expected over all of the Transition Zone area around and west of the Cascades, but in no great numbers. The specimens referred to this dark form were collected by Luther J. Goldman, one at 5,000 feet altitude on O'Leary Peak, 10 miles south of McKenzie Bridge, on July 2, 1914; another collected the same dato at McKenzie Bridge by Charles Shelton; another taken by Goldman August 23 at Fremont, in the eastern foothills of the Cascades; and two taken by Alex Walker at Tillamook, August 10. 1921, and Blaine, September 8, 1924.

General habits.-Most of the specimens taken were shot in the evening twilight as they flew rapidly along the edge of the forest or over open meadows near the tall timber. There is little known of the actual habits of these bats, either where they spend the day or where they go for the winter hibernation.

\section{MYOTIS EVOTIS CHRYSONOTUS (J. A. ALLEN)}

\section{Desert Golden Bat}

Vespertilio chrysonotus J. A. Allen, Amer. Mus. Nat. Hist. Bull. 8: 240, 1896.

Type-Collected at Kinney Ranch, Sweetwater County, Wyo., by W. W. Granger, July 21, 1895. 
General characters.-Size and proportions about the same as in typical Myotis evotis, but color lighter and brighter; upper parts a golden buff, lower parts buffy or dull whitish; ears and membranes black or dusky.

Measurements.-Adult male from Cedar Mountains: Total length, $85 \mathrm{~mm}$; tail, 44 ; foot, 10 ; ear (dry), 17 ; humerus, 36 ; spread of wings, 242 . Adult female from Sisters: $96 ; 45 ; 10 ; 18 ; 37$. An Arizona specimen weighed $7.2 \mathrm{~g}$.

Distribution and habitat.-Arid regions from eastern Oregon to North Dakota and southern Mexico. Specimens are referred to this form from Oregon collected at Disaster Peak, Cedar Mountains, Harney, Burns, Twelve Mile Creek, Cornucopia, Wallowa Lake, Fossil, Lehman, Deschutes River, and Sisters (fig. 93). Some of these specimens, however, are more or less intermediate with the more western and darker colored evotis. The records indicate that chrysonotus is a common bat over the open country of eastern Oregon in Upper Sonoran and Transition Zones, apparently spending the summer in or near the edges of the Transition.

On June 14, 1915, Preble shot one of these bats at about 7,000 feet altitude on the slope of Disaster Peak, in the extreme southeastern corner of the State, as it flew over the willow-fringed creek in the evening. There were cottonwood trees 2 miles down the creek and cliffs on the other side half a mile away, but no nearer refuge for a bat. Later, on July 26, in the Cedar Mountains of eastern Oregon he saw a bat flying slowly along the side of the mountain about the middle of the forenoon. It alighted on some rocks close to the water of a spring, evidently intending to drink, and was captured and converted into a specimen. It was extremely lean, and its flight suggested that it was weak from hunger, thirst, or disease, which probably accounted for its appearance in daytime.

In early July 1896, Preble and the writer each shot one at the lower edge of yellow pines on Twelve Mile Creek, where they seemed to be the commonest bat in the open sagebrush valley. Another was collected on Squaw Creek, near the town of Sisters in open yellow pine timber by L. J. Goldman on July 26, 1914, and another 28 miles northwest of Burns by M. E. Peck on August 9, 1912. An old alcoholic specimen in the United States National Museum collection from Camp Harney was undoubtedly taken by Bendire in the seventies while he was stationed there, but is without other data. An alcoholic specimen from Wallowa Lake, secured by W. C. Kendall, September 24, 1897, gives the latest fall record for the State and suggests the probability of a wintering cave at no great distance.

General habits.-These are quick, strong flying bats and not collected in great numbers even where common. In places they are found around buildings and not infrequently come in through open windows or doors in search of their food insects. They are sometimes found in caves and hollow trees, but not in large colonies.

To what extent they are migratory is not known but this probably depends on the location of wintering caves and summer breeding and feeding grounds. Oregon is well supplied with extensive and little known caverns, and undoubtedly with many available to bats and not to larger animals. When the great value of bats to man is better realized their winter retreats will be studied and carefully guarded.

Food habits.-Beyond the mere facts that they are seen zigzagging against the sky, rapidly snapping up flying insects, and that their 
stomachs are found filled with finely masticated insect remains, little is known of their actual food habits and food supply.

\section{MYOTIS VOLANS LONGICRUS (TRUE)}

\section{LONG-LEGGED BAT}

Vespertilio longicrus True, Science 8: 588, 1886.

Type.-Collected in vicinity of Puget Sound, Wash., by David Starr Jordan. Cataloged December 16, 1886.

General characters.-Small, tibia long, about $18 \mathrm{~mm}$; ears short and bluntly rounded, fur on underside of wings extending to elbows; color dark chestnut or cinnamon brown above, sometimes blackish; smoky brown below; ears and membranes blackish.

Measurements.-Adult female from McKenzie Bridge: Total length, $90 \mathrm{~mm}$; tail, 41 ; foot, 9 ; ear (dry), 9 ; humerus, 37 . Male from Port Townsend, Wash. : $90.6 ; 42.8 ; 8 ; 13 ; 40$.

Distribution and habitat.-The humid coast and mountain region from Admiralty Island, Alaska, to Monterey County, Calif. Oregon specimens are recorded by Miller and Allen from McKenzie Bridge, east base Cascade Mountains, east of Mount Thielsen, and two alcoholics from Baker County. In the university collection at Eugene are specimens from Oakridge, Eugene, Mercer, Grants Pass, and Galice, and in Jewett's collection at Portland are specimens from Estacada and $\mathrm{Ne}$ tarts (fig. 94).

General habits.-On August 25, 1896, a specimen was taken on Upper Sink Creek in the yellow pine forest near the eastern base of Mount Thielsen, far from human habitation and far from any exposed rocks. Nearly 20 years later, on June 29

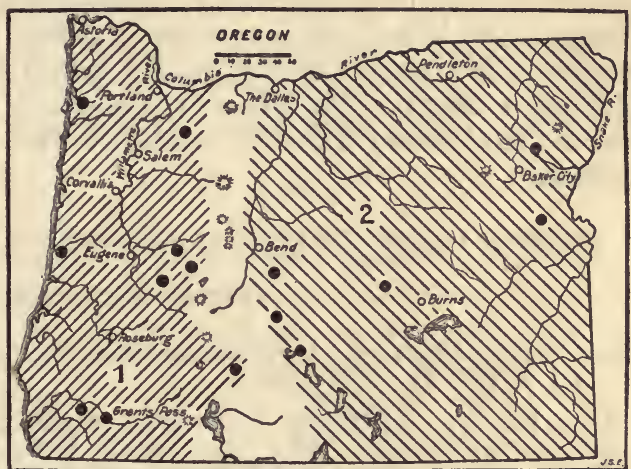

Frgurm 94.-Range in Oregon of: 1, Myotis volans longicrus; $2, \boldsymbol{M}$. v. interior. and July 4, 1915, 1 male and 1 female of these little dark-colored bats were collected near McKenzie Bridge at the edge of the dense forest. Among the several other species of small Myotis, indistinguishable on the wing, they were shot from the air as they darted back and forth across open spaces in the forest where they could be seen against the evening sky. On July 6, L. J. Goldman shot another at the Lost Creek Ranger Station, 10 miles southeast of the bridge.

\section{MYOTIS VOLANS INTERIOR MILLER}

\section{INTERIOR BAT}

Myotis longicrus interior Miller, Biol. Soc. Wash. Proc. 27: 211, 1914.

Type.-Collected near Twining, Taos County, N. Mex., by Vernon Bailey, July $23,1904$.

General characters.-Size and form as in typical $M$. v. longiorus, but color lighter and more reddish or yellowish; upper parts dark hazel to light chestnut; 
lower parts dull tawny or pale buffy in immature specimens; ears and membranes dark brown or blackish.

Measurements.-Adult female from Fremont: Total length, $98 \mathrm{~mm}$; tail, 42 ; foot, 10; ear (dry), 11; forearm, 40. Another female from same place: 101; $45 ; 10: 11 ; 40$.

Distribution and habitat.-The arid interior region from eastern IVashington and Oregon to Wyoming and Colorado and south into Mexico (fig. 94). Oregon specimens are recorded by Miller and Allen from Fremont, Paulina Lake, Silver Lake, and Ironside, while others from southeastern Washington, western Idaho, and northern Nevada would indicate a range over all of arid eastern Oregon. A specimen in the Jewett collection from Sageview in Harney County seems to be of this form.

General habits.-At Paulina Lake, L. J. Goldman collected 4 of these bats on August 14 and 16, 1904, shooting them as they flew over the water of the lake in the evening twilight. All were males, indicating a colony of males in the vicinity. On August 22, 23, and 24 at Fremont, a little farther south, he collected 4 more specimensall females. This probably indicates a breeding colony in the vicinity, as the sexes of bats are generally well segregated during the breeding season. A female collected at West Silver Creek on September 2 may have belonged to this same colony. Other records for Oregon are based on a specimen taken by Anthony at Ironside in northern Malheur County, and 1 taken by Jewett near Sageview in Harney County. So little is known of the specific habits of this species that every record should contribute a valuable bit of information.

\section{MYOTIS CALIFORNICUS CALIFORNICUS (AUDUBON AND BACHMAN)}

\section{LtTtue California Bat}

Vespertilio californicus Audubon and Bachman, Acad. Nat. Sci. Phila., Jour. (1) vol. 8 (pt. 2) : $285,1842$.

Type locality.-California. No type specified.

General characters.-Size very small, with tiny feet; ears relatively large, reaching beyond tip of nose when laid forward; color of upper parts bright tawny; lower parts pale tawny or buffy; ears and membranes brownish black. Measurements.-Total length, about $80 \mathrm{~mm}$; tail, 40 ; foot, 6.4 ; ear, 11.6 ; forearm, 30; spread of wings, 219. Weight of adults 3.7-5 g (Grinnell, $1918, p .251$ ).

Distribution and habitat.-From Sonora and Baja California northward in the deserts and interior valleys to eastern Oregon and southeastern Washington (fig. 95). Oregon specimens are recorded from Blue River, Mount Hood, Sisters, Elgin, Wallowa Lake, Silver Lake, and Crown Rock (on the lower John Day River). The specimens from west of the Cascades are more or less intermediate in characters.

These tiny, bright-colored bats are undoubtedly distributed over most of eastern Oregon, although few specimens have been taken, and these mainly in Transition Zone localities.

General habits.-The scarcity of specimens does not mean that the bats are scarce. In this case it means that they are small, quick, and crooked fliers, not colonial in habits (at least not so in summer), and not easily procured by even the most skillful collectors and expert wing shots. Among other species of small bats, indistinguish- 
able on the wing, often found swarming around barns and old buildings, or along the canyon walls or the edges of a forest, they are discernible only during a brief span of twilight. For the 15 or 20 minutes before actual darkness the eager collector shoots rapidly as the bats cross a span of clear western sky, and if favored by skill and good luck afterward picks up a few specimens, sometimes comprising several species, sometimes all of one kind. One of these little bats may come into a room through open door or window and be knocked down with a towel or sack and secured for a specimen, or a few may be picked from cracks in the rocks or dark retreats in attics or walls, but the $\mathrm{n} u \mathrm{mbers}$ collected or identified are of little significance as an index to the actual numbers that are flying all night and collecting their insect. food.

In autumn they disappear to sleep away the winter in some cave or mine shaft or safe retreat and are not seen again until the warm days of spring.

Breeding habits.-There seem to be no actual breed-

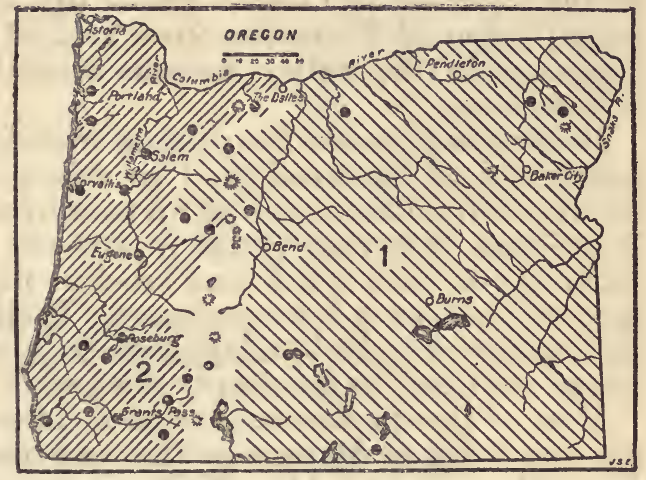

Figurg 95.-Range of two small bats in Oregon: 1 , Myotis californicus californicus; $2, M$. c. caurinus. ing records for Oregon although specimens have been collected during the spring and early summer when undoubtedly they were on their breeding grounds. In other parts of its range records show that one young, born apparently in June, is the usual number.

Food habits.-Of specimens collected the stomachs are usually full of insect remains so finely masticated that only with a high-power microscope can one determine even the groups to which the insects belong. Apparently all are flying species, captured on the wing, but of the actual feeding habits of the bats comparatively little is known.

\section{MYOTIS CALIFORNICUS CAURINUS MILLER}

\section{NoRTHWEst CoAst Bat}

Myotis californicus caurinus Miller, North Amer. Fauna No. 13, p. 72, 1897.

Type.-Collected at Massett, Queen Charlotte Islands, British Columbia, by J. H. Keen in 1895 .

General characters. - Size slightly larger than typical californicus, and color darker. Upper parts argus brown of Ridgway; lower parts slightly paler, about sudan brown, near chestnut above and hazel below; ears and membranes blackish.

Measurements.-Two specimens from Queen Charlotte Islands: Total length, 81 and $87 \mathrm{~mm}$; tail, 36 and 39 ; foot, 8 and 7 ; forearm, 30 . One male from McKenzie Bridge: $78 ; 32 ; 7 ; 12 ; 32$. Oregon specimens are slightly smaller than typical.

Distribution and habitat.-Humid area of the Pacific coast from the southern Alaska islands south to northwestern California and the vicinity of San Francisco Bay. In Oregon specimens are re- 
corded by Miller and Allen from Brownsboro, Corvallis, Philomath, Eugene, Marmot, McKenzie Bridge, Prospect, Tillamook, Reston, and Lookingglass (fig. 95). Others examined in the Jewett collection are from Holly, Linn County; Mercer, Lane County; Remote, Coos County; Gold Beach, Curry County; and still others in the University collection at Eugene from Roseburg, Douglas County; Galice, Josephine County; Grants Pass, and Fish Lake in Jackson County. In the Alex Walker collection specimens have been identified by the Grinnells from Blaine and Tillamook.

A few individuals from the Willamette Valley are so light that they are referred to californicus, but most of the specimens from west of the Cascades in Oregon are of this dark-brown form. They occupy the humid Transition Zone area of the State and are generally abundant in the valley forests, around buildings, and along the watercourses.

General habits.-In the dusk of evening these little brown midgets swarm out of the woods and go skimming over the still surface of streams and ponds, scooping up mouthfuls of water until their thirst is satisfied, then they dodge in and out among the trees or around buildings in such quick and crooked flight that even a good wing shot will get but a few specimens. Their habits differ from those of californicus merely in adaptation to a better forested area as their colors are toned to the deeper shadows.

Most of the specimens have been collected during the summer, but one was taken at Marmot at the west base of Mount Hood as late as September 12, and Alex Walker collected them at Blaine in Tillamook County, on November 24 and 25. Cantwell took another at Philomath on March 12, and Walker another at Blaine on March 26. For the other 4 or 5 months of the year they disappear for their winter quarters, probably in caves or other retreats for hibernation.

Cantwell shot two at the Rogers Ranch, near Parkdale at the north base of Mount Hood, on the evening of March 27, 1919, after a warm bright day, although 2 feet of snow still covered the ground and no insects were noted in the air.

\section{MYOTIS SUBULATUS MELANORHINUS (MERRIAM)}

\section{BLACK-NOSED BAT}

Vespertilio melanorhinus Merriam, North Amer. Fauna No. 3, p. 46, 1890.

Type-Collected at Little Spring, north base of San Francisco Mountain, Ariz., by C. Hart Merriam and Vernon Bailey on August 4, 1889.

General characters. - Size small, about as in $M$. californicus, ears slightly larger, color much the same but nose and face blackish. Color of upper parts bright golden brown, the muzzle, chin, and sides of head from mouth to ear dull blackish; lower parts dull buffy; ears black and membranes brownish black.

Measurements.-Type specimen: Total length, $83 \mathrm{~mm}$; tail, 43; ear (fresh), 13 ; foot, 7 ; forearm, 32 . One specimen from Zuni Mountains, N. Mex.: Total length, 78; tail, 38; foot, 7.5; ear (dry), 13; forearm, 33 . An adult male from mouth of the Deschutes: $80 ; 38 ; 8 ; 12 ; 31$. Weight of female $4.7 \mathrm{~g}$ (Grinnell, Dixon, and Linsdale, $1930, p$. 456).

Distribution and habitat.-From New Mexico, west Texas, and Lower California to eastern Oregon and Washington. Oregon specimens recorded by Miller and Allen are from Burns, Homestead, Millers (at mouth of Deschutes), Riverside, Rockville, Sheaville, 
Rome, Skull Spring, Twelve Mile Creek, and Warner Valley (fig. 96). There is one from Bly, Wash., in the extreme southeastern corner, close to the Oregon line.

These localities carry the animal's range over the arid part of eastern Oregon and indicate a rather abundant species in mainly Upper Sonoran Zone. They have been collected from April 12 at the mouth of the Deschutes to September 26 in Warner Valley.

General habits.-On the wing these little bats are indistinguishable f r o m Myotis californicus, and even in the hand require close scrutiny to detect the

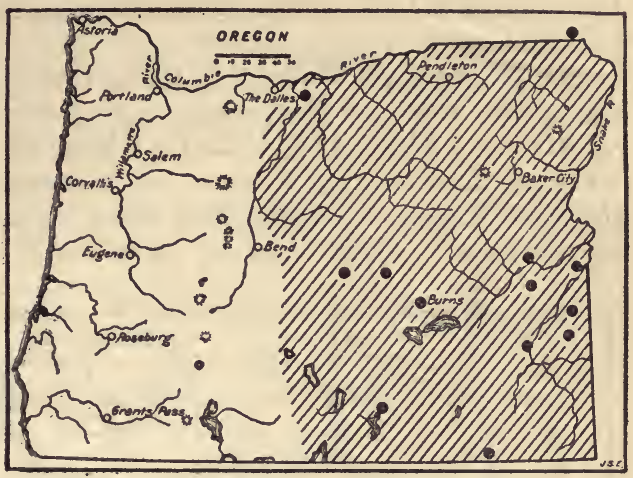

Figure 96.-Range of black-nosed bat, Myotis subulatus melanorhinus, in Oregon.

dusky nose and face. In habits they seem to be equally close or else to have been mistaken for californicus, as there are no field notes attributed to them.

\section{EPtesiCUs FUSCUS FUSCUS (Peale and Beauvois)}

Big Brown Bat

Vespertila fuscus Peale and Beaurois, Catal. Raisonné, Mus. Peale, Philadelphia, p. 18, 1796 (p. 14, English ed.)

Type locality.-Philadelphia, Pa.

General characters-Size large, expanse of wings about 13 inches; fur long and glossy, color bright brown; membranes blackish, total number of teeth 32. Color of upper parts bright tan brown; lower parts slightly paler; membranes, feet, ears, and nose black or blackish.

Measurements.-Spread of wings, $324 \mathrm{~mm}$. Total length, 117 ; tail, 50 ; feet, 11 ; forearm, 44. Weight $12-15 \mathrm{~g}$ when not excessively fat. Weight of five males 14.6-22.7 g (Grinnell, Dixon, and Linsdale, 1930, p. 456).

Distribution and habitat.-These large brown bats range clear across the northern United States and are more or less common over practically all of Oregon at one season or another (fig. 97). Their breeding range seems to be mainly in the Transition Zone, but in late summer they are found in the Canadian Zone timber of the mountains and in spring or late summer may be found in the lowest valleys. Not until the bats have been banded and more carefully studied in the field at all seasons will it be possible to speak intelligently of their ranges and migratory habits.

General habits.-These are rather conspicuous strong flying buts, coming out early in the twilight, and after visiting the nearest water for a series of copious drinks begin the quest for flying insects among the trees, along streams, or about buildings or rocks. Their flight is rapid but not so quick and crooked as that of the smaller species and generally more specimens are secured than of many smaller kinds that are just as numerous. 
Generally they are found living in old buildings, under bark of dead trees, in caves or cracks of cliffs, or seams of canyon walls, where they hang up during the daylight hours. In winter they seek the larger caves or walls of buildings, where a uniform temperature enables them to pass the cold season in a state of torpor, called hibernation.

At Eugene on June 21, 1914, these bats were actually numerous along the river as they came out of the town at early dusk and flew slowly over the water. In fact they flew so slowly that 4 specimens were secured out of 6 shots, an unusual record for bat shooting, but the slow flight was explained when each of the 4 specimens was found to contain a large foetus, practically ready for birth. The next

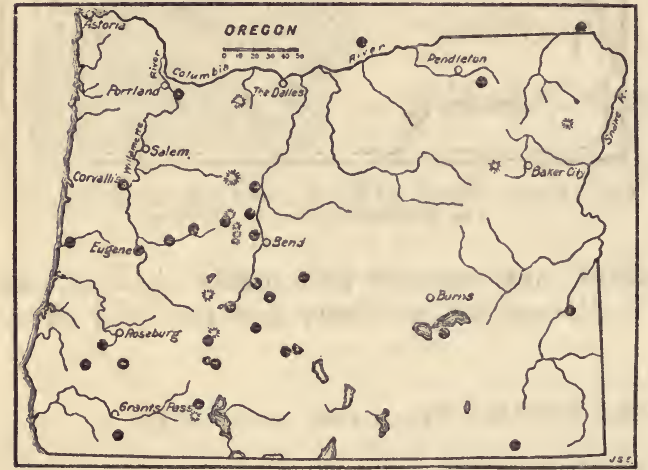

FigURE 97.-Range of big brown bat, Eptesicus fuscus fuscus, in Oregon. day at Vida, farther up the McKenzie River, the writer again found these bats common but flying so high over the treetops that they were mostly out of shotgun range. A dozen or 20 were often in sight at one time, circling and zigzagging in quest of flying insects, but after much shooting with heavy loads only 2 were brought down. On the evening of June 26 they came down and flew low enough for a good series of specimens

to be secured, all of which proved to be females carrying each a fully developed foetus which was fully a quarter of the size and weight of the mother. No scales were available for weighing them, but the size of the young as compared with that of the mother was astonishing. With stomachs also distended with insects the old bats were shaped like toads, and it was no wonder they flew slowly and high up where the air was unobstructed.

A few days earlier these bats had been found common on Spencer Butte, near Eugene, where they flew so rapidly through the treetops that no specimens were secured, and on July 18 at a 5,000-foot camp at the north base of Three Sisters Peaks a few were collected as they flew rapidly through the lodgepole pines, but these were all males as were probably those on Spencer Butte. Also all but one of those collected at McKenzie Bridge early in July were males.

The young born in the latter part of June are soon able to fly and catch their own food and by the middle of August are nearly full grown. This is the mating season, and the males and females are generally found together in about equal numbers.

After the mating season the bats begin to store up fat for the winter sleep and will often double in weight before the cold weather begins. Very fat individuals will sometimes weigh up to $22 \mathrm{~g}$.

One of these bats collected by Luther J. Goldman at West Silver Creek, 10 miles southwest of Silver Lake, on September 3, 1914, was already very fat and probably ready for hibernation in the near 
vicinity. Goldman reported them as then rarely seen and probably mostly already hibernating. Another collected by Preble at Fort Klamath on September 14, 1896, gives the latest record for the State. Another bat reported by Stanley G. Jewett at Miller's, near the mouth of the Deschutes River, on April 14, 1915, and thought to be this species would give the earliest record for appearance in spring if correctly determined. These records would indicate about 7 months of hibernation which probably explains the 10-month period of gestation, extending approximately from the middle of August to the middle of June in this species.

Food habits.-These big brown bats are hearty feeders with large stomachs, but little is known of their actual food supply. The stomach contents indicate a wide range of species of insects, but few of the species have been carefully determined. At Vida they were feeding high in the air mostly beyond the range of the heaviest loads of fine shot, and the few secured seemed to be filled up with some kind of high-flying beetle. One of the bats had a small striped beetle in its mouth when it struck the ground, but this was lost.

At the Arnold Ice Caves, 14 miles southeast of Bend, the brown bats were common, flying out and in the mouth of one of the large cave openings, and zigzagging back and forth under the broad archway of the entrance. Often they would alight on some point of the roof and sit for a moment eating their insect prey, and under these feeding spots the ground was strewn with wings of moths, beetles, and flies. A few of the wings saved and referred to the Bureau of Entomology and identified by H. E. Dyer represented several species in the genera Euoxia and Cucullia of the Noctuid moths and others in the genera Nemora and Stamnodes of the Geometrid moths. The species could not be determined from so scant material. The wings of a crane fly (Tipulidae) were also identified.

Economic status.-During the greater part of the months of insect activity these bats are found in greatest abundance among the forest trees where they glean their insect food and probably serve as an important factor in the protection of our forests. The specific insects eaten are not well known, but the stomach contents of the bats show a large proportion of moth and beetle remains, and these would presumably include serious enemies of the trees. Until a more detailed study of bats is made it will not be known how much is owed to these useful workers of the night.

\section{LASIONYCTERIS NOCTIVAGANS (LF CONTE)}

\section{SILVER-HAIRED BAT}

$\nabla$ [espertilio] noctivagans Le Conte, McMurtrie's Cuvier, Animal Kingdom, v. 1, p. $431,1831$.

Type locality.-Eastern United States.

General characters.-Size medium, spread of wings about 12 inches, ears short and wide (pl. 52, A); tragus short; upper surface of tail membrane hairy ; fur long and soft; general colors blackish with silvery frosting of white hair tips over back and belly ; total number of teeth 36 . Color of upper parts clear black or brownish black with pure white tips over back; lower parts black or dark brown, with a few white-tipped hairs over belly; membranes. feet, ears, and nose black or blackish.

Measurements. - Spread of wings, $300 \mathrm{~mm}$. Total length, 100; tail, 40 ; hind foot, 9 ; forearms, 42. Weight of one small individual in spring, $8 \mathrm{~g}$, but the Grinuells give weights up to 10 and $12 \mathrm{~g}$. 
Distribution and habitat.-These wide-ranging bats cover the greater part of the United States and much of Canada in their breeding and migration ranges. In Oregon specimens have been collected at various seasons over practically the whole State (fig. 98). Their breeding range, however, is apparently restricted to the Transition and Canadian Zones.

General habits.-More than almost any other bat these are forestdwelling animals, especially in the breeding season. During their long and irregular migrations they may be found in any of the open valleys and low country on their way to caves or wintering grounds farther south. In early summer they are one of the commonest bats in the mountain forests where they fly at night among the branches of the trees and usually spend the day in hollow trees or under the

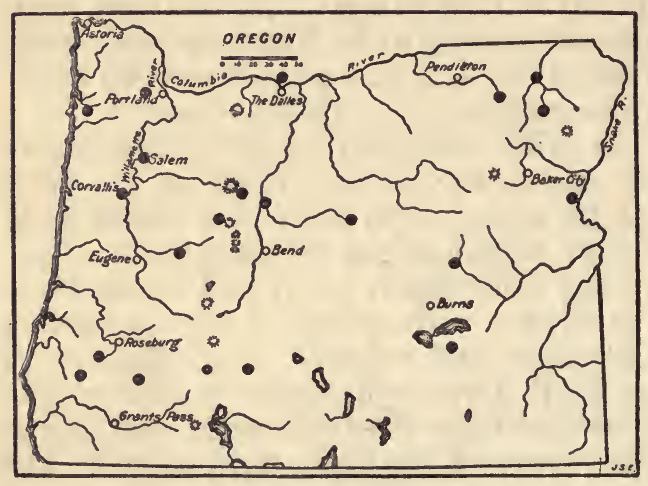

FIGURE 98.-Range of silver-haired bat, Lasionycteris noctivagans, in Oregon.

loose bark of dead trees. They come out rather late in the evening and are not easily shot against the evening sky as they fly from one grove to another in quest of their winged prey.

On May 29, 1896, Preble secured 3 specimens as they flew among the yellow pines near Elgin in the Blue Mountains, and on June 10, 2 were collected in the timber north of old Camp Harney. Another was secured on

the Ochoco River, 20 miles east of Prineville, one evening in June, probably close to its breeding ground. At the little town of Sisters, in the yellow pine on the east base of the Cascades, Luther Goldman collected several specimens late in July, and another at Bend on August 3. On August 25, 1896, Merriam secured a specimen among the yellow pines east of Mount Thielsen. R. H. Becker collected a half-grown young just able to fly at 6,000 feet altitude in the Kiger Gorge in the Steens Mountains, on August 21,1916 . He reported them as fairly common among the aspens in the canyon, but difficult to shoot as they came into the open for only a brief instant in their rapid flight. In western Oregon M. E. Peck secured specimens in Douglas County near Anchor and Reston in July and August 1916. On August 2, 1912, he had collected a specimen at Belknap Springs on the Upper McKenzie River and another in the Blue Mountains at Meacham on July 21, 1915. In the agricultural college collection at Corvallis there is a specimen collected in that vicinity on October 13, 1919, by Bitney and $\mathrm{H}$. E. Feller, and in the Merriam collection 1 from Beaverton collected by A. W. Anthony in 1884, but without specific date. In the Jewett collection are specimens from Remote, taken September 10, 1922, and the West Fork of Wallowa River taken July 22, 1925, and in the University of Oregon collection are 1 from Sisters, taken July 25, 1914, and 1 from Triangle Lake, Lane County, taken May 29, 1912. 
In the Walker collection are 2 specimens taken at Tillamook on June 28, 1914, and September 22, 1924 . These scattered localities over the State do not give a definite idea of the range and abundance of the bats, because in the heavy timber where they are most abundant few specimens can be obtained owing to the dense foliage and early darkness.

Little is known of their general habits and still less of their places for spending the winter months. Specimens are occasionally taken in spring or fall as far south as Texas and New Mexico, but it seems probable that they have regular migratory routes to certain caves or to warm valleys where they spend the winter.

Economic status.-These bats are undoubtedly of special value in protecting the forests from insects although there is little positive information as to the species of insects consumed.

\section{PIPISTRELLUS HESPERUS HESPERUS (H. ALLEN)}

\section{LITtue Canyon Bat}

Scotophilus hesperus H. Allen, Monograph Bats of North Amer., p. 43, 1864.

Type.-Collected at Old Fort Yuma, Calif., by Maj. G. H. Thomas, United States Army; cataloged October 31, 1861.

General characters.-Size very small (pl. 52, B), spread of wings 8 or 9 inches, color pale buffy gray, strongly contrasted with black ears and membranes; ear's rather short; tragus blunt with tip bent forward; total number of teeth, 34. Color of fur buffy gray, all over; membranes, feet, ears, and nose black or blackish.

Measurements. - Spread of wings, 204 to 225. Total length, 75; tail, 30 ; foot, 7 ; forearm, 30. Weight of adults 4 or $5 \mathrm{~g}$, males averaging smaller than females.

Distribution and habitat.-From a wide range over lower Sonoran deserts from Texas to eastern California and Nevada these tiny bats come into the valleys of eastern and northern Oregon in rather limited numbers (fig. 99). Specimens have been taken from Watson, Riverside, Princeton, Alvord Valley, both sides of the Columbia at the mouth of the Deschutes, and Almota, Wash. In summer temperature these valleys are close to Lower Sonoran Zone, although not marked by sufficient number of species to be mapped as such. The presence of the bats here may be considered as either an element of Lower

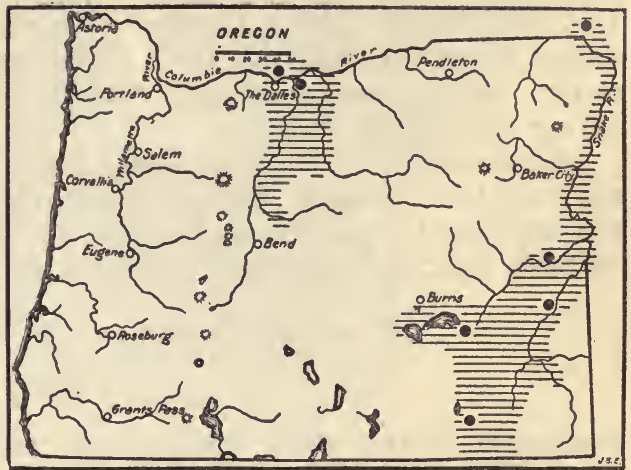

Figure 99.-Range of little canyon bat, Pipistrellus hesperus, in Oregon.

Sonoran or as a slight overlapping of range into the edge of Upper Sonoran Zone.

General habits. - The name of canyon bat has been given these midgets from their abundance in the canyons of the deserts where they fairly swarm out of the cliffs and canyon walls in the early 
evening hours and hurry to the nearest water to quench their thirst. They have even been seen to come out at midday to get a drink of water and go dipping down to the surface, scooping up mouthful after mouthful of the refreshing fluid. Their flight is quick and crooked as they zigzag overhead in quest of winged prey and their skill as hunters is shown by the full stomachs of those shot for specimens only 15 or 20 minutes after they have been flying.

Their homes are back in cracks and caverns of the cliffs where they sleep through the daylight hours. The young are raised in suitable places where food and shelter attract colonies of breeding females. The winter sleep or hibernation carries them through the period of cold and scarcity of food. As to what extent they migrate to and from winter and summer ranges there is little evidence. At Watson in the Owyhee Canyon Preble found them abundant in July 1915, and of a series of 13 specimens all but 2 were females. In the late afternoon, sometimes half an hour before sundown they would often make their appearance along the river, evidently driven by thirst from their dry retreats and come slowly and steadily down the slopes, wasting no time in search of food but intent on quenching their thirst.

This was evidently a breeding colony, as 1 of the females collected on July 19 contained 2 large embryos and 1 taken on July 21 was nursing young. Judging from many records 2 young is the usual number, and these are born generally in July. Breeding females usually contain embryos throughout May and June, and Preble's record of July 19 is the latest for embryos that has come to the writer's knowledge.

Jewett and Gabrielson collected several of these tiny bats in the canyon of Trout Creek at the southern end of Alvord Valley on June 21, 1930, where considerable numbers were seen flying about shortly after sundown. Another specimen was obtained about the middle of October 1930, at the Brown Ranch near Princeton in the Malheur Valley. Jewett collected a male at the mouth of the Deschutes River on April 15, 1915, which seems to be the earliest Oregon record, but no late records are available to indicate dates of hibernation or migration.

The stomach contents of these little bats show a well masticated mass of small insects, but no accurate determination of the species has been made, and the undoubted value to agriculture of these little animals cannot be stated in definite terms.

\section{NYCTERIS CINEREA (PEAlE and Beauvois)}

\section{HOARY BAT}

Vespertilio cinereus Peale and Beauvois, Catal. Raisonné, Mus. Peale, Philadelphia, p. 18, 1796 (p. 15 of English ed.).

Type locality.-Philadelphia, Pa.

General characters. - Size large, spread of wings about 16 inches, ears short and rounded, partially furred, with black naked rims; top of feet and tail membranes furry; fur full and soft; teeth 32 ; color yellowish brown, frosted with white above and below; throat and wing linings, clear buffy.

Measurements.-Average specimen: Spread of wings, about $380 \mathrm{~mm}$. Total length, 140 ; tail, 60 ; foot, 13 ; forearm, 53 . Weight of adult male $20 \mathrm{~g}$, not fat and stomach empty. 

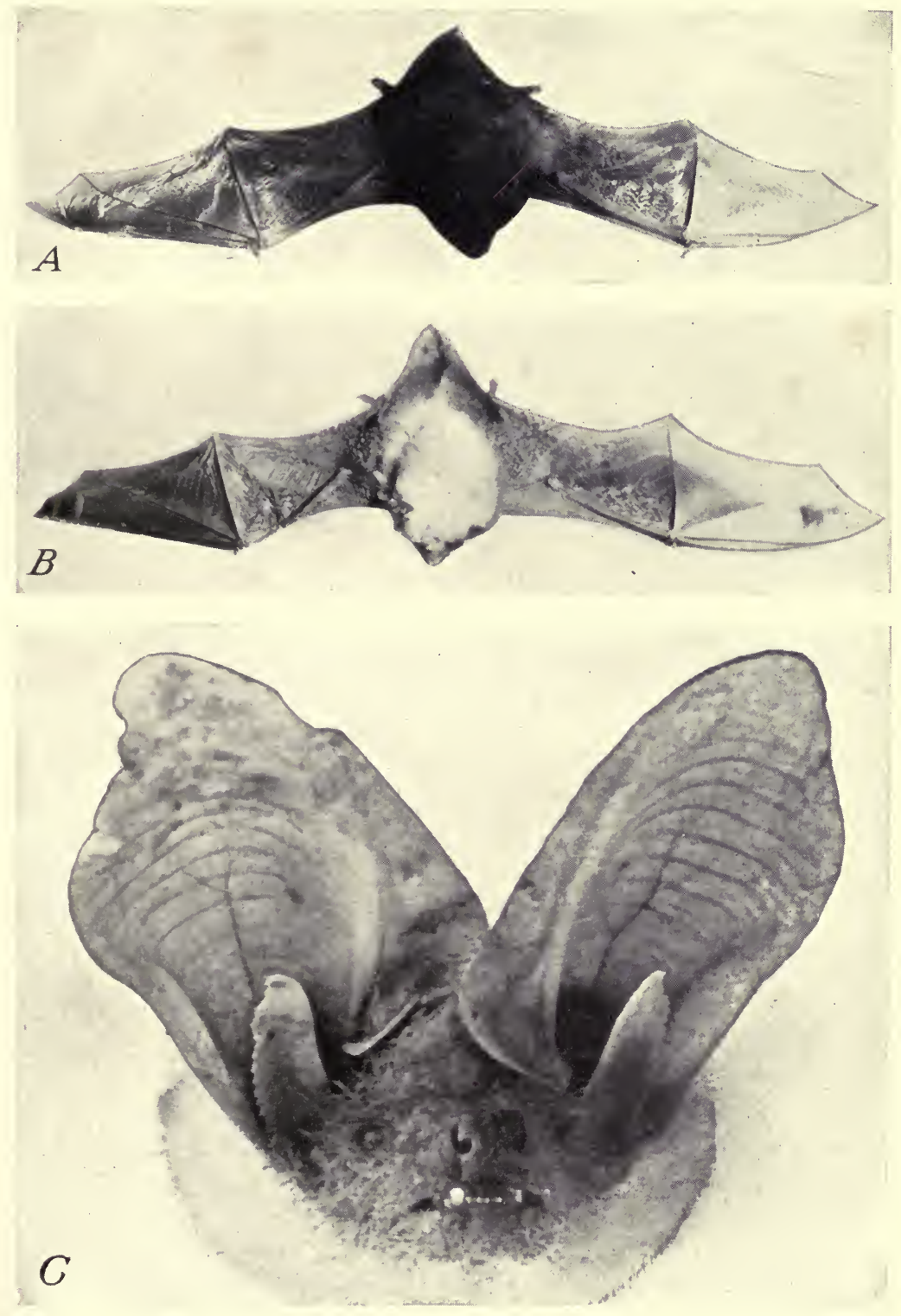

SOME OREGON BATS.

$A$. Silver-haired bat; $B$, little canyon bat, smallest of Oregon bats; $C$, Pacific pale bat (about natural sizc; photographed by A. Brazier Howell). 

Distribution and habitat.-These large gray bats, from a breeding range across the northern United States and Canada and south in the boreal mountain forests, migrate in the fall to the low valleys and the southern border of the United States and thus cover, at one season or another, a large part of the continent. They undoubtedly occur over all of Oregon as the few records carry them across the State (fig. 100).

General habits.-Unlike any other species of Oregon bat, these beautiful, big, soft-furred animals hang themselves up during the day in the foliage of trees, usually in dense leafy masses near the tips of drooping branches where head downward with folded wings they sleep until the twilight begins, then on strong wings fly rapidly a $\mathrm{m}$ on $\mathrm{g}$ the treetops in search for food. Their large size, light color, and short ears afford easy recognition marks, even on the wing.

On July 8, 1914, Luther J. Goldman shot one of these big bats at Lost Creek, 10 miles east of McKenzie Bridge on the west slope of the Cascades. It was a male and apparently the first record

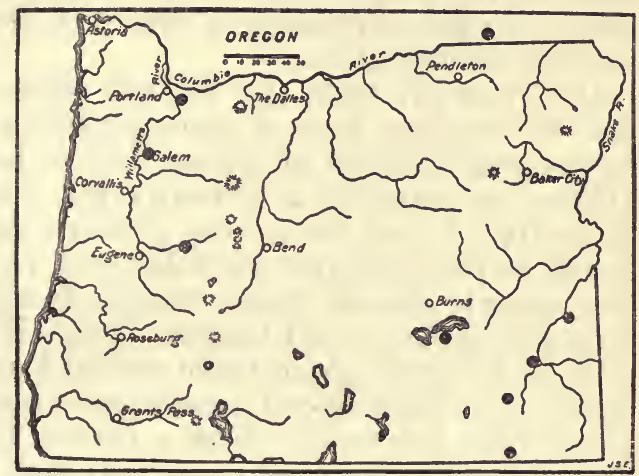

FIGURE 100.-Range of the hoary bat, Nycteris cinerea, in Oregon.

of the species for the State. On October 18, 1917, M. E. Peck collected a female at Salem where at that season it may well have been a migrant. On October 9, 1924, Alex Walker collected a female near Tillamook.

On June 15,1915 , in a canyon on the east slope of Disaster Peak, near the southeastern corner of the State, Preble found one of these bats hanging from a leafy twig of aspen about 8 feet from the ground, the branch being grasped by both hind feet about $11 / 4$ inches apart, the palms opposite. It was collected for a specimen and proved to be an adult male. Another large bat seen flying higher up the slope the previous evening was thought to be the same species. Three days later he collected another male on Crooked Creek, 22 miles southwest of Rome, where it had evidently been spending the day in a grove of poplars near the ranch. About a month later he reported seeing several others among the large cottonwoods around a ranch near Watson farther down the Owyhee River. They did not leave their leafy retreats, however, until so late in the evening that it was too dark for successful bat shooting, and no specimens were secured, although at least three individuals were recognized on the wing.

Stanley G. Jewett, Jr., reports the capture of a hoary bat in east Portland on September 14, 1930. It was found hanging in a Persian (English) walnut tree near the sidewalk on a well-traveled street in the residential section of the city and about 8 feet above the 
ground. It was an adult female in very full pelage, and measured $161 / 8$ inches from tip to tip of wings and $51 / 8$ inches from tip of nose to tip of tail. This probably represents a record during migration, where the bat was merely resting for the day (Murrelet 11 (3) : 75, 1930).

At the Ranger Station near Voltage on the south side of Malheur Lake, Wilbur Springer brought the writer a fine old male hoary bat on September 7, 1920. It had been found clinging to the cellar door one cold morning and was partially torpid. There were no trees in the vicinity and the bat had evidently been forced to take a board as a substitute. It was kept alive for a few days in a half-torpid state and perhaps would have hibernated if suitable quarters had been available, although it was not fat and was evidently on its southward migration.

On June 27, 1928, the writer's sister, Anna Bailey Mills, found one of these big bats, a male, probably on its way north, hanging in the green foliage of a plum tree in her orchard near Fallon, Nev. It was captured in a butterfly net and kept for several days in captivity. It did not eat the cutworm moths put in its box and only licked at pieces of raw meat but was very thirsty on the second day and eagerly drank water from a teaspoon, licking it up with its long and rather broad tongue. Later it proved to be fond of warm milk and lapped up all there was in a spoon and then licked out the spoon with the long red tongue just as a little dog would lick out its plate. The bat would climb a branch in the cage and hang for the day by the hooked hind claws and with wings folded neatly around it sleep quietly until evening. On the sixth day it was found dead in the cage, the liquid diet evidently not proving sufficiently nourishing for its hearty system. Not a large individual, it measured 5 inches in total length, with a wing spread of 14 inches.

Breeding habits. - The mamma€ of the hoary bats are arranged in two pairs on the sides of the breast, and the young are usually two in number, born in late June or early July and carried clinging to the body of the mother until able to fly. Merriam has some evidence to show that the mating season is in August, but the breeding habits are not well known.

Hibernation.-Whether these bats commonly hibernate or go far enough south on their autumnal migrations to find a mild climate and abundant insect life during the winter is not well known. Occasionally one is found hanging up in a bush or tree in a semitorpid condition, but there seem to be no records of their occurring in any considerable numbers in caves or other suitable winter cover.

\section{CORYNORHINUS RAFINESQUII TOWNSENDII (COOPER)}

\section{JACK-RABBIT Bat; So-CAPUAL of the Chinook (J. K. T.)}

Plecotus townsendii Cooper, Amer. Lyceum Nat. Hist., New York 4: 73, 1837.

Type locality.-Fort Vancouver, Wash.

General characters. - Size medium, spread of wings about a foot; ears thin and very long over an inch, nose with two prominent lumps at sides, membranes thin and naked, color dark, teeth 36 . Color of typical specimens from Comox, British Columbia, and Vida, Oreg., dark, sooty brown, slightly lighter below, ears, feet, and membranes dark brown like fur. 
Measurements.-Adult male from Vida: Spread of wings, about $300 \mathrm{~mm}$. Total length, 100; tail, 47; foot, 10; forearm, 41. Another from McKenzie Bridge: 108, 49, 12, 44.

Distribution and habitat.-This darkest form of the long-eared bats inhabits the humid Transition Zone of the northwest coast region from southern British Columbia to northwestern California, including most of Oregon west of the Cascades (fig. 101). Specimens, when obtained, from the Upper Rogue River Valley. will probably prove to be intermedius instead of typical townsendii.

General habits.-These long-eared bats are generally cave dwellers, and their erratic distribution is thus evidently influenced by the presence of caves, buildings, or other suitable cover. The first record of the form was made by J. K. Townsend in 1835, while at Fort Vancouver, on the Columbia River across from Portland. He said they were rather common in the Columbia River district, frequenting the storehouses attached to the post and seldom emerging from them even at night. They were protected by the men of the Hudson's Bay Co. for their services in destroying the dermestes that abounded in their fur establishments $(1839, p .324)$.

A specimen in the Jewett collection taken in

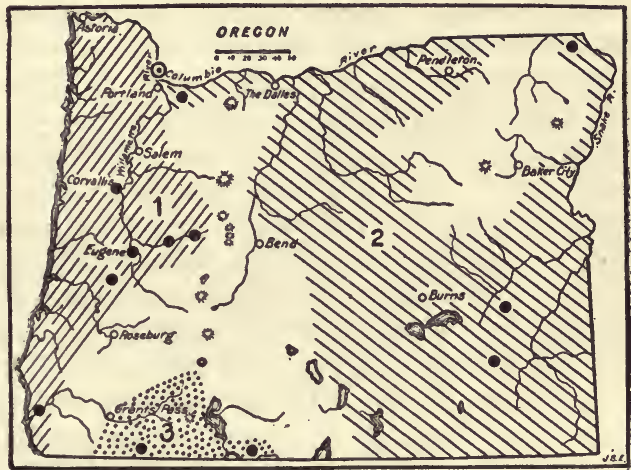

FIGURF 101.-Range of three long-eared bats in Oregon : 1 , Corynorhinus rafinesquii townsendii; $2, O$. $r$ pallescens; $3,0 . r$. intermedius. Type locality circled.

Portland, September 5, 1928, is an adult male. It is the nearest to an actual topotype seen and is of the very dusky form of the coast region.

In 1914 a bat cave was reported at the eastern edge of Portland and only a few miles from where Townsend secured the specimens that later formed the basis for the description of the species. There were said to be hundreds of these long-eared bats in the cave at all times of the year, but when Jewett visited it a little later hoping to secure a series of actual topotypes of the species, he found that vandals had been there before him and set fire to the bat guano and smoked out the whole bat colony. At a still later visit the bats had not returned, and no recent reports from this cave have been received. In the university collection at Eugene is a specimen captured in the Administration Building at the university.

At Vida, on the McKenzie River east of Eugene, one of these bats was brought to the writer from a house where it was captured by someone a couple of miles down the river. At McKenzie Bridge, farther up the river, two of these bats were found hanging during the day in an empty cabin in the woods and another in a closet at the school house. Two others were shot in the evening near there as they circled overhead at the edge of the woods, but it is a strange fact that they are rarely collected by shooting except close to some cave or building where they live. 
The food and breeding habits of this dark form are little known but probably do not differ materially from those of the other subspecies of the group.

\section{CORYNORHINUS RAFINESQUII PALLESCENS MILLER}

Pale JaCk-RABbit Bat

Corynorhinus macrotis pallescens Miller, North Amer. Fauna No. 13, p. 52, 1897.

Type.-Collected at Keam Canyon, Navajo County, Ariz., August 3, 1894, by A. K. Fisher.

General characters.-Paler and brighter in color than townsendii or intermedius. Other characters about the same. Typical specimens light fawn or sorrel brown, paler below, ears and membranes slightly darker brown than the fur.

Measurements.-Adult male from Malheur Cave: Expanse of wings, 305 $\mathrm{mm}$. Total length, 102; tail, 51; foot, 11; ear, 36. Weight $10.7 \mathrm{~g}$ (not fat).

Distribution and habitat.-This pale form of the long-eared bats probably occupies the whole Upper Sonoran valley country of eastern Oregon, although but few localities are represented by specimens (fig. 101). It has a wide range over both Upper and Lower Sonoran Zones of the arid region from Oregon to Mexico. There are specimens from Malheur Cave, about 20 miles east of Malheur Lake, and from a cave about 15 miles southwest of Carol, on the western edge of Malheur County, and Cantwell reported them near Paradise in the Grand Ronde Canyon, but did not collect any specimens.

General habits. - These are cave-dwelling bats and in eastern Oregon they inhabit the lava caves probably more generally than at present known. On August 13, 1920, the Malheur Cave, about 20 miles east of Malheur Lake, was visited and a few of these bats were found hanging from the broadly arched lava roof of the main tunnel. The air of the cave was cool, but the bats were active and easily alarmed. Only one specimen was secured, an adult male in thin summer condition.

On February 17, 1916, E. F. Mickey, of Jordan Valley, visited a lava cave farther south in western Malheur County where, in April of the previous year, he had seen several hundred bats clinging to the roof. He found them there again and collected and sent to the Biological Survey a series of specimens of the pale jack-rabbit bats. He picked them from the roof of the cave where they were hanging 8 to 12 feet from the floor, mainly 1 in a place, but a bunch of 3 were found clinging' together. This cave has a small entrance and the temperature is evidently sufficiently uniform for a winter resort of bats. It is a well-known fact that they cannot winter either in caves where the temperature reaches the freezing point or in those where the air is too warm.

Breeding habits.-With these bats the mating season seems not to be definitely known, but it must be in late summer, as small embryos are found in females just entering hibernation in September and October. For the approximate date of birth of the young there are numerous records, but none so definite as that obtained by $\mathbf{E}$. $\mathbf{R}$. Hall from a breeding cave at the north end of Pyramid Lake, Nev., only a little south of the Oregon line. Of 19 adult females found hanging from the roof of the cave on June 28, 1924, 14 carried each 1 small young clinging to her body, 1 young was found still attached 
to the mother by the umbilical cord, another was only half born, and 3 of the females still contained each a large foetus ready for birth. This fixes June 28 as a fairly accurate date of birth for young of this species in this latitude and gives an excellent foundation for further observations on habits of these valuable animals. Now it is necessary to know at what age the young begin to fly and catch their own food, whether they are carried by the mother until they can fly, their weight at birth, and when they first fly. Data are also lacking on the exact mating season and period of gestation, the kinds and quantities of insects eaten, the extent and nature of migrations from summer to winter resorts, and many other details of life history.

Hibernation.-Generally these bats are found hibernating in caves of winter temperature ranging between $50^{\circ}$ and $60^{\circ} \mathrm{F}$. and rather dry air. They usually remain in a torpid condition from September to April, or about 7 or 8 months, varying according to the climate outside. During the period of torpor they hang head downward from the roof or side walls of the cave, wings folded at sides, ears coiled close to sides of head, and the body as cold as the surrounding air. They have the feeling and general appearance of death, but on being warmed and moved about at any time during the winter, they gradually return to life. Back in their cool quarters again, however, they return in a few hours to the full torpor of inanition and apparently remain so until the spring awakening. In autumn they are usually fat, and on their first awakening in spring still well supplied with fat, which is gradually consumed before insect life becomes so abundant as to afford an ample supply of food.

\section{CORYNORHINUS RAFINESQUII INTERMEDIUS H. W. GRINNELL}

\section{INTERMEDIATE JACK-RABBIT BAT}

Corynorhinus rafinesquii macrotis H. W. Grinnell, Calif. Univ. Pubs., Zool. 12: $320,1914$.

Type.-Collected at Auburn, Placer County, Calif., by J. C. Hawver, July 31, 1909.

General characters.-Color intermediate between the dusky and larger townsendii on the northwest and the paler, smaller pallescens of the desert country east of the Sierra Nevada. General color natal brown above, slightly paler below, ears and membrane brownish.

Measurements. - Spread of wings, about $300 \mathrm{~mm}$. Total length, average, 102 ; tail, 49 ; foot, 10 ; forearm, 42. Weight of one from Modoc Cave $8 \mathrm{~g}$.

Distribution and habitat.-From an extended range over Upper Sonoran Zone of the interior valleys of California this dull-colored form of long-eared bat comes close to the Oregon line at the Modoc lava caves, California, and probably includes those of the Klamath Valley in Oregon (fig. 101).

General habits.-While there is not an identified specimen of this dull-colored bat from Oregon, a typical specimen taken from the great lava cave in the Modoc lava beds just over the line in California insures its occurrence in this part of the State. Four of these were found on October 13, 1920, hanging head down from the walls of the old lava tunnel, torpid, cold, and helpless, with ears coiled like ram's horns at the sides of their heads. They were hanging singly, one in a place, and when unhooked and tied up together in a handkerchief they soon limbered up, uncoiled their ears, opened their mouth and began to squeak and fight and warm up. They are said to gather 
in large bunches, as large as a bushel basket in winter in the back of the caves where the cold is less intense. The 4 specimens taken were all females, and the 1 saved contained one very small embryo, the size of a no. 8 shot. It was only moderately fat and with empty stomach weighed $8 \mathrm{~g}$.

\section{ANTROZOUS PALLIDUS PACIFICUS MERRIAM}

\section{Pacific Pale Bat :}

Antrozous pallidus pacificus Merriam, Biol. Soc. Wash. Proc. 11: 180, 1897.

Type-Collected at Old Fort Tejon, Canada de las. Uvas, Calif., June 28, 1891, by C. Hart Merriam.

General characters.- Size large, much larger and darker than pallidus, spread of wings about 14 inches; ears large and wide (pl. 52,C) about an inch long, wide apart; teeth 28 . Color buffy yellow all over, upper parts heavily washed with sepia or light brown; ears and membranes dull dark brown.

Measurements. - Spread of wings, about $355 \mathrm{~mm}$. Total length of type specimen, adult male from alcohol, 113 ; tail, 43 ; foot, 13 ; forearm, 59 . Of adult female from Alila, Calif., measured in the flesh: 114; 40; 15 . Another from Bear Valley, San Bernardino Mountains: 121; 44; 14.5. Weight of female just before birth of 2 young $19 \mathrm{~g}$ (Grinnell, Dixon, and Linsdale, 1930, p. 457).

Distribution and habitat.-These large bats have been collected in a few localities in western Oregon, but their main range is in the Upper Sonoran valley country of California, west of the Sierra and

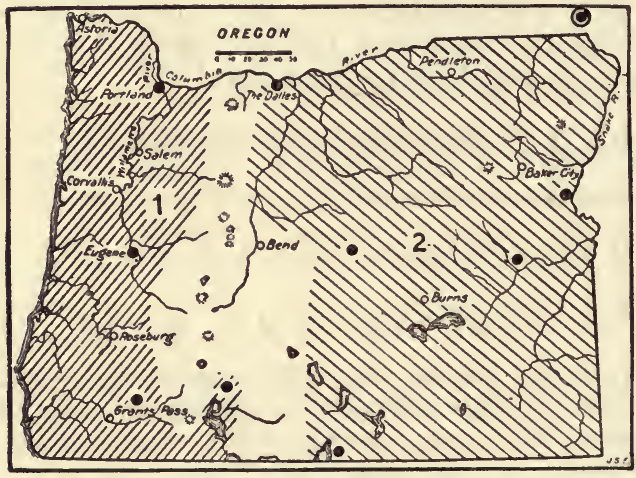

Frgurm 102.-Range of the large pale bats in Oregon : 1 , Antrozous palliäus pacificus; $2, A$. p. cantwelli. San Bernardino Mountains and south into Mexico (fig. 102). From Oregon there are 2 specimens in the Jewett collection taken by Elmer Williams on September 16, 1923, from a big hollow yellow pine on the ridge between Salt Creek and Evans Creek in the northwest corner of Jackson County, about 40 miles north of Rogue River post office and at an altitude of about 4,000 feet. When the writer visited the place with Williams in July 1927 the tree had apparently been burned, but the 2 bats saved were from a colony of apparently several hundred inhabiting the hollow pine. Williams reported the guano a foot deep on the ground at the base of the tree, indicating a regular residence for this colony. The specimens were later examined at Portland and proved to be the dark colored pacificus.

In the collection of the University of Oregon at Eugene is a specimen of this large dark form that seems to be typical pacificus, an adult male collected May 14, 1914.

Two specimens in the Merriam collection, now a part of the United States National Museum collection, were taken at Fort Klamath by Bendire in 1883, and having been in alcohol for 45 years, have almost lost their color. However, the skulls and teeth show these to be the large form pacificus. 
Leo Simon, a careful bird student of Portland, told the writer of seeing a large number of large light-colored bats flying around the tower of one of the churches in that city early in the evenings about the middle of August 1927. The good description of size and color given indicates that these bats are of this genus and the date would indicate a breeding colony. More specimens of these bats are greatly needed from the western Oregon Transition Zone valleys, as the present scanty material does not warrant more than a provisional decision on their subspecific status.

General habits.-During the daytime these large pale bats usually hide away in caves, cracks of the rocks, hollow trees, inside of old buildings, hollow_walls, under roofs, or any dark cover where they are well concealed and protected. At early dusk they begin to come out and usually fly directly to the nearest still water where they drink by repeatedly dipping to the surface, then begin their search for insect food. A part of their food is captured on the wing, but unlike most bats they feed extensively on many flightless forms of insects and small creeping things that are captured on the ground. The Grinnells, Heller, Howell, and Hatt have given interesting evidence of their feeding on scorpions, Jerusalem crickets, grasshoppers, sphinx moths, beetles, and other large insects that fly or walk and also show that the bats usually bring the larger insects to definite feeding spots where they hang up to eat them at leisure, leaving telltale heads, legs, and wings on the floor below. This does not necessarily mean that smaller insects are not snapped up and eaten on the wing, as is often indicated by the zigzag hunting flight of the bats, even though their flight is less quick and erratic than that of most species.

Breeding habits.-Old females collected in May and up to the close of June usually contain 1 or 2 embryos each and have the 2 mammae arranged 1 on each side of the breast, just back of the wing base. Apparently the females gather in colonies in some suitable safe retreat for the breeding season, while the males keep by themselves in other places or scatter over the country.

There seems to be no definite evidence as to the date of the mating season, but in California large foetuses about ready for birth have been noted on June 28, and a young bat scarcely able to fly and probably a week or 10 days old was taken on July 7 .

\section{ANTROZOUS PALLIDUS CANTWELLI, SUBSPECIES NOVUM}

\section{Large Gray Bat}

Type-From Rogersburg, Asotin County, Wash. U. S. National Museum, Biological Survey collection, No. 232362, female adult, collected May 28, 1918, by George G. Cantwell. Original number, 1211.

General characters.-Larger and darker colored than pallidus, with especially darker ears and membranes. Smaller and paler than pacificus, but with about the same dark-colored ears and membranes and conspicuously smaller skull and lighter dentition. In a way intermediate between the two long recognized forms but not referable to either and with a wide distribution in a different type of country from either. Color of upper parts dull buffy drab, washed with smoky brown; lower parts pale buff or creamy white; ears and membranes dark brown.

Measurements.-Of type, female adult: Total length, $120 \mathrm{~mm}$; tail, 48 ; forearm, 55 ; foot, 15 ; ear (dry), 26 . Skull, basal length,. 17; zygomatic breadth, 13 ; interorbital constriction, 4.3 ; length of upper molar series, 5.5 . 
Distribution and habitat.-This large medium pale bat ranges over probably all of the Upper Sonoran Zone of eastern Oregon, southeastern Washington, and northern Nevada (fig. 102). There are specimens from Twelve Mile Creek, Crook County; Riverside, Malheur County; Home, Baker County; and The Dalles, Wasco County.

The specimen from The Dalles, collected by Dr. Suckley, July 2, 1855 , is now represented in the National Museum collection by a fragment of the skull only, the rostrum and lower jaws, but from the teeth it seems referable to this form rather than to pacificus.

A single specimen from Twelve Mile Creek was taken on July 3, 1896 , and others at Riverside on July 20, still others at Home on June 30, 1916. Apparently these are all breeding or breeding-season records.

General habits.-In most cases these bats are found in the canyons or near cliffs and canyon walls where they find shelter in caves and cracks among the rocks. At Riverside, Sheldon in passing. a high cliff heard a continuous squeaking up among the rocks and with a long stick poked out several of the bats and shot a couple of them in the bright light of midday. At the type locality of the species Cantwell found them flying in large numbers near a cliff where there was a bat cave, but where the bats were hidden away beyond reach.

In western Nevada on June 27, 1927, on the western edge of the Carson Valley there was a breeding colony of these bats located in small cavities in the roof of an open cavern. They were constantly squeaking and making many sharp little querulous sounds as if crowded for room and quarreling for the best places. They were entirely out of reach by any convenient method, and to procure some specimens it was necessary to fire a small load of fine shot into one of the cracks in the roof. A considerable number of the freetailed bats (Tadarida mexicana) were brought down and 2 of the pale bats, each with 2 young clinging to her nipples. The two smaller young were apparently but a day old, male and female, eyes closed, hairless and with rudimentary wings more like hands than wings, the thumb with sharp hook and fingers only partly webbed. The hind claws were well developed, sharp, curved, and highly functional in clinging to the body of the mother. The mouths were well armed with minute, sharp, and curved teeth of the milk dentition, exceedingly efficient in clinging to the mother's wide flat nipples. Even a little of the surrounding fur seemed to be drawn into the mouth with the nipple as an aid to maintaining a hold. The two larger young clung so tightly to the nipples of their dead mother that in trying to remove them there seemed danger of pulling their heads off. They clung with both teeth and claws, and the old bat could easily be picked up by taking hold of one of the young. Their strongest instinct seemed to be to hold on.

The next day one of the young bats was removed from its dead mother and placed on the breast of the female that was only slightly injured. It at once caught a mouthful of fur, and soon found the nipple and got a good hold of it. The old bat soon recognized the fact that it was not her own young and tried to push it away with her wings but failing in this she took hold of its head in her mouth and forcibly tore it loose from her breast, and pushed it from her, leaving tooth marks in its head and one ear. 
The old bat with one of her young clinging to her was hung up overnight in a thin cloth sack out of doors where the temperature was decidedly chilly and in the morning both mother and young were fully torpid, cold, and unable to move, but the young still securely attached to the nipple and with hooked claws to its mother's fur. Brought into a warm room they soon returned to a fully active state, both warming up and limbering up simultaneously. It seems that temporary hibernation of both old and young is generally possible at any time of year with these as with other bats when the temperature drops below a certain level.

\title{
ORDER MARSUPIALIA: MARSUPIALS
}

\author{
Family DIDELPHIDAE: Opossums
}

\section{DIDELPHIS VIRGINIANA VIRGINIANA KERB}

\section{VIRGINIA OPOSSUM}

Didelphis virginiana Kerr, Animal Kingdom, p. 193, 1792.

Type locality.-Virginia.

General characters. - In size about the same as an ordinary house cat, with pointed nose, naked ears, long, nearly naked and prehensile tail, an abdominal pouch in females where the small and embryonic young are carried and nursed until large enough to come out, or for about 76 days after birth. Fur long and soft, of a light gray appearance; underfur white or creamy in color.

Measurements.-About $780 \mathrm{~mm}$ in total length; tail, 298; foot, 70. Weight of adults about 6 to 8 pounds.

Distribution and habitat.-Southeastern United States, from southern New York to Nebraska and Texas. Introduced and well established in California and Oregon.

Jewett and Dobyns $(1929, p$. 351) have provided an interesting account of the Virginia opossum in Oregon. During the past 6 or 7 years, they reported fur trappers along McKay and Birch Creeks and tributaries in Umatilla County had taken opossums in traps set for mink and skunk. There is knowledge of 50 or more being taken in this section. During the trapping season of 1927 and 1928 at least 12 were taken by local trappers. Besides those taken along these streams signs of them have been noted along the Umatilla River above Pendleton, and there are unverified reports of them along the Walla Walla River above Milton. They seem to be well established and thriving in this part of the State.

One collected on September 9, 1928, in Umatilla County and sent to the Biological Survey for identification proved to be typical Didelphis virginiana virginiana. Investigations brought to light records of at least four opossums brought into Umatilla County and liberated between 1910 and 1921. Sam Walker, an old pioneer on McKay Creek, told of a pair of opossums being liberated by one of his neighbors about 1912, and Walker had one that escaped about the same time.

L. E. Roy, of Pilot Rock, reported that one sent to him from Oklahoma had escaped about 1921. For such rapid breeders here was ample material for stocking a new region where food and climate are so favorable to the natural requirements of the species. Fortunately the opossums have sufficient value for food, fur, and sport to preclude any danger of their becoming a pest. 


\section{BIBLIOGRAPHY}

ANONYMOUS.

1884. Habits of the PANTHirr. Amer. Nat. 18: 1160-1163.

Aruen, G. M.

1916. THE WHALEBone whales of NeW england. Boston Soc. Nat. Hist. Mem. 8, pp. 107-322, illus.

1919. BATS From MOUNT WHITNEY, CALIForNia. Jour. Mammal. 1: 1-5.

1920. DOGS OF THE AMERICAN ABoRIGINES. Harvard Col. Mus. Compar. Zool. Bull. 63: 431-517, illus.

ALLEN, J. A.

1870. ON THE GARED SEALS (OTARIADAE), WITH DETAILFD DESCRTPTIONS OF THE NORTH PACIFIO SPECIES. Harvard Col. Mus. Compar. Zool. Bull. $2: 1-89$, illus.

1876a. THE AMERICAN BISONS, LIVING AND EXTTNCT. 246 pp., illus. Cambridge. (Harvard Col. Mus. Compar. Zool. Mem. 4, no. 10.)

1876b. GEOGRAPHICAI VARIATION AMONG NORTH AMERTCAN MAMMALS, ESPEcratLy IN RESPECT to sIZE. U. S. Geol. and Geogr. Survey Ter. Bull. 2: [309]-344.

1880. HISTORY OF NORTH AMERICAN PINNIPEDS, A MONOGRAPH OF THE WAL RUSES, SEA LION8, SEA BEARS, AND SEALS OF NORTH AMERICA. U. S. Geol. and Geogr. Survey Ter. Misc. Pub. 12, 785 pp., illus.

1898. THE SEA OTTER. Amer. Nat. 32: 356-358.

ANDREW S, R. C.

1909. HABITS OF THE FINBACK AND HUMPBACK WHALES OF THE EASTERN NORTH PACIFTC. Amer. Mus. Nat. Hist. Bull. 26:213-226, illus.

1914. MONOGRAPHS OF THE PACIFIO CETACFA: THE CALTFORNIA GRAY WHALE (RHACHIANECTES glaucus Cope). Amer. Mus. Nat. Hist. Mem. (n. s.) $1: 229-287$, illus.

ANTHONY, H. E.

1913. Mam mals of Northern malHeub county, oregon. Amer. Mus. Nat. Hist. Bull. 32: 1-27, illus.

1928. FLELD BOOK OF NORTH AMERIOAN MAMMALS; DESCRIPTIONS OF EVERT MAMMAL, KNOWN NORTH OF THE RIO GRANDE, TOGETHER WITH BRIEG ACCOUNTS OF HABITS, GEOGRAPHICAL RANGES, ETC. 625 pp., illús.

BALIFY, V. New York, London.

1897. Reviston OF the american voles OF the genUs eVotomys. Biol. Soc. Wash. Proc. 11: 113-138, illus.

1900. REVIBION OF AMERICAN VOLES OF THE GENUS MICROTUS. North Amer. Fauna $17,88 \mathrm{pp}$., illus.

1915. REVISION OF THE POCKET GOPHERS OF THE GENUS THOMOMYS. North Amer. Fauna 39, 136 pp., illus.

1927. BEAVER HABITS AND EXPERIMENTS IN BEAVER CULTURE. U. S. Dept. Agr. Tech. Bull. 21, 40 pp., illus.

1935. A NEW NAME FOR THש ROCKY mountain eick. Biol. Soc. Wash. Proc. 48: 187-189.

BAIRD, S. F.

1857. Mammals of North america. Pacific R. R. Rept., v. 8, 757 pp., illus. BетL, W. B.

1921a. DeAth to THE RoDents. U. S. Dept. Agr. Yearbook 1920:421-438, illus.

1921b. HuntiNg Down the stock kmulkRs. U. S. Dept. Agr. Yearbook 1920: 289-300, illus.

Cox, $\mathbf{R}$.

1832. ADVENTURES ON THE COLUMBTA RIVER IN 1811-1817. $330 \mathrm{pp}$.

DAT, W. H.

1869. NOTE ON THE "BLOWING" OF wHALES. Amer. Nat. $3: 333-334$.

DE ONG, E. R.

1919. Parasites which afFect the food value of rabBits. Calif. Fish and Game 5:142-143, illus. 
DICE, L. R.

1919. THE MAMMALS OF SOUTHEAsteRn WAghington. Jour. Mammal. 1: 10-22, illus.

1926. Notes ON PACIFTo coAst rabBits and PIKAS. Mich. Univiv., Mus. Zool.

Dixon, JosepH Occasional Papers 166, 28 pp.

1916. DOES THE GRIZZLY BEAR STILL EXIST IN CAIIFORNIA? Callf. Fish and Game 2: 65-69, illus.

1919. NOTES ON THE NATURAL HISTORY OF THE BUSHY-TAILED WOOD RATE OF CALIFornia. Calif. Univ. Pubs., Zool. 21:49-74, illus.

1920. control of the coyote in calmornia. Calif. Agr. Expt. Sta. Bull. 320 , pp. [379] -397 , illus.

1922. Control OF the POCKET gopher in california. Calif. Agr. Expt. Sta.

Douglas, D. Bull. 340, pp. 337-350, illus.

1829. OBSERVATIONS ON TWO UNDESCRIBED SPECIES OF NORTH AMERICAN MAM-

Eusiot, D. G. BALIA. Zool. Jour. 4: 330-332.

1899. CATALOGUE OF MAMMALS FROM THE OLYMPIC MOUNTAIN, WASHINGTON, WITH DESCRIPTIONS OF NEW species. Field Columbian Mus. Pub. 32 (Zool. Ser. 1, no. 13) : 241-276, illus.

1903a. A LIST OF MAMMALS OBTAINED BY EDMUND HELLER, COLLECTOR FOR THE MUSEUM, FROM THE COAST REGION OF NORTHERN CALIFORNIA AND OREGoN. Field Columbian Mus. Pub. 76 (Zool. Ser. 3, no. 11) : 175-197.

1903b. DESCRIPTION OF APPARENTLY NEW SPECIES OF MAMMALS OF THE GENERA HETEROMYS AND URSU FroM WASHINGTON AND MEXICO. Field Columbian Mus. Pub. 80 (Zool. Ser. 3, no. 13) : 233-237.

Evermann, B. W.

1919. THE NORTHERN FUR-SEAL PROBLEM AS A TYPE OF MANY PROBLKMS IN MARINe zoology. Sci. Monthly 9: 263-282, illus. Also in Papers on Exploration of the North Pacific Ocean. Calif. Univ., Scripps Inst. Biol. Research Bull. 9: 13-26.

1921a. THE NUEVO STELLER SEA LION BOOKERY. Jour. Mammal. 2 : 16-19, illus. 1921b. FUR SEALS OFF THE FARALLONS. Science (n. S.) 54: 547-548.

1922. WHY NOT SAVE THE MARINE MaMMALS OF THE PACIFIC? Pan-Pacific Union Bull. (n. s.) 34: 12-16.

FINIEX, W. L.

1908. REPORT . . . Bird-Lore 10: 291-295, illus.

1925. COUGAR KHLS A BOY. Jour. Mammal. 6: 197-199.

Franchere, G.

1854. NARRATIVE OF A VOYAGE TO THE NORTHWEST COAST OF AMERTCA IN THE YEARS 1811, 1812, 1813, AND 1814. English ed. transl. and edited by J. V. Huntington, $376 \mathrm{pp}$. New York.

1904. NARRATIVE OF A VOYAGE TO THE NORTHWEST COAST, 1811-1814. In

Fremont, J. C. Thwaites, R. G., Early Western Travels, v. 6, pp. 167-410.

1845. REPORT OF THE EXPLORING EXPEDITION TO THE ROCKY MOUNTAINS IN THE YEAR 1842, AND TO OREGON, AND NORTHERN CALIFORNIA IN THE YEARS 1843-44. 693 pp., illus. (28th Cong., $2 d$ sess. Sen.).

GARRIELSON, I. N.

1921. CONTBOLIING RODENT AND OTHER SMAIL ANIMAL PESTS IN OREGON. Oreg. Agr. Col. Ext. Serv. Bull. 335, 20 pp.

Golmman, E. A.

1910. Revision of the wOOd rats of THE gENUS NeOtoma. North Amer. Fauna 31, 124 pp., illus.

Greenwood, W. H., Newcombe, F. C., and Fraser, C. M.

1918. SEA-LION QUESTION IN BRITISH ColUMBIA. Contrib. Canad. Biol. 38a, $39 \mathrm{pp}$.

Grin Next, G. B.

1897. RANGE OF THE PRONG-HORNED ANTELOPE IN 1896. Forest and Stream 48: 5-6, illus.

and FanNin, J.

1890. RANGE OF THE WHITE GOAT. Forest and Stream 34:62-64, illus.

Grinnelx, H. W.

1918. a synopsis of the bats of California. Calif. Univ. Pubs., Zool. 17 : 223-404, illus. 
GRINNELL, J.

1908. the biota of the san bernardino mountains. Calif. Univ. Pubs., Zool. 5: 1-170, illus.

1913. A Distributional uist of the mammals of california, Calif. Acad. Sci. Proc. (4) 3: [265] -390 , illus.

1921. REVISED IIST OF THE SPECIES IN THE GENUS DIPODOMYS. Jour. Mammal. 2: 94-97.

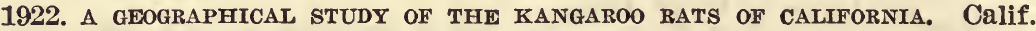
Univ. Pubs., Zool. 24 : 1-124, ilus.

1923. A sYSTEMATIO IIST OF THE MAMMALS OF daIIFornia. Calif. Univ. Pubs., Zool. 21: [313]-324.

1929. THE TWO RACES OF BLACK BEAR IN CALIFORNIA. Calif. Univ. Pubs., Zool. 32: [395]-408, illus.

and Dixon, Josepr.

1918. CALIFORNIA GROUND SQUTIRRELS: A BULLETTN DEALING WITH IITE HISTORIES, HABITS, AND CONTROL OF THE GROUND SQUIRRELS IN CAliforia. Calif. State Comn. Hort. Monthly Bull. 7: [595]-708, illus.

1923. THE SYstematic status OF THE MoUNTAIN LION OF CALTFORNIA. Calif. Univ. Pubs., Zool. 21: [325]-332, illus.

Drxon, Joseph, and Linsdate, J. M.

1930. VERTEBRATE NATURAL HISTORY OF A SECTION OF NORTHERN CALIFORNIA THRough the LASSEN PEAK region. Calif. Univ. Pubs., Zool, 35, 594 pp., illus.

and STORER, T. I.

1924. ANIMAL LIFE IN THE YOSEMITE; AN ACCOUNT OF THE MAMMALS, BIRDS, REPTILES, AND AMPHIBIANS IN A CROSS-SECTION OF THE SIERBA NEVADA. Calif. Univ. Mus. Vertebrate Zool. Contrib. 752 pp., illus. Berkeley, Calif.

Harl, H. M., and Grin NELL, J.

1919. LIFE zONE INDICATORS IN CAITFORnia. Calif. Acad. Sci. Proc. (4)

HENRY, A. 9: [37]-67.

1897. HENRY AND THOMPSON JOURNALs, 1799-1814. Edited by E. Coues. 3 v. Higarins, E.

1919. PORPOISE CAPTURED. Calif. Fish and Game 5: 157.

HOLIISTER, N.

1911. A systematio synopsis of the muskrats. North Amer. Fauna 32, 47 pp., illus.

HOOKER, W. J.

1836. A BRIEF MEMOIR OF THE LIFE OF DAVID DOUGLAS WITH EXTRACTS FROM HIS LETTERS. In Hooker, W. J., Companion to the Botanical Magazine ... v. 2, pp. 79-182. London.

HoRnadaY, W. T.

1889. THE EXTERMINATION OF THE AMERICAN BISON, WITH A SKETCH OF ITS DISCOVERY AND LIFE HISTORY. Smithsn. Instn. Rept. 1887 (pt. 2) : $367-548$, illus.

1906. CAMP-FIRES IN THE CANADIAN ROCKIES. 353 pp., illus. New York.

HowerL, A. B.

1920. SOME CALIFORNIAN EXPERIENCES WITH BAT ROOSTS. Jour. Mammal. 1: 169-177, illus.

1921. DESCRIPTION OF A NEW SPECTES OF PHENACOMYS FROM OREGON. JOur. Mammal. 2: 98-100, illus.

1926. VOLES OF THE GENUS PHENACOMYS. I. REVISION OF THE GENUS PHEINACOMYS. II. LIFE HISTORY OF THE RED TREE MOUSE (PHEINACOMYS LoNGICAUdUS). North Amer. Fauna 48, 66 pp., illus.

HOWELL, A. H.

1901. REVISION OF THE SKUNKS OF THE GENUS CHINCHA [MEPHITIS]. North Amer. Fauna 20,62 pp., illus.

1906. REVISION OF THE SKUNKS OF THE GENUS SPILOGALE. North Amer. Fauna 26, 55 pp., illus.

1914. REVISION OF THE AMERICAN HARVEST MICE (GENUS RETTHRODONTOMYS). North Amer. Fauna 36, 97 pp., illus.

1915. REVISION OF THE AMERICAN MARMOTs. North Amer. Fauna 37, 80 pp., illus.

1918. REVISION OF THE AMERIOAN FLYING SQUIRREIs. North Amer. Fauna 44, $64 \mathrm{pp}$., illus. 
Hower., A. H.-Continued.

1924. REVISION OF THE AMERICAN PIKAS (GENUS OCHOTONA). North Amer. Fauna 47, 57 pp., illus.

1929. REVISION OF THE AMERICAN CHIPMUNKS (GENUS TAMIA\& AND EUTAMIAS).

HUEY, L. M.

North Amer. Fauna 52, 157 pp., illus.

1928. NOTES ON the CALIFORNIA GRAY whale. Jour. Mammal. 9: 71-73.

HUNT, H. H.

1920. FOOD OF the вовсAт. Calif. Fish and Game 6:37.

JACKsON, H. H. T.

1915. A REVIEW OF the AMERICAN MOLes. North Amer. Fauna 38, 100 pp., illus.

JENKINS, J. T.

1922. NEW SPECTES AND IUBSPECTES OF SOREX FROM WESTERN AMERICA. Wash. Acad. Sci. Jour. 12: 262-264.

1921. A HISTORY OF THE WHALE FTSHERIES, FROM THE BASQUE FISHERTES OF THE TENTH CENTURY TO THE HUNTING OF THE FINNER WHALE AT THE PRESENT DATE. 336 pp., illus. London. [Reviewed by F. A. Lucas

JEWETT, S. G. in Science (n. s.) 56:109-111. 1922.]

1921. PRIBILOF FUR SEAL ON THE OREGON COAST. JOUr. Mammal. 2: 235.

1925. SECOND OCCURRENCE OF THE PRIBILOF FUR SEAL ON THE OREGON COAST. Jour. Mammal. 6: 200.

and DoByns, H. W.

1929. THE VIRGINIA OPOSSUM IN ORDGON. Jour. Mammal. 10: 351.

KEILOGG, R.

1918. A REVISION OF THE MICROTUS CALIFORNICUS GROUP OF MEADOW MICE. Calif. Univ. Pubs., Zool. 21: 1-42, illus.

1928. THE HISTORY OF THE WHALES, THEIR ADAPTATION TO LIFE IN THE WATER. Quart. Rev. Biol. 3: 29-76, 174-208, illus.

LEECHMAN, D.

1929. FLEDCE BEARING DOGS. THEY HAVE PASSED BUT TRACES OF THEM REMAIN. Nature Mag. 14: 176-178, illus.

LEWIS, M., and Clark, W.

1893. HISTORY OF THE EXPEDITION UNDER THE COMMAND OF LEWIS AND CLARK. Edited by E. Coues. 4 v. New York.

1904-5. ORIGINAL JOURNALS OF THE LEWIS AND CLARK EXPEDITION, 1804-1806. Edited by R. G. Thwaites. 8 v., illus.

LORD, J. K.

1866. THE NATURALIST IN VANCOUVER ISLAND AND BRITISH COLUMBIA. 2 V., illus. London.

McCracken, $\mathrm{H}$.

1920. WHEN THE SEA OTTER FLOURISHED . . Forest and Stream 90: 298, 332-333.

MAILLIARD, J.

1927. THE BIRDS AND Mammals of MODOO COUNTY, OALIFORNia. Calif. Acad. Sci. Proc. (4) 16: [261]-359, illus.

MATHER, S. T.

1921. REPORT OF THE DIRECTOR OF THE NATIONAL PARK SERVICE FOR THE FTSCAL YEAR ENDING JUNE 30, 1921, AND THE TRAVEL SEASON 1921. 306 pp. Washington.

MERRIAM, C. H.

1890. RESULTS OF A BIOLOGICAL SURVEX OF THE SAN FRANCISCO MOUNTAIN REgION AND DESERT OF THE LITTLE COLORAdo, ARIzONA. North Amer. Fauna 3: 1-101, illus.

1891. RESULTS OF A BIOLOGICAL RECONNAISSANCE OF SOUTH CENTRAL IDAHO, SOUTH OF LATITUDE $45^{\circ}$ AND EAST OF THE THIRTY-EIGHTH MERIDIAN, MADE DURING THE SUMMER OF 1890, WITH ANNOTATED LISTS OF THE MAMMALS AND BIRDS, AND DESCRIPTIONS OF NEW SPECIES. North Amer. Fauna 5: 1-108, illus.

1895. SYNOPSIS OF THE AMERICAN SHREWS OF THE GENUS sOREX. North Amer. Fauna 10: 57-100, illus.

1896a. PRELIMINARY SYYNOPSIS OF THE AMERICAN BEARS. Biol. Soc. Wash. Proc. 10: 65-83, illus.

1896b. SYNOPSIS OF THE WEASELS OF NORTH AMERICA. North Amer. Fauna $11,44 \mathrm{pp}$., illus.

1897. THE MAMMALS OF MOUNT MAZAMA, OREgoN. Mazama 1: 204-230. 
Mgraram, C. H.-Continued.

1899. RESULTS OF A BIOLOGICAL SURVEY OF MOUNT SHASTA, CALIFORNIA. North Amer. Fauna 16, 179 pp., illus.

1918. REVIEW OF THE GRIZŻLY AND BIG BROWN BEARS OF NORTH AMERICA (GENUS URSUS), WITH DESCRIPTION OF A NEW GENUS, VETULAROTOS. North Amer. Fauna 41, 136 pp., illus.

1921. FORMER RANGE OF MOUNTAIN SHERP IN NORTHERN CALIFORNIA. JOUr. Mammal. 2: 239.

1926. THE BUFFALO IN NORTHEASTERN CALIFORNIA. Jour. Mammal. 7: 211214.

Merriam, J. C.

1930. THE living PAst. 144 pp., illus. New York.

MILJER, G. S., JR.

1897. REVISION OF THE NORTH AMERICAN BATS OF THE FAMILY VESPERTILIONIDAE. North Amer. Fauna 13, 140 pp., illus.

1923. the telescoping of the cetacean skull. Smithsn. Misc. Coll. 76, no. 5, 70 pp., illus.

1924. LIST OF NORTH AMERICAN RECENT MAMMALS, 1923. U. S. Natl. Mus. Bull. 128, 673 pp.

and Artuen, G. M.

1928. THE AMERICAN BATS OF THE GENERA MYOTIS AND PIZONYX. U. S. Natl. Mus. Bull. 144, 218 pp., illus.

MOORE, A. W.

1933. FoOd habIts of TOWNSENd AND COAST Moles. Jour. Mammal. 14: $36-40$.

NeLsoN, E. W.

1899. REVISION OF THE SQUTRRELS OF MEXICO AND CENTRAL AMHRICA. Wash. Acad. Sci. Proc. 1: 15-110, illus.

1909. THE RABBITS OF NORTH AMERICA. North Amer. Fauna 29, 314 pp., illus.

1925. status of the pronghorned antelope, 1922-1924. U. S. Dept. Agr. Bull. 1346, 64 pp., illus.

and Goldman, E. A.

1930. SIX NEW RACCOONS OF THE PROCYON LOTOR GROUP. Jour. Mammal. 11: $453-459$.

NEWBERRY, J. S.

1857. REPORT UPON THE ZOOLOGX OF THE ROUTE. In Explorations and Surveys for a Railroad Route from the Mississippi River to the Pacific Ocean. Pacific R. R. Rept. 6 (pt. 4) : 67.

OGden, P. S.

1909-10. JOURNALS OF PETER SKENE OGDEN 1825-1826, 1826-1827. Oreg. Hist. Soc. Quart. 10: 331-365, 1909; 11: 201-222, 1910.

OsGood, W. H.

1900. REVISION OF THE POCKET MICE OF THE gENUS PEROgNATHUS. North Amer. Fauna 18, 72 pp., illus.

1901. NATURAL HISTORY OF QUEEN CHARLOTTE ISLANDS, BRITISH COLUMBIA. NATURAL HISTORY OF THE COOK INLET REGION, ALASKA. North Amer. Fauna, 21, 87 pp., illus.

1909. REVISION OF THE MICE OF THE AMERICAN GENUS PEROMYSCUS. North Amer. Fauna 28, 285 pp., illus.

PEALE, T. R.

1839-42. MANUSCRIPT JOURNALS. 4 books. [In Library of Congress.]

1848-58. UNITED STATES EXPLORING EXPEDITION UNDER COMMAND OF CHARLES wILKes. Mammalia and Ornithology, v. 8, 338 pp., 1848; ed. 2, 466 pp., by J. Cassin, 1858.

PeCK, M. E.

1925a. A PRELIMINARY SKETCH OF THE PLANT REGIONS OF OREGON. I. WESTERN oregon. Amer. Jour. Bot. 12: 33-49, illus.

1925b. A PRELIMINARY SKETCH OF THE PLANT REGIONS OF ORDGON. II. THE CASCADE MOUNTAINS AND EASTWARD. Amer. Jour. Bot. 12: 69-81.

PIPER, C. V.

1906. Flora of the state of Washington. U. S. Natl. Mus. Contrib. U. S. Pocock, R. I. Natl. Herbarium, 11, 637 pp., illus.

1922. ON THE EXTERNAL CHARACTERS AND CLASSIFICATION OF THE MUSTELIDAE.

PoweLL, $\mathrm{S}$.

Zool. Soc. London Proc. 1921: 803-837, illus.

1894. A HUNTING TRIP to okegon. Shooting and Fishing $17: 181-183$, illus. 
Prebite, E. A.

1899. REVISION OF THE JUMPING MICE of THE genUs zapUs. North Amer.

RABOT, C. Fauna 15, 42 pp., illus.

1914. THE Whale Fisheries of tHe world. Smithsn. Instn. Ann. Rept. 1913: $481-489$, illus.

RICHARDSON, J.

1829. FAUNA BOREALI-AMERICANA; OR THE ZOOLOGY OF THE NORTHERN PARTS OF BRITISH AMERICA . . PT. 1, THE QUADRUPEDS. 300 pp., illus.

RowLEY, J. London.

1929. LIFE HISTORY OF THE SEA LIONS ON THE CALIFORNIA COAST. Jour. Mam-

Russeet, I. C. mal. $10: 1-36$, illus.

1903. PRELIMINARY REPORT ON ARTESIAN BASINS IN SOUTHWESTERN IDAHO AND southeastern oregon. U. S. Geol. Survey Water-Supply and Scammon, C. M. Irrig. Paper 78, 53 pp., illus.

1869. ON THE CETACEANS OF THE WESTERN COAST OF NORTH AMERICA. Edited by E. D. Cope. Acad. Nat. Sci. Phila. Proc. $21: 13-63$, illus.

1874. THE MARINE MAMMALS OF THE NORTHWESTERN COAST OF NORTH AMERICA, DESCRIBED AND ILLUSTRATED, TOGETHER WITH AN ACCOUNT OF THE AMERICAN WHALE FISHERY. 319 pp., illus. San Francisco and New York.

SCHEFFER, T. H.

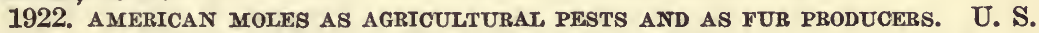
Dept. Agr. Farmers' Bull. 1247, 23 pp., illus.

1928. PRECARIOUS STATUS OF THE SEAL AND SEA-LION ON OUR NORTHWEST

Seton, E. T. COAST. Jour. Mammal. 9: 10-16.

1909. LIFE HISTORIES OF NORTHERN ANIMALS. AN ACCOUNT OF THE MAMMALS of MaNitoBa. v. 1, 1, Grass-eaters. 673 pp., illus. New York.

1925-28. LIVES OF GAME ANIMALS: AN ACCOUNT OF THOSE LAND ANIMALS IN AMERICA, NORTH OF THE MEXICAN BORDER, WHICH ARE CONSIDERED

Shaw, W. T. "GAME", 4 v., illus. Garden City, N. Y.

1921. MOISTURE AND ALTITUDE AS FACTORS IN DETERMINING THE SEASONAL ACTIVITIES OF THE TOWNSEND GROUND SQUIRREL IN WASHINGTON. Ecology 2: 189-192, illus.

1925. BREEDING AND DEVELOPMENT OF THE COLUMBIAN GROUND SQUIRREL. Jour. Mammal. 6: 106-113, illus.

SHELDoN, C.

1909. LYNX KILI wID SHEEP. Forest and Stream 72: 173, illus.

Sincliatr, W. J.

1904. explorations of the potter Creek cave. Calif. Univ. Pubs., Amer.

SмIтH, C. P. Archaeology and Ethnology 2(1): 1-27, illus.

1927. A Distributional catalog of the lupines of oregon. Dudley Herbarium Stanford Univ. Contrib. v. 1, no. 1, 55 pp.

StarbuOK, A.

1878. HISTORY OF THE AMERICAN WHALE FISHERIES FROM ITS INCEPTION TO THE YEAR 1876. U. S. Commr. Fish and Fisheries Rept. 1875-76, appendix A, 768 pp., illus.

StakKs, E. C.

1922. History of dalmornia shore whaling. Calif. Fish and Game Comn. Bull. 6, $38 \mathrm{pp}$.

Suckley, G., and GrbBs, G.

1860. REPORT UPON THE MAMMALS COLLECTED ON THE SURVEY. In Explorations and Surveys for a Railroad Route from the Mississippi River to the Pacific Ocean, 1853-1855, chs. 2-3. Pacific R. R. Rept. 12 (book 2) : 89-139. (Ch. 2 by Suckley, ch. 3 by Suckley and Gibbs.)

SUDWorth, G. B.

1908. FOREST tRees of THE PACIFIC slope. U. S. Dept. Agr., Forest Serv., 441 pp., illus.

1927. CHECK IIST OF THE FOREST TREES OF THE UNITED STATES: THETR NAMES and ranges. U. S. Dept. Agr. Misc. Circ. 92, 295 pp. 
TAYLOR, W. P.

1915. DESCRIPTION OF A NEW SUBGENUS (ARBORIMUS) OF PHENACOMYS, WITH A CONTRIBUTION TO KNOWLEDGE OF THE HABITS AND DISTRIBUTION OF PHENACOMYS LoNGICAUdUS TRUe. Calif. Acad. Sci. Proc. (4) 5: [111]-161, illus.

and SHAw, W. T.

1927. MAMMALS AND BIRDS OF MOUNT RAINIER NATIONAL PARK. Dept. Int., TIDESTROM, $\mathbf{I}$. Nat. Park Serv., 249 pp., illus.

1925. Flora of utah and Nevada. U. S. Natl. Mus. Contrib. U. S. Natl. Herbarium 25, 665 pp., illus.

TOWNSEND, C. H.

1888. FIELD NOTES ON THE MAMMALS, BIRDS, AND REPTILES OF NORTHERN CAIIFORNIA. U. S. Natl. Mus. Proc. (1887) 10: 159-241, illus.

1899. PELAgIO SEALING, With NOTES ON THE FUR SEALS OF GUADALUPE, THE GALAPAGOS, AND LOBOS ISLANDS. In Jordan, D. S., and others. Fur Seals and Fur-Seal Islands of the North Pacific Ocean, pt. 3, pp. 223-274, illus.

TOWNSEND, J. K.

1839. NARRATIVE OF A JOURNEY ACROSS THE ROCKY MOUNTAINS TO THE COLUMBIA RIVER AND A VISIT TO THE SANDWICH ISLANDS, CHIII, ETO. . . . 352

True, F. W. pp. Philadelphia.

1885. SUGGESTIONS TO LIGHT-HOUSE KEEPERS AND OTHERS RETATIVE TO COLLECTING AND PRESERVING SPECTMENS OF WHALES AND PORPOISES. U. S. Commr. Fisheries Ann. Rept. 1883: 1157-1181.

1889. CONTRIBUTIONS TO THE NATURAL HISTORY OF THE CETACEANS, A REVIEW OF THE FAMILY DELPHINIDAE. U. S. Natl. Mus. Bull. 36, 191 pp., illus.

1904. THE WHALEBONE WHALES OF THE WESTERN NORTH ATLANTIC COMPARED WITH THOSE OCCURRING IN EUROPEAN WATERS, WITH SOME OBSERVATIONS ON THE SPECIES OF THE NORTH PACIFIC. Smithsn. Contrib. Knowledge 33, 332 pp., illus.

1910. AN ACCOUNT OF THE BEAKED WHALES OF THE FAMILY ZIPHIIDAE IN THE COLLECTION OF THE UNITED STATES NATIONAL MUSEUM, WITH REMARKS ON SOME SPECTMENS IN OTHER AMERICAN MUSEUMS. U. S. Natl. Mus. Bull. 73, 89 pp., illus.

VAN Denburgh, J.

1922. THE REPTILES OF WESTERN NORTH AMERICA; AN ACCOUNT OF THE SPECIES KNOWN TO INHABIT CALIFORNIA, OREGON, WASHINGTON, IDAHO, UTAH, NEVADA, ARIZONA, BRITISH COLUMBIA, SONORA, AND LOWER CALIFORNIA.

WALKER, A. 2 v., illus. San Francisco. (Calif. Acad. Sci. Occas. Papers 10.)

1928. SOME OREGON PHENACOMYS. Jour. Mammal. 9: 254-255.

1930. NOTES ON THE FOREST PHENACOMYS. Jour. Mammal. 11:233-235.

Webster, E. B.

1920. THE KING OF THE OLYMPICS. THE ROOSEVELT ELK AND OTHER MAMMALS of THE OLYMPIC MOUntains. 227 pp., illus. Port Angeles, Wash.

WIGHT, H. M.

1918. THE LIFE HISTORY AND CONTROL OF THE POCKET GOPHER IN THE WIL LAMETTE valuey. Oreg. Agr. Expt. Sta. Bull. 153, 55 pp., illus. 1928. FOOD HABITS OF TOWNSEND'S MOLE, SCAPANUS TOWNSENDII (BACHMAN).

WILkES, C. Jour. Mammal. 9: 19-33.

1845. NARRATIVE OF THE UNITED STATES EXPLORING EXPEDITION DURING THE WRIGHT, W. H. YEARS $1838,1839,1840,1841,1842$. v. 4 , illus. Philadelphia.

1909. THE GRIZZLY BEAR; THE NARRATTVE OF A HUNTER-NATURALIST, HISTORICAL, SOIENTIFIC, AND ADVENTUROUS. 274 pp., illus. New York. 


\section{GLOSSARY OF INDIAN NAMES OF MAMMALS}

Adete (Wasco) : Western mink.

Agabastam (Wasco) : Pacific fisher.

Akowa (Wasco) : California badger.

Apiscus (Wasco): Columbia Valley skunk.

Ap-poe-poe (Chinook): Douglas's squirrel

Cha-o (Klamath) : Prong-horned antelope.

Chaw-sis (K la math): California skunk.

Chi (K la math): Oregon snowshoe hare.

Chik-chik-no (Wasco) : Yellow-bellied marmot.

Chil-las (Klamath): Golden-mantled ground squirrel.

Cho-cho (Klamath): Western bushytailed wood rat.

Cho-cliuck (K l a m a t h) : Douglas's ground squirrel.

Cudon (Wasco): Columbian gray squirrel.

Dos-lotch (Klamath): Mountain lion.

Eja ah (Piute) : Mountain coyote.

Elocus (Wasco): Oregon snowshoe hare.

E-luck-ke (Clatsop): Southern sea otter.

Elula (Wasco) : Columbian black-tailed deer.

Emah-ki-kini (Blackfeet): Mountain sheep.

Équa (Wasco) : Cascade bobcat.

Eskilox (Wasco) : Northwestern timber wolf.

Eskinkua (Wasco) : Olympic black bear.

Gannok (Wasco) : Pacific coast beaver.

Gil-wa (Klamath): Peale's meadow mouse.

Giska (Wasco): Washington weasel.

Goo'-choo (Pit River Indians, Piute): Oregon bison.

Goop (Piute) : Sage squirrel.

Goot'tsoo (Piute): Oregon bison.

Gowack (Klamath) : Sierra chickaree.

Hak-ne-sha (Piute): Nevada beaver.

Hohni (Cheyenne): Plains wolf.

Hohost ("Chopunnish"): Idaho grizzly.

Hoonah (Piute) : California badger.

Ka-moo (Piute): Oregon jack rabbit.

Ke-du (Piute): Pale yellow-bellied marmot.

Ketch-Ketch (K l a math) : Mountain weasel.

$7209^{\circ}-36-26$
Kla-pa (Klamath) : Western mink. Klë'-uh-un (Kwakiool): Steller's sea lion.

Kok-kotch (Klamath) : Klamath flying squirrel.

Koknik (Wasco) : Mountain goat.

Ko-la-a Was (Klamath): Mountain coyote.

Kolta (Klamath) : Western otter.

Koltz (Klamath): California badger.

Koop (Piute) : Sage squirrel.

K u a - p a (P i u te) : Oregon ground squirrel.

Kud-ah'-tikh (Aleut): Dall's porpoise. Lok (Klamath) : Klamath grizzly.

Meko-ka (Klamath): White-footed mouse.

Me-sas (Klamath): Oregon ground squirrel.

Mo-e (Klamath) : Yellow-bellied marmot.

Molok (Wasco) : Olympic elk.

Mo-nana-tam-has (Klamath): Mazama pocket gopher.

Moos-mus (Klamath): Columbian black-tailed deer.

Mowitch (Indians) : Columbian whitetailed deer.

Nannooks (Wasco) : Western otter.

Netate (Tolowa of Crescent City, Calif.): Brown mountain beaver.

Pahtsugo (Piute) : Western otter.

Pahuna-ah (Piute) : Western mink.

Pa-mota (Piute): Peale's meadow mouse.

Pamúse (Piute): Rocky Mountain muskrat

Pap (Klamath): Pacific marten.

Patucha (Piute) : Rocky Mountain elk.

Pejahana (Piute) : Yellowstone bat.

Pieyanin (Klikitat) : Mountain goat.

Pomaze (Piute) : Sonoran deer mouse.

Pome (Klamath): Shasta beaver.

Poolalik (Walla Walla and $\mathrm{Nez}$ Percé) : White-tailed jack rabbit.

Poonúche (Piute) : Great Basin skunk.

Quis-quis (Chinook) : Townsend's chipmunk.

Quoipa (Piute) : Rimrock sheep.

Sewellel (Indian): Brown mountain beaver

Sketch-loo-is (Klamath) : Oregon gray fox.

So-Capual (Chinook) : Jack-rabbit bat.

Sonaha (Piute) : Idaho grizzly; small Yellowstone Park grizzly.

Swo-wah (Nisqually) : Mountain lion.

401 
Ta-pu-oo (Piute) : Oregon cottontail. Ta-watz (Piute): Antelope squirrel. Te-ka-wa (Piute): Western bushytailed wood rat.

Te-ná (Piute) : Prong-horned antelope. Tetno (Walla Walla and Nez Percé): Townsend's ground squirrel.

Toka'kuacha (Piute): Idaho black bear.

Too-hoo-0o (Piute) : Rocky Mountain bobcat.

To-qua-to-hoo-oo (Piute): Mountain lion.

Tse-gu-00 (Piute) : Pygmy rabbit.

Tsnoon (Warm Springs Indians) : Rimrock sheep.

Tuhúya (Piute): Rocky Mountain mule deer.

Tu-petse-quotsu (Piute): Oregon bison.
Wal-kot-ska (Klamath) : Cascade bobcat.

Wa-nie (Piute): Cascade red fox.

Wan-na (Klamath): Cascade red fox. Wapolapísna (Piute): Great Basin spotted skunk.

Wapota Pitsua (Piute): Columbian five-toed kangaroo rat.

Waschoi (Wasco): Douglas's ground squirrel.

Was-la (Klamath) : Allen's chipmunk ; Klamath chipmunk.

We-tam (Klamath) : Idaho black bear. Wo-t a h (Piute): Golden-mantled ground squirrel.

Yackkah ("Chopunnish") : Idaho black bear.

Ya-ze-ba (Piute): Dalles pocket gopher.

Yuho (Klamath) : Oregon bison. 


\section{INDEX}

[New names and principal page references to a species in boldface; synonyms in italic]

abditus, Microtus mordax, 32, 209, 210. Abromys lordi, 248.

Agaphelus glaucus, 338.

alascensis, Callorhinus, 34, 333.

Myotis lucifugus, 34, 368.

albipes, Phenacomys, 32, 199.

albolimbatus, Sciurus douglasii, 31, 120 , $122,123,125$.

Alces gigas, 31, 76, shirasi, $31,77$.

alexandrinus, Mus, 169.

Rattus rattus, $32,169$.

alpinus, Scapanus latimanus, 34, 350, 352.

altifrontalis, Euarctos americanus, 34, $320,321$. Ursus, 321.

amblyceps, Euarctos, 319.

americana, Antilocapra, 70. Rupicapra, 61.

americanus, Oreamnos americanus, 61. Ursus, 319.

Ammospermophilus leucurus, 32, 143. amoenus, Eutamias amoenus, 32, 133, 135.

Sorex vagrans, 34, 366.

Tamias, 133.

angusticeps, Microtus californicus, 20. Microtus mordax, 32, 209.

Anisonyx rufa, 225.

Anna Creek, type locality, 256.

Antelope, 2, 15, 55, 56, 58, 61, 276, 278. American, 70.

prong-horned, 31, 70.

Antelope, type locality, 155.

Anthony, H. E., 3.

Antilocapra americana, 70. oregona, 31, 70 .

Antilocapridae, 70 .

Antrozous cantwelli, 34, 390, 391. pacificus, 34, 390. pallidus, 390.

apicalis, Neotoma fusca, 173.

Aplodontia, 289. pacifica, 21, 33, 225, 228. rufa, $21,33,225,228$.

Aplodontiidae, 225.

Arotogale muricus, 292.

Arctomys avarus, 161. columbianus, 147.

douglasii, 144. flaviventris, 159.

arizonensis, Mustela, 289, 290. Mustela longicauda, 33, 287. Putorius, 287. artemisia, Lepus, 107.

artemisiae, Lagurus curtatus, 214.

Microtus curtatus, 214.

Peromyscus maniculatus, 32,183 , 185.

Sitomys americanus, 185.

Arvicola californica, 207.

macropus, 211.

montana, 202.

$\operatorname{mordax}, 208$.

(Mynomes), 204, 208, 211.

nanus, 204.

oregoni, 212.

pauperrima, 214.

townsendii, 206.

arvicoloides, Aulacomys, 210.

Microtus richardsoni, 33, 210, 211.

Ashland, type locality, 366 .

Astoria, type locality, 212, 358.

ater, Orca, 348.

Orclnus, 348.

athabascae, Bison, 57.

Atophyrax bendirii, $\mathbf{3 5 7}$. palmeri, 358.

atrogriseus, Thomomys nevadensis, 251.

Aulacomys arvicoloides, 210.

avara, Marmota flaviventris, 24, 32, $159,161$.

avarus, Arctomys flaviventer, 161.

Badger, 56, 103, 105, 107, 162, 278. California, 34, 305.

baileyi, Castor canadensis, 33, 219, 223.

bairdi, Microtus oregoni, 33, 212, 213. Sorex obscurus, $34,360,361,363$.

bairdii, Berardius, 344 .

Delphinus, 345.

Lepus americanus, 31, 93.

Balaena musculus, 341. physalus, 339. sieboldii, 336.

Balaenas, 348.

Balaenidae, 336.

Balaenoptera borealis, 340. davidsoni, 340. physalus, 339. velifera, 339.

Balaenopteridae, 339.

bangsi, Glaucomys sabrinus, 32, 165 . Sciuropterus alpinus, 165.

Bassaris raptor, 317.

Bassariscidae, 317.

Bassariscus nevadensis, 318. oregonus, 317. raptor, 34,317 . 
Bat, 15.

big-eared, little, 34,372 .

black-nosed, 34,378 .

brown. See Brown bat.

California, little, $34,376$.

canyon, little, 13, 34, 383.

coast, Northwest, 34, 377.

desert golden, 34, 373.

dusky, 34, 372 .

golden, desert, 34, 373.

gray, large, 34, 391.

hoary, $28,34,384$.

interior, $34,375$.

jack-rabbit. See Jack-rabbit bat.

large gray, $34,391$.

little big-eared, 34,372 .

little California, 34, 376.

little canyon, $13,34,383$.

long-legged, 34, 375 .

Northwest coast, $34,377$.

Pacific pale, 12, 34, 390.

pale, Pacific, 12, 34, 390 .

silver-haired, $28,34,381$.

Tejon, 34, 370.

Yellowstone, 34, 369.

Bear, 274, 300, 316, 325.

big brown, 326 .

black. See Black bear.

brown, big, 326.

cinnamon, 319.

grizzly. See Grizzly. skunk, 299.

Beaver, 2, 56.

mountain. See Mountain beaver.

Nevada, 33, 223.

Pacific coast, 33, 218.

Shasta, 33, 222.

Beaverton, type locality, 109.

Becker, Robert H., 3.

bendirii, Atophyrax, 357.

Sorex bendirii, 34,357 .

Berardius bairdii, 344 .

Bibliography, 394.

Bighorn, 2, 28.

Oregon, 65.

rimrock, 31, 64, 65 .

Rocky Mountain, 31 63, 65.

Birds, 12, 15, 20, 21, 23, 24, 28, 31, 36.

Bison, Oregon, 31, 57.

Bison athabascae, 57.

bison, 57.

oregonus, 31, 57.

Black bear, 55, 56, 325, 326, 327.

Idaho, $34,319$.

Olympic, 34, 321.

Blackfish, 348.

Scammon's, 346.

Blacktail, 86.

Black-tailed deer, 55, 56, 90, 273.

Columbian, 21, 31, 84, 86 .

Bobcat, 55, 56, 64, 98, 105, 107, 313, 315. Cascade, 33, 268.

coast, Northwest, 21, 269.

Northwest Coast, 21, 269.

Oregon, 33, 269.

Rocky Mountain, 33, 267. borealis, Balaenoptera, 340.

Balaenoptera velifera, 340 .

Delphinapterus, 346.

Lissodelphis, 346.

Odocoileus virginianus, 92.

bottae, Thomomys bottae, 253.

Bovidae, 57.

Brachylagus idahoensis, 31, 110.

brevicaudus, Onychomys leucogaster, 178.

Brown bat, Alaska little, 34, 368.

big, 34, 379.

little, Alaska, 34, 368.

Brown bear, big, 326 .

Brownsboro, type locality, 241.

brunnescens, Ochotona fenisex, 116. Ochotona princeps, 31, 113, 116.

Brush rabbit, 107, 287.

Oregon, 21, 109.

redwood, 31, 109.

Buffalo, 57.

white, 61.

bulbivorum, Diplostoma, 249.

bulbivorus; Thomomys, 21, 33, 225, 249, 254.

bullatus, Glaucomys sabrinus, 32,163 , 166.

Bushy-tailed wood rat, dusky, 32, 173. western, $32,171$.

Cacomistle, 317.

californiana, Otaria, 332. Ovis canadensis, 31, 63, 64.

californianus, Euarctos, 321.

Ovis, 64.

Zalophus, 34, 332.

Californica, Arvicola, 207.

Lepus, 99.

californicus, Clethrionomys californicus, 32, 191, 192.

Dipodomys heermanni, 33, 235, 240, 241.

Evotomys, 191.

Lepus californicus, 31, 99.

Microtus californicus, 32, 206, 207.

Myotis californicus, $34,376,377$. $378,379$.

Sciurus hudsonius, 123.

Sorex ornatus, 366.

Vespertilio, 376.

Callorhinus alascensis, 34, 333.

Callospermophilus castanurus, 142. chrysodeirus, 32, 139, 142, 143.

cinerascens, 139.

connectens, 32, 142.

saturatus, 139

trinitatis, 32, 139, 142.

canadensis, Canis familiaris, 280.

Cervus, 79.

Lynx canadensis, 33, 271.

Ovis canadensis, $31,63,64,65$.

canicaudus, Microtus, 32, 205.

Canidae, 272, 279.

Canis canadensis, 280.

familiaris, $33,279$.

gigas, $33,272$. 
Canis klamathensis, 280.

laniger, 280.

lestes, 33, 276.

nebracensis, 276.

novacalidoniae, 280.

nubilus, 33, 272, 273, 274.

cantwelli, Antrozous pallidus, 34, 390, 391.

canus, Citellus, 14.

Citellus mollis, 32, 149, 152, 155, 157.

Spermophilus mollis, 155.

Canyon mouse, Idaho, 32, 186.

Carcajou, 299.

carissima, Leuconoe, 369.

Myotis, 369.

Myotis lucifugus, 34, 369.

Cascade Range, near Columbia River, type locality, 61.

cascadensis, Sciurus douglasii, 31, 120, $122,124$.

Vulpes fulvus, 33, 281, 284 .

castanurus, Callospermophilus, 142.

Castor balleyi, 33, 219, 223.

pacificus, 33, 218, 222.

shastensis, 33, 219, 222.

Castoridae, 218.

Cat, civet, $312,314,317$.

domestic, 265.

house, 33, 265.

phoby, 312.

catadon, Physeter, 343.

catus, Felis, 33, 265.

caurina, Martes caurina, 33, 295. Mustela, 295.

caurinus, Myotis californicus, 34, 377.

Cervidae, 76.

Cervus canadensis, 79 .

columbiana, 86.

leucurus, 89.

lewisii, 86, 90.

macrotis, 83.

nelsoni, $31,78,81$.

occidentalis, 81.

roosevelti, 31,81 .

Cetaceans, 34.

Chickaree, orange-bellied, 119.

Sierra, 123.

yellow-bellied, 122.

Chincha major, 311. notata, 310.

Chipmunk, 268, 278, 283, 287, 295, 296, 297, 298, 307.

Allen's 32, 131.

Canadian Mountain, 136.

Cooper's, 32, 129.

desert, 137.

Great Basin, 137.

Hollister's 32, 136.

Klamath, 23, 32, 133.

mountain, Canadian, 136.

ochraceous, 32, 137.

painted, 137.

redwood, 32, 130.

sagebrush, 32, 137.

Siskiyou, 32, 130.
Chipmunk, Townsend's, 21, 32, 127. yellow, 137.

yellow-bellied, 23, 32, 135.

chrysodeirus, Cailospermophilus castanurus, 142, 143.

Callospermophilus chrysodeirus, 32, 139, 142.

Tamias, 139.

chrysonotus, Myotis evotis, 34, 373. Vespertilio, 373.

cicognanii, Mustela, 293.

c in e r a s c e n s, Callospermophilus lateralis, 139.

cinerea, Nycteris, 34, 384.

cinereus, Vespertilio, 384.

cinnamomum, Euarctos americanus, 34, $319,321$.

Ursus americanus, 319.

Citellus canus, 14, 32, 149, 152, 155, 157.

columbianus, $32,147,149$.

douglasii, 32, 144.

elegans, 158.

mollis, 32, 152, 154, 157.

nevadensis, $32,158$.

oregonus, $32,149,152,159$.

richardsonii, 158 .

townsendii, 14, 32, 151.

vigilis, 14, 32, 152, 156.

Civet, 312.

Civet cat, 56, 312, 314, 317.

Clethrionomys californicus, 32, 191, 192.

mazama, 32, 191, 192.

obscurus, $32,191,192$.

saturatus, 32, 191, 193.

Columbia River, type region, 225.

Banks of, 144, 249.

Falls of, 64 .

Mouth of, 86, 89.

columbiana, Cervus macrotis, 86.

columbianus, Arctomys, 147.

Citellus, 149.

Citellus columbianus, 32, 147.

Odocoileus columbianus, $31,84,86$.

Perodipus ordi, 235.

Perodipus ordii, 33, 235, 239.

Perognathus, 14.

Perognathus lordi, 245, 248.

Thomomys, 15, 33, 254, 260.

Thomomys fuscus, 260.

communis, Phocaena, 349.

connectens, Callospermophilus chrysodeirus, 32, 142.

Cony, 112, 296.

Blue Mountain, 31, 114.

brown, 28, 31, 116.

Cascade, 116.

dusky, 28, 31, 116.

Jewett's, 28, 114.

Taylor's 28, 112.

Warner Mountain, 31, 112.

Coon, canyon, 316.

cooperi, Eutamias townsendii, 32, 127,

129, 130.

Tamias, 129. 
Cornucopia, type locality, 114.

Corynorhinus intermedius, 34, 387, 389. pallescens, 34, 387, 388 . townsendii, 34, 386.

Cottontail, 109, 278. Oregon, 31, 107. sagebrush, 107.

Cougar, 315. Oregon, 33, 261. Rocky Mountain, 33, 261, 264.

Cowfish, 345.

Coyote, 55, 56, 64, 98, 103, 105, 107, 240, $268,273,284,313,321$. mountain, 33, 276. northwestern, 276.

Crater Lake, type locality, 234, 352.

Creeping mouse, Baird's, 33, 213. Oregon, 21, 33, 212.

Cricetodipus parvus, 244.

crinitus, Hesperomys, 186.

Peromyscus crinitus, 32, 186.

Crooked River, 20 miles southeast of

Prineville, type locality, 188. curtatus, Microtus, 214.

\section{dalli, Phocaena, 349.}

Phocoenoides, 349.

davidsoni, Balaenoptera, 340.

Deer, 2, 55, 58, 70, 80, 261, 264, 268, $273,274,276,278$.

black-tailed. See Black-tailed deer. mule. See Mule deer.

white-tailed. S e e White-tailed deer.

yellow-tailed, 31, 90, 91.

Deer mouse, Gambel's, $32,181$.

ruddy, 21, 32, 182.

sagebrush, 32, 185.

Sonoran, 32, 184.

Delphinapterus borealis, 346.

Delphinidae, 345.

Delphinus bairdii, 345.

delphis, 345.

griseus, 348.

orca, 348.

phocoena, 349.

delphis, Delphinus, 345.

Dice, Lee R., 3.

Didelphiidae, 393.

Didelphis virginiana, 34, 393.

dilatus, Scapanus latimanus, 34, 350, 351 ,

Diplostoma bulbivorum, 249.

Dipodomys californicus, 33, 235, 240, 241.

gabrielsoni, 33, 235, 241.

spectabilis, 239 .

Dog, Carrier Indian, 280.

Clallum Indian, 280.

domestic, 33, 279.

Indian, 280.

Klamath Indian, 280.

Plains Indian, 280.

short-legged Indian, 280.

Dolphin, 346, 347, 348.

Baird's, 345.

common, 345. dorsata, Mazama, 61.

douglasii, Arctomys, 144.

Citellus, 32, 144.

Geomys, 254.

Sciurus douglasii, 31, 119, 122.

Spermophilus, 144.

Thomomys douglasii, 33, 254.

Drainage, 8.

Dusky shrew, 34, 360.

Baird's, 34, 361.

Cascade, 34, 362.

Olympic, 34, 362.

elegans, Citellus, 158.

Elgin, type locality, 234.

Elk, 2, 28, 31, 55, 56, 274, 278.

Olympic, 81.

Rocky Mountain, 23, 28, 78, 81 .

Roosevelt's 21, 79, 81, 273.

Ely, type locality, 254.

energumenos, Lutreola, 33.

Lutreola vison, 293.

Putorius vison, 293.

Enhydra nereis, 34, 302.

epixanthum, Erethizon epixanthum, 33,

228.

epixanthus, Erethizon, 228.

Eptesicus fuscus, 34, 379.

Erethizon epixanthum, 33, 228. epixanthus, 228.

Erethizontidae, 228.

Euarctos altifrontalis, 34, 320, 321 . amblyceps, 319.

californianus, 321.

cinnamomum, 34, 319, 321.

Eubalaena sieboldii, 336.

Eumetopias jubata, 34, 330 . stelleri, 330.

Eutamias amoenus, 32, 133, 135. cooperi, 32, 127, 129, 130 .

ludibundus, 32, 133, 136.

luteiventris, 32, 133, 135 .

ochraceus, 32, 133, 137.

ochrogenys, 32, 127, 130.

pictus, 32, 137.

propinquus, 133.

scrutator, 137.

senex, 32, 127, 130, 131.

siskiyou, $32,127,130$.

townsendii, 32, 127, 129, 130, 131.

evotis, Myotis evotis, 34, 372.

Myotis lucifugus, 374.

Vespertilio, 372.

Evotomys californious, 191.

mazama, 192.

obscurus, 192.

saturatus, 193.

excelsus, Procyon lotor, 34, 315, 316.

familiaris, Canis, 33, 279.

Fantail, 89.

Farewell Bend, type locality, 259.

fasciatus, Lynx, 21.

Lynx rufus, 33, 267, 269. 
Felidae, 261.

Felis catus, 33, 265. hippolestes, 33, 262, 264. oregonensis, 33, 261.

Fiber mergens, 33, 215, 217. occipitalis, 33, 215, 218. osoyoosensis, 33, 215, 218.

Finley, William L., 3.

Fisher, 308, 315. Pacific, 33, 298.

Fisher, Albert K., 3.

Fisher, Walter K., 3.

Flagtail, 89.

flaviventris, Arctomys, 159.

Marmota, 161.

Marmota flaviventris, 32, 159.

Florence, type locality, 218.

Flying squirrel, 28.

Bangs's, 32, 165.

Cascade, 32, 164.

Idaho, 28.

Klamath, 32, 165.

Oregon, 21, 32, 163.

Sawtooth Mountain, 32, 166.

Forests, mammals in, 56, 79, 85, 88, 323 .

Fort Klamath, type locality, 95,133 , 139, 311, 351, 357.

Fort Umpqua, type locality, 173, 363.

Fox, 56, 103, 107, 240, 284, 298, 313.

black, 282.

cross, 282, 284.

desert, 15.

gray. See Gray fox.

long-eared, Nevada, 33, 285.

Nevada long-eared, 33, 285.

red. See Red fox.

silver, 282.

tree, 286.

yellow, 281.

fuliginosus, Glaucomys sabrinus, 32, $163,164,165$.

Sciuropterus alpinus, 164.

fumosa, Ochotona fenisex, 31, 113, 116. fusca, Neotoma cinerea, $32,171,173$. Neotoma occidentalis, 173.

fuscipes, Neotoma fuscipes, 32, 174.

fuscogriseus, Onychomys leucogaster, $32,177$.

fuscus, Eptesicus fuscus, 34, 379.

Thomomys clusius, 259.

Thomomys fuscus, $33,255,259$.

Vespertila, 379.

Gabrielson, Ira N., 3.

gabrielsoni, Dipodomys heermanni, 33, $235,241$.

gambelii, Hesperomys, 181.

Peromyscus, 185, 186.

Peromyscus maniculatus, 32, 181, 184.

Geomyidae, 249.

Geomys douglasii, 254. toronsendii, 251.

gibbsii, Neurotrichus gibbsii, 34, 354 . Urotrichus, 354. gigas, Alces americana, 31, 76 .

Canis lycaon, 33, 272.

Lupus, 272.

gilberti, Peromyscus truei, 32, 187, 188, 189.

Sitomys, 187.

gillii, Tursiops, 345 .

Glaciation, 10.

Glacier Peak, type locality, 213.

Glaucomys bangsi, 32, 165. bullatus, $32,163,166$. fuliginosus, 32, 163, 164, 165.

klamathensis, $32,163,165,166$.

latipes, 166.

oregonensis, $32,163,164$.

sabrinus, 165.

glaucus, Agaphelus, 338.

Rhachianectes, 338.

Globicephalus scammonii, 346.

Glutton, 299.

Goat, 65.

mountain, 61.

white, 31, 61.

Gold Beach, type locality, 258.

Goldman, Luther, 3.

Gopher, 283, 287.

Grampus, common, 348.

Grampus griseus, 348. stearnsii, 348.

Grants Pass, type locality, 252, 291.

Grasshopper mouse, Oregon, 14, 32, 177, 242.

Gray digger, 144.

Gray fox, 12.

Oregon, 33, 286.

Gray squirrel, 278.

Columbian, 117.

silver, $21,31,117$.

griseus, Delphinus, 348.

Grampus, 348.

Sciurus griseus, 31, 117.

Grizzly, 320.

Idaho, 34, 328.

Klamath, 34, 323.

Yellowstone Park, small, 34, 329.

Ground hog, 159, 161.

Ground squirrel, 268, 278, 283, 287, 288, 295, 298, 307, 310, 311.

Columbian, 32, 147.

copperhead, 32, 142.

Douglas's, 21, 32, 144.

golden-mantled, 23, 32, 139.

gray, 14, 155.

Nevada, 32, 158.

Oregon, 23, 32, 149.

Piute, 32, 154.

speckled, 14, 151, 156.

tawny-mantled, 32, 142.

Townsend's, 13, 32, 151.

Gulo luscus, 34, 299.

Halicyon richardii, 335.

Hare, brown, 96.

Snowshoe. See Snowshoe hare.

Townsend's, 97.

varying, 28. 
Hart Mountain (Mount Warner), type locality, 70.

Harvest mouse, California, 32, 190. desert, 32, 189. large-eared, 14.

helleri, Thomomys, 20. Thomomys monticola, 33, 255, 258.

Hesperomys crinitus, 186. gambelii, 181. sonoriensis, 184.

hesperus, Pipistrellus hesperus, 34, 383. Scotophilus, 383. Thomomys, 20, 33, 255.

Heteromyidae, 235.

hippolestes, Felis concolor, 33, 262, 264.

Hollister, Ned, 3.

Holodiscus, 83.

Homestead, type locality, 142.

horribllis, Ursus, 328, 329.

Horsfall, R. Bruce, 3.

Howell, A. Brazier, 3.

Howell, Arthur H., 3.

Ibex, 65 .

idahoensis, Brachylagus, 31, 110. Lepus, 110.

Ursus, 34, 324, 328, 329.

imperator, Ursus, 329.

Indian dogs, 280.

Indian names, 54. See also Glossary, 401.

interior, Myotis longicrus, 375. Myotis volans, 34, 375.

intermedius, Corynorhinus macrotis, 389.

Corynorhinus rafinesquii, 34, 387, 389.

Phenacomys intermedius, 32, 194, 200, 201.

Ironside, type locality, 177.

Jack rabbit, 278, 311.

black-tailed, 14, 97.

California, 12, 31, 99.

Oregon, 31, 100, 101.

western white-tailed, 31, 97.

white-tailed, western, 31, 97.

Jack-rabbit bat, 34,386 .

intermediate, 34,389 .

pale, $34,388$.

Jewett, Stanley G., 3.

jewetti, Ochotona californicus, 113.

Ochotona schisticeps, 31, 114.

jubata, Eumetopias, 34, 330.

Phoca, 330.

Jumping mouse, 21.

Blue Mountain, 33, 234.

mountain, 28, 33, 234.

northwest, 33, 231.

Oregon, 28.

Pacific, 33, 233.

Kangaroo mouse, 234.

Kangaroo rat, 17, 242, 268, 285, 287, 288, 307.

California, northern, 33, 240.

Columbian five-toed, 33, 235.
Kangaroo rat, five-toed, 14.

five-toed, Columbian, 33, 235.

Gabrielson's, 33, 241.

Northern California, 33, 240.

Preble's, 33, 239.

Rogue River, 12.

Killer, black, 348.

Pacific, 347.

klamathensis, Canis familiaris, 280.

Glaucomys sabrinus, $32,163,165$, 166.

Lepus, 94.

Lepus americanus, 31, 94, 95.

Sciuropterus alpinus, 165.

Ursus, 34, 323, 329.

Lagenorhynchus obliquidens, 347.

Lagurus artemisiae, 214.

laniger, Canis, 280.

lanuginosus, Sciurus, 122.

Lasionycteris noctivagans, 34,381 .

Latax nereis, 302.

laticeps, Thomomys bottae, 33, 250, 253.

latifrons, Spilogale phenax, 34, 312, 314.

latimanus, Scapanus, 351.

latipes, Glaucomys sabrinus, 166.

Launcefield, Mr., 3.

Least weasel, Rocky Mountain, 33, 293. Sierra, 33, 292.

Leporidae, 93.

leptus, Mustela cicognanii, 33, 292, 293. Putorius streatori, 293.

Lepus artemisiae, 107.

bairdii, 31, 93.

californica, 99.

californicus, 31, 99.

idahoensis, 110.

klamathensis, 31, 94, 95.

nuttallii, 107.

townsendii, 31, 97.

vigilax, 99.

wallawalla, 31, 97, 100, 101.

washingtonii, $31,94,95,96$.

lestes, Canis latrans, 33, 276.

leucodon, Thomomys bottae, 33, 250, 252.

Leuconoe carissima, 369.

leucurus, Ammospermophilus leucurus, $32,143$.

Cervus, 89.

Odocoileus virginianus, $31,89,92$, 93.

Tamias, 143.

lewisii, Cervus, 86, 90.

Life zones, 11.

Arctic-Alpine, 30.

birds, breeding, table of, 36 .

Canadian, 25.

crop adaptations, 17, 24.

Hudsonian, 29.

mammals, table of, 31 .

plants, table of, 40 .

reptiles, table of, 35 .

Transition, 19.

Upper Sonoran, 12. 
Lissodelphis borealis, 346.

littoralis, Tamias townsendi, 127.

Lobo, 274.

longicauda, Phenacomys, 199.

Reithrodon, 190.

longicaudus, Mustela, 288.

Phenacomys, 21, 32, 194, 198, 199, 200.

Reithrodontomys megalotis, 32, $189,190$.

longicrus, Myotis volans, 34, 375. Vespertilio, 375.

lordi, Abromys, 248.

Perognathus, 14.

Perognathus lordi, 33, 245, 248.

Loring, J. Alden, 3.

lucifugus, Myotis, 368, 369, 372.

ludibundus, Eutamias amoenus, 32,133 , 136.

Lupus gigas, 272.

luscus, Gulo luscus, 34, 299. Ursus, 299.

luteiventris, Eutamias amoenus, 32, 133, 135.

Tamias quadrivittatus, 135.

Lutra pacifica, 34, 301.

Lutreola energumenos, 33, 293.

Lynx, Canada, 28, 33, 94, 271.

Lynx canadensis, 33, 271.

fasciatus, $21,33,267,269$.

pallescens, 33, 267, 268.

uinta, 33, 267, 269.

macrocephalus, Physeter, 343.

macropus, Arvicola, 211.

Microtus richardsoni, 33, 211.

Mynomes, 211.

macrotis, Cervus, 83.

Odocoileus hemionus, 31, 83.

macrourus, Microtus mordax, 210.

Odocoileus virginianus, 92.

Vulpes fulvus, 33, 282, 284.

major, Chincha occidentalis, 311. Mephitis occidentalis, 34, 308, 311. Zapus, 234.

Malheur Lake, type locality, 57.

Maneater, 299.

mariposae, Sorex montereyensis, 359. Sorex trowbridgil, 34, 359.

Marmot, pale yellow-bellied, 32, 161. yellow-bellied, 28, 32, 159.

Marmota avara, 24, 32, 159, 161. flaviventris, 32, 159, 161.

Marshfield, type locality, 194.

Marten, 28, 56, 288, 298, 300, 308, 315. Pacific, 33, 295.

Rocky Mountain, 28, 33, 297.

Martes caurina, 33, 295.

origenes, 33, 296, 297.

pacifica, 33, 298.

sierrae, 296.

Mazama dorsata, 61.

mazama, Clethrionomys californicus, $32,191,192$.

Evotomys, 192.

Thomomys, 258.

Thomomys monticola, 33, 255, 256.
McCoy, type locality, 205.

Meadow mouse, 20, 278, 311, 312.

California, 12, 32, 207.

Cascade, 33, 210.

coast, 32, 209.

dwarf, 32, 204.

gray-tailed, 21, 32, 205.

large-footed, 28, 33, 211.

Peale's, 32, 202.

Rocky Mountain, 28, 32, 208.

Tillamook, 32, 210.

Townsend's, 21, 32, 206.

megacephalus, Microdipodops, 244.

megalotis, Reithrodon, 189.

Reithrodontomys megalotis, 32, 189, 190.

Megaptera nodosa, 342.

versabilis, 342.

melanorhinus, Myotis subulatus, 34, 378.

Vespertilio, 378.

Mephitis major, 34, 308, 311.

notata, 34, 308, 310 .

occidentalis, 34, 308, 310, 311.

spissigrada, 34, 308, 310.

mergens, Fiber zibethicus, 33, 215, 217.

merriami, Sorex, 34, 367.

Mesoplodon stejnegeri, 345.

Mice, 268, 278, 283, 287, 288, 295, 296,

297, 298, 307, 310, 312, 319.

Microdipodops megacephalus, 244. oregonus, 33, 241.

Microtus, 358.

abditus, 32, 209, 210.

angusticeps, 20, 32, 209.

artemisiae, 214.

arvicoloides, 33, 210, 211.

bairdi, 33, 212, 213.

californicus, 32, 206, 207.

canicaudus, 32, 205.

macropus, 33, 211.

macrourus, 210.

montanus, 32, 202, 205, 207, 208.

mordax, 32, 208.

nanus, 32, 204, 205.

oregoni, 33, 212.

pauperrimus, 24, 33, 212, 214.

pennsylvanicus, 202, 206.

townsendii, 32, 206, 208, 210.

Mink, 56, 288, 297, 301, 313, 315.

western, 33, 293.

mirus, Ursus, 34, 324, 329.

missoulae, Oreamnos americanus, 62.

Mole, coast, 34, 353.

Gibbs's, 34, 354.

Klamath, 34, 351.

Mazama, 34, 352.

mountain, 28.

Scheffer's, 13, 34, 353.

Townsend's, 34, 349, 353.

mollipilosus, Perognathus, 14.

Perognathus parvus, 33, 245, 247.

Sciurus douglasii, 122.

mollis, Citellus mollis, 32, 152, 154, 157.

Spermophilus, 154.

monochroura, Neotoma, 174.

montana, Arvicola, 202. 
montanus, Microtus, 205, 207, 208. Microtus montanus, 32, 202. Oreamnos, 61.

Ovis, 61.

Zapus trinotatus, 33, 232, 234.

monticola, Penognathus, 244, 247.

Sorex vagrans, 34, 365.

Moose, 56.

Alaska, 31, 76.

giant, 76.

Rocky Mountain, 31, 77.

mordax, Arvicola, 208.

Microtus mordax, 32, 208.

Mynomes, 208.

Mount Hood, type locality, 122.

Mount Jefferson, type locality, 116, 362.

Mount Mazama, type locality, 192.

Mountain beaver, 21, 288, 297.

brown, 33, 225.

Pacific, 33, 228.

Mountain burrowers, 225.

Mountain devil, 299.

Mountain goat, 31, 61 .

Mountain lion, 55, 56, 64, 87, 261, 264, 321.

Mountain sheep, 15, 28, 56, 62, 63, 272, 278.

desert, 24.

rimrock, 13, 64.

Mouse, 316.

brown scorpion, 177.

canyon, Idaho, 32, 186.

cliff, silky, 14.

creeping. See Creeping mouse.

deer. See Deer mouse.

gnome, Oregon, 33, 241.

grasshopper, Oregon, 14, 32, 177, 242.

harvest. See Harvest mouse.

house, 32, 169.

Idaho canyon, 32, 186.

jumping. See Jumping mouse.

kangaroo, 234.

lemming, 28.

meadow. See Meadow mouse.

Oregon gnome, 33, 241.

Oregon grasshopper, 14, 32, 177, 242.

pocket. See Pocket mouse.

pygmy, 24, 33, 214.

red-backed. See Red-backed mouse.

scorpion, brown, 177.

silky cliff, 14.

tree. See Tree mouse.

western woods, 182.

white-footed. See White-footed mouse.

woods, western, 182.

Mule deer, 15, 28, 55, 56, 87, 88.

Rocky Mountain, 23, 24, 28, 31, 83.

muricus, Arctogale, 292.

Mustela cicognanii, 33, 292.

Putorius, 292.

Muridae, 167.

Murie, O. J,, 3.
Mus alexandrinus, 169.

musculus, 32,169 .

norvegicus, 167.

rattus, 168.

musculus, Balaena, 341.

Mus musculus, 32, 169.

Sibbaldus, 341.

Muskrat, 2, 56, 295.

Nevada, 33, 217.

Oregon coast, 33, 218.

Rocky Mountain, 33, 215.

Mustela arizonensis, 33, 287, 289, 290.

caurina, 295.

cicognanii, 293.

leptus, 33, 292, 293.

longicaudus, 288.

muricus, 33, 292.

noveboracensis, 290.

oregonensis, 33, $290,291$.

oribasus, 288.

origenes, 297.

pacifica, 298.

saturata, 33, 288, 289.

streatori, 33, 291, 293.

washingtoni, 33, 290.

Mustelidae, 287.

Myotis alascensis, 34, 368.

californicus, 34, 376, 377, 378, 379 .

carissima, 34, 369.

caurinus, $34,377$.

chrysonotus, $34,373$.

evotis, 34, 372, 374.

interior, $34,375$.

longicrus, $34,375$.

lucifugus, 368, 369, 372 .

melanorhinus, 34, 378 .

saturatus, $34,371,372$.

sociabilis, 34,370 .

yumanensis, 372 .

nanus, Arvicola, 204.

Microtus nanus, 32, 204, 205.

Mynomes, 204.

Narrows, type locality, 239.

nasicus, Thomomys monticola, 33, 255, 259.

navigator, Neosorex, 355.

Sorex palustris, $34,355$.

nebracensis, Canis, 276.

neglecta, Taxidea americana, 305.

Taxidea taxus, 34, 305.

nelsoni, Cervus canadensis, $31,78,81$.

Ovis, 69.

Neosorex navigator, 355.

Neotoma apicalis, 173.

fusca, 32, 171, 173.

fuscipes, $32,174$.

monochroura, 174.

nevadensis, 32, $175,176$.

occidentalis, 32, 171, 174.

nereis, Enhydra lutris, 34, 302.

Latas lutris, 302.

Netul River, type locality, 269.

Neurotrichus gibbsii, 34, 354. 
neradensis, Bassariscus astutus, 318 .

Citellus elegans, 32, 158.

Neotoma lepida, 32, 175, 176.

Perognathus, 33, 248.

Thomomys, 15.

Thomomys townsendii, 33, 250, 252.

Vulpes macrotis, 33, 285.

Zapus, 234.

Newport, type locality, 228.

niger, Thomomys, 21, 33, 254, 256.

nigrescens, Reithrodontomys megalotis, 189.

noctivagans, Lasionycteris, 34, 381.

Vespertilio, 381.

nodosa, Megaptera, 342.

Nonvolcanic areas, 6.

norvegicus, Mus, 167.

Rattus, 32, 167.

notata, Chincha occidentalis, 310.

Mephitis occidentalis, 34, 308, 310. novacalidoniae, Canis familiaris, 280 . noveboracensis, Mustela, 290.

nubilus, Canis lycaon, 33, 272, 273, 274.

nuttallii, Lepus, 107.

sylvilagus, 109.

Sylvilagus nuttallii, 31, 107.

Nycteris cinerea, 34,384 .

obliquidens, Lagenorhynchus, 347.

obscurus, Clethrionomys californicus, 32, 191, 192.

Evotomys, 192.

Sorex obscurus, 34, 360, 361, 362. ocoidentalis, Cervus, 81.

Mephitis occidentalis, 34, 308, 310 , 311.

Neotoma cinerea, $32,171,174$.

occipitalis, Fiber zibethicus, 33, 215, 218.

Ochotona, 110, 112.

brunnescens, 31, 113, 116.

fumosa, 31, 113, 116.

jewetti, 31, 113, 114.

taylori, 31, 112.

Ochotonidae, 112.

ochraceus, Eutamias amoenus, 32, 133, 137.

ochrogenys, Eutamias townsendi, 130. Eutamias townsendii, 32, 127, 130. ochrourus, Odocoileus virginianus, 31 , 90, 91.

Odocoileus borealis, 92 .

columbianus, $31,84,86$.

leucurus, $31,89,92,98$.

macrotis, $31,83$.

macrourus, 92.

ochrourus, 31, 90, 91.

olympicus, Phenacomys intermedius, 32, 194, 201.

Onychomys brevicaudus, 178.

fuscogriseus, 32, 177.

torridus, 179.

Opossum, Virginia, 34, 393.

orarius, Scapanus orarius, $34,353,354$.

Orca, 348.

Orca ater, 348.

rectipinna, 347. orca, Delphinus, 348.

Orcinus, 348.

Orcinus ater, 348.

orca, 348.

rectipinna, 347.

Oreamnos americanus, 61.

missoulae, 62.

montanus, 61.

oregona, Antilocapra americana, 31, 70.

oregonensis, Felis concolor, 33, 261.

Glaucomys sabrinus, 32, 163, 164 .

Mustela xanthogenys, 33, 290, 291.

Pteromys, 163.

Putorius xanthogenys, 291.

oregoni, Arvicola, 212.

Microtus oregoni, 33, 212.

oregonus, Bassariscus flavus, 317.

Bison bison, 31, 57.

Citellus, 32, 149, 152, 159.

Microdipodops megacephalus, 33, 241.

Spermophilus, 149.

Thomomys, 21.

Thomomys douglasii, 33, 254.

Zapus princeps, 33, 232, 234.

oribasus, Mustela, 288.

origenes, Martes caurina, 33, 296, 297. Mustela caurina, 297.

orophilus, Phenacomys, 200.

osoyoosensis, Fiber zibethicus, 33, 215, 218.

Otaria californiana, 332.

Otariidae, 330.

Otter, 56, 219, 223.

sea. See Sea otter.

western, 34, 301.

Ovis californiana, $31,63,64$.

californianus, 64.

canadensis, 31, 63, 64, 65 .

montanus, 61.

nelsoni, 69.

pacifica, Aplodontia, 21.

Aplodontia rufa, 33, 225, 228.

Lutra canadensis, 34, 301.

Lutra hudsonica, 301.

Martes pennanti, 33, 298.

Mustela canadensis, 298.

Procyon lotor, 34, 315.

Procyon psora, 315.

pacificus, Antrozous pallidus, 34, 390.

Castor canadensis, 33, 218, 222.

Sorex pacificus, $34,363,364$.

Zapus trinotatus, 33, 232, 233.

pallescens, Corynorhinus macrotis, 388.

Corynorhinus rafinesquii, 34,387 , 388.

Lynx fasciatus, 268.

Lynx rufus, 33, 267, 268.

pallidus, Antrozous, 390.

Palmer, Theodore S., 3.

palmeri, Atophyrax bendirii, 358.

Sorex bendirii, 34, 358.

Panther, 261, 264, 325.

parvus, Cricetodipus, 244.

Perognathus, 14, 249.

Perognathus parvus, 33, 244, 247. 
pauperrima, Arvicola, 214.

pauperrimus, Microtus, 24, 33, 212, 214.

Peck, Morton E., 3.

Pekan, 298.

pennsylvanicus, Microtus, 202, 206.

perimekurus, Peromysous, 182.

Permilia Lake, type locality, 116, 362. permiliensis, Sorex obscurus, 34, 360, 362.

Perodipus columbianus, 33, 235, 239. preblei, 33, 239.

Perognathus columbianus, 14, 245, 248. lordi, 14, 33, 245, 248.

mollipilosus, 14, 33, 245, 247.

monticola, 244.

nevadensis, 33, 248.

parvus, 14, 33, 244, 247, 249.

Peromyscus artemisiae, 32, 183, 185. crinitus, 32, 186.

gambelii, 32, 181, 184, 185, 186.

gilberti, 32, 187, 188, 189 .

perimekurus, 182.

preblei, 32, 187, 188.

rubidus, 32, 181, 182.

sonoriensis, 32, 183, 184.

truei, 188, 189.

Phenacomys, mountain, 32, 200.

Olympic, 32, 201.

white-footed, 21, 32, 199.

Phenacomys albipes, 32, 199.

intermedius, 32, 194, 200, 201.

longicauda, 199.

longicaudus, $21,32,194,198,199$, 200.

olympicus, 32, 194, 201.

orophilus, 200.

silvicola, 21, 32, 194, 198.

silvicolus, 198.

phenax, Spilogale, 314.

Phoca jubata, 330.

richardii, $34,335$.

Phocaena communis, 349.

dalli, 349.

phocoena, 349.

vomerina. 349.

Phocidae, 335.

phocoena, Delphinus, 349.

Phocaena, 349.

Phocoenoides dalli, 349.

physalus, Balaena, 339.

Balaenoptera, 339.

Physeter catodon, 343. macrocephalus, 343.

Physeteridae, 343.

Physiographic features, 4.

pictus, Eutamias minimus, 32, 137.

Tamias minimus, 137.

Pika, 31, 112.

Pine Creek, head of, near Cornucopia, type locality, 114.

Pipistrellus hesperus, 34, 383.

Plant cover, 11.

Plants, 12, 15, 20, 21, 23, 24, 28, 29, $30,40,44,49,50,52$.

Plecotus townsendii, 386.
Pocket gopher, 14, 20, 21, 268, 278, 288,

$297,307$.

black, 33, 256.

brown, 23, 28, 33, 259.

camas, 33, 225, 249.

Columbia, 13, 33, 260.

Dalles, 13, 33, 260.

Deschutes, 33, 259.

Douglas's, 33, 254.

Heller's, 33, 258.

Humboldt Bay, 33, 253.

Mazama, 28, 33, 256.

Nevada, 33, 252.

Oregon, 33, 254.

Townsend's, 33, 251.

West coast, 33, 255.

white-toothed, 12, 33, 252.

Pocket mouse, 14, 17, 242.

Columbian, 248.

Coues's, 33, 247.

Nevada, 33, 248.

northwest, 13, 33, 248.

Oregon, 33, 244.

Porcupine, 55, 56, 278.

yellow-haired, 33, 228.

Porpoise, 34, 348 .

bay, 349 .

common, 347.

Dall's, 349.

harbor, 349.

northern right whale, 346.

right whale, northern, 346.

striped, $\mathbf{3 4 7}$.

Portland, type locality, 249.

Preble, Edward A., 3.

preblei, Perodipus microps, 33, 239.

preblei, Peromyscus truei, 32, 187, 188.

preblei, Sorex, 34, 367, 368.

princeps, Zapus, 234.

Procyon excelsus, 34, 315, 316.

pacifica, 34, 315.

Procyonidae, 315.

Prongbuck, 70.

Pronghorn, Oregon, 70.

propinquus, Eutamias amoenus, 133.

Prospect, type locality, 192, 233.

Pteromys oregonensis, 163.

Putorius arizonensis, 287.

energumenos, 293.

leptus, 293.

muricus, 292.

oregonensis, 291.

saturatus, 289.

streatori, 291.

washingtoni, 290.

quadratus, Thomomys, 15.

Thomomys quadratus, 33, 254, 260.

Rabbit, 268, 278, 283, 288, 289, 296, 298 , 299, 307, 316.

brush. See Brush rabbit.

cottontail. See Cottontail.

Idaho, 24.

jack. See Jack rabbit.

pygmy, 31, 110, 278. 
Rabbit, red, 96.

\section{sage, 110.}

snowshoe, 28, 272, 278.

Washington, 21.

Raccoon, 56, 307, 315.

northwestern, 34, 315.

Snake River Valley, 34, 315, 316. raptor, Bassaris, 317.

Bassariscus astutus, 34, 317.

Rat, 297, 310, 312.

barn, 167.

black, 32, 168.

brown, 167.

house, 167.

kangaroo. See Kangaroo rat.

Norway, 32, 167.

roof, 32,169 .

sewer, 167.

wharf, 167.

wood. See Wood rat.

Rattus alexandrinus, 32, 169.

norvegicus, $32,167$.

rattus, 32,168 .

rattus, Mus, 168.

Rattus rattus, $32,168$.

rectipinna, Orca, 347.

Orcinus, 347.

Red-backed mouse, 28.

British Columbia, 32, 193.

California, 21, 32, 191.

dusky, 32, 192.

Mazama, 32, 192.

Red fox, 28.

Cascade, 33, 281, 284.

Rocky Mountain, 33, 284.

Reithrodon longioauda, 190. megalotis, 189.

Reithrodontomys longicaudus, 32, 189, 190.

megalotis, 32, 189, 190.

nigrescens, 189.

Reptiles, 15, 35.

Rhachianectes glaucus, 338.

Rhachianectidae, 338.

richardii, Halicyon, 335.

Phoca richardii, 34, 335.

richardsoni, Sciurus hudsonicus, 31, $120,124,125$.

richardsonii, Citellus, 158.

Ringtail, 12, 34, 317.

Rockchuck, 159.

roosevelti, Cervus canadensis, 31, 81.

Rorqual, 348.

lesser, 340.

Rudolphi's, 340.

Roseburg, type locality, 314.

rubidus, Peromyscus maniculatus, 32,

181, 182.

Peromyscus oreas, 182.

rufa, Anisonyx, 225.

Aplodontia, 21.

Aplodontia rufa, 33, 225, 228.

Rupicapra americana, 61.

Sable, American, 295.

sabrinus, Glaucomys sabrinus, 165.
Sage squirrel, 154.

gray, 32, 155.

speckled, 32, 156.

saturata, Mustela longicauda, 33, 288, 289.

saturatus, Callospermophilus lateralis, 139.

Clethrionomys gapperi, 32, 191, 193.

Evotomys gapperi, 193.

Myotis yumanensis, $34,371,372$. Putorius, 289.

saxatilis, Spilogale gracilis, 34, 312, 314.

Scalops townsendii, 349 .

scammonii, Globicephalus, 346.

Scapanus alpinus, $34,350,352$.

dilatus, $34,350,351$.

latimanus, 351.

orarius, $34,353,354$.

schefferi, 34,353 .

townsendii, 34, 349, 353.

truei, 351.

schefferi, Scapanus orarius, 34, 353.

Sciuridae, 117.

Sciuropterus bangsi, 165.

fuliginosus, 164.

Jlamathensis, 165.

Sciurus albolimbatus, 31, 120 122, 123, 125.

californicus, 123.

cascadensis, 31, 120, 122, 124.

douglasii, 31, 119, 122.

griseus, 31, 117.

lanuginosus, 122.

mollipilosus, 122.

richardsoni, 31, 120, 124, 125.

Scotophilus hesperus, 383.

scrutator, Eutamias minimus, 137.

Seal, 20, 301, 304, 330, 347.

fur, northern, 34, 333.

hair, 34, 335.

harbor, 335.

leopard, 335.

northern fur, 34, 333.

spotted, 335.

Sea lion, 20, 304, 347, 348.

California, 34, 332.

northern, 330 .

Steller's 34, 330, 333.

Sea otter, 20,34 .

southern, 302.

senex, Eutamias townsendii, 32, 127, $130,131$.

Tamias, 131.

Seton, type locality, 256.

setosus, Sorex obscurus, 34, 360, 362.

shastensis, Castor canadensis; 33, 219, 222.

Castor subauratus, 222.

Sheep, bighorn. S€e Bighorn.

lava-bed, 64.

mountain. See Mountain sheep.

rimrock, 31, 64, 69.

Sheldon, Harry H., 3.

Shelton, Alfred C., 3.

shirasi, Alces americana, 31, 77. 
Shrew, 20.

Bendire's, 34, 357.

dusky. See Dusky shrew.

Merriam's 34, 367.

mountain, 28.

Pacific, 34, 363.

Palmer's, 34, 357, 358.

Preble's, 34, 368.

Rocky Mountain, 34, 365.

Rocky Mountain water, 34, 355.

Sierra, 34, 366.

Siskiyou, 34, 366.

Trowbridge's, 34, 358.

vagrant, 34,364 .

water, Rocky Mountain, 34, 355.

Yaquina, 34, 364.

Yosemite, 34, 359.

Sibbaldius sulfureus, 341.

Sibbaldus musculus, 341.

sieboldii, Balaena, 336.

Eubalaena, 336.

sierrae, Martes caurina, 296.

silvicola, Phenacomys, 21, 32, 194, 198.

silvicolus, Phenacomys, 198.

siskiyou, Eutamias townsendii, 32, 127, 130.

Sitomys artemisiae, 185. gilberti, 187.

Siuslaw River, near mouth of, type locality, 256.

Skunk, 56, 103, 105, 107.

California, 34, 308.

Columbia Valley, 34, 310.

Great Basin, 34, 311.

hydrophobia, 312, 314.

Puget Sound, 34, 310.

Spotted. See Spotted skunk.

Snowshoe hare, Oregon, 31, 95.

Rocky Mountain, 31, 93.

Washington, 31, 96.

sociabilis, Myotis yumanensis, 34, 370.

Soil conditions, 10.

sonoriensis, Hesperomys, 184.

Peromyscus maniculatus, 32, 183, 184.

Sorex amoenus, 34, 366.

bairdi, $34,360,361,363$.

bendirii, $34,357$.

californicus, 366.

mariposae, $34,359$.

merriami, 34, 367.

monticola, 34, 365.

navigator, 34,355 .

obscurus, $34,360,361,362$.

pacificus, $34,363,364$.

palmeri, 34, 357, 358 .

permiliensis, $34,360,362$.

preblei, 34, 367, 368 .

setosus, $34,360,362$.

trigonirostris, 34,366 .

trowbridgii, $34,358$.

vagrans, $34,364,366$.

yaquinae, $20,34,363,364$.

Soricidae, 355.

spectabilis, Dipodomys, 239.
Spermophilus canus, 155.

douglasii, 144.

mollis, 154.

oregonus, 149.

townsendii, 151.

Spilogale latifrons, 34, 312, 314. phenax, 314.

saxatilis, 34, 312, 314.

spissigrada, Mephitis occidentalis, 34, $308,310$.

Spotted skunk, Great Basin, 34, 312. little, 15.

Oregon, 34, 314.

Squirrel, 296, 297, 299.

antelope, 14, 32, 143.

black-tailed, 125.

burrowing, 147.

calico, 139.

Cascade, 28, 31, 122.

digger, 144.

Douglas's, 21, 31, 119, 124.

flying. See Flying squirrel.

gray. See Gray squirrel.

ground. See Ground squirrel.

pine, 268, 278.

Piute, 154.

Richardson's, 28, 31, 125.

sage. See Sage squirrel.

sand, white-tailed, 143.

Sierra, 31.

white-tailed sand, 143.

stearnsii, Grampus, 348.

stejnegeri, Mesoplodon, 345 .

stelleri, Eumetopias, 330.

Streator, Clark P., 3.

streatori, Mustela, 293.

Mustela cicognanil, 33, 291.

Putorius, 291.

sulfureus, Sibbaldius, 341.

Swan Lake Valley, type locality, 149.

Swift, Nevada, 285.

Sylvilagus nuttallii, 31, 107, 109. ubericolor, 31, 107, 109.

Talpidae, 349.

Tamias amoenus, 133.

chrysodeirus, 139.

cooperi, 129.

leucurus, 143.

littoralis, 127.

luteiventris, 135.

pictus, 137.

senex, 131.

townsendii, 127.

Taxidea neglecta, 34, 305. taxus, 305.

taxus, Taxidea taxus, 305.

taylori, Ochotona schisticeps, 31, 112.

The Dalles, type locality, 117, 260.

Thomomys atrogriseus, 251.

bottae, 253.

bulbivorus, $21,33,225,249,254$.

columbianus, $15,33,254,260$.

douglasii, 33, 254.

fuscus, $33,255,259$.

helleri, 20, 33, 255, 258. 
Thomomys hesperus, 20, 33, 255.

laticeps, 33, 250, 253.

leucodon, 33, 250, 252.

mazama, 33, 255, 256, 258.

nasicus, 33, 255, 259.

nevadensis, 15, 33, 250, 252.

niger, 21, 33, 254, 256.

oregonus, $21,33,254$.

quadratus, $15,33,254,260$.

townsendii, 14, 33, 250, 251, 252. wallowa, 259.

Tillamook, type locality, 198, 210, 255.

Torrey, Harry Beal, 3.

torridus, Onychomys, 179.

townsendi, Urocyon californicus, 286.

Urocyon cinereoargenteus, 33, 286.

townsendii, Arvicola, 206.

Citellus, 14, 32, 151.

Corynorhinus rafinesquii, 34, 386.

Eutamias, 129, 130.

Eutamias townsendil, 32, 127, 130, 131.

Geomys, 251.

Lepus townsendii, $\mathbf{3 1}, 97$.

Microtus, 32, 206, 208, 210.

Plecotus, 386.

Scalops, 349.

Scapanus, 34, 349, 353.

Spermophilus, 151.

Tamias, 127.

Thomomys, 14.

Thomomys townsendii, 33, 250, $251,252$.

Tree mouse, 21.

dusky, 32, 198.

red, $32,194$.

trigonirostris, Sorex ornatus, 34, 366.

trinitatis, Callospermophilus chryso-

deirus, 32, 139, 142.

trinotatus, Zapus, 21.

Zapus princeps, 21.

Zapus trinotatus, 33, 231, 234.

trowbridgii, Sorex trowbridgii, $34,358$.

truei, Peromyscus truei, 188, 189. Scapanus, 351.

Tursiops gillii, 345.

ubericolor, Sylvilagus bachmani, 31, 107, 109.

vinta, Lynx, 269.

Lynx rufus, 33, 267.

Umatilla, type locality, 235.

Urocyon townsendi, 33, 286.

Urotrichus gibbsii, 354 .

Ursidae, 319.

Ursus altifrontalis, 321.

cinnamomum, 319.

horribilis, 328,329 .

idahoensis, $34,324,328,329$.

imperator, 329.

klamathensis, 34, 323, 329.

luscus, 299.

mirus, 34, 324, 329.

vagrans, Sorex vagrans, 34, 364, 366. Vale, type locality, 107, 156. velifera, Balaenoptera, 339.

versabilis, Megaptera, 342.

Vespertila fuscus, 379 .

Vespertilio californicus, 376.

chrysonotus, 373.

cinereus, 384.

evotis, 372.

longicrus, 375.

melanorhinus, 378.

noctivagans, 381.

Vespertilionidae, $\mathbf{3 6 8}$.

vigilax, Lepus californicus, 99.

vigilis, Citellus, 14.

Citellus canus, 156.

Citellus mollis, 32, 152, 156.

virginiana, Didelphis virginiana, 34, 393.

Volcanic areas, 4.

Vole, water, $210,211$.

vomerina, Phocaena, 349.

Vulpes cascadensis, 33, 281, 284.

marcrourus, 33, 282, 284.

nevadensis, 33, 285.

Walker, Alexander, 3.

Walker's Ranch, Pleasant Valley, type locality, 210.

wallawalla, Lepus californicus, 31, 97, $100,101$.

Lepus texianus, 101.

wallowa, Thomomys quadrutus, 259.

Walrus, 348.

Wapiti, Rocky Mountain, 31, 78.

Roosevelt's, 31, 81.

washingtoni, Mustela, 33, 290.

Putorius, 290.

washingtonii, Lepus, 95.

Lepus americanus, 31, 94, 96.

Water shrew, Rocky Mountain, 34, 355.

Water vole, 210, 211.

Weasel, 56, 297, 301.

Arizona, 33, 287.

bridled, Oregon, 33, 291.

Cascade, 33, 289.

least. See Least weasel.

mountain, 287.

Oregon bridled, 33, 291.

Puget Sound, 33, 291.

Washington, 33, 290.

white, 315.

Western Oregon Mountains, type 10cality, 261.

Whale, 34.

Atlantic finback, 339.

Baird's beaked, 344 .

beaked, 344, 345 .

blue, 341.

California gray, 338.

common finback, 339.

finback, 339, 340 .

finner, $339,340$.

gray, California, 338.

humpback, Pacific, 342.

little piked, 340 .

Pacific humpback, 342.

Pacific right, 336.

piked, little, 340 . 
Whale, Pollack, 340.

right, Pacific, 336.

sardine, 340.

Sei, $339,340$.

sharp-headed finner, 340.

sperm, 343.

Stejneger's beaked, 345.

sulphur-bottom, 341.

white, 348.

White-footed mouse, 179, 181, 182, 242.

Gambel's, 23.

Gilbert's, 32, 187.

Preble's, 32, 188.

Whitetail, 89.

Idaho, 91.

White-tailed deer, 56, 84, 87, 91, 98.

Columbian, 31, 89.

Oregon, 21.

Wildcat, 315.

Wild Horse Creek, type locality, 241.

Willamette River, type locality, Falls of, 89.

Lower mouth of, 25 miles below Portland, 127.

Williamson River, 18 miles southeast of Fort Klamath, type locality, 357.

Wolf, 56, 86, 87, 103, 284, 321, 325.

black, 272.

buffalo, 274.

gray, 272, 273, 274.

northwestern timber, 33, 272.

plains, 33, 274.
Wolf, Sycan, 275.

timber, northwestern, 33, 272.

Wolverine, 28, 34, 299.

Woodchuck, 24, 159, 161, 268, 278, 307.

Wood rat, 268, 278, 287, 288, 296, 307, $313,319$.

brown-footed, 12.

bushy-tailed. See Bushy-tailed wood rat.

desert, 14.

dusky, 21.

dusky-footed, 32, 174.

Nevada, 32, 176.

Woods mouse, western, 182.

Yaquina Bay, type locality, 364 .

yaquinae, Sorex pacificus, $20,34,363$, 364.

Yellow head, 139.

yumanensis, Myotis, 372.

Zalophus californianus, 34, 332.

Zapodidae, 231.

Zapus major, 234.

montanus, 33, 232, 234.

nevadensis, 234.

oregonus, 33, 232, 234.

pacificus, 33, 232, 233.

princeps, 234.

trinotatus, 21, 33, 231, 234.

Ziphiidae, 344.

Zones. See Life zones. 





